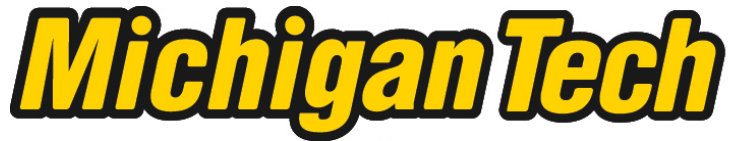 \\ Michigan Technological University Create the Future Digital Commons @ Michigan Tech
}

Dissertations, Master's Theses and Master's Reports - Open

Dissertations, Master's Theses and Master's

Reports

2008

\section{Comparison of common dredging equipment air emissions}

Mark J. Anderson P.E.

Michigan Technological University

Follow this and additional works at: https://digitalcommons.mtu.edu/etds

Part of the Civil and Environmental Engineering Commons

Copyright 2008 Mark J. Anderson P.E.

\section{Recommended Citation}

Anderson, Mark J. P.E., "Comparison of common dredging equipment air emissions ", Master's Thesis, Michigan Technological University, 2008.

https://doi.org/10.37099/mtu.dc.etds/215

Follow this and additional works at: https://digitalcommons.mtu.edu/etds

3 Part of the Civil and Environmental Engineering Commons 


\title{
A COMPARISON OF \\ COMMON DREDGING EQUIPMENT AIR EMISSIONS
}

\author{
By \\ Mark J. Anderson, P.E.

\begin{abstract}
A THESIS
Submitted in partial fulfillment of the requirements

for the degree of

MASTER OF SCIENCE IN CIVIL ENGINEERING
\end{abstract}

MICHIGAN TECHNOLOGICAL UNIVERSITY

2008

Copyright (C) Mark J. Anderson 2008 

THIS THESIS, “A COMPARISON OF COMMON DREDGING EQUIPMENT AIR EMISSIONS," IS HEREBY APPROVED IN PARTIAL FULFILLMENT OF THE REQUIREMENTS FOR THE DEGREE OF MASTER OF SCIENCE IN CIVIL ENGINEERING.

\section{DEPARTMENT:}

CIVIL AND ENVIRONMENTAL ENGINEERING

Signatures:

Thesis Advisor

Brian D. Barkdoll, P.E.

Associate Professor

Department Chair

William M. Bulleit, P.E.

Professor and Chair

Date 



\begin{abstract}
The purpose of this study is to provide a procedure to include emissions to the atmosphere resulting from the combustion of diesel fuel during dredging operations into the decision-making process of dredging equipment selection. The proposed procedure is demonstrated for typical dredging methods and data from the Illinois Waterway as performed by the U.S. Army Corps of Engineers, Rock Island District. The equipment included in this study is a 16-inch cutterhead pipeline dredge and a mechanical bucket dredge used during the 2005 dredging season on the Illinois Waterway.

Considerable effort has been put forth to identify and reduce environmental impacts from dredging operations. Though environmental impacts of dredging have been studied no efforts have been applied to the evaluation of air emissions from comparable types of dredging equipment, as in this study. By identifying the type of dredging equipment with the lowest air emissions, when cost, site conditions, and equipment availability are comparable, adverse environmental impacts can be minimized without compromising the dredging project

A total of 48 scenarios were developed by varying the dredged material quantity, transport distance, and production rates. This produced an "envelope" of results applicable to a broad range of site conditions.

Total diesel fuel consumed was calculated using standard cost estimating practices as defined in the U.S. Army Corps of Engineers Construction Equipment Ownership and Operating Expense Schedule (USACE, 2005). The diesel fuel usage was estimated for all equipment used to mobilize and/or operate each dredging crew for every scenario.

A Limited Life Cycle Assessment (LCA) was used to estimate the air emissions from two comparable dredging operations utilizing SimaPro LCA software. An Environmental Impact Single Score (EISS) was the SimaPro output selected for comparison with the cost per $\mathrm{CY}$ of dredging, potential production rates, and transport distances to identify possible decision points.

The total dredging time was estimated for each dredging crew and scenario. An average hourly cost for both dredging crews was calculated based on Rock Island District 2005 dredging season records (Graham 2007/08).

The results from this study confirm commonly used rules of thumb in the dredging industry by indicating that mechanical bucket dredges are better suited for long transport distances and have lower air emissions and cost per CY for smaller quantities of dredged material. In addition, the results show that a cutterhead pipeline dredge would be preferable for moderate and large volumes of dredged material when no additional booster pumps are required. Finally, the results indicate that production rates can be a significant factor when evaluating the air emissions from comparable dredging equipment.
\end{abstract}





\section{TABLE OF CONTENTS}

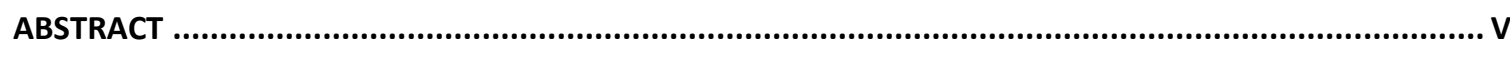

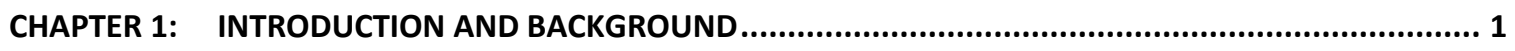

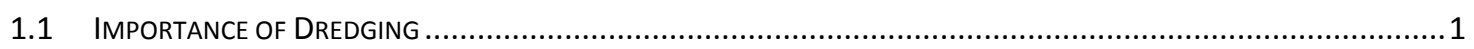

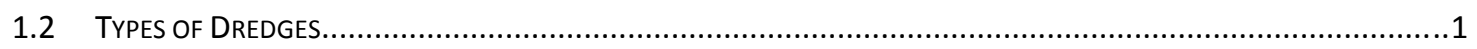

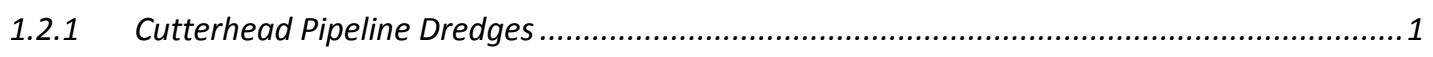

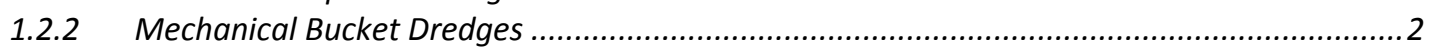

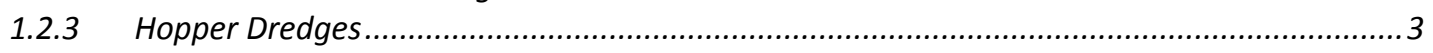

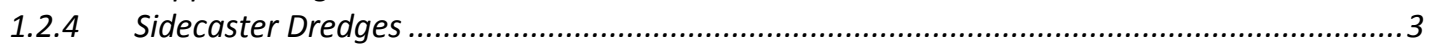

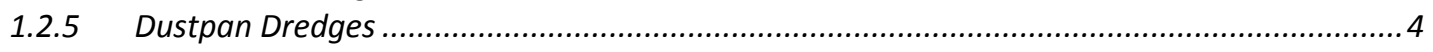

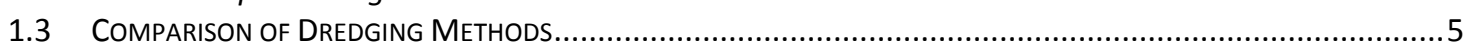

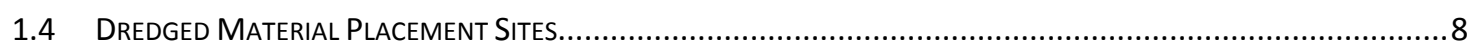

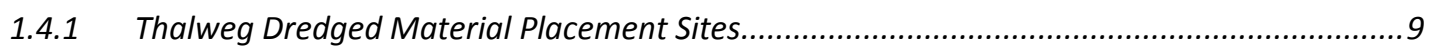

1.4.2 Bankline Dredged Material Placement Sites .......................................................................9

1.4.3 Near Shore Dredged Material Placement Sites ............................................................... 10

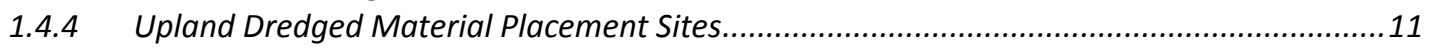

1.4.5 Confined Dredged Material Placement Sites .......................................................................11

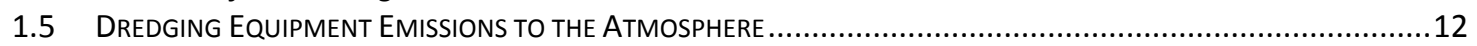

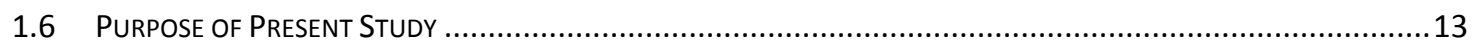

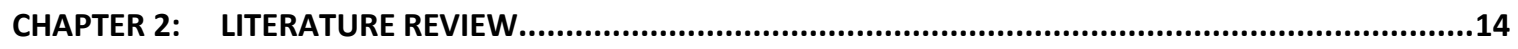

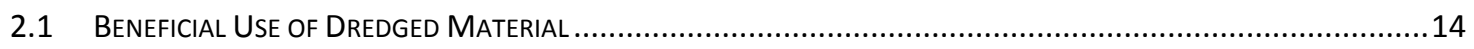

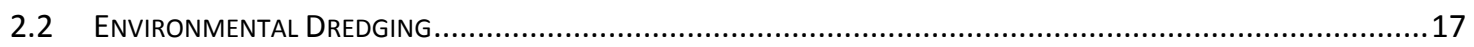

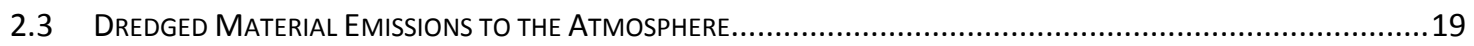

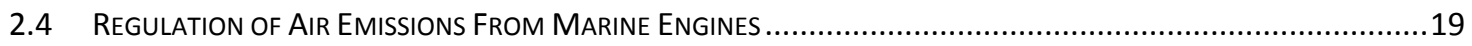

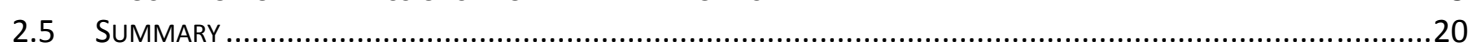

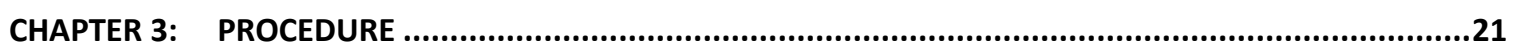

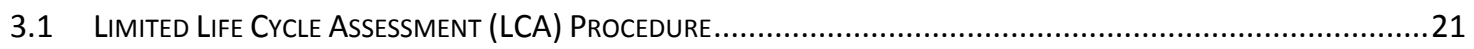

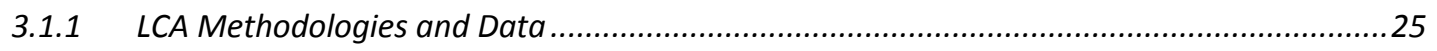

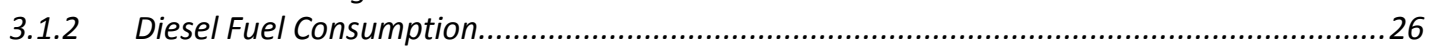

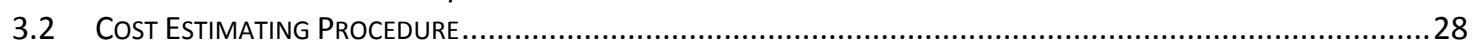

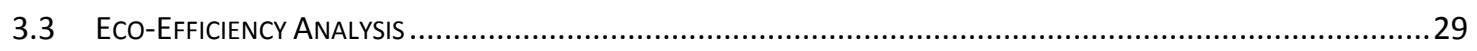

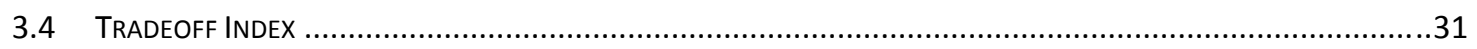

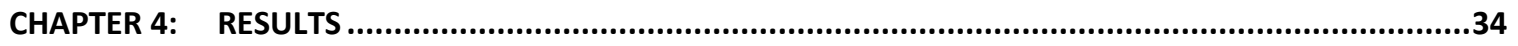

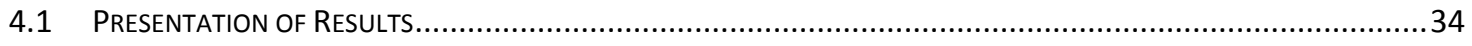

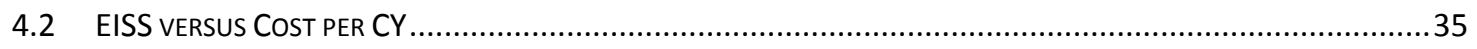

4.2.1 Variable Transport Distances and Constant Dredged Material Volumes ..............................36

4.2.2 Variable Dredged Material Volumes and Constant Transport Distances ................................38

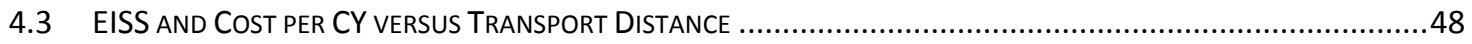

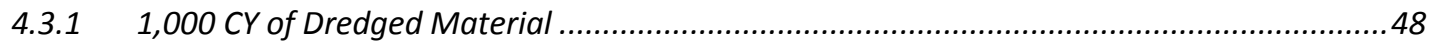

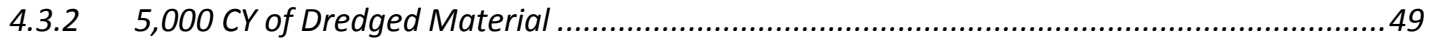

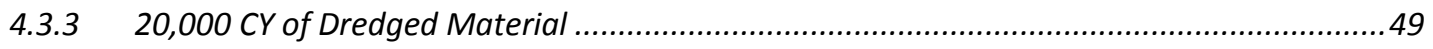

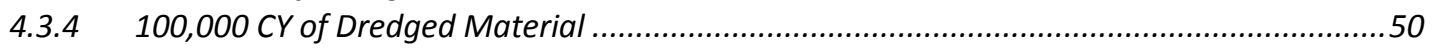

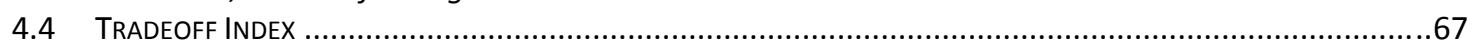

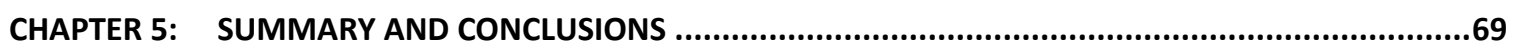

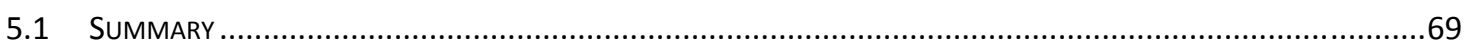

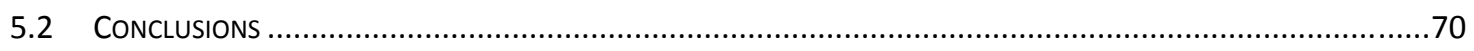




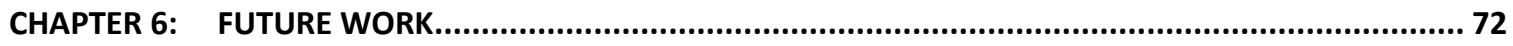

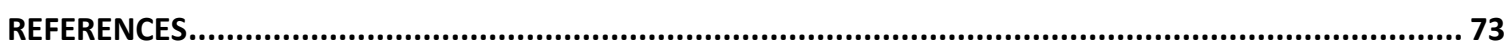

\section{APPENDICES}

Appendix A: Glossary

Appendix B: Dredging Fuel Consumption Calculation Tables

B.1: Fuel Consumption Calculation Tables, Dredged Material Volume: 1,000 Cubic Yards

B.2 Fuel Consumption Calculation Tables, Dredged Material Volume: 5,000 Cubic Yards

B.3 Fuel Consumption Calculation Tables, Dredged Material Volume: 20,000 Cubic Yards

B.4 Fuel Consumption Calculation Tables, Dredged Material Volume: 100,000 Cubic Yards

Appendix C: Dredging Cost Estimate Calculation Tables

Appendix D: Limited Life Cycle Assessment Output Tables

D.1: Limited Life Cycle Assessment Output Tables by Volume and Distance: Characterization

D.2 Limited Life Cycle Assessment Output Tables by Volume and Distance: Inventory

D.3 Limited Life Cycle Assessment Output Tables by Volume and Distance: Single Score

D.4 Limited Life Cycle Assessment Output Tables by Distance: Characterization

D.5 Limited Life Cycle Assessment Output Tables by Distance: Inventory

D.6 Limited Life Cycle Assessment Output Tables by Distance: Single Score

Appendix E: Copyright Permission Documentation 


\section{TABLE OF FIGURES}

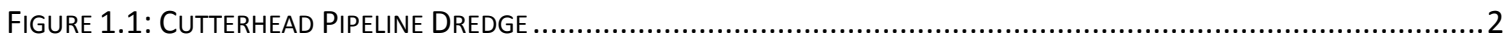

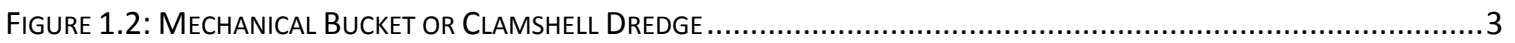

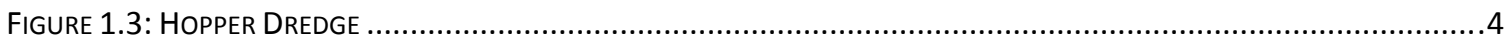

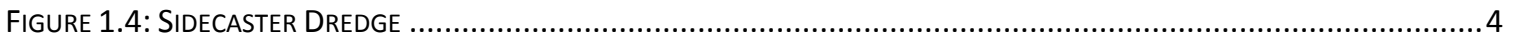

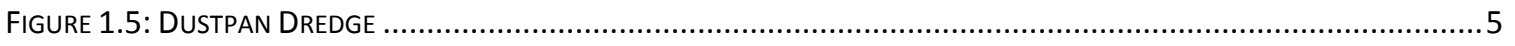

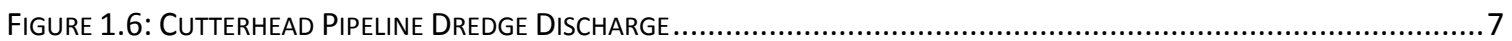

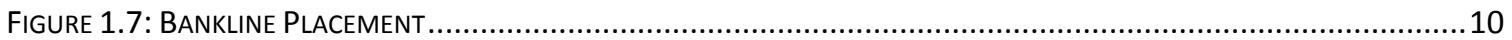

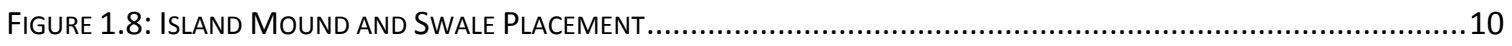

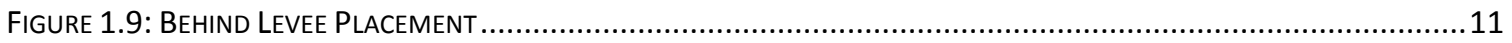

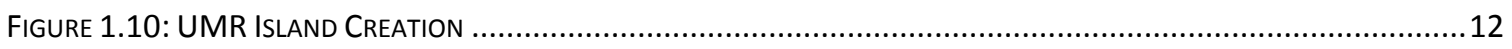

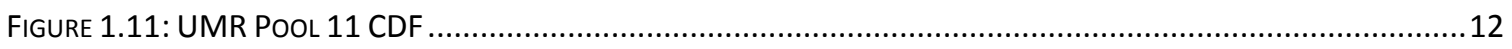

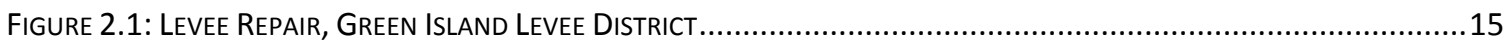

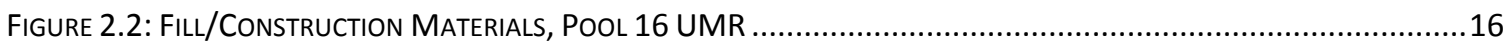

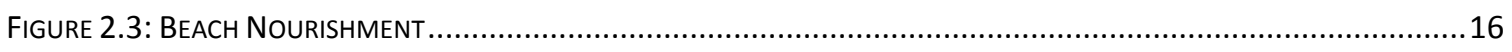

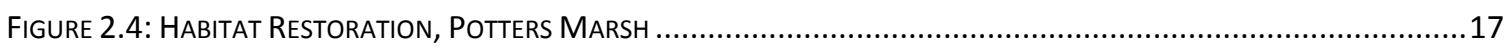

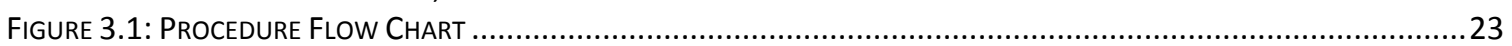

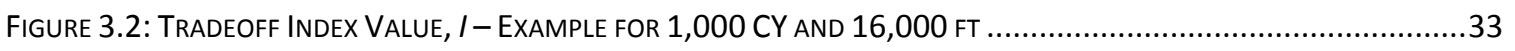

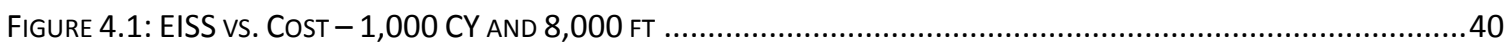

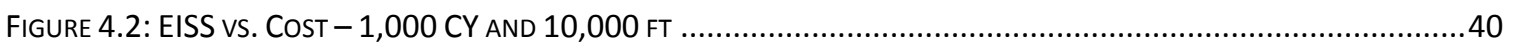

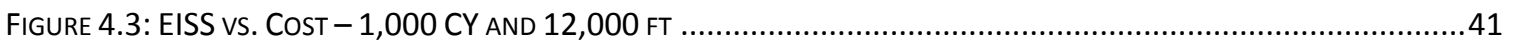

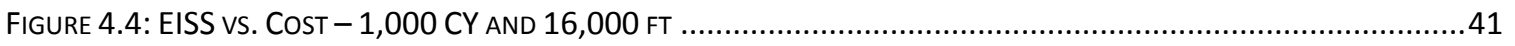

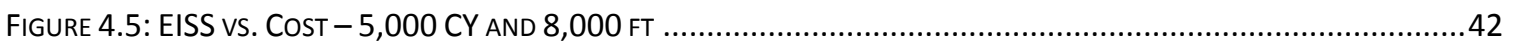

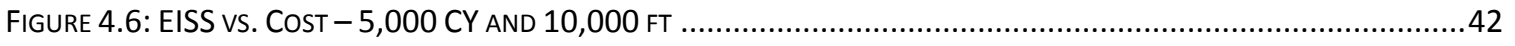

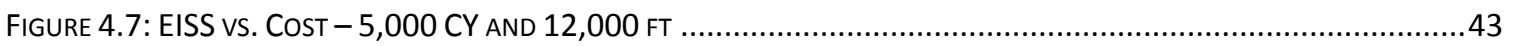

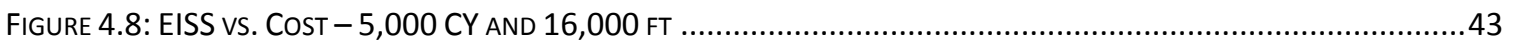

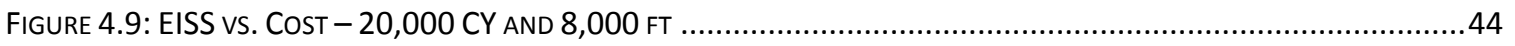

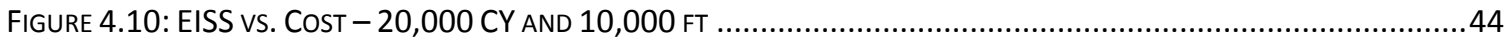

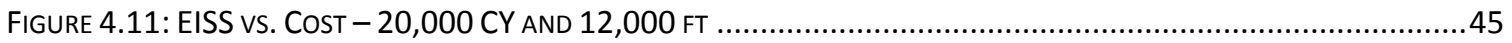

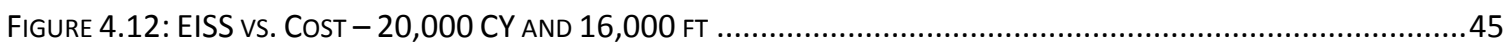

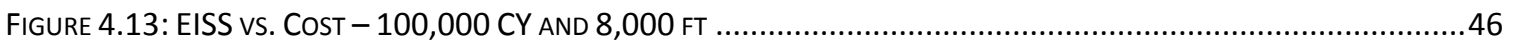

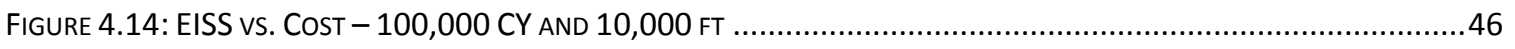

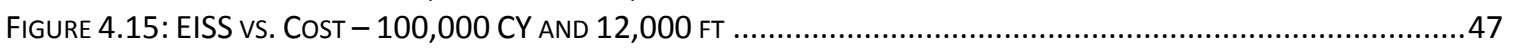

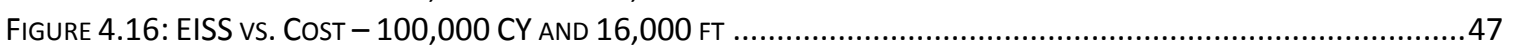

Figure 4.17: EISS AND COSt vs. TRANSPORT Distance: 1,000 CY - All PROduction RATES ...................................51

FiguRE 4.18: EISS AND COST VS. TRANSPORT DiSTANCE: 1,000 CY - HIGH PRODUCTION RATE ....................................52

Figure 4.19: EISS AND COST VS. TRANSPORT DistANCE: 1,000 CY - AVERAgE PRODUCTION RATE ..............................53

Figure 4.20: EISS AND COST VS. TRANSPORT DistANCE: 1,000 CY - LOW PRODUCTION RATE .....................................54

Figure 4.21: EISS AND COST VS. TRANSPORT DistANCE: 5,000 CY - AlL PRODUCTION RATES .....................................55

Figure 4.22: EISS AND COST VS. TRANSPORT DiSTANCE: 5,000 CY - HIGH PRODUCTION RATE .....................................56

Figure 4.23: EISS AND COST VS. TRANSPORT Distance: 5,000 CY - AVERAge Production RATE ..............................57

FiguRE 4.24: EISS AND COST VS. TRANSPORT DiSTANCE: 5,000 CY - LOW PROduCTION RATE ....................................58

Figure 4.25: EISS AND COST VS. TRANSPORT DistANCE: 20,000 CY - AlL PRODUCTION RATES ..................................59

Figure 4.26: EISS AND COST VS. TRANSPORT DistANCE: 20,000 CY - HIGH PRODUCTION RATE ................................60

Figure 4.27: EISS AND COSt VS. TRANSPORT DistanCE: 20,000 CY - AVERAge PRODUCTION RATE .............................61

FiguRE 4.28: EISS AND COST VS. TRANSPORT DiSTANCE: 20,000 CY - LOW PRODUCTION RATE ..................................62

FIgURE 4.29: EISS AND COST VS. TRANSPORT DistANCE: 100,000 CY - AlL PRODUCTION RATES ...............................63

Figure 4.30: EISS AND COST VS. TRANSPORT DistANCE: 100,000 CY - HIGH PROduction RATE ...............................64

Figure 4.31: EISS AND COST VS. TRANSPORT DistANCE: 100,000 CY - AVERAGE PROduction RATE ..........................65

FiguRE 4.32: EISS AND COST VS. TRANSPORT DISTANCE: 100,000 CY - LOW PRODUCTION RATE ...............................66 


\section{Table of Tables}

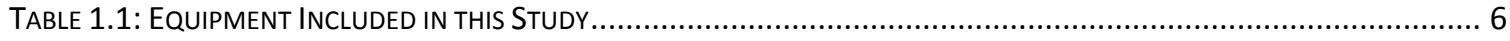

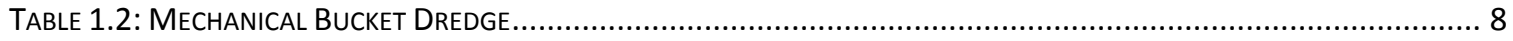

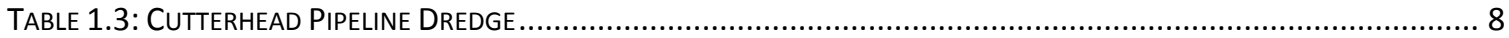

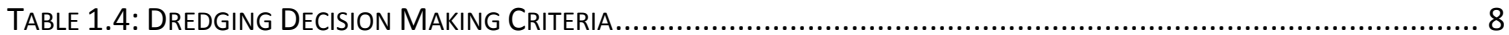

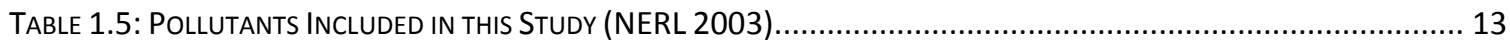

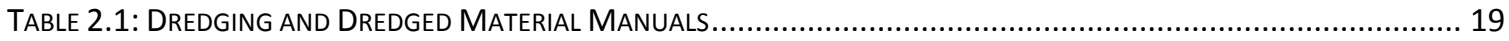

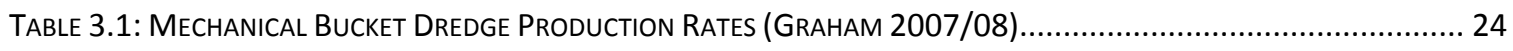

Table 3.2: Cutterhead Pipeline Dredge Production Rates (Graham 2007/08) ............................................ 25

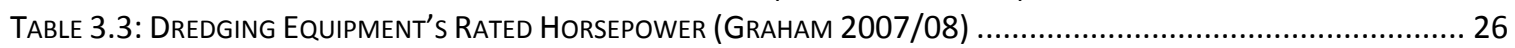

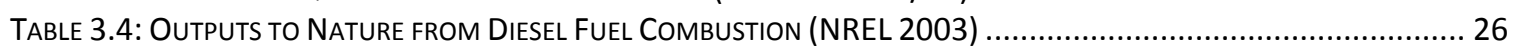

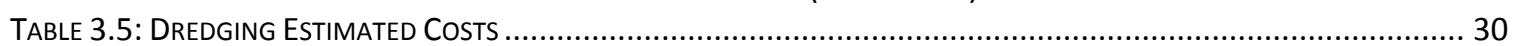

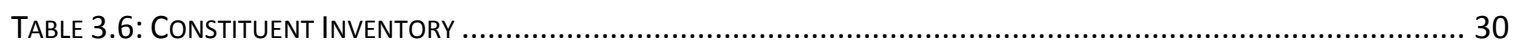

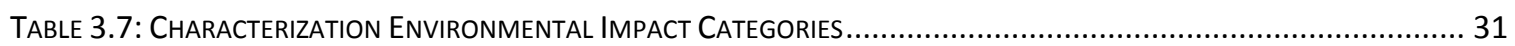

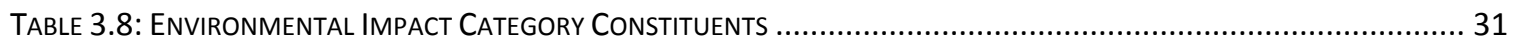

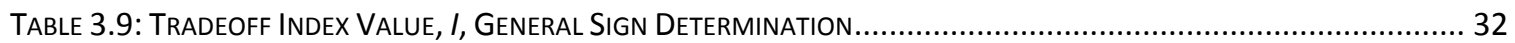

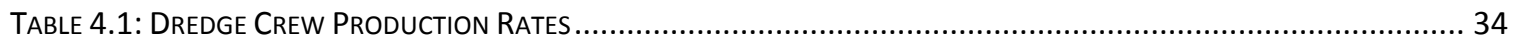

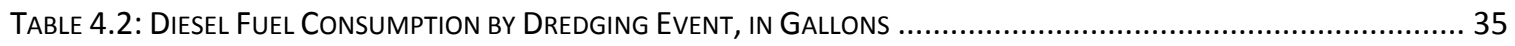

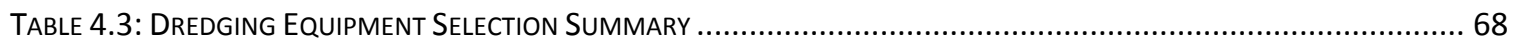

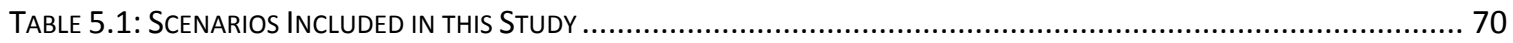




\section{CHAPTER 1: INTRODUCTION AND BACKGROUND}

\subsection{Importance of Dredging}

Dredging is the underwater excavation of accumulated sediments. The removal of sediment from a water body can be done for several reasons. The primary purposes are: navigation, mining, ecosystem restoration, and the removal of contaminants. Once sediment has been removed from the channel it is referred to as dredged material. In fiscal year (FY) 2006 the U. S. Army Corps of Engineers (USACE) dredged a total of 204.2 million cubic yards (CY) of sediment (NDC 2007). Navigation maintenance dredging accounted for 137.8 million $\mathrm{CY}$ or $67.5 \%$ of this total. Two types of dredging equipment performed $66.6 \%$ of the total dredging completed in FY 2006. Cutterhead pipeline dredges removed 118.6 million CY of material or $58.1 \%$ and mechanical dredges removed 17.4 million CY or $8.5 \%$ of the total material dredged in 2006 .

Navigation maintenance dredging is an integral and necessary operational component of our waterborne transportation system. Waterborne commerce in the United States totaled 2,588 million short tons in 2006 (IWR 2006). Of that total 702.1 million short tons were transported within the Mississippi River System with 490.6 million short tons being classified as internal traffic. Internal traffic is defined as "vessel movements (origin and destination) which take place solely on inland waterways. An inland waterway is one geographically located within the boundaries of the contiguous 48 states or within the boundaries of the State of Alaska" (IWR 2006). Nearly 25\% or 120.4 million short tons of the Mississippi River System internal traffic were transported on the Illinois Waterway. The waterborne transportation system would be crippled if navigation maintenance dredging was not performed in a regular and timely manor.

\subsection{Types of Dredges}

There are numerous types of dredges used for the various purposes including: cutterhead pipeline (CPD), mechanical bucket or clamshell (MBD), hopper, sidecaster, and dustpan dredges. Each type of dredge is well suited for different site conditions (both dredge cut and placement site), sediment characteristics, quantities of sediment to be dredged, production rates, and distance that the material must be transported to a placement site (USACE 1983).

\subsubsection{Cutterhead Pipeline Dredges}

Cutterhead pipeline dredges have an arm or ladder with a rotating cutterhead located at the intake end of the dredge (Figure 1.1). This ladder is lowered down to the channel bottom where the cutterhead dislodges the sediment and a pump transports the dredged material and water slurry through a discharge pipeline to the placement site. The slurry is approximately $10 \%$ to $20 \%$ dredged material and $80 \%$ to $90 \%$ water. The placement site must be designed to contain the dredged material slurry long enough for the sediment to settle out and have a gravity feed or pump to return the excess water to the channel. Cutterhead pipeline dredges are available in a wide range of sizes, 
designated by the diameter of the discharge pipe that can vary from 8 inches up to 36 inches or more and are the most commonly used dredge type in the United States (USACE 1983).

Cutterhead pipeline dredges are capable of excavating most types of sediment including: clay, silt, sand, and gravel, large dredges are even able to excavate some corals and softer rock formations. Production can be done on an almost continuous basis resulting in economical and efficient operations for larger volumes of dredged material. Cutterhead pipeline dredges are not well suited for work in open-water without encountering operational and safety problems cause by high waves. Also, the discharge pipeline can potentially interfere with navigation. In order to minimize any negative effects to navigation, the dredge will need to stop production and move the dredge, discharge pipeline, or both out of the navigation channel. Additionally, debris and obstructions will tend to clog or damage the rotating cutterhead and should be avoided whenever possible (USACE 1983).

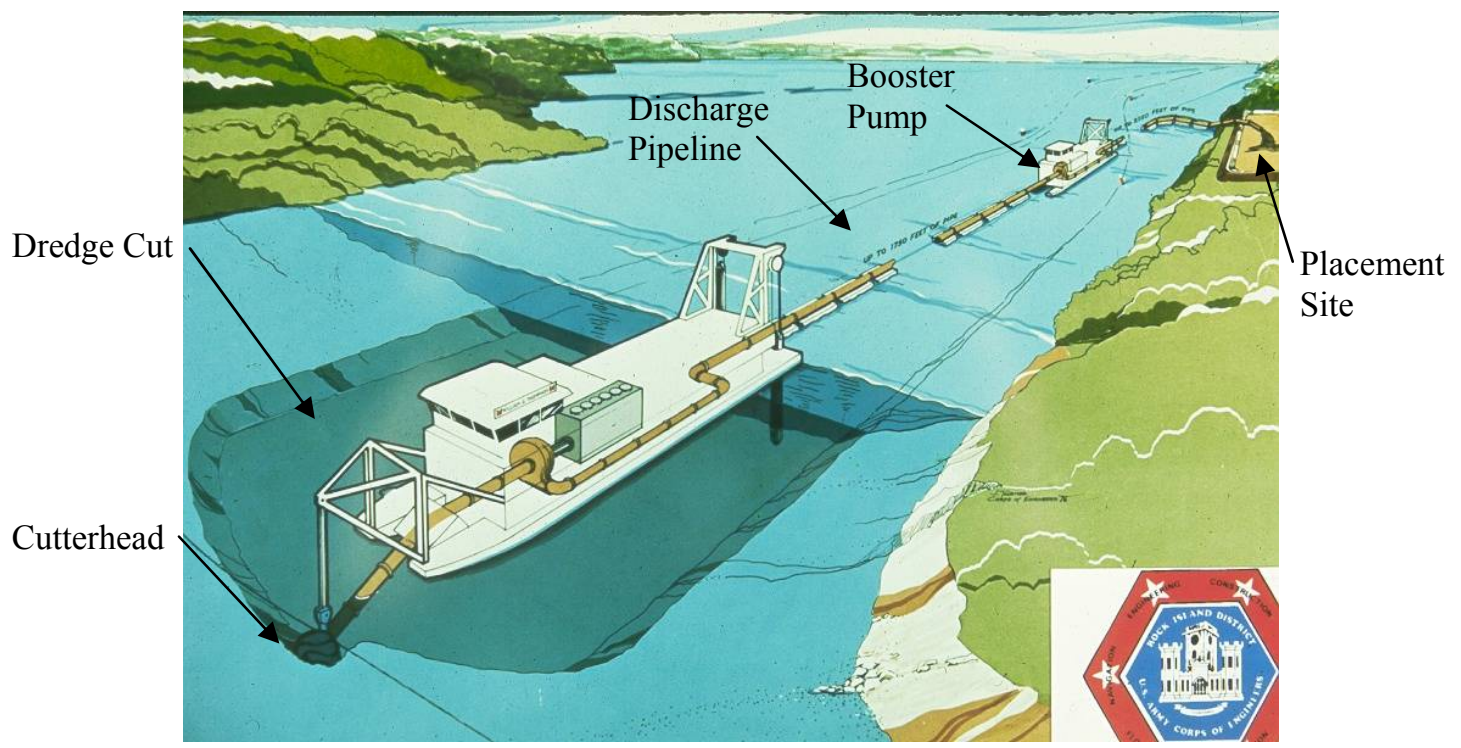

Figure 1.1: Cutterhead Pipeline Dredge

(Figure courtesy of U. S. Army Corps of Engineers, Rock Island District [Date Unknown] Unpublished Figure) (Documentation can be found in Appendix E)

\subsubsection{Mechanical Bucket Dredges}

A mechanical bucket or clamshell dredge uses a crane or an excavator similar to excavators used in the construction and/or mining industries to mechanically scoop the sediment from the channel bottom and place it on a barge for transport to the placement site (Figure 1.2). Different types of buckets, such as clamshell, excavator, or dragline, can be used depending on the dredging requirements. This type of dredge is very durable and capable of removing most types of sediment including: clay, sand, gravel, and blasted rock but is inefficient for the removal of soft fine-grained sediment. Mechanical bucket dredges are capable of removing most debris and obstruction making them well suited for debris laden dredge cuts. Dredged material is transported to placement sites on barges 
limiting production rates relative to cutterhead pipeline dredges and making mechanical bucket dredges well suited for long transport distances (USACE 1983).

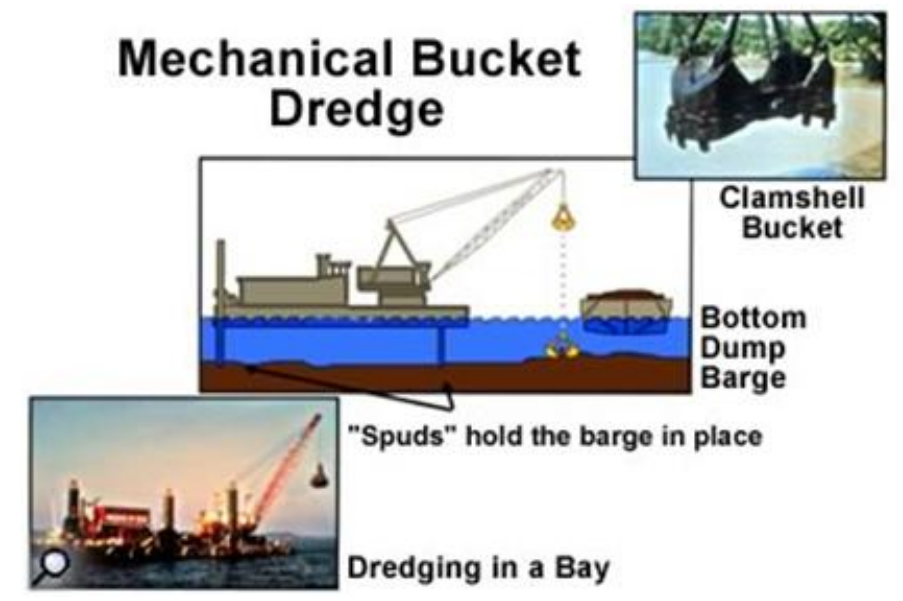

Figure 1.2: Mechanical Bucket or Clamshell Dredge

(USACE 2008)(Documentation can be found in Appendix E)

\subsubsection{Hopper Dredges}

Hopper dredges are self-propelled seagoing vessels making them ideally suited for openwater and high traffic areas (Figure 1.3). These dredges are capable of removing sediment from the navigation channel without interfering with traffic, are maneuverable, and well suited for open-water or ocean placement of dredged material. They operate by lowering a suction head on a drag arm and pumping sediment into a hopper within the vessel hull. The dredge then travels to the placement site and empties the hopper either through an opening in the bottom of the hopper or by pumping the dredged material to an upland placement site. Hopper dredges are deep draft vessels that are not capable of operations in shallow waters, near structures, or when precise control on the dredge cut is required. Hopper dredges are best suited for removal of loose, unconsolidated sediment. Since the same vessel dredges and transports the dredged material, dredging operations cannot be done on a continuous basis, limiting overall production rates (USACE 1983).

\subsubsection{Sidecaster Dredges}

Sidecaster dredges are a shallow draft seagoing vessel specifically designed for remote open water areas (Figure 1.4). These dredges are typically self-sustaining and can operate with minimal support requirements. Sediment is pumped from the channel through a suction head on a drag arm and discharged overboard through a suspended discharge pipeline. These dredges are designed to be easily and rapidly deployed and to initiate dredging immediately upon arrival at the dredge cut. Sidecaster dredges require adequate water depth to reach the dredge cut and may be limited to dredging only during high tides. Open water disposal of the dredged material is the only disposal capability for sidecaster dredges. Because the discharge is relatively close to the dredge, some material 
may migrate back into the navigation channel due to tidal and littoral currents (USACE 1983)

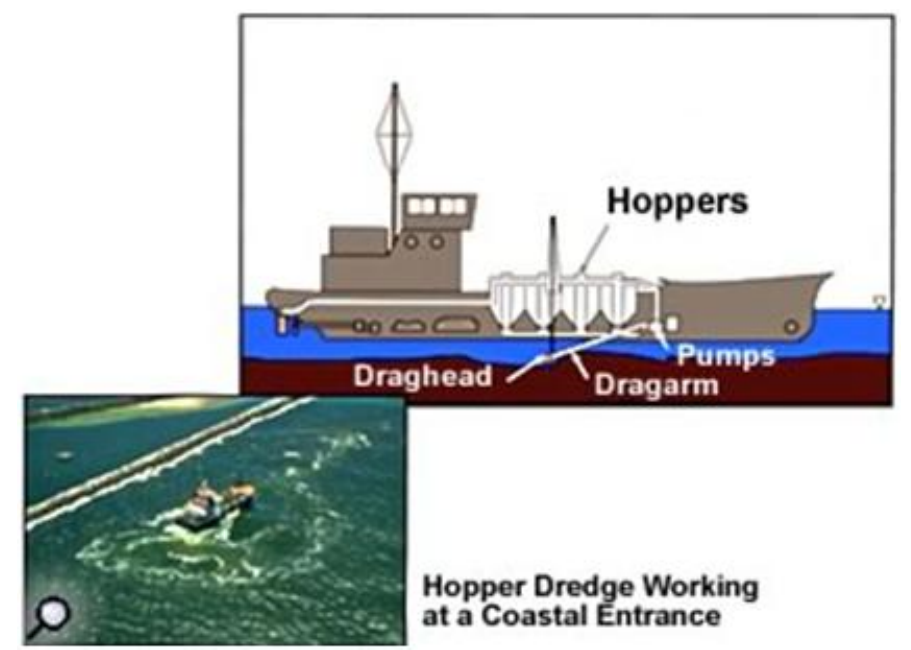

Figure 1.3: Hopper Dredge

(USACE 2008) (Documentation can be found in Appendix E)

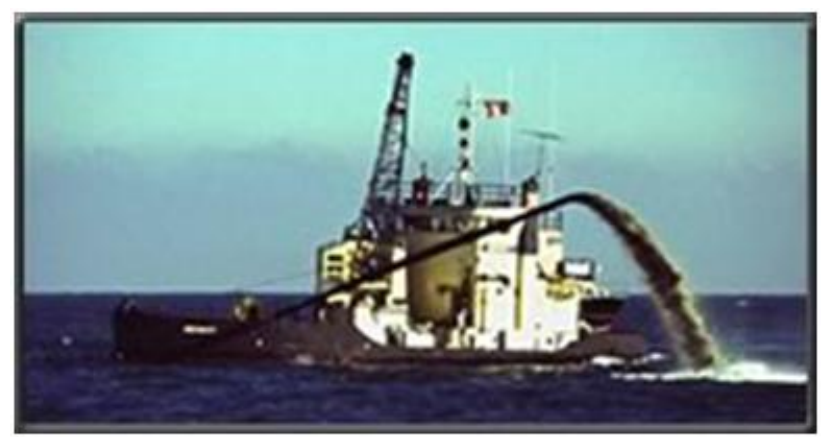

Figure 1.4: Sidecaster Dredge

(USACE 2008) (Documentation can be found in Appendix E)

\subsubsection{Dustpan Dredges}

Dustpan dredges were designed to remove primarily sand and gravel from shallow locations making them unsuitable for open or rough water locations. These dredges utilize water jets located in a dustpan head to dislodge sediments which are pumped through a pipeline and discharged into open water outside the navigation channel (Figure 1.5). Typically, the discharge is only 800 to 1,000 feet from the dredge and is not designed for long transport distances or upland placement sites. Dustpan dredges are capable of rapid mobilization, high production rates, and can easily move out of the navigation channel to avoid unwanted commercial vessel delays (USACE 1983). 


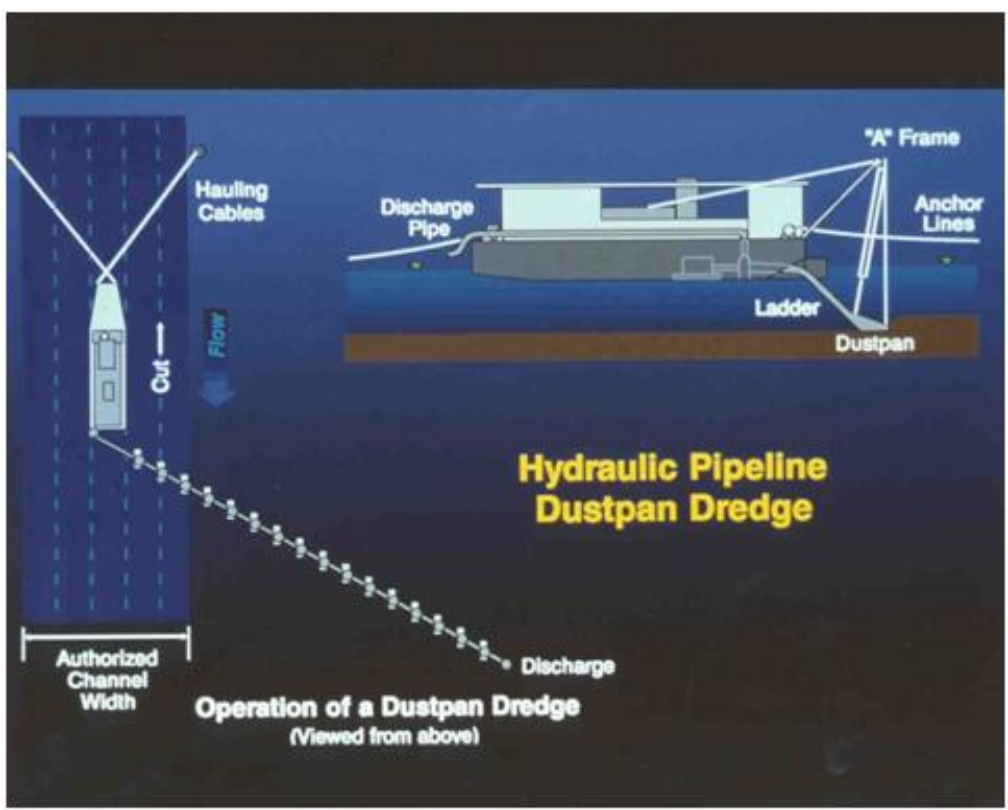

Figure 1.5: Dustpan Dredge

(USACE 2006) (Documentation can be found in Appendix E)

\subsection{Comparison of Dredging Methods}

The type of equipment included in this analysis will be limited to that which is commonly used for navigation channel maintenance dredging on the Illinois Waterway (IWW) and Upper Mississippi River (UMR) within the U. S. Army Corps of Engineers, Rock Island District. The equipment selected was used by Rock Island District for navigation channel maintenance dredging on the IWW during the 2005 dredging season (Table 1.1). It included a 16-inch cutterhead pipeline dredge owned and operated by an independent contractor and a mechanical bucket dredge owned and operated by Rock Island District (Graham 2007/08).

Cutterhead pipeline dredges are capable of pumping dredged material approximately 5,000 to 12,000 feet with just the pump on the dredge itself, depending on the size dredge, elevation change to the placement site, and sediment characteristics. In order to transport dredged material over longer distances, additional inline booster pumps must be added (Figure 1.1). Typically, only two booster pumps can be efficiently added to the dredging process, increasing the transport distance by 1,000 to 3,000 feet per booster pump. If the distance between the dredge cut and placement site exceeds the total distance with booster pumps then an intermediate placement site within the water body must be identified and approved. The sediment would be dredged to this intermediate placement site then the dredge would be moved from the original dredge cut to the intermediate placement site and the material would be dredged a second time and transported to the final placement site, commonly referred to as re-handling or double handling the dredged material. This process significantly increases the environmental impacts and the cost per CY which usually makes a cutterhead pipeline dredge unsuitable for dredging and transporting dredged material distances greater than that reachable with 
two booster pumps. The transport distances for the 16-inch contractor-owned dredge used by Rock Island District for the 2005 dredging season are 8,000 feet for the dredge alone, with each booster pump capable of increasing the transport distance by 2,000 feet. Once a cutterhead pipeline dredge has been mobilized and set up at a dredge cut it is capable of nearly continuous dredging with few interruptions except for routine maintenance for the equipment, movement of the discharge pipeline to minimize delays to navigation, and relocation of the pipeline within one or to another placement site. This results in relatively high production rates. Cutterhead pipeline dredges generate a considerable quantity of water that must be managed at the placement site (Figure 1.6) to meet water quality standards.

\section{Table 1.1: Equipment Included in this Study}

\begin{tabular}{|c|c|c|c|}
\hline \multicolumn{2}{|c|}{$\frac{\text { Mechanical Bucket }}{\text { Dredge }}$} & \multicolumn{2}{|c|}{$\frac{\text { Cutterhead Pipeline }}{\underline{\text { Dredge }}}$} \\
\hline Equipment & Quantity & Equipment & Quantity \\
\hline Excavator & 1 & Main Engine & 1 \\
\hline M/V LaSalle & 2 & Cutter Head Engine & 1 \\
\hline Gen Set (LaSalle) & 1 & Booster Pumps & 2 \\
\hline Dozer (D6T) & 1 & $\begin{array}{l}\text { Spud Hyd Drive } \\
\text { Engine }\end{array}$ & 1 \\
\hline Dozer (950G) & 1 & $\begin{array}{l}\text { Gen Set (Dredge- } \\
300 \mathrm{~kW})\end{array}$ & 1 \\
\hline $\begin{array}{l}\text { Gen Set (Crane } \\
\text { Barge) }\end{array}$ & 2 & $\begin{array}{l}\text { Gen Set (Dredge- } \\
35 \mathrm{~kW})\end{array}$ & 1 \\
\hline & & Tender (Max) & 1 \\
\hline & & Tender (Scotty) & 1 \\
\hline & & $\begin{array}{l}\text { Tender (Debra Ann) } \\
\text { (Mob Only) }\end{array}$ & 1 \\
\hline & & Tractor & 1 \\
\hline & & Tractor & 1 \\
\hline & & Crissafully Pump & 1 \\
\hline & & Anchor Barge & 3 \\
\hline & & Crane & 1 \\
\hline & & Light Plants & 2 \\
\hline
\end{tabular}

Mechanical bucket dredges are well suited when the dredge material must be transported distances greater than 12,000 feet. Once the material has been dredged and loaded onto a barge it can be transported long distances without requiring re-handling. Another situation where mechanical bucket dredges are well suited is for small quantities of material to be dredged from one location, because they are relatively quick and inexpensive, compared to cutterhead pipeline dredges, to mobilize and demobilize. Another consideration for dredging equipment is the distance from the river channel to the placement site. Either an excavator or a dozer would be used to transfer the dredged material from the barge to the placement site as long as the site is adjacent to the river channel. If the placement site is not immediately adjacent to the channel, material dredged by a mechanical bucket dredge would need to be transferred from the barge to a truck for transport overland to the placement site. This would add expense, negative 
environmental impacts, and reduce production rates over a cutterhead pipeline dredge. A cutterhead pipeline dredge could extend the discharge pipeline over land to the placement site as long as the total transport distance doesn't exceed the maximum distance for that dredge.

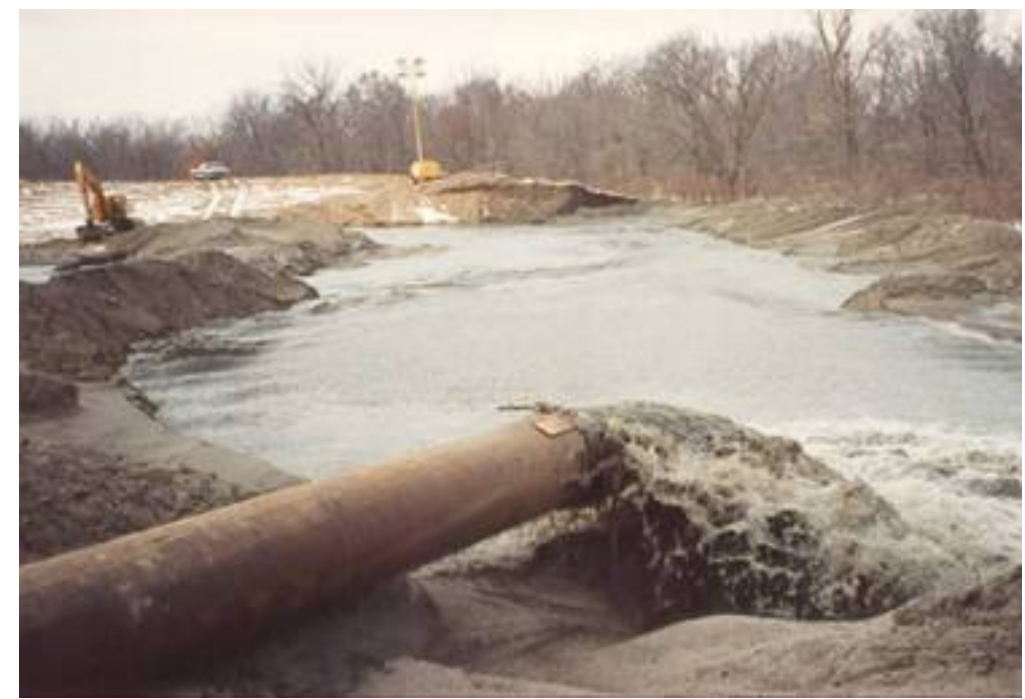

Figure 1.6: Cutterhead Pipeline Dredge Discharge

(Figure courtesy of U. S. Army Corps of Engineers, Rock Island District [Date Unknown] Unpublished Photograph) (Documentation can be found in Appendix E)

Each type of dredge has distinct advantages and disadvantages that contribute to the decision-making process (Tables 1.2 and 1.3) (USACE 1983). Mechanical bucket dredges are quicker and more economical to mobilize, are capable of transporting dredged material over long distances, require less supporting equipment, and have relatively low production rates. Cutterhead pipeline dredges are more difficult and costly to mobilize, are limited in the distance they can transport dredged material, require more support equipment, and have relatively high production rates. In general terms this means that mechanical bucket dredges are better suited to small quantities of material to be dredged at a given location and/or long (greater than 12,000 feet) transport distances while cutterhead pipeline dredges are better suited to large quantities and shorter transport distances (less than 12,000 feet).

Typically, dredging decision makers utilize multiple criteria for selection of dredging equipment and placement site for each dredge cut(s) (Table 1.4) (USACE 2003A). These criteria are used to identify and implement the most suitable combination of equipment and placement site(s) for navigation channel maintenance dredging over a 20 to 40 year planning horizon. 
Table 1.2: Mechanical Bucket Dredge

\begin{tabular}{|l|l|}
\hline Advantages & Disadvantages \\
\hline Rugged and reliable & Lower production rates \\
\hline $\begin{array}{l}\text { Capable of removing hard packed } \\
\text { material }\end{array}$ & $\begin{array}{l}\text { Difficult to retain fine/loose } \\
\text { sediment with conventional bucket } \\
\text { Inefficient for short transport } \\
\text { areas }\end{array}$ \\
\hline $\begin{array}{l}\text { Efficient for long transport } \\
\text { distances }\end{array}$ & $\begin{array}{l}\text { Additional controls required for } \\
\text { contaminated sediment }\end{array}$ \\
\hline $\begin{array}{l}\text { Relatively low } \\
\text { mobilization/demobilization costs }\end{array}$ & \\
\hline Has ability to remove debris & \\
\hline Return water not an issue & \\
\hline
\end{tabular}

Table 1.3: Cutterhead Pipeline Dredge

\begin{tabular}{|l|l|}
\hline Advantages & Disadvantages \\
\hline $\begin{array}{l}\text { Capable of dredging most types of } \\
\text { sediment }\end{array}$ & $\begin{array}{l}\text { Cohesive material and debris can } \\
\text { block cutterhead }\end{array}$ \\
\hline $\begin{array}{l}\text { Capable of pumping dredged } \\
\text { material directly to placement site }\end{array}$ & $\begin{array}{l}\text { Dredging slurry is } 80 \% \text { to } 90 \% \\
\text { water and 10\% to 20\% sediment }\end{array}$ \\
\hline Higher production rates & Debris may reduce efficiency \\
\hline $\begin{array}{l}\text { Cost effective for large volumes of } \\
\text { dredged material }\end{array}$ & $\begin{array}{l}\text { Return water management must be } \\
\text { incorporated into design }\end{array}$ \\
\hline $\begin{array}{l}\text { Cost effective within pumping } \\
\text { distance of placement site }\end{array}$ & Relatively high mobilization costs \\
\hline $\begin{array}{l}\text { Readily available in wide range of } \\
\text { sizes }\end{array}$ & Pipeline may obstruct navigation \\
\hline
\end{tabular}

Table 1.4: Dredging Decision Making Criteria

\begin{tabular}{|l|l|}
\hline Volume of material to be dredged & Width and depth of dredge cut \\
\hline Type of material to be dredged & Access to the dredge cut \\
\hline Distance to placement site & Potential beneficial use applications \\
\hline Access to the placement site & Potential for debris within dredge cut \\
\hline $\begin{array}{l}\text { Production rates for various types of } \\
\text { equipment }\end{array}$ & $\begin{array}{l}\text { Required time frame for dredged material } \\
\text { consolidation }\end{array}$ \\
Return water management & Dredging equipment availability \\
\hline $\begin{array}{l}\text { National Environmental Policy Act } \\
\text { (NEPA) Compliance }\end{array}$ & \\
\hline
\end{tabular}

\subsection{Dredged Material Placement Sites}

Dredged material placement sites used in Rock Island District fall into five broad categories including: thalweg, bankline, near shore, upland, and confined. The thalweg is the deepest part of a river channel cross section which usually has the highest flow rates. A bankline placement site would be within the flood plane and immediately adjacent to 
the river channel. Beach nourishment would be one example of a bankline placement site (Figure 1.7). Near shore placement sites would also be located within the flood plane but further away from the river channel than a bankline placement site. Upland placement sites are located outside of the flood plane, frequently behind a levee (Figure 1.9). Confined disposal placement sites are engineered facilities that contain dredged material within a specified footprint (Figure 1.11).

\subsubsection{Thalweg Dredged Material Placement Sites}

Thalweg placement of dredged material could be done using either a cutterhead pipeline or mechanical bucket dredge. The site would be located in a reach of river that is particularly deep, usually 20 to 30 feet in depth or more, this compares to the navigation channel mandated minimum depth of nine feet. Not all reaches of the UMR or IWW have thalweg conditions that are suitable for dredged material placement. This is not a particularly desirable option since it does not remove the sediment from the river channel and could result in additional environmental impacts. There are some advantages to thalweg placement that must be taken into account before eliminating this type of placement site from consideration. Thalweg placement is economical as long as the distance between the dredge cut and placement site are within the dredges transport distance capabilities. Also, there is no return water to manage when using a cutterhead pipeline dredge.

\subsubsection{Bankline Dredged Material Placement Sites}

Bankline placement could be done using either a cutterhead pipeline or mechanical bucket dredge. The dredged material is placed on the river shore or bankline (Figure 1.7) for habitat restoration, beach replenishment or nourishment, or erosion protection. A bankline placement site for habitat restoration could be to stabilize tree root systems that have been exposed due to erosion, increase the land surface elevation in areas to provide safe havens for wildlife to use during flood events (Figure 1.8), and create or enhance islands. Recreational facilities along the river are highly desirable to state and local governments along with the public. Dredged material can be used to nourish beaches and enhance the recreational experiences for boaters and swimmers. On occasion dredged material can be placed on banklines for erosion protection of cultural and historic sites that are not easily accessible for more traditional erosion protection systems such as riprap. In addition, dredged material can be used as short-term erosion protection or as fill to restore a bankline in preparation for riprap or some other erosion protection system. 


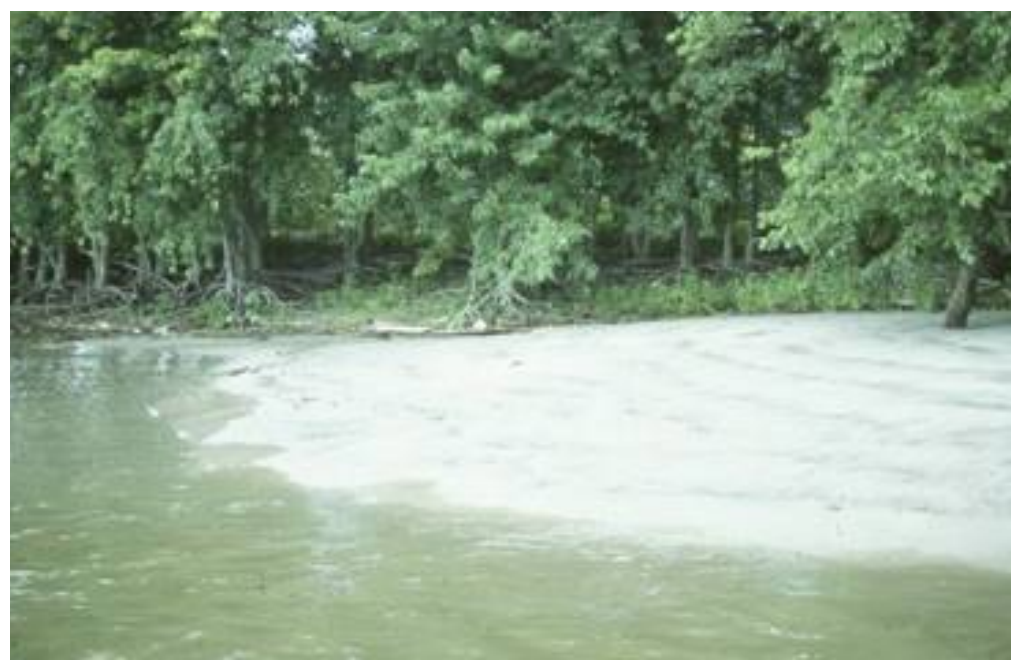

Figure 1.7: Bankline Placement

(Figure courtesy of U. S. Army Corps of Engineers, Rock Island District [Date Unknown] Unpublished Photograph) (Documentation can be found in Appendix E)

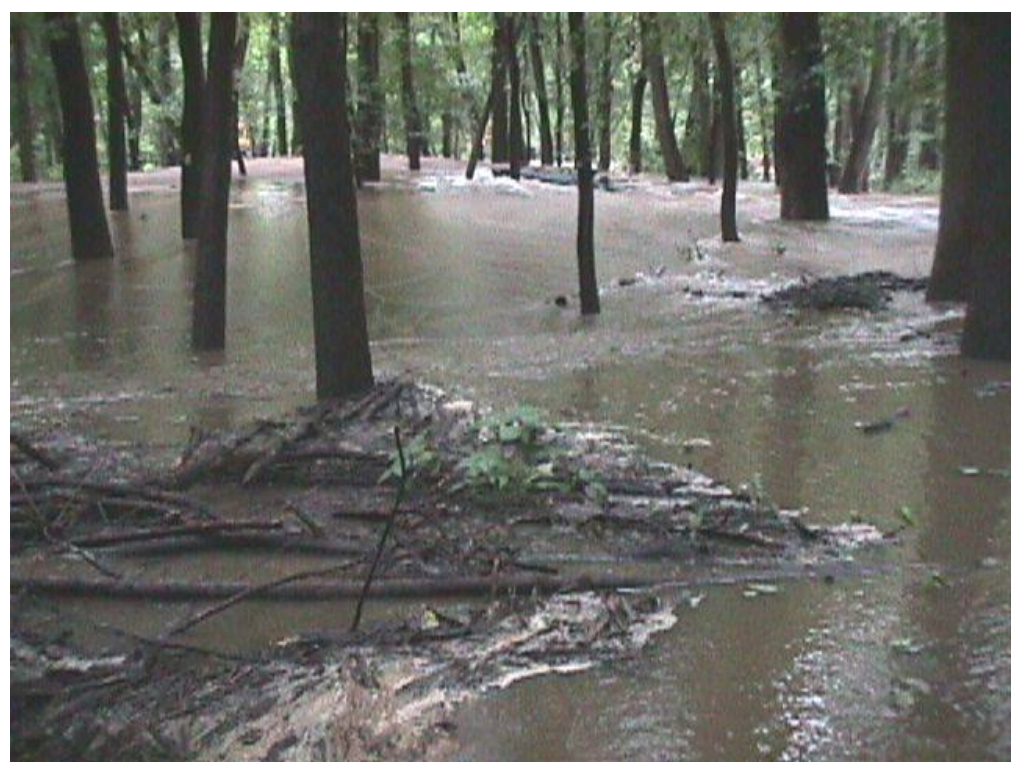

Figure 1.8: Island Mound and Swale Placement

(Figure courtesy of U. S. Army Corps of Engineers, Rock Island District [Date Unknown]

Unpublished Photograph) (Documentation can be found in Appendix E)

\subsubsection{Near Shore Dredged Material Placement Sites}

Near shore placement sites would include those sites that are within the floodplain but beyond the bankline. These placement sites can be used for habitat restoration similar to bankline sites or as long-term placement sites. The preferential option for long-term placement sites is typically to locate them outside of the floodplain to avoid adverse impacts to flood water surface elevations and the risk of re-suspension of the sediment and transport back into the river channel during high water events. However there are 
locations where the floodplain extends beyond practical and economical limits of transporting dredged material so near shore sites must be considered.

\subsubsection{Upland Dredged Material Placement Sites}

Upland sites are located outside the floodplain and are typically the preference of resource and regulatory agencies since they will have no impact on flood water surface elevations and they eliminate the potential for transport back into the river channel during floods. Upland sites could include: placement on the landside of levees (as long as the level of flood protection is not increased) (Figure 1.9); placement on existing agricultural fields; beneficial use stockpiles; and for habitat restoration.

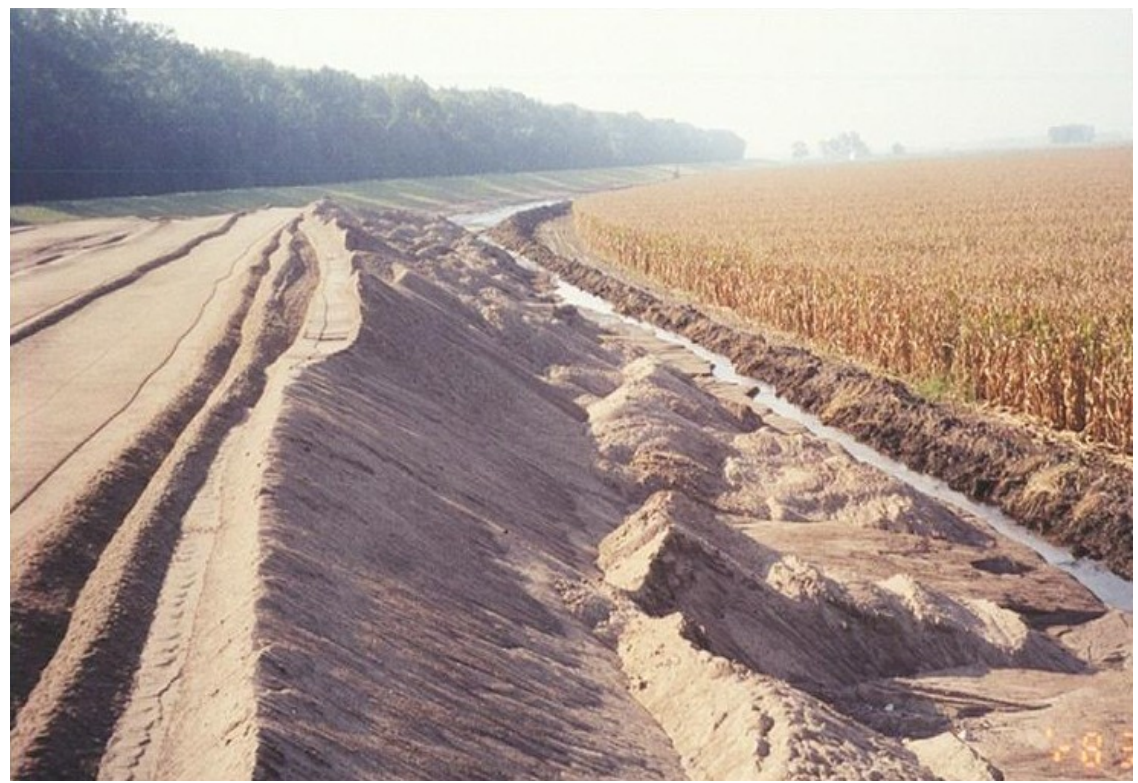

Figure 1.9: Behind Levee Placement

(Figure courtesy of U. S. Army Corps of Engineers, Rock Island District [Date Unknown] Unpublished Photograph) (Documentation can be found in Appendix E)

\subsubsection{Confined Dredged Material Placement Sites}

Confined dredged material placement facilities (CDF) are engineered and constructed sites that will retain the dredged material within a specified footprint. CDFs can be used for island creation (Figure 1.10), long-term dredged material placement sites (Figure 1.11), commercial and recreational site development, and for contaminated dredged material to ensure contaminates do not migrate off-site. 


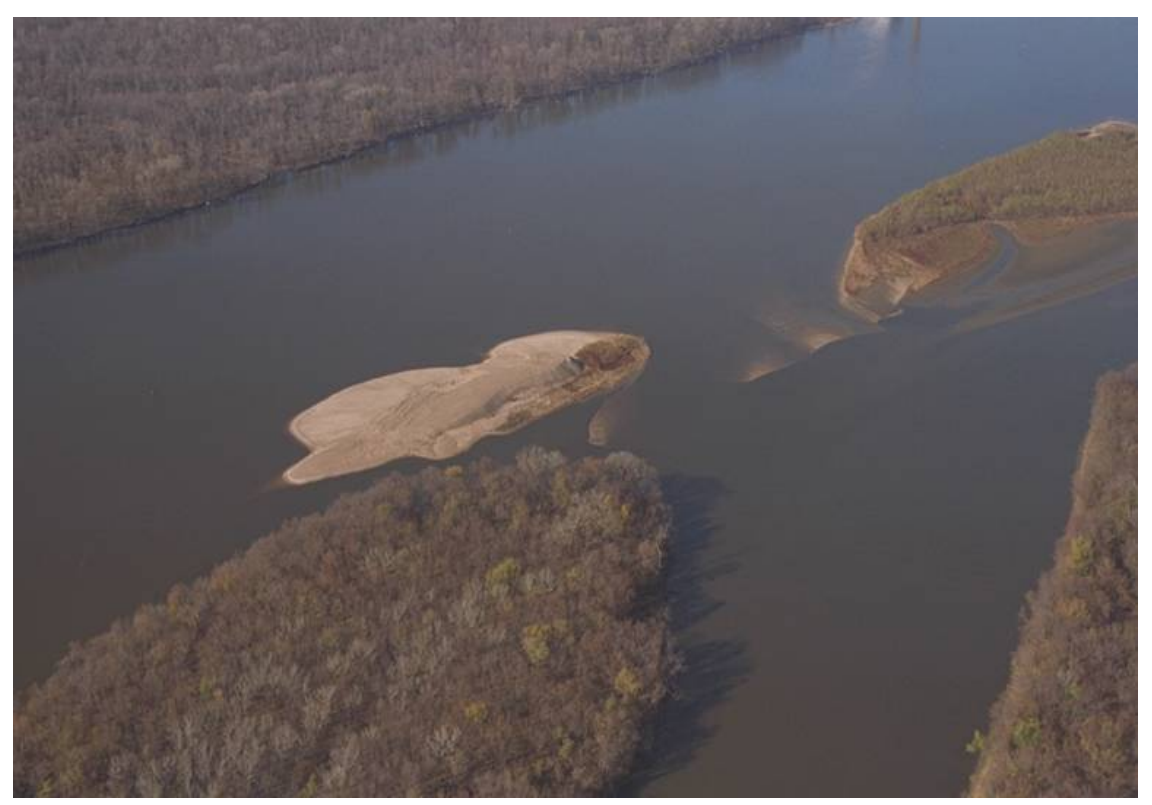

Figure 1.10: UMR Island Creation

(Figure courtesy of U. S. Army Corps of Engineers, Rock Island District [Date Unknown] Unpublished Photograph) (Documentation can be found in Appendix E)

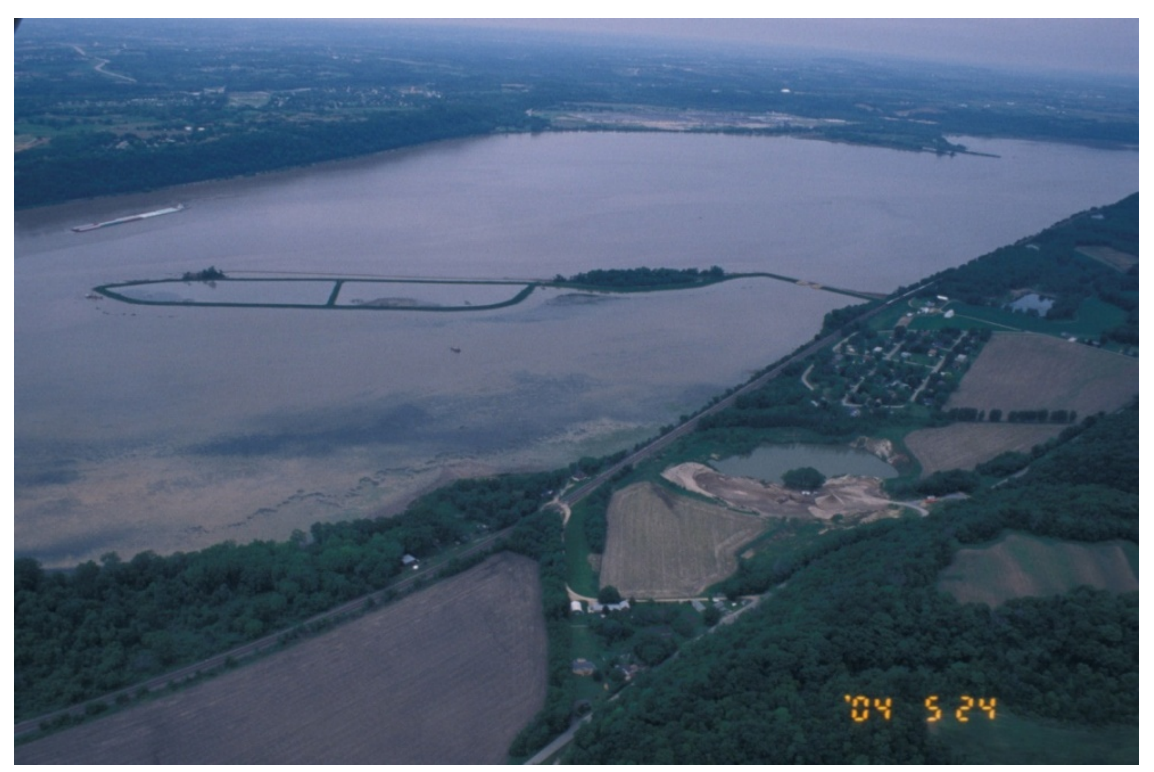

Figure 1.11: UMR Pool 11 CDF

(Figure courtesy of U. S. Army Corps of Engineers, Rock Island District [Date Unknown] Unpublished Photograph) (Documentation can be found in Appendix E)

\subsection{Dredging Equipment Emissions to the Atmosphere}

Navigation channel maintenance dredging equipment used on the IWW and UMR, as with most locations, needs to be mobile and capable of operation without an external power source, making diesel fuel the predominate choice. All of the equipment included in this study is diesel powered (Table 1.1). The combustion of diesel fuel 
releases pollutants into the atmosphere that can be quantified and compared between dredging crews to determine the lowest adverse environmental impacts for each type of equipment and scenario. Common pollutants found in emissions from diesel fuel combustion in industrial equipment are listed in Table 1.5 (NREL, 2003). These contaminants impact air quality and may add to global climate change considerations.

Table 1.5: Pollutants Included in this Study (NERL 2003)

\begin{tabular}{|l|l|l|}
\hline Acectaldehyde & Formaldehyde & Propene \\
\hline Acrolein & Methane & Toluene \\
\hline Benzene & Nitric Oxide & Sulfur oxides \\
\hline $\begin{array}{l}\text { Carbon dioxide } \\
\text { (fossil) }\end{array}$ & $\begin{array}{l}\text { PAtrogen oxide } \\
\text { PAomatic } \\
\text { aromeyclic } \\
\text { hydrocarbons }\end{array}$ & $\begin{array}{l}\text { Xylenes } \\
\text { (unspecified) }\end{array}$ \\
\hline Carbon monoxide & Particulates (PM10) & \\
\hline
\end{tabular}

\subsection{Purpose of Present Study}

The purpose of this paper is to provide a procedure to incorporate air emission impacts into the decision-making process for dredging equipment selection. The proposed procedure is demonstrated for typical dredging methods and other data from the Illinois Waterways as performed by the U.S. Army Corps of Engineers, Rock Island District. In this process, emissions to the atmosphere resulting from the combustion of diesel fuel in comparable types of dredging equipment were evaluated. A total of 48 scenarios were developed by varying quantity of material dredged, transport distance, and production rate. Air emissions were calculated for each type of dredging equipment and scenario using SimaPro Life Cycle Assessment (LCA) software. SimaPro characterizes each constituent into one or more impact categories (Tables 3.7 and 3.8). Each impact category was multiplied by weighting factors in SimaPro yielding common units that can be totaled to provide an Environmental Impact Single Score (EISS). See Chapter 3 for a detailed explanation if the limited LCA procedure and eco-efficiency analysis. Total cost for each scenario analyzed was estimated and normalized on a per CY basis for ease in comparison with the EISS across multiple scenarios. The results will provide a tool to help dredging decision-makers select equipment that will reduce air emissions at a comparable cost per $\mathrm{CY}$, thus improving the sustainability of navigation channel maintenance dredging. 


\section{CHAPTER 2: LITERATURE REVIEW}

The U.S. Army Corps of Engineers (USACE) was first tasked with maintaining and improving a waterborne navigations system in 1824 . Deepening and clearing out rivers and harbors was added to the USACE responsibilities in 1826 (USACE 2007) and remains an integral part of the USACE mission. Typical types of equipment and placement sites utilized for navigation channel maintenance dredging are outlined in Sections 1.2 and 1.4 respectively. USACE, both independently and in collaboration with the U. S. Environmental Protection Agency (USEPA), have developed several manuals for dredging operations, including dredged material placement sites, and environmental impacts from dredging (Table 2.1).

Even though navigation maintenance dredging has been done for hundreds of years the environmental effects are fairly recent considerations. Environmental impacts of dredging have been studied and documented with most of the information having been developed over the past 10 to 15 years (Bridges 2008). The areas of primary focus have been the identification and implementation of beneficial uses for dredged material, environmental dredging, emissions to air from the placement and/or re-suspension of contaminated dredged material, and the regulation of emissions to the air from marine engines. Though environmental impacts of dredging have been studied, no efforts have been applied to the evaluation of air emissions from comparable types of dredging equipment, as in this study.

\subsection{Beneficial Use of Dredged Material}

Beneficial use of dredged material is defined as "utilizing dredged sediments as resource materials in productive ways" (DOTS 2006). Dredged material may be utilized as construction materials, aquaculture, topsoil, beach nourishment, berm creation, capping, land creation, land improvement, fill, shore erosion protection, habitat enhancement, and wetland restoration (DOTS 2006).

The Great Lakes Commission, responding to the findings of the Great Lakes Beneficial Use Task Force, has identified the beneficial use of dredged material as a "priority management option" and has adopted a resolution for increasing federal funding, research, and USACE authority for beneficial use (Pebbles 2002). The emphasis on identifying and implementing beneficial uses for Great Lakes dredged material will help to minimize environmental impacts from dredging but does not address the air emissions from dredging equipment.

The loss of Louisiana coastal wetlands is being addressed through the beneficial use of dredged material. USACE, New Orleans District has utilized approximately 27 million CY of the 90 million CY of sediment dredged from federal navigation channels for coastal wetlands restoration projects. This has resulted in the restoration of approximately 10,000 acres of wetlands (Creef and Mathies 2002).

The Illinois River, a major segment of the Illinois Waterway, is part of a large flyway for North American migratory birds. Extensive sedimentation in the backwaters has severely degraded this habitat. The restoration of this migratory flyway will require the removal and placement of a considerable volume of sediment (Marlin and Darmody 
2002). Beneficial use applications for this dredged material are being investigated including: island creation and enhancement, topsoil, fill, and urban renewal (Marlin and Darmody 2002).

USACE, Rock Island District has been actively involved in identifying and implementing beneficial uses for navigation channel maintenance dredged material. Examples of beneficial uses for dredged material from the IWW and UMR are levee repair (Figure 2.1), island creation (Figure 1.10), fill/construction materials (Figure 2.2), beach nourishment (Figure 2.3), and habitat enhancement (Figure 1.8 and 2.4).

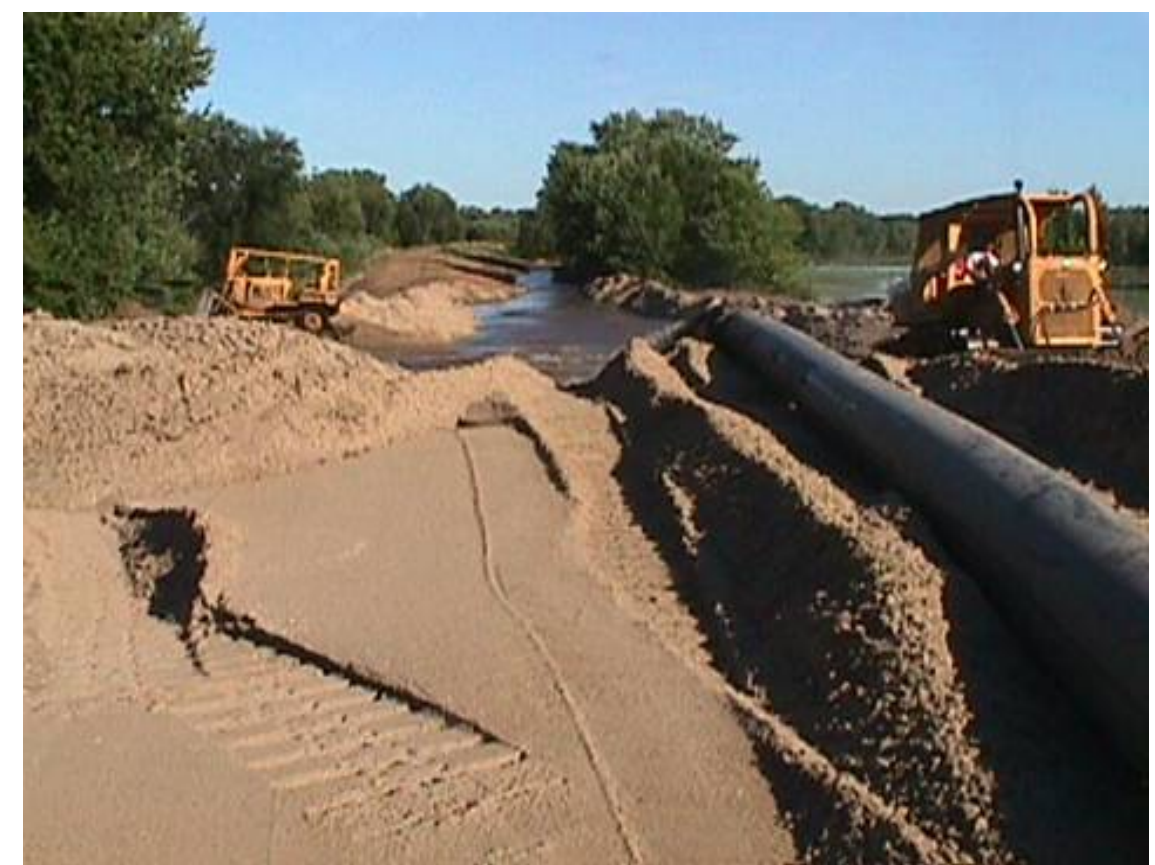

Figure 2.1: Levee Repair, Green Island Levee District

(Figure Courtesy of U. S. Army Corps of Engineers, Rock Island District [Date Unknown] Unpublished Photograph) (Documentation can be found in Appendix E) 


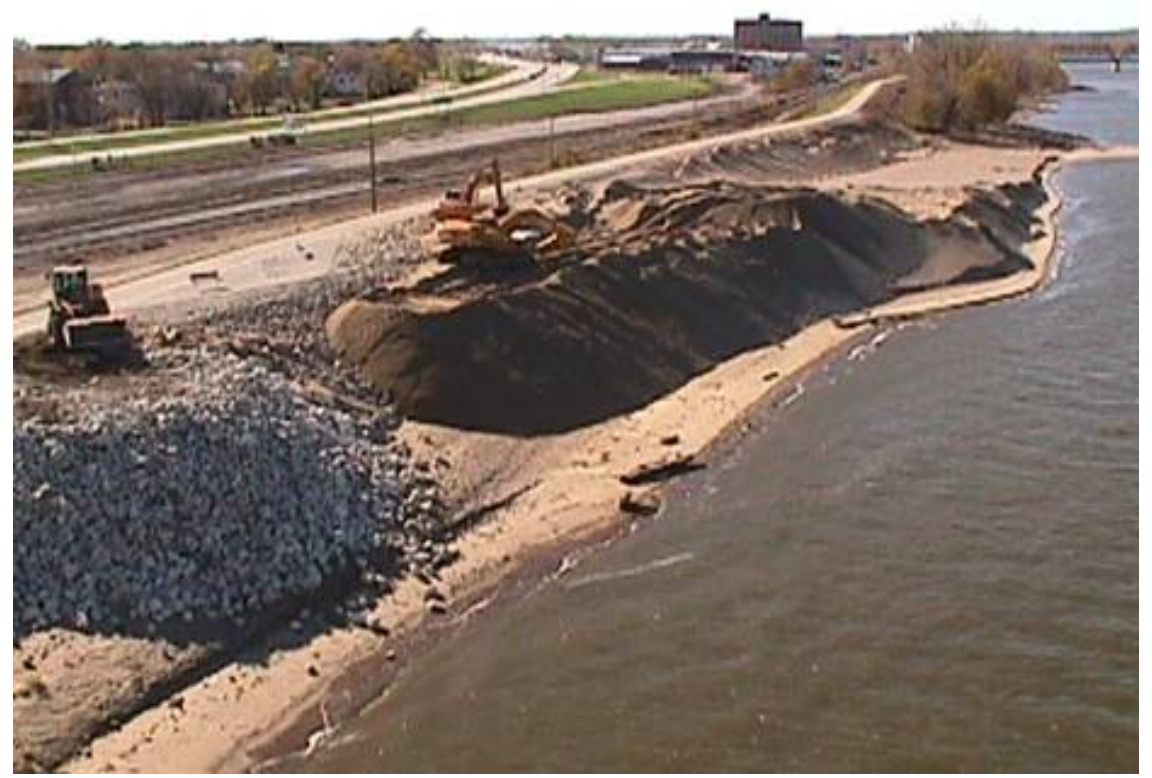

Figure 2.2: Fill/Construction Materials, Pool 16 UMR

(Figure courtesy of U. S. Army Corps of Engineers, Rock Island District [Date Unknown] Unpublished Photograph) (Documentation can be found in Appendix E)

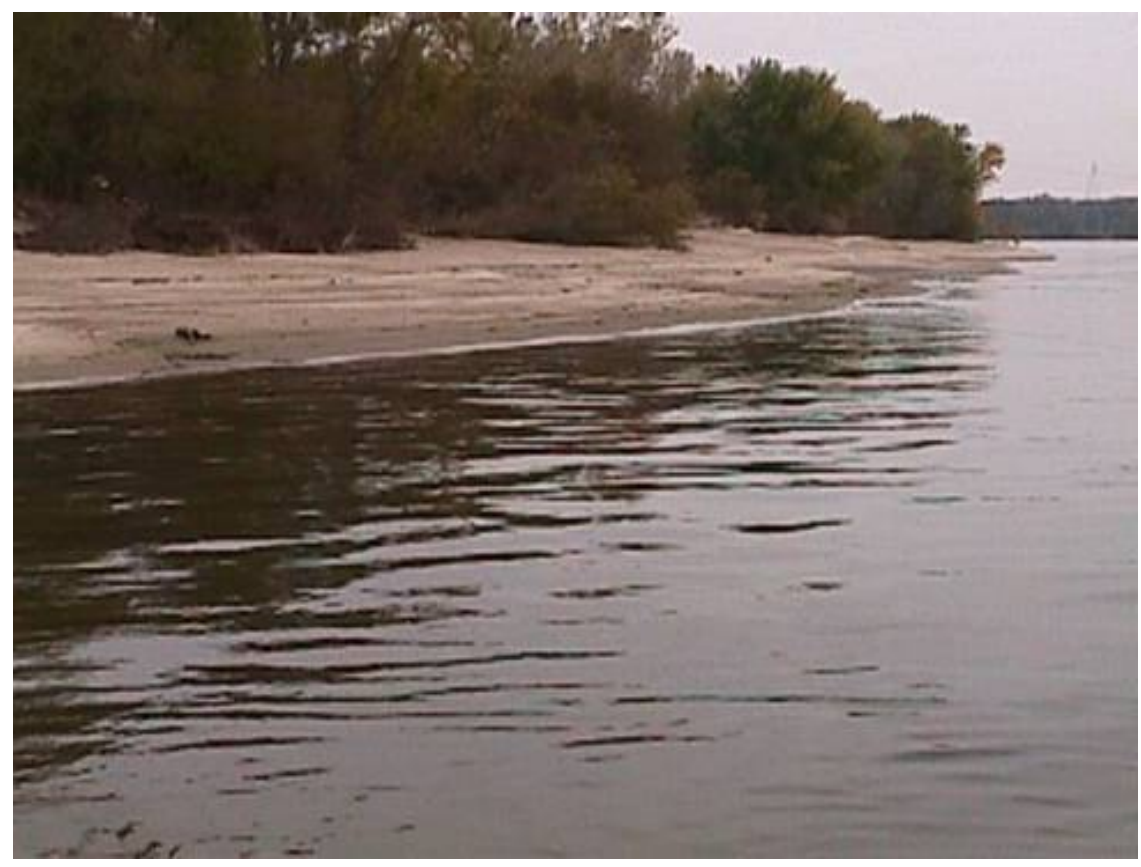

Figure 2.3: Beach Nourishment

(Figure courtesy of U. S. Army Corps of Engineers, Rock Island District [Date Unknown] Unpublished Photograph) (Documentation can be found in Appendix E) 


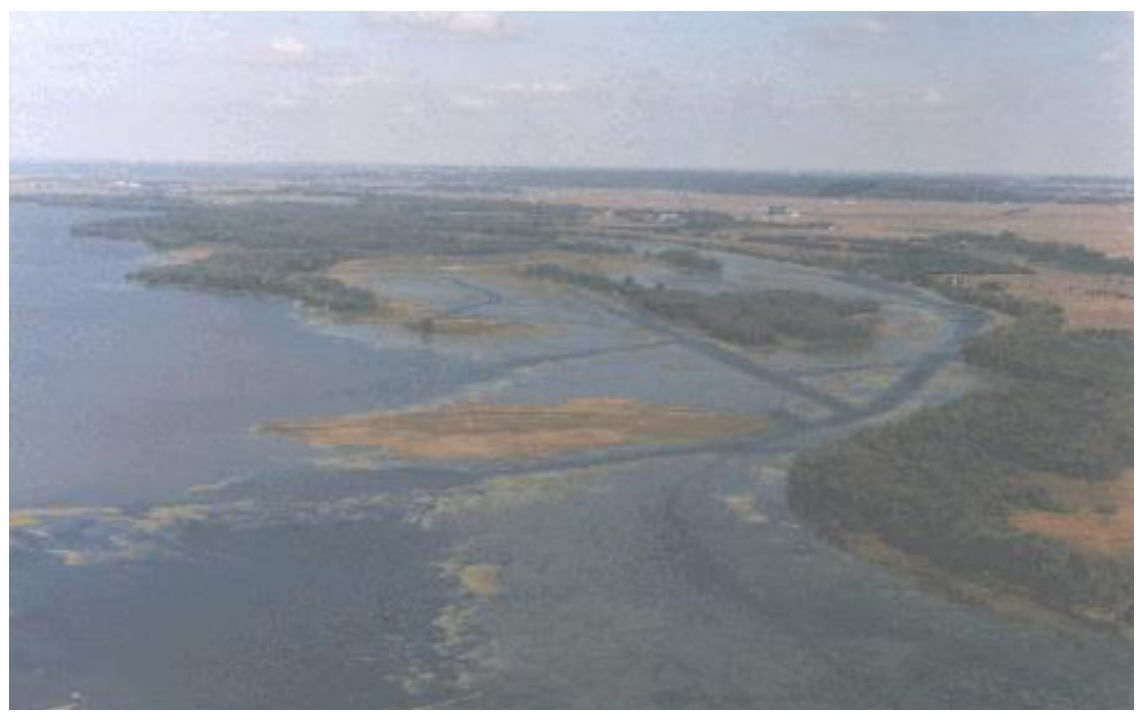

Figure 2.4: Habitat Restoration, Potters Marsh

(Figure courtesy of U. S. Army Corps of Engineers, Rock Island District [Date Unknown] Unpublished Photograph) (Documentation can be found in Appendix E)

\subsection{Environmental Dredging}

Environmental dredging can be defined as "dredging performed specifically for the removal of contaminated sediments for the purpose of remediating environmental risks" (USCAE 2008-B). An environmental dredging workshop sponsored by the U.S. Army Corps of Engineers (USACE) and U.S. Environmental Protection Agency (USEPA) focused on re-suspension of sediments, release of contaminants from in-situ and suspended sediments, residual contaminated sediments, and environmental risks (Bridges 2008). None of these focus areas included the air emissions from dredging operations.

According to W. D. Rokosch and N. J. Berg, selection of the best dredging technique for a particular project should be based on several criteria including: dredging location conditions such as water depth, extent of dredge cut, navigation, structural obstructions, sediment characteristics, potential for debris, and underwater structures; environmental regulations; cost considerations; and the positive and negative effects of the dredging operations (Rokosch and Berg 2002). None of the considerations for selection of dredging techniques are air emissions from the dredging equipment.

Several stakeholders from four European countries, France, the United Kingdom, Belgium, and the Netherlands, developed New!Delta, a project to promote the sustainable development of ports and port related activities. One of New!Delta's strategies is sustainable dredging defined as "a strategy in which management of dredging operations is a part of an integrated estuary management that strikes a balance between environmental, economic, social and technical aspects while respecting the legal requirements" (NEW!Delta 2007). The focus of their sustainable dredging strategy is on the potential changes to the physical and sedimentary processes, ecology and habitats, and the existing and future use of the estuary. The primary effects of dredging and dredged material disposal, as outlined in their report, include changes to the 
hydromorphology, loss of habitat, sedimentation, suspended sediment and turbidity, dispersion of contaminated sediment, reduction in oxygen levels, and disturbances such as noise, light, and movement (New!Delta 2007). Again, there is no consideration for the air emissions from the dredging equipment included in their sustainable dredging strategy.

A rating system similar to that used with Leadership in Energy and Environmental Design (LEED) could be utilized to promote sustainable port development and operation (Abood 2007). The LEED system includes the following six categories: "1.) sustainable sites, 2.) water efficiency, 3.) energy and atmosphere, 4.) materials and resources, 5.) indoor environmental quality, and 6.) innovation and design process". A total of 69 points can be awarded within these categories. According to Abood LEED Categories 4, Materials and Resources, and 6, Innovation, would be the primary sources for dredging and dredged material placement to achieve points (Abood 2007). These points could be received for beneficial use of dredged material, enhancement of aquatic life, and minimizing the loss of habitat. In addition, LEED Categories 2, Water Efficiency, and 5, Indoor Environmental Quality could achieve points for dredged material treatment and reductions in dredging equipment air emissions (Abood 2007). Specifically, Abood identifies the reduction in emissions from ships through the use of alternative fuels, retrofitting engines, addition of emission reduction devices such as catalysts, and reductions in light loading and tidal delays by deepening channels. Interestingly, the deepening of channels would require additional dredging that could increase rather than reduce air emissions. This study addresses reductions in air emissions but does not look at selecting the dredging equipment that would reduce emissions while maintaining navigation channel dredging.

The U.S. Environmental Protection Agency (USEPA) and USACE have collaborated in the development of a document titled "Evaluating the Environmental Effects of Dredged Material Management Alternatives - A Technical Framework" (USEPA, 2004). This framework provides overall guidance for the application of detailed testing manuals developed by USACE and USEPA (Table 2.1). These technical testing and design manuals address aquatic and terrestrial impacts from the dredging and placement operations, including the potential for volatization of contaminants into the atmosphere. None, however, consider the air emissions from the dredging equipment in the design and equipment selection process. 
Table 2.1: Dredging and Dredged Material Manuals

\begin{tabular}{|c|c|c|}
\hline Manual & Agency & Published \\
\hline $\begin{array}{l}\text { Evaluating Environmental Effects of Dredged Material } \\
\text { Management Alternatives - A Technical Framework (USEPA } \\
\text { 2004) }\end{array}$ & $\begin{array}{l}\text { EPA and } \\
\text { USACE }\end{array}$ & 2004 \\
\hline Dredging and Dredged Material Disposal (USACE 1983) & USACE & 1983 \\
\hline Beneficial Uses of Dredged Material (USACE 1987-A) & USACE & 1987 \\
\hline Confined Disposal of Dredged Material (USACE 1987-B) & USACE & 1987 \\
\hline $\begin{array}{l}\text { Evaluation of Dredged Material Proposed for Ocean Disposal } \\
\text { (Ocean Testing Manual) (USEPA 1991) }\end{array}$ & $\begin{array}{l}\text { EPA and } \\
\text { USACE }\end{array}$ & 1991 \\
\hline $\begin{array}{l}\text { Evaluation of Dredged Material for Discharge in } \\
\text { Waters of the U.S. - Testing Manual (Inland Testing Manual) } \\
\text { (USEPA 1998) }\end{array}$ & $\begin{array}{l}\text { EPA and } \\
\text { USACE }\end{array}$ & 1998 \\
\hline $\begin{array}{l}\text { Evaluation of Dredged Material Proposed for Disposal at } \\
\text { Island, Nearshore, or Upland Confined Disposal Facilities - } \\
\text { Testing Manual (Upland Testing Manual) (USACE 2003-B) }\end{array}$ & USACE & 2003 \\
\hline
\end{tabular}

\subsection{Dredged Material Emissions to the Atmosphere}

Emissions to the atmosphere from dredging operations include the volatization of chemicals from contaminated dredged material within both the placement site and resuspended in the water column and emissions from marine engines used to power dredging equipment. The rate at which specific chemicals volatize from dredged material has been studied using various models. Volatization rates for hydrophobic organic compounds from four different locations were modeled to tentatively rank the magnitude of emission rates. The four locations were the dredging location or cut, the exposed placement site location, the ponded placement site location, and the placement site location with vegetated cover (Valsaraj 1995). The results indicated that the greatest emissions resulted from the exposed placement site followed by the dredge cut location with high levels of suspended solids (Valsaraj 1995). Air quality impacts from odorous or toxic compounds in dredged material and effects on inhabitants near dredging operations can be costly to control (Zimmer 2004). Multiple models were tested with differing operational and remediation alternatives. The results were evaluated against acute air quality standards and odor threshold (Zimmer 2004). Neither of these studies considered the air emissions from dredging equipment.

\subsection{Regulation of Air Emissions From Marine Engines}

Air emissions such as Nitrogen Oxides (NOx) from marine engines are being regulated under both the USEPA's "Control of Emissions of Air pollution from New Marine Compression Ignition Engines at or Above $37 \mathrm{~kW}$ " and Individual State Implementation Plans (SIP) (Gore 2002). Actions taken to comply with these standards include using shore power instead of marine power when tied up to pier, voluntarily reducing speed when in port to below normal, and potentially limiting industrial equipment operations to a specified number of hours each day (Gore 2002). These 
standards address air emissions but do not examine the dredging equipment selection process as a source for reducing emissions to the atmosphere.

The significance of United States port air quality concerns are increasing. In response, the USEPA generated the transportation and general conformity rules (Rhoads 2004). These rules require project sponsors to include air quality analysis in their planning process. An approach has been developed based on emission reduction plans that allow projects to maintain general conformity status. Cost estimates are developed that include the type and size of equipment to be used, production rates, hours of operation, and labor requirements that meet existing standards without supplementary air emission control considerations (Rhoads 2004). This approach utilizes a similar approach to that done in this study for quantifying air emissions from diesel equipment but does not use the results for selection of equipment. Nor does it focus on navigation maintenance dredging but considers all equipment required for unspecified projects.

\subsection{Summary}

Considerable effort has been put forth to identify and reduce environmental impacts from dredging operations. Reductions in adverse impacts have been achieved through the identification and implementation of beneficial uses for dredged material, development of environmental dredging techniques, minimization of the volatization of compounds from contaminated dredged material, and striving toward compliance with air quality standards. The reuse of dredged material for construction materials, aquaculture, topsoil, beach nourishment, berm creation, capping, land creation, land improvement, fill, shore erosion protection, habitat enhancement, and wetland restoration has minimized the need for long-term placement sites and the resulting impacts to both aquatic and terrestrial environments. Removal of contaminated sediments minimizes the risk of contaminants migrating into the water column or biota. Identifying solutions that minimize volatization of contaminates from dredged material either from a placement site or when re-suspended in the water column help to reduce environmental impacts. In addition, the adaptation of air quality standards for marine engines reduces adverse impacts to the environment. All of these efforts significantly improve the sustainability of dredging operations and reduce environmental impacts. One potential area for reducing adverse environmental impacts that is conspicuously missing from this list is the quantification and selection of comparable dredging equipment based on the air emissions. By identifying the type of dredging equipment with the lowest air emissions, when cost, site conditions, and equipment availability are comparable, environmental impacts can be minimized without compromising the dredging project. 


\section{CHAPTER 3: PROCEDURE}

A Limited Life Cycle Assessment (LCA) was used to evaluate the adverse environmental impacts, specifically harmful emissions to the atmosphere, resulting from two comparable dredging operations. The primary purpose of this study is to provide dredging decision makers with a tool to help select equipment for each dredging operation that will reduce the negative environmental impacts as defined in this LCA.

\subsection{Limited Life Cycle Assessment (LCA) Procedure}

Since the selection process would be limited to the dredging equipment available within a given region and would not include the purchase or disposal of that equipment, this LCA was limited to the "use" phase only. Additionally, it could be argued that the long life span of most dredging equipment would result in the manufacture and disposal phases contributing negligible impacts relative to the use phase. Finally, a limited LCA was utilized due to inadequate availability of data for any type of dredging or comparable construction equipment.

The procedure developed for this study utilizes existing tools to define and calculate fuel consumed, air emissions, and cost per CY for the identified scenarios (Figure 3.1). A total of 13 tasks make up the procedure. Task 1: Identify Dredging Equipment, determine what size and type of equipment is available through contract or organizationally owned; Task 2: Identify Air Emission Data, define what air emission data will be used as an input for the Eco-Efficiency Analysis. This could be from NREL (Section 3.1.1) as used in this study or from another source; Task 3: Determine Production Rates, Identify the anticipated production rates for dredging equipment evaluated using this procedure considering sediment characteristics and volume, maintaining navigation, transport distance, placement site location and management, and potential equipment down time; Task 4: Determine Dredging Volume: calculate the anticipated dredging volume based on hydrographic surveys and channel design template; Task 5: Determine Transport Distance: calculate total transport distance based on dredge cut and placement site location; Task 6: Formulate Scenarios, used the information from tasks 3 through 5 to define potential scenarios for evaluation; Task 7: Calculate Transport and Dredging Times, following the steps outlined in Section 3.1.2; Task 8: Calculate Fuel Consumption: following the steps outlined in Section 3.1.2; Task 9: Perform EcoEfficiency Analysis, following steps outlined in Section 3.3; Task 10: Estimate Cost per Cubic Yard: following steps outlined in Section 3.2 or another cost estimating procedure; Task 11: Calculate Tradeoff Index Value, following steps outlined in Section 3.4; Task 12: Evaluate Results, using the steps and graphs outlined in Chapter 4; and Task 13: Select Dredging Equipment, Select the dredging equipment that will produce the least air emissions based on the results evaluated in Task 12 .

This procedure is applied to compare common channel maintenance dredging equipment used on the IWW in this study. However, the procedure and tools defined for this study can easily be utilized to compare types of dredging equipment from different location and/or purposes. 
Multiple scenarios were developed to produce an "envelope" of results applicable to a broad range of site conditions. A total of 48 scenarios were analyzed that varied the quantity of material to be dredged, transport distances from the dredge cut to the placement site, and production rates for each type of dredging equipment. The production rates and transport distances used in this study are based on Rock Island District historical records. The range of dredged material volumes, however, was selected by the author to identify transition points between the two types of dredging equipment in this study.

The volume of dredged material included a relatively small quantity of $1,000 \mathrm{CY}$, intermediate quantities of 5,000 CY and 20,000 CY, and a large quantity of $100,000 \mathrm{CY}$. This range of volumes was designed to provide scenarios targeted at the strengths of each type of dredging equipment in this study. Typically, it is more economical to use a mechanical bucket dredge for small quantities of dredged material at multiple locations and also when transport distances are longer than a cutterhead pipeline dredge is capable of pumping without re-handling. Cutterhead pipeline dredges tend to be more cost effective for large quantities of dredged material at a given location with relatively short pumping distances.

Transport distances were selected based on the capabilities of the cutterhead pipeline dredge. The maximum distance the cutterhead pipeline dredge can typically pump dredged material slurry without using a booster pump is 8,000 feet, the addition of one booster pump extends this to 10,000 feet and two booster pumps allow for a 12,000 foot transport distance. The longest transport distance of 16,000 feet was intended to evaluate a scenario where the cutterhead pipeline dredge would need to double-handle the material to reach the placement site. Double-handling of dredged material is not generally considered an acceptable option due to the adverse impacts to the aquatic environment that could result. This range of transport distance, again, was selected to target strengths of both types of equipment evaluated and assumes sandy sediment typically found in the Illinois Waterway (IWW) where these dredges operated during the 2005 season. 


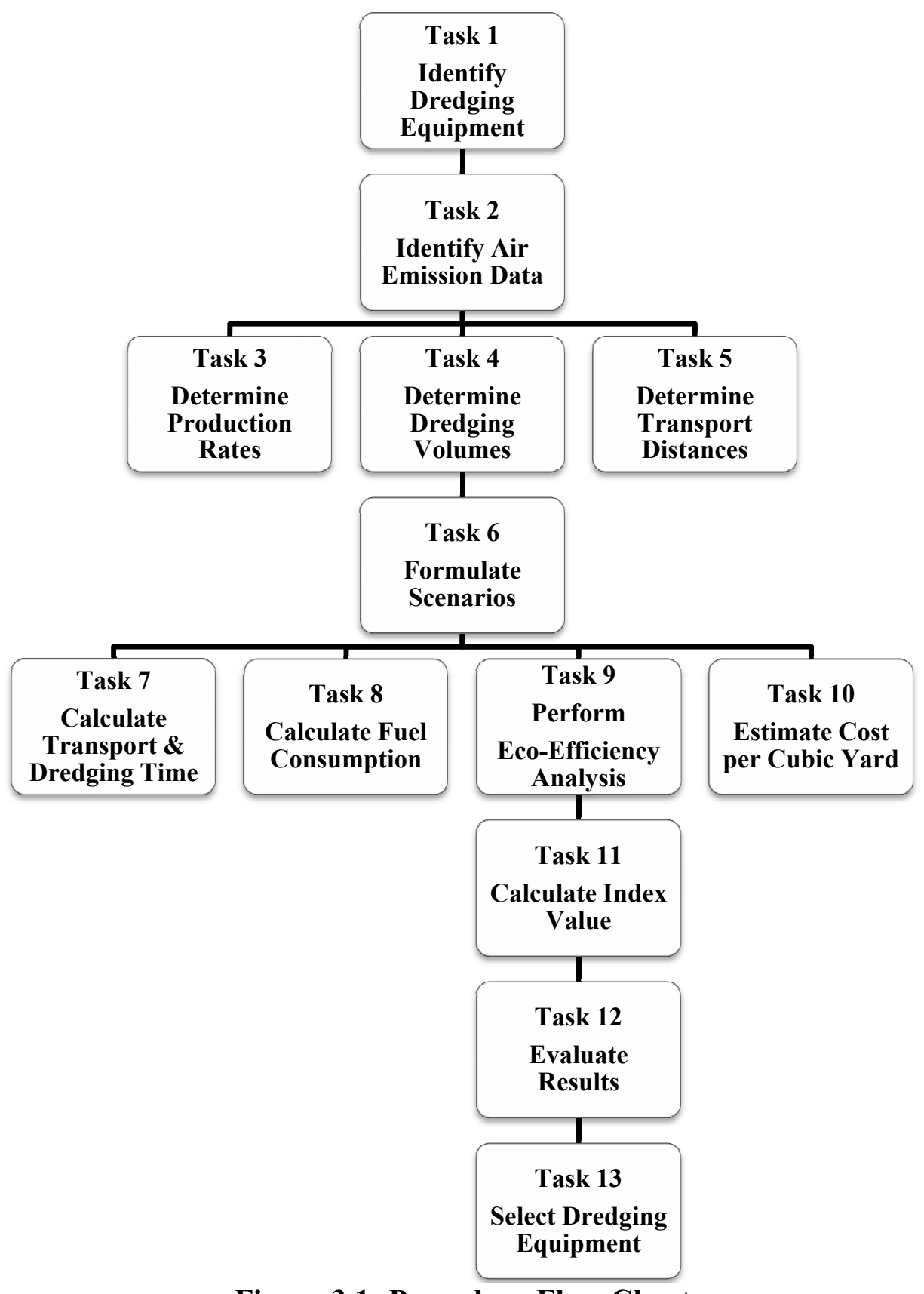

Figure 3.1: Procedure Flow Chart

Production rates can vary depending on many factors including: the type of material being dredged, minimizing potential delays to navigation, transport distance, placement site location and management, and equipment down time. Because the production rate can vary from one dredging event to the next, a range was used in this analysis. The production rates selected included the lowest, average, and highest rates for each crew. For the mechanical bucket dredge crew the volume and total number of days, at 10 hours per day, for each event done during the 2005 dredging season were used to calculate low, average, and high production rates (Graham 2007/08) (Table 3.1). The 
dredging events included were limited to those with sandy material to be consistent with the events done by the cutterhead pipeline dredge. The cutterhead pipeline dredge production rate was calculated using the total time on-site and volume for each dredging event (Graham 2007/08) (Table 3.2). The same contractor-owned dredged was used for navigation channel maintenance dredging for the 2002, 2003, and 2005 season. Including all three years expanded the number of events from 7 to 25 yielding production rates that better reflected this crew's capabilities.

Table 3.1: Mechanical Bucket Dredge Production Rates (Graham 2007/08)

\begin{tabular}{|c|c|c|c|c|c|}
\hline $\begin{array}{c}\text { Month } \\
\text { Dredged }\end{array}$ & Dredge Cut & Days & Hrs/day & Total CY & $\begin{array}{c}\text { Production } \\
\text { Rate } \\
\text { (CY/hr) }\end{array}$ \\
\hline \multirow[t]{2}{*}{ Apr } & RIVER MILE 87.7 BEARDSTOWN & 7 & 10 & $3,560.0$ & 50.9 \\
\hline & $\begin{array}{l}\text { RIVER MILE } 87.7 \text { LAST R.I. BARGE- } \\
\text { END OF BEARDSTOWN }\end{array}$ & 9 & 10 & $11,150.1$ & 61.9 \\
\hline May & $\begin{array}{l}\text { RIVER MILE } 244 \text { MARSEILLES } \\
\text { LOWER CUT "A\&B" }\end{array}$ & 15 & 10 & $3,826.6$ & 25.5 \\
\hline \multirow[t]{2}{*}{ June } & $\begin{array}{l}\text { RIVER MILE } 247 \text { MARSEILLES } \\
\text { CANAL CUT "A" }\end{array}$ & 6 & 10 & $1,592.2$ & 26.5 \\
\hline & $\begin{array}{l}\text { RIVER MILE } 247 \text { MARSEILLES } \\
\text { CANAL CUT "B" }\end{array}$ & 3 & 10 & 981.5 & 32.7 \\
\hline \multirow[t]{4}{*}{ July } & $\begin{array}{l}\text { RIVER MILE } 241 \text { BULLS ISLAND CUT } \\
\text { "A" }\end{array}$ & 4 & 10 & $1,785.0$ & 44.6 \\
\hline & $\begin{array}{l}\text { RIVER MILE } 241 \text { BULLS ISLAND CUT } \\
\text { "B" }\end{array}$ & 7 & 10 & $4,166.4$ & 59.5 \\
\hline & $\begin{array}{l}\text { RIVER MILE } 241 \text { BULLS ISLAND CUT } \\
\text { "C" }\end{array}$ & 1 & 10 & 397.4 & 39.7 \\
\hline & $\begin{array}{l}\text { RIVER MILE } 241 \text { BULLS ISLAND CUT } \\
\text { "D" }\end{array}$ & 3 & 10 & $1,104.2$ & 36.8 \\
\hline \multirow[t]{3}{*}{ Aug } & RIVER MILE 229.9 LEFT, CUT "A" & 7 & 10 & $2,150.2$ & 30.7 \\
\hline & RIVER MILE 229.9 LEFT, CUT "B" & 11 & 10 & $3,432.3$ & 31.2 \\
\hline & RIVER MILE 229.9 LEFT, CUT "C" & 1 & 10 & 198.4 & 19.8 \\
\hline \multirow[t]{2}{*}{ Sept } & RIVER MILE 229.9 LEFT, CUT "C" & 10 & 10 & $3,295.3$ & 33.0 \\
\hline & RIVER MILE 270.8 LEFT, CUT "A" & 2 & 10 & 601.4 & 30.1 \\
\hline \multirow[t]{2}{*}{ Oct } & RIVER MILE 270.8 LEFT, CUT "A" & 9 & 10 & $3,583.6$ & 39.8 \\
\hline & $\begin{array}{l}\text { RIVER MILE } 271.8 \text { LEFT, DRESDEN } \\
\text { UPPER CELL }\end{array}$ & 1 & 10 & 210.8 & 21.1 \\
\hline \multirow{3}{*}{\multicolumn{5}{|c|}{$\begin{array}{rr}\text { Minimum } \\
\text { Average } \\
\text { Maximum }\end{array}$}} & 20 \\
\hline & & & & & 36 \\
\hline & & & & & 62 \\
\hline
\end{tabular}


Table 3.2: Cutterhead Pipeline Dredge Production Rates (Graham 2007/08)

\begin{tabular}{|c|c|c|c|c|c|c|c|}
\hline $\begin{array}{c}\text { Year } \\
\text { Dredged }\end{array}$ & $\begin{array}{c}\text { Volume } \\
\text { Dredged } \\
(C Y) \\
\end{array}$ & $\begin{array}{l}\text { Total } \\
\text { Time } \\
\text { (hrs) } \\
\end{array}$ & $\begin{array}{c}\text { Production } \\
\text { Rate } \\
(\mathrm{CY} / \mathrm{hr}) \\
\end{array}$ & $\begin{array}{c}\text { Year } \\
\text { Dredged }\end{array}$ & $\begin{array}{c}\text { Volume } \\
\text { Dredged } \\
(C Y) \\
\end{array}$ & $\begin{array}{l}\text { Total } \\
\text { Time } \\
\text { (hrs) } \\
\end{array}$ & 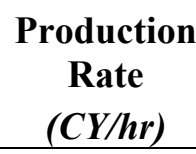 \\
\hline 2005 & 68,487 & 449 & 153 & 2003 & 15,830 & 82 & 192 \\
\hline 2005 & 72,439 & 479 & 151 & 2002 & 28,313 & 316 & 90 \\
\hline 2005 & 15,085 & 264 & 57 & 2002 & 9,572 & 88 & 109 \\
\hline 2005 & 30,957 & 611 & 51 & 2002 & 15,232 & 130 & 117 \\
\hline 2005 & 25,936 & 423 & 61 & 2002 & 22,547 & 190 & 119 \\
\hline 2005 & 17,873 & 180 & 99 & 2002 & 6,186 & 84 & 74 \\
\hline 2005 & 10,044 & 61 & 165 & 2002 & 5,273 & 56 & 94 \\
\hline 2003 & 51,997 & 597 & 87 & 2002 & 5,114 & 67 & 76 \\
\hline 2003 & 40,430 & 259 & 156 & 2002 & 14,766 & 187 & 79 \\
\hline 2003 & 13,633 & 187 & 73 & 2002 & 6,682 & 103 & 65 \\
\hline 2003 & 18,525 & 126 & 147 & 2002 & 17,206 & 144 & 119 \\
\hline 2003 & 19,450 & 220 & 89 & \multirow{3}{*}{\multicolumn{3}{|c|}{$\begin{array}{l}\text { MINIMUM } \\
\text { AVERAGE } \\
\text { MAXIMUM }\end{array}$}} & 51 \\
\hline 2003 & 27,492 & 169 & 162 & & & & 108 \\
\hline 2003 & 8,380 & 70 & 119 & & & & 192 \\
\hline
\end{tabular}

\subsubsection{LCA Methodologies and Data}

Navigation channel maintenance dredging equipment used on the IWW and Upper Mississippi River (UMR), as with most locations, needs to be mobile and capable of operation without an external power source, making diesel fuel the predominate choice. All of the equipment included in this study is diesel powered (Table 3.3). The combustion of diesel fuel releases pollutants to the atmosphere that can be quantified and compared between dredging crews to determine the lowest adverse environmental impacts for each type of equipment and scenario.

The pollutant data used for this LCA are emissions from diesel fuel combustion in industrial equipment per 1,000 gallons of fuel burned (NREL, 2003) (Table 3.4). This data was entered into SimaPro LCA software as a process then applied to each of the scenarios yielding the environmental impacts for each quantity dredged, transport distance, and production rate. The diesel powered equipment with the rated horsepower required to mobilize and operate each type of dredge was taken from U.S. Army Corps of Engineers, Rock Island District (Graham 2007/08) records for the 2005 dredging season (Table 3.3). 
Table 3.3: Dredging Equipment's Rated Horsepower (Graham 2007/08)

\begin{tabular}{|c|c|c|c|c|c|}
\hline \multicolumn{3}{|c|}{ Mechanical Bucket Dredge } & \multicolumn{3}{|c|}{ Cutterhead Pipeline Dredge } \\
\hline Equipment & Qty & $\begin{array}{l}\text { Rated } \\
\text { Horsepower }\end{array}$ & Equipment & Qty & $\begin{array}{l}\text { Rated } \\
\text { Horsepower }\end{array}$ \\
\hline Excavator & 1 & 429 & Main Engine & 1 & 960 \\
\hline M/V LaSalle & 2 & 400 & Cutter Head Engine & 1 & 200 \\
\hline Gen Set (LaSalle) & 1 & 80 & Booster Pumps & 2 & 700 \\
\hline Dozer (D6T) & 1 & 200 & Spud Hyd Drive Engine & 1 & 125 \\
\hline Dozer (950G) & 1 & 183 & Gen Set (Dredge-300kW) & 1 & 400 \\
\hline $\begin{array}{l}\text { Gen Set (Crane } \\
\text { Barge) }\end{array}$ & 2 & 225 & Gen Set (Dredge-35kW) & 1 & 60 \\
\hline & & & Tender (Max) & 1 & 400 \\
\hline & & & Tender (Scotty) & 1 & 400 \\
\hline & & & $\begin{array}{l}\text { Tender (Debra Ann) } \\
\text { (Mob Only) }\end{array}$ & 1 & 400 \\
\hline & & & Tractor & 1 & 140 \\
\hline & & & Tractor & 1 & 80 \\
\hline & & & Crissafully Pump & 1 & 160 \\
\hline & & & Anchor Barge & 3 & 125 \\
\hline & & & Crane & 1 & 125 \\
\hline & & & Light Plants & 2 & 25 \\
\hline
\end{tabular}

Table 3.4: Outputs to Nature from Diesel Fuel Combustion (NREL 2003)

\begin{tabular}{|l|r|l|r|}
\hline Substance & $\begin{array}{l}\text { Mass } \\
(l b s)\end{array}$ & Substance & $\begin{array}{l}\text { Mass } \\
(l b s)\end{array}$ \\
\hline Acectaldehyde & 0.1064 & Nitrogen oxide & 0.5661 \\
\hline Acrolein & 0.0128 & $\begin{array}{l}\text { PAH, polycyclic } \\
\text { aromatic hydrocarbons }\end{array}$ & 0.0233 \\
\hline Benzene & 0.1294 & Particulates (PM10) & 13.7727 \\
\hline Butadiene & 0.0054 & Propene & 0.3578 \\
\hline Carbon dioxide (fossil) & $22,543.4325$ & Toluene & 0.0567 \\
\hline Carbon monoxide & 117.0765 & Sulfur oxides & 4.9956 \\
\hline Formaldehyde & 0.1637 & VOC (unspecified) & 11.2820 \\
\hline Methane & 1.1152 & Xylenes & 0.0395 \\
\hline Nitric Oxide & 440.7493 & & \\
\hline
\end{tabular}

\subsubsection{Diesel Fuel Consumption}

The diesel fuel usage was estimated for all equipment used to mobilize or operate each dredging crew for every scenario (Appendix B). Each piece of diesel powered equipment was identified for use during the transportation and/or dredging phase of the 26 
operation. The time for each dredging crew and phase was estimated based on average travel speeds, distance traveled for mobilization and transport of dredged material, volume of dredged material, and three production rates (low, average, and high). Travel speeds for each dredging crew were based on Rock Island District historical data (Graham 2007/08).

Each dredge traveled from a storage/maintenance facility to the initial dredge cut. The mechanical bucket dredge is owned and operated by the U.S. Army Corps of Engineers, Rock Island District, and is based in Illinois. The cutterhead pipeline dredge is owned and operated by an independent contractor and is based in Michigan. Total distance each dredge traveled, including mobilizing from the respective storage/maintenance facility to the initial dredge cut, between each dredge cut, and back to the base facility, was averaged over the total number of dredge cuts completed that season. A total dredged material transport distance, for the mechanical bucket dredge, was calculated using the total volume of material to be dredged, average barge capacity, and distance between the dredge cut and the placement site. The sum of the average mobilization distance and the transport distance yielded a total travel distance for each dredging crew and event. This total travel distance was divided by the average travel speed yielding a total transport time (Eq. 3.1). A total dredging time was then calculated using the volume of material to be dredged and production rates shown in Tables 3.1 and 3.2 (Eq. 3.2). Additionally, for the cutterhead pipeline dredge, the dredging time is increased for delays that result when dredging operations cease to allow navigation vessels to pass and for managing the dredged material at the placement site. Both the vessel passing time and the placement site time are calculated based on historical percentages from Rock Island District (Graham 2007/08). There are two possible vessel passing scenarios, one when the cutterhead pipeline dredge discharge pipeline crosses the navigation channel $(19 \%)$ and the other when it does not $(10 \%)$. For the crossing pipeline the dredge must cease operations and the pipeline must be separated to allow vessels to pass. The pipeline and dredge must only be moved clear of the navigation channel for the non-crossing pipeline. For this study, 100 percent of the dredging operations were assumed to be done with a crossing pipeline. This results in a 32 percent increase for the placement site time and a 19 percent increase for the crossing pipeline time.

$$
\begin{aligned}
& \text { TransportTime }(\text { hrs })=\frac{\text { RiverMilesTraveled }(\text { miles })}{\text { AverageSpeed }(m p h)} \\
& \text { DredgingTime } \left.(\text { hrs })=\frac{\text { DredgedMaterial }(\mathrm{CY})}{\text { ProductionRate }(C Y / h r)} *(1+\text { Crossing\%+Placement\% })\right)
\end{aligned}
$$

Total fuel consumed was calculated using standard cost estimating practices as defined in the U.S. Army Corps of Engineers Construction Equipment Ownership and Operating Expense Schedule (USACE, 2005). The process uses the rated brake horsepower (BHP) for each piece of equipment, a horsepower factor (HPF) which is based on an average percentage of the full horsepower being utilized during normal 
operations, a fuel factor (FF) in gallons/(brake horsepower-hour) (Eq. 3.3), an average weight of the diesel fuel consumed ( $7 \mathrm{lbs} /$ gallon), the average fuel consumed in lbs./(brake horsepower-hour), and the total time each piece of equipment is in operation (Eq. 3.4).

$$
F F=\frac{H P F^{*} \frac{\text { FuelConsumed }}{\text { BHP-Hour }}}{\text { FuelWeight/gallon }}
$$

When specific horsepower ratings for a given piece of equipment were not included in the records comparable equipment was selected from the U.S. Army Corps of Engineers Construction Equipment Ownership and Operating Expense Schedule (USACE, 2005). The only change in required equipment over the various scenarios evaluated is the number of booster pumps for the cutterhead pipeline dredge.

Once total times in hours for the transportation and dredging operations were calculated for each scenario the total fuel consumed could be calculated (Eq. 3.4) and input into SimaPro. The total environmental burdens could then be compared to typical decision making criteria. Currently, navigation channel maintenance dredging decisions are based on the cost per cubic yard of material dredged, operational constraints (transport distance, water borne access to the placement site, and overland distance from the channel to the placement site), National Environmental Policy Act (NEPA) compliance, and equipment availability (Table 1.4)) (USACE 2003-A). The placement site constraints, NEPA compliance, and equipment availability are typically defined by factors beyond the scope of this study. Therefore, the environmental burdens for each scenario will be compared with the economic cost of dredging, potential production rates, and transport distances to identify possible decision points.

\subsection{Cost Estimating Procedure}

The cost per cubic yard of dredged material varies based on several factors including: equipment required, volume of material to be dredged, transport distance, mobilization time and distance, placement site conditions and operations, and the potential for stoppages to avoid adverse impacts on navigation. The total dredging time for each scenario was estimated using a template developed by Rock Island District, Operations Division (Graham 2007/08). This template calculates total dredging time based on the anticipated production rate for that dredge, the volume of sediment to be removed, mobilization/demobilization time, down time for placement site operations, delays required to maintain navigation, and re-handling of the dredged material if required. Three production rates were used for each dredging crew and scenario (low, average, and high) as defined under the LCA Procedure section (Tables 3.1 and 3.2). Four dredged material volumes were analyzed ranging from 1,000 CY to $100,000 \mathrm{CY}$ as outlined in Section 3.1, Limited LCA Procedure. Mobilization/demobilization time, as calculated under the fuel consumption section, was also included. The cutterhead 
pipeline dredge crew has down time for delays to maintain an open navigation channel, manage the dredged material at the placement site, and for re-handling the dredged material when required that must be accounted for when estimating total dredging time. There are two possible options for maintaining an open navigation channel, one where the cutterhead pipeline dredge discharge pipeline crosses the navigation channel and the other when the discharge pipeline does not. For the crossing option the average increase is $19 \%$ of the dredging time and the non-crossing option average is $10 \%$ of the dredging time, both based on Rock Island District historic data (Graham 2007/08). In this study all dredging was assumed to include the crossing option. To allow for management of the dredged material within the placement site dredging operations must cease. This additional time was also calculated as a percentage of dredging time based on Rock Island District historic data (Graham 2007/08). The average increase in time for dredged material management at all types of placement sites is $32 \%$. Additional time for rehandling the dredged material, including mobilization/demobilization, was calculated following the same procedure as the initial dredging event. The times for initial and rehandling dredging events were then added together, when applicable.

An average hourly cost for both the cutterhead pipeline dredge and mechanical bucket dredge crews was calculated based on Rock Island District 2005 dredging season records (Graham 2007/08). The total cost of non-emergency dredging done by the cutterhead pipeline dredge crew $(\$ 1,171,980)$ was divided by the total number of days worked, at 24 hours per day (1,680 hours), yielding a cost of $\$ 698 /$ hour. For the mechanical bucket dredge crew, records indicate a total cost for the dredging events included in this study of $\$ 887,214$ and a total time worked of 1,335 hours, resulting in an average cost of $\$ 665 /$ hour. See Appendix $C$ for the complete cost estimating procedure and data.

The total time was multiplied by the average cost per hour for each dredging crew yielding a total cost for each scenario in this study. The total cost is then divided by the volume of dredged material for each scenario resulting in a cost per cubic yard (Table 3.5). Normalizing the cost for dredging, on a per cubic yard basis, provides a common scale that allows comparison across multiple scenarios.

\subsection{Eco-Efficiency Analysis}

This study utilized the emissions from diesel fuel combustion in industrial equipment (NREL, 2003) to define the constituents and mass emitted per gallon of diesel fuel burned. In addition, SimaPro requires the selection of a method used to calculate the environmental burdens for each scenario (Appendix D). The method selected was "Ecoindicator 95 V2.05 / Europe e". Utilizing this method with SimaPro yielded multiple output results:

- Inventory of pollutants (Table 3.6),

- Summary characterization of environmental impact categories (Table 3.7),

- Individual characterization for each environmental impact category with included constituents (Table 3.8),

- Environmental Impact Single Score (EISS). 
SimaPro uses weighting factors as multipliers for the impact category results. These weighted values are in common units of points and can then be added together to provide an Environmental Impact Single Score (EISS). The EISS was used to evaluate the environmental burdens for each scenario in this study.

Table 3.5: Dredging Estimated Costs

\begin{tabular}{|c|c|c|c|c|c|c|c|c|c|c|c|}
\hline \multicolumn{3}{|c|}{$8,000 \mathrm{ft} \& 1,000 \mathrm{CY}$} & \multicolumn{3}{|c|}{$8,000 \mathrm{ft} \& 5,000 \mathrm{CY}$} & \multicolumn{3}{|c|}{$8,000 \mathrm{ft} \& 20,000 \mathrm{CY}$} & \multicolumn{3}{|c|}{$8,000 \mathrm{ft} \& 100,000 \mathrm{CY}$} \\
\hline $\begin{array}{l}\text { Prod. } \\
\text { Rate }\end{array}$ & $M B D$ & $C P D$ & $\begin{array}{l}\text { Prod. } \\
\text { Rate }\end{array}$ & $M B D$ & $C P D$ & $\begin{array}{l}\text { Prod. } \\
\text { Rate }\end{array}$ & $M B D$ & $C P D$ & $\begin{array}{l}\text { Prod. } \\
\text { Rate }\end{array}$ & $M B D$ & $C P D$ \\
\hline Low & $\$ 56.36$ & $\$ 51.10$ & Low & $\$ 37.87$ & $\$ 26.75$ & Low & $\$ 34.41$ & $\$ 22.19$ & Low & $\$ 33.48$ & $\$ 20.97$ \\
\hline$A v g$ & $\$ 41.58$ & $\$ 40.19$ & $A v g$ & $\$ 23.09$ & $\$ 15.85$ & $A v g$ & 63 & $\$ 11.28$ & $A v g$ & $\$ 18.70$ & $\$ 10.06$ \\
\hline High & $\$ 33.83$ & $\$ 35.92$ & High & $\$ 15.35$ & $\$ 11.58$ & High & $\$ 11.88$ & $\$ 7.01$ & High & $\$ 10.96$ & $\$ 5.79$ \\
\hline \multicolumn{3}{|c|}{$10,000 \mathrm{ft} \& 1,000 \mathrm{CY}$} & \multicolumn{3}{|c|}{$10,000 \mathrm{ft} \& 5,000 \mathrm{CY}$} & \multicolumn{3}{|c|}{$10,000 \mathrm{ft} \& 20,000 \mathrm{CY}$} & \multicolumn{3}{|c|}{$10,000 \mathrm{ft} \& 100,000 \mathrm{CY}$} \\
\hline $\begin{array}{l}\text { Prod. } \\
\text { Rate }\end{array}$ & $M B D$ & $C P D$ & $\begin{array}{l}\text { Prod. } \\
\text { Rate }\end{array}$ & $M B D$ & $C P D$ & $\begin{array}{l}\text { Prod. } \\
\text { Rate }\end{array}$ & $M B D$ & $C P D$ & & $M B D$ & $C P D$ \\
\hline Low & $\$ 56.36$ & & Low & $\$ 3$ & $\$ 26.75$ & Low & +1 & 9 & Low & 18 & $\$ 20.97$ \\
\hline$A v g$ & $\$ 41.58$ & $\$ 40$ & $A v g$ & $\$ 23.09$ & $\$ 15$ & Avg & 53 & $\$ 11.28$ & Avg & $\$$ & $\$ 10.06$ \\
\hline High & $\$ 33.83$ & $\$ 35.92$ & High & $\$ 15.35$ & $\$ 11.58$ & High & $\$ 11.88$ & $\$ 7.01$ & High & $\$ 10.96$ & $\$ 5.79$ \\
\hline \multicolumn{3}{|c|}{$12,000 \mathrm{ft} \& 1,000 \mathrm{CY}$} & \multicolumn{3}{|c|}{$12,000 \mathrm{ft} \& 5,000 \mathrm{CY}$} & \multicolumn{3}{|c|}{$12,000 \mathrm{ft} \& 20,000 \mathrm{CY}$} & \multicolumn{3}{|c|}{$12,000 \mathrm{ft} \& 100,000 \mathrm{CY}$} \\
\hline $\begin{array}{l}\text { Prod. } \\
\text { Rate }\end{array}$ & $M B D$ & $C P D$ & $\begin{array}{l}\text { Prod. } \\
\text { Rate }\end{array}$ & $M B D$ & $C P D$ & $\begin{array}{l}\text { Prod. } \\
\text { Rate }\end{array}$ & $M B D$ & $C P D$ & $\begin{array}{l}\text { Prod. } \\
\text { Rate }\end{array}$ & $M B D$ & $C P D$ \\
\hline Low & $\$ 56.36$ & & Low & $\$ 37.87$ & $\$ 26.75$ & Low & 41 & $\$ 22.19$ & Low & $\$ 3$ & $\$ 20.97$ \\
\hline$A v g$ & & & Avg & & & Avg & & $\$ 1$ & & & $\$ 10.06$ \\
\hline High & $\$ 33.83$ & $\$ 35.92$ & High & $\$ 15.35$ & $\$ 11.58$ & High & $\$ 11.88$ & $\$ 7.01$ & High & $\$ 10.96$ & $\$ 5.79$ \\
\hline \multicolumn{3}{|c|}{$16,000 \mathrm{ft} \& 1,000 \mathrm{CY}$} & \multicolumn{3}{|c|}{$16,000 \mathrm{ft} \& 5,000 \mathrm{CY}$} & \multicolumn{3}{|c|}{$16,000 \mathrm{ft} \& 20,000 \mathrm{CY}$} & \multicolumn{3}{|c|}{$16,000 \mathrm{ft} \& 100,000 \mathrm{CY}$} \\
\hline $\begin{array}{l}\text { Prod. } \\
\text { Rate }\end{array}$ & $M B D$ & $C P D$ & $\begin{array}{l}\text { Prod. } \\
\text { Rate }\end{array}$ & $M B D$ & $C P D$ & $\begin{array}{l}\text { Prod. } \\
\text { Rate }\end{array}$ & $M B D$ & $C P D$ & $\begin{array}{l}\text { Prod. } \\
\text { Rate }\end{array}$ & $M B D$ & $C P D$ \\
\hline Low & $\$ 56.36$ & $\$ 72.18$ & Low & $\$ 37.87$ & $\$ 47.50$ & Low & $\$ 34.41$ & $\$ 42.88$ & Low & $\$ 33.48$ & $\$ 41.64$ \\
\hline$A v g$ & $\$ 41$ & $\$ 50$ & $A v \xi$ & $\$ 23$ & $\$ 25.69$ & $A v g$ & 63 & $\$ 21.06$ & $A v g$ & $\$ 18.70$ & $\$ 19.83$ \\
\hline High & $\$ 33.83$ & $\$ 41.83$ & High & $\$ 15.35$ & $\$ 17.15$ & High & $\$ 11.88$ & $\$ 12.52$ & High & $\$ 10.96$ & $\$ 11.29$ \\
\hline
\end{tabular}

Table 3.6: Constituent Inventory

\begin{tabular}{|l|l|l|}
\hline Acectaldehyde & Formaldehyde & Propene \\
\hline Acrolein & Methane & Toluene \\
\hline Benzene & Nitric Oxide & Sulfur oxides \\
\hline $\begin{array}{l}\text { Carbon dioxide } \\
\text { (fossil) }\end{array}$ & $\begin{array}{l}\text { PAtrogen oxide } \\
\text { aromatic } \\
\text { aydrocyclic } \\
\text { (unspecified) } \\
\text { Xylenes }\end{array}$ \\
\hline Carbon monoxide & Particulates (PM10) & \\
\hline
\end{tabular}


Table 3.7: Characterization Environmental Impact Categories

\begin{tabular}{|l|l|}
\hline $\begin{array}{l}\text { Environmental } \\
\text { Impact Category }\end{array}$ & $\begin{array}{l}\text { Equivalent } \\
\text { Units }\end{array}$ \\
\hline Greenhouse Effects & $\mathrm{kg} \mathrm{CO}_{2}$ \\
\hline Acidification & $\mathrm{kg} \mathrm{SO}_{2}$ \\
\hline Eutrophication & $\mathrm{kg} \mathrm{PO} 4$ \\
\hline Carcinogens & $\mathrm{kg} \mathrm{SPM}$ \\
\hline Winter Smog & $\mathrm{kg} \mathrm{B}(\mathrm{a}) \mathrm{P}$ \\
\hline Summer Smog & $\mathrm{kg} \mathrm{C}_{2} \mathrm{H}_{4}$ \\
\hline
\end{tabular}

Table 3.8: Environmental Impact Category Constituents

\begin{tabular}{|l|l|}
\hline $\begin{array}{l}\text { Environmental } \\
\text { Impact Category }\end{array}$ & Constituents \\
\hline Greenhouse Effects & $\begin{array}{l}\text { Acetaldehyde } \\
\text { Carbon Dioxide, Fossil } \\
\text { Methane }\end{array}$ \\
Acidification & $\begin{array}{l}\text { Nitric Oxide } \\
\text { Sulfur Oxides } \\
\text { Nitrogen Oxides }\end{array}$ \\
Carcinogens & $\begin{array}{l}\text { Nitric Oxide } \\
\text { Nitrogen Oxides }\end{array}$ \\
\hline Winter Smog & $\begin{array}{l}\text { Polycyclic Aromatic Hydrocarbons, PAH } \\
\text { Benzene }\end{array}$ \\
\hline Summer Smog & $\begin{array}{l}\text { Particulates, }<10 \text { um } \\
\text { Sulfur Oxides }\end{array}$ \\
\hline
\end{tabular}

\subsection{Tradeoff Index}

For certain scenarios of production rate, transport distance, and volume there may be a clear choice of dredging method if both the cost and EISS are lower. There are some scenarios, however, where one criterion (cost or EISS) is higher and the other lower. In these scenarios, it is helpful to the decision maker to know if a small increase in cost will result in a large or small decrease in EISS. To quantify the cost and EISS tradeoff, a Tradeoff Index $I$ is introduced to identify whether one type of dredge was the better choice and quantify the magnitude of the benefits obtained (Eq. 3.5). This index is calculated using the inverse slope of the Index Value Line which connects the cutterhead pipeline and mechanical bucket dredges values for the EISS and cost per CY at each production rate (Figure 3.2). The Index Value line is illustrated using a double gray line, the cutterhead pipeline dredge (CPD) is shown in red with dashed lines and triangular markers, and the mechanical bucket dredge (MBD) is represented with blue solid lines and square markers. Entering the EISS and cost values for the cutterhead pipeline dredge 
first generates an Index Value where the sign provides a general determination (Table 3.9).

In the event $I$ is negative one type of dredge has a lower EISS value while the second type of dredge has a lower cost per CY resulting in no clear choice between dredging equipment. A positive value of $I$ indicates that one of the dredge types has a lower EISS value and cost per CY but the decision-maker will need to look at the results to determine which type of equipment would be the better choice.

High $I$ values identify situations in which there is a high reduction in environmental impacts for a small increase in cost and, therefore may be considered worth employing. The converse is true for low values of $I$.

Terms used in Eq. 3.5 and Figure 3.2 are defined as follows:

- CPD - Cutterhead Pipeline Dredge

- MBD - Mechanical Bucket Dredge

- EISS - Environmental Impact Single Score

- Cost - Cost per Cubic Yard

- High - High Production Rate

- Avg - Average production Rate

- Low - Low Production Rate

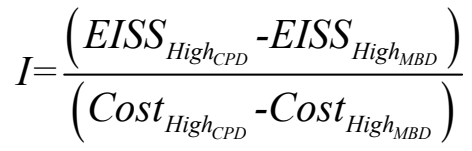

Table 3.9: Tradeoff Index Value, I, General Sign Determination

\begin{tabular}{|c|cc|l|}
\hline Numerator & Denominator & $\begin{array}{l}\text { Tradeoff } \\
\text { Index Value }\end{array}$ & Determination \\
\hline Positive & Positive & Positive & $\begin{array}{l}\text { Mechanical } \\
\text { Bucket Dredge }\end{array}$ \\
\hline Positive & Negative & Negative & No Clear Choice \\
\hline Negative & Positive & Negative & $\begin{array}{l}\text { No Clear Choice } \\
\text { Cutterhead } \\
\text { Pipeline Dredge }\end{array}$ \\
\hline Negative & Negative & Positive \\
\hline
\end{tabular}




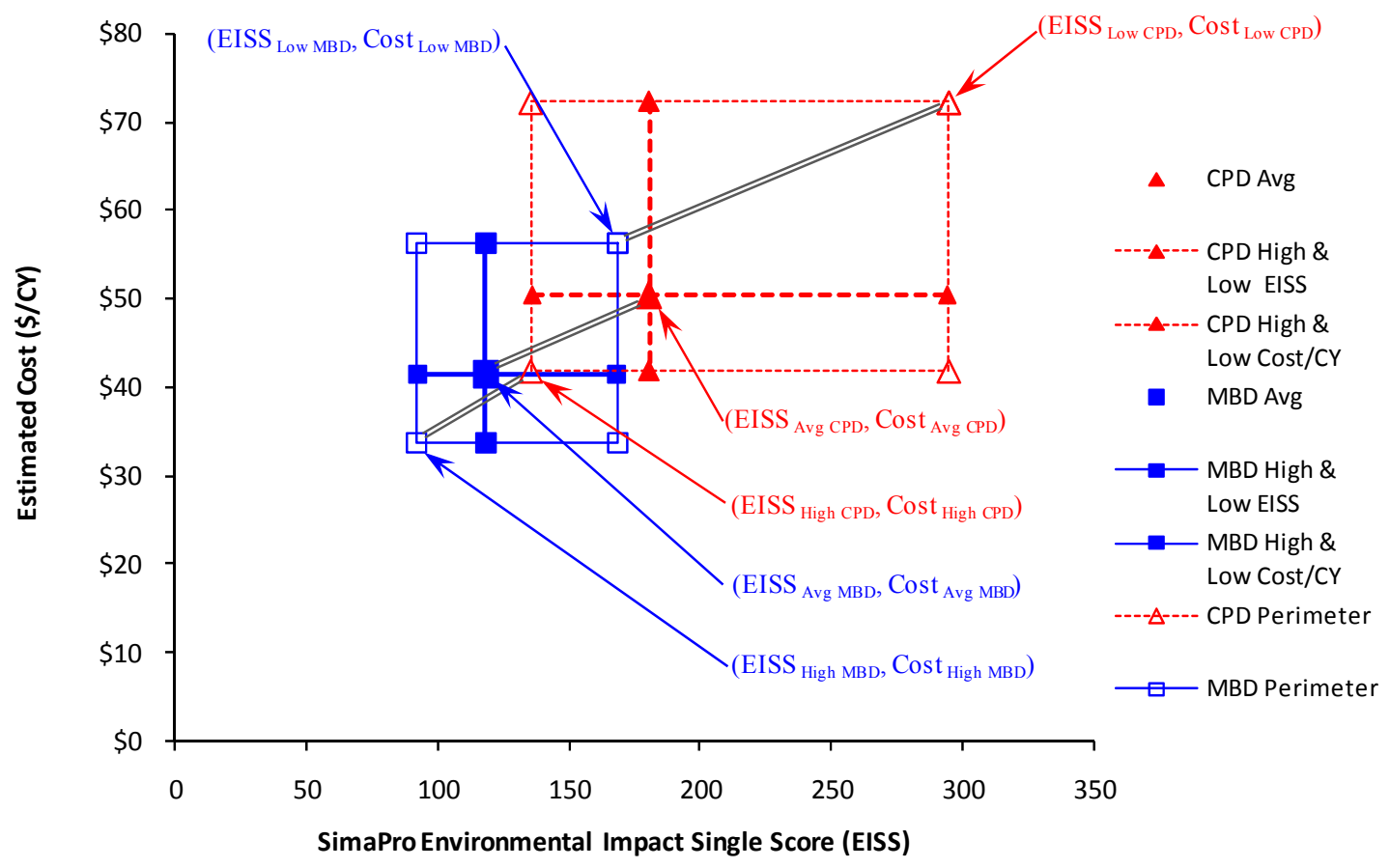

Figure 3.2: Tradeoff Index Value, $I$ - Example for $1,000 \mathrm{CY}$ and $16,000 \mathrm{ft}$ 


\section{CHAPTER 4: RESULTS}

A total of 48 scenarios were analyzed comparing two types of dredging equipment, the cutterhead pipeline dredge and the mechanical bucket dredge. The parameters varied included the quantity of material to be dredged, transport distances from the dredge cut to the placement site, and production rates for each type of dredging equipment. See Section 3.1 for a complete explanation of these parameters. This yielded an "envelope" of results applicable to a broad range of potential site conditions.

The volume of dredged material ranged from a relatively small quantity of 1,000 cubic yards (CY) to intermediate quantities of 5,000 CY and 20,000 CY up to a large quantity of $100,000 \mathrm{CY}$. Transport distances were selected based on the typical capabilities of the cutterhead pipeline dredge: alone with no booster pumps $(8,000 \mathrm{ft})$; with one booster pump $(10,000 \mathrm{ft})$; with two booster pumps $(12,000 \mathrm{ft})$; and a maximum distance that would require double-handling of the dredged material $(16,000 \mathrm{ft})$. This range of transport distances was selected to target strengths of both types of equipment evaluated and assumes sandy sediment typically found in the Illinois Waterway (IWW) where these dredges operated during the 2005 season. Production rates can vary from one dredging event to the next depending on multiple factors including: the type of material being dredged, minimizing potential delays to navigation, transport distance, placement site location and management, and equipment down time. Therefore, a range was used in this analysis. The production rates selected included the lowest, average, and highest rates for each dredging crew (Table 4.1) based on Rock Island District records. See Section 3.1 for complete production rate procedures and data (Graham 2007/08). The dredging events included were limited to those with sandy material to be consistent with the events done by the cutterhead pipeline dredge.

Table 4.1: Dredge Crew Production Rates

\begin{tabular}{|r|c|c|}
\hline \multirow{2}{*}{} & \multicolumn{2}{|c|}{$\begin{array}{c}\text { Production Rate } \\
(C Y / h r)\end{array}$} \\
\cline { 2 - 3 } & CPD & MBD \\
\hline Low & 51 & 20 \\
\hline Average & 108 & 36 \\
High & 192 & 62 \\
\hline
\end{tabular}

\subsection{Presentation of Results}

The total diesel fuel consumed for each dredging crew and scenario was calculated as outlined in Section 3.1.2 with the volumes summarized in Table 4.2. The diesel fuel consumed could be used to evaluate each scenario and determine which dredging equipment would have the lowest emissions to the atmosphere since the relationship between emissions and fuel consumed is linear. However, comparing diesel fuel consumed alone would not adequately illustrate the potential reduction in environmental impacts. Using a limited LCA provides the capability to evaluate by the quantity of each constituent emitted (Table 3.6), each environmental impact category 
(Table 3.7), and by a total Environmental Impact Single Score (EISS). See Section 3.3 for the Eco-efficiency Analysis.

Table 4.2: Diesel Fuel Consumption by Dredging Event, in Gallons

\begin{tabular}{|c|c|c|c|c|c|c|c|c|c|c|c|c|}
\hline & \multicolumn{3}{|c|}{$1,000 \mathrm{CY}$} & \multicolumn{3}{|c|}{$5,000 \mathrm{CY}$} & \multicolumn{3}{|c|}{$20,000 \mathrm{CY}$} & \multicolumn{3}{|c|}{$100,000 \mathrm{CY}$} \\
\hline \multirow{4}{*}{ 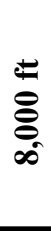 } & $\begin{array}{l}\text { Prod. } \\
\text { Rate }\end{array}$ & MBD & CPD & $\begin{array}{l}\text { Prod. } \\
\text { Rate }\end{array}$ & MBD & PD & $\begin{array}{l}\text { Prod. } \\
\text { Rate }\end{array}$ & MBD & CPD & $\begin{array}{l}\text { rod. } \\
\text { ate }\end{array}$ & ИВБ & CPD \\
\hline & Min & 5,140 & 5,818 & Min & 19,807 & 19,379 & Min & 74,807 & 70,233 & Min & 368,142 & 341,454 \\
\hline & vg & 3,573 & 4,028 & Avg & 11,970 & 10,432 & Avg & 43,460 & 34,446 & Avg & 211,405 & 162,523 \\
\hline & Max & 2,751 & 3,328 & Max & 7,862 & 6,930 & Max & 27, & & Max & 125 & 92,481 \\
\hline \multirow{4}{*}{ 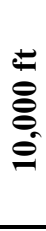 } & $\begin{array}{l}\text { rod. } \\
\text { ate }\end{array}$ & MBD & CPD & $\begin{array}{l}\text { Prod. } \\
\text { Rate }\end{array}$ & MBD & CPD & Rate & MBD & CPD & Rate & MBD & CPD \\
\hline & Min & 5,178 & 6,670 & Min & 19,994 & 23,642 & Min & 75,554 & 87,287 & Min & 371,878 & 426,725 \\
\hline & Avg & 3,610 & 4,431 & Avg & 12,157 & 12,445 & Avg & 44,207 & 42,500 & Avg & 215,141 & 202,790 \\
\hline & Iax & 2,789 & 3,554 & Max & 8,049 & 8,062 & Max & 27,775 & 24,968 & Max & 132,980 & 115,131 \\
\hline \multirow{4}{*}{$\begin{array}{l} \pm \\
\text { 응 } \\
\text { ㅇ }\end{array}$} & Rate & MBD & CPD & Rate & MBD & CPD & Rate & MBD & CPD & Rate & MBD & CPD \\
\hline & Min & 5,215 & 7,523 & Min & 20,181 & 27,906 & Min & 76,302 & 104,341 & Min & 375,614 & 511,995 \\
\hline & Avg & 3,648 & 4,834 & Avg & 12,344 & 14,459 & Avg & 44,954 & 50,553 & Avg & 218,877 & 243,057 \\
\hline & Max & 2,826 & 3,781 & Max & 8,236 & 9,195 & Max & 28,522 & 29,498 & Max & 136,716 & 137,781 \\
\hline \multirow{4}{*}{$\begin{array}{l}\text { E } \\
8 \\
8 \\
8\end{array}$} & $\begin{array}{l}\text { Prod. } \\
\text { Rate }\end{array}$ & MBD & CPD & $\begin{array}{l}\text { Prod. } \\
\text { Rate }\end{array}$ & MBD & CPD & $\begin{array}{l}\text { Prod. } \\
\text { Rate }\end{array}$ & MBD & CPD & Rate & MBD & CPD \\
\hline & Min & 5,280 & 9,241 & Min & 20,507 & 36,363 & Min & 77,609 & 138,071 & Min & 382,152 & 680,514 \\
\hline & Avg & 3,713 & 5,663 & Avg & 12,671 & 18,470 & Avg & 46,262 & 66,499 & Avg & 225,414 & 322,653 \\
\hline & Max & 2,891 & 4,262 & Max & 8,563 & 11,466 & Max & 29,830 & 38,482 & Max & 143,254 & 182,569 \\
\hline
\end{tabular}

The results from the limited LCA will be presented in two alternate forms. First as a comparison of EISS versus cost per CY for each volume of dredged material and transport distance and second as a comparison of EISS and cost per CY versus transport distance for each volume of dredged material. The inclusion of total cost per cubic yard of dredged material in the evaluation allows a decision to be made that balances economics and environmental impacts.

\subsection{EISS versus Cost per CY}

A total of four dredged material volumes and four transport distances yields 16 EISS-versus-cost scenarios to be evaluated (Figures 4.1-4.16). Each graph is formatted with the cutterhead pipeline dredge in red (lighter shade) with triangular markers and dashed lines and the mechanical bucket dredge in blue (darker shade) with square markers and solid lines. The largest marker is for the average production rate and cost for each dredging crew with the medium sized markers signifying the low and high cost per $\mathrm{CY}$ at the EISS for the average production rate and the smallest markers signifying the low and high EISS at the average cost per CY. The EISS and cost axis scales are held constant for each volume of dredged material. It was not realistic to set a single scale for all volumes of dredged material because of the wide range of values, particularly the EISS which went from a low of 87 to a high of 21,678 , over the four volumes of dredged 
material. Additionally, utilizing the same axis scale across multiple dredging volumes is not necessary for this study since the quantity of dredged material is determined by the site conditions. This style of graph allows the decision-maker to compare the cost and EISS for different types of dredging equipment and production rates. Impacts to the EISS and cost per CY resulting from changes in production rate can easily be seen and incorporated into the selection process for dredging equipment.

\subsubsection{Variable Transport Distances and Constant Dredged Material Volumes}

One way to evaluate dredging equipment air emissions is to consider a constant volume of dredged material over increasing transport distances. This is the most desirable graphical evaluation process because graphs with the same quantity of dredged material have the same scales. This type of analysis would be more applicable when the volume cannot be changed but multiple placement site locations, and thus multiple transport distances, are being considered.

For small volumes such as the 1,000 CY scenario the mechanical bucket dredge has a lower EISS for all transport distances included in this study. In addition, the cost per CY for the mechanical bucket dredge is lower for the longest transport distance at all production rates, slightly lower for all transport distances when the production rate is high, and slightly higher for the low and average production rates at 8,000 feet, 10,000 feet, and 12,000 feet (Figures 4.1, 4.2, 4.3 and 4.4). The selection of a mechanical bucket dredge would result in lower air emissions for small quantities of dredged material at a lower to comparable cost depending on the transport distance and production rate.

When the volume increases to 5,000 CY, at an 8,000 foot transport distance, the EISS is lower for the cutterhead pipeline dredge at all production rates (Figure 4.5). The EISS increases at a faster rate for the cutterhead pipeline dredge as the transport distance gets longer resulting in a slightly higher EISS at 10,000 feet and a higher EISS than the mechanical bucket dredge for the 12,000 and 16,000 foot distances (Figures 4.6, 4.7 and 4.8). The cutterhead pipeline dredge has a lower cost per CY than the mechanical bucket dredge for $8,000,10,000$, and 12,000 foot transport distances but this reverses at the 16,000 foot transport distance with the mechanical bucket dredge having a lower cost per CY (Figures 4.5, 4.6, 4.7 and 4.8). As previously stated, the mechanical bucket dredge is more efficient for the 16,000 foot transport distance (Figure 4.8). The cutterhead pipeline dredge has lower air emissions and cost per CY for the 8,000 foot scenario, making it the better choice from both the environmental and economic perspectives (Figure 4.5). The cutterhead pipeline dredge has a lower cost per CY and comparable EISS at 10,000 feet for average and high production rates making it as better choice than the mechanical bucket dredge (Figure 4.6). At 10,000 feet with a low production rate and 12,000 feet for all production rates a decision would have to be made between lower costs or lower air emissions (Figures 4.6 and 4.7).

In the cases considering 20,000 CY of dredged material the EISS and cost per CY for the cutterhead pipeline dredge is lower than for the mechanical bucket dredge at an 8,000 foot transport distance (Figure 4.9). The EISS for the cutterhead pipeline dredge increases, relative to the mechanical bucket dredge, as the transport distance increases and booster pumps or double-handling are added. At 10,000 feet the EISS is lower for 
the cutterhead pipeline dredge at a high production rate, slightly lower at an average production rate, and higher at a low production rate (Figure 4.10). For both 12,000 and 16,000 foot transport distances the mechanical bucket dredge has a lower EISS (Figures 4.11 and 4.12). The cost per CY, on the other hand, is higher for the mechanical bucket dredge for all scenarios except the 16,000 foot transport distance where the mechanical bucket dredge is slightly lower, due primarily to the double-handling of the dredged material by the cutterhead pipeline dredge (Figure 4.12). Selection of a cutterhead pipeline dredge makes sense environmentally and economically for the 8,000 foot transport distances for all production rates (Figures 4.9). At 10,000 feet the cutterhead pipeline dredge has a lower EISS and cost per CY for average and high production rates with a choice required between lower cost or EISS at the low production rate (Figure 4.10). The mechanical bucket dredge has a lower EISS and higher cost per CY at 12,000 feet for all production rates (Figure 4.11). With a lower EISS and cost per CY the mechanical bucket dredge is the better choice for a transport distance of 16,000 feet at all production rates (Figure 4.12).

For large volumes such as the $100,000 \mathrm{CY}$ scenario the EISS and cost per CY are lower for the cutterhead pipeline dredge at an 8,000 foot transport distance (Figure 4.13). The EISS increases as the distance increases and is slightly lower for the cutterhead pipeline dredge at 10,000 feet for average and high production rates while remaining higher than the mechanical bucket dredge for low production rates (Figure 4.14). At 12,000 feet the EISS is higher for the cutterhead pipeline dredge at all production rates with the largest difference at the low production rate (Figure 4.15). The EISS for a mechanical bucket dredge is lower at all production rates when the transport distance reaches 16,000 feet (Figure 4.16). The cost per CY is lower for the cutterhead pipeline dredge for all scenarios except for a 16,000 foot transport distance where it is slightly higher for the average and high production rates but could be considered comparable. The cost per CY for a cutterhead pipeline dredge at a low production rate is higher. The cutterhead pipeline dredge is clearly a better choice for 8,000 feet at all production rates and 10,000 feet with average or high production rates since the EISS is lower to comparable and the cost is lower than the mechanical bucket dredge (Figures 4.13 and 4.14). At 10,000 feet with a low production rate the cutterhead pipeline dredge has a slightly higher EISS (Figure 4.14). For the 12,000 foot transport distance the cutterhead pipeline dredge has a lower cost per CY but the EISS is higher, forcing a choice between lower environmental impacts or cost (Figure 4.15). When double-handling is required for the cutterhead pipeline dredge the mechanical bucket dredge, with a lower EISS and cost per CY, is definitely the better selection (Figure 4.16).

In all cases where double-handling of the dredged material is necessary because transport distance exceeds the cutterhead pipeline dredge pumping capabilities the mechanical bucket dredge has a lower EISS and cost per CY. This makes the mechanical bucket dredge the obvious choice for transport distances greater than 16,000 feet (Figures 4.4, 4.8, 4.12 and 4.16). A mechanical bucket dredge is typically more efficient for long transport distances, which is consistent with the findings of this study. 


\subsubsection{Variable Dredged Material Volumes and Constant Transport Distances}

A second way to analyze this data is to compare the four volumes of dredged material with the transport distance held constant. A certain amount of care needs to be taken when comparing these graphs since the EISS and cost per CY scales change as the quantity changes. This would be applicable if there is only one dredge cut and placement site location to be considered and the volume of dredged material could be varied to stay within a total cost ceiling, for example.

In all instances with a 16,000 foot transport distance the EISS and cost per CY were higher for the cutterhead pipeline dredge (Figures 4.4, 4.8, 4.12 and 4.16). In all cases except the 1,000 CY scenario the cost was only slightly higher and could be considered comparable. When the transport distance reaches a point where a cutterhead pipeline dredge would be required to double-handle the dredged material a mechanical bucket dredge is more efficient than a cutterhead pipeline dredge from both an air quality and economic standpoint. These results are consistent with the strengths of a mechanical bucket dredge crew to be well suited for long transport distances, as outlined in Section 1.3 .

When considering the 12,000 foot transport distance the mechanical bucket dredge had lower EISS and higher cost per CY for all cases except for the 1,000 CY scenario, where the cost is only slightly higher for the average and high production rates and could be considered comparable (Figures 4.7, 4.11 and 4.15). When the low production rate for $1,000 \mathrm{CY}$ is considered the mechanical bucket dredge has both a lower EISS and cost per CY (Figure 4.3). Additionally, there is a wider variation between dredging crews in cost and EISS as the production rate decreases. For the 1,000 $\mathrm{CY}$ volume the mechanical bucket dredge has a lower EISS with lower to comparable cost per CY depending on the production rate, making it the more efficient choice (Figure 4.3). As the volume increases the difference in EISS between the types of dredges decreases while the cost difference increases, particularly for the low and average production rates (Figures 4.7, 4.11 and 4.15). This would require a decision between reducing air emissions and lower cost.

In the cases with a 10,000 foot transport distance the cost per CY for the 1,000 CY scenario is lower for the mechanical bucket dredge at the high production rate and slightly higher but comparable at the average and low production rates (Figure 4.2). The EISS is lower for the mechanical bucket dredge than that for the cutterhead pipeline dredge at all production rates for this scenario. As the quantity of dredged material increases the EISS shifts to comparable at 20,000 CY for high and average production rates and remains lower for the mechanical bucket dredge at low production rates (Figures 4.6 and 4.10). At 100,000 CY the cutterhead pipeline dredge has a lower EISS except at low production rates where the mechanical bucket dredge has a lower EISS (Figure 4.14). The cost per CY for the cutterhead pipeline dredge remains lower than that for the mechanical bucket dredge for the 5,000,20,000, and 100,000 CY scenarios at all production rates (Figures 4.6, 4.10 and 4.14). Selection of a mechanical bucket dredge for small volumes of dredged material, irregardless of transport distance, would be the most efficient choice both environmentally and economically. However, as the volume of material to be dredged increases the cutterhead pipeline dredge would be the 
better choice as long as production rates are average to high. When a low production rate is anticipated a choice between air quality and economics would be required.

For the shortest transport distance of 8,000 feet the mechanical bucket dredge has a lower EISS for 1,000 CY across all three production rates with a slightly lower cost per $\mathrm{CY}$ at a high production rate and a slightly higher cost at average and low production rates (Figure 4.1). The cost and EISS increase for the mechanical bucket dredge, relative to the cutterhead pipeline dredge, as the volume of dredged material increases. At 5,000 CY the EISS is slightly lower and the cost is significantly lower for the cutterhead pipeline dredge (Figure 4.5). In the 20,000 CY and 100,000 CY cases the cutterhead pipeline dredge has a lower EISS and cost per CY than those for the mechanical bucket dredge (Figures 4.9 and 4.13). In all cases, except for 1,000 CY, selection of a cutterhead pipeline dredge would result in both reduced air emissions and cost per CY. For a small volume of dredged material the mechanical bucket dredge remains the better choice based on environmental impacts with the cost per CY dependent on the anticipated production rate. 


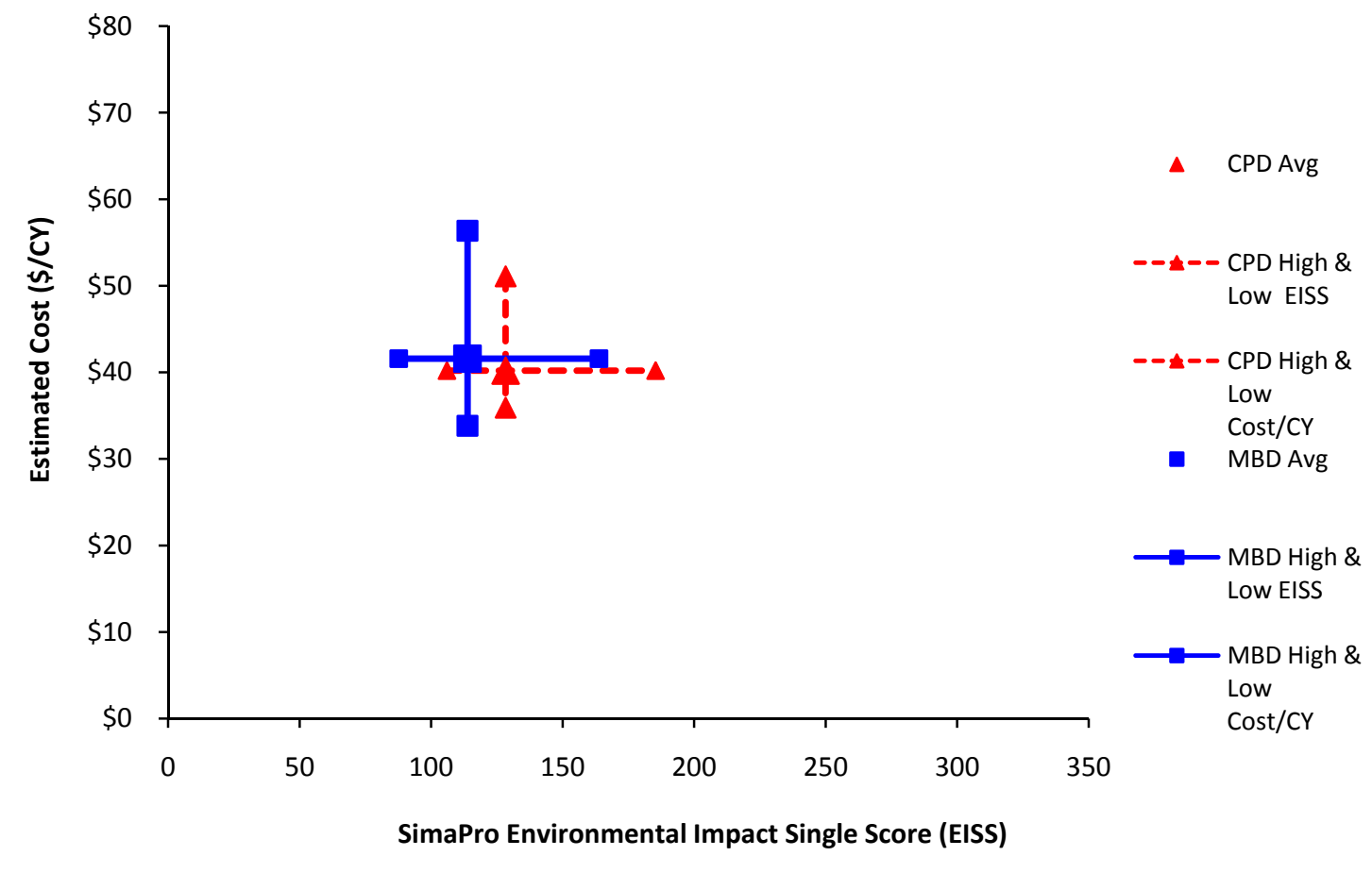

Figure 4.1: EISS vs. Cost - 1,000 CY and 8,000 ft

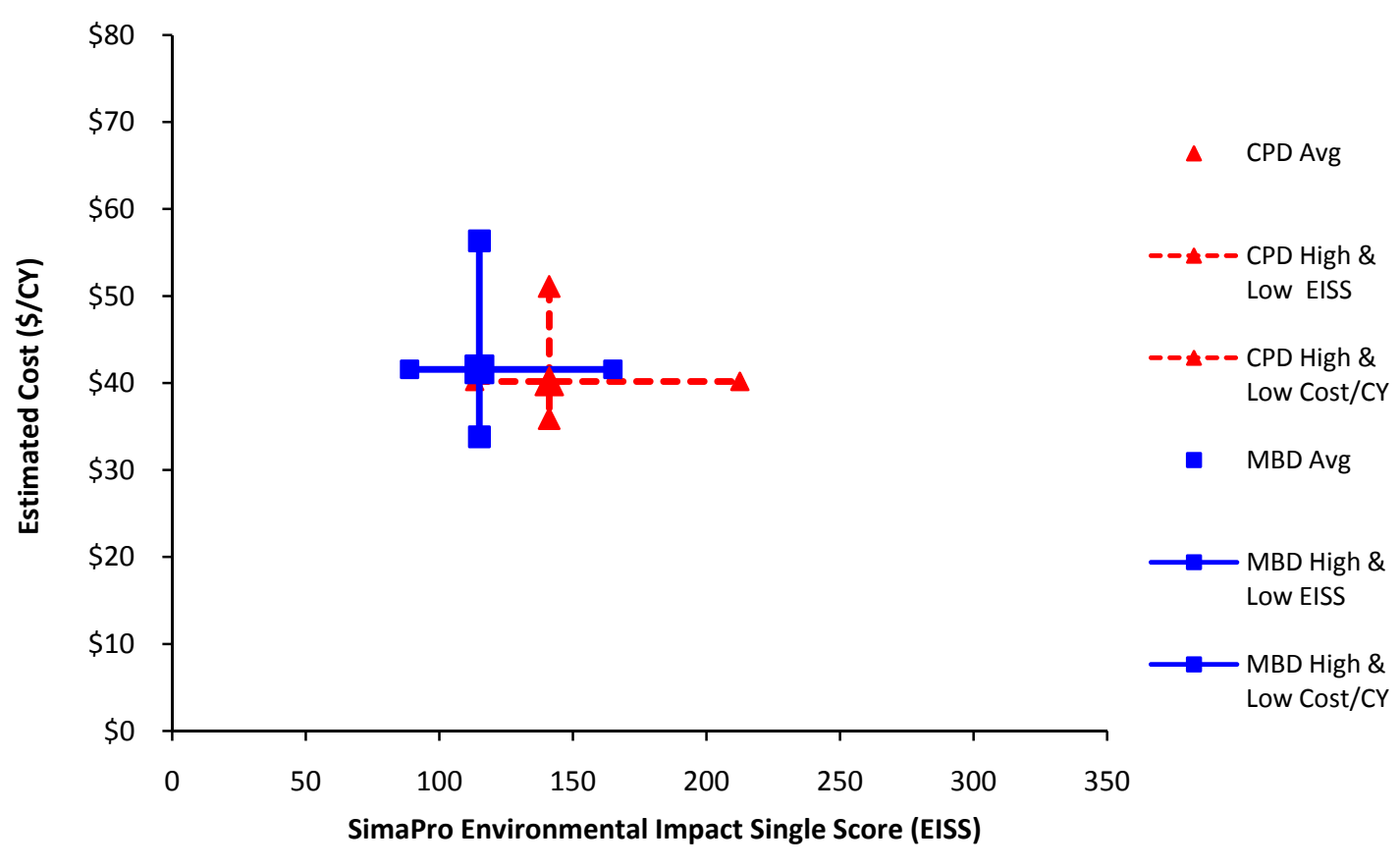

Figure 4.2: EISS vs. Cost $-1,000 \mathrm{CY}$ and $10,000 \mathrm{ft}$ 


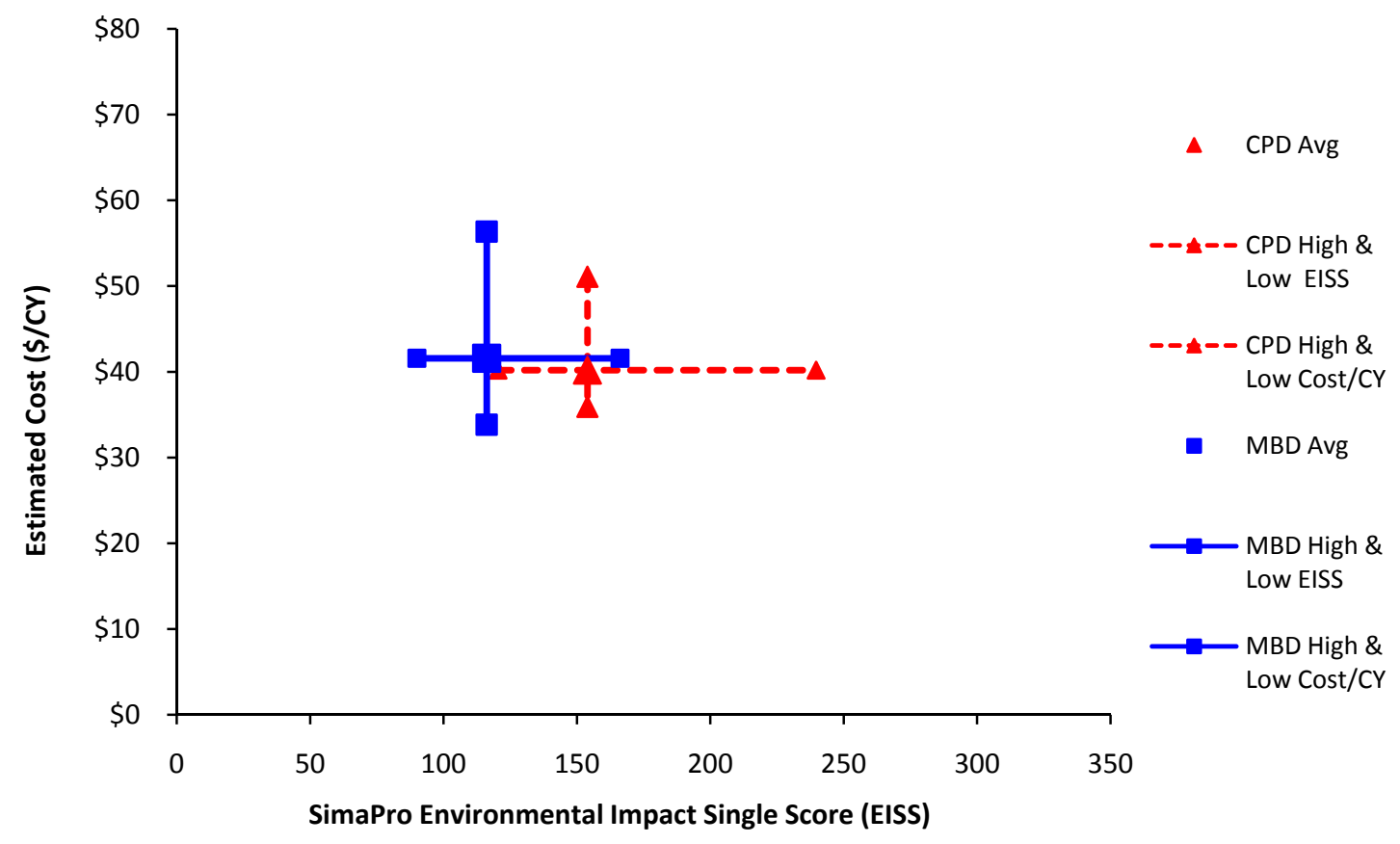

Figure 4.3: EISS vs. Cost - 1,000 CY and 12,000 ft

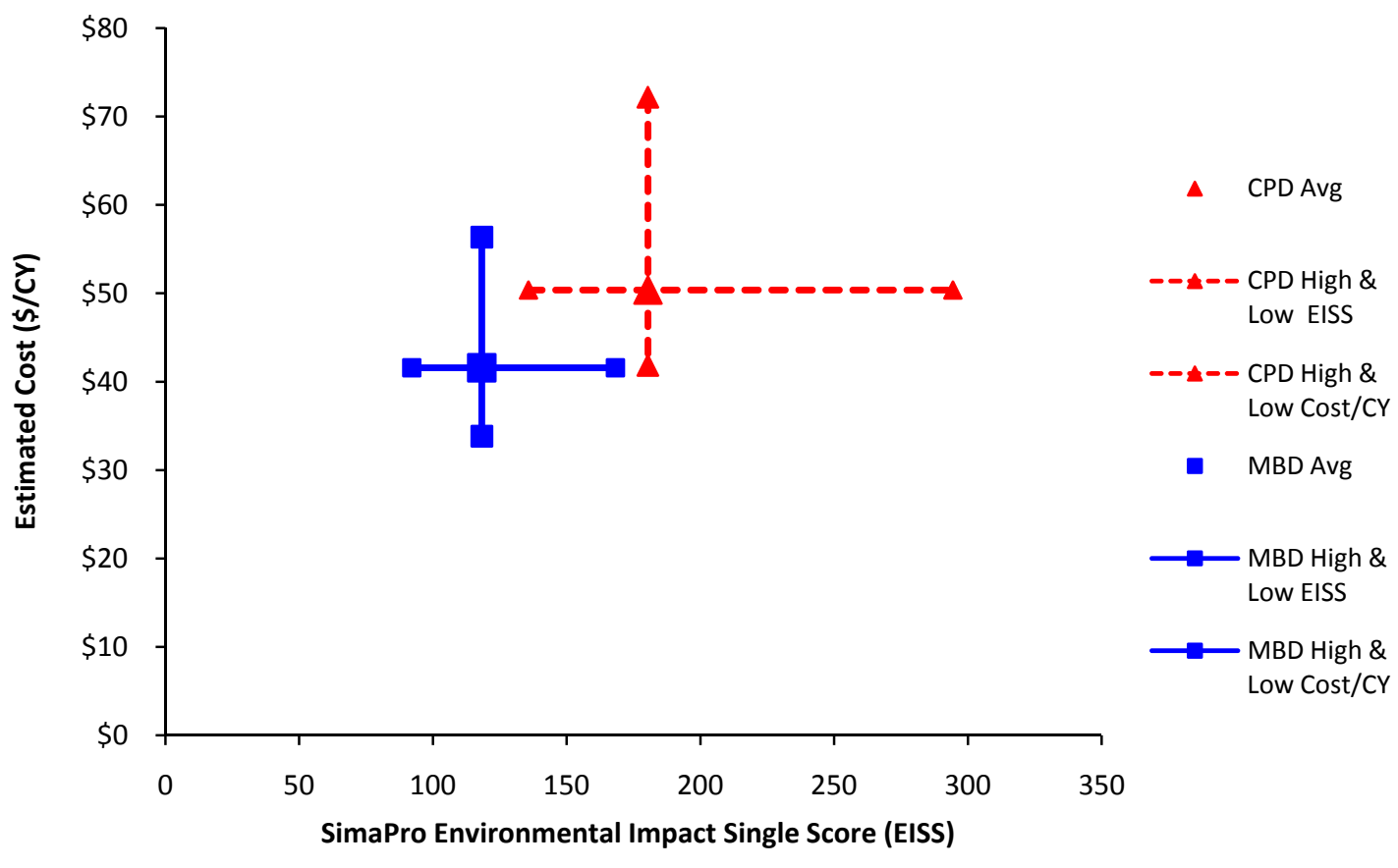

Figure 4.4: EISS vs. Cost $-1,000 \mathrm{CY}$ and $16,000 \mathrm{ft}$ 


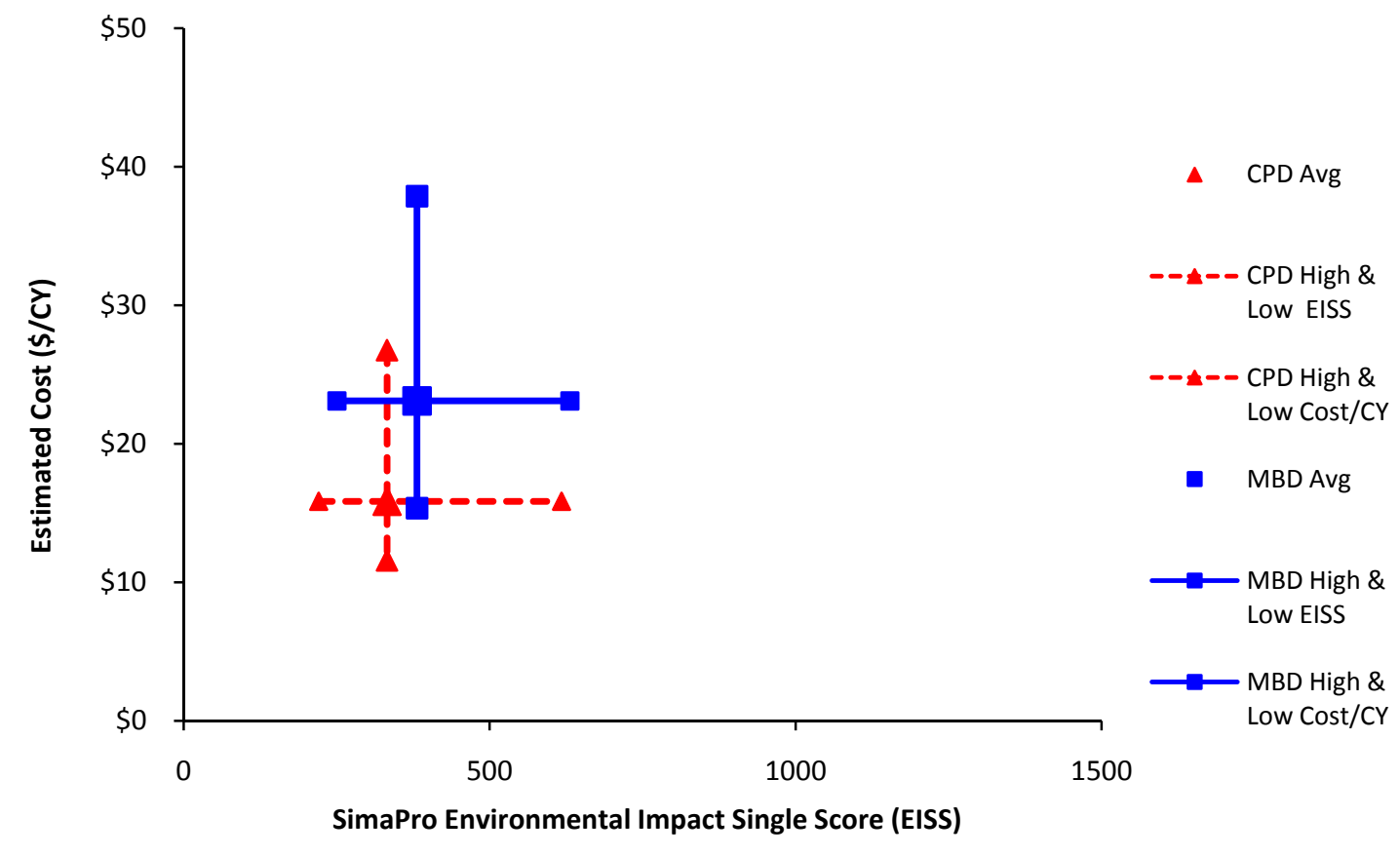

Figure 4.5: EISS vs. Cost - 5,000 CY and 8,000 ft

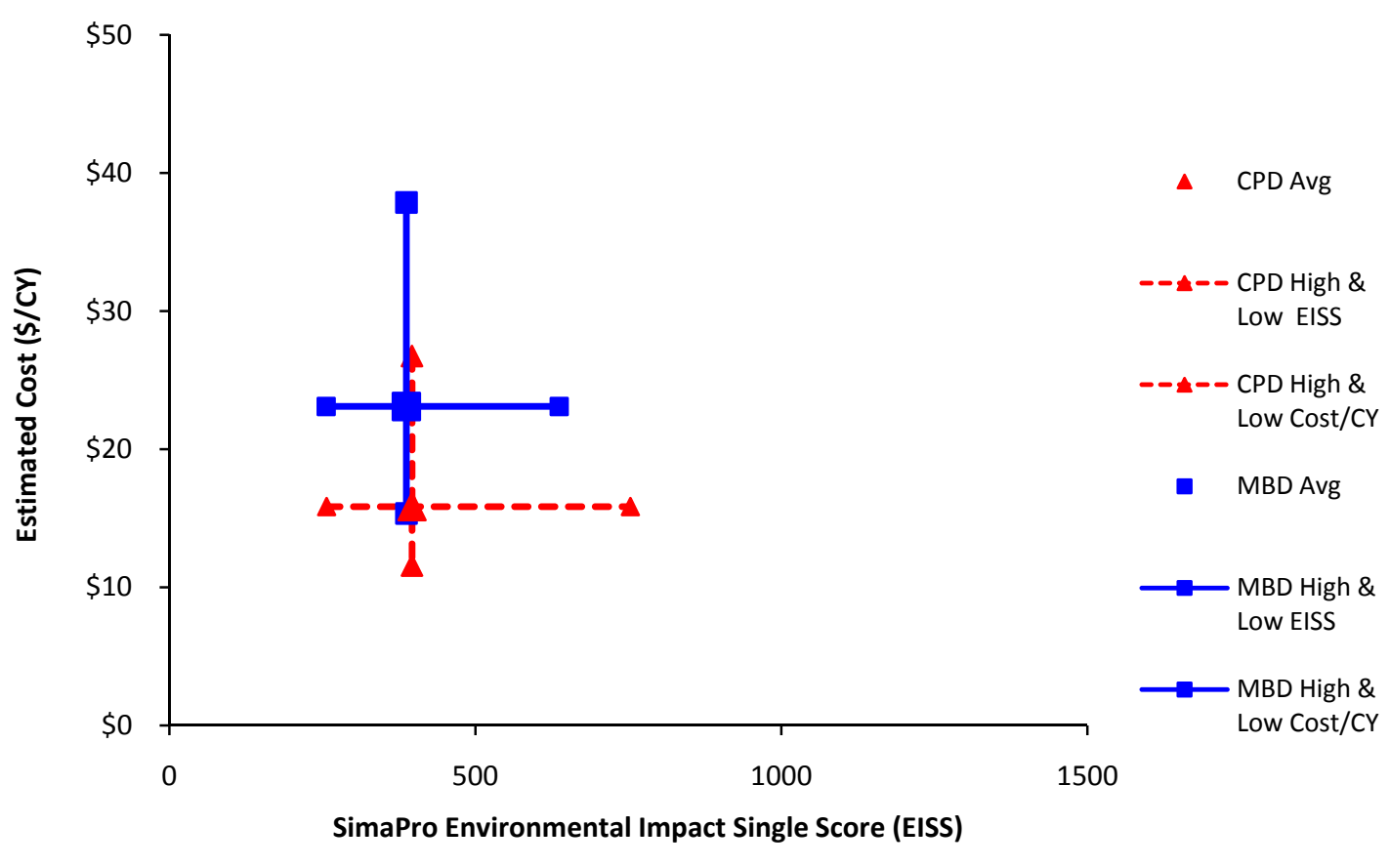

Figure 4.6: EISS vs. Cost $-5,000 \mathrm{CY}$ and $10,000 \mathrm{ft}$ 


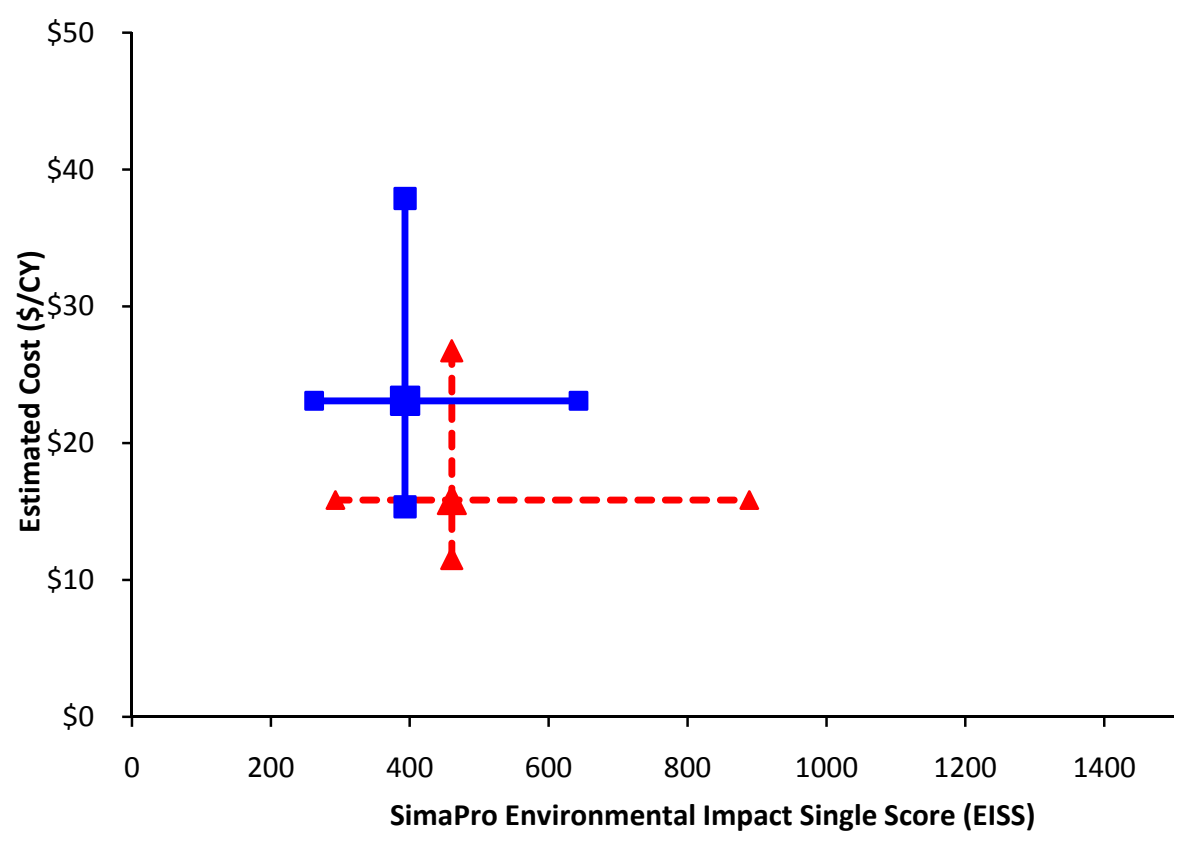

- CPD Avg - - A- - CPD High \& Low EISS $--\ldots--$ CPD High \& Low Cost/CY

- MBD Avg

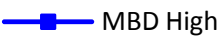
\& Low EISS

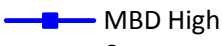
\& Low Cost/CY

Figure 4.7: EISS vs. Cost $-5,000 \mathrm{CY}$ and $12,000 \mathrm{ft}$

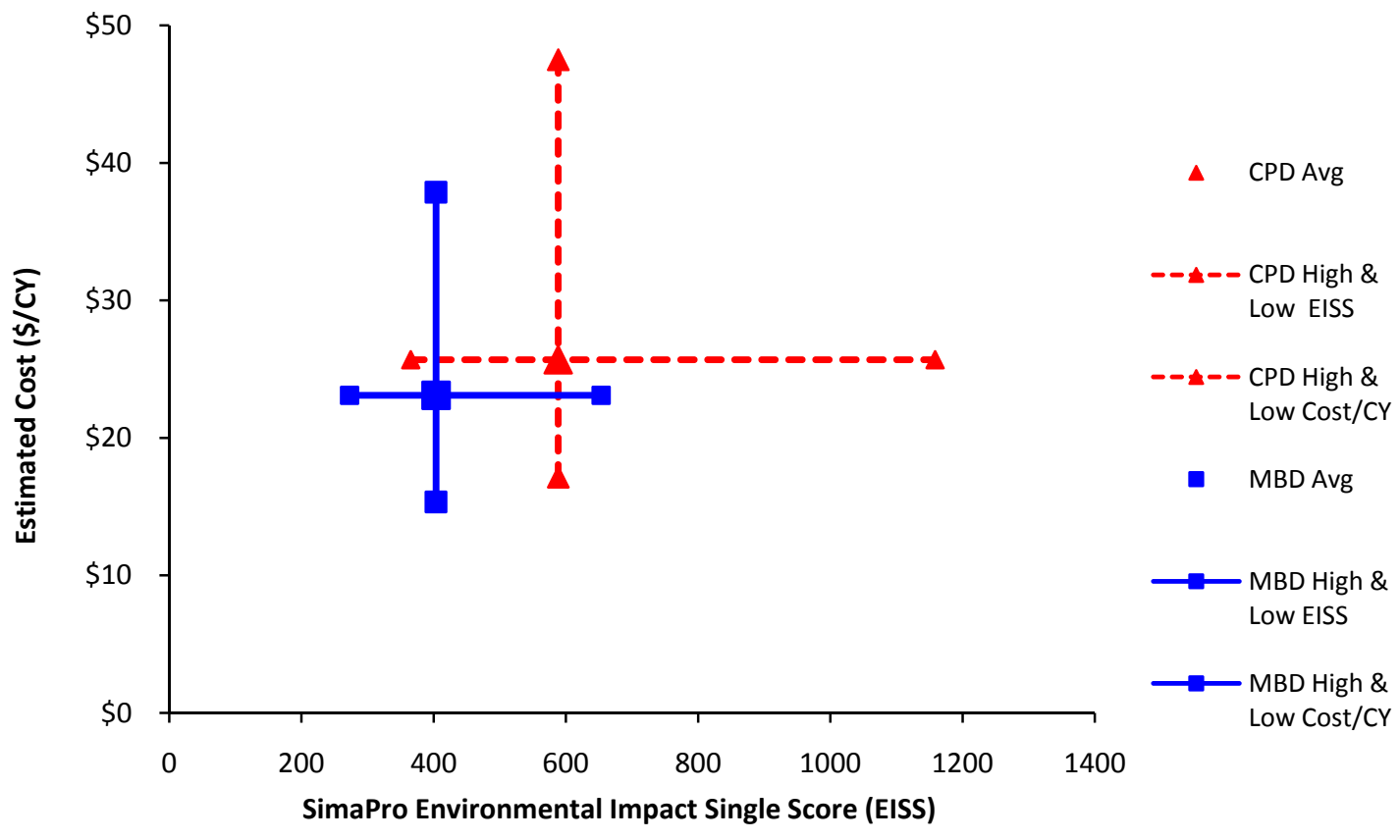

Figure 4.8: EISS vs. Cost $-5,000 \mathrm{CY}$ and $16,000 \mathrm{ft}$ 


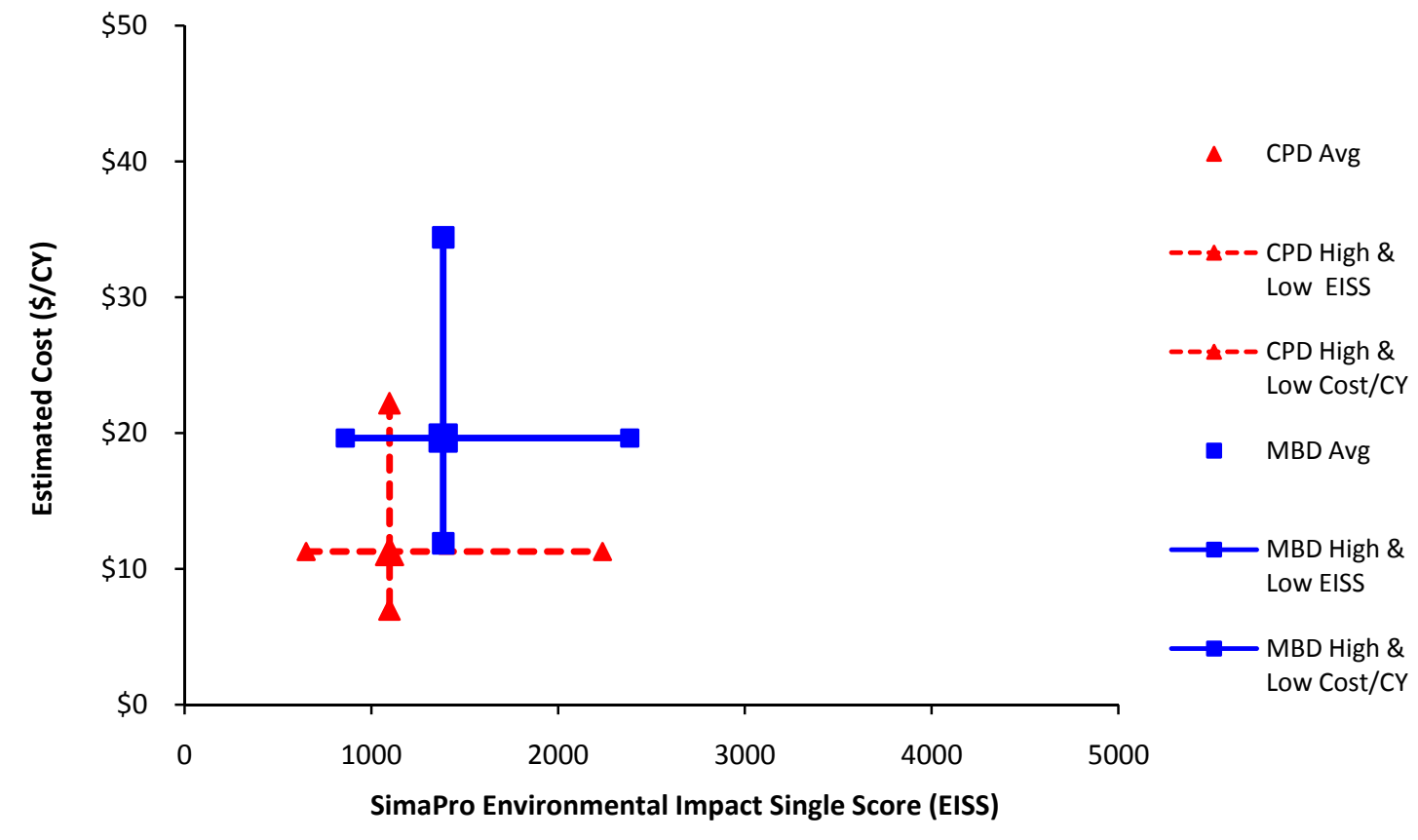

Figure 4.9: EISS vs. Cost - 20,000 CY and 8,000 ft

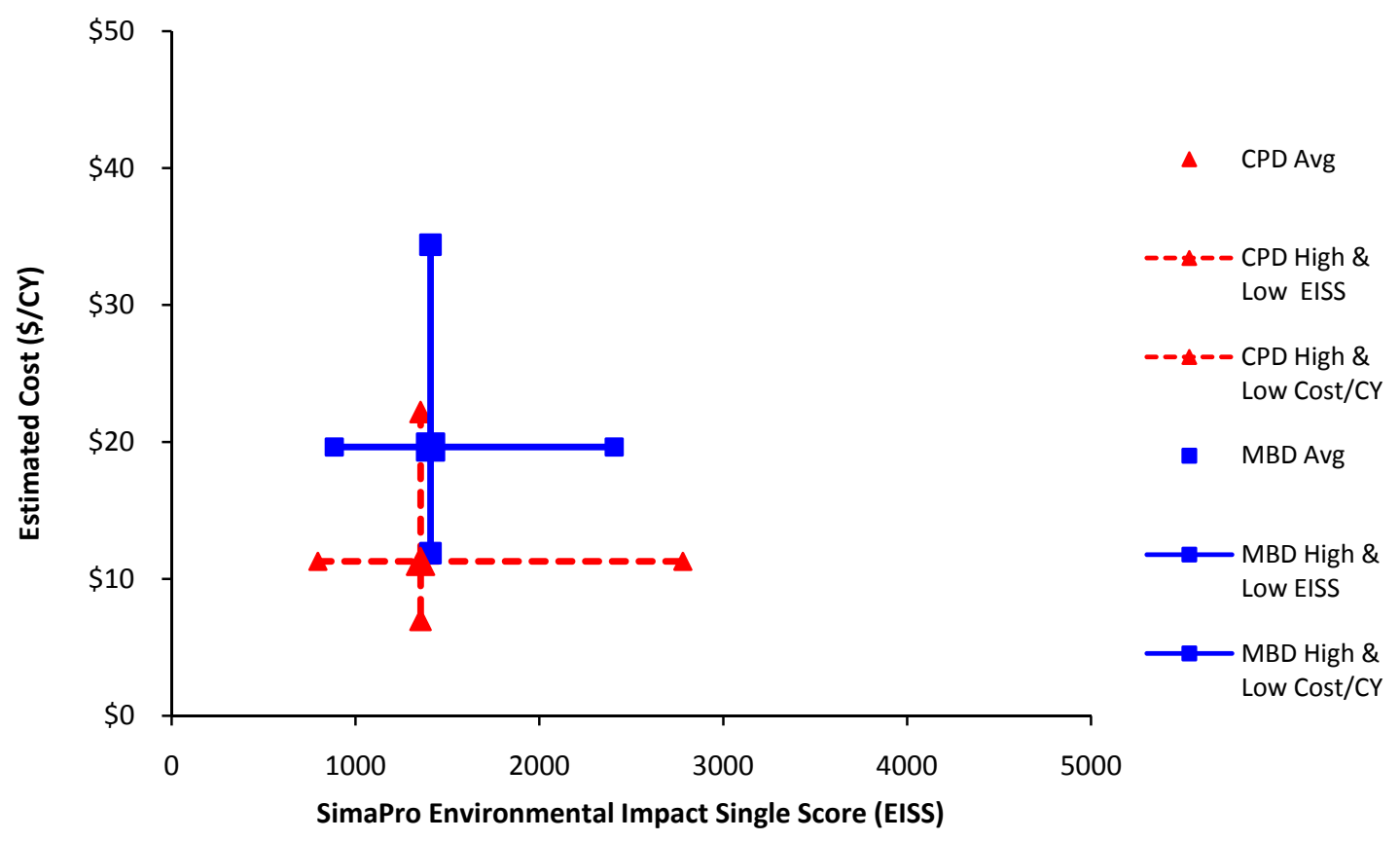

Figure 4.10: EISS vs. Cost - 20,000 CY and 10,000 ft 


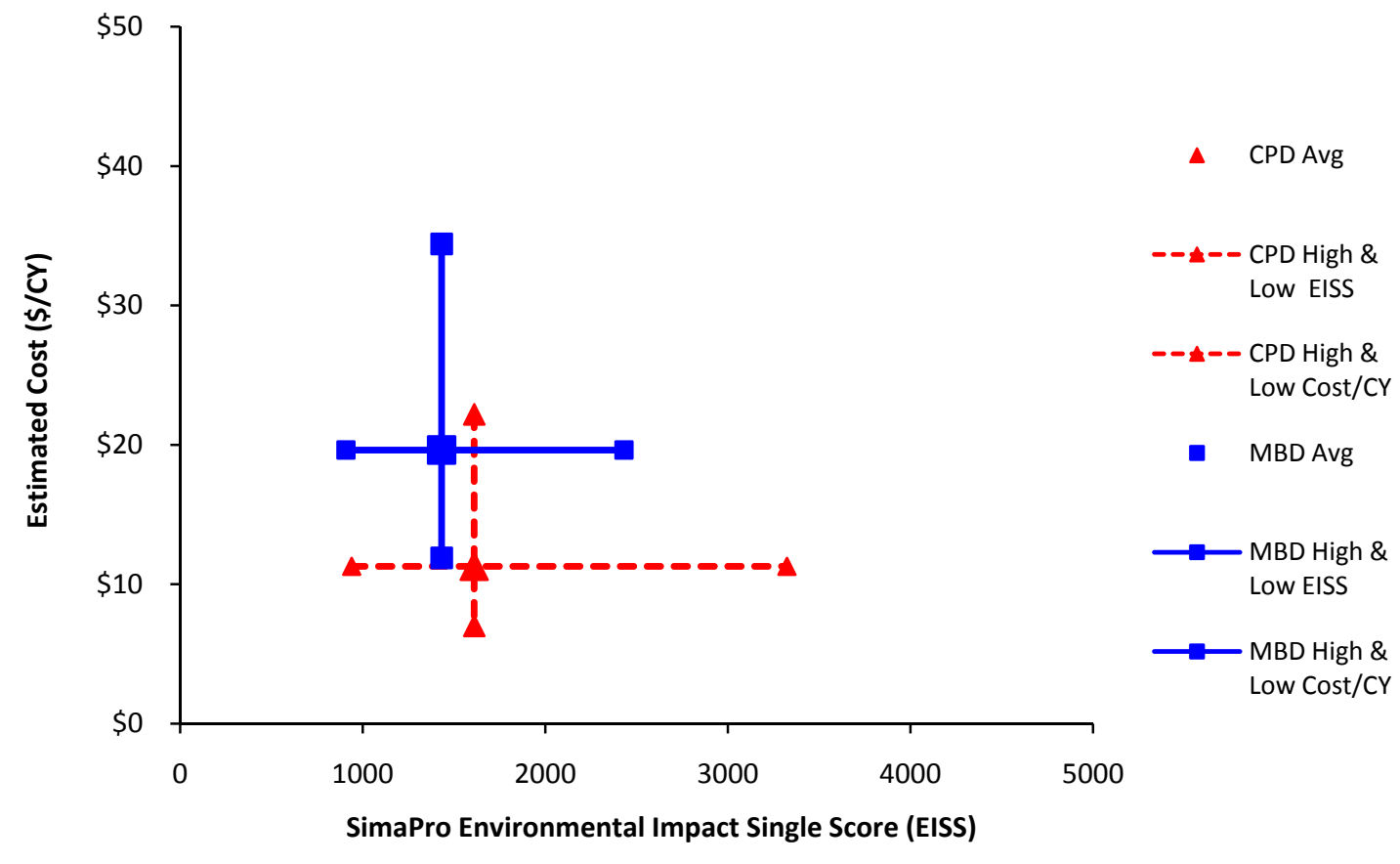

Figure 4.11: EISS vs. Cost - 20,000 CY and 12,000 ft

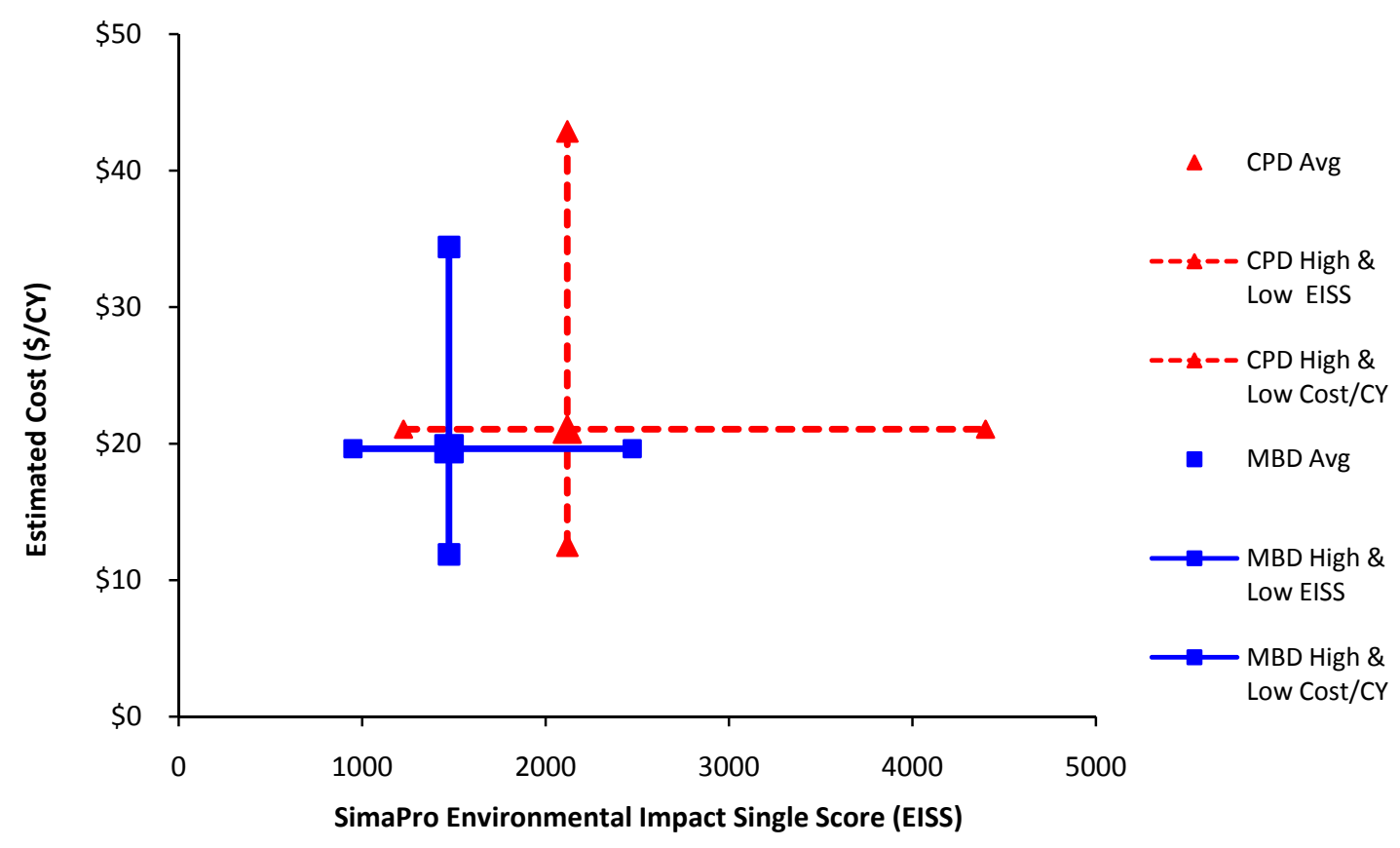

Figure 4.12: EISS vs. Cost $-20,000 \mathrm{CY}$ and $16,000 \mathrm{ft}$ 


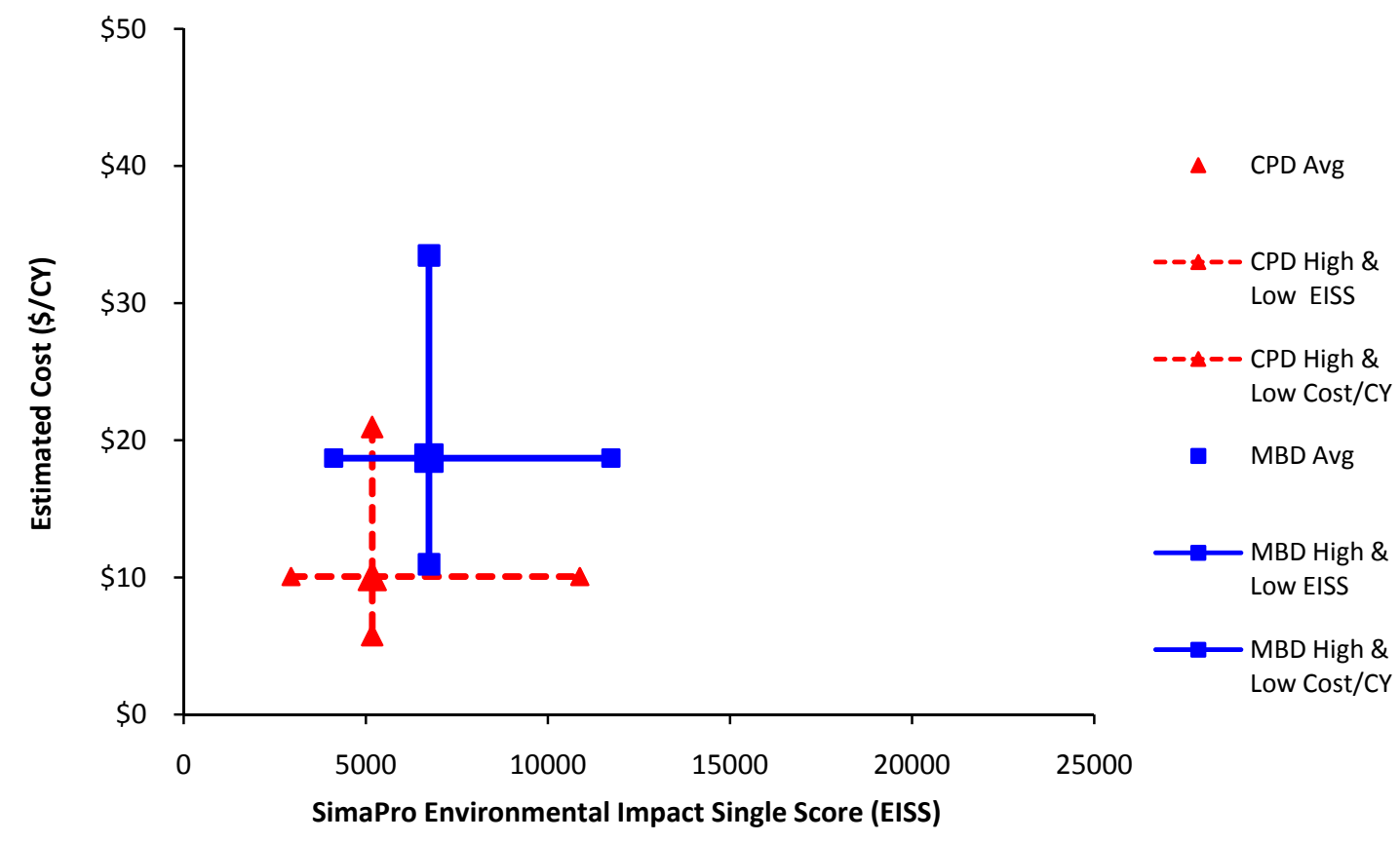

Figure 4.13: EISS vs. Cost $-100,000 \mathrm{CY}$ and $8,000 \mathrm{ft}$

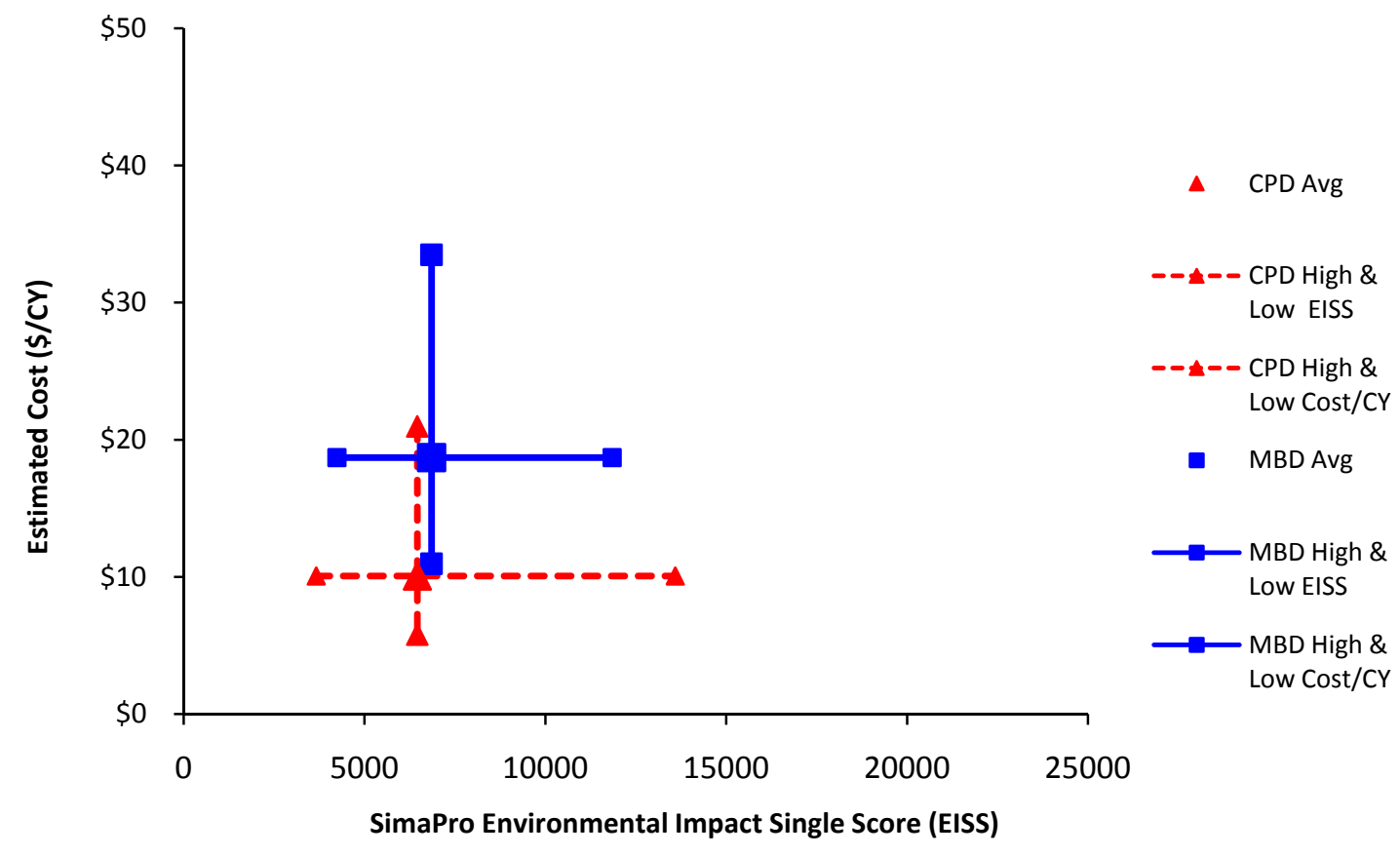

Figure 4.14: EISS vs. Cost - 100,000 CY and 10,000 ft 


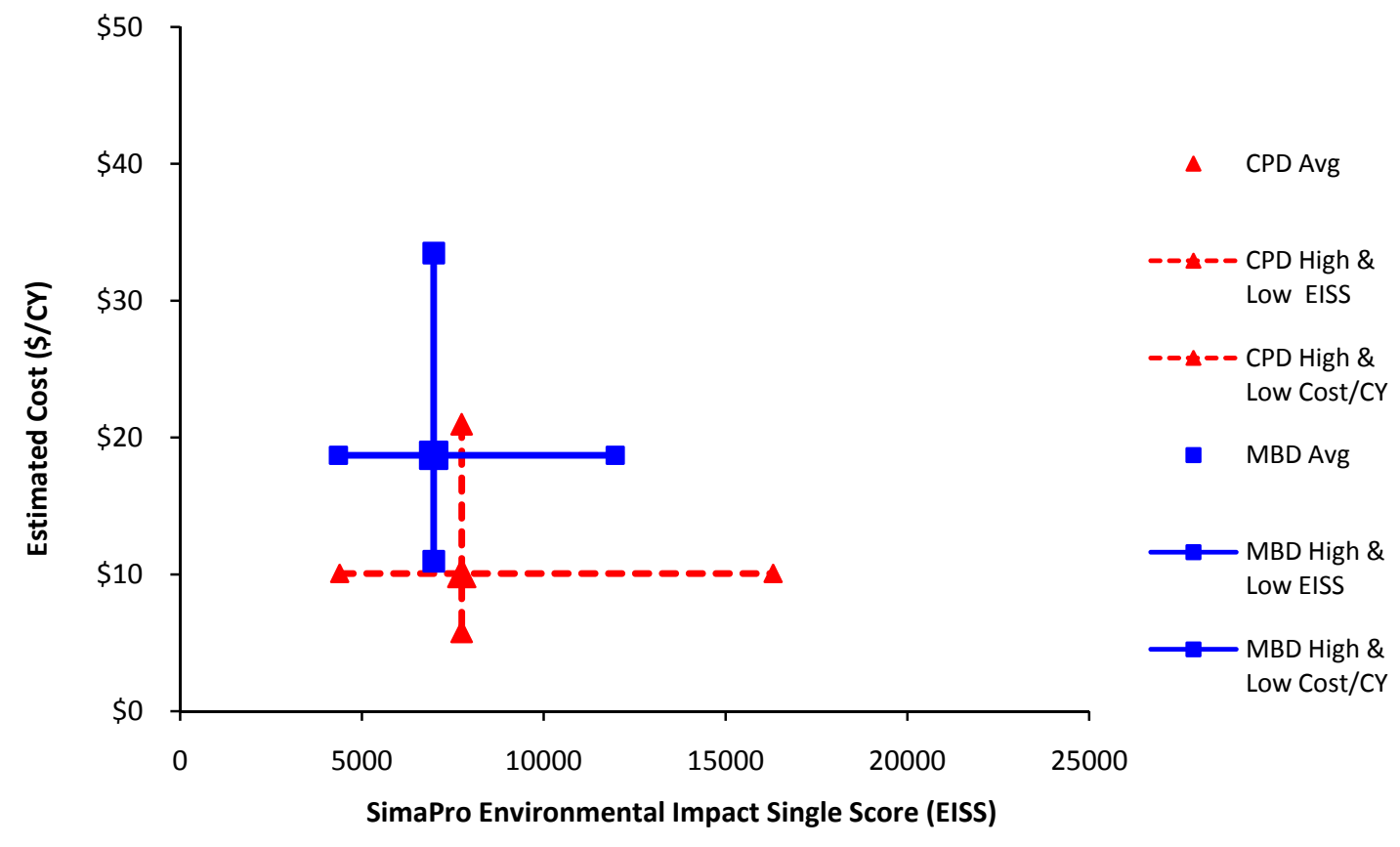

Figure 4.15: EISS vs. Cost $-100,000 \mathrm{CY}$ and $12,000 \mathrm{ft}$

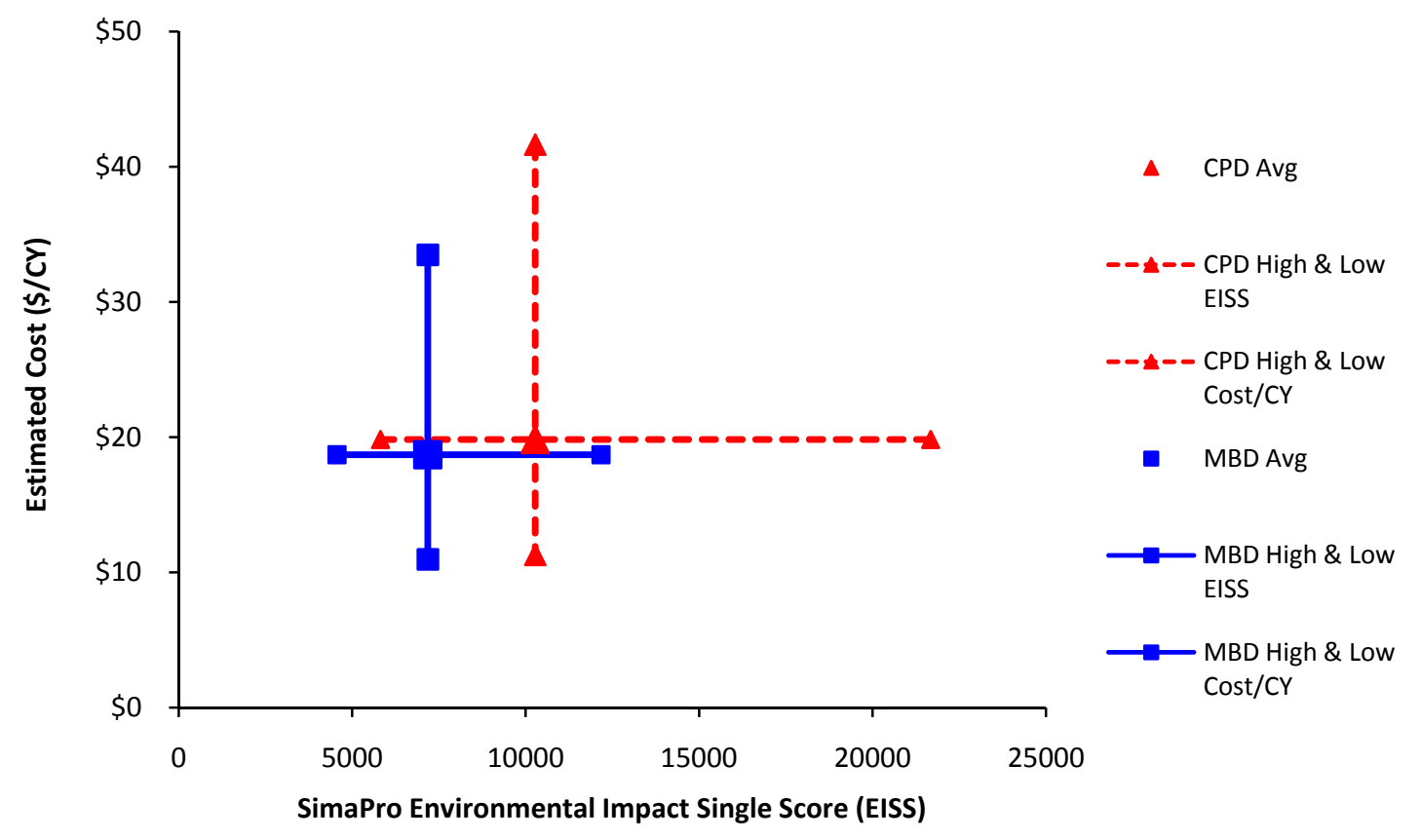

Figure 4.16: EISS vs. Cost $-100,000 \mathrm{CY}$ and $16,000 \mathrm{ft}$ 


\subsection{EISS and Cost per CY versus Transport Distance}

A range of dredged material volumes are the basis for these graphs. For each quantity there are four graphs (Figures $4.17-4.32$ ), one that includes all three production rates and then three more, one for each production rate. All of the graphs are formatted the same for continuity. Dashed lines represent the EISS versus transport distance while the solid lines are for the cost per $\mathrm{CY}$ versus transport distance. The solid markers indicate the cutterhead pipeline dredge and the open markers signify the mechanical bucket dredge. The production rates are indicated by the shape of the markers, square for the low production rate, diamond markers for the average production rate, and triangular for the high production rate. Colors are distinctive and consistent throughout the graphs with each combination of dredge type, production rate, and cost or EISS have its own color of line and marker. The scales are consistent for each volume of dredged material but do change as the volume increases, similar to the EISS versus cost per CY graphs. The "all production rate" graphs show how a dredge's rate of production impacts the EISS and cost per CY across all transport distances considered. If, however, the rate of production for both the cutterhead pipeline and mechanical bucket dredges are known then a graph focusing on only one production rate is cleaner and easier to read. This graph illustrates how the EISS and cost for both dredge crews compares as transport distances increase. Decision-makers can then easily see and select the type of dredge that will have the lowest adverse impacts to air quality and cost per CY for a specific dredging project.

\subsubsection{1,000 CY of Dredged Material}

For a small volume of dredged material, such as the 1,000 CY scenario, and a high production rate (Figure 4.18) clearly shows that the mechanical bucket dredge has a lower EISS and cost per CY across all transport distances. As the production rate decreases to the average level the mechanical bucket dredge continues to have a lower EISS for all distances (Figure 4.19). The cost per CY is slightly lower, but could be considered comparable, for the cutterhead pipeline dredge for all transport distances except where double-handling is required. At the 16,000 foot distance the mechanical bucket dredge has a lower cost per CY. A low production rate yields similar results to the average rate with one exception (Figure 4.20). The difference in cost per CY for $8,000,10,000$, and 12,000 foot transport distances is greater and could no longer be considered comparable. For these three distances the cutterhead pipeline dredge has a lower cost per CY.

At a high production rate the mechanical bucket dredge would clearly be the better choice from both an air quality and economic perspective for all transport distances (Figure 4.18). The mechanical bucket dredge would have lower adverse impacts to air quality for the average production rate with a comparable to lower cost per CY depending on the transport distance, making it preferable over the cutterhead pipeline dredge (Figure 4.19). At a low production rate the decision-maker would have to make a choice between lower EISS or cost for all transport distances except 16,000 feet where the mechanical bucket dredge yields lower air emissions at a lower cost per CY (Figure 4.20). 


\subsubsection{5,000 CY of Dredged Material}

When the quantity of dredged material is increased to 5,000 CY some of the decision points become a little less clearly defined. At the high production rate the cutterhead pipeline dredge has an advantage over the mechanical bucket dredge in the cost per CY for transport distance less than or equal to 12,000 feet (Figure 4.22). This reverses at 16,000 feet with the mechanical bucket dredge having a lower cost. The EISS for the cutterhead pipeline dredge is lower at 8,000 feet and is comparable between the two dredge types at 10,000 feet (Figure 4.22). The cutterhead pipeline dredge EISS increases as the transport distance extends while the mechanical bucket dredge has an almost constant EISS resulting in a lower EISS for the mechanical bucket dredge at 12,000 and 16,000 feet (Figure 4.22). When an average production rate is considered the mechanical bucket dredge has a slightly higher EISS at 8,000 feet transitioning to slightly lower at 10,000 feet and increasingly lower as the transport distance increases to 16,000 feet (Figure 4.23). The cost per CY is similar to the high production rate with the advantage in favor of the cutterhead pipeline dredge for all transport distances except 16,000 feet. At a low production rate the cutterhead pipeline dredge has a slightly lower EISS at 8,000 feet increasing to a higher level at 10,000, 12,000, and 16,000 feet (Figure 4.24). The costs per CY results are similar to the average production rate but the differences are more pronounced (Figures 4.23 and 4.24).

The cutterhead pipeline dredge would be the better choice at a short transport distance and also at 10,000 feet with a high production rate due to a lower cost and comparable EISS (Figures 4.22, 4.23 and 4.24). However, at the intermediate transport distances of 10,000 and 12,000 feet a decision-maker would have a choice to make between lower costs or lower EISS regardless of the production rate, except for 10,000 feet at a high production rate, with the difference for both EISS and cost increasing between dredge types as the production rate decreases. When double-handling of the dredged material is required the mechanical bucket dredge has lower EISS and cost per $\mathrm{CY}$ at all production rates making it clearly the better choice (Figures 4.22, 4.23 and 4.24).

\subsubsection{0,000 CY of Dredged Material}

Increasing the volume of dredged material to $20,000 \mathrm{CY}$ results in very little change in the decision points over the 5,000 CY volume values (Figures 4.26, 4.27 and 4.28). At a high production rate with 8,000 and 10,000 foot transport distances the cutterhead pipeline dredge has a lower EISS and cost per CY (Figure 4.26). The cost advantage continues for the cutterhead pipeline dredge at the 12,000 foot distance while the EISS is slightly higher at 12,000 feet. The mechanical bucket dredge has a lower EISS and slightly lower cost per CY when a 16,000 foot distance is considered. The two types of dredges compare similarly when moving from a high to an average production rate (Figures 4.26 and 4.27). The low production rate results in a slightly lower EISS at 8,000 feet for the cutterhead pipeline dredge but the mechanical bucket dredge has an increasing advantage once the transport distance reaches 10,000 feet and greater (Figure 
4.28). The cost per CY is lower for the cutterhead pipeline dredge for distances less than or equal to 12,000 feet but the mechanical bucket dredge has a lower cost at 16,000 feet.

The cutterhead pipeline dredge would be the logical choice for short transport distances across all production rates and also at 10,000 feet for average and high production rates (Figures 4.26, 4.27 and 4.28). However, low production rates at 10,000 feet and all production rates at 12,000 feet would require a choice between lower impacts to air quality or lower costs (Figures 4.26, 4.27 and 4.28). As with the smaller quantities of dredged material selecting the mechanical bucket dredge would result in lower environmental impacts and costs for the 16,000 foot transport distance at all production rates (Figures 4.26, 4.27 and 4.28).

\subsubsection{0,000 CY of Dredged Material}

For a large volume of dredged material such as the $100,000 \mathrm{CY}$ used in this study the mechanical bucket dredge has a lower EISS for the 12,000 and 16,000 foot transport distances at all production rates except for 12,000 feet with a high production rate where both dredges have a comparable EISS (Figures 4.30, 4.31 and 4.32). At 10,000 feet the mechanical bucket dredge EISS ranges from slightly higher than a cutterhead pipeline dredge for a high production rate to lower at the low rate. The cutterhead pipeline dredge has a lower EISS for all production rates at an 8,000 foot transport distance. The cost per $\mathrm{CY}$ for the cutterhead pipeline dredge is lower for all production rates at 8,000 to 12,000 feet and comparable to higher at 16,000 feet.

Selection of the cutterhead pipeline dredge for an 8,000 foot transport distance at all production rates would result in lower air emissions and cost per CY (Figures 4.30, 4.31 and 4.32). At 10,000 feet the cutterhead pipeline dredge has a lower EISS and cost for average and high production rates, making it the logical choice (Figures 4.30 and 4.31). The cutterhead pipeline dredge has a comparable EISS and lower cost per CY at 12,000 feet with a high production rate (Figure 4.30). If a low production rate is being considered then a choice would need to be made between lower air emissions and cost at both the 10,000 and 12,000 foot distances (Figure 4.32). A similar choice would be necessary at 12,000 feet for with an average production rate (Figure 4.31). In the case of a 16,000 foot transport distance the mechanical bucket dredge would have both a lower EISS and cost per CY for all production rates (Figures 4.30, 4.31 and 4.32). 


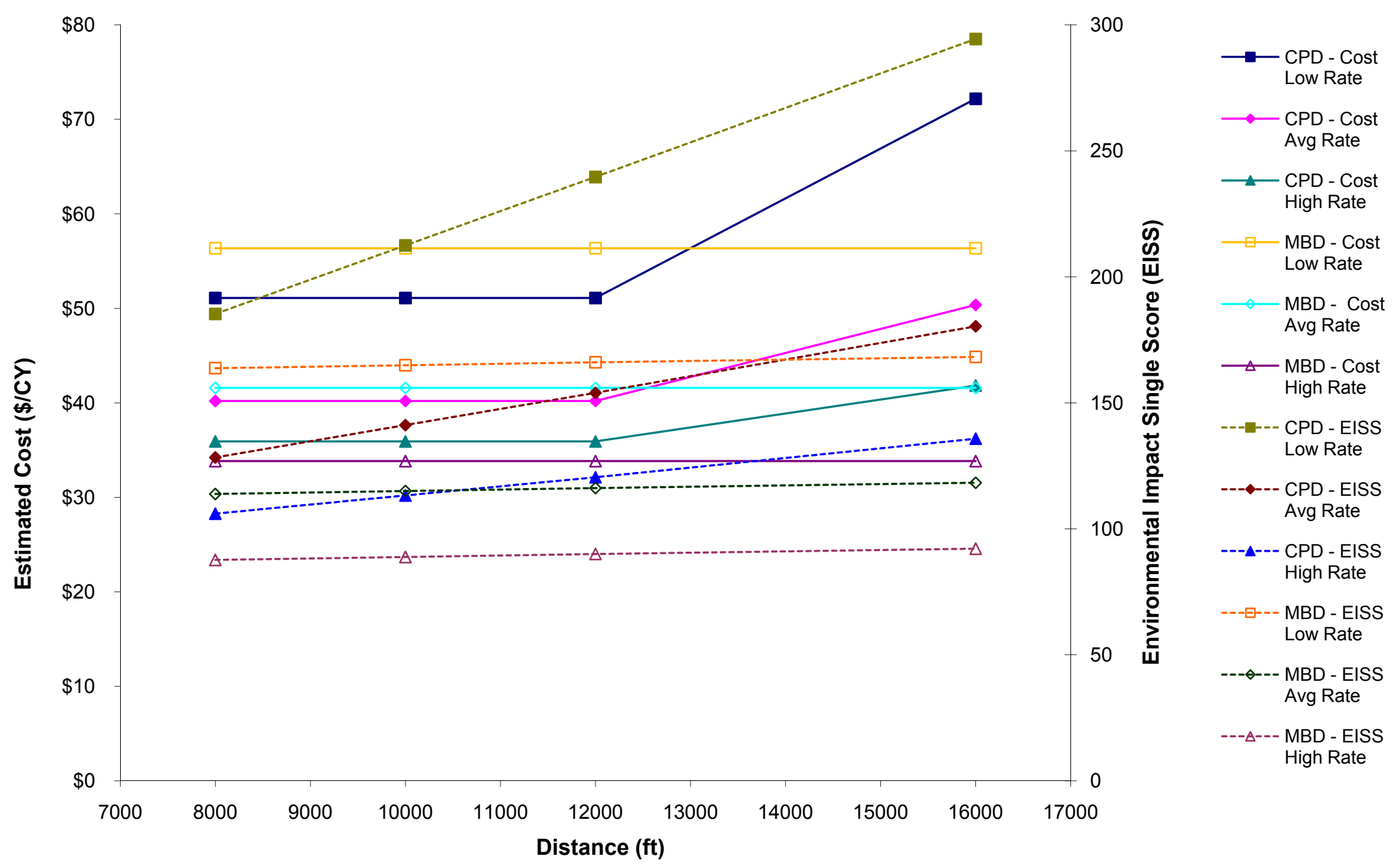

Figure 4.17: EISS and Cost vs. Transport Distance: 1,000 CY - All Production Rates 


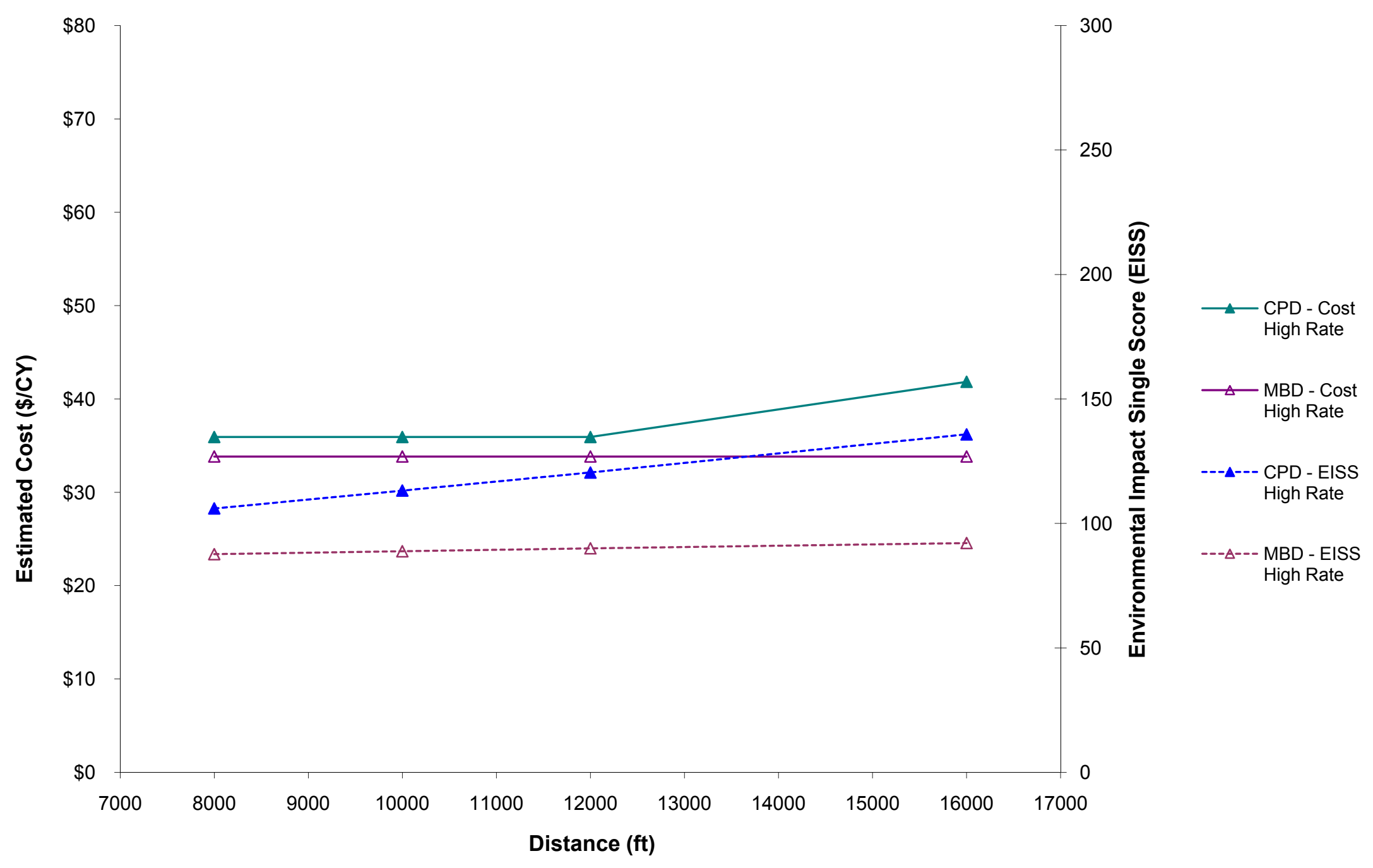

Figure 4.18: EISS and Cost vs. Transport Distance: 1,000 CY - High Production Rate 


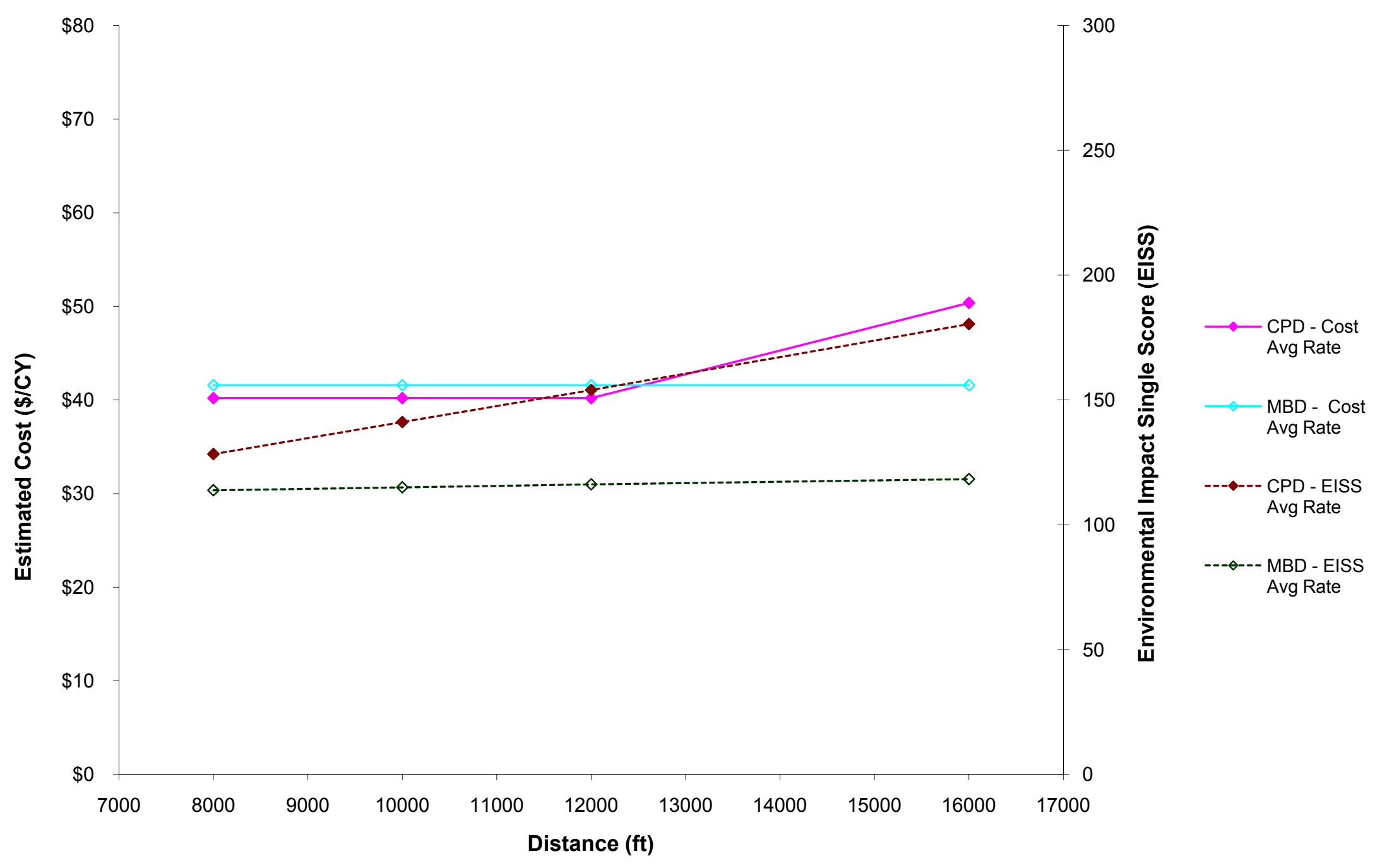

Figure 4.19: EISS and Cost vs. Transport Distance: 1,000 CY - Average Production Rate 


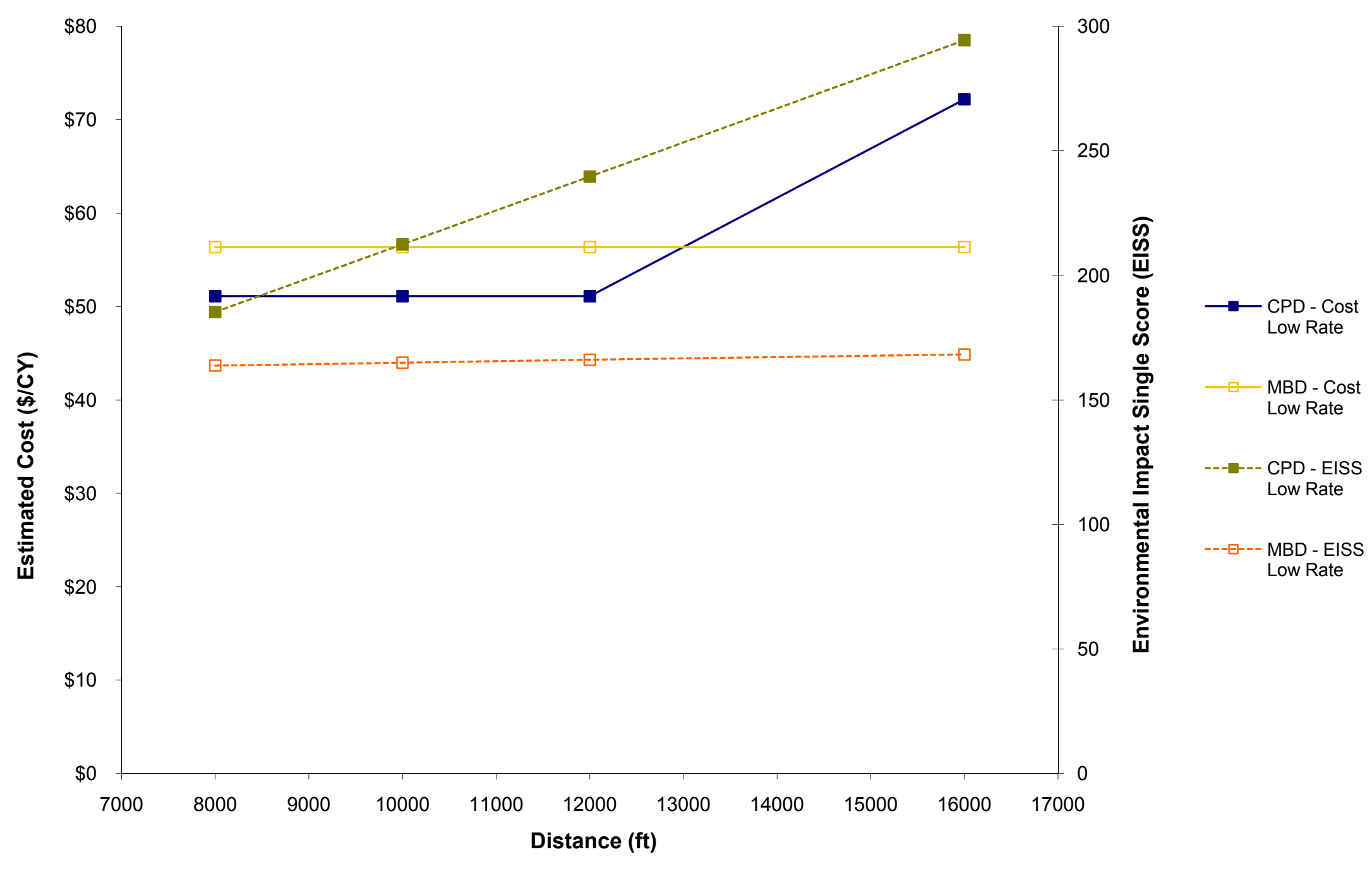

Figure 4.20: EISS and Cost vs. Transport Distance: 1,000 CY - Low Production Rate 


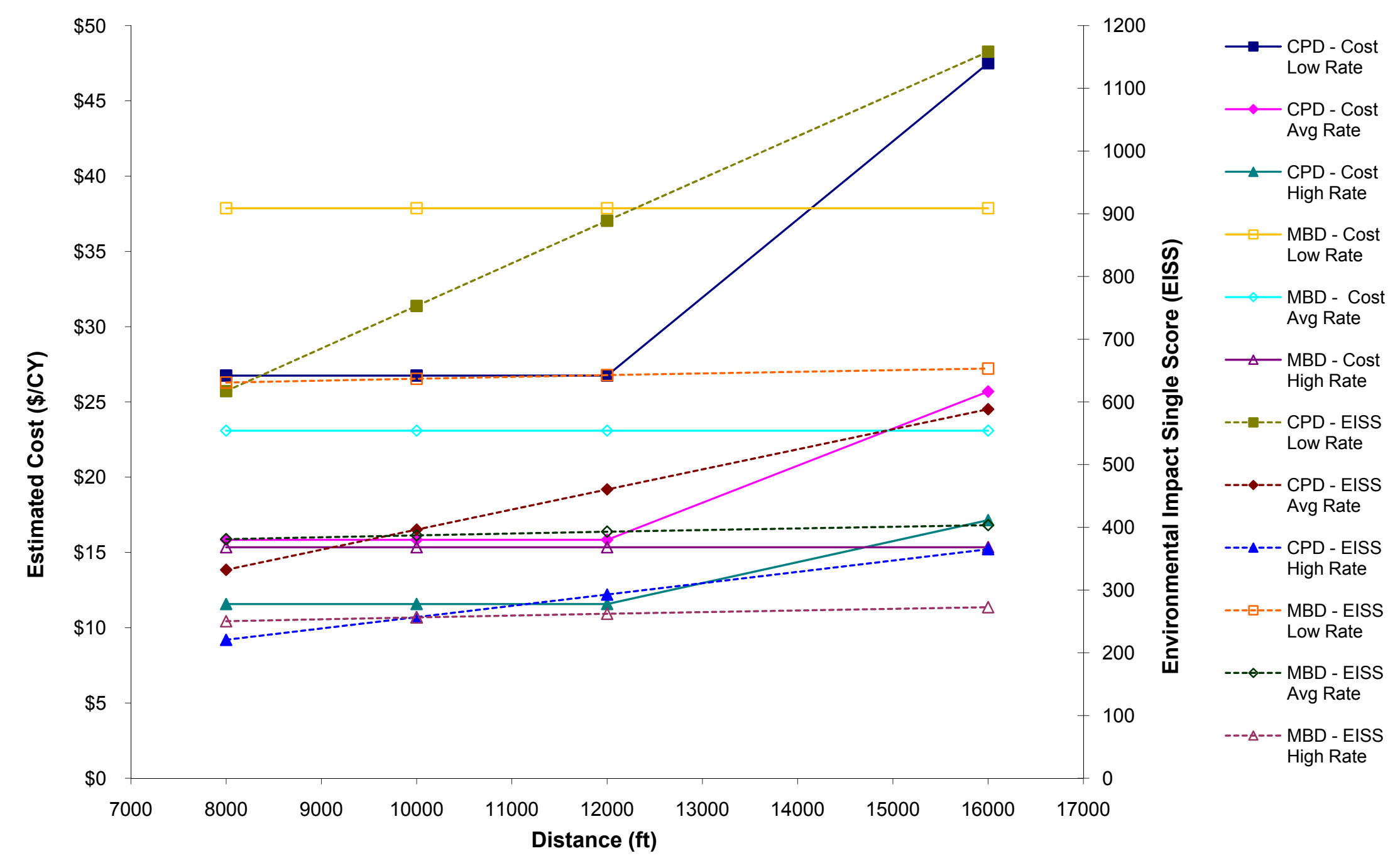

Figure 4.21: EISS and Cost vs. Transport Distance: 5,000 CY - All Production Rates 


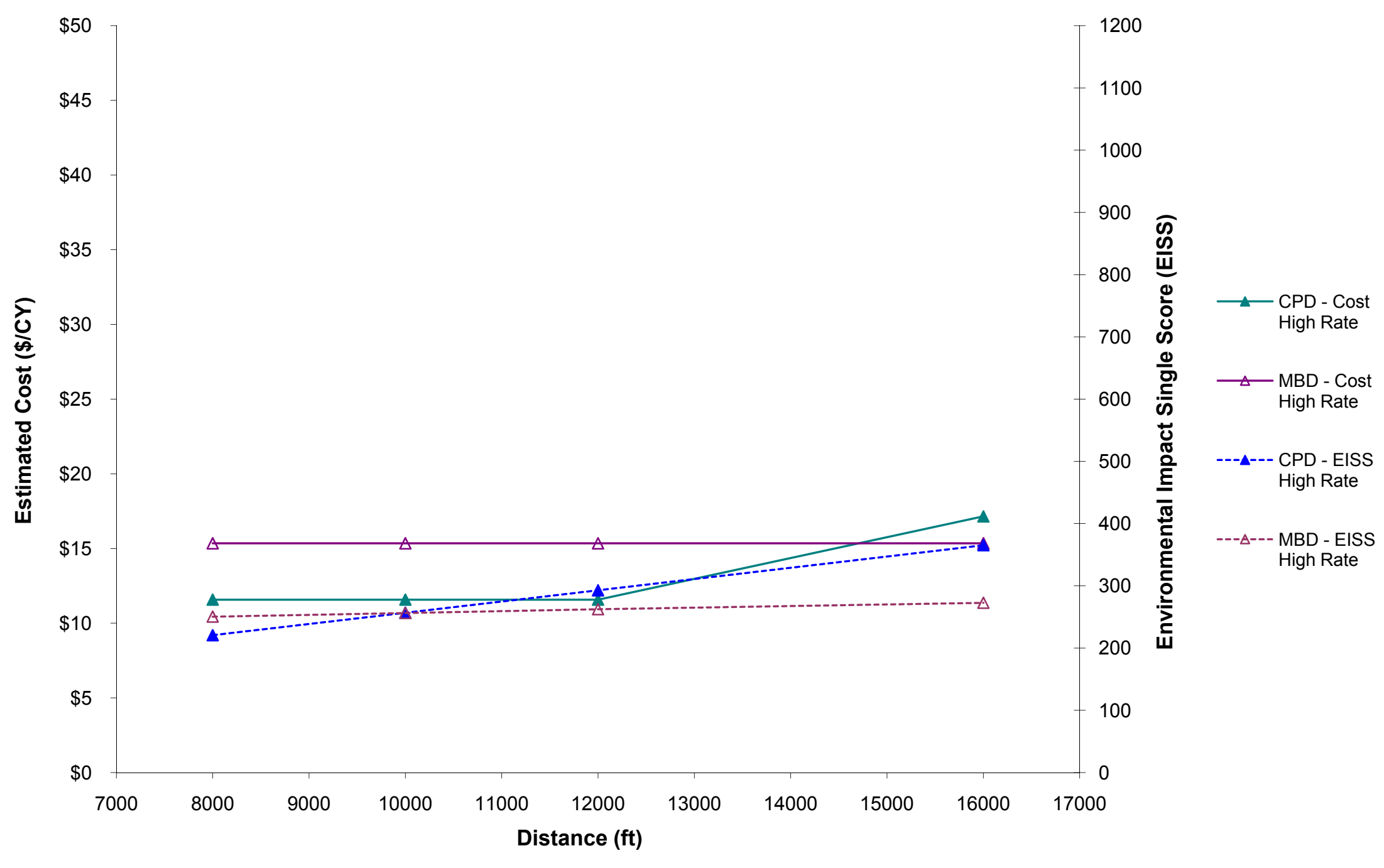

Figure 4.22: EISS and Cost vs. Transport Distance: 5,000 CY - High Production Rate 


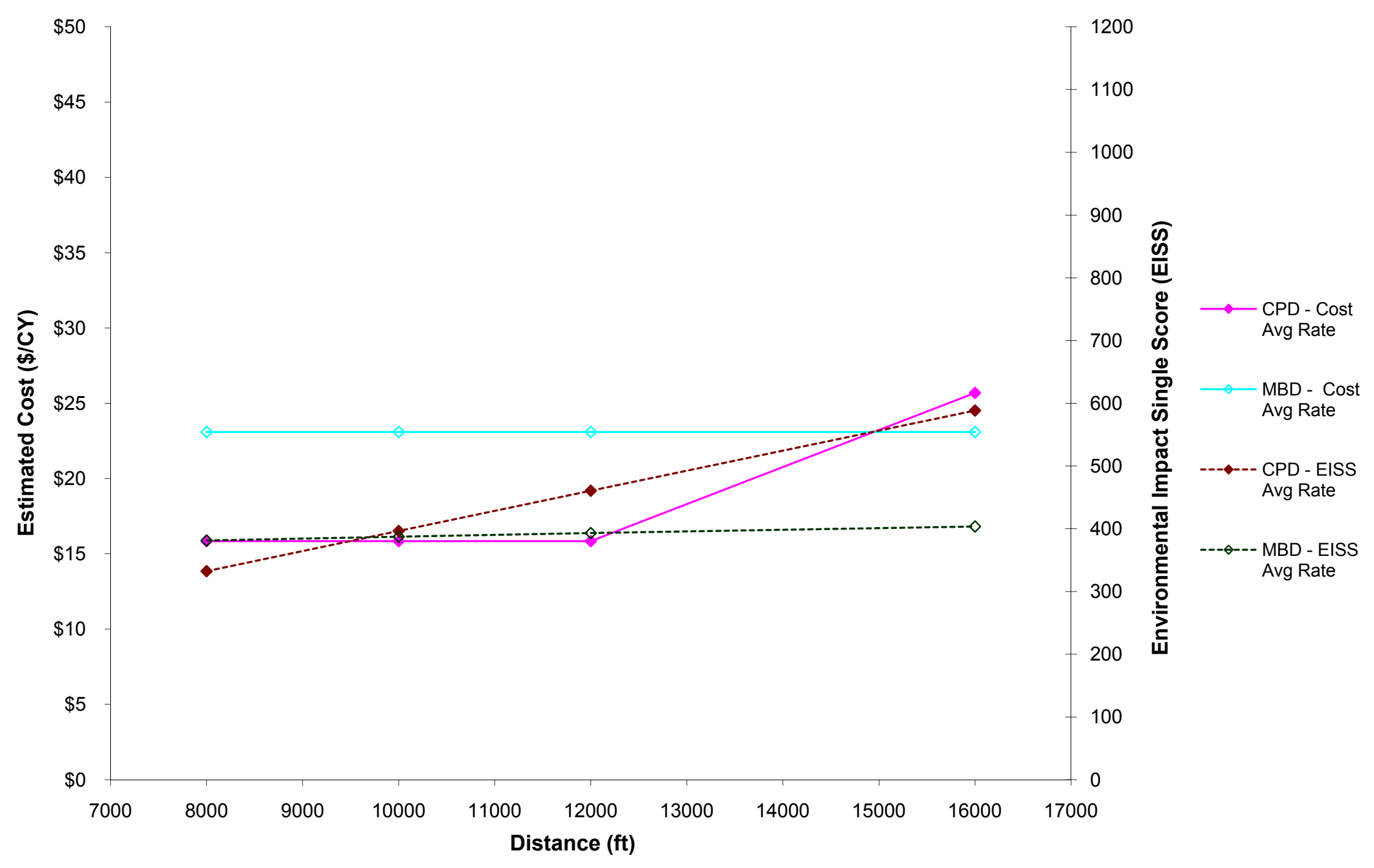

Figure 4.23: EISS and Cost vs. Transport Distance: 5,000 CY - Average Production Rate 


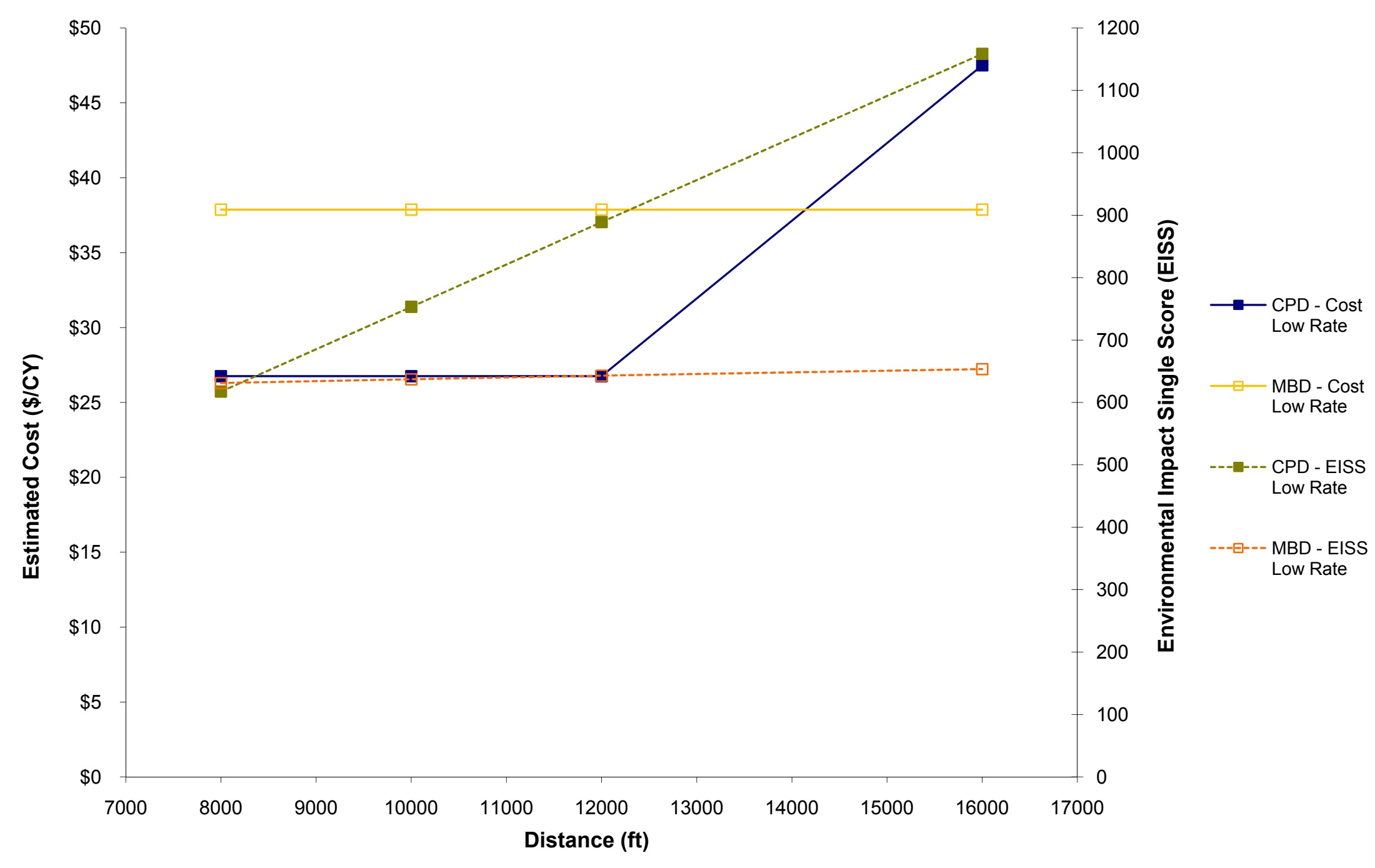

Figure 4.24: EISS and Cost vs. Transport Distance: 5,000 CY - Low Production Rate 


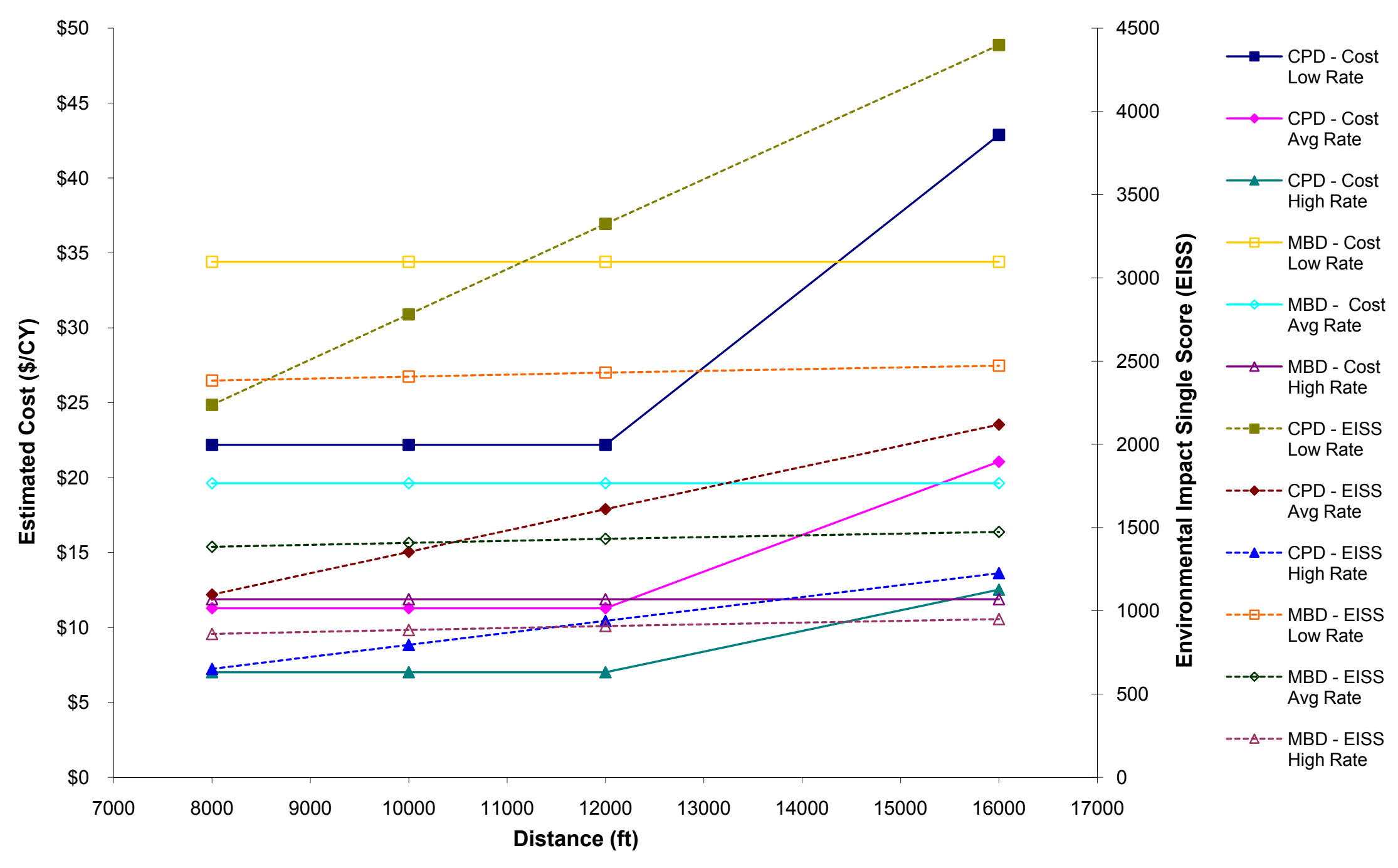

Figure 4.25: EISS and Cost vs. Transport Distance: 20,000 CY - All Production Rates 


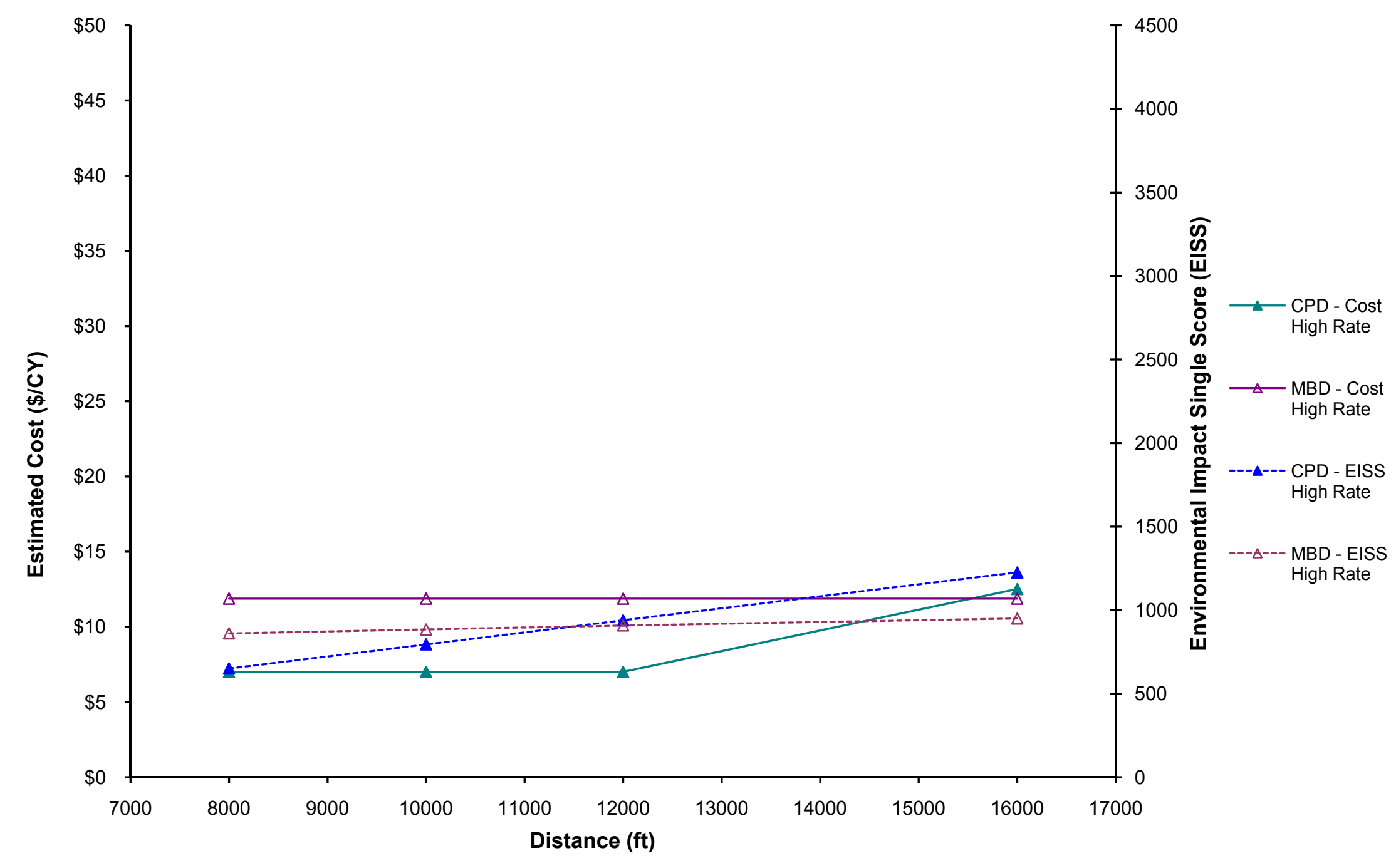

Figure 4.26: EISS and Cost vs. Transport Distance: 20,000 CY - High Production Rate 


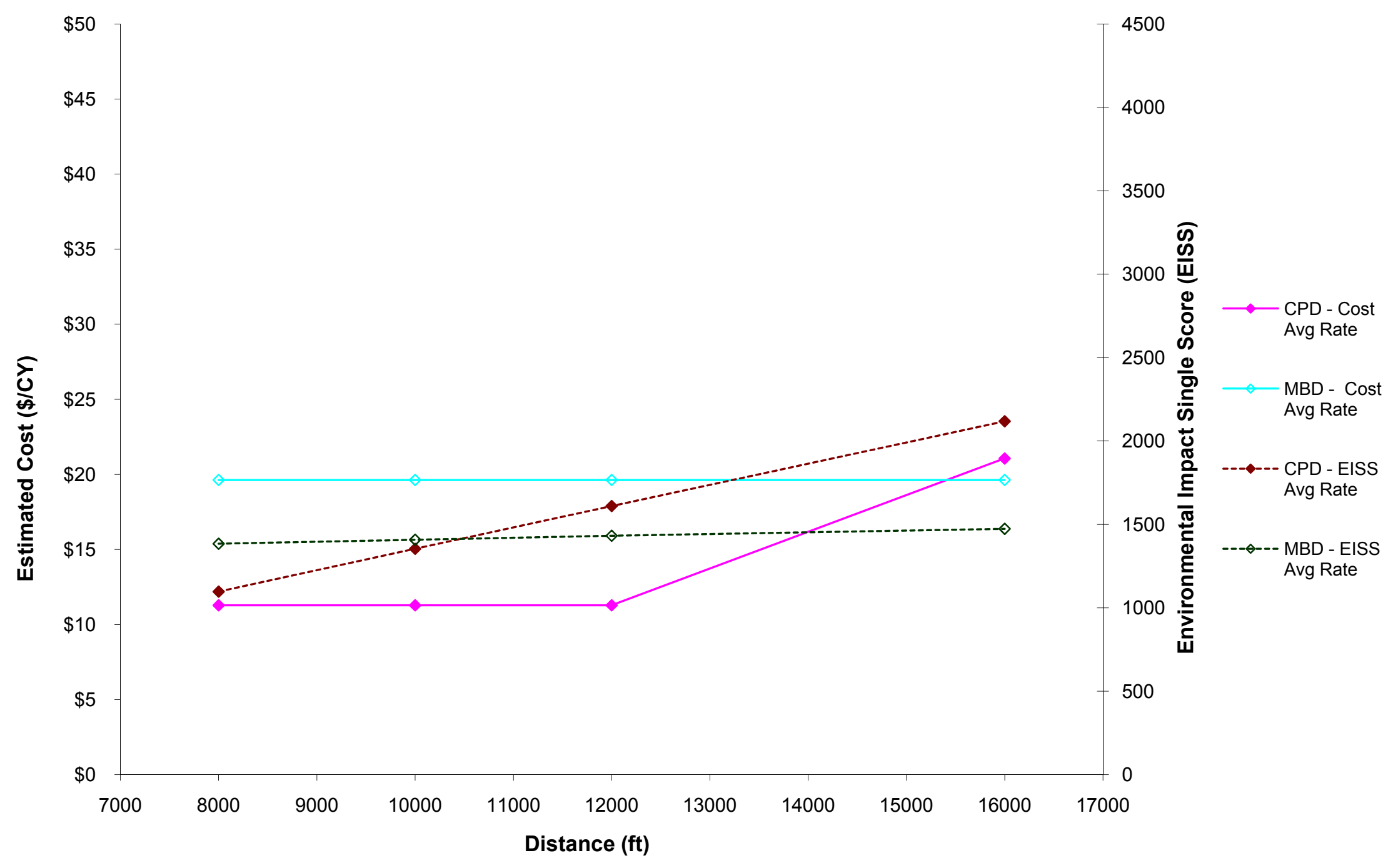

Figure 4.27: EISS and Cost vs. Transport Distance: 20,000 CY - Average Production Rate 


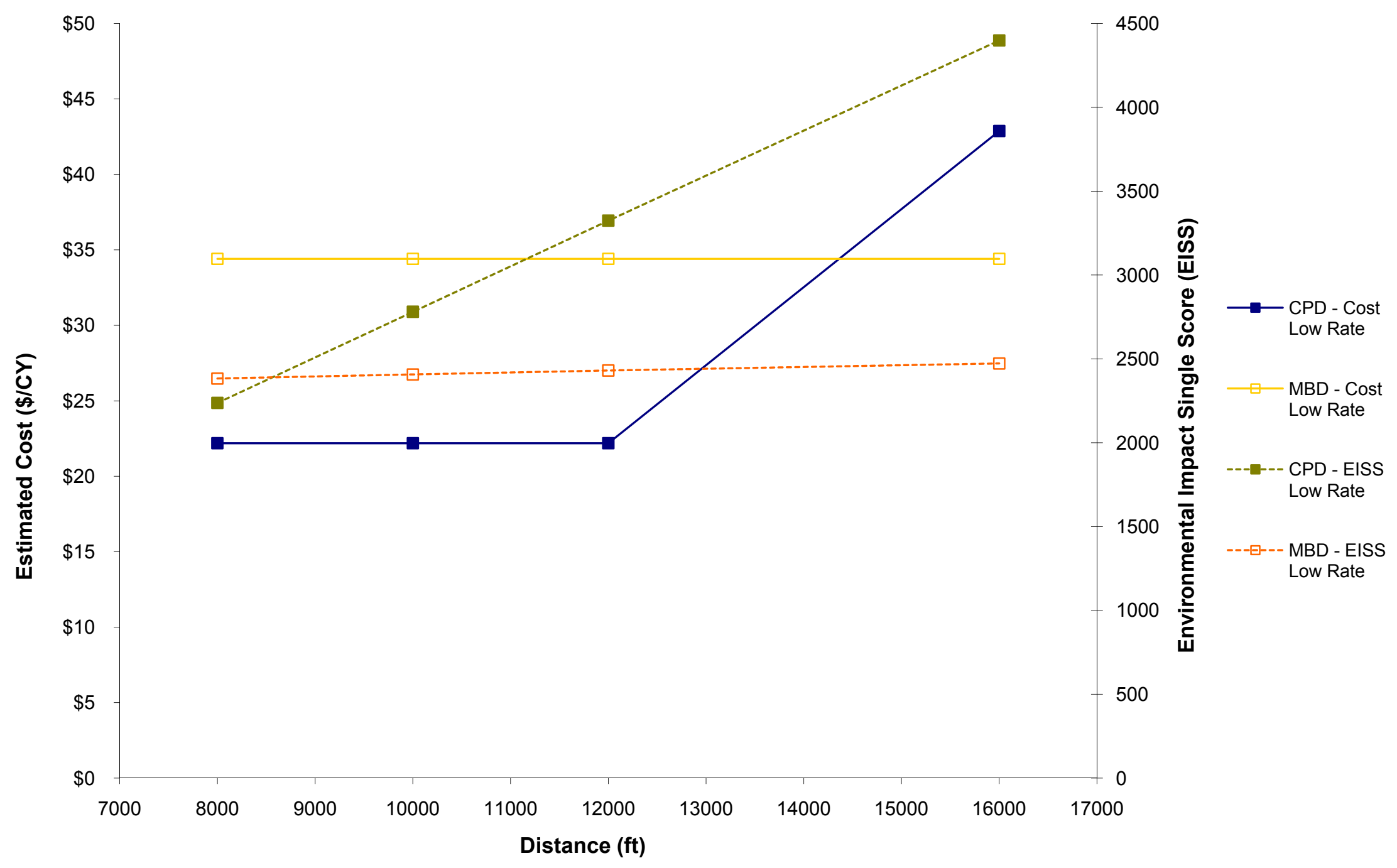

Figure 4.28: EISS and Cost vs. Transport Distance: 20,000 CY - Low Production Rate 


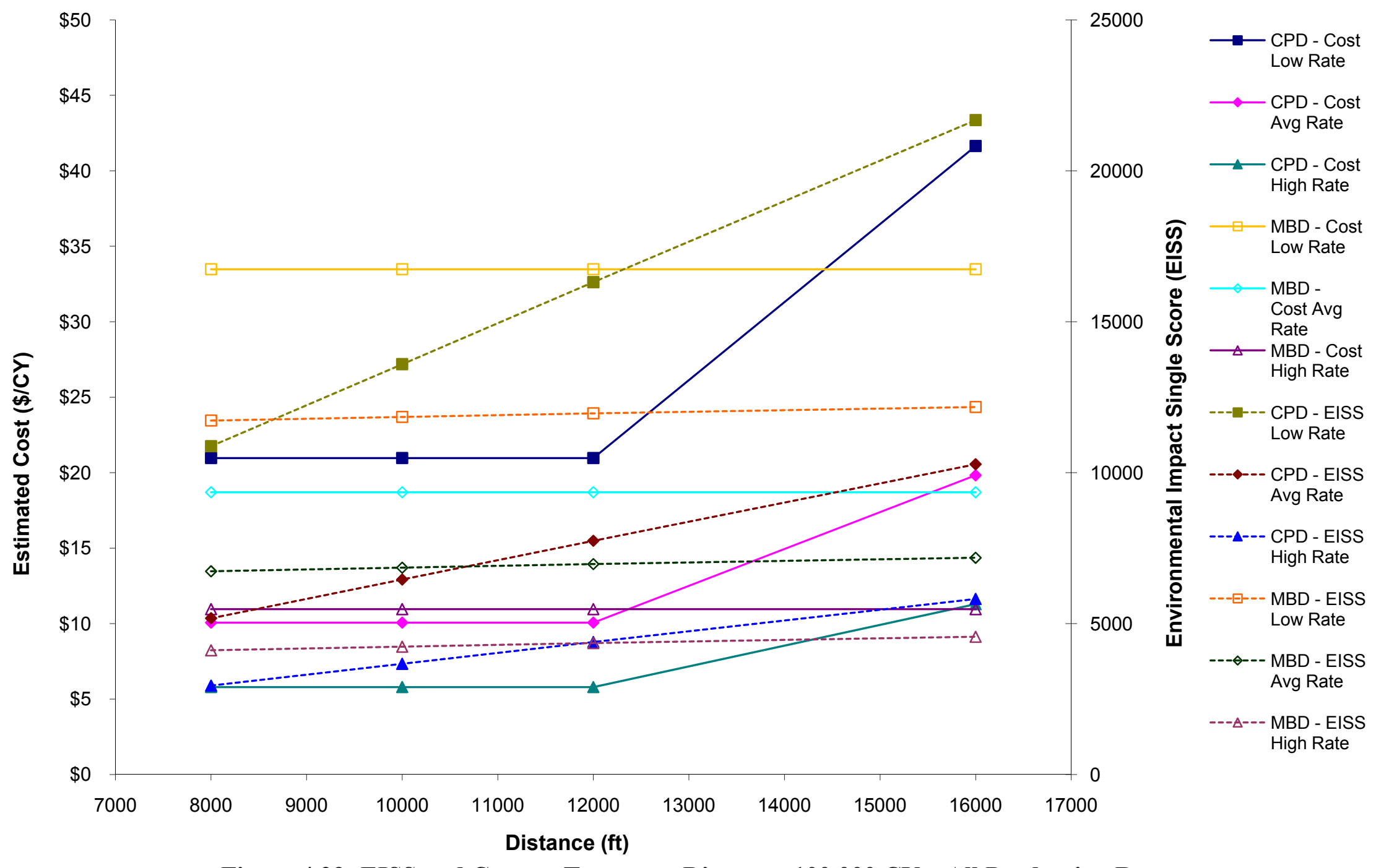

Figure 4.29: EISS and Cost vs. Transport Distance: 100,000 CY - All Production Rates 


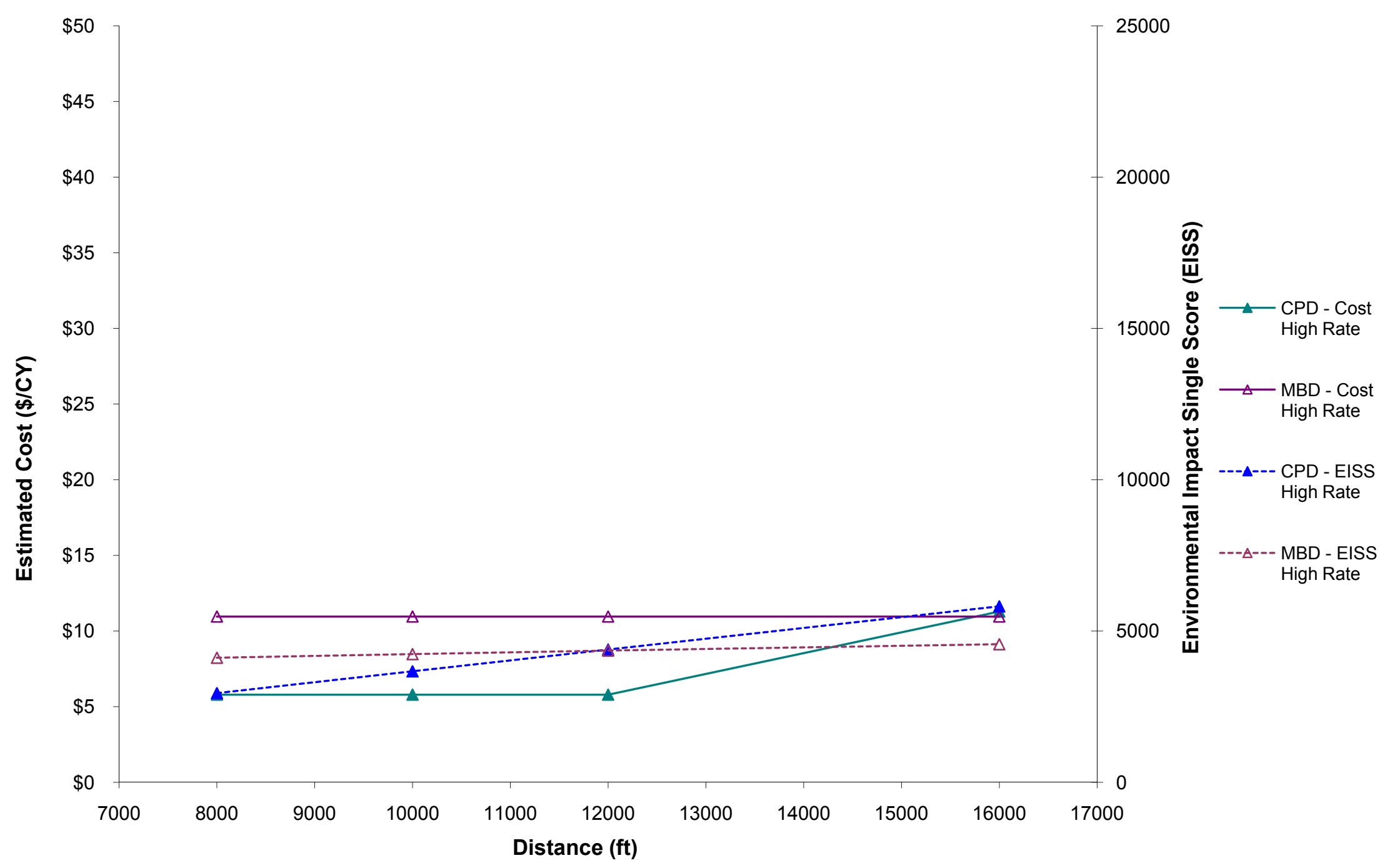

Figure 4.30: EISS and Cost vs. Transport Distance: 100,000 CY - High Production Rate 


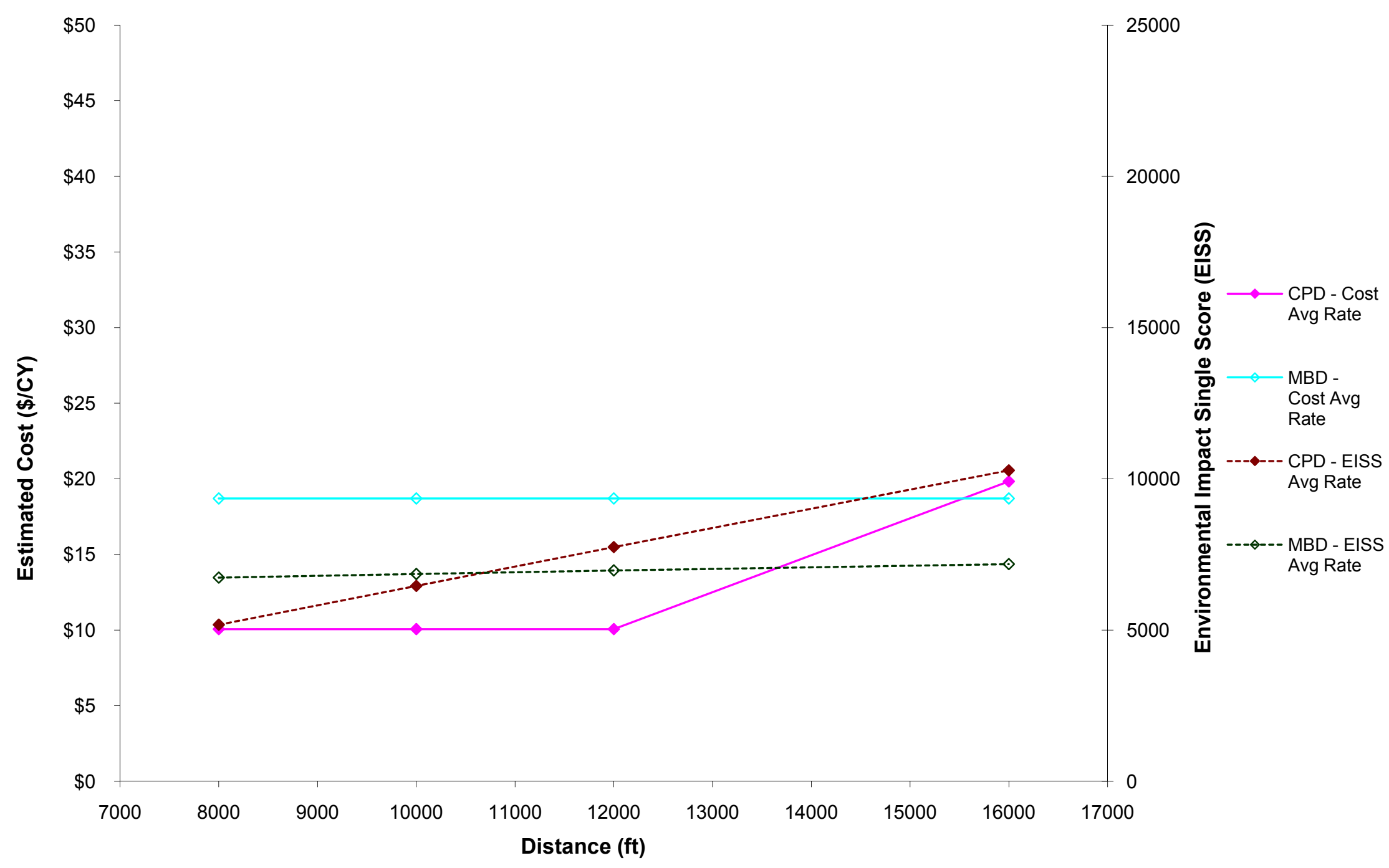

Figure 4.31: EISS and Cost vs. Transport Distance: 100,000 CY - Average Production Rate 


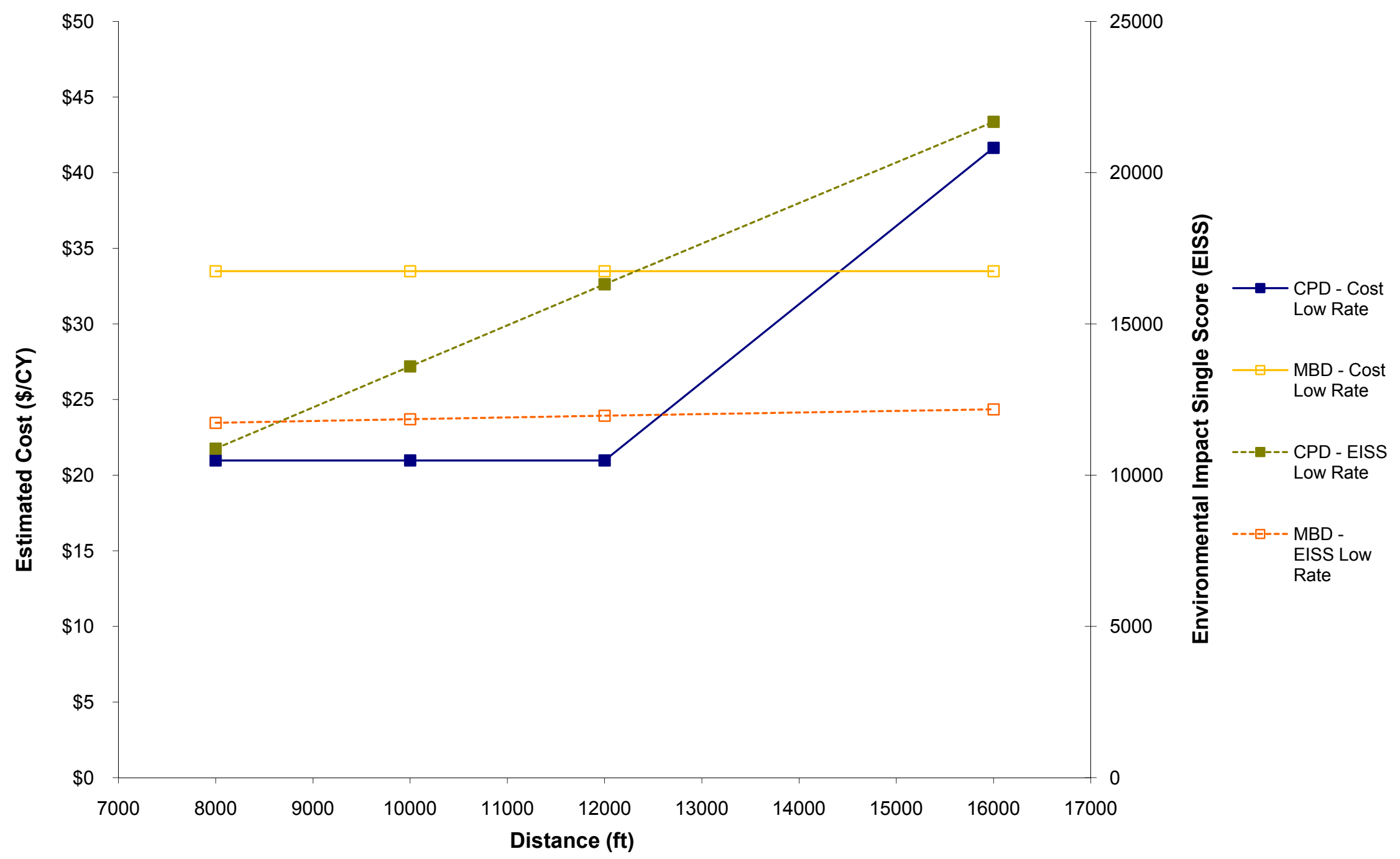

Figure 4.32: EISS and Cost vs. Transport Distance: 100,000 CY - Low Production Rate 


\subsection{Tradeoff Index}

The values of the Tradeoff Index, $I$ are seen in Table 4.3. It can be seen that the selection of a cutterhead pipeline dredge would be preferable for moderate and large volumes of dredged material when no additional booster pumps are required, in this study that includes transport distances less than or equal to 8,000 feet. The addition of one booster pump changes the results to be more dependent on the production rate for transport distances greater than or equal to 12,000 feet with no clear choice for 5,000 CY at all production rates. Increasing the number of booster pumps to two yields "No Clear Choice" across all production rates (Table 4.3).

The production rate has a definite impact on the results. In five of 16 scenarios, or approximately 31 percent, changing the production rate altered the determination from "No Clear Choice" to one of the dredging crews having a lower EISS and cost (Table 4.3). This indicates that the expected production rates are significant factors when evaluating the air emissions from comparable dredging equipment. 
Table 4.3: Dredging Equipment Selection Summary

(High values of $I$ indicate a large change in EISS for a small change in cost)

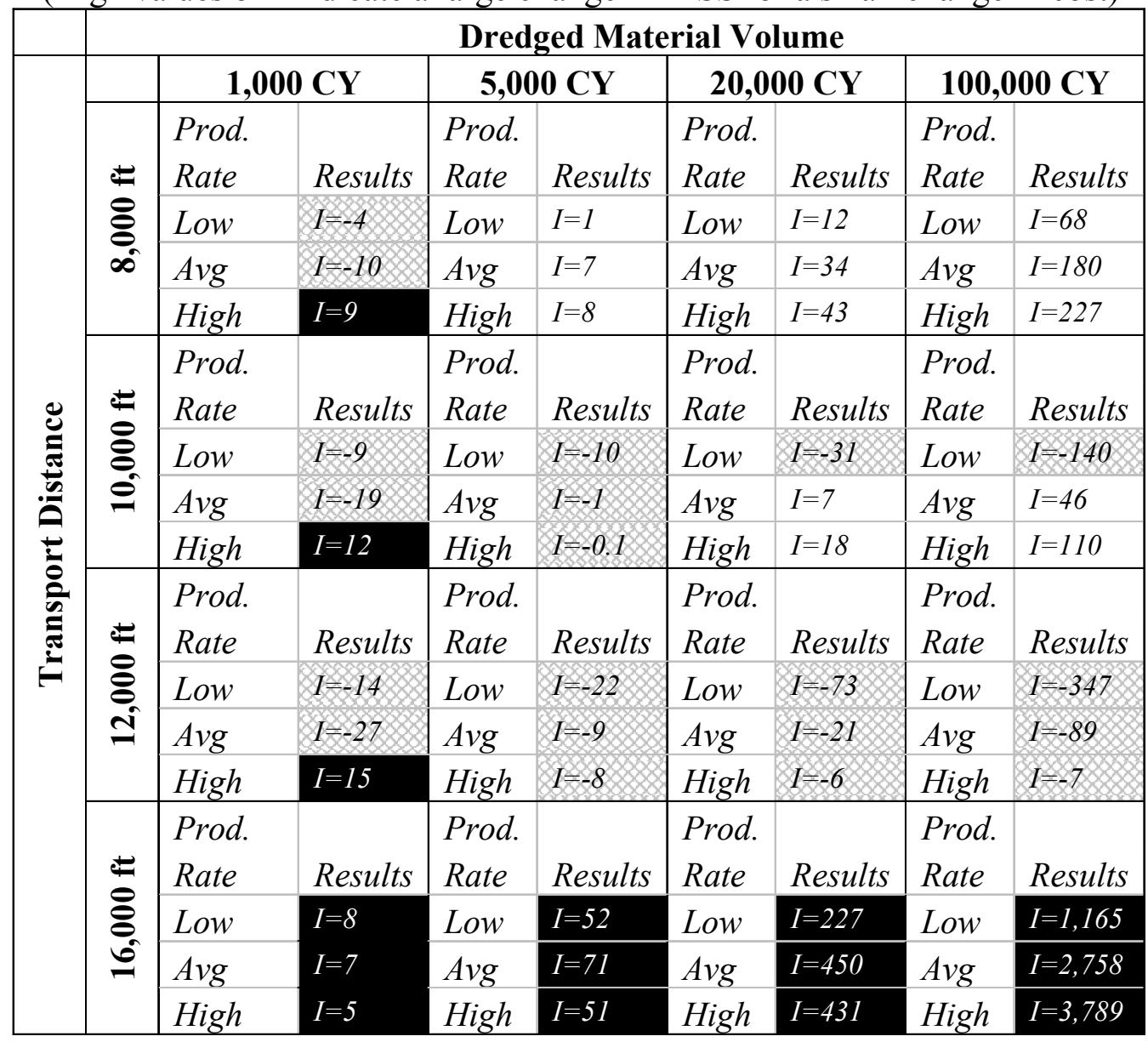

Legend

\begin{tabular}{|l|l|}
\hline $\begin{array}{l}\text { Mechanical Bucket Dredge has Lower EISS } \\
\text { and Lower Cost per CY }\end{array}$ \\
$\begin{array}{l}\text { Cutterhead Pipeline Dredge has Lower EISS } \\
\text { and Lower Cost per CY }\end{array}$
\end{tabular}




\section{CHAPTER 5: SUMMARY AND CONCLUSIONS}

\subsection{Summary}

This study is the first to provide a procedure for evaluating emissions to the atmosphere resulting from the combustion of diesel fuel in commonly used types of dredging equipment. Specifically, the equipment included in this study was a 16-inch cutterhead pipeline dredge and a mechanical bucket dredge used during the 2005 dredging season on the Illinois Waterway (IWW) (Graham 2007/08). Both dredging crews included all of the supporting equipment necessary for mobilization, dredging, dredged material transport, and placement site management operations for all possible scenarios in this study (Table 1.1). The procedure outlined in this study is not limited to the equipment used for navigation channel maintenance dredging in the IWW. It can easily be used for comparison of air emissions between dredging equipment for a wide range of applications.

A total of 48 scenarios were analyzed in this study that varied the quantity of material to be dredged, transport distances from the dredge cut to the placement site, and production rates for each type of dredging equipment. The production rates and transport distances used in this study are based on Rock Island District historical records. The range of dredged material volumes, however, was selected by the author to identify transition points between the two types of dredging equipment in this study.

Total fuel consumed was calculated using standard cost estimating practices as defined in the U.S. Army Corps of Engineers Construction Equipment Ownership and Operating Expense Schedule (USACE, 2005). The diesel fuel usage was estimated for all equipment used to mobilize or operate each dredging crew for every scenario (Table 4.2). Each piece of diesel powered equipment was identified for use during the transportation and/or dredging phase of the operation. The time for each dredging crew and phase was estimated based on average travel speeds, distance traveled for mobilization and transport of dredged material, volume of dredged material, delays to allow navigation vessels to pass, delays for managing dredged material at the placement site, and three production rates (low, average, and high). Travel speeds and production rates for each dredging crew were based on Rock Island District historical data (Graham 2007/08).

A Limited Life Cycle Assessment (LCA) was used to evaluate the adverse environmental impacts, specifically the emissions to the atmosphere, resulting from two comparable dredging operations. The primary purpose of this study is to provide dredging decision makers with a tool to help select equipment for each dredging operation that will reduce the negative environmental impacts as defined in this LCA. Since the selection process would be limited to the dredging equipment available within a given region and would not include the purchase or disposal of that equipment this LCA was limited to the "use" phase only.

This study utilized the emissions from diesel fuel combustion in industrial equipment (Table 3.4) (NREL, 2003) to define the constituents and mass emitted per gallon of diesel fuel burned. This data was entered into SimaPro LCA software as a 
process then applied to each of the scenarios (Table 5.1) yielding the environmental impacts for each quantity dredged, transport distance, and production rate.

Table 5.1: Scenarios Included in this Study

("Low", "Avg", and "High" refer to production rates)

\begin{tabular}{|c|c|c|c|c|c|c|c|c|c|c|c|c|c|}
\hline & \multicolumn{12}{|c|}{ Dredged Material Volume (CY) } \\
\hline & & \multicolumn{3}{|c|}{1,000} & \multicolumn{3}{|c|}{5,000} & \multicolumn{3}{|c|}{20,000} & \multicolumn{3}{|c|}{100,000} \\
\hline \multirow{4}{*}{ 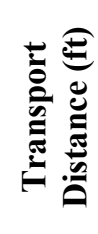 } & 8,000 & Low & Avg & High & Low & $A v g$ & High & Low & $A v g$ & High & Low & $A v g$ & High \\
\hline & 10,000 & Low & $A v g$ & High & Low & $A v g$ & Iigh & Low & $4 v g$ & High & Low & $A v g$ & High \\
\hline & 12,000 & Low & Avg & $h$ & Low & $g$ & $g h$ & Low & $v g$ & Iigh & Low & $g$ & High \\
\hline & 16,000 & Low & $A v g$ & High & Low & $A v g$ & High & Low & $A v g$ & High & Low & $A v g$ & High \\
\hline
\end{tabular}

The total dredging time for each scenario was estimated using a template developed by Rock Island District, Operations Division (Graham 2007/08). This template calculates total dredging time based on the anticipated production rate for that dredge, the volume of sediment to be removed, mobilization/demobilization time, down time for placement site operations, delays required to maintain navigation, and rehandling of the dredged material if required.

Total cost for each scenario analyzed was estimated and also normalized on a per CY basis for ease in comparison with the Environmental Impact Single Score (EISS). The total dredging time for each scenario was estimated using a template developed by Rock Island District, Operations Division (Graham 2007/08). An average hourly cost for both the cutterhead pipeline dredge and mechanical bucket dredge crews was calculated based on Rock Island District 2005 dredging season records (Graham 2007/08). The total time was multiplied by the average cost per hour for each dredging crew yielding a total cost for each scenario in this study. The total cost is then divided by the volume of dredged material for each scenario resulting in a cost per cubic yard (Table 3.5). Normalizing the cost for dredging, on a per cubic yard basis, provides a common scale that allows comparison across multiple scenarios.

The total environmental burdens could then be compared to typical decision making criteria (Table 1.4) (USACE 2003-A). The EISS for each scenario were compared with the cost per $\mathrm{CY}$ of dredging, potential production rates, and transport distances to identify possible decision points. The results will provide a tool to help dredging decision-makers select equipment that will reduce air emissions at a comparable cost per $\mathrm{CY}$, thus improving the sustainability of navigation channel maintenance dredging.

\subsection{Conclusions}

The evaluation of EISS versus cost per CY completed in this study support the commonly-accepted position that mechanical bucket dredges are better suited for long transport distances where a cutterhead pipeline dredge would be required to doublehandle the dredged material (Table 4.3). This is consistent with common practice of avoiding double-handling of dredged material, if at all possible, to minimize the adverse 
aquatic environmental impacts to an intermediate placement site. In addition, the results indicate that mechanical bucket dredges have lower air emissions and cost per CY for smaller quantities of dredged material. This can be attributed to the mechanical bucket dredge's ability to be mobilized easily and economically relative to a cutterhead pipeline dredge. See Chapter 4 for a detailed explanation of the conclusions drawn for each specific scenario and evaluation format.

For scenarios with no clear choice of dredging method, the Tradeoff Index, $I$, gives guidance in determining if a modest cost increase will result in a large emission reduction or not to enable decision-makers to make an informed choice (Table 4.3). From Table 4.3 it can be seen that $I$ increases with transport distance for most no clear choice cases, suggesting that at higher transport distances, a small additional cost may be worth it to decrease air emissions by a relatively large amount. In addition, $I$ almost always increases with dredging material volume as well. Also, for a low dredged material volume $I$ increases with production, but the converse is true for moderate and high dredged material volumes. This suggests that at low volumes, higher production rates may be worth some extra costs, but that lower production rates may be worth extra cost at moderate and high volumes. 


\section{CHAPTER 6: FUTURE WORK}

This study proposes a process to evaluate dredging equipment emissions to the atmosphere using two specific types and sizes of comparable dredges. It utilizes an established USACE procedure for estimating the cost of fuel consumed by construction equipment and a Limited LCA to calculate the emissions per gallon of diesel fuel burned. This procedure could be expanded and improved on in multiple ways.

Documenting actual fuel usage data for the dredges and supporting equipment evaluated across a broad range of projects would help validate the diesel fuel consumption estimating procedure. In addition, actual data would better define how much fuel is consumed during mobilization, dredging, and transportation operations. This would better reflect the impacts of mobilization and transport distance on the total air emissions.

Expanding the scope of equipment analyzed to include both larger and smaller cutterhead pipeline and mechanical bucket dredges would provide a more universal tool applicable to a broad range of applications. Decision-makers could then consider altering not only the type of equipment selected to minimize air emissions but also the size of the dredge to maximize efficiency. This could also be expanded to include different types of mechanical excavation and suction pipeline dredges.

Similarly, the evaluation of a much wider range of potential production rates could potentially expand and enhance the procedure. This would allow decision-makers to consider the type and size of equipment as well as how site conditions and selection of a placement site impact efficiency and air emissions.

Collection of air quality measurements during the various dredging operations would improve the correlation between gallons of diesel fuel burned and the resulting emissions. This could be accomplished by collecting field data from comparable dredging equipment at similar sites. Conducting a study where a cutterhead pipeline and mechanical bucket dredge removed sediment from the same dredge cut would provide an even more realistic comparison of the two types of dredging equipment.

Another potential area for future work would be to evaluate the use of alternative fuels for dredging operations. Currently diesel fuel is the predominant fuel used in dredges and supporting equipment. There are some instances where an electric powered dredge is being used, particularly in larger ports to meet air quality standards. This fuel source severely limits the mobility of the dredge and applications where it could be utilized. However, the potential to use bio-fuels, natural gas, or other alternative fuels should be evaluated for efficiency and reductions in air emissions. 


\section{REFERENCES}

Abood, K. A., (2007). "Sustainable and Green Ports; Application of Sustainability Principles to Port Development and Operation", Proc. Ports 200730 years of Sharing Ideas, 1997 - 2007, ASCE, San Diego, CA.

Bridges, T. S., Ells, S., Hayes, D., Mount, D., Nadeau, S.C., Palermo, M.R., Patmont, C., and Schroeder, P. (2008). The Four Rs of Environmental Dredging: Resuspension, Release, Residual, and Risk. United States Army Corps of Engineers Dredging Operations and Environmental Research Program, Washington D.C., GPO.

Creef, E. D, and Mathies, L. G., (2002). "Investigation of the Excavation, Transport and beneficial use of Illinois River Dredged Material", Proc. Third Specialty Conference on Dredging and Dredged Material Disposal, ASCE, Orlando, FL.

Gore, D. J., (2002). "Maritime Administration's Formulation of a Maritime Energy and Clean Emissions Program", Proc. 2002 Spring Technical Conference of the American Society of Mechanical Engineers International Combustion Engine Division, International Combustion Engine Division, ASME. Rockford, IL

Graham, Willis. "Dredge Information." Personal communication. 28 Nov. 2007 to 19 June 2008

Compiled Under the Supervision of, Institute for Water Resources (IWR), U.S. Army Corps of Engineers (2006) "Waterborne Commerce of the United States Calendar year 2006, Part 5 National Summaries", Alexandria, VA

Marlin, J. C. and Darmody, R. G., (2002). "Beneficial Use of Great Lakes Dredged Material", Proc. Third Specialty Conference on Dredging and Dredged Material Disposal, ASCE, Orlando, FL.

New!Delta (2007). "Framework for a Sustainable Dredging Strategy", www.newdelta.org (11 November 2007)

Pebbles, V., (2002). "Beneficial Use of Great Lakes Dredged Material”, Proc. Third Specialty Conference on Dredging and Dredged Material Disposal, ASCE, Orlando, FL.

Rhoads, R., (2004) “A Breath of Fresh Air?”. Dredging and Port Construction, 31(Nov), 16-19

Rokosch, W. D. and Berg, N. J., (2002). "Dredging Efficiently - dredging techniques and its effects to the environment." Proc., Third Specialty Conference on Dredging and Dredged Material Disposal, ASCE, Orlando, FL. 
United States Army Corps of Engineers (USACE) (2007), "A Brief History", http://www.hq.usace.army.mil/History/brief.htm (2 July 2008)

UASCE (1987-A). Beneficial Uses of Dredged Material. EM 1110-2-5026, Washington D.C., GPO

UASCE (1987-B). Confined Disposal of Dredged Material. EM 1110-2-5027,

Washington D.C., GPO

UASCE (2005). Construction Equipment Ownership and Operating Expense Schedule, Region III. EP 111-1 -8, Vol. 3, Washington D.C., GPO

UASCE (1983). Dredging and Dredged Material Disposal. EM 1110-2-5025, Washington D.C., GPO

UASCE (2003-A). Dredged Material Management Plan for Dredged Material Placement, Upper Mississippi River Miles 300.2 - 303.4, Pools 22 and 24, Site Plan for the Lock and Dam 22 Reach, Lock and Dam 22 Upper and Lower Approach Dredge Cuts. Rock Island IL, U.S. Army Corps of Engineers, Rock Island District

UASCE (2003-B). Evaluation of Dredged Material Proposed for Disposal at Island, Nearshore, or Upland Confined Disposal Facilities - Testing Manual. ERDC/EL TR-031, Washington D.C., GPO

USACE (2008), "U.S. Army Corps of Engineers Education Center" http://education.usace.army.mil/index.cfm (8 July 2008)

USACE (2006), "U.S. Army Corps of Engineers, St. Louis District, Dredging and Channel Maintenance" http://www.mvs.usace.army.mil/navigation1/dredge.html (16 July 2008)

United States Department of Energy, National Renewable Energy Laboratory (NREL) (2003). "Diesel Combustion in Industrial Equipment" http://www.nrel.gov/ (20 February 2008)

United States Environmental Protection Agency (USEPA) (1998). Evaluation of Dredged Material Proposed for Discharge in Waters of the U.S. - Testing Manual. EPA-823-B-98004, Washington D.C., GPO

USEPA (1991). Evaluation of Dredged Material Proposed for Ocean Disposal - Testing Manual. EPA503/8-91/001, Washington D.C., GPO

USEPA (2004). Evaluating Environmental Effects of Dredged Material Management Alternatives - A Technical Framework. EPA842-8-92-008, Washington D.C., GPO 
Navigation Data Center, U.S. Army Corps of Engineers (NDC) (2007). "The United States Waterway System Transportation Facts", http://www.iwr.usace.army.mil/ndc/factcard/fc07/factcard.pdf (9 June 2008)

Valsaraj, K. T., Thibodeaux, L. J., and Reible, D. D., (1995). "Modeling Air Emissions from Contaminated Sediment Dredged Materials", Proc. 1995 Symposium on Dredging, Remediation and Containment of Contaminated Sediments, ASTM, Montreal, CAN

Zimmer, M. P., Schewe, G. J., and Wagner, J., (2004). “Comparison of Air Concentrations and Odors From ISCST3 and AERMOD Modeling: Implications for Remediation", Proc. Air and Waste Management Association's 97 $7^{\text {th }}$ Annual Conference and Exhibition, A and WMA; Cinergy Corp., Indianapolis, IN 
APPENDIX A GLOSSARY 


\section{APPENDIX A - GLOSSARY}

BHP - Brake Horsepower

CDF - Confined Dredged Material Disposal Facility, an engineered and constructed site for the containment of dredged material within a specified foot print

CPD - Cutterhead Pipeline Dredge

CY - Cubic Yard

EISS - Environmental Impact Single Score

FF - Fuel Factor, a calculated value in gallons per BHP - hour for each type of equipment

HPF - Horsepower Factor, the average percentage of full horsepower utilized during normal operations for each type of equipment

IWW - Illinois Waterway

LCA - Life Cycle Assessment

LEED - Leadership in Energy and Environmental Design

MBD - Mechanical Bucket Dredge

NEPA - National Environmental Policy Act

Short Tons $-2,000$ Pounds

USACE - United States Army Corps of Engineers

USEPA - United States Environmental Protection Agency 
APPENDIX B

\section{DREDGING FUEL CONSUMPTION CALCULATION TABLES}




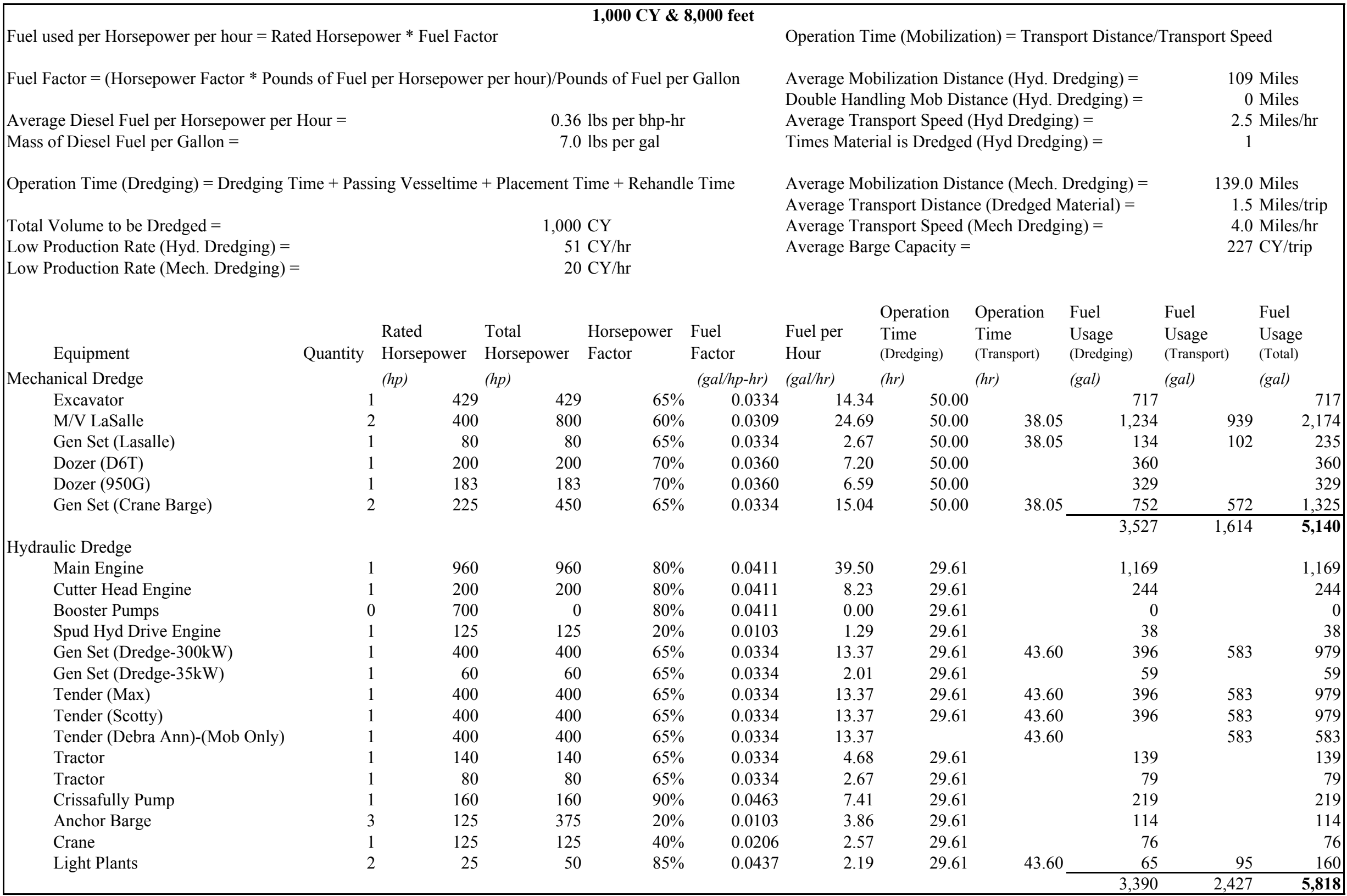




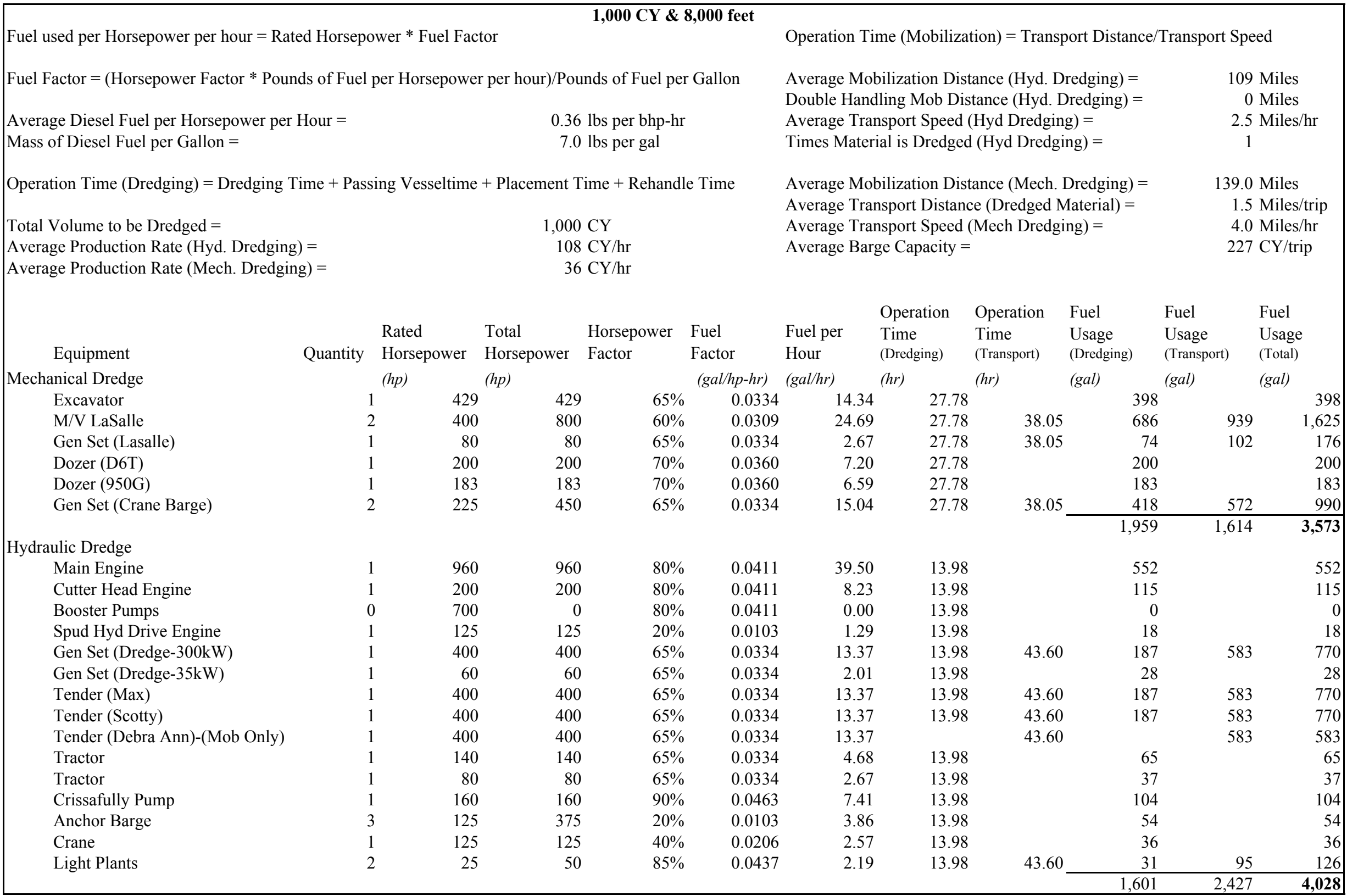


LCA Fuel Usage_1k CY.xIsx 1k 8000 ft Max

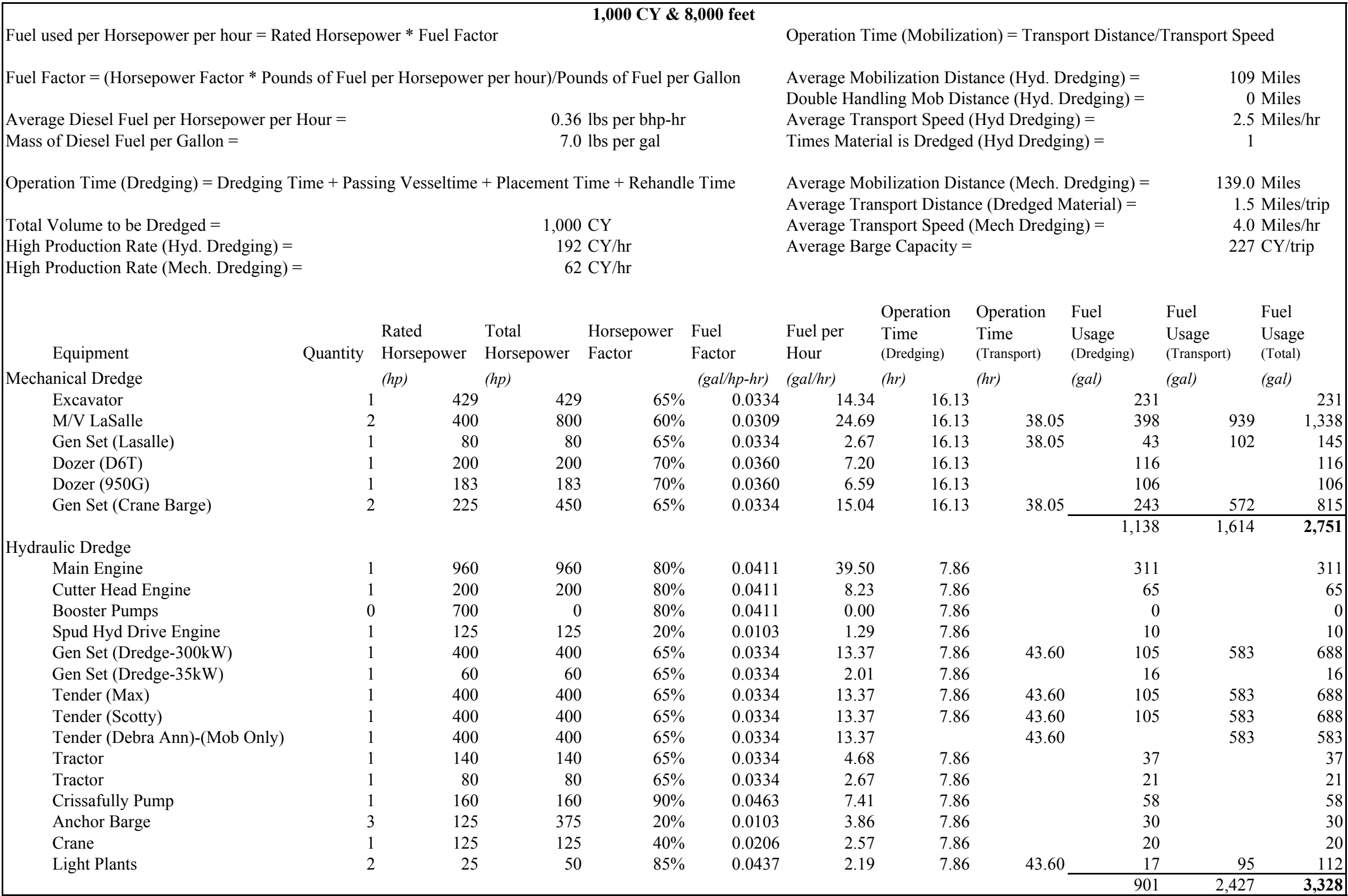




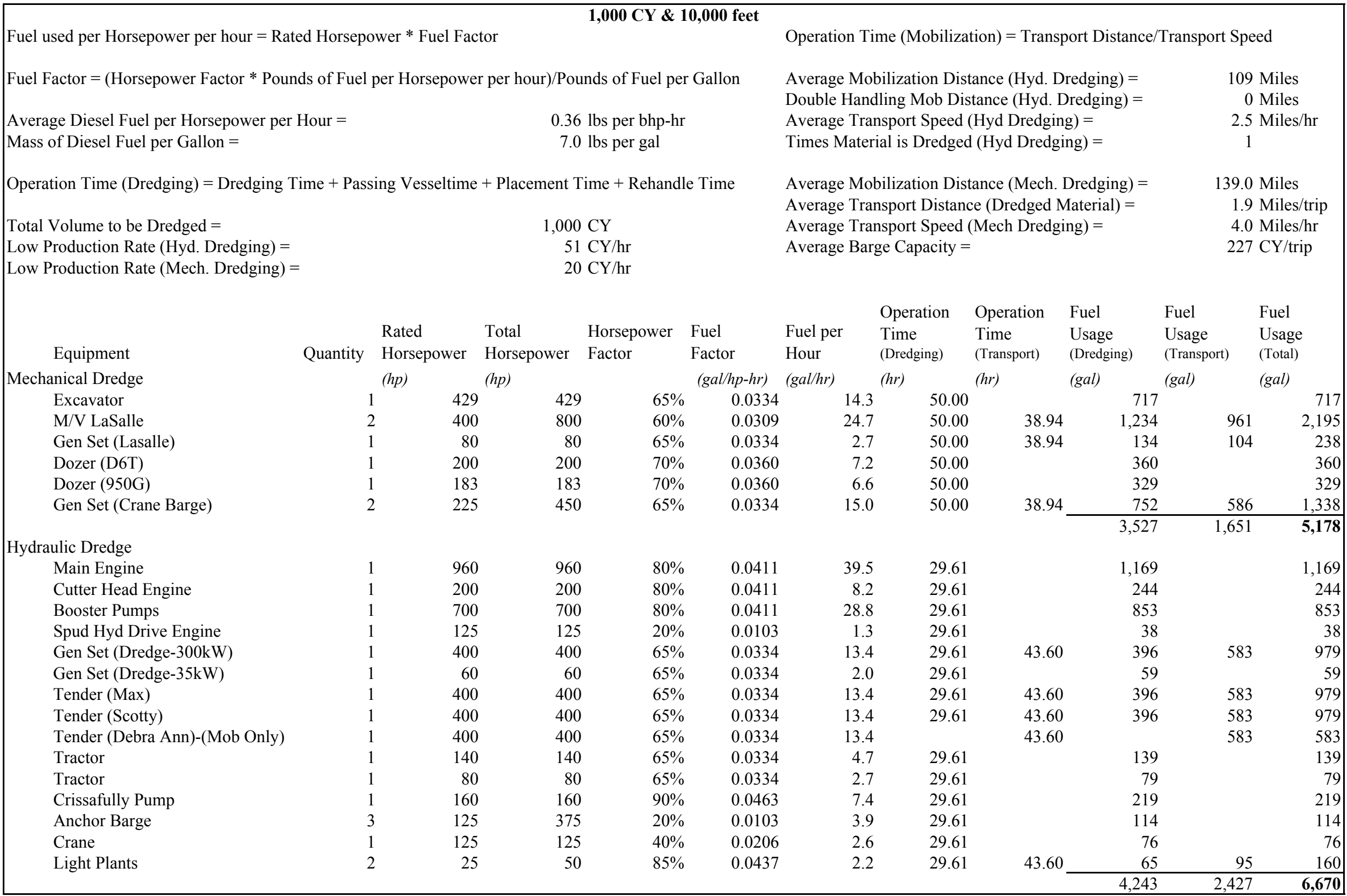




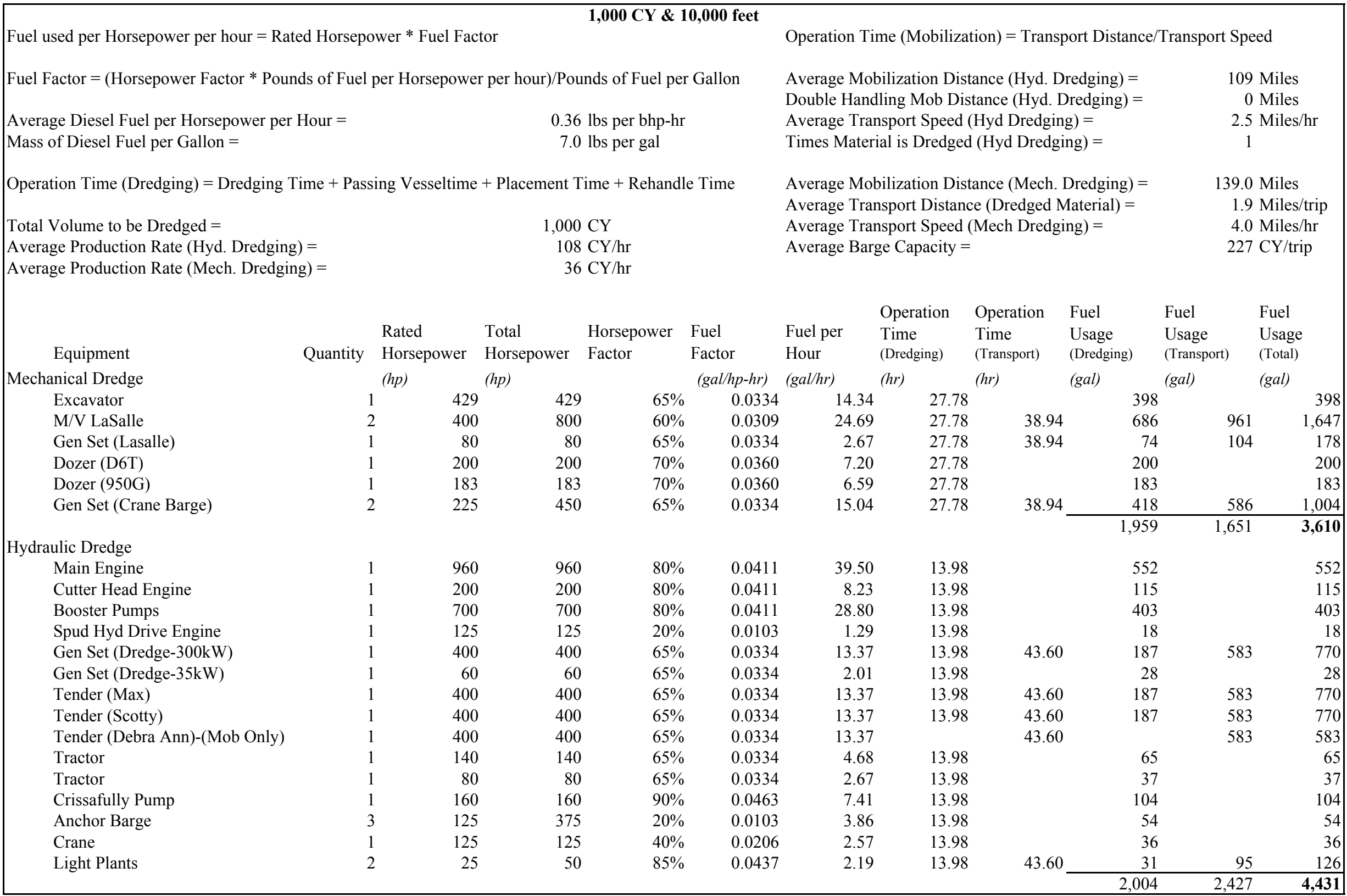


LCA Fuel Usage_1k CY.xlsx 1k $10000 \mathrm{ftMax}$

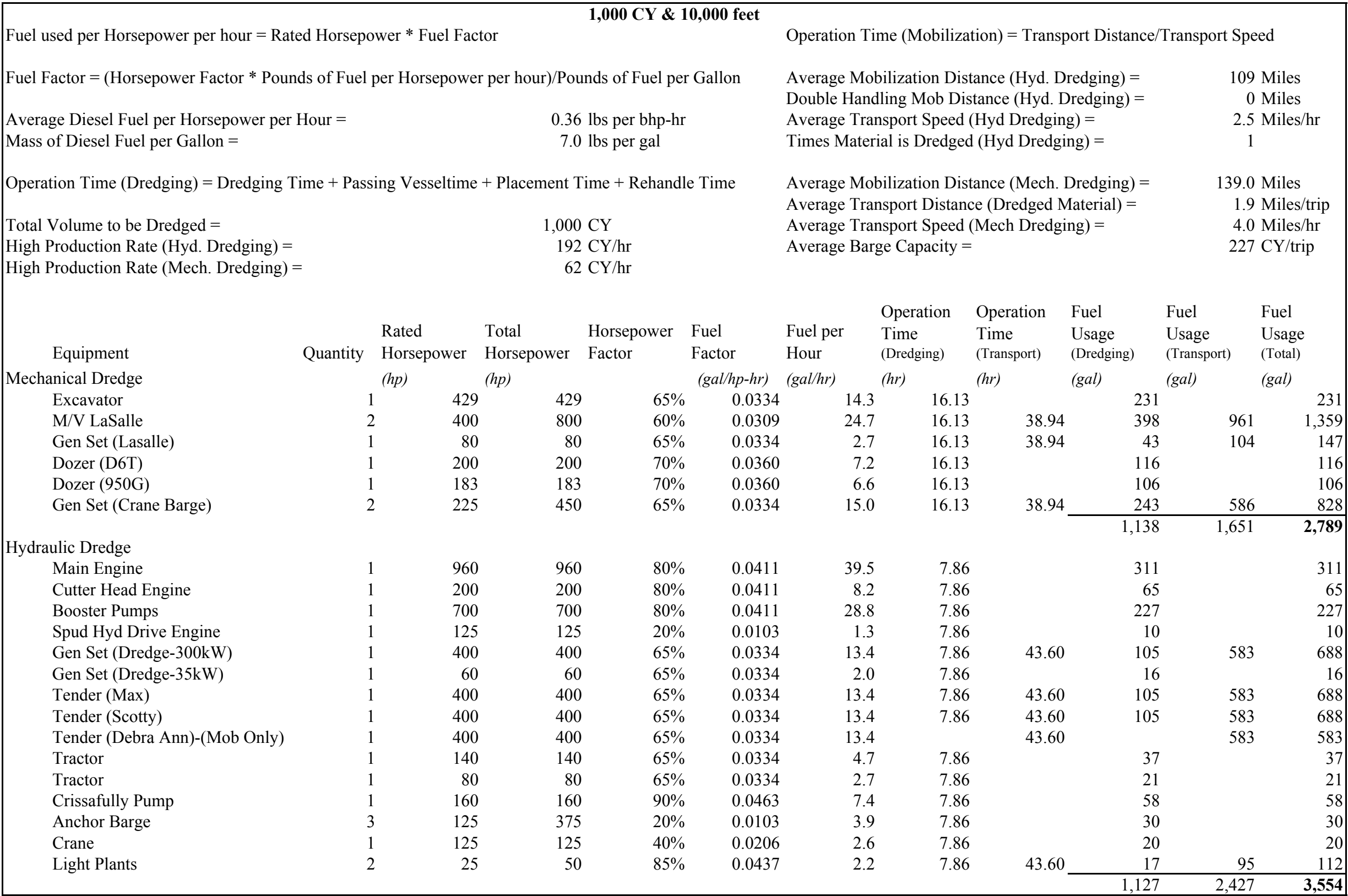


LCA Fuel Usage_1k CY.xIsx 1k $12000 \mathrm{ft}$ Min

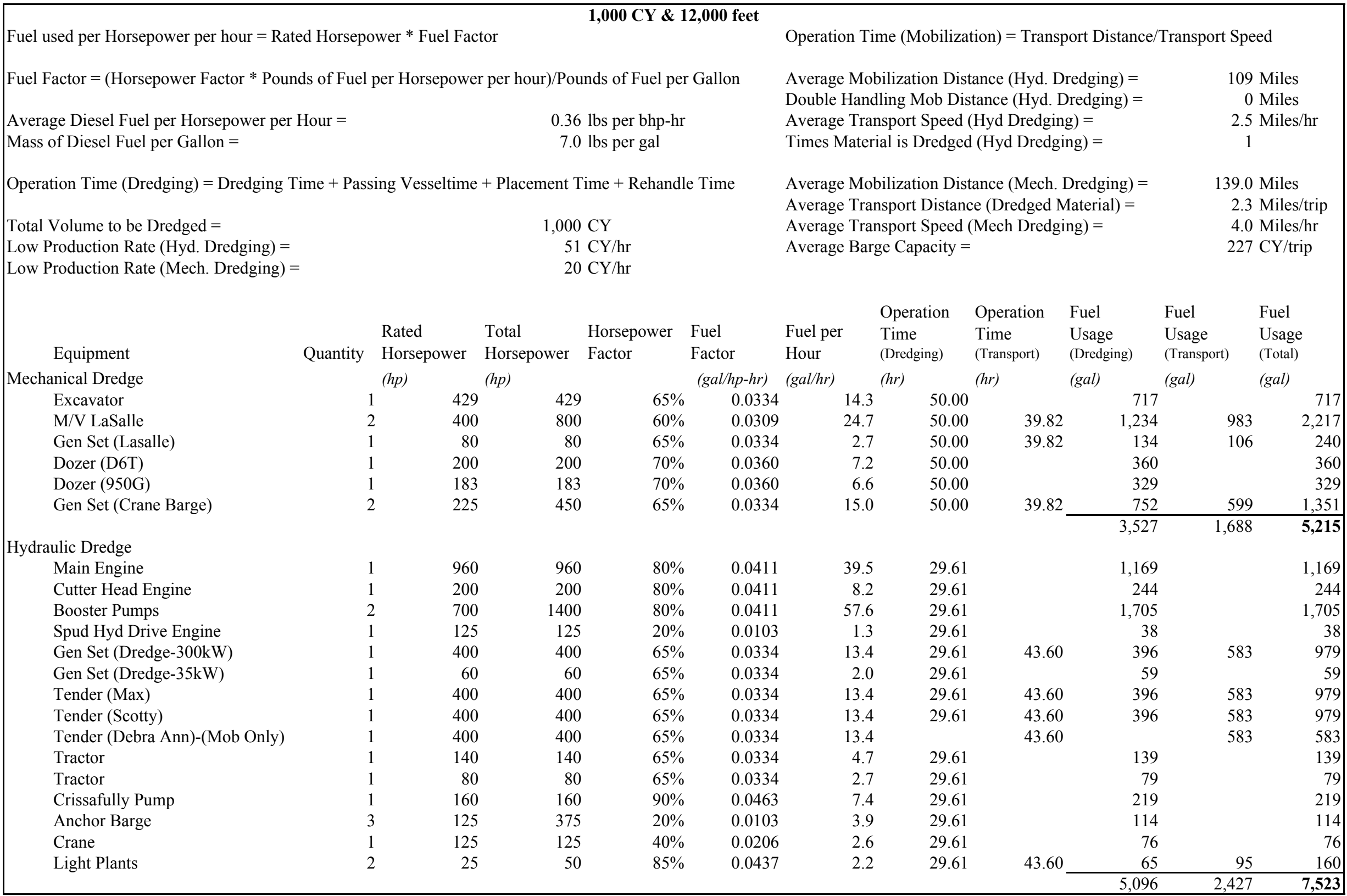




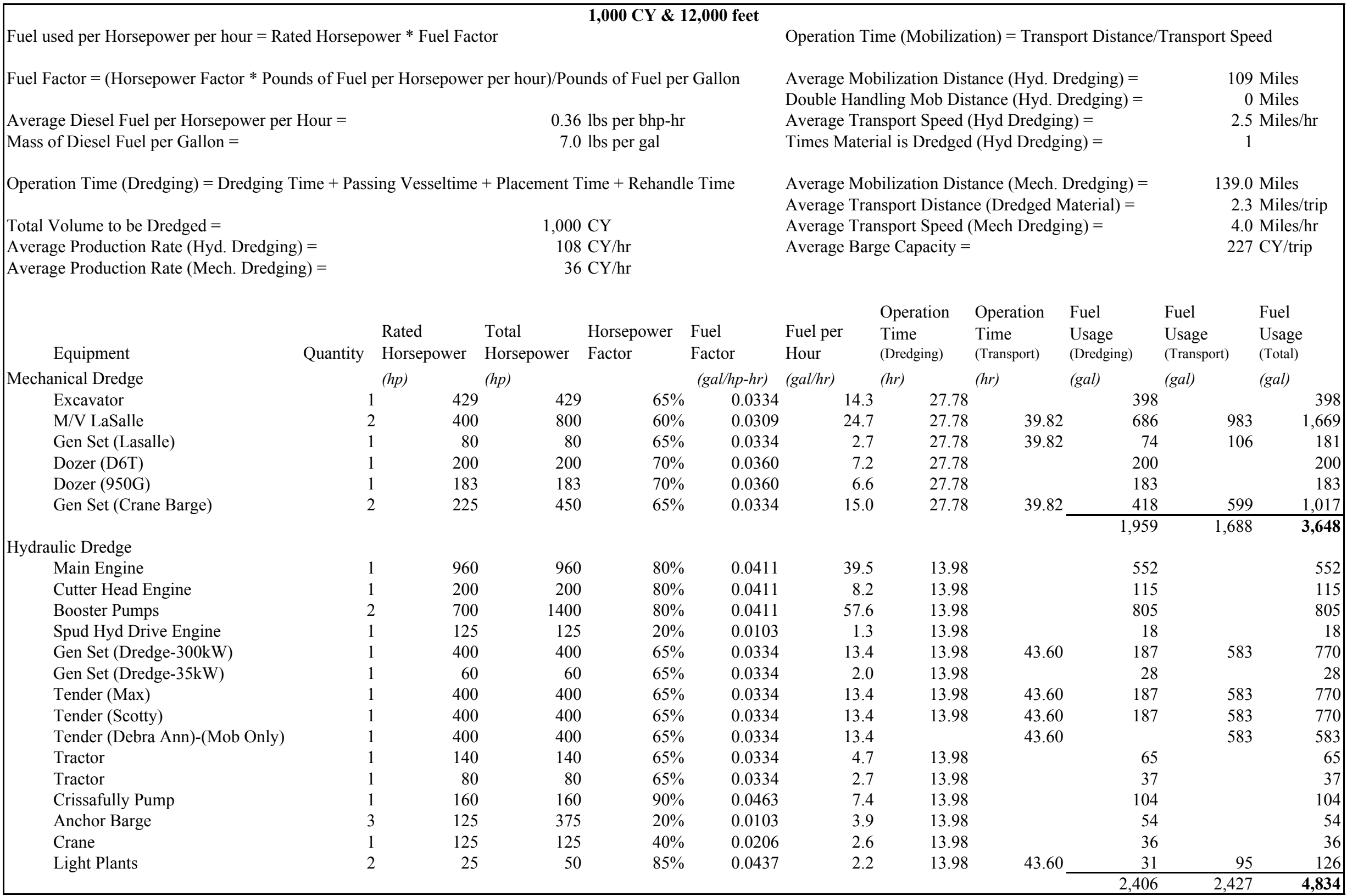




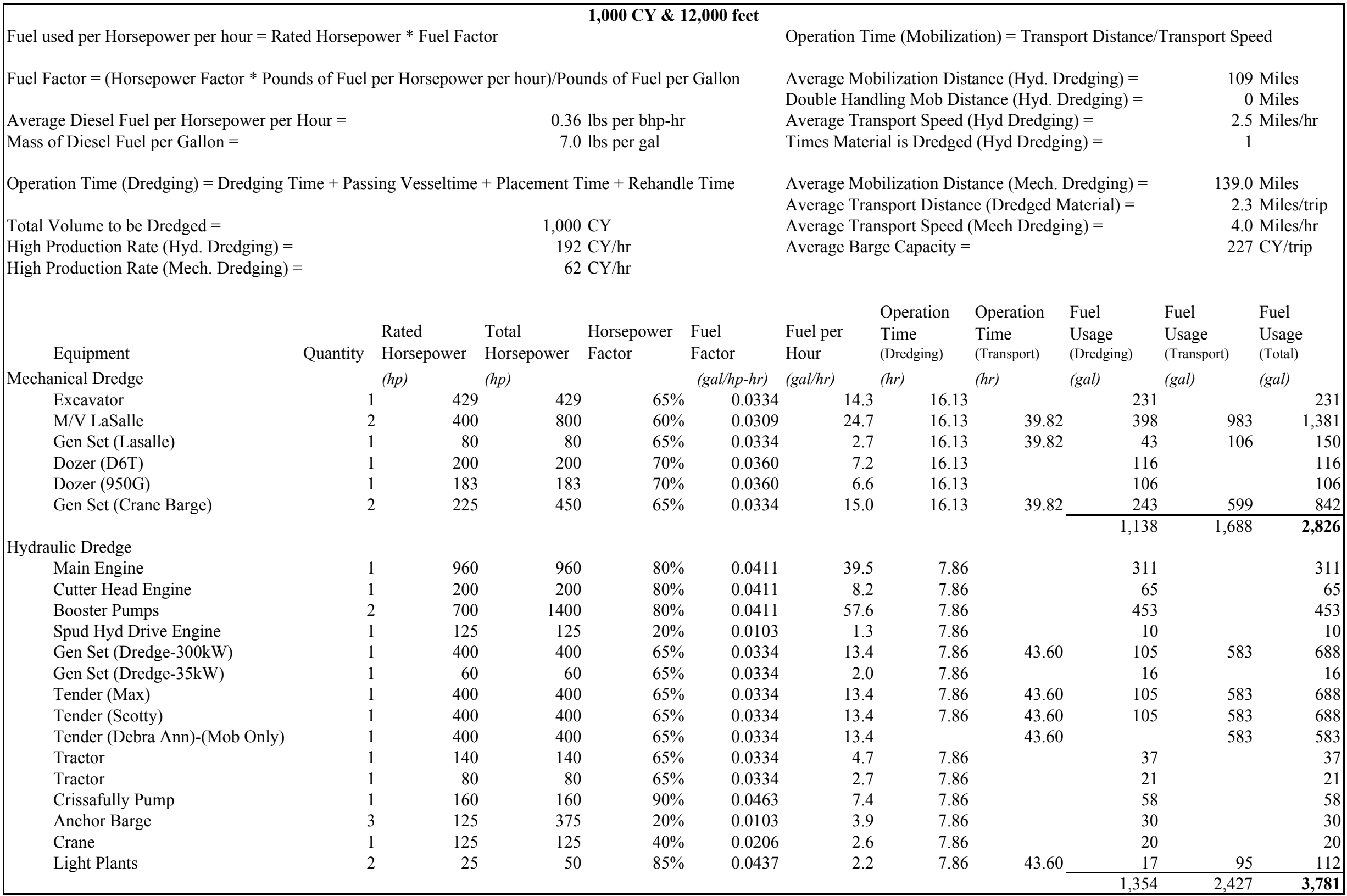


LCA Fuel Usage_1k CY.xIsx 1k $16000 \mathrm{ft}$ Min

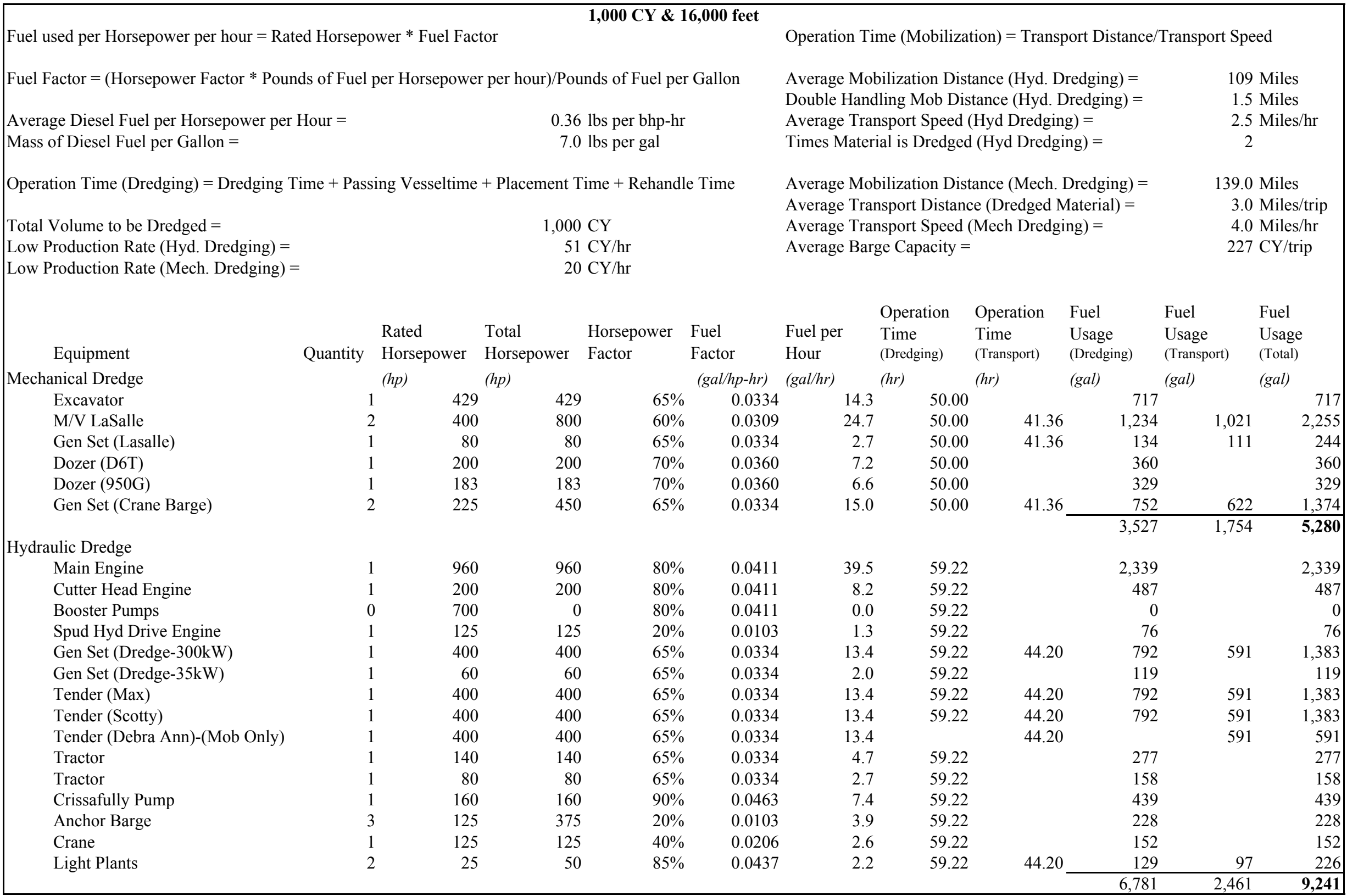


LCA Fuel Usage_1k CY.xIsx 1k $16000 \mathrm{ft}$ Avg

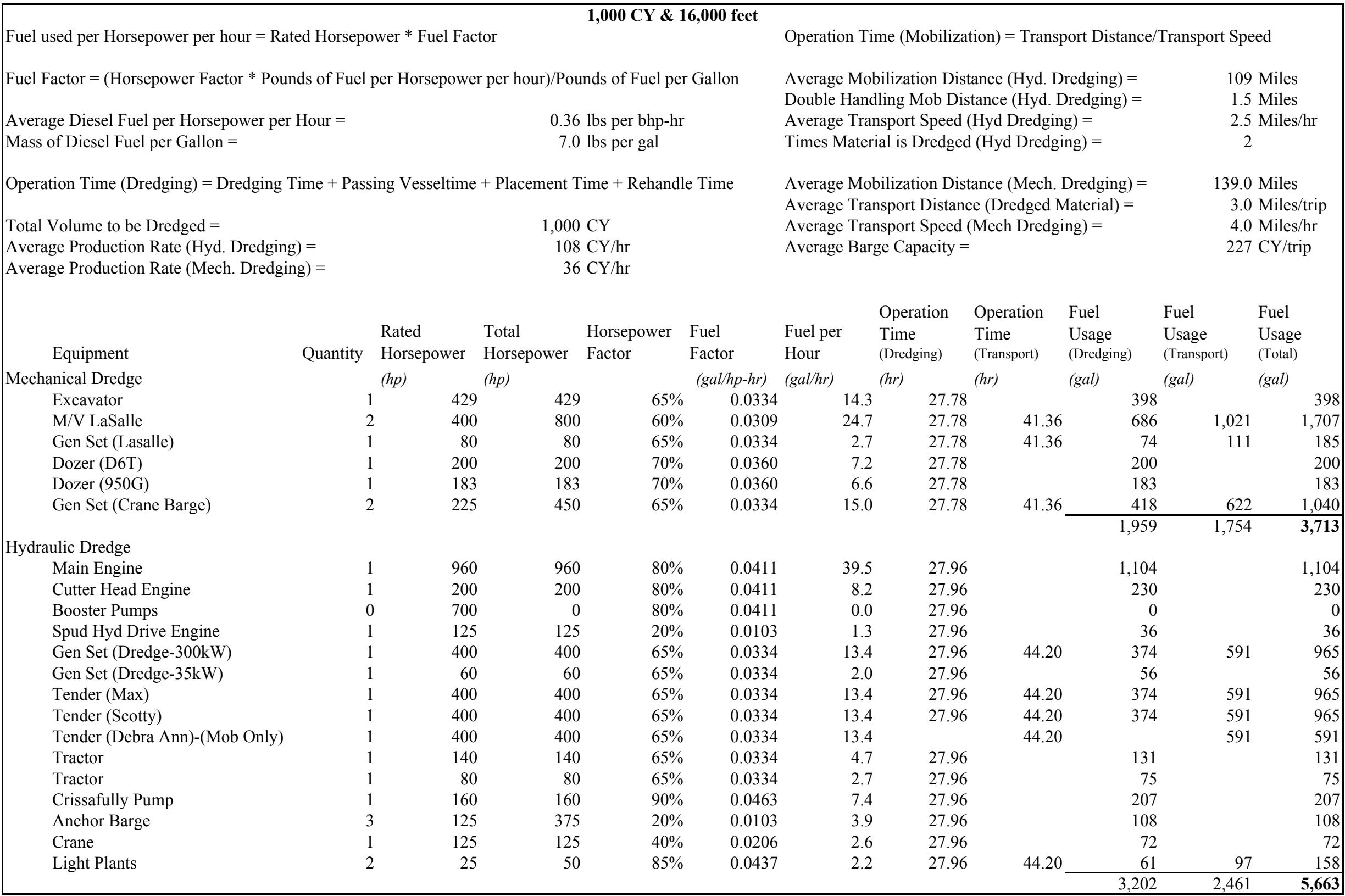




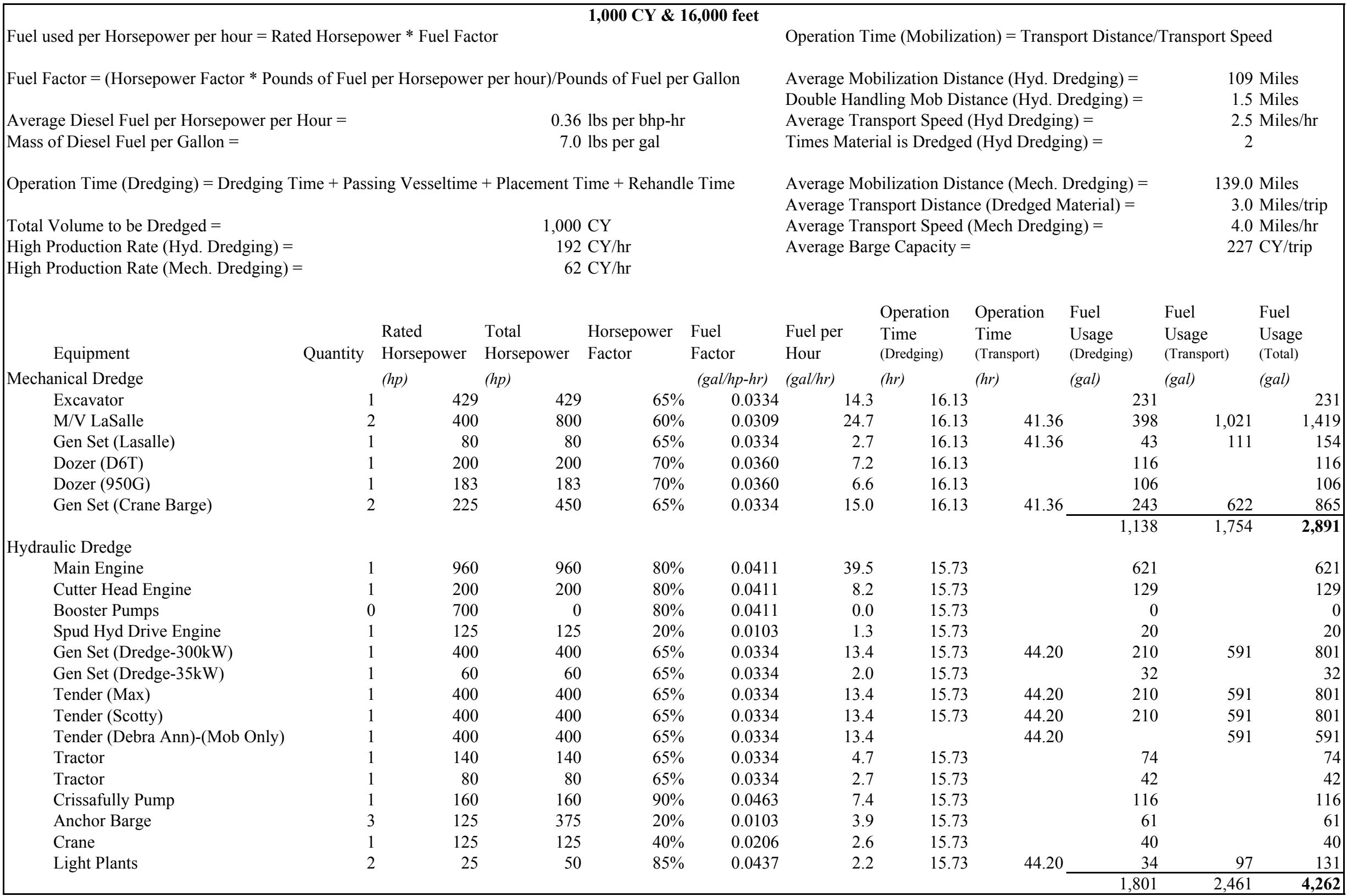


LCA Fuel Usage_5k CY.xlsx 5k 16000 ft Avg

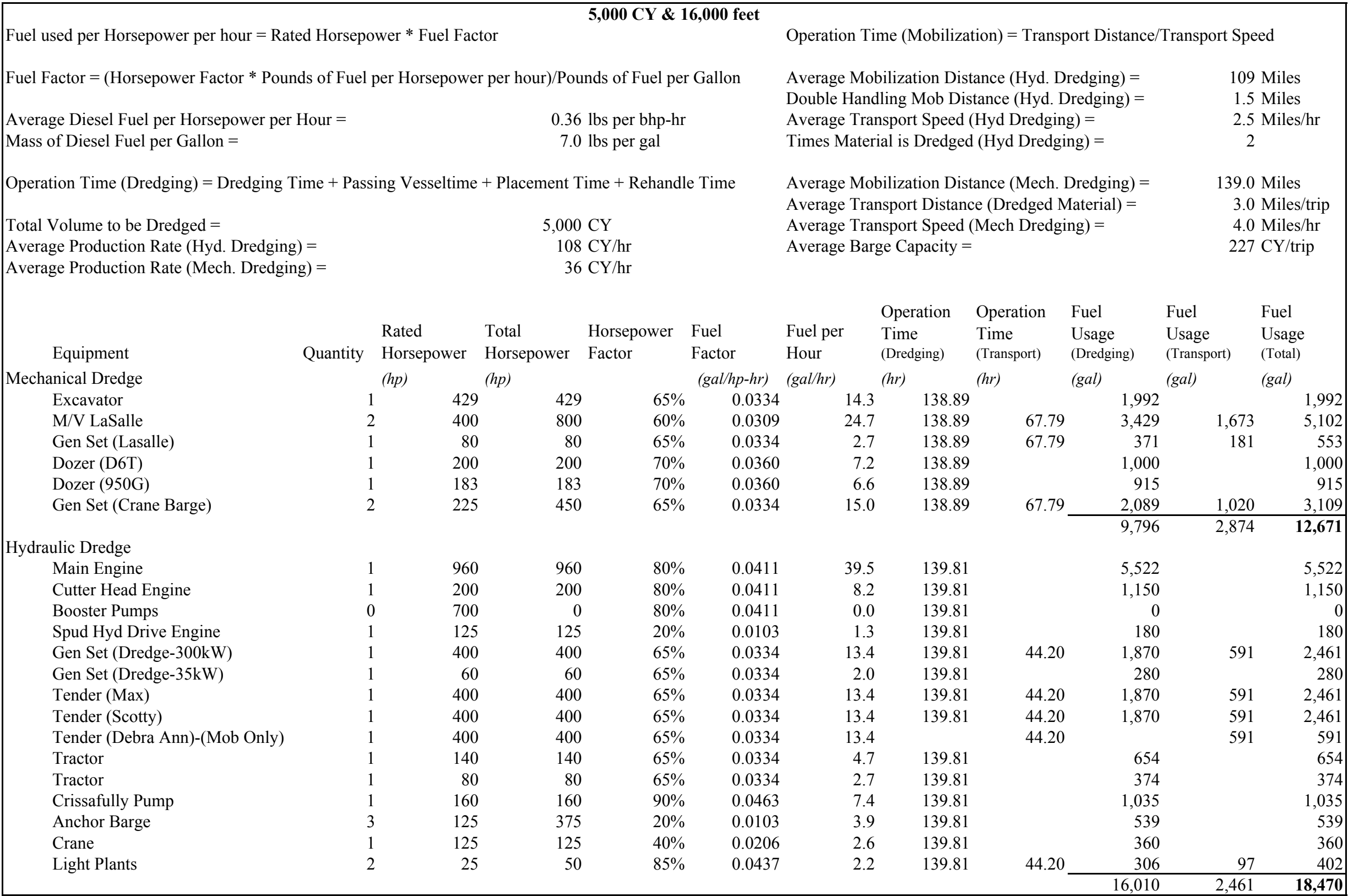




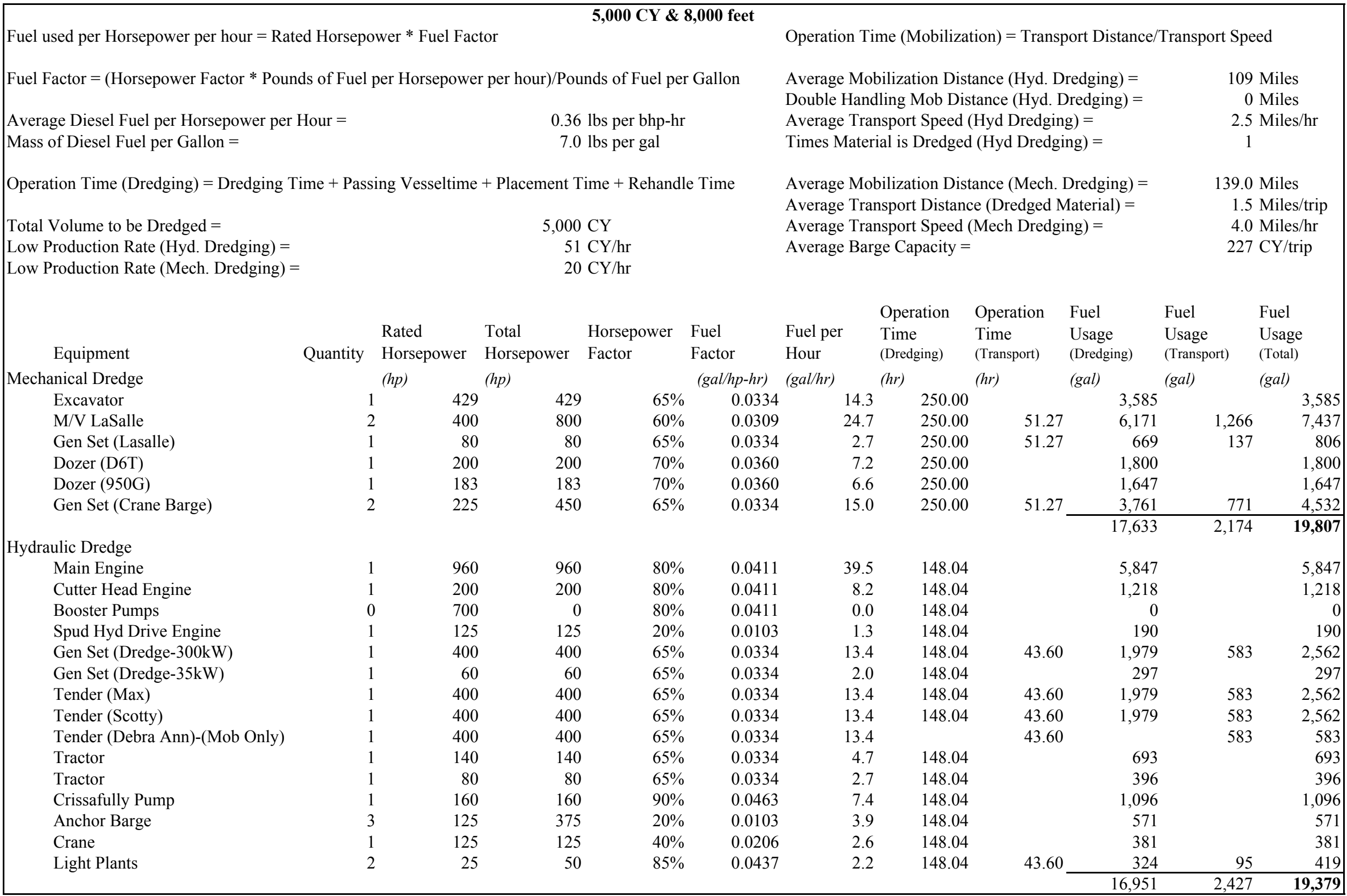




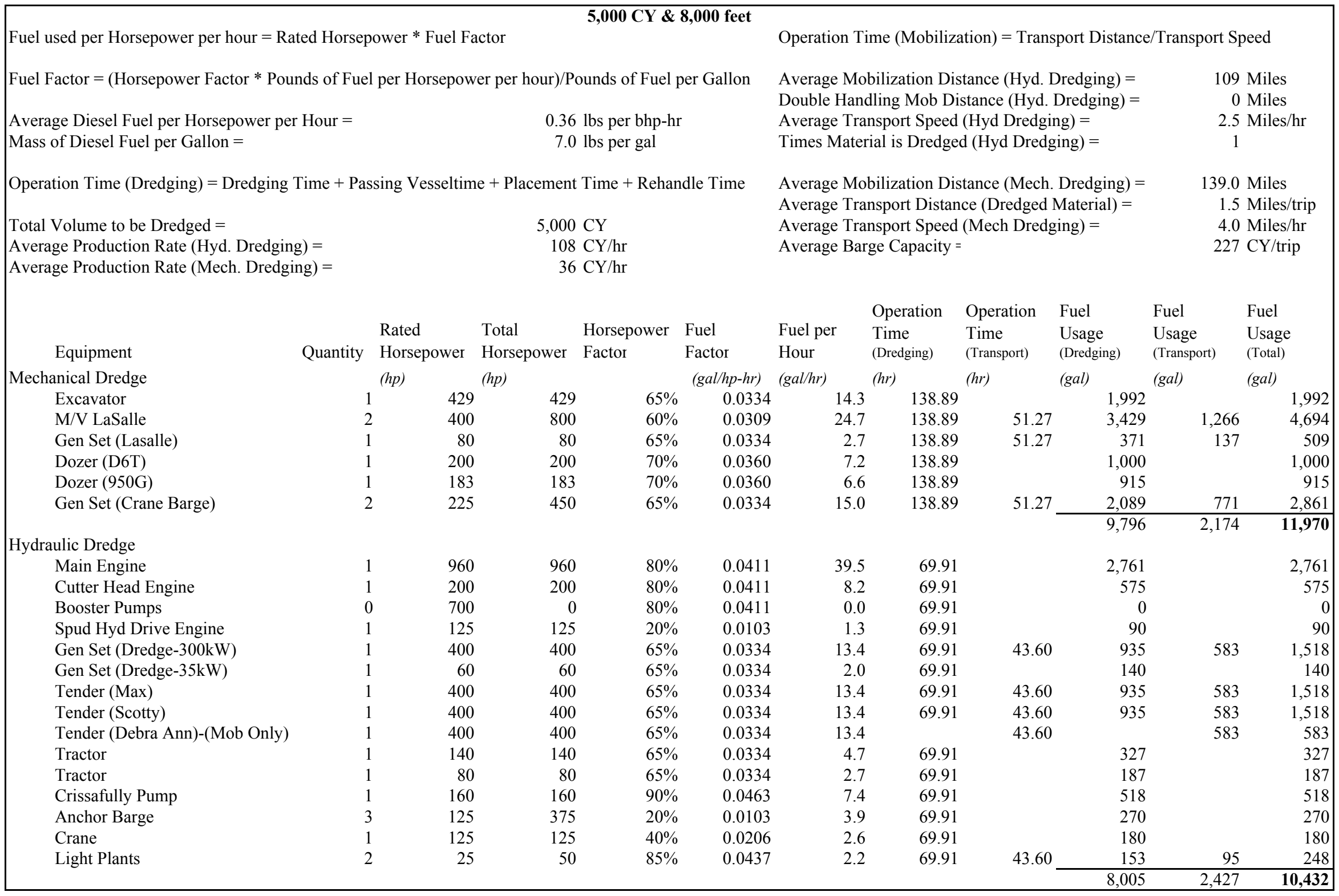


LCA Fuel Usage 5k CY.xlsx 5k $8000 \mathrm{ft}$ Max

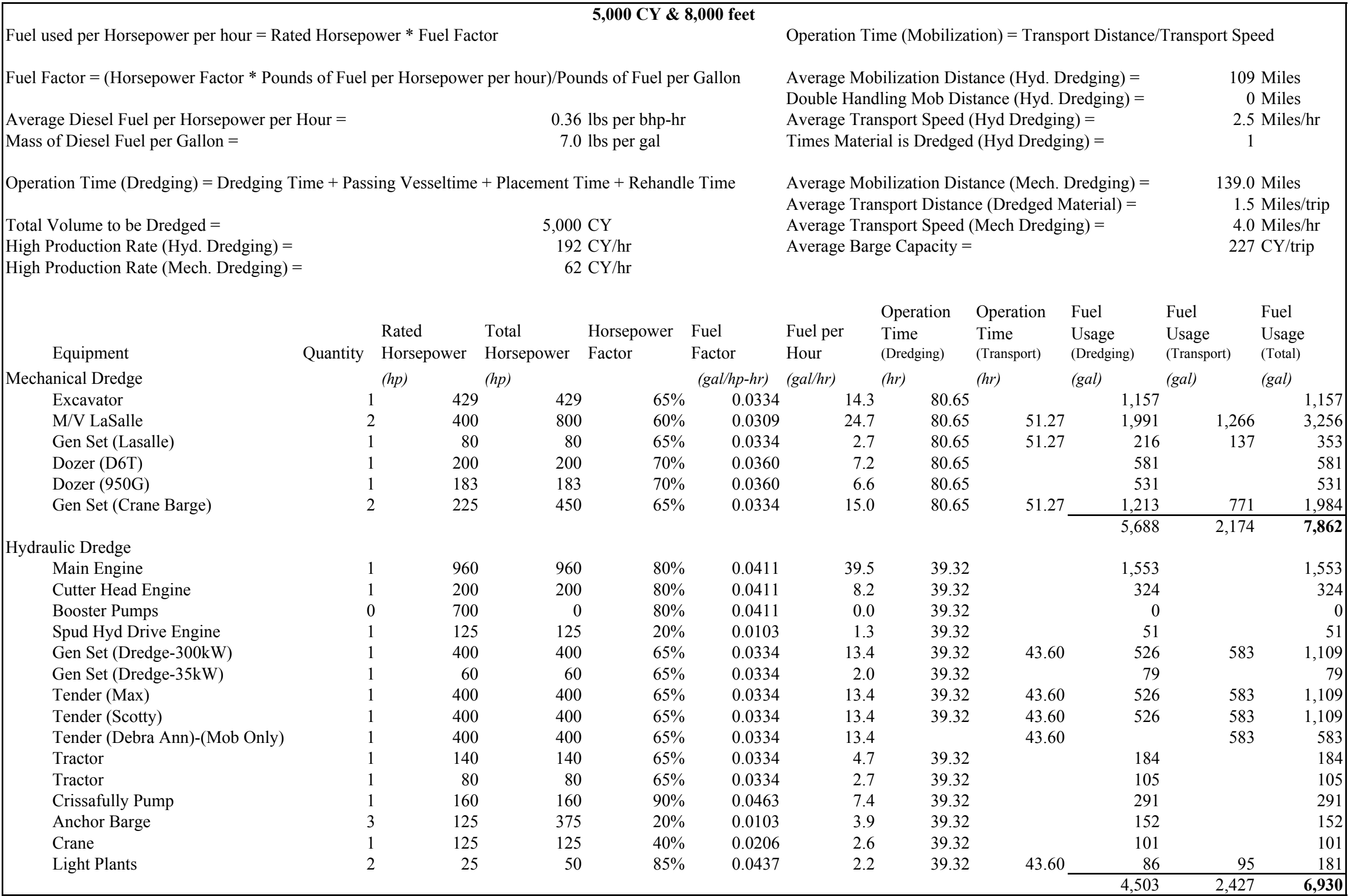


LCA Fuel Usage_5k CY.xIsx 5k $10000 \mathrm{ftMin}$

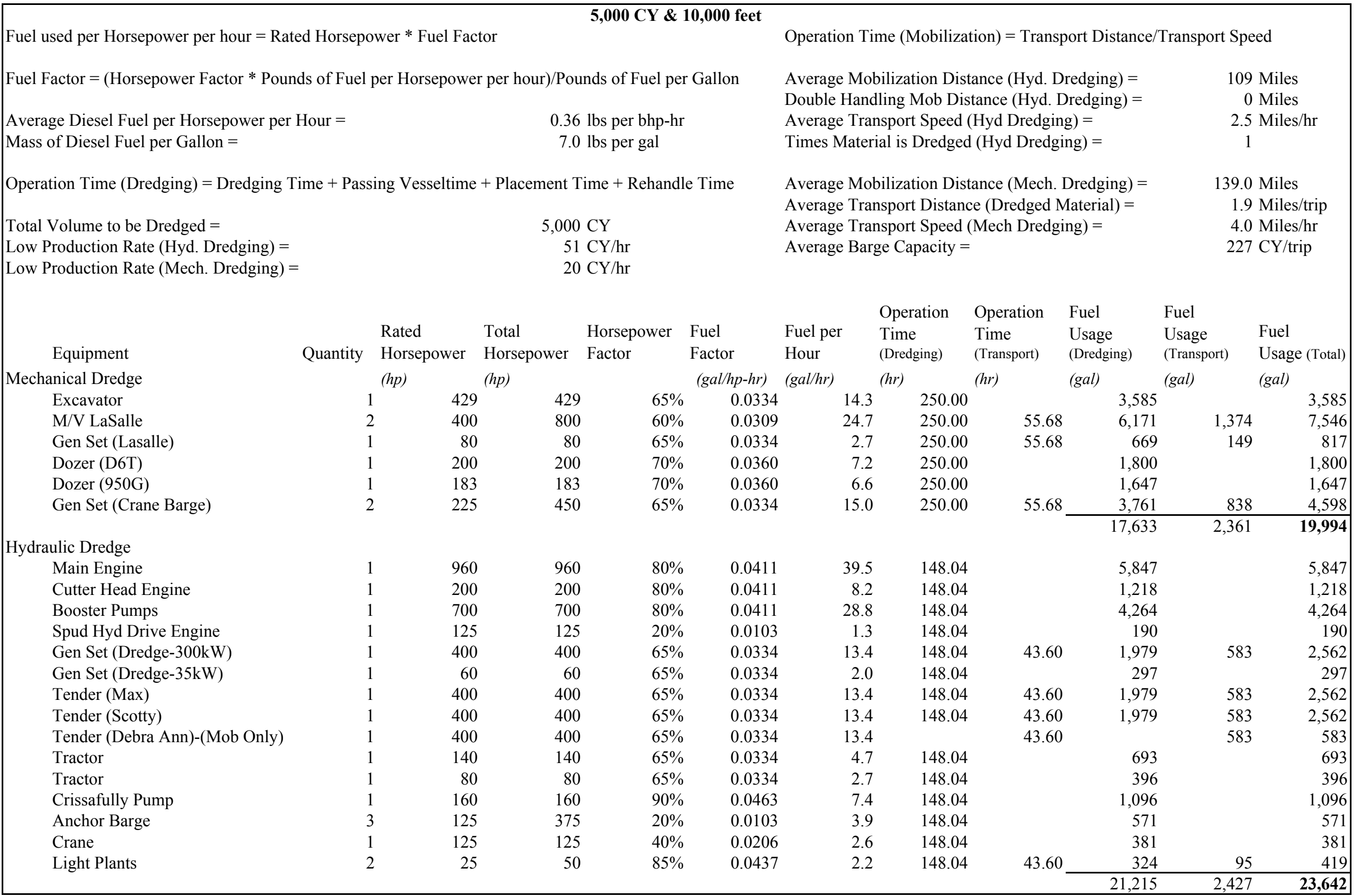


LCA Fuel Usage_5k CY.xlsx 5k $10000 \mathrm{ft}$ Avg

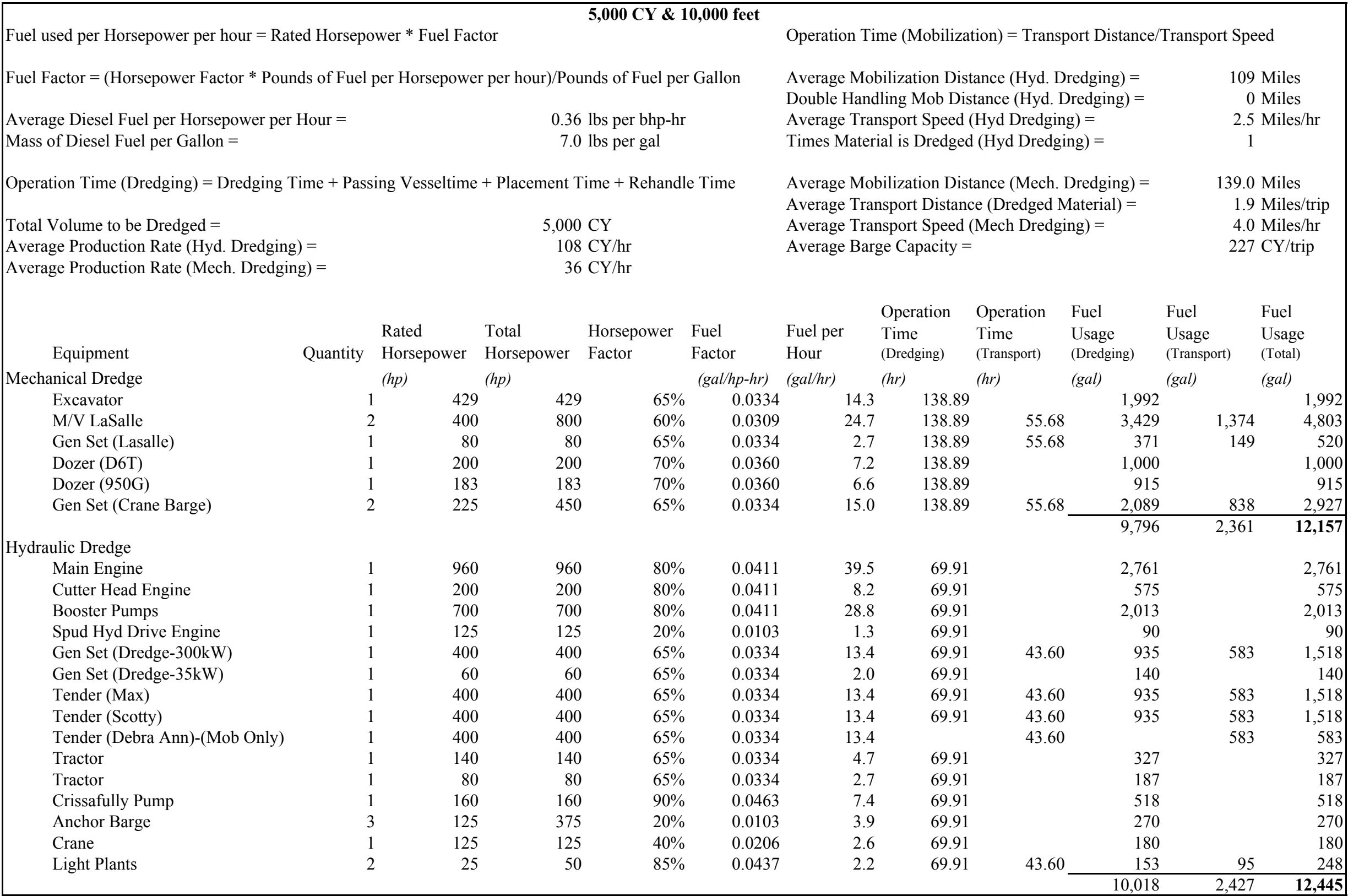




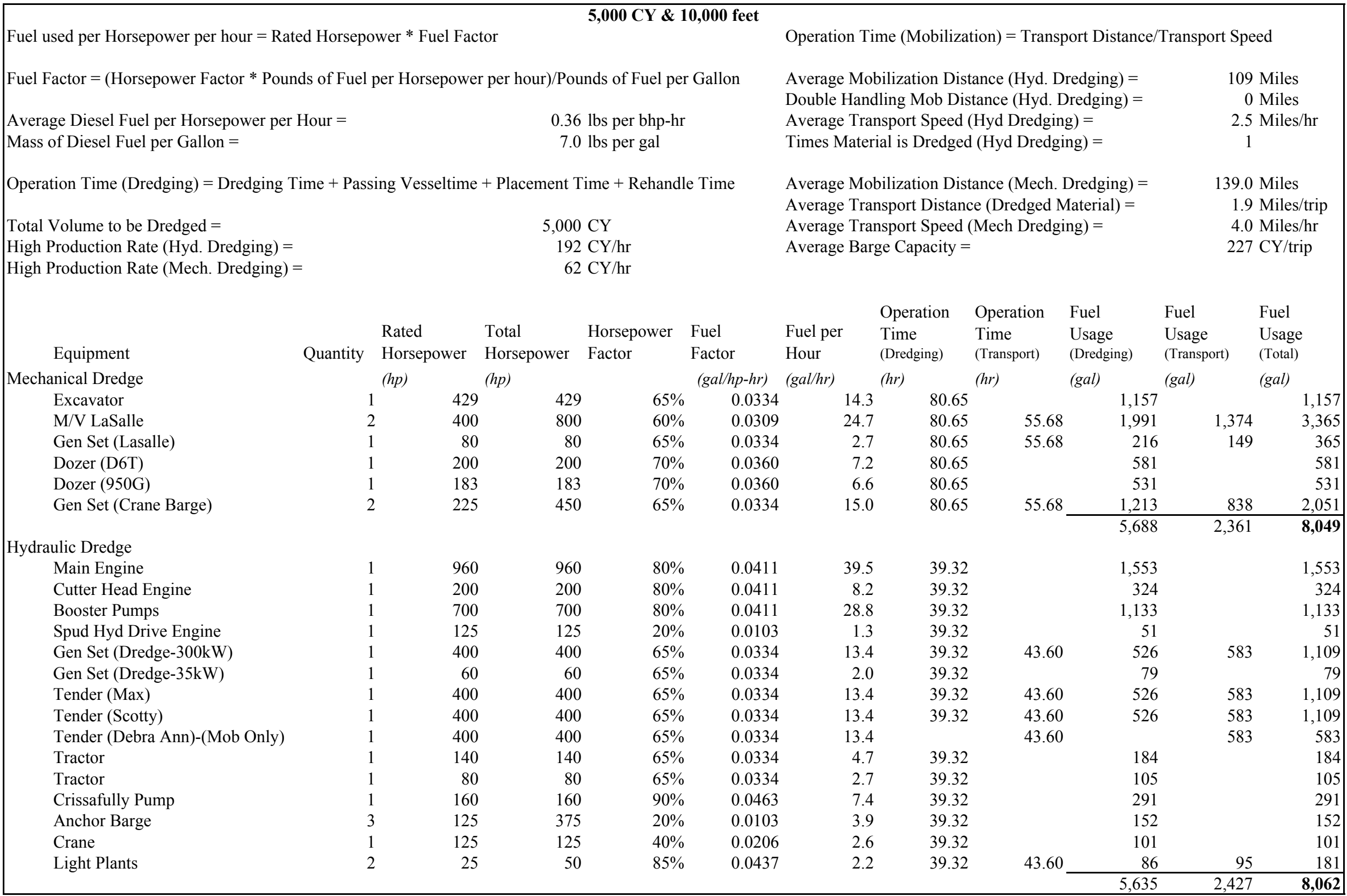




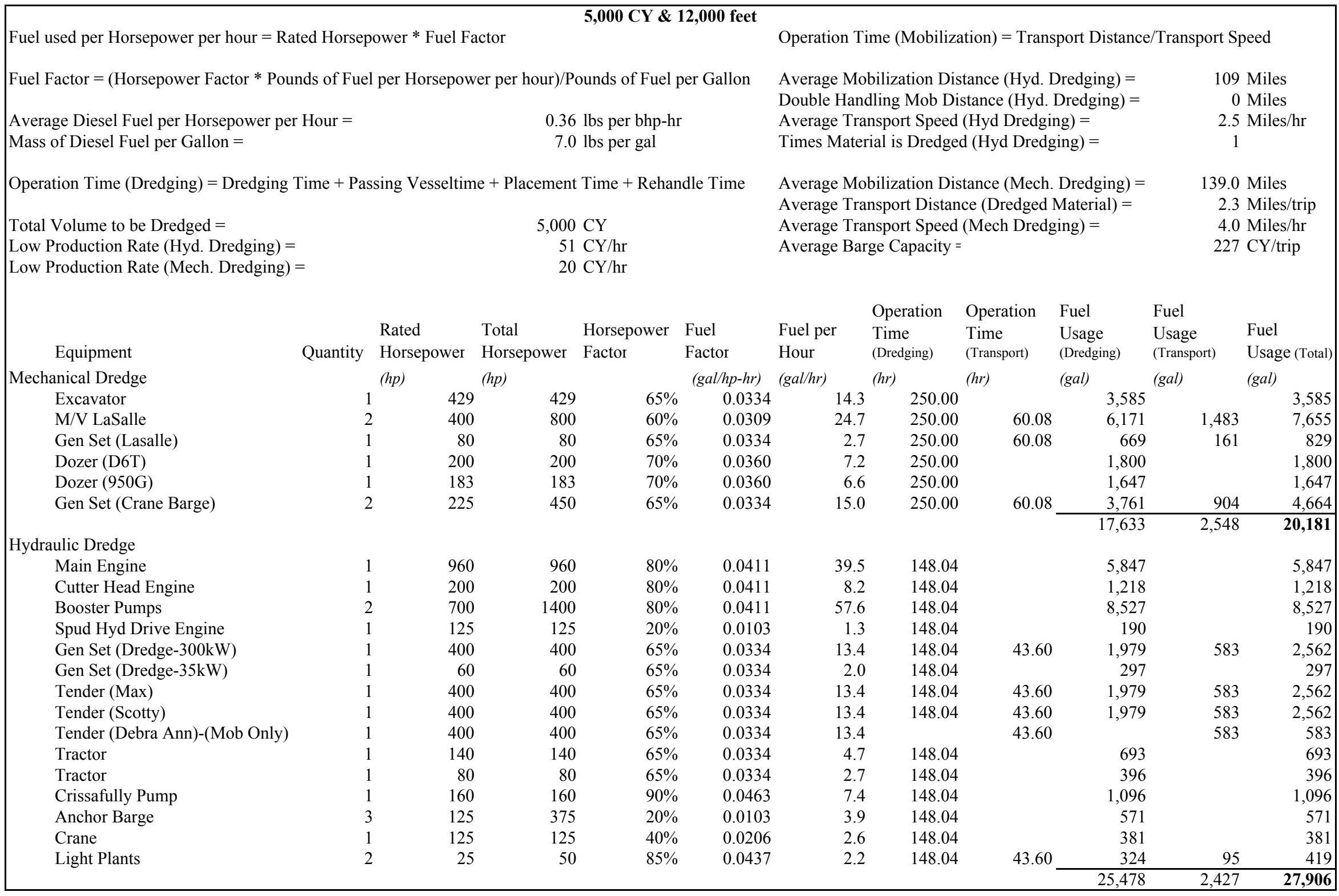




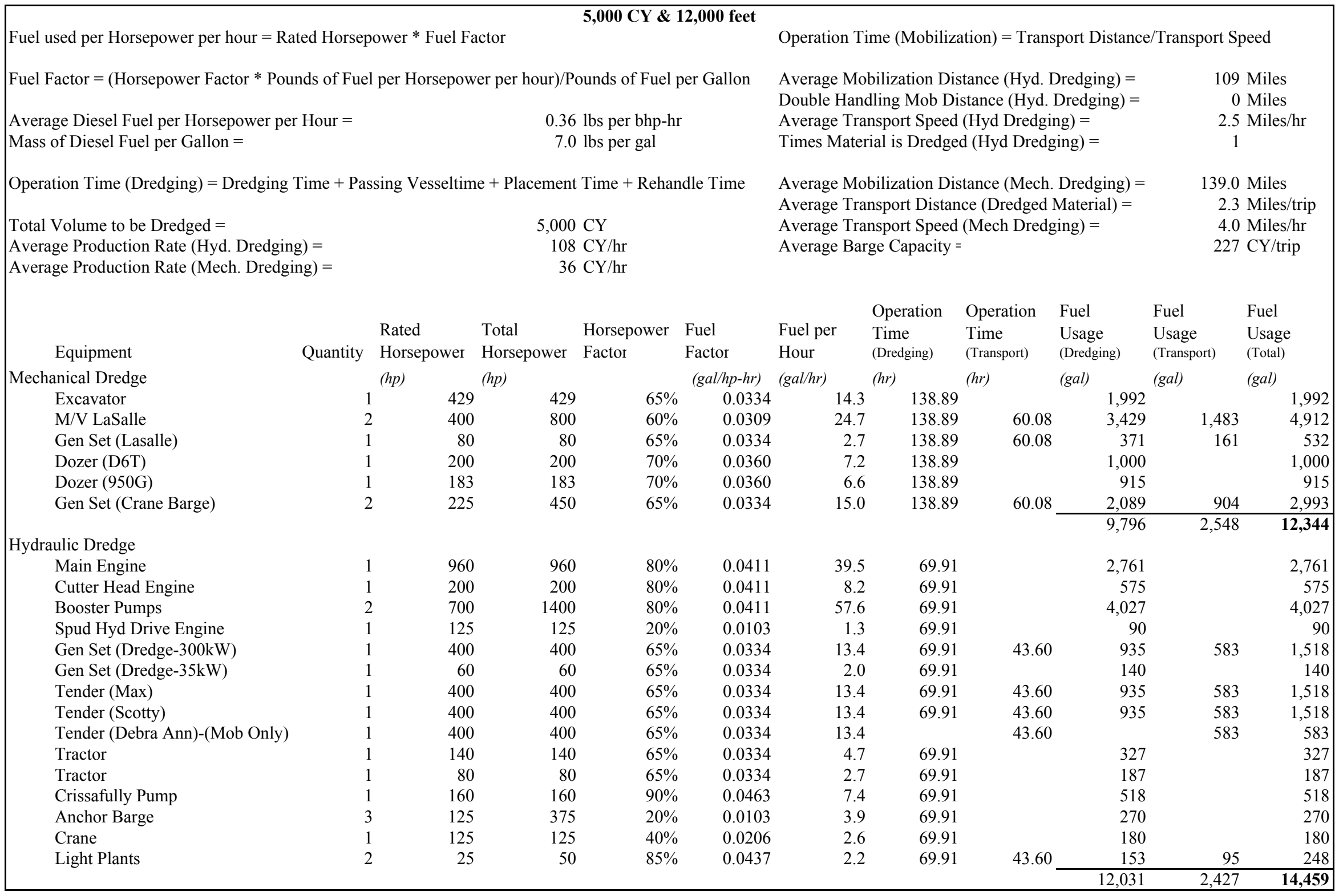




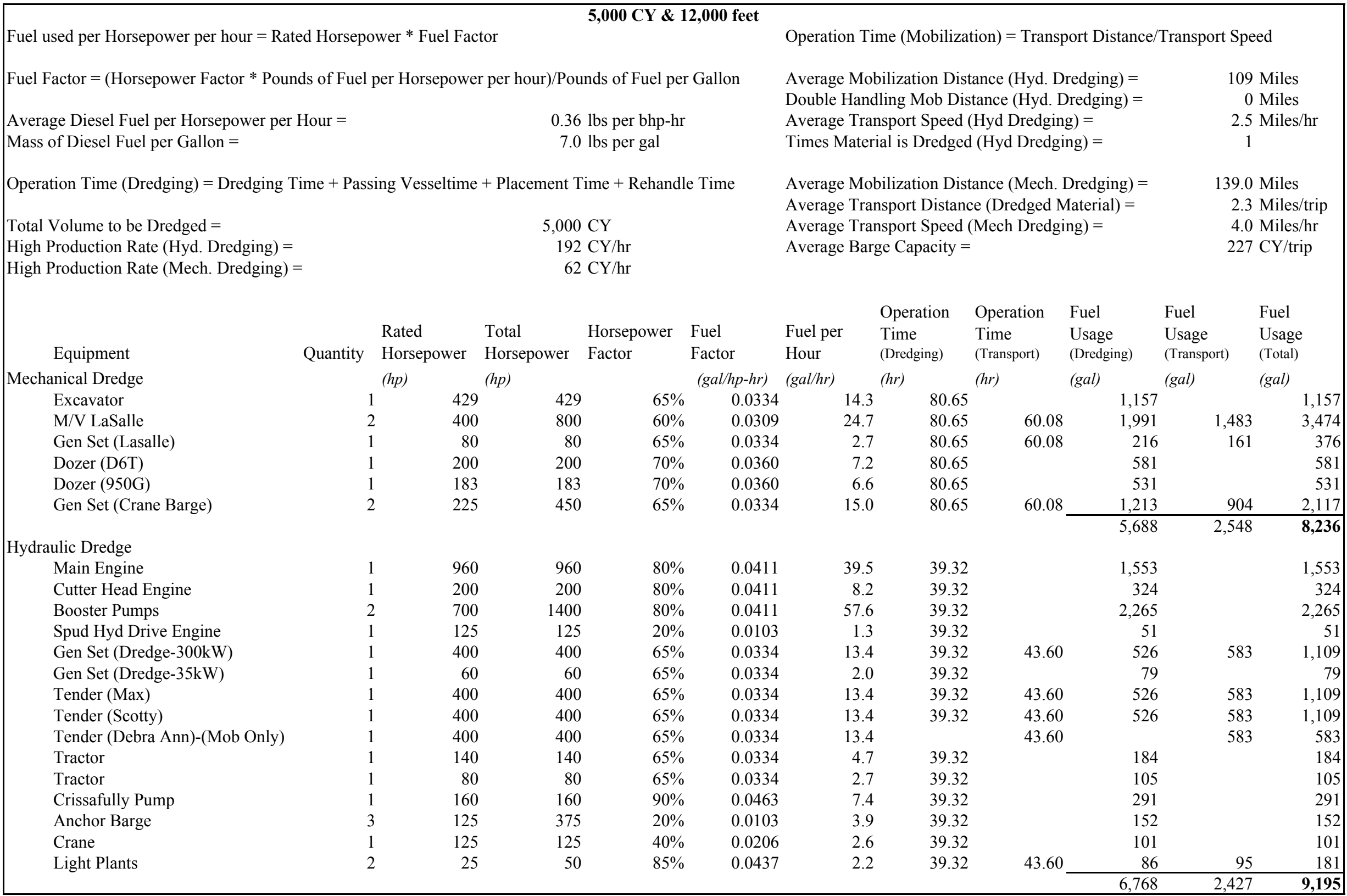




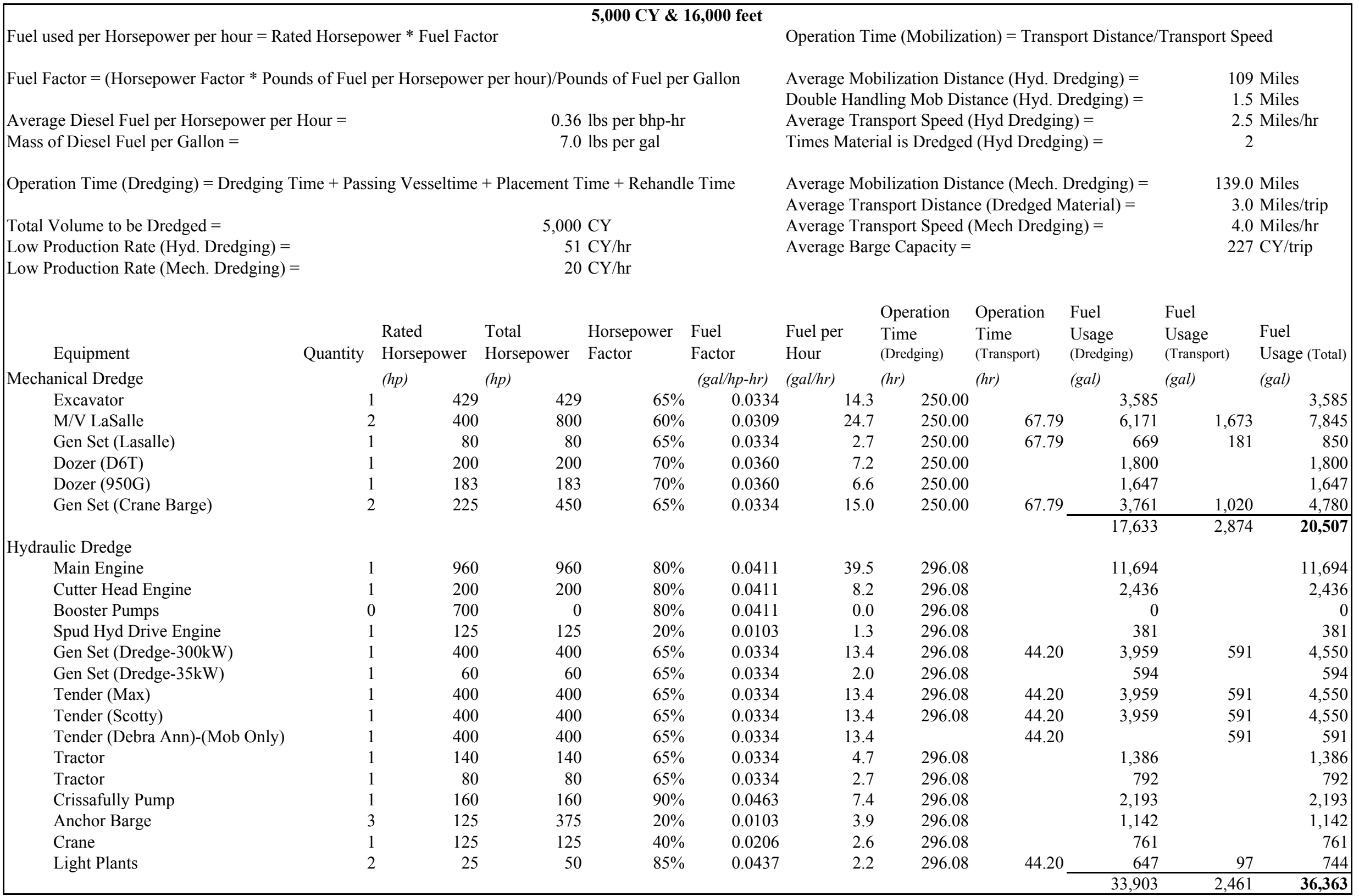




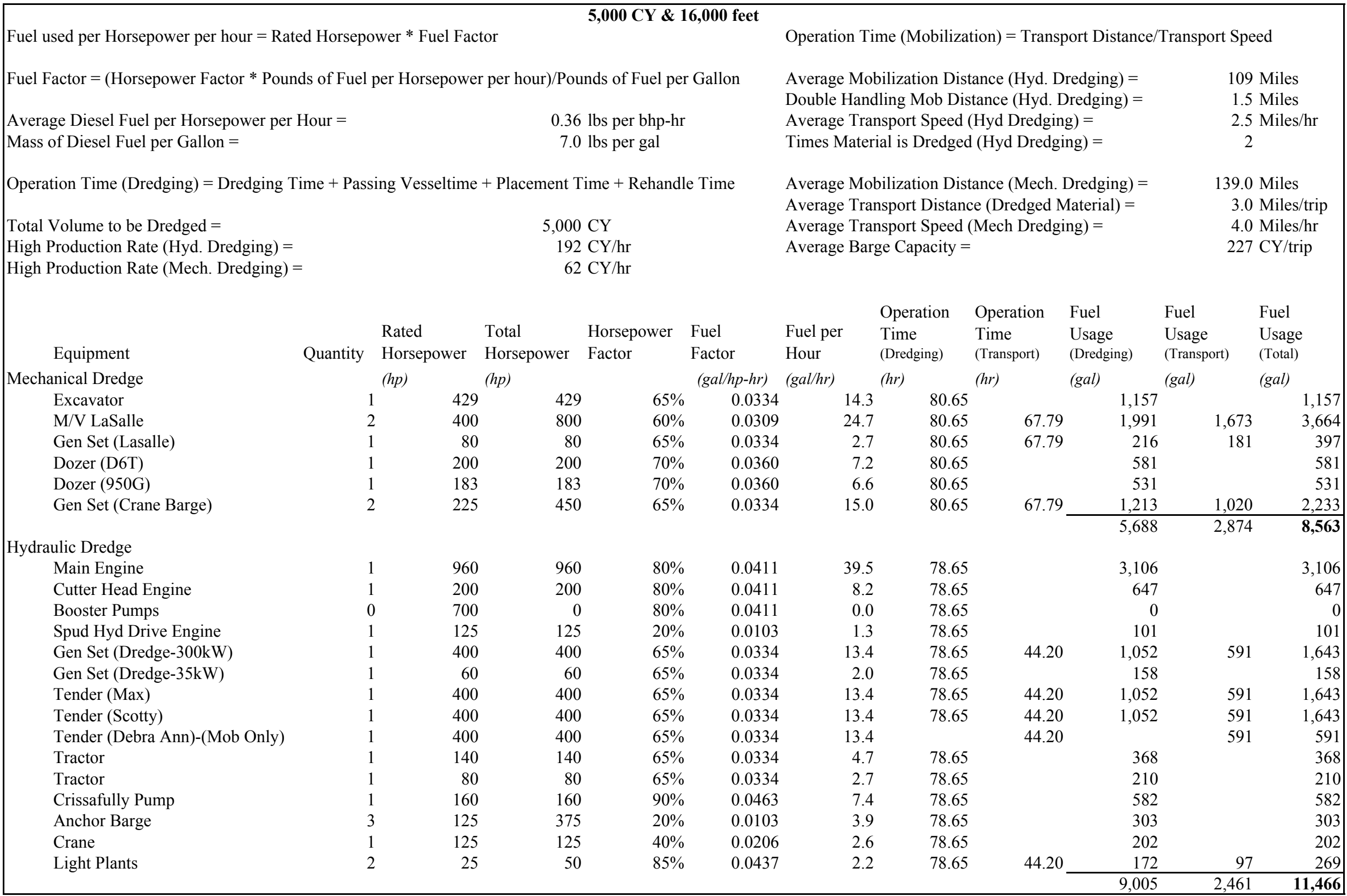




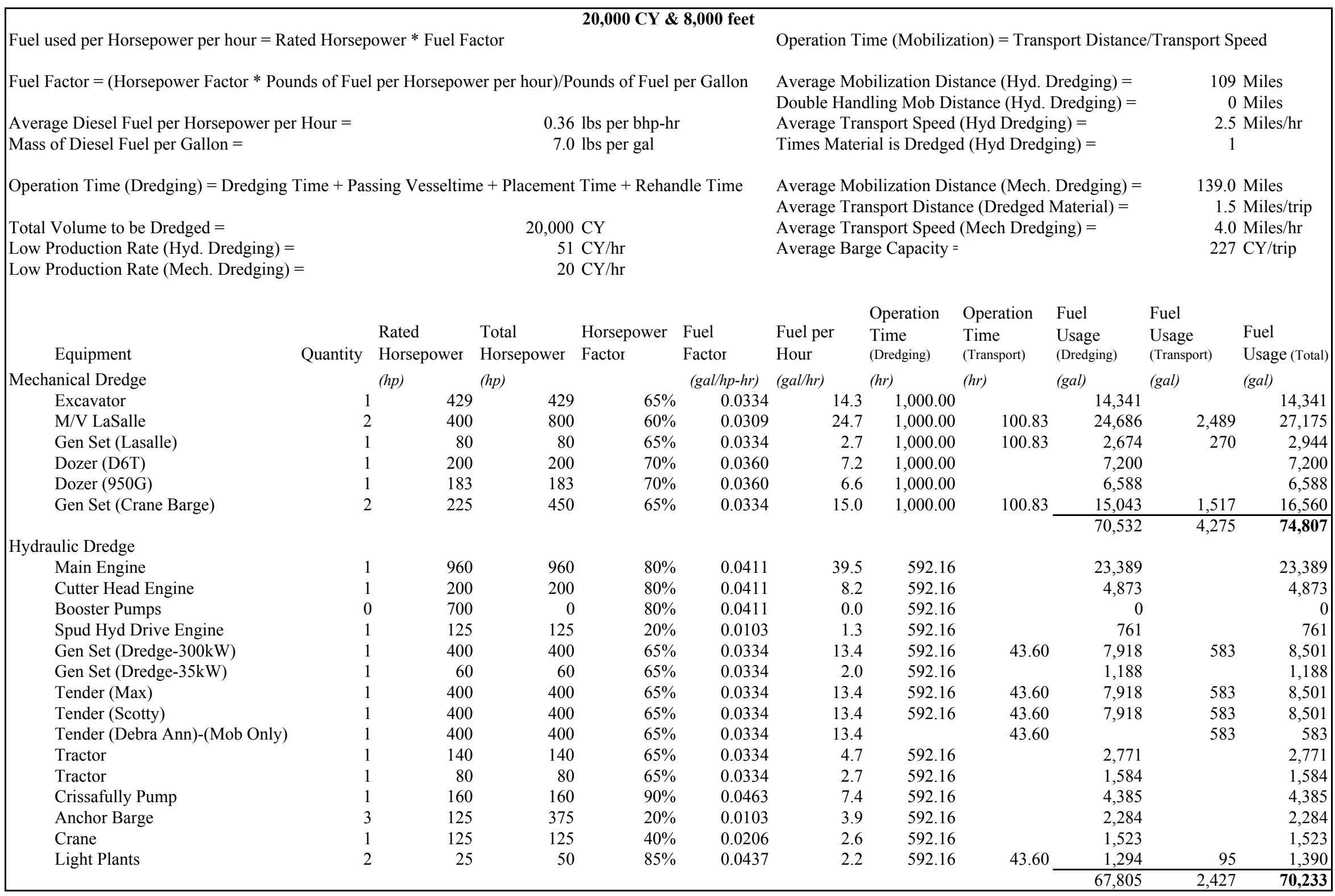




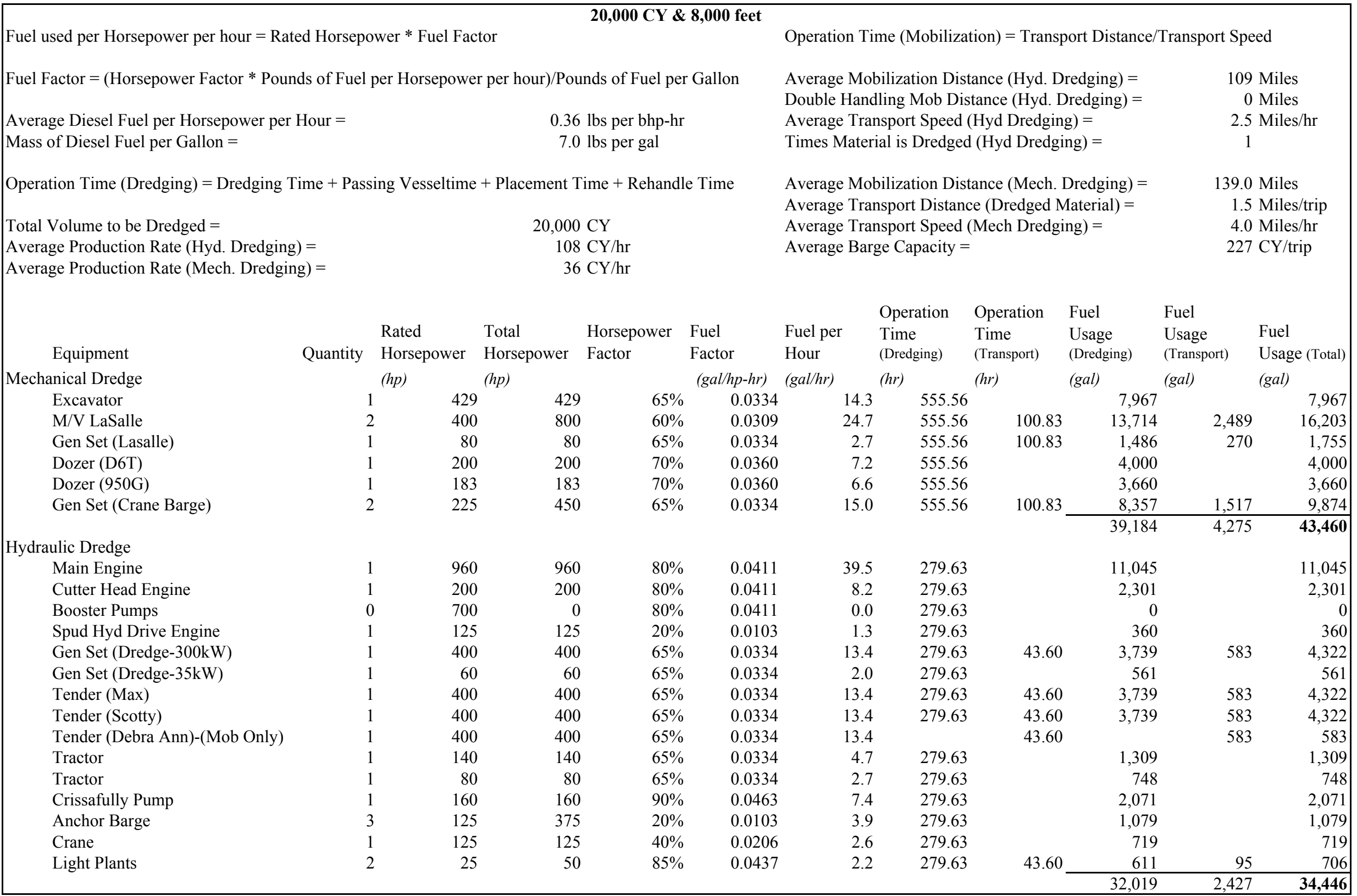




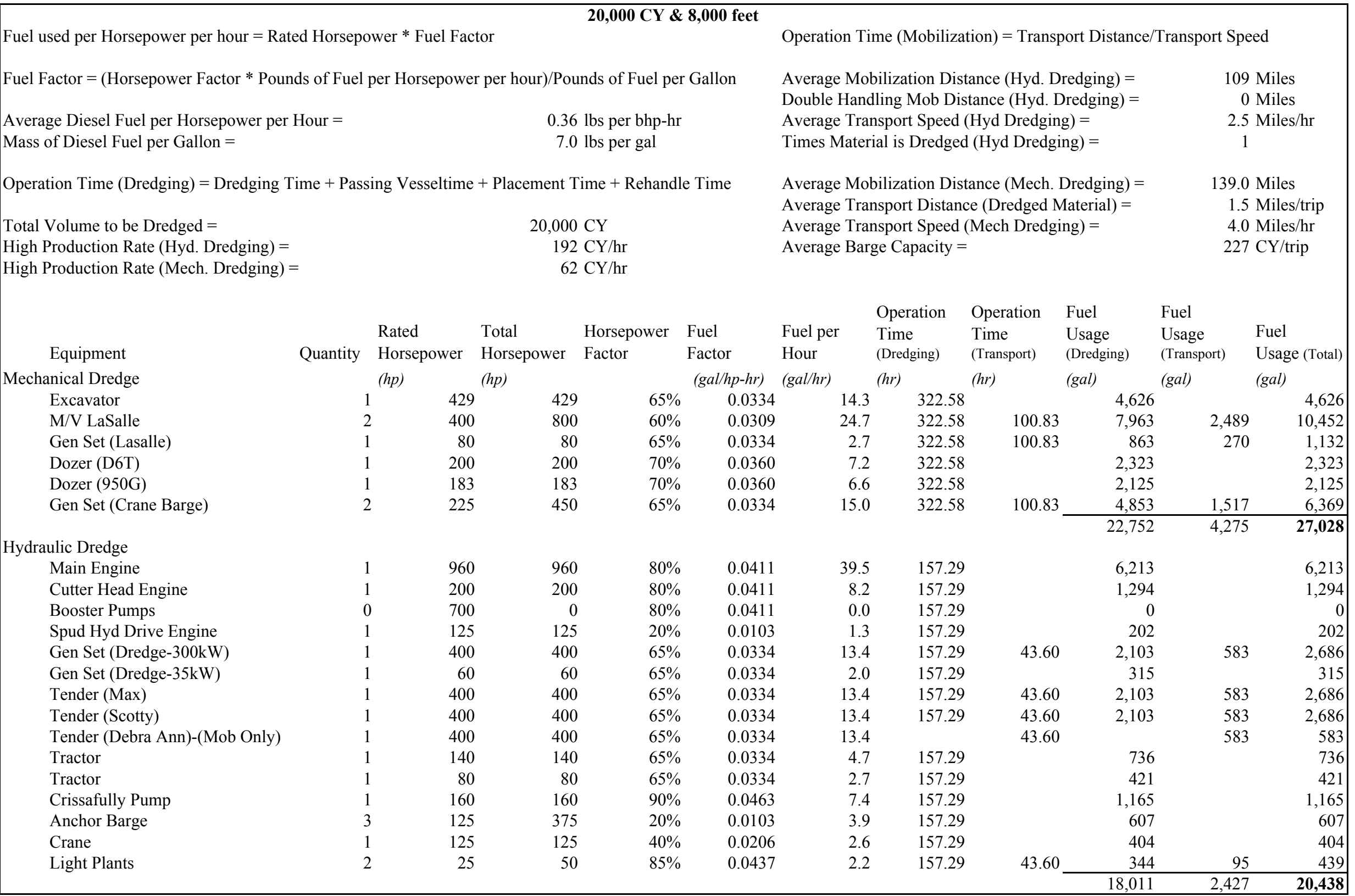




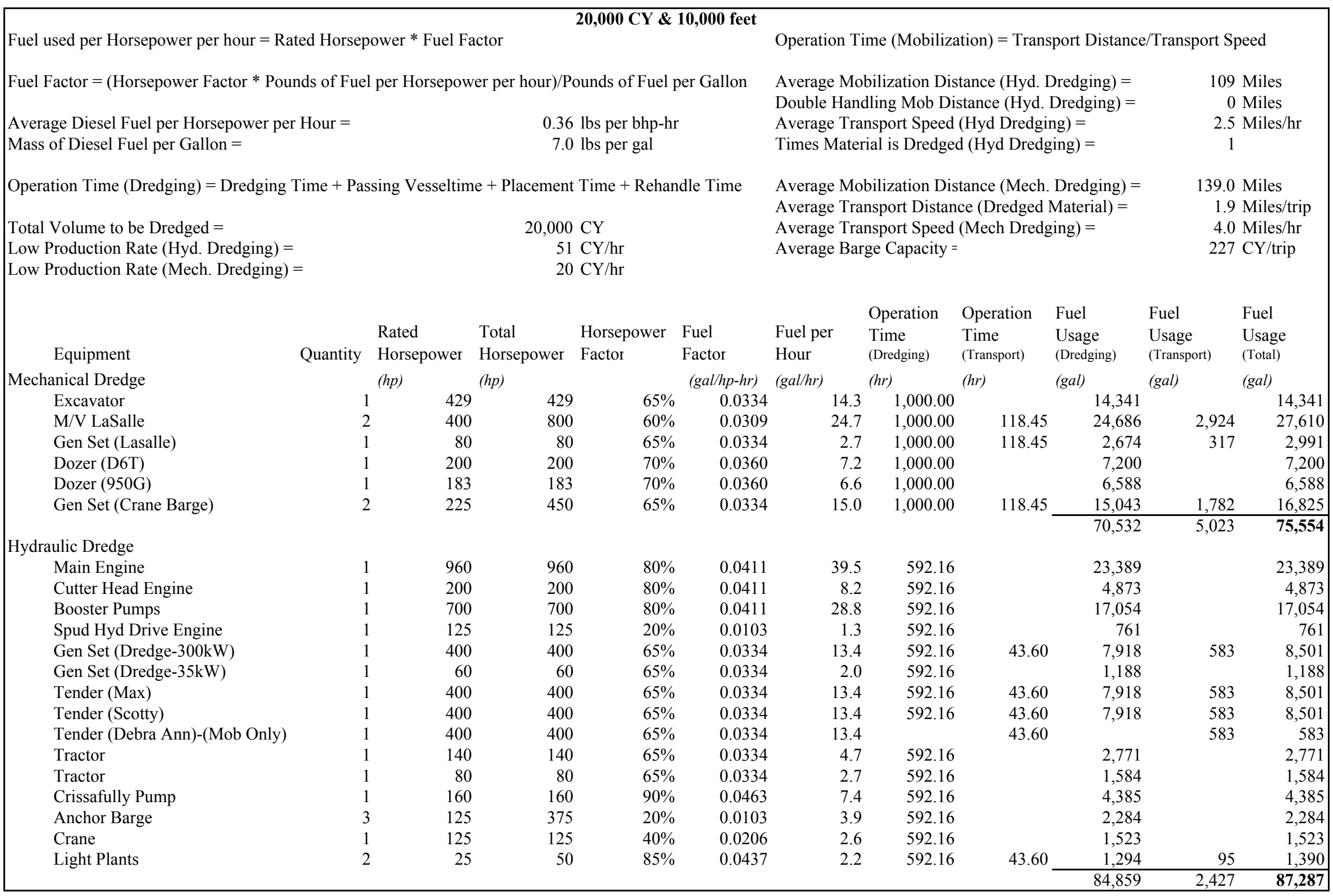




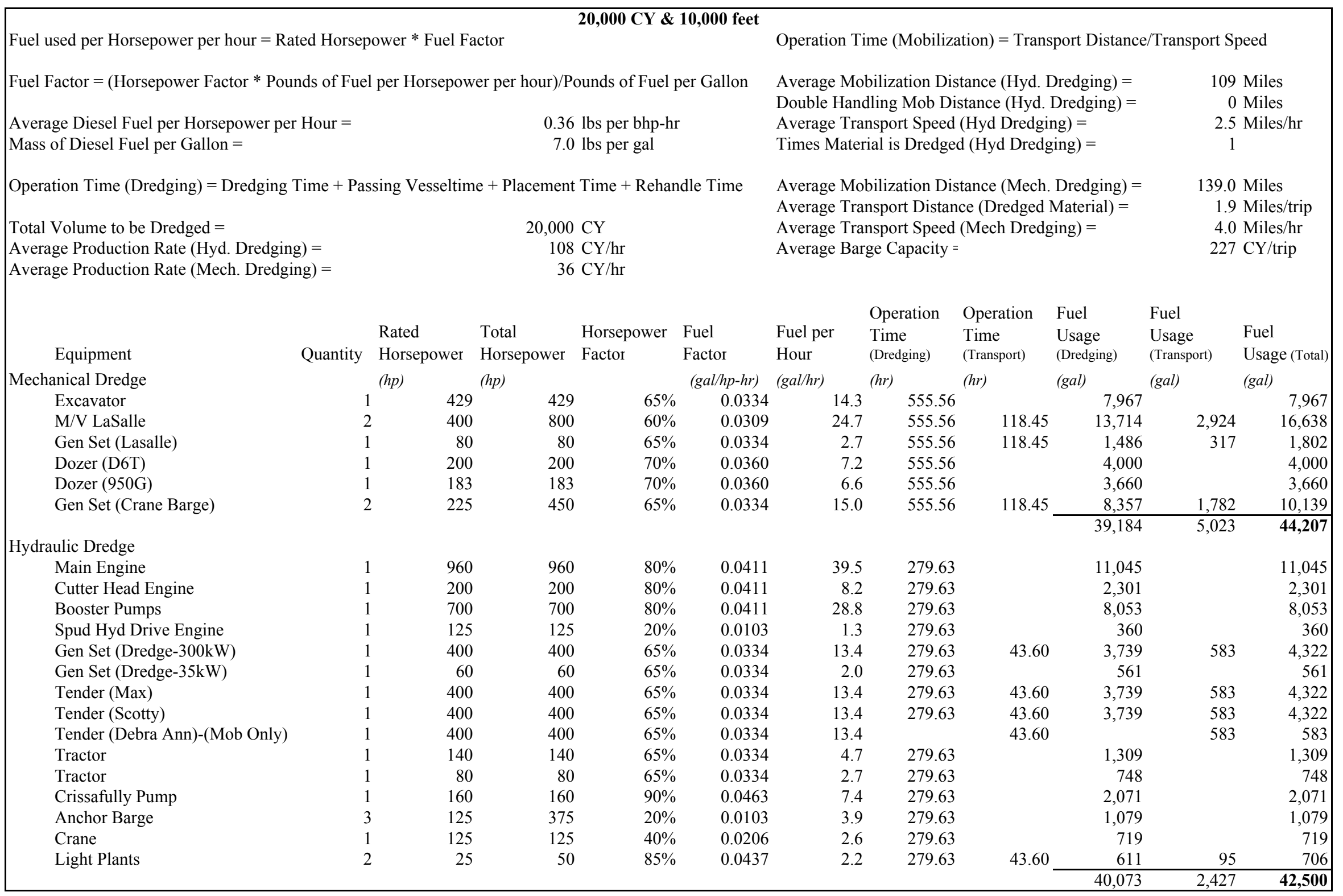




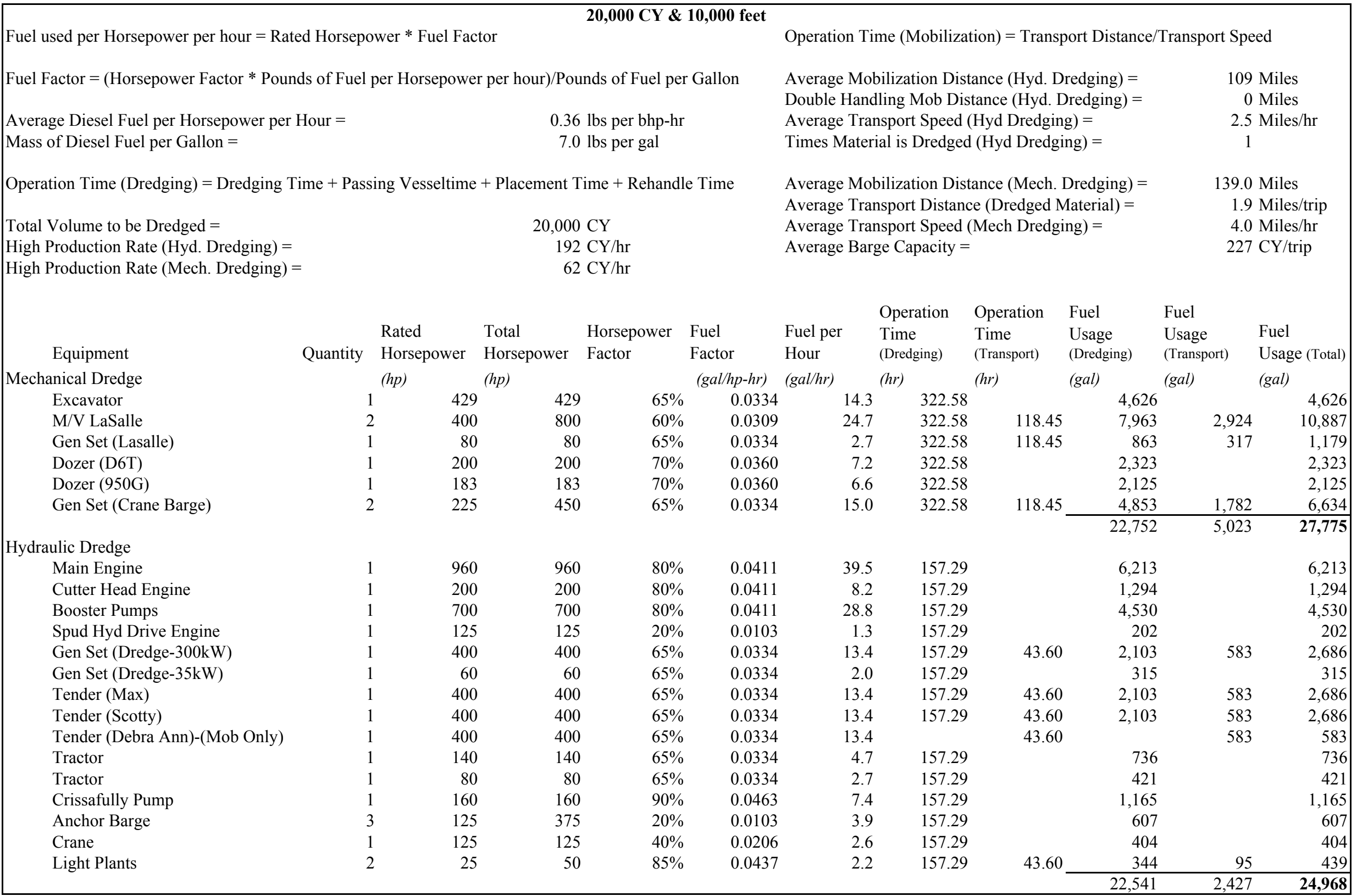




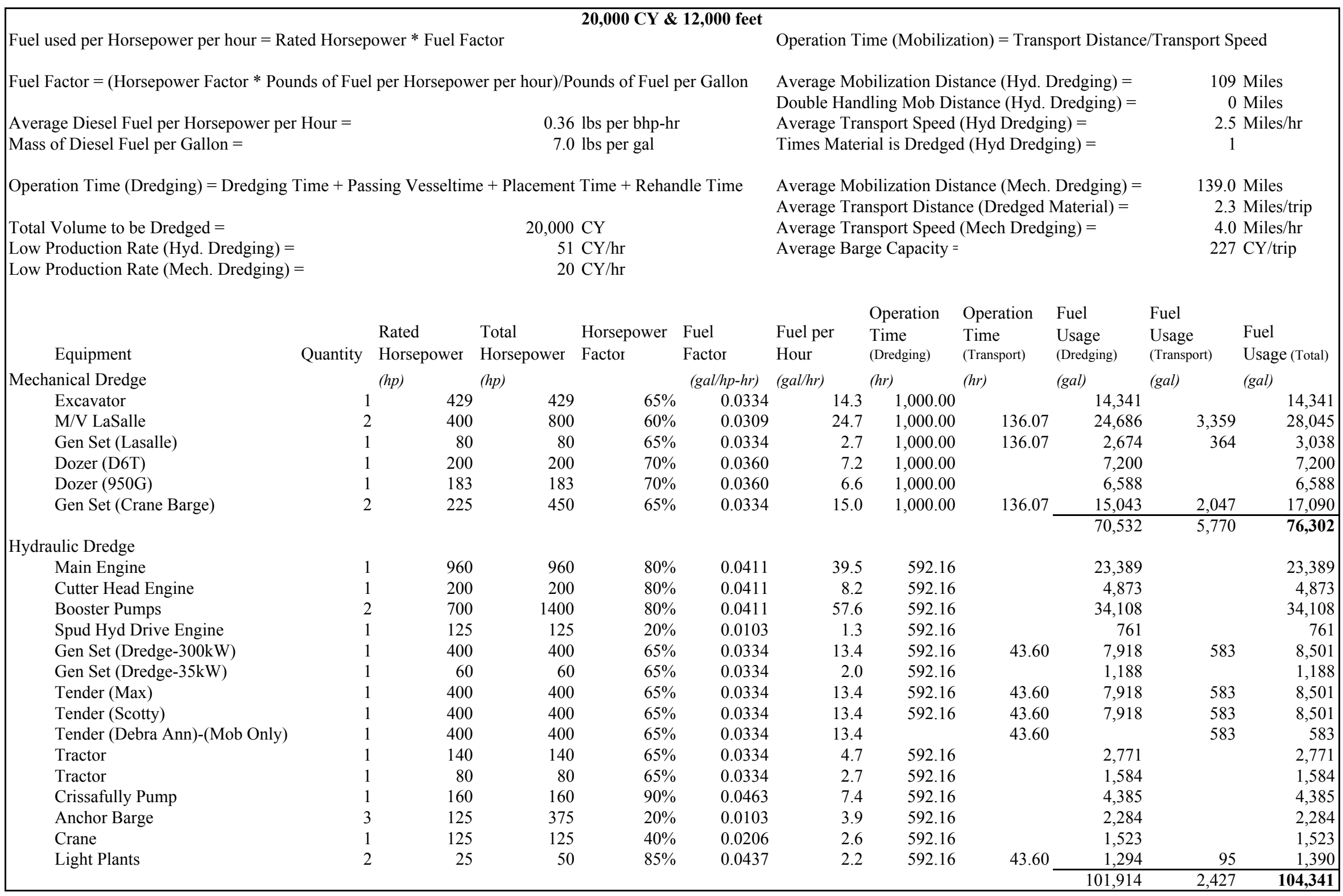




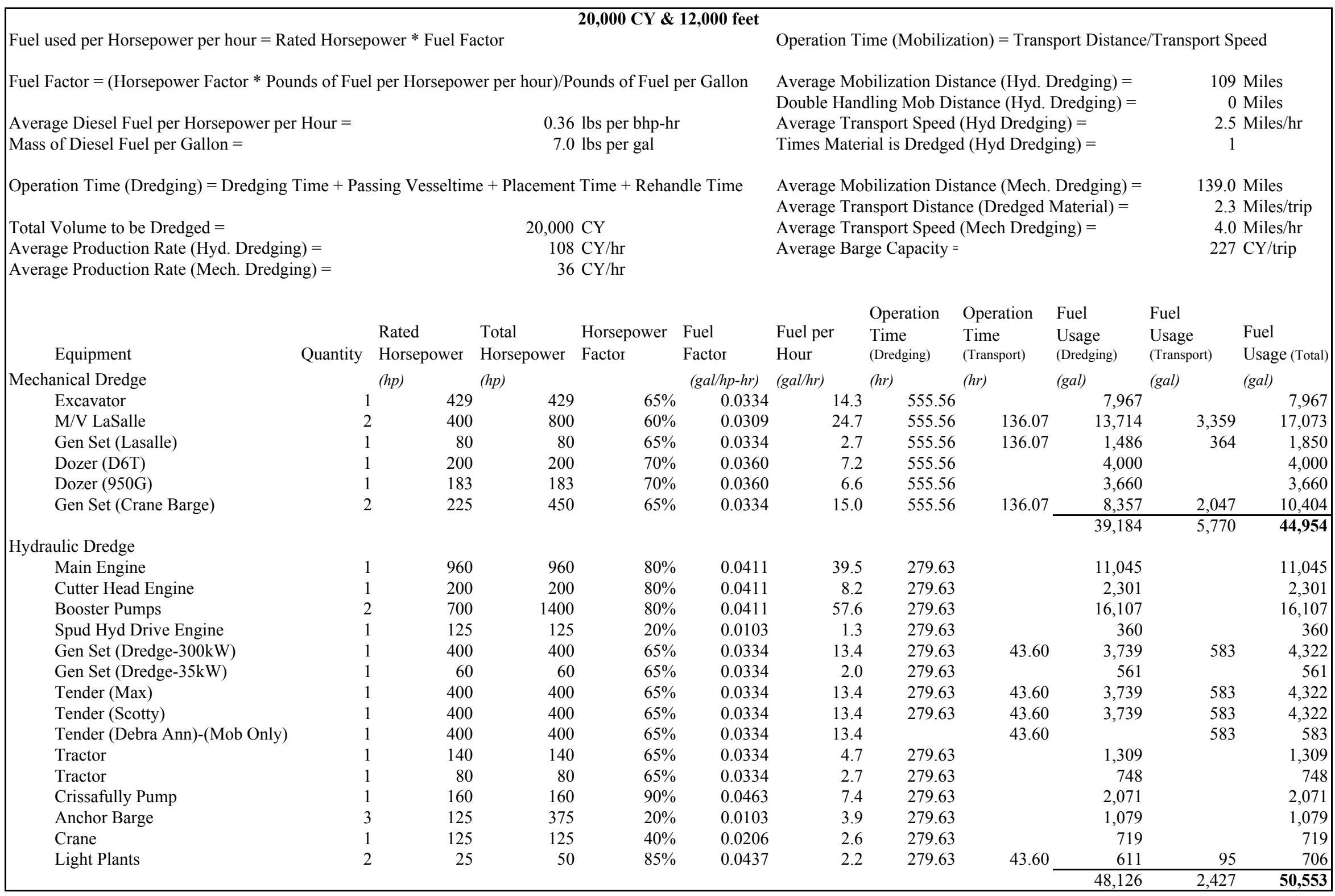




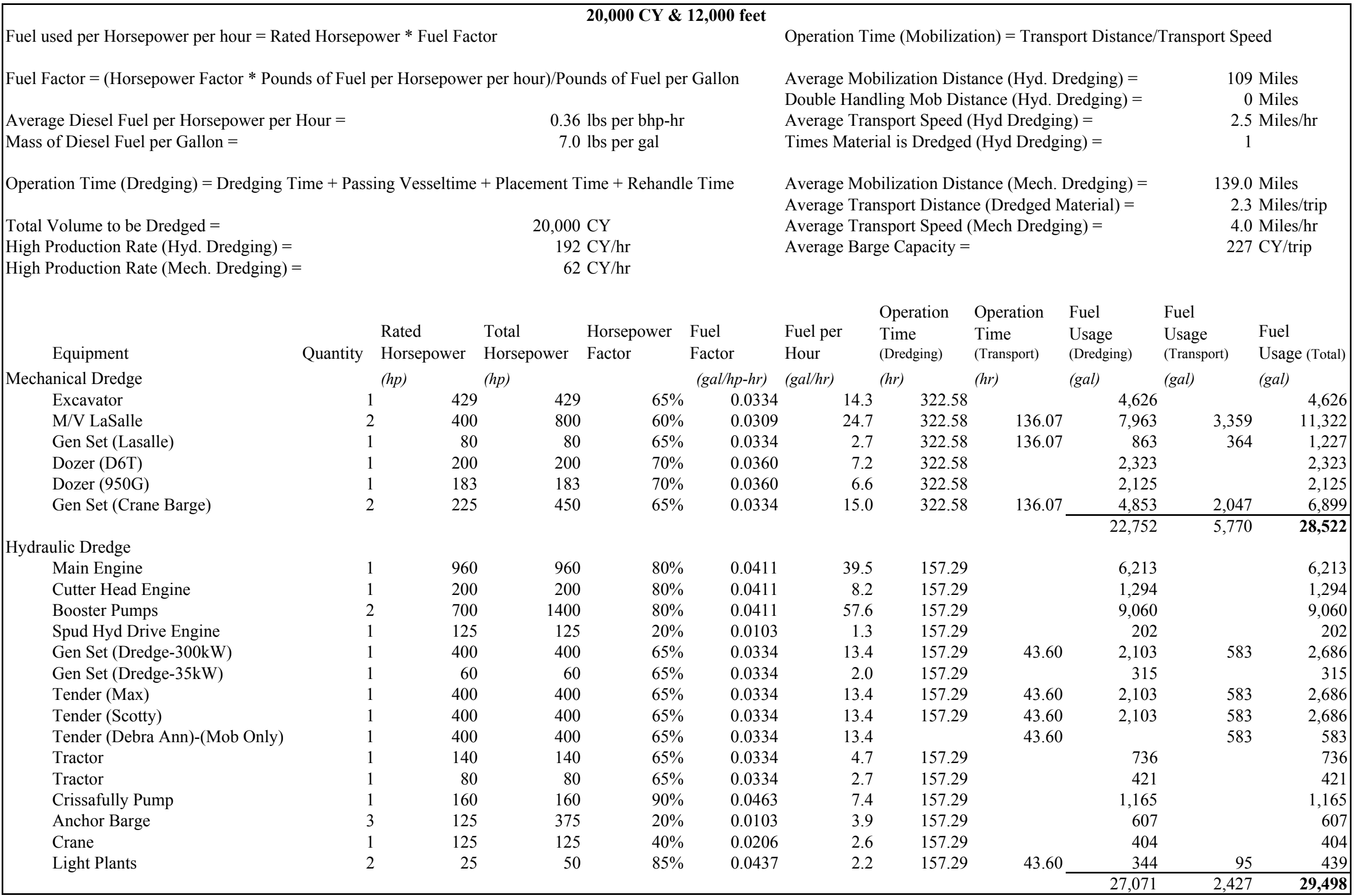




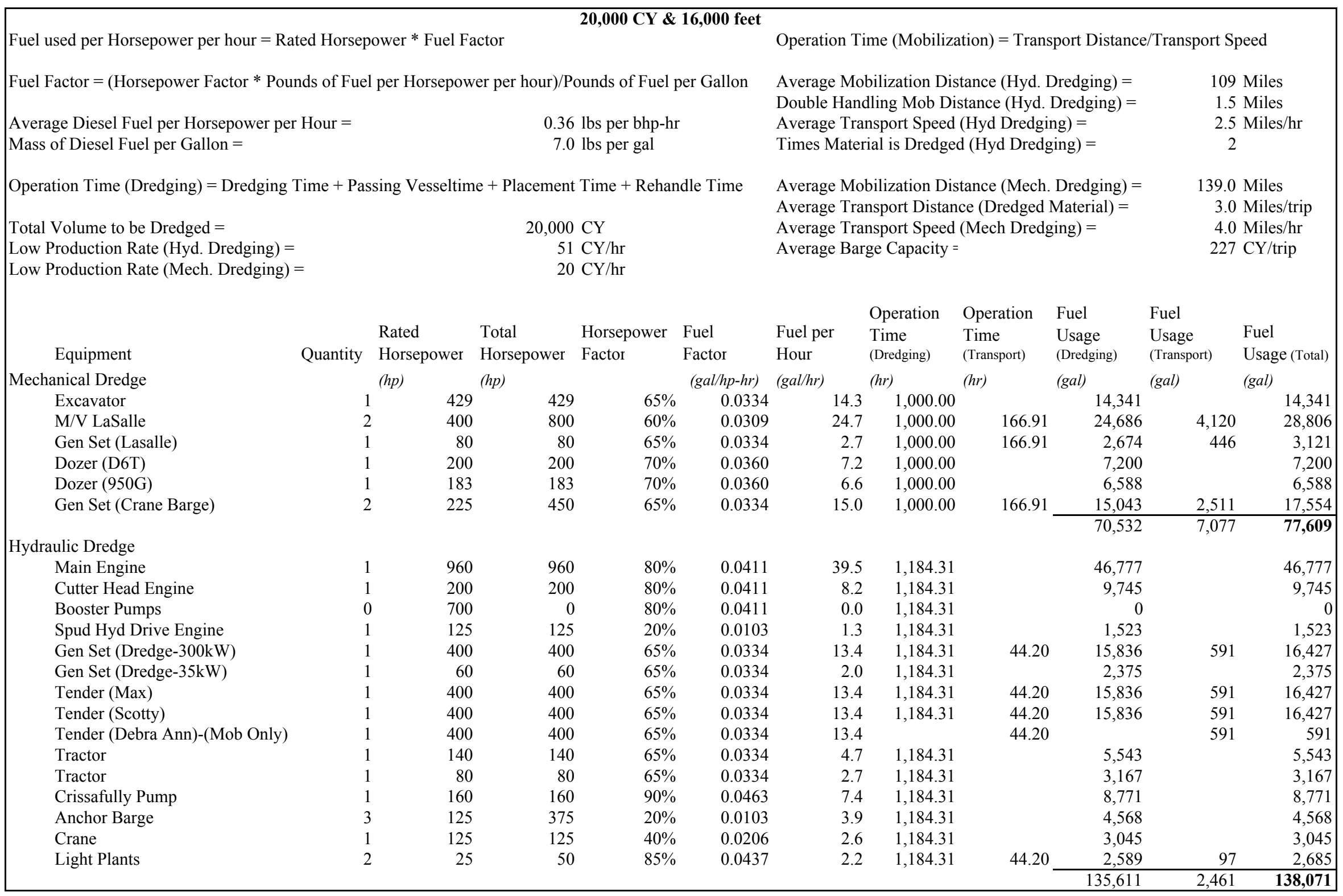




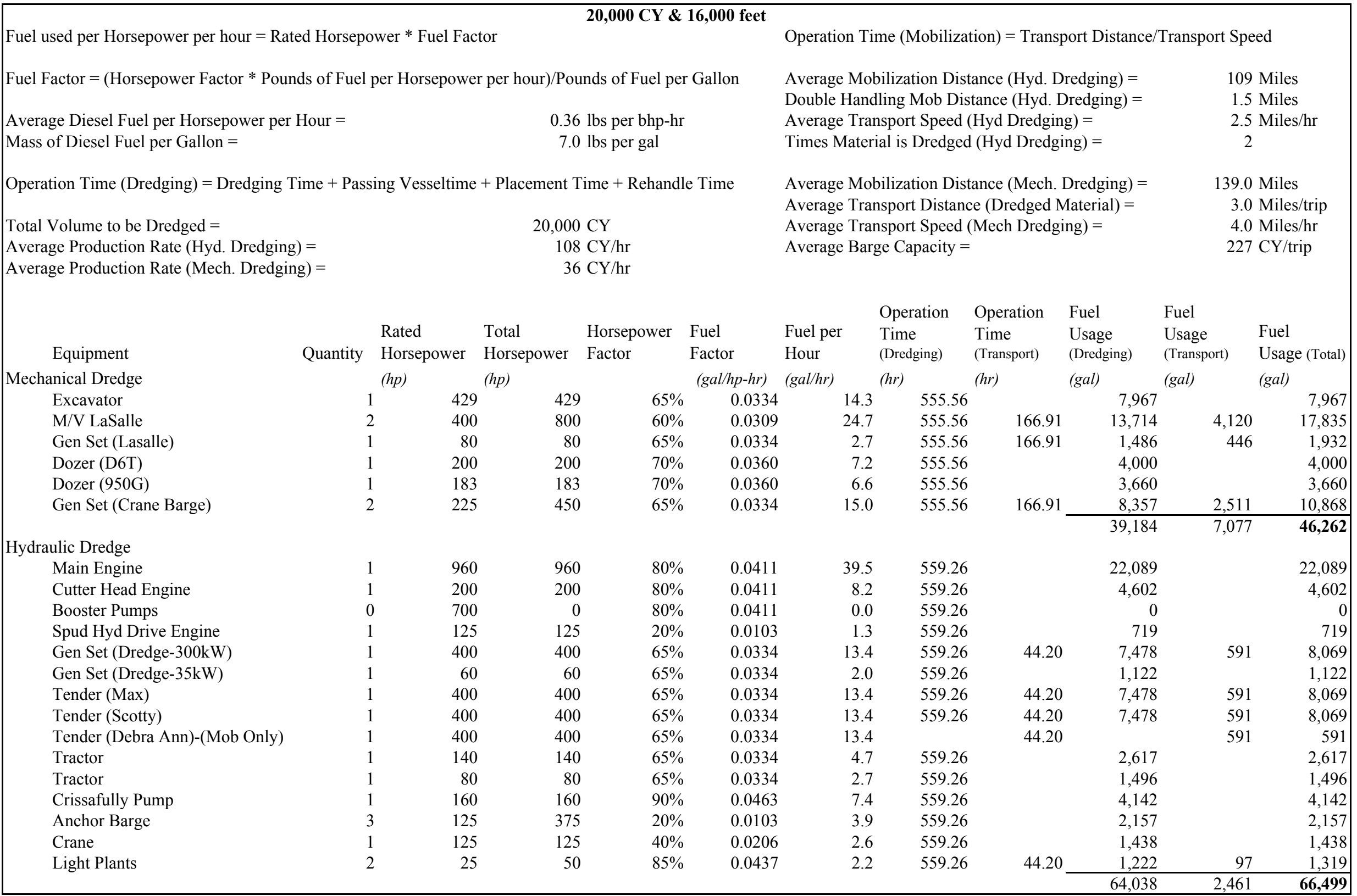




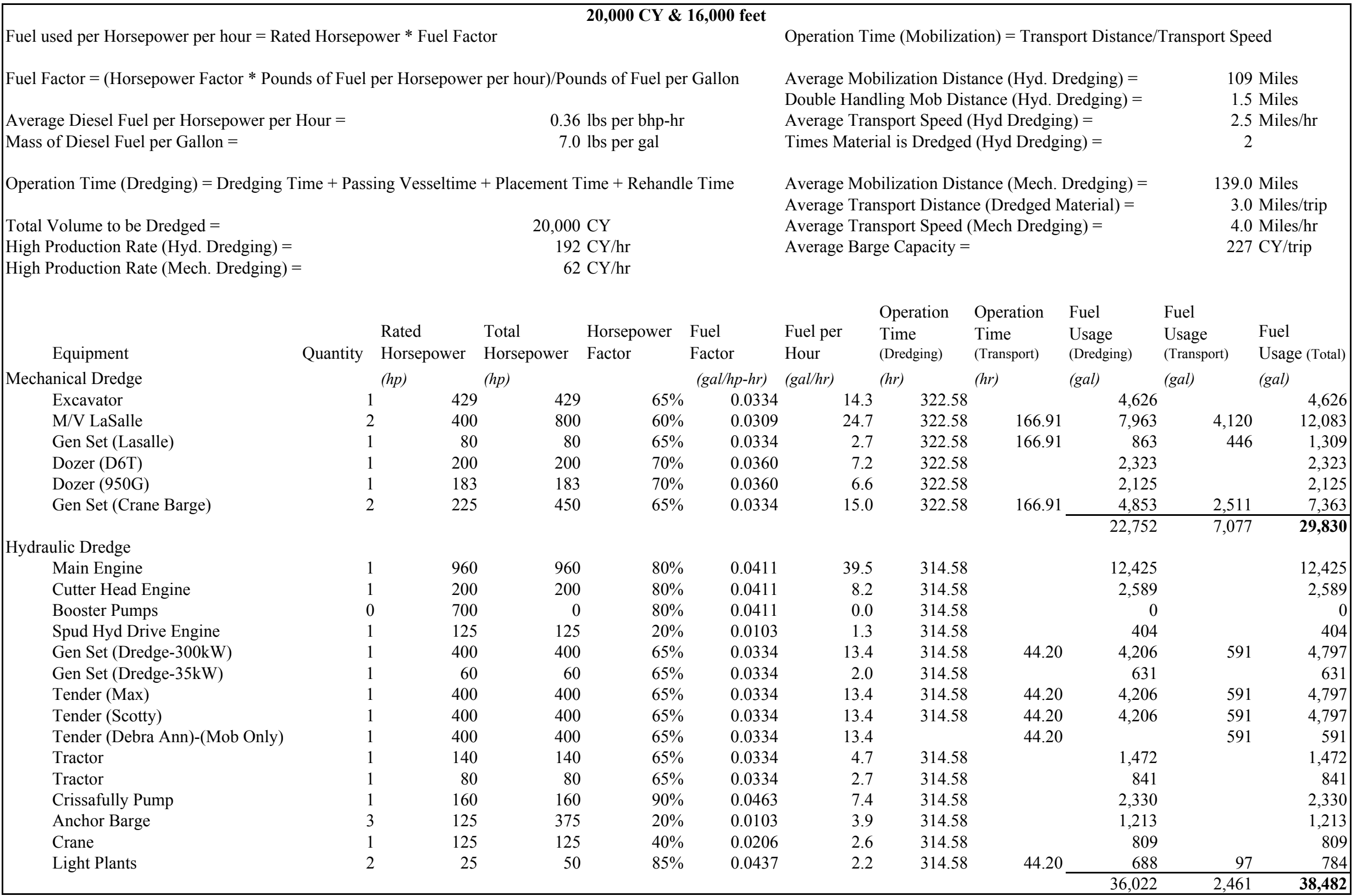




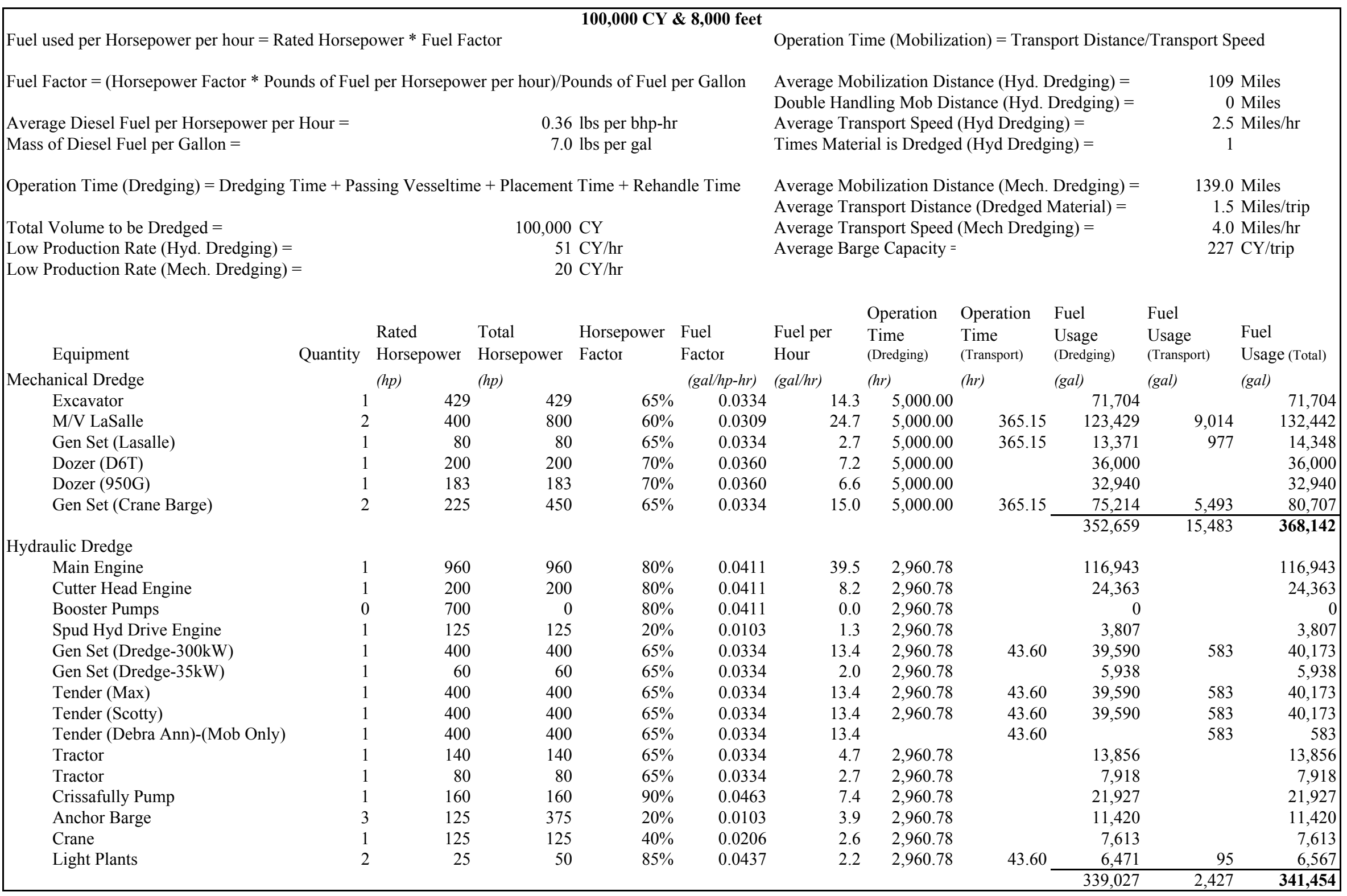


LCA Fuel Usage_100k CY.xlsx 100k 8000 ft Avg

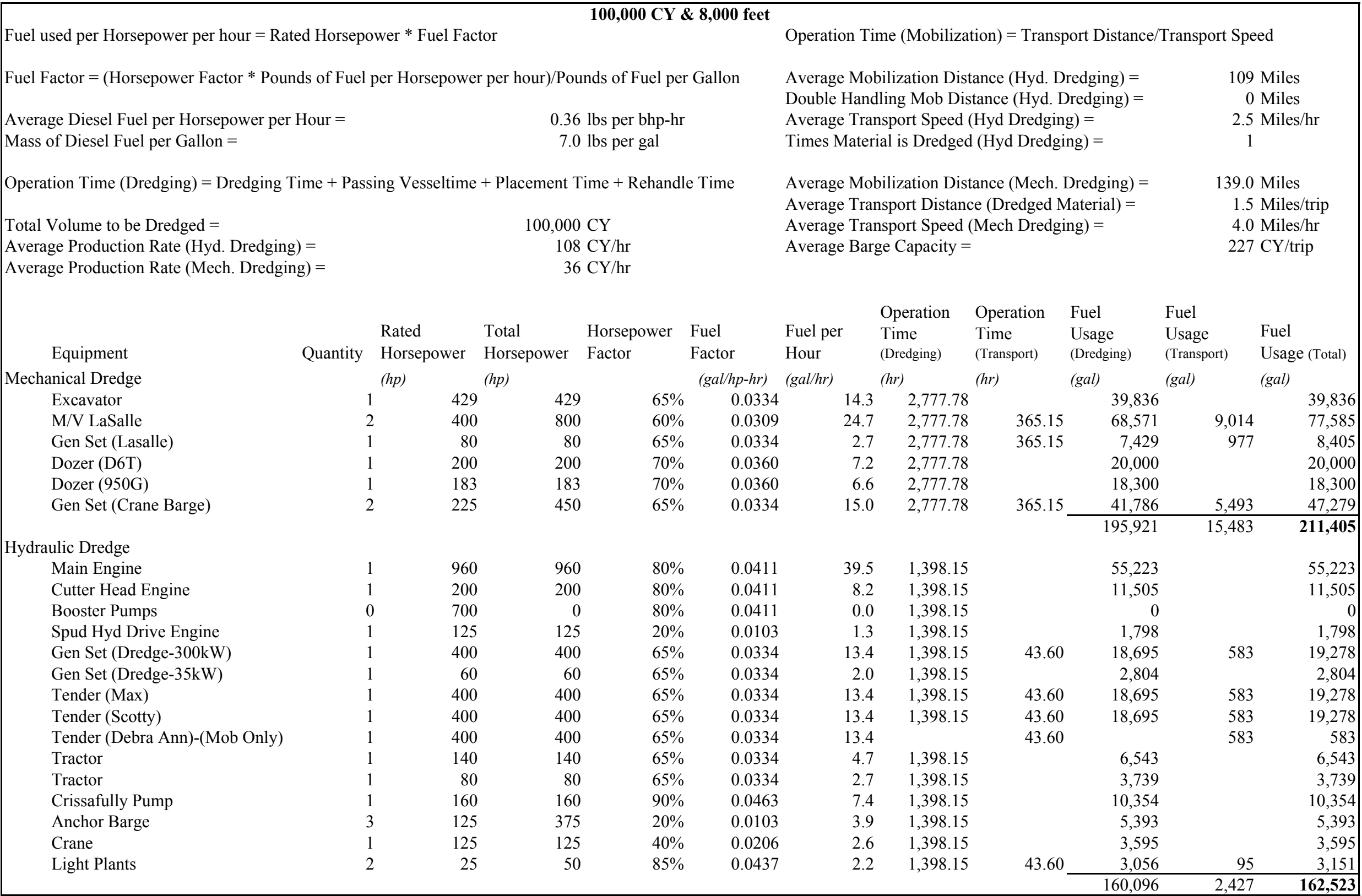




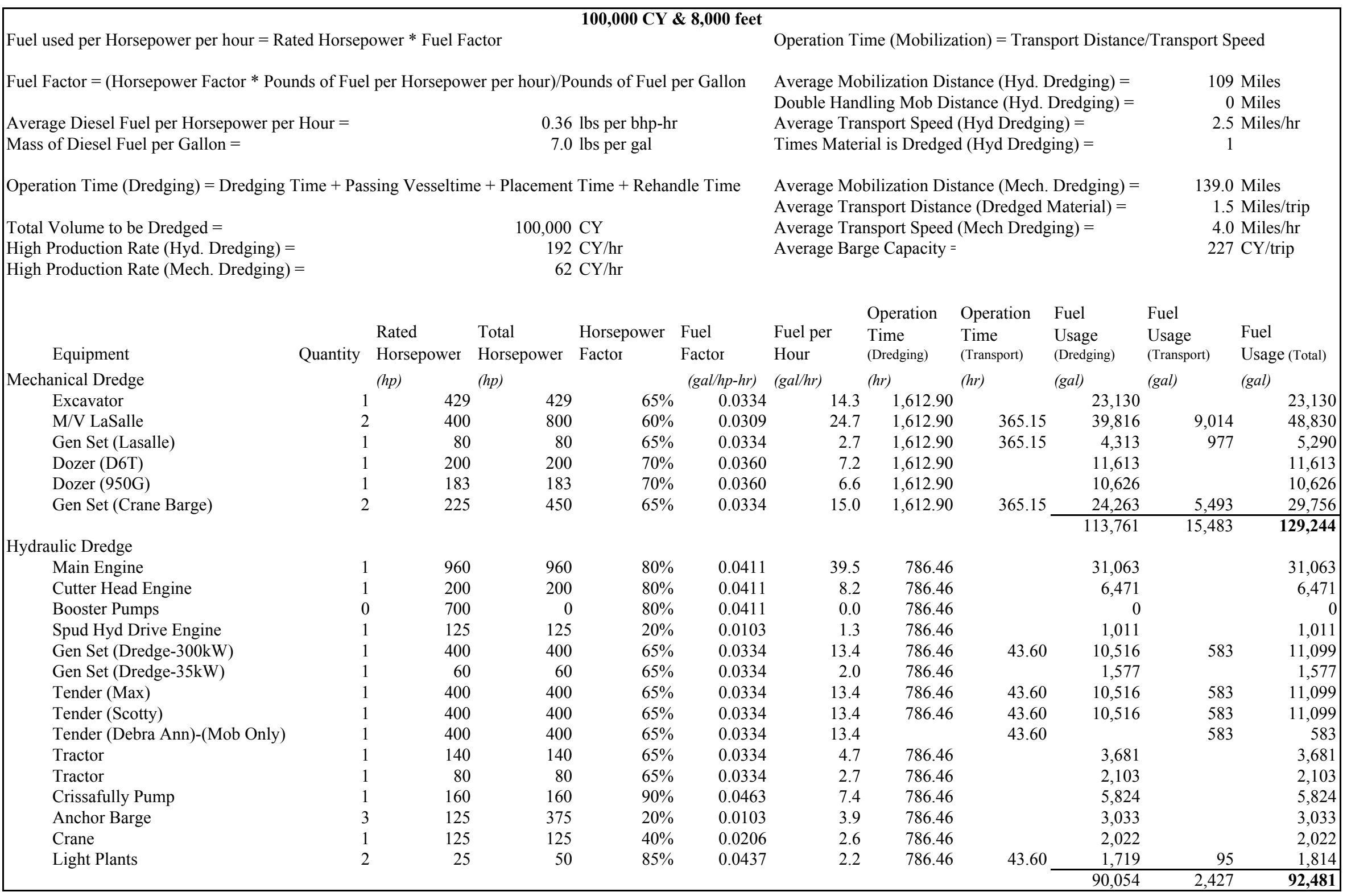




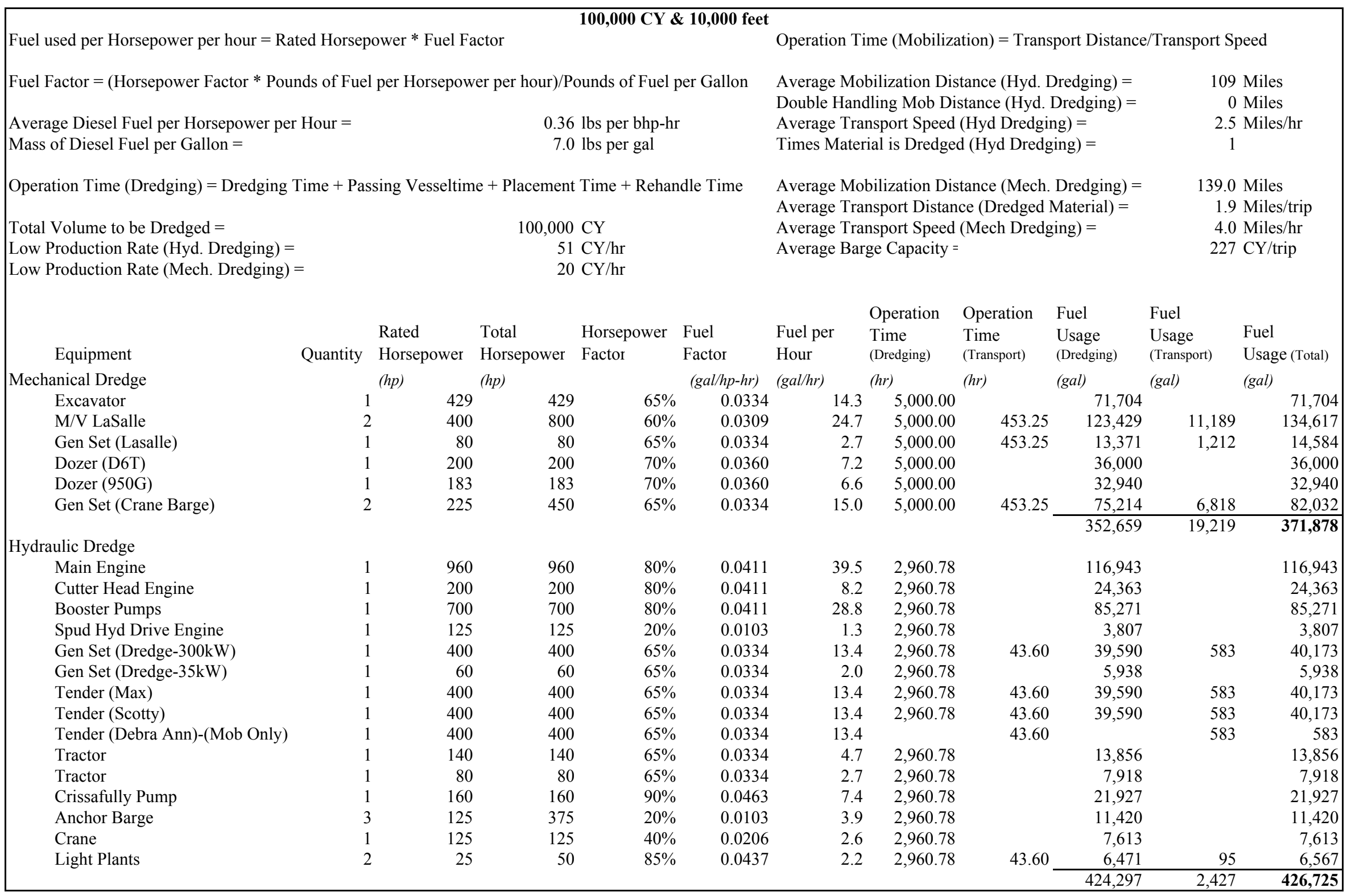




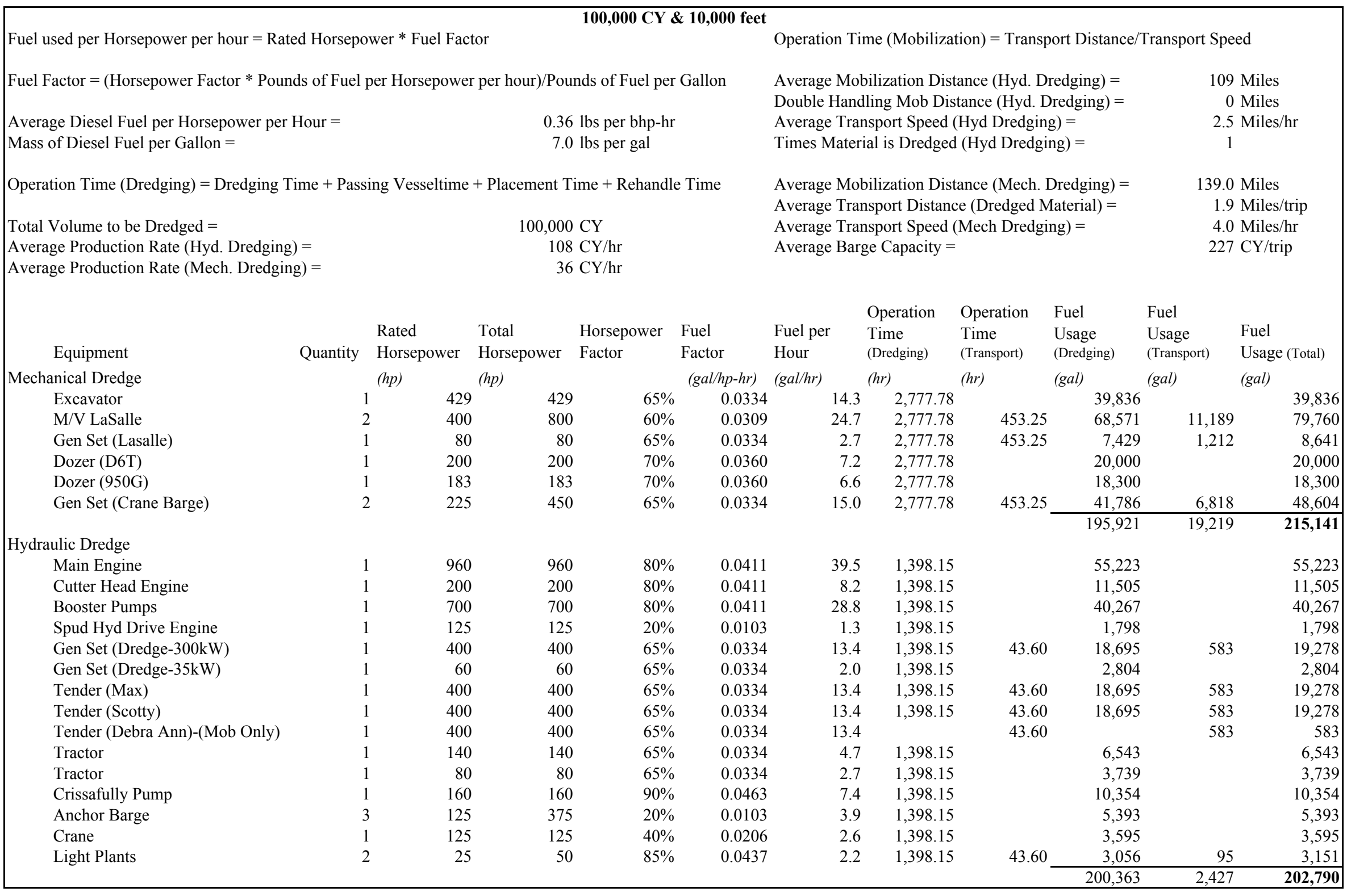




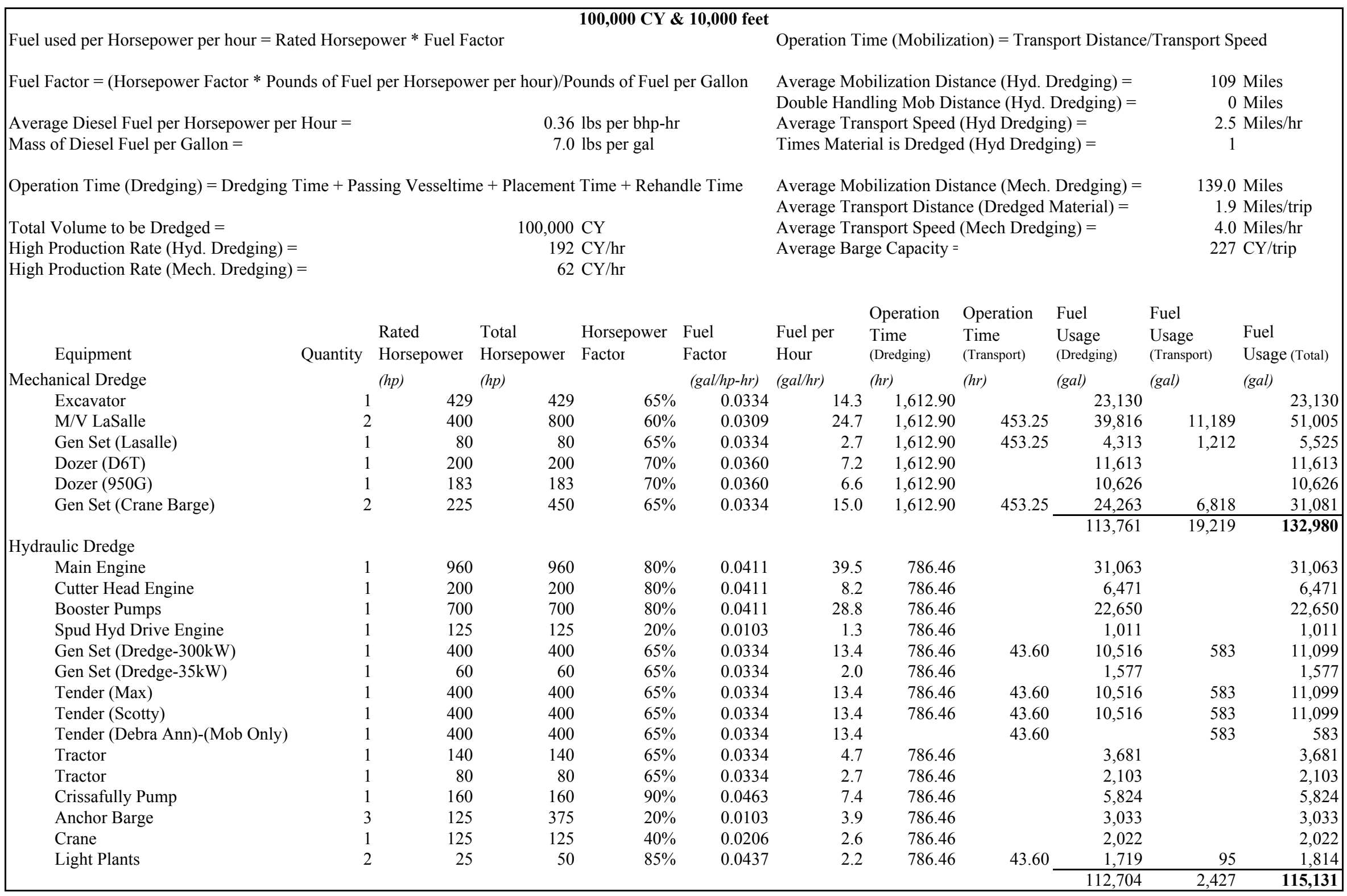




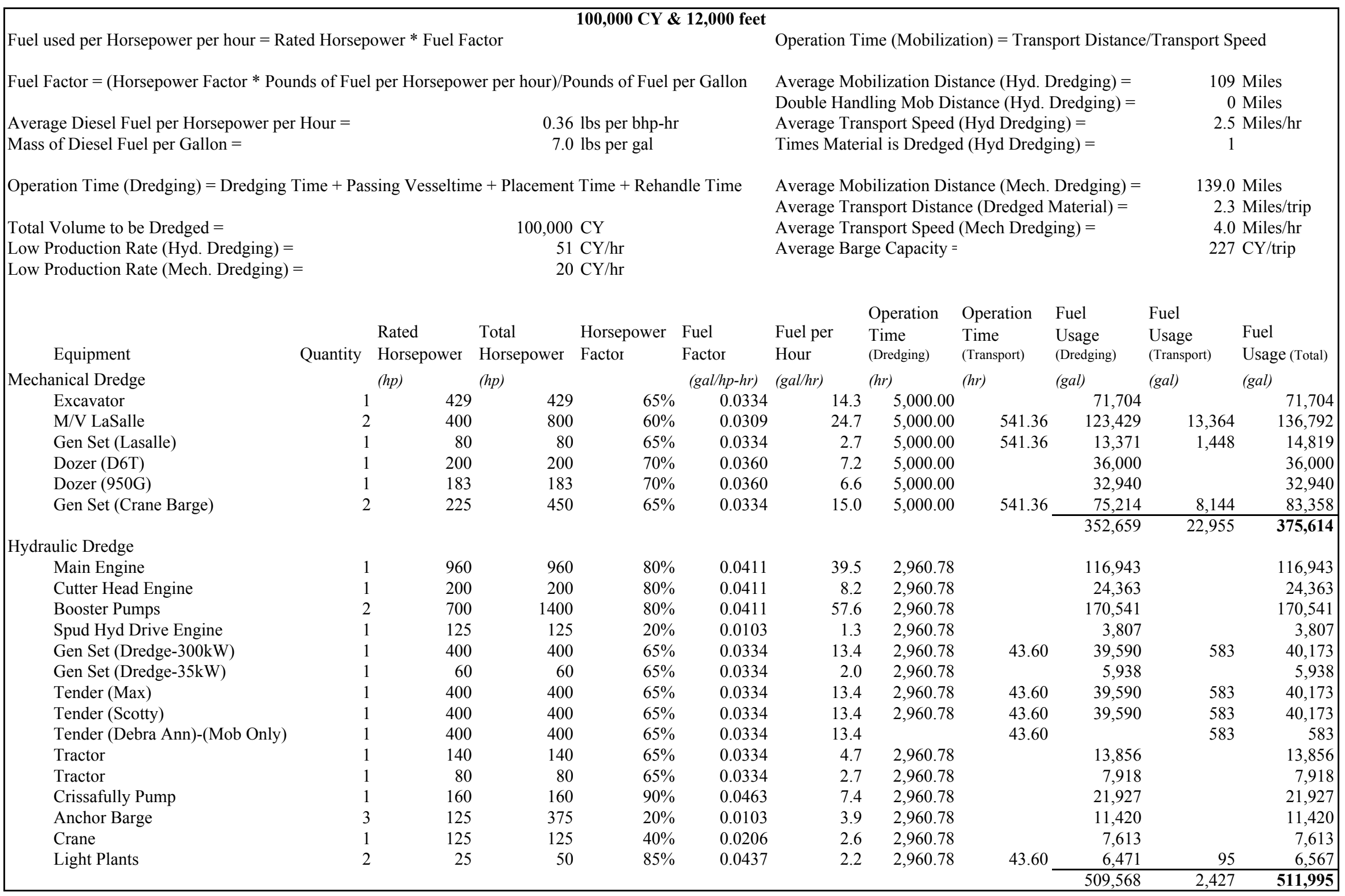




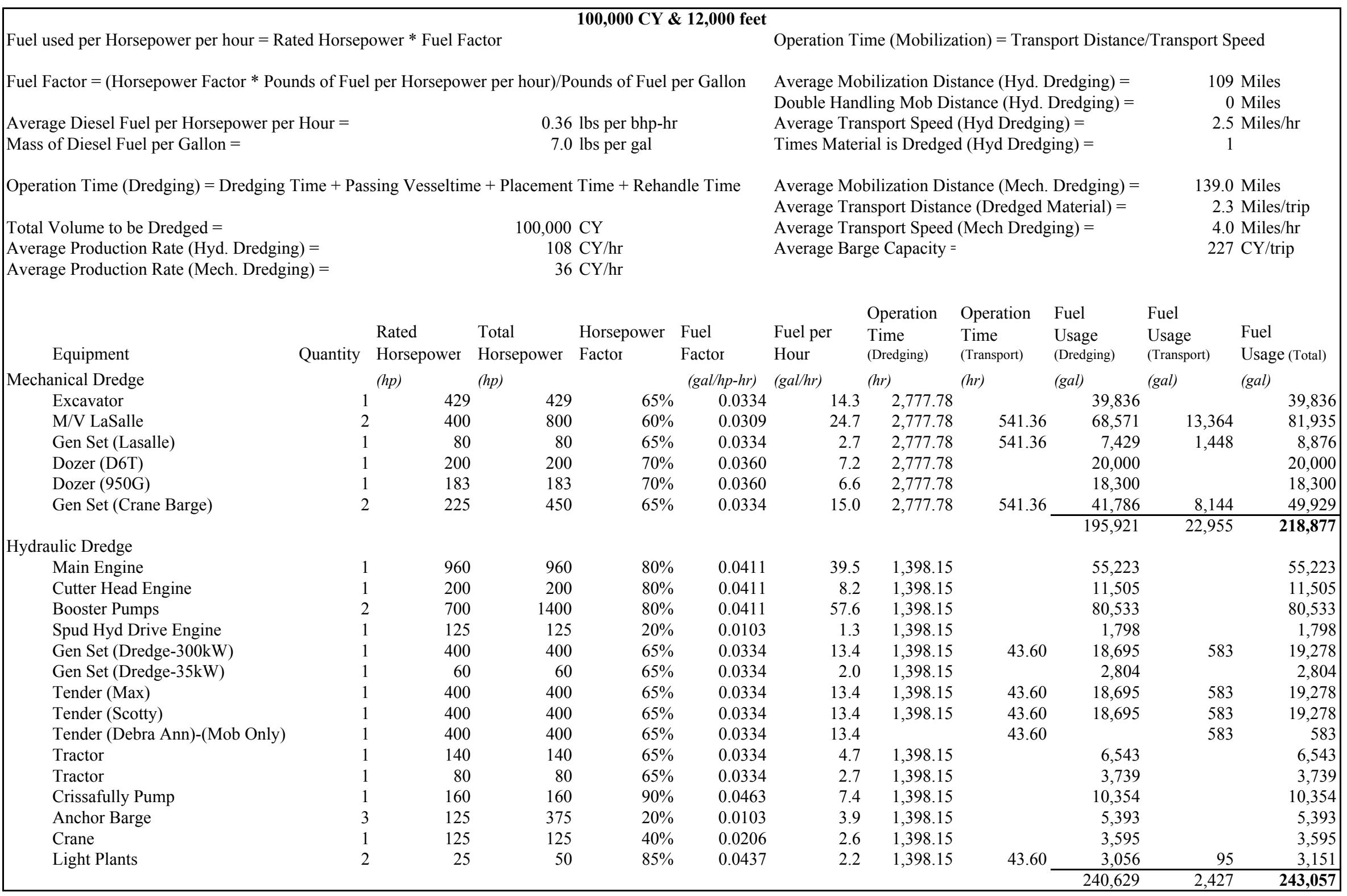




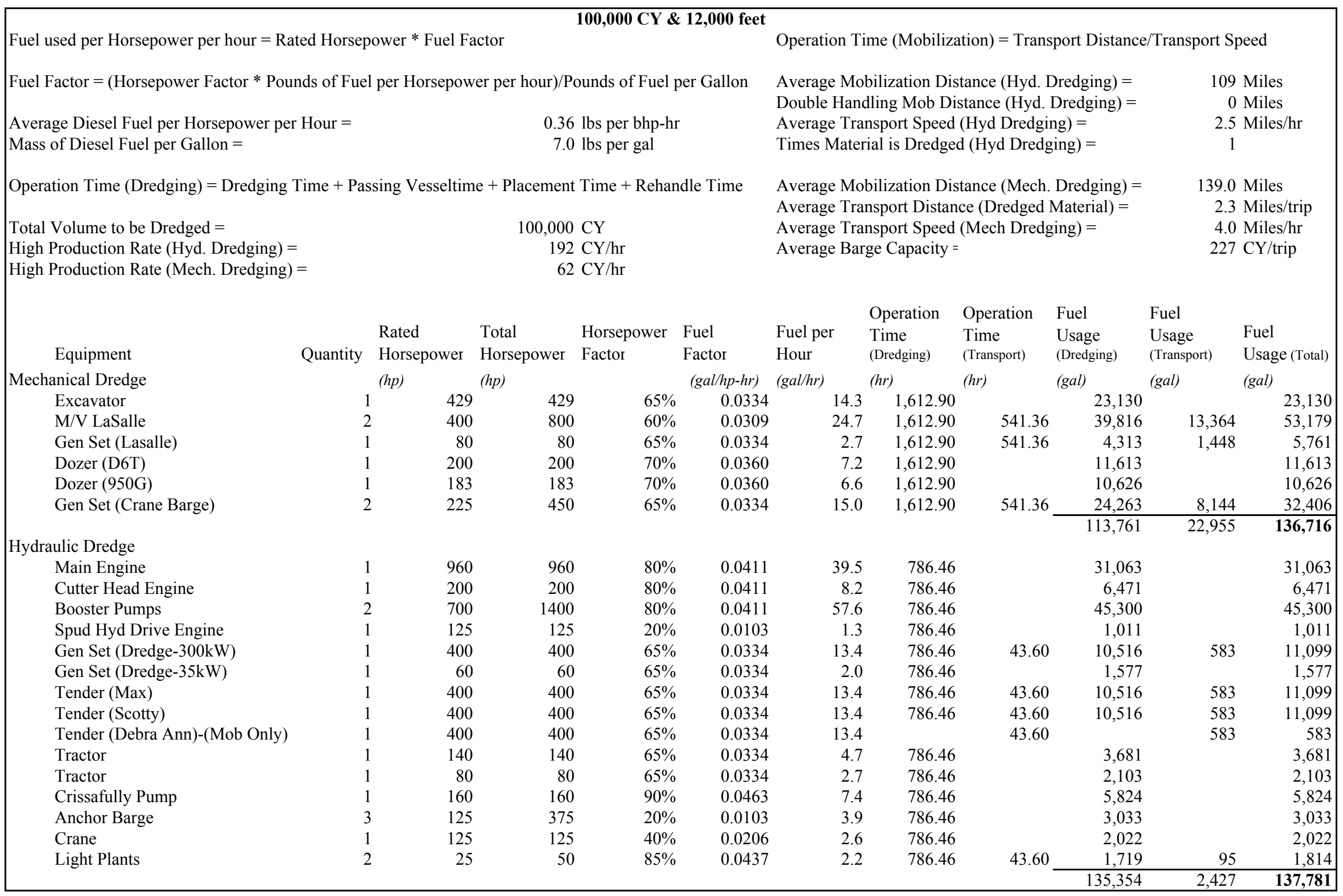




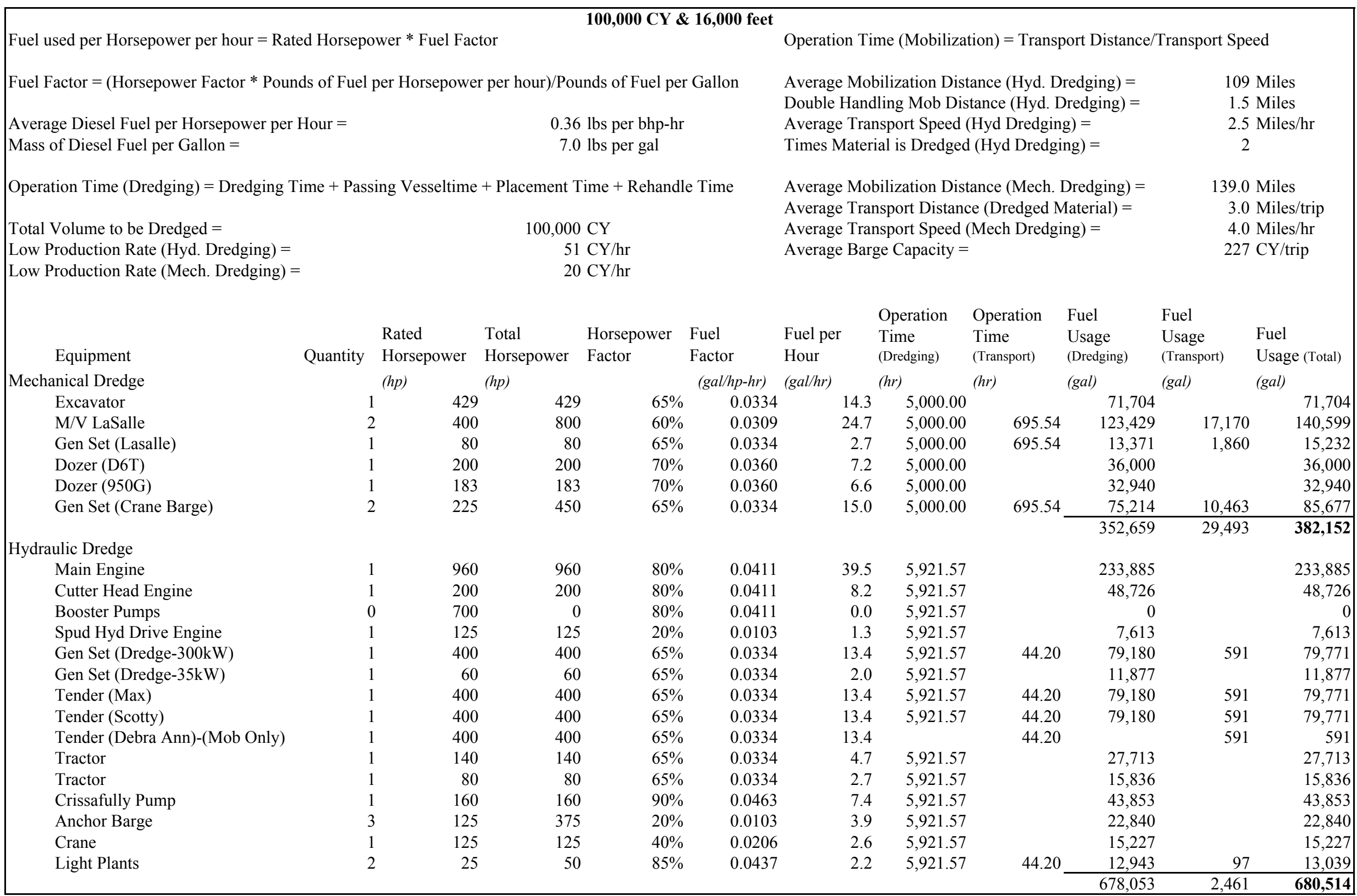




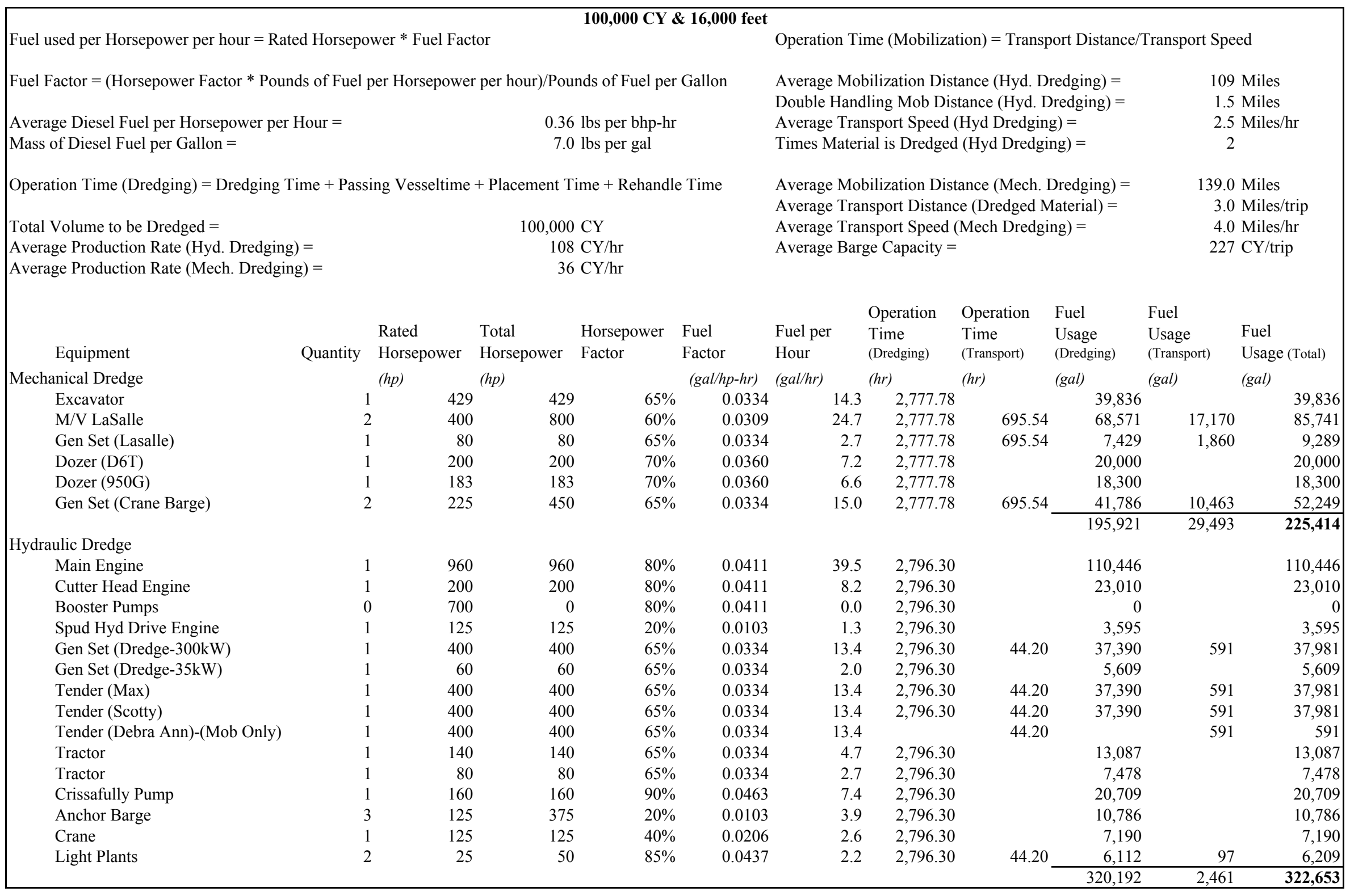




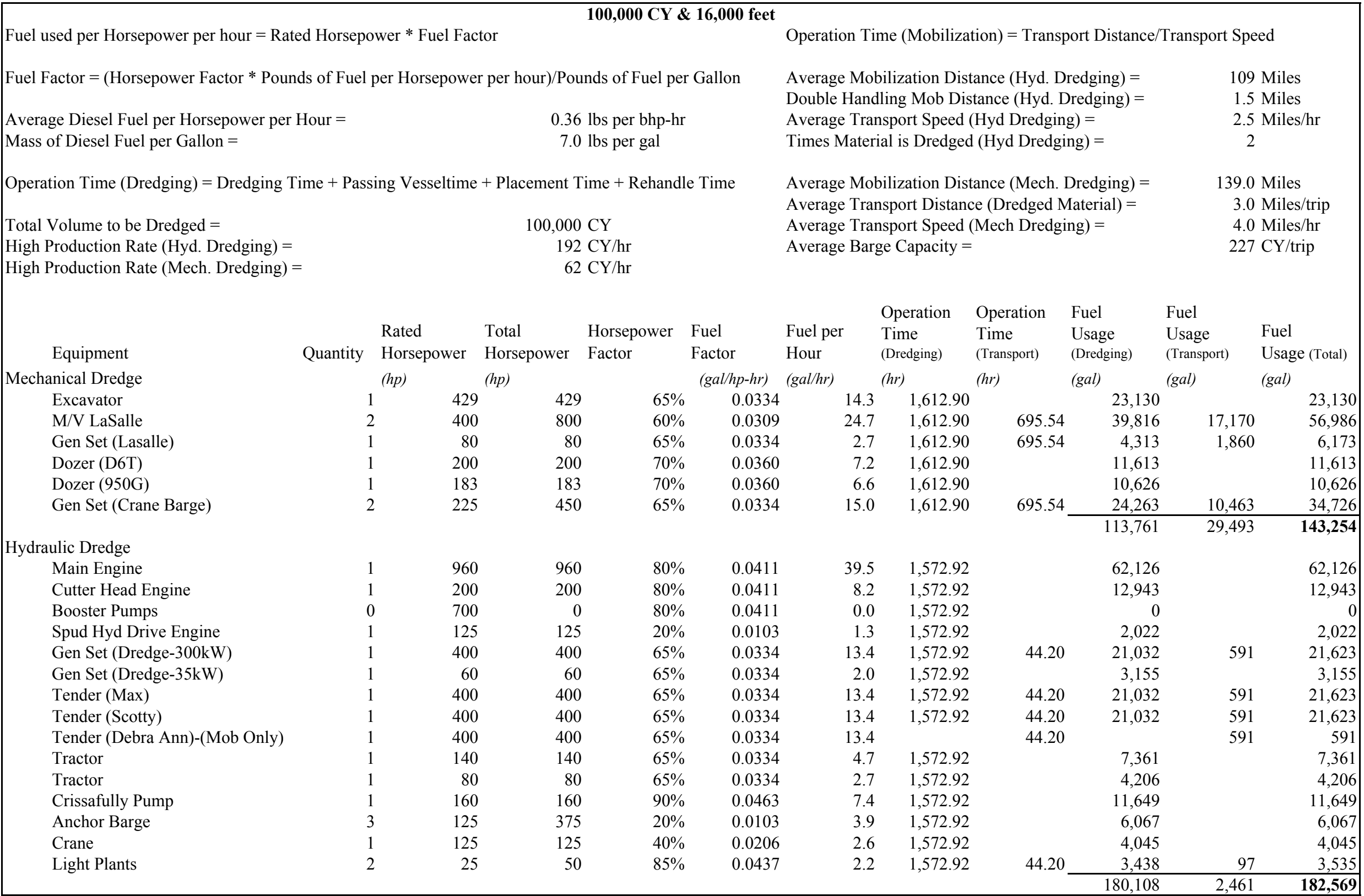




\section{APPENDIX C}

\section{DREDGING \\ COST ESTIMATE \\ CALCULATION TABLES}




\begin{tabular}{|c|c|c|c|c|c|c|c|c|c|c|c|c|c|c|c|c|c|c|c|c|c|}
\hline \multicolumn{3}{|c|}{ QUANTITY: } & \multicolumn{2}{|c|}{1,000} & \multicolumn{2}{|l|}{ CY } & \multirow[b]{2}{*}{ 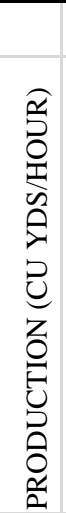 } & & \multirow[b]{2}{*}{ 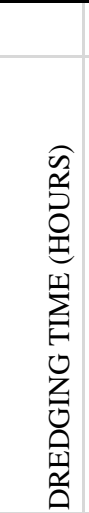 } & \multirow[b]{2}{*}{ 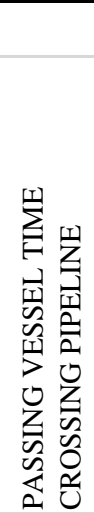 } & \multirow[b]{2}{*}{ 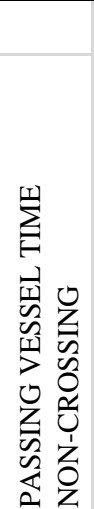 } & \multirow[b]{2}{*}{ 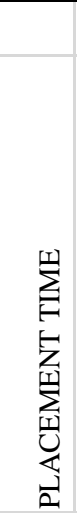 } & \multirow[b]{2}{*}{ 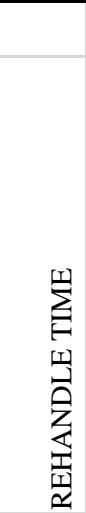 } & \multirow[b]{2}{*}{ 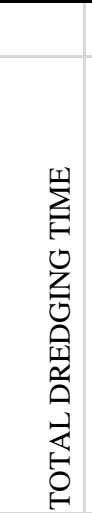 } & \multirow[b]{2}{*}{ 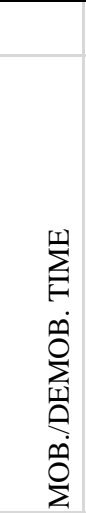 } & \multirow{2}{*}{\multicolumn{2}{|c|}{ 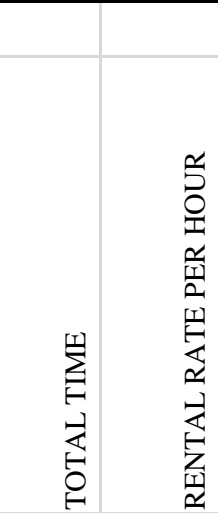 }} & \multirow[b]{2}{*}{$\begin{array}{l}\sum_{1}^{-1} \\
\underbrace{}_{1} \\
>1 \\
\vdots \\
0 \\
0 \\
0\end{array}$} & \multicolumn{3}{|r|}{$6 / 23 / 200$} \\
\hline 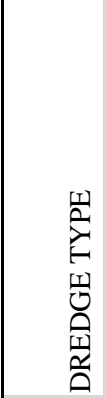 & 占 & 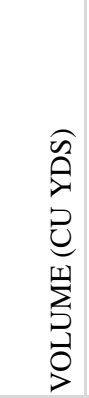 & 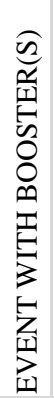 & 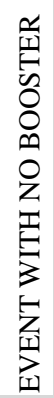 & 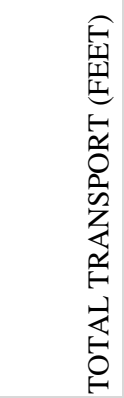 & 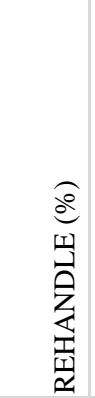 & & & & & & & & & & & & & 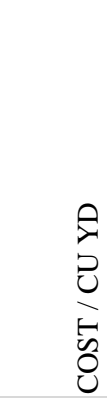 & & \\
\hline \multirow[t]{2}{*}{ HYD. } & $\# 1$ & 1,000 & 0 & 1 & 8,000 & $0 \%$ & 51 & Min & 19.61 & 3.73 & 0.00 & 6.27 & 0.00 & 29.61 & 43.60 & 73.21 & $\$ 698$ & $\$ 51,099$ & $\$ 51.10$ & $100 \%$ & crossing line \\
\hline & & & & & & & & & & $19 \%$ & $10 \%$ & $32 \%$ & & & & & & & & $0 \%$ & non-crossing line \\
\hline \multirow[t]{2}{*}{ HYD. } & & 1,000 & 0 & 1 & 8,000 & $0 \%$ & 108 & Avg & 9.26 & 1.76 & 0.00 & 2.96 & 0.00 & 13.98 & 43.60 & 57.58 & $\$ 698$ & $\$ 40,192$ & $\$ 40.19$ & $100 \%$ & crossing line \\
\hline & & & & & & & & & & $19 \%$ & $10 \%$ & $32 \%$ & & & & & & & & $0 \%$ & non-crossing line \\
\hline \multirow[t]{2}{*}{ HYD. } & & 1,000 & 0 & 1 & 8,000 & $0 \%$ & 192 & Max & 5.21 & 0.99 & 0.00 & 1.67 & 0.00 & 7.86 & 43.60 & 51.46 & $\$ 698$ & $\$ 35,922$ & $\$ 35.92$ & $100 \%$ & crossing line \\
\hline & & & & & & & & & & $19 \%$ & $10 \%$ & $32 \%$ & & & & & & & & $0 \%$ & non-crossing line \\
\hline \multirow[t]{2}{*}{ HYD. } & \#2 & 1,000 & 1 & 0 & 10,000 & $0 \%$ & 51 & Min & 19.61 & 3.73 & 0.00 & 6.27 & 0.00 & 29.61 & 43.60 & 73.21 & $\$ 698$ & $\$ 51,099$ & $\$ 51.10$ & $100 \%$ & crossing line \\
\hline & & & & & & & & & & $19 \%$ & $10 \%$ & $32 \%$ & & & & & & & & $0 \%$ & non-crossing line \\
\hline \multirow[t]{2}{*}{ HYD. } & & 1,000 & 1 & 0 & 10,000 & $0 \%$ & 108 & Avg & 9.26 & 1.76 & 0.00 & 2.96 & 0.00 & 3.98 & 43.60 & 57.58 & $\$ 698$ & $\$ 40,192$ & $\$ 40.19$ & $100 \%$ & crossing line \\
\hline & & & & & & & & & & $19 \%$ & $10 \%$ & $32 \%$ & & & & & & & & $0 \%$ & non-crossing line \\
\hline \multirow[t]{2}{*}{ HYD. } & & 1,000 & 1 & 0 & 10,000 & $0 \%$ & 192 & Max & 5.21 & 0.99 & 0.00 & 1.67 & 0.00 & 7.86 & 43.60 & 51.46 & $\$ 698$ & $\$ 35,922$ & $\$ 35.92$ & $100 \%$ & crossing line \\
\hline & & & & & & & & & & $19 \%$ & $10 \%$ & $32 \%$ & & & & & & & & $0 \%$ & non-crossing line \\
\hline \multirow[t]{2}{*}{ HYD. } & \# 3 & 1,000 & 2 & 0 & 12,000 & $0 \%$ & 51 & Min & 19.61 & 3.73 & 0.00 & 6.27 & 0.00 & 29.61 & 43.60 & 73.21 & $\$ 698$ & $\$ 51,099$ & $\$ 51.10$ & $100 \%$ & crossing line \\
\hline & & & & & & & & & & $19 \%$ & $10 \%$ & $32 \%$ & & & & & & & & $0 \%$ & non-crossing line \\
\hline \multirow[t]{2}{*}{ HYD. } & & 1,000 & 2 & 0 & 12,000 & $0 \%$ & 108 & Avg & 9.26 & 1.76 & 0.00 & 2.96 & 0.00 & 13.98 & 43.60 & 57.58 & $\$ 698$ & $\$ 40,192$ & $\$ 40.19$ & $100 \%$ & crossing line \\
\hline & & & & & & & & & & $19 \%$ & $10 \%$ & $32 \%$ & & & & & & & & $0 \%$ & non-crossing line \\
\hline \multirow[t]{2}{*}{ HYD. } & & 1,000 & 2 & 0 & 12,000 & $0 \%$ & 192 & Max & 5.21 & 0.99 & 0.00 & 1.67 & 0.00 & 7.86 & 43.60 & 51.46 & $\$ 698$ & $\$ 35,922$ & $\$ 35.92$ & $100 \%$ & crossing line \\
\hline & & & & & & & & & & $19 \%$ & $10 \%$ & $32 \%$ & & & & & & & & $0 \%$ & non-crossing line \\
\hline \multirow[t]{2}{*}{ HYD. } & \#4 & 1,000 & 0 & 1 & 16,000 & $100 \%$ & 51 & Min & 19.61 & 3.73 & 0.00 & 6.27 & 29.61 & 59.22 & 44.20 & 103.42 & $\$ 698$ & $\$ 72,184$ & $\$ 72.18$ & $100 \%$ & crossing line \\
\hline & & & & & & & & & & $19 \%$ & $10 \%$ & $32 \%$ & & & & & & & & $0 \%$ & non-crossing line \\
\hline \multirow[t]{2}{*}{ HYD. } & & 1,000 & 0 & 1 & 16,000 & $100 \%$ & 108 & Avg & 9.26 & 1.76 & 0.00 & 2.96 & 13.98 & 27.96 & 44.20 & 72.16 & $\$ 698$ & $\$ 50,370$ & $\$ 50.37$ & $100 \%$ & crossing line \\
\hline & & & & & & & & & & $19 \%$ & $10 \%$ & $32 \%$ & & & & & & & & $0 \%$ & non-crossing line \\
\hline HYD. & & 1,000 & 0 & 1 & 16,000 & $100 \%$ & 192 & Max & 5.21 & 0.99 & 0.00 & 1.67 & 7.86 & 15.73 & 44.20 & 59.93 & $\$ 698$ & $\$ 41,831$ & $\$ 41.83$ & $100 \%$ & crossing line \\
\hline & & & & & & & & & & $19 \%$ & $10 \%$ & $32 \%$ & & & & & & & & $0 \%$ & non-crossing line \\
\hline
\end{tabular}




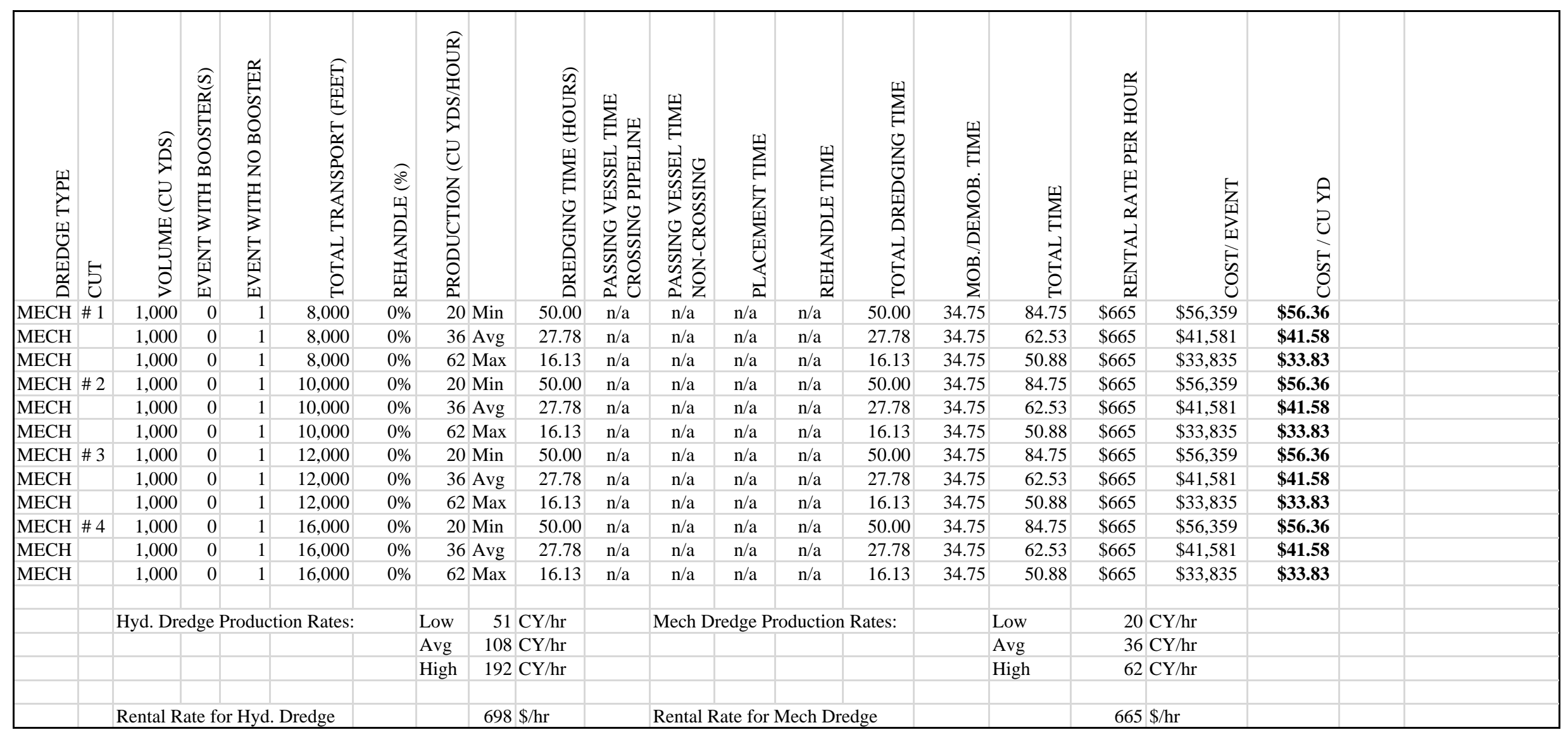




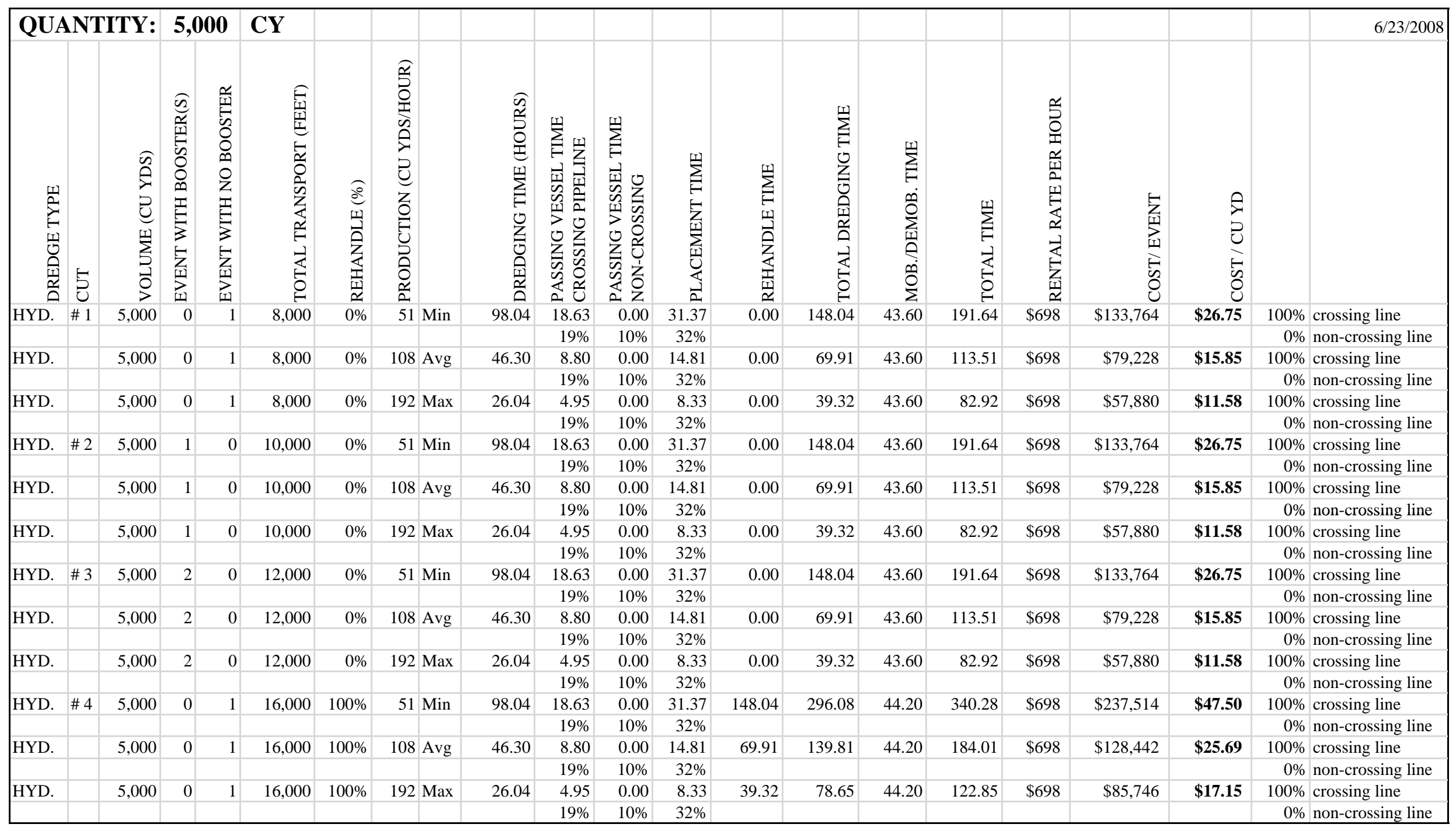




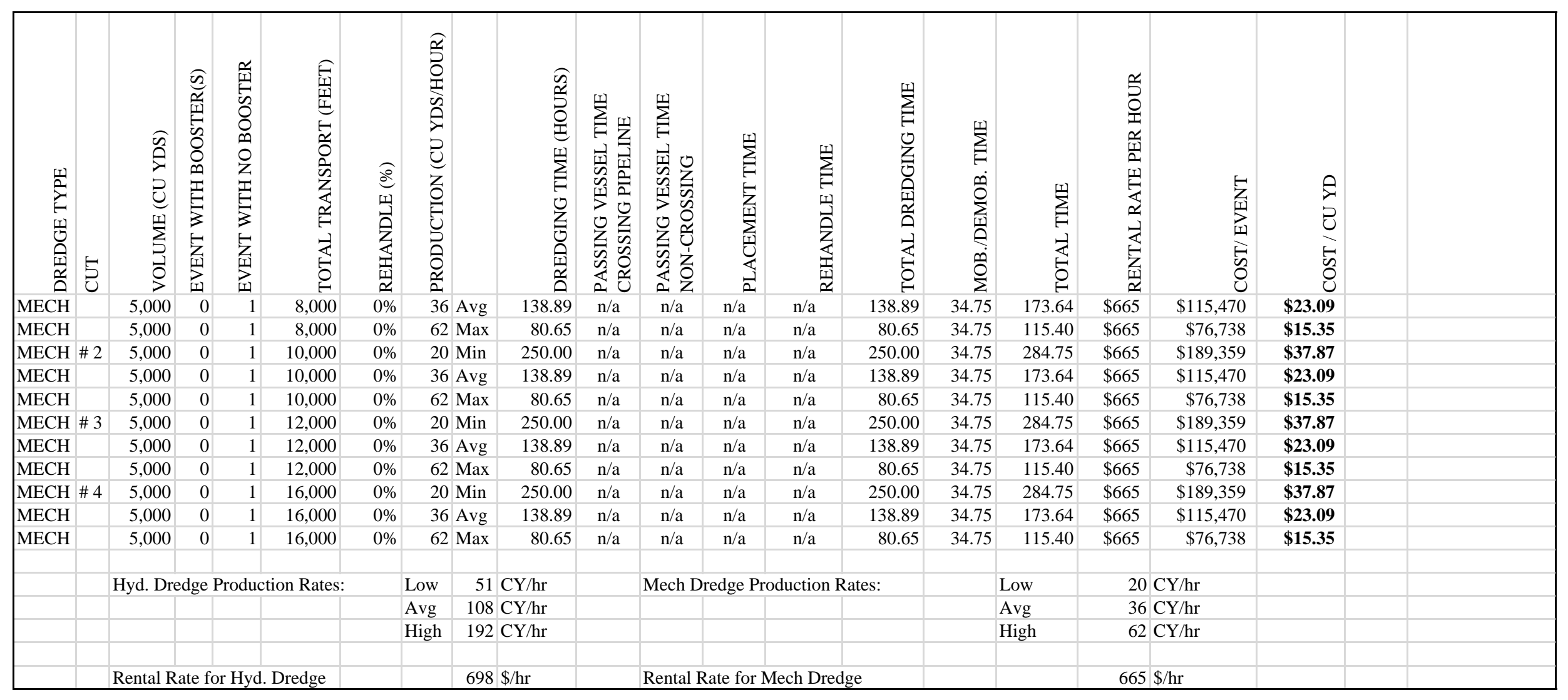


QUANTITY: $20,000 \quad$ CY

\begin{tabular}{|l|l|l|l|l|l|l|l|}
\hline & & & & $19 \%$ & $10 \%$ & $32 \%$ \\
\hline
\end{tabular}

\begin{tabular}{|l|r|r|r|r|r|r|r|r|r|r|r|}
\hline HYD. & 20,000 & 0 & 1 & 8,000 & $0 \%$ & 108 Avg & 185.19 & 35.19 & 0.00 & 59.26 \\
\hline
\end{tabular}

\begin{tabular}{|l|r|r|r|r|r|r|r|r|r|r|}
\hline HYD. & 20,000 & 0 & 1 & 8,000 & $0 \%$ & 192 Max & 104.17 & 19.79 & 0.00 & 33.33 \\
\hline
\end{tabular}

\begin{tabular}{|l|r|r|r|r|}
\hline & & & & \\
\hline
\end{tabular}

\begin{tabular}{|l|r|r|r|r|r|r|r|r|r|r|r|r|}
\hline & & & & & $19 \%$ & $10 \%$ & $32 \%$ \\
\hline HYD. \# 2 & 20,000 & 1 & 0 & 10,000 & $0 \%$ & 51 Min & 392.16 & 74.51 & 0.00 & 125.49 \\
\hline
\end{tabular}

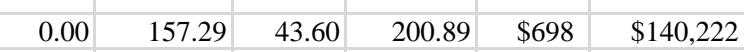

\begin{tabular}{r|r|r}
$19 \%$ & $10 \%$ & $32 \%$ \\
\hline
\end{tabular}

\begin{tabular}{|l|r|r|r|r|r|r|r|r|r|r|r|}
\hline HYD. & 20,000 & 1 & 0 & 10,000 & $0 \%$ & 108 Avg & 185.19 & 35.19 & 0.00 & 59.26 \\
\hline
\end{tabular}

HYD. \begin{tabular}{|l|l|l|r|}
\hline 20,000 & 1 & 0 & 10,000 \\
\hline
\end{tabular} \begin{tabular}{l|l|}
$0 \%$ & $192 \mathrm{Max}$ \\
\hline
\end{tabular}

\begin{tabular}{|r|r|r|r|r|}
\hline 104.17 & 19.79 & 0.00 \\
\hline
\end{tabular}

\begin{tabular}{|r|r|}
\hline 33.33 \\
\hline
\end{tabular}

\begin{tabular}{|l|l|r|r|r|}
\hline 0.00 & 592.16 & 43.60 & 635.76 & $\$ 698$ \\
\hline
\end{tabular}

$\$ 443,758$

\begin{tabular}{|l|r|r|r|r|}
\hline 0.00 & 279.63 & 43.60 & 323.23 & $\$ 698$ \\
\hline
\end{tabular}

$\$ 225,614$

\begin{tabular}{|l|l|l|l|l|l|}
\hline 0.00 & 157.29 & 43.60 & 200.89 & $\$ 698$ & $\$ 140,222$ \\
\hline
\end{tabular}

\begin{tabular}{|l|l|l|l|l|l|l|l|l|r|r|r|}
\hline HYD. & \# 3 & 20,000 & 2 & 0 & 12,000 & $0 \%$ & 51 Min & 392.16 & 74.51 & 0.00 & 125.49 \\
\hline
\end{tabular}

\begin{tabular}{|l|r|r|r|r|r|}
\hline 000 & 592.16 & 43.60 & 635.76 & $\$ 698$ & $\$ 443,758$ \\
\hline
\end{tabular}

\begin{tabular}{|r|r|r|}
\hline & & \\
\hline
\end{tabular}

\begin{tabular}{|l|r|r|r|r|r|r|r|r|r|r|r|}
\hline HYD. & 20,000 & 2 & 0 & 12,000 & $0 \%$ & 108 Avg & 185.19 & 35.19 & 0.00 & 59.26 \\
\hline
\end{tabular}

\begin{tabular}{|l|l|l|l|l|l|}
\hline 0.00 & 279.63 & 43.60 & 323.23 & $\$ 698$ & $\$ 225,614$ \\
\hline
\end{tabular}

\$20.89 $\$ 698$

$\$ 140,222$

\begin{tabular}{|l|r|r|r|r|r|r|r|r|r|r|r|}
\hline HYD. & 20,000 & 2 & 0 & 12,000 & $0 \%$ & 192 & Max & 104.17 & 19.79 & 0.00 & 33.33 \\
\hline
\end{tabular}

\begin{tabular}{|r|r|r|r|r|r|r|r|r|r|r|r|r|}
\hline HYD. $\# 4$ & 20,000 & 0 & 1 & 16,000 & $100 \%$ & 51 Min & 392.16 & 74.51 & 0.00 & 125.49 \\
\hline
\end{tabular}

\begin{tabular}{|l|l|l|l|l|l|}
\hline 592.16 & 1184.31 & 44.20 & 1228.51 & $\$ 698$ & $\$ 857,503$ \\
\hline
\end{tabular}

HYD.

20,000

\begin{tabular}{l|l|l|l|l}
1 & 16,000 & $100 \%$ & 108 & Avg \\
\hline
\end{tabular}

\begin{tabular}{|r|r|r|}
\hline 185.19 & 35.19 & 10.00 \\
\hline
\end{tabular}

26

HYD.

\begin{tabular}{|l|l|l|l|l|l|}
\hline 20,000 & 0 & 1 & 16,000 & $100 \%$ & 192 \\
\hline
\end{tabular}

\begin{tabular}{|r|r|r|r|}
\hline 104.17 & 19.79 & $10 \%$ & $32 \%$ \\
\hline
\end{tabular}

\begin{tabular}{|l|l|r|}
\hline $19 \%$ & $10 \%$ & $32 \%$ \\
\hline
\end{tabular}

\begin{tabular}{|l|l|l|l|l|l|}
\hline 157.29 & 314.58 & 44.20 & 358.78 & $\$ 698$ & $\$ 250,431$ \\
\hline
\end{tabular}

22.19 $100 \%$ crossing line $0 \%$ non-crossing line

\$7.01 100\% crossing line $0 \%$ non-crossing line $100 \%$ crossing line $0 \%$ non-crossing line

$\mathbf{1 1 . 2 8} 100 \%$ crossing line $0 \%$ non-crossing line $00 \%$ crossing line $0 \%$ non-crossing line $00 \%$ crossing line $0 \%$ non-crossing line $00 \%$ crossing line $0 \%$ non-crossing line

\begin{tabular}{l|l}
$\mathbf{\$ 7 . 0 1}$ & $100 \%$ crossing line
\end{tabular} $0 \%$ non-crossing line $100 \%$ crossing line $0 \%$ non-crossing line $100 \%$ crossing line $0 \%$ non-crossing line crossing line $0 \%$ non-crossing line 


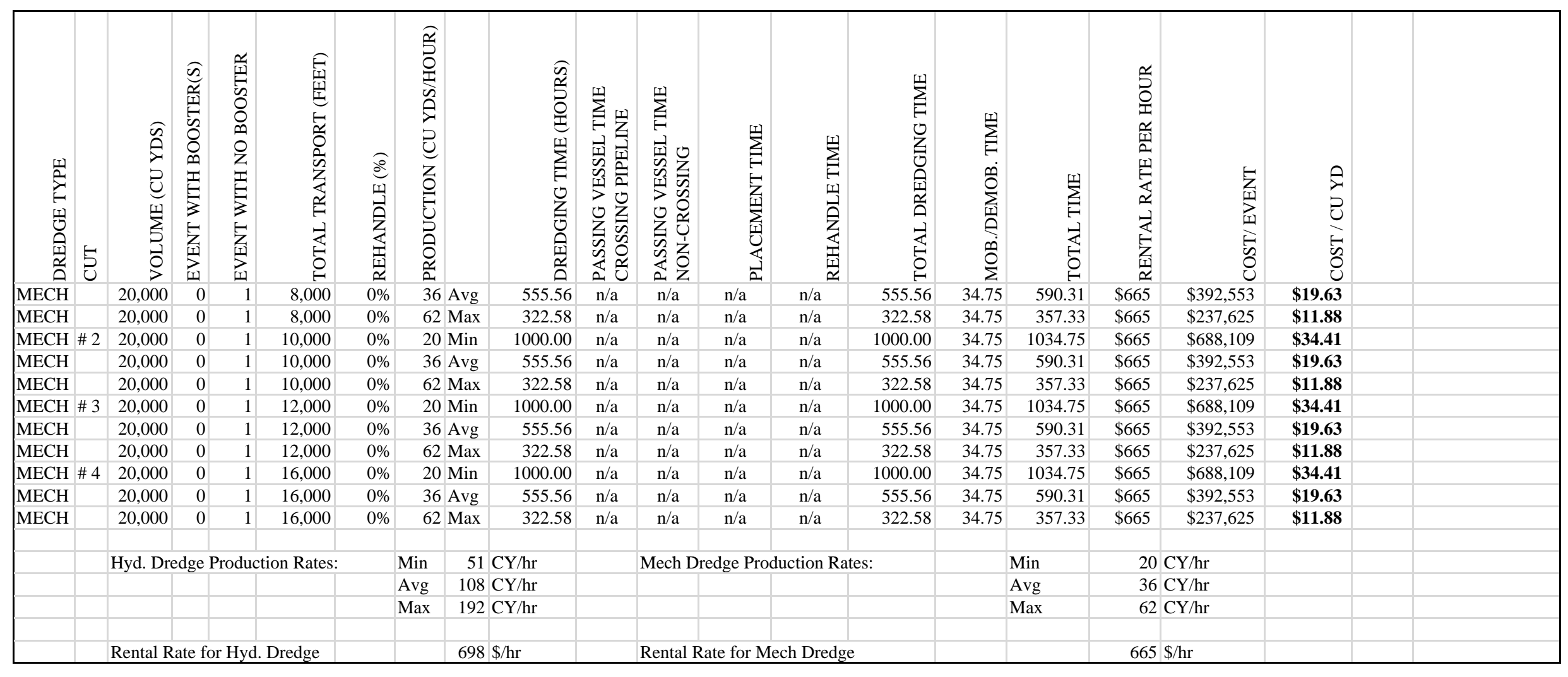




\begin{tabular}{|c|c|c|c|c|c|c|c|c|c|c|c|c|c|c|c|c|c|c|c|c|c|}
\hline \multicolumn{4}{|c|}{ QUANTITY: } & \multicolumn{2}{|c|}{100,000} & \multicolumn{2}{|l|}{$\mathbf{C Y}$} & & \multirow[b]{2}{*}{ 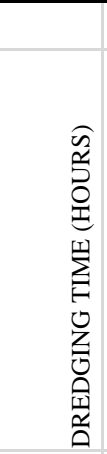 } & \multirow[b]{2}{*}{ 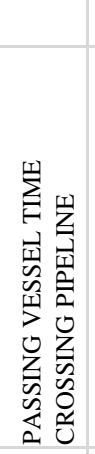 } & \multirow[b]{2}{*}{ 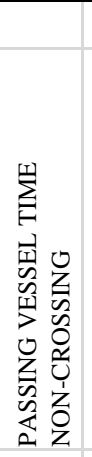 } & \multirow[b]{2}{*}{ 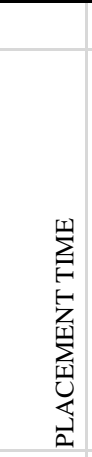 } & \multirow[b]{2}{*}{ 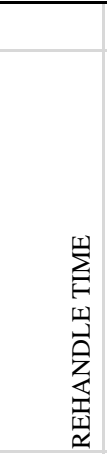 } & \multirow[b]{2}{*}{ 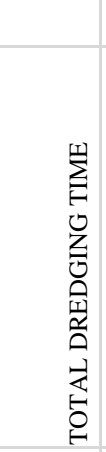 } & \multirow[b]{2}{*}{ 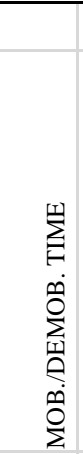 } & \multirow{2}{*}{\multicolumn{2}{|c|}{ 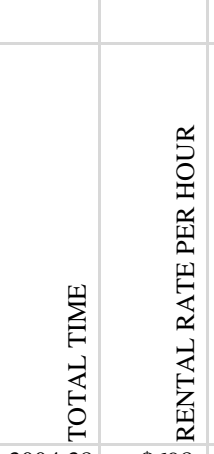 }} & \multirow[b]{2}{*}{$\begin{array}{l}z_{1}^{5} \\
\text { 11 } \\
0 \\
0 \\
0 \\
0\end{array}$} & \multirow[b]{2}{*}{ 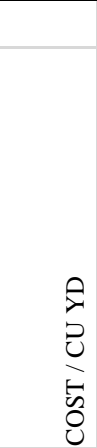 } & \multirow{2}{*}{\multicolumn{2}{|c|}{$6 / 23 / 2008$}} \\
\hline 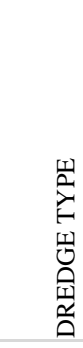 & 占 & 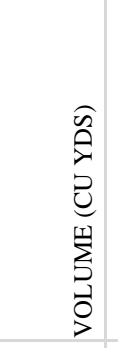 & 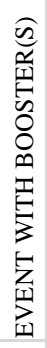 & 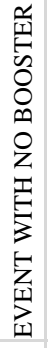 & 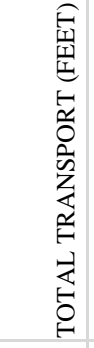 & 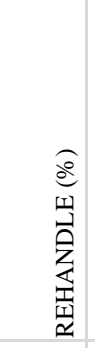 & 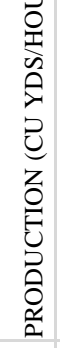 & & & & & & & & & & & & & & \\
\hline \multirow[t]{2}{*}{ HYD. } & \# 1 & 100,000 & 0 & 1 & 8,000 & $0 \%$ & 51 & Min & 1960.78 & 372.55 & 0.00 & 627.45 & 0.00 & 2960.78 & 43.60 & 3004.38 & $\$ 698$ & $\$ 2,097,060$ & $\$ 20.97$ & $100 \%$ & crossing line \\
\hline & & & & & & & & & & $19 \%$ & $10 \%$ & $32 \%$ & & & & & & & & $0 \%$ & non-crossing line \\
\hline \multirow[t]{2}{*}{ HYD. } & & 100,000 & 0 & 1 & 8,000 & $0 \%$ & 108 & Avg & 925.93 & 175.93 & 0.00 & 296.30 & 0.00 & 1398.15 & 43.60 & 1441.75 & $\$ 698$ & $\$ 1,006,340$ & $\$ 10.06$ & $100 \%$ & crossing line \\
\hline & & & & & & & & & & $19 \%$ & $10 \%$ & $32 \%$ & & & & & & & & $0 \%$ & non-crossing line \\
\hline \multirow[t]{2}{*}{ HYD. } & & 100,000 & 0 & 1 & 8,000 & $0 \%$ & 192 & Max & 520.83 & 98.96 & 0.00 & 166.67 & 0.00 & 786.46 & 43.60 & 830.06 & $\$ 698$ & $\$ 579,381$ & $\$ 5.79$ & $100 \%$ & crossing line \\
\hline & & & & & & & & & & $19 \%$ & $10 \%$ & $32 \%$ & & & & & & & & $0 \%$ & non-crossing line \\
\hline \multirow[t]{2}{*}{ HYD. } & \#2 & 100,000 & 1 & 0 & 10,000 & $0 \%$ & 51 & Min & 1960.78 & 372.55 & 0.00 & 627.45 & 0.00 & 2960.78 & 43.60 & 3004.38 & $\$ 698$ & $\$ 2,097,060$ & $\$ 20.97$ & $100 \%$ & crossing line \\
\hline & & & & & & & & & & $19 \%$ & $10 \%$ & $32 \%$ & & & & & & & & $0 \%$ & non-crossing line \\
\hline \multirow[t]{2}{*}{ HYD. } & & 100,000 & 1 & 0 & 10,000 & $0 \%$ & 108 & Avg & 925.93 & 175.93 & 0.00 & 296.30 & 0.00 & 1398.15 & 43.60 & 1441.75 & $\$ 698$ & $\$ 1,006,340$ & $\$ 10.06$ & $100 \%$ & crossing line \\
\hline & & & & & & & & & & $19 \%$ & $10 \%$ & $32 \%$ & & & & & & & & $0 \%$ & non-crossing line \\
\hline \multirow[t]{2}{*}{ HYD. } & & 100,000 & 1 & 0 & 10,000 & $0 \%$ & 192 & Max & 520.83 & 98.96 & 0.00 & 166.67 & 0.00 & 786.46 & 43.60 & 830.06 & $\$ 698$ & $\$ 579,381$ & $\$ 5.79$ & $100 \%$ & crossing line \\
\hline & & & & & & & & & & $19 \%$ & $10 \%$ & $32 \%$ & & & & & & & & $0 \%$ & non-crossing line \\
\hline \multirow[t]{2}{*}{ HYD. } & $\# 3$ & 100,000 & 2 & 0 & 12,000 & $0 \%$ & 51 & Min & 1960.78 & 372.55 & 0.00 & 627.45 & 0.00 & 2960.78 & 43.60 & 3004.38 & $\$ 698$ & $\$ 2,097,060$ & $\$ 20.97$ & $100 \%$ & crossing line \\
\hline & & & & & & & & & & $19 \%$ & $10 \%$ & $32 \%$ & & & & & & & & $0 \%$ & non-crossing line \\
\hline \multirow[t]{2}{*}{ HYD. } & & 100,000 & 2 & 0 & 12,000 & $0 \%$ & 108 & Avg & 925.93 & 175.93 & 0.00 & 296.30 & 0.00 & 1398.15 & 43.60 & 1441.75 & $\$ 698$ & $\$ 1,006,340$ & $\$ 10.06$ & $100 \%$ & crossing line \\
\hline & & & & & & & & & & $19 \%$ & $10 \%$ & $32 \%$ & & & & & & & & $0 \%$ & non-crossing line \\
\hline \multirow[t]{2}{*}{ HYD. } & & 100,000 & 2 & 0 & 12,000 & $0 \%$ & 192 & $\operatorname{Max}$ & 520.83 & 98.96 & 0.00 & 166.67 & 0.00 & 786.46 & 43.60 & 830.06 & $\$ 698$ & $\$ 579,381$ & $\$ 5.79$ & $100 \%$ & crossing line \\
\hline & & & & & & & & & & $19 \%$ & $10 \%$ & $32 \%$ & & & & & & & & $0 \%$ & non-crossing line \\
\hline \multirow[t]{2}{*}{ HYD. } & $\# 4$ & 100,000 & 0 & 1 & 16,000 & $100 \%$ & 51 & Min & 1960.78 & 372.55 & 0.00 & 627.45 & 2960.78 & 5921.57 & 44.20 & 5965.77 & $\$ 698$ & $\$ 4,164,107$ & $\$ 41.64$ & $100 \%$ & crossing line \\
\hline & & & & & & & & & & $19 \%$ & $10 \%$ & $32 \%$ & & & & & & & & $0 \%$ & non-crossing line \\
\hline \multirow[t]{2}{*}{ HYD. } & & 100,000 & 0 & 1 & 16,000 & $100 \%$ & 108 & Avg & 925.93 & 175.93 & 0.00 & 296.30 & 1398.15 & 2796.30 & 44.20 & 2840.50 & $\$ 698$ & $\$ 1,982,666$ & $\$ 19.83$ & $100 \%$ & crossing line \\
\hline & & & & & & & & & & $19 \%$ & $10 \%$ & $32 \%$ & & & & & & & & $0 \%$ & non-crossing line \\
\hline HYD. & & 100,000 & 0 & 1 & 16,000 & $100 \%$ & 192 & Max & 520.83 & 98.96 & 0.00 & 166.67 & 786.46 & 1572.92 & 44.20 & 1617.12 & $\$ 698$ & $\$ 1,128,747$ & $\$ 11.29$ & $100 \%$ & crossing line \\
\hline & & & & & & & & & & $19 \%$ & $10 \%$ & $32 \%$ & & & & & & & & $0 \%$ & non-crossing line \\
\hline
\end{tabular}




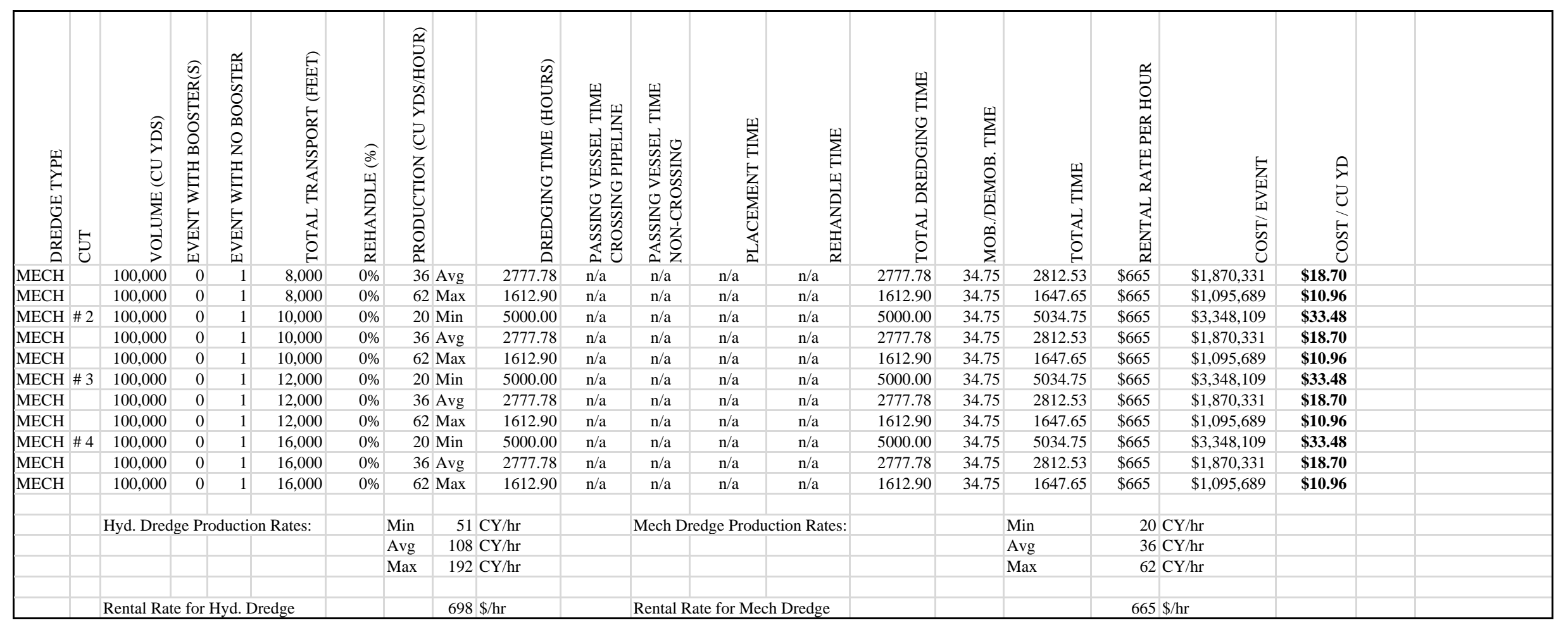




\begin{tabular}{|c|c|c|c|c|c|c|c|c|c|c|c|}
\hline \multicolumn{3}{|c|}{8,000 ft \& $1,000 \mathrm{CY}$} & \multicolumn{3}{|c|}{$8,000 \mathrm{ft} \& 5,000 \mathrm{CY}$} & \multicolumn{3}{|c|}{$8,000 \mathrm{ft} \& 20,000 \mathrm{CY}$} & \multicolumn{3}{|c|}{$8,000 \mathrm{ft} \& 100,000 \mathrm{CY}$} \\
\hline $\begin{array}{l}\text { Prod. } \\
\text { Rate }\end{array}$ & $M B D$ & $C P D$ & $\begin{array}{l}\text { Prod. } \\
\text { Rate }\end{array}$ & $M B D$ & $C P D$ & $\begin{array}{l}\text { Prod. } \\
\text { Rate }\end{array}$ & $M B D$ & $C P D$ & $\begin{array}{l}\text { Prod. } \\
\text { Rate }\end{array}$ & $M B D$ & $C P D$ \\
\hline Low & $\$ 56.36$ & $\$ 51.10$ & Low & COST / C & $\$ 26.75$ & Low & COST / C & $\$ 22.19$ & Low & COST / C & $\$ 20.97$ \\
\hline Avg & $\$ 41.58$ & $\$ 40.19$ & Avg & $\$ 23.09$ & $\$ 15.85$ & Avg & $\$ 19.63$ & $\$ 11.28$ & Avg & $\$ 18.70$ & $\$ 10.06$ \\
\hline High & $\$ 33.83$ & $\$ 35.92$ & High & 35 & 58 & High & 88 & $\$ 7.01$ & High & 96 & $\$ 5.79$ \\
\hline \multicolumn{3}{|c|}{$10,000 \mathrm{ft} \& 1,000 \mathrm{CY}$} & \multicolumn{3}{|c|}{$10,000 \mathrm{ft} \& 5,000 \mathrm{CY}$} & \multicolumn{3}{|c|}{$10,000 \mathrm{ft} \& 20,000 \mathrm{CY}$} & \multicolumn{3}{|c|}{$10,000 \mathrm{ft} \& 100,000 \mathrm{CY}$} \\
\hline $\begin{array}{l}\text { Prod. } \\
\text { Rate }\end{array}$ & $M B D$ & $C P D$ & $\begin{array}{l}\text { Prod. } \\
\text { Rate }\end{array}$ & $M B D$ & $C P D$ & $\begin{array}{l}\text { Prod. } \\
\text { Rate }\end{array}$ & $M B D$ & $C P D$ & $\begin{array}{l}\text { Prod. } \\
\text { Rate }\end{array}$ & $M B D$ & $C P D$ \\
\hline Low & 6.36 & $\$ 51.10$ & Low & & 75 & Low & 41 & 2.19 & Low & 3.48 & 0.97 \\
\hline Avg & $\$ 41.58$ & $\$ 40.19$ & Avg & 9 & $\$ 15.85$ & Avg & .63 & 11.28 & Avg & $\$ 18.70$ & $\$ 10.06$ \\
\hline High & $\$ 33.83$ & $\$ 35.92$ & High & $\$ 15.35$ & $\$ 11.58$ & High & $\$ 11.88$ & $\$ 7.01$ & High & $\$ 10.96$ & $\$ 5.79$ \\
\hline \multicolumn{3}{|c|}{$12,000 \mathrm{ft} \& 1,000 \mathrm{CY}$} & \multicolumn{3}{|c|}{$12,000 \mathrm{ft} \& 5,000 \mathrm{CY}$} & \multicolumn{3}{|c|}{$12,000 \mathrm{ft} \& 20,000 \mathrm{CY}$} & \multicolumn{3}{|c|}{$12,000 \mathrm{ft} \& 100,000 \mathrm{CY}$} \\
\hline $\begin{array}{l}\text { Prod. } \\
\text { Rate }\end{array}$ & $M B D$ & $C P D$ & $\begin{array}{l}\text { Prod. } \\
\text { Rate }\end{array}$ & $M B D$ & $C P D$ & $\begin{array}{l}\text { Prod. } \\
\text { Rate }\end{array}$ & $M B D$ & $C P D$ & $\begin{array}{l}\text { Prod. } \\
\text { Rate }\end{array}$ & $M B D$ & $C P D$ \\
\hline Low & $\$ 56.36$ & $\$ 51.10$ & Low & $\$ 37.87$ & $\$ 26.75$ & Low & $\$ 34.41$ & $\$ 22.19$ & Low & $\$ 33.48$ & $\$ 20.97$ \\
\hline Avg & $\$ 41.58$ & $\$ 40.19$ & Avg & $\$ 23.09$ & $\$ 15.85$ & Avg & $\$ 19.63$ & $\$ 11.28$ & Avg & $\$ 18.70$ & $\$ 10.06$ \\
\hline High & $\$ 33.83$ & $\$ 35.92$ & High & $\$ 15.35$ & $\$ 11.58$ & High & $\$ 11.88$ & $\$ 7.01$ & High & $\$ 10.96$ & $\$ 5.79$ \\
\hline \multicolumn{3}{|c|}{$16,000 \mathrm{ft} \& 1,000 \mathrm{CY}$} & \multicolumn{3}{|c|}{$16,000 \mathrm{ft} \& 5,000 \mathrm{CY}$} & \multicolumn{3}{|c|}{$16,000 \mathrm{ft} \& 20,000 \mathrm{CY}$} & \multicolumn{3}{|c|}{$16,000 \mathrm{ft} \& 100,000 \mathrm{CY}$} \\
\hline $\begin{array}{l}\text { Prod. } \\
\text { Rate }\end{array}$ & $M B D$ & $C P D$ & $\begin{array}{l}\text { Prod. } \\
\text { Rate }\end{array}$ & $M B D$ & $C P D$ & $\begin{array}{l}\text { Prod. } \\
\text { Rate }\end{array}$ & $M B D$ & $C P D$ & $\begin{array}{l}\text { Prod. } \\
\text { Rate }\end{array}$ & $M B D$ & $C P D$ \\
\hline Low & $\$ 56.36$ & $\$ 72.18$ & Low & $\$ 37.87$ & & Low & $\$ 34.41$ & $\$ 42.88$ & Low & $\$ 33.48$ & $\$ 41.64$ \\
\hline Avg & $\$ 41.58$ & $\$ 50.37$ & Avg & $\$ 23.09$ & $\$ 25.69$ & Avg & $\$ 19.63$ & $\$ 21.06$ & Avg & $\$ 18.70$ & $\$ 19.83$ \\
\hline High & $\$ 33.83$ & $\$ 41.83$ & High & $\$ 15.35$ & $\$ 17.15$ & High & $\$ 11.88$ & $\$ 12.52$ & High & $\$ 10.96$ & $\$ 11.29$ \\
\hline
\end{tabular}




\section{APPENDIX D}

\section{LIMITED \\ LIFE CYCLE ASSESSMENT OUTPUT TABLES}




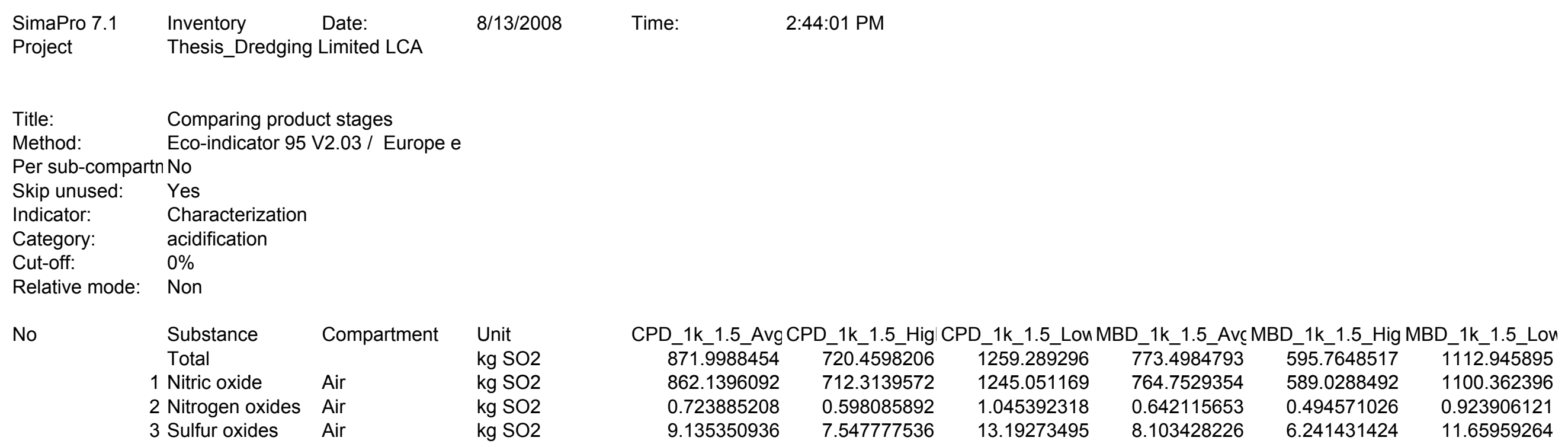

$\begin{array}{cccccc}\text { CPD_1k_1.5_Avg CPD_1k_1.5_Hig CPD_1k_1.5_Lon MBD_1k_1.5_Avç MBD_1k_1.5_Hig MBD_1k_1.5_Lon } \\ 871.9988454 & 720.4598206 & 1259.289296 & 773.4984793 & 595.7648517 & 1112.945895 \\ 862.1396092 & 712.3139572 & 1245.051169 & 764.7529354 & 589.0288492 & 1100.362396 \\ 0.723885208 & 0.598085892 & 1.045392318 & 0.642115653 & 0.494571026 & 0.923906121 \\ 9.135350936 & 7.547777536 & 13.19273495 & 8.103428226 & 6.241431424 & 11.65959264\end{array}$




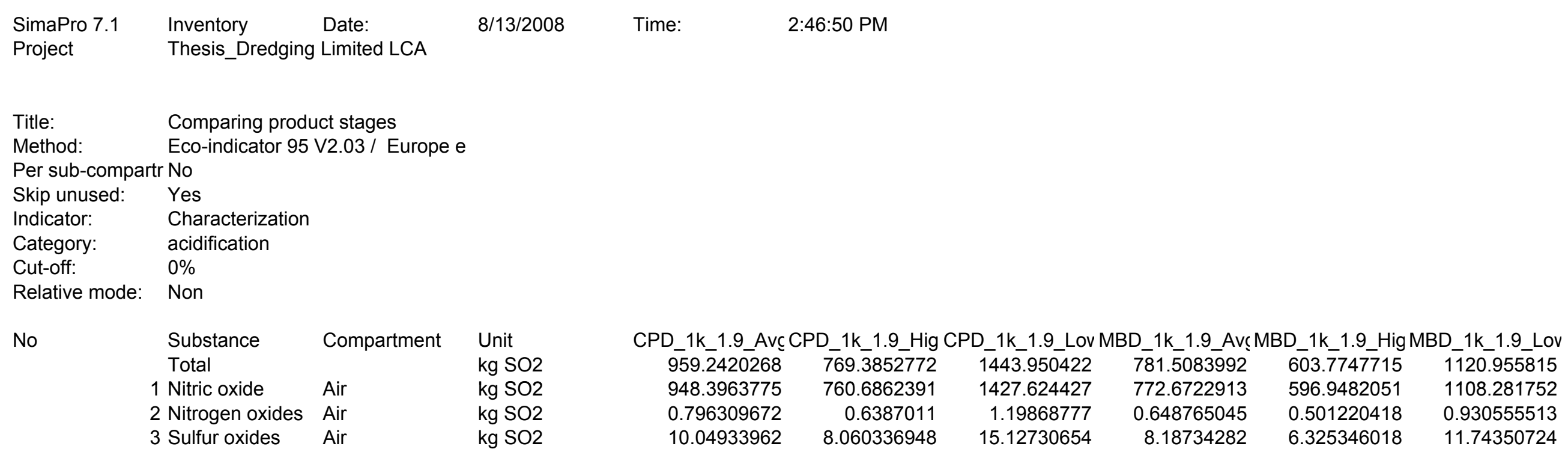




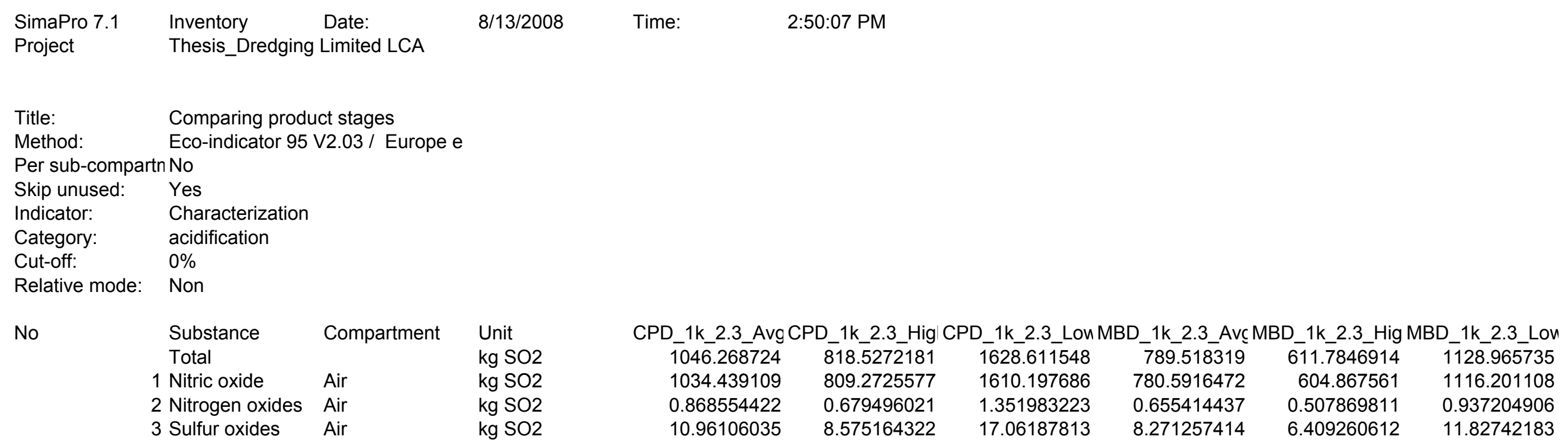

CPD_1k_2.3_Avg CPD_1k_2.3_Hig CPD_1k_2.3_Lou MBD_1k_2.3_Avç MBD_1k_2.3_Hig MBD_1k_2.3_Lon $\begin{array}{llllll}1046.268724 & 818.5272181 & 1628.611548 & 789.518319 & 611.7846914 & 1128.965735\end{array}$ 


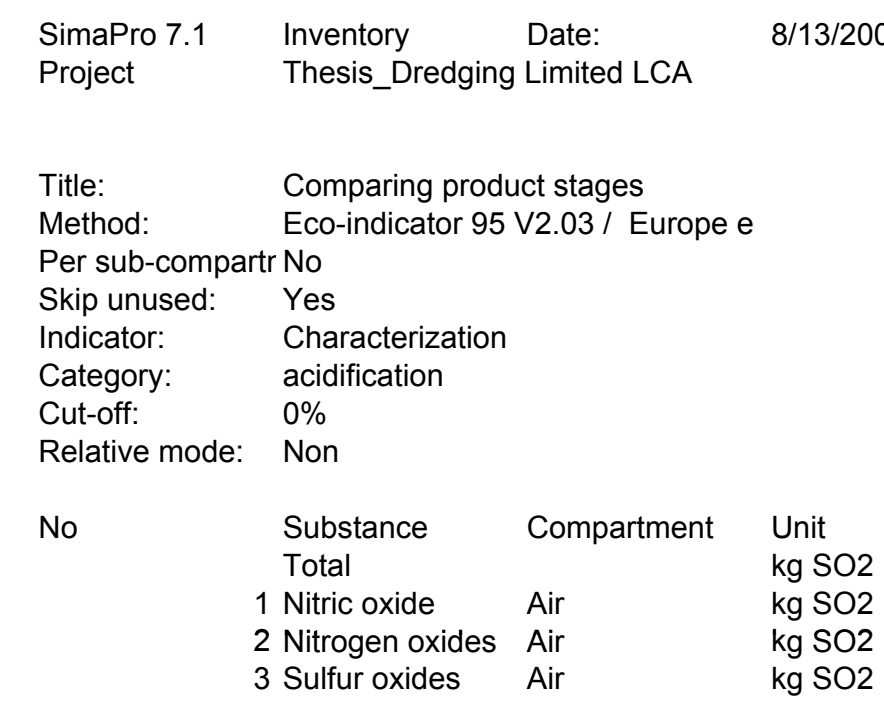

Time:

2:53:00 PM
CPD_1k_3.0_AvçCPD_1k_3.0_Hig CPD_1k_3.0_Lov MBD_1k_3.0_Avị MBD_1k_3.0_Hig MBD_1k_3.0_Lov $\begin{array}{llllll}1225.95071 & 922.6561765 & 2000.748096 & 803.8062842 & 626.0726566 & 1143.2537\end{array}$ $\begin{array}{llllll}1212.089525 & 912.2241843 & 1978.12668 & 794.7180658 & 618.9939796 & 1130.327526\end{array}$ $\begin{array}{llllll}1.017716468 & 0.765938122 & 1.660910401 & 0.667275516 & 0.519730889 & 0.949065984\end{array}$ $\begin{array}{llllll}12.84346881 & 9.666054044 & 20.9605048 & 8.420942906 & 6.558946104 & 11.97710732\end{array}$ 


\begin{tabular}{|c|c|c|c|}
\hline SimaPro 7.1 & Inventory & Date: & $8 / 13 / 200$ \\
\hline Project & Thesis_Dredging & Limited LCA & \\
\hline Title: & Comparing prod & t stages & \\
\hline Method: & Eco-indicator 95 & /2.03 / Europe e & \\
\hline Per sub-compar & $\mathrm{m}$ No & & \\
\hline Skip unused: & Yes & & \\
\hline Indicator: & Characterization & & \\
\hline Category: & acidification & & \\
\hline Cut-off: & $0 \%$ & & \\
\hline Relative mode: & Non & & \\
\hline No & $\begin{array}{l}\text { Substance } \\
\text { Total }\end{array}$ & Compartment & $\begin{array}{l}\text { Unit } \\
\text { kg SO2 }\end{array}$ \\
\hline & 1 Nitric oxide & Air & $\mathrm{kg} \mathrm{SO} 2$ \\
\hline & 2 Nitrogen oxides & Air & $\mathrm{kg} \mathrm{SO} 2$ \\
\hline & 3 Sulfur oxides & Air & $\mathrm{kg} \mathrm{SO} 2$ \\
\hline
\end{tabular}

CPD 5k 1.5 Avg CPD 5k 1.5 High CPD 5k 1.5 Low MBD 5k 1.5 Avg MBD 5k 1.5 Higr MBD_5k 1.5 Low

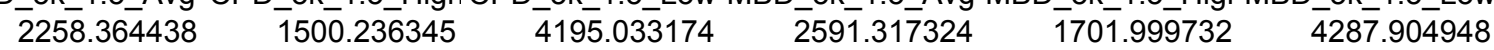
$\begin{array}{llllll}2232.830289 & 1483.273955 & 4147.602122 & 2562.01865 & 1682.756109 & 4239.423843\end{array}$

$\begin{array}{llllll}1.874769238 & 1.245413231 & 3.482484499 & 2.151168307 & 1.412906034 & 3.559581509\end{array}$

$\begin{array}{llllll}23.65937958 & 15.71697666 & 43.94856764 & 27.14750514 & 17.83071724 & 44.92152333\end{array}$




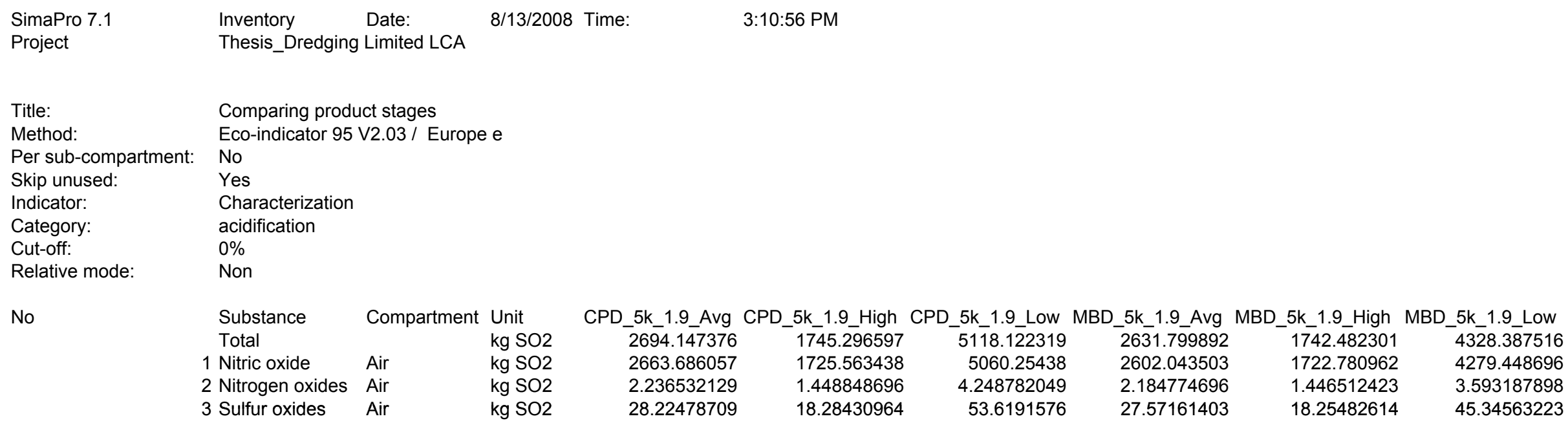

CPD 5k 1.9 Avg CPD 5k 1.9 High CPD 5k 1.9 Low MBD 5k 1.9 Avg MBD 5k 1.9 High MBD 5k 1.9 Low

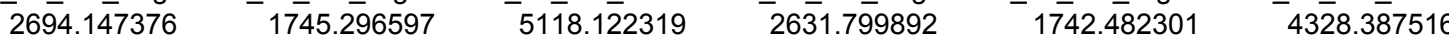
$\begin{array}{llllll}2663.686057 & 1725.563438 & 5060.25438 & 2602.043503 & 1722.780962 & 4279.448696\end{array}$ $\begin{array}{llllll}2.236532129 & 1.448848696 & 4.248782049 & 2.184774696 & 1.446512423 & 3.593187898\end{array}$ $\begin{array}{llllll}28.22478709 & 18.28430964 & 53.6191576 & 27.57161403 & 18.25482614 & 45.34563223\end{array}$ 


\begin{tabular}{|c|c|c|c|c|c|c|c|c|c|}
\hline $\begin{array}{l}\text { SimaPro } 7.1 \\
\text { Project }\end{array}$ & $\begin{array}{l}\text { Inventory } \\
\text { Thesis_Dredging }\end{array}$ & $\begin{array}{l}\text { Date: } \\
\text { Limited LCA }\end{array}$ & $8 / 13 / 2008$ & Time: & 3:13:35 PM & & & & \\
\hline $\begin{array}{l}\text { Title: } \\
\text { Method: } \\
\text { Per sub-compartment: } \\
\text { Skip unused: } \\
\text { Indicator: } \\
\text { Category: } \\
\text { Cut-off: } \\
\text { Relative mode: }\end{array}$ & $\begin{array}{l}\text { Comparing produ } \\
\text { Eco-indicator } 95 \\
\text { No } \\
\text { Yes } \\
\text { Characterization } \\
\text { acidification } \\
0 \% \\
\text { Non }\end{array}$ & $\begin{array}{l}\text { Ict stages } \\
\text { V2.03 / Europe }\end{array}$ & $\mathrm{e}$ & & & & & & \\
\hline No & $\begin{array}{l}\text { Substance } \\
\text { Total } \\
1 \text { Nitric oxide } \\
2 \text { Nitrogen oxides } \\
3 \text { Sulfur oxides }\end{array}$ & $\begin{array}{l}\text { Compartment } \\
\text { Air } \\
\text { Air } \\
\text { Air }\end{array}$ & $\begin{array}{l}\text { Unit } \\
\text { kg SO2 } \\
\text { kg SO2 } \\
\text { kg SO2 } \\
\text { kg SO2 }\end{array}$ & $\begin{array}{r}\text { CPD_5k_2.3_Avg } \\
3129.930314 \\
3094.541825 \\
2.59829502 \\
32.7901946\end{array}$ & $\begin{array}{r}\text { CPD_5k_2.3_High } \\
1990.573332 \\
1968.066958 \\
1.652463875 \\
20.85391059\end{array}$ & $\begin{array}{r}\text { CPD_5k_2.3_Low } \\
6040.99498 \\
5972.692601 \\
5.014899884 \\
63.28747961\end{array}$ & $\begin{array}{r}\text { MBD_5k_2.3_Avg } \\
2672.28246 \\
2642.068356 \\
2.218381085 \\
27.99572293\end{array}$ & $\begin{array}{r}\text { MBD_5k_2.3_High } \\
1782.964869 \\
1762.805815 \\
1.480118812 \\
18.67893503\end{array}$ & $\begin{array}{r}\text { MBD_5k_2.3_Low } \\
4368.870084 \\
4319.473549 \\
3.626794287 \\
45.76974112\end{array}$ \\
\hline
\end{tabular}




\begin{tabular}{|c|c|c|c|c|c|c|c|c|c|}
\hline $\begin{array}{l}\text { SimaPro } 7.1 \\
\text { Project }\end{array}$ & $\begin{array}{l}\text { Inventory } \\
\text { Thesis_Dredging }\end{array}$ & $\begin{array}{l}\text { Date: } \\
\text { Limited LCA }\end{array}$ & $8 / 13 / 2008$ & Time: & 3:17:11 PM & & & & \\
\hline $\begin{array}{l}\text { Title: } \\
\text { Method: } \\
\text { Per sub-compartment: } \\
\text { Skip unused: } \\
\text { Indicator: } \\
\text { Category: } \\
\text { Cut-off: } \\
\text { Relative mode: }\end{array}$ & $\begin{array}{l}\text { Comparing produ } \\
\text { Eco-indicator } 95 \\
\text { No } \\
\text { Yes } \\
\text { Characterization } \\
\text { acidification } \\
0 \% \\
\text { Non }\end{array}$ & $\begin{array}{l}\text { Ict stages } \\
\text { V2.03 / Europe }\end{array}$ & $\mathrm{e}$ & & & & & & \\
\hline No & $\begin{array}{l}\text { Substance } \\
\text { Total } \\
1 \text { Nitric oxide } \\
2 \text { Nitrogen oxides } \\
3 \text { Sulfur oxides }\end{array}$ & $\begin{array}{l}\text { Compartment } \\
\text { Air } \\
\text { Air } \\
\text { Air }\end{array}$ & $\begin{array}{l}\text { Unit } \\
\text { kg SO2 } \\
\text { kg SO2 } \\
\text { kg SO2 } \\
\text { kg SO2 }\end{array}$ & $\begin{array}{r}\text { CPD_5k_3.0_Avg } \\
3998.681895 \\
3953.470884 \\
3.319484528 \\
41.8915261\end{array}$ & $\begin{array}{r}\text { CPD_5k_3.0_High } \\
2482.209226 \\
2454.144181 \\
2.0605928 \\
26.00445229\end{array}$ & $\begin{array}{r}\text { CPD_5k_3.0_Low } \\
7872.235852 \\
7783.228587 \\
6.535094764 \\
82.47217017\end{array}$ & $\begin{array}{r}\text { MBD_5k_3.0_Avg } \\
2742.856348 \\
2711.844302 \\
2.276967624 \\
28.73507854\end{array}$ & $\begin{array}{r}\text { MBD_5k_3.0_High } \\
1853.538757 \\
1832.581761 \\
1.538705351 \\
19.41829064\end{array}$ & $\begin{array}{r}\text { MBD_5k_3.0_Low } \\
4439.443973 \\
4389.249495 \\
3.685380825 \\
46.50909673\end{array}$ \\
\hline
\end{tabular}




\begin{tabular}{|c|c|c|c|c|c|c|c|c|c|}
\hline $\begin{array}{l}\text { SimaPro } 7.1 \\
\text { Project }\end{array}$ & $\begin{array}{l}\text { Inventory } \\
\text { Thesis_Dredging }\end{array}$ & $\begin{array}{l}\text { Date: } \\
\text { Limited LCA }\end{array}$ & $8 / 13 / 2008$ & Time: & 2:56:47 PM & & & & \\
\hline $\begin{array}{l}\text { Title: } \\
\text { Method: } \\
\text { Per sub-compartment: } \\
\text { Skip unused: } \\
\text { Indicator: } \\
\text { Category: } \\
\text { Cut-off: } \\
\text { Relative mode: }\end{array}$ & $\begin{array}{l}\text { Comparing produ } \\
\text { Eco-indicator } 95 \\
\text { No } \\
\text { Yes } \\
\text { Characterization } \\
\text { acidification } \\
0 \% \\
\text { Non }\end{array}$ & $\begin{array}{l}\text { uct stages } \\
\text { V2.03/ Europe }\end{array}$ & & & & & & & \\
\hline No & $\begin{array}{l}\text { Substance } \\
\text { Total } \\
1 \text { Nitric oxide } \\
2 \text { Nitrogen oxides } \\
3 \text { Sulfur oxides }\end{array}$ & $\begin{array}{l}\text { Compartment } \\
\text { Air } \\
\text { Air } \\
\text { Air }\end{array}$ & $\begin{array}{l}\text { Unit } \\
\text { kg SO2 } \\
\text { kg SO2 } \\
\text { kg SO2 } \\
\text { kg SO2 }\end{array}$ & $\begin{array}{r}\text { CPD_20k_1.5_Avg } \\
7457.018925 \\
7372.706301 \\
6.190404638 \\
78.12221905\end{array}$ & $\begin{array}{r}\text { CPD_20k_1.5_High } \\
4424.506555 \\
4374.480967 \\
3.672980607 \\
46.35260736\end{array}$ & $\begin{array}{r}\text { CPD_20k_1.5_Low } \\
15204.12684 \\
15032.22171 \\
12.62162511 \\
159.2835072\end{array}$ & $\begin{array}{r}\text { MBD_20k_1.5_Avg } \\
9408.192111 \\
9301.818589 \\
7.810160691 \\
98.56336056\end{array}$ & $\begin{array}{r}\text { MBD_20k_1.5_High } \\
5850.921746 \\
5784.768426 \\
4.857111599 \\
61.29620897\end{array}$ & $\begin{array}{r}\text { MBD_20k_1.5_Low } \\
16194.54261 \\
16011.43936 \\
13.4438135 \\
169.6594333\end{array}$ \\
\hline
\end{tabular}




\begin{tabular}{|c|c|c|c|c|c|c|c|c|c|}
\hline $\begin{array}{l}\text { SimaPro } 7.1 \\
\text { Project }\end{array}$ & $\begin{array}{l}\text { Inventory } \\
\text { Thesis_Dredging }\end{array}$ & $\begin{array}{l}\text { Date: } \\
\text { Limited LCA }\end{array}$ & $8 / 13 / 2008$ & Time: & 2:59:37 PM & & & & \\
\hline $\begin{array}{l}\text { Title: } \\
\text { Method: } \\
\text { Per sub-compartment: } \\
\text { Skip unused: } \\
\text { Indicator: } \\
\text { Category: } \\
\text { Cut-off: } \\
\text { Relative mode: }\end{array}$ & $\begin{array}{l}\text { Comparing produ } \\
\text { Eco-indicator } 95 \\
\text { No } \\
\text { Yes } \\
\text { Characterization } \\
\text { acidification } \\
0 \% \\
\text { Non }\end{array}$ & $\begin{array}{l}\text { uct stages } \\
\text { V2.03/Europe }\end{array}$ & & & & & & & \\
\hline No & $\begin{array}{l}\text { Substance } \\
\text { Total } \\
1 \text { Nitric oxide } \\
2 \text { Nitrogen oxides } \\
3 \text { Sulfur oxides }\end{array}$ & $\begin{array}{l}\text { Compartment } \\
\text { Air } \\
\text { Air } \\
\text { Air }\end{array}$ & $\begin{array}{l}\text { Unit } \\
\text { kg SO2 } \\
\text { kg SO2 } \\
\text { kg SO2 } \\
\text { kg SO2 }\end{array}$ & $\begin{array}{r}\text { CPD_20k_1.9_Avg } \\
9200.583647 \\
9096.557446 \\
7.637815627 \\
96.388385\end{array}$ & $\begin{array}{r}\text { CPD_20k_1.9_High } \\
5405.180529 \\
5344.066972 \\
4.487081896 \\
56.62647522\end{array}$ & $\begin{array}{r}\text { CPD_20k_1.9_Low } \\
18896.05045 \\
18682.40266 \\
15.68645588 \\
197.9613311\end{array}$ & $\begin{array}{r}\text { MBD_20k_1.9_Avg } \\
9570.122383 \\
9461.918 \\
7.944586246 \\
100.2597961\end{array}$ & $\begin{array}{r}\text { MBD_20k_1.9_High } \\
6012.852018 \\
5944.867837 \\
4.991537154 \\
62.99264455\end{array}$ & $\begin{array}{r}\text { MBD_20k_1.9_Low } \\
16356.47288 \\
16171.53877 \\
13.57823905 \\
171.3558689\end{array}$ \\
\hline
\end{tabular}




\begin{tabular}{|c|c|c|c|c|c|c|c|c|c|}
\hline $\begin{array}{l}\text { SimaPro } 7.1 \\
\text { Project }\end{array}$ & $\begin{array}{l}\text { Inventory } \\
\text { Thesis_Dredging }\end{array}$ & $\begin{array}{l}\text { Date: } \\
\text { Limited LCA }\end{array}$ & $8 / 13 / 2008$ & Time: & 3:02:25 PM & & & & \\
\hline $\begin{array}{l}\text { Title: } \\
\text { Method: } \\
\text { Per sub-compartment: } \\
\text { Skip unused: } \\
\text { Indicator: } \\
\text { Category: } \\
\text { Cut-off: } \\
\text { Relative mode: }\end{array}$ & $\begin{array}{l}\text { Comparing produ } \\
\text { Eco-indicator } 95 \\
\text { No } \\
\text { Yes } \\
\text { Characterization } \\
\text { acidification } \\
0 \% \\
\text { Non }\end{array}$ & $\begin{array}{l}\text { Uct stages } \\
\text { V2.03 / Europe }\end{array}$ & & & & & & & \\
\hline No & $\begin{array}{l}\text { Substance } \\
\text { Total } \\
1 \text { Nitric oxide } \\
2 \text { Nitrogen oxides } \\
3 \text { Sulfur oxides }\end{array}$ & $\begin{array}{l}\text { Compartment } \\
\text { Air } \\
\text { Air } \\
\text { Air }\end{array}$ & $\begin{array}{l}\text { Unit } \\
\text { kg SO2 } \\
\text { kg SO2 } \\
\text { kg SO2 } \\
\text { kg SO2 }\end{array}$ & $\begin{array}{r}\text { CPD_20k_2.3_Avg } \\
10943.93188 \\
10820.19455 \\
9.085046904 \\
114.652283\end{array}$ & $\begin{array}{r}\text { CPD_20k_2.3_High } \\
6385.854504 \\
6313.652977 \\
5.301183185 \\
66.90034308\end{array}$ & $\begin{array}{r}\text { CPD_20k_2.3_Low } \\
22588.19055 \\
22332.79766 \\
18.75146636 \\
236.641423\end{array}$ & $\begin{array}{r}\text { MBD_20k_2.3_Avg } \\
9731.836171 \\
9621.803375 \\
8.078832087 \\
101.9539637\end{array}$ & $\begin{array}{r}\text { MBD_20k_2.3_High } \\
6174.565806 \\
6104.753211 \\
5.125782996 \\
64.68681216\end{array}$ & $\begin{array}{r}\text { MBD_20k_2.3_Low } \\
16518.18667 \\
16331.42415 \\
13.71248489 \\
173.0500365\end{array}$ \\
\hline
\end{tabular}




$\begin{array}{llll}\text { SimaPro 7.1 } & \text { Inventory } & \text { Date: } & \text { 8/13/2008 Time: } \\ \text { Project } & \text { Thesis_Dredging Limited LCA } & & \text { 3:05:13 PM }\end{array}$

Title:

Method:

Per sub-compartment:

Skip unused:

Indicator:

Category:

Cut-off:

Relative mode:

No
Comparing product stages

Eco-indicator 95 V2.03 / Europe e

No

Characterization

acidification

$0 \%$

Non

Substance Compartment Unit

Total

1 Nitric oxide

$\mathrm{kg} \mathrm{SO} 2$

2 Nitrogen oxides Air

3 Sulfur oxides
CPD_20k_3.0_Avg CPD_20k_3.0_High CPD_20k_3.0_Low MBD_20k_3.0_Avg MBD_20k_3.0_High MBD_20k_3.0_Low $14395.99087 \quad 8330.966129 \quad 29890.42318$

$\begin{array}{ll}14233.22291 & 8236.77224 \\ 11.95075533 & 29552.46776\end{array}$

$\begin{array}{lll}11.95075533 & 6.915907266 & 24.81337598\end{array}$

150.817205

313.1420493
10014.78118
9901.549271

8.313717382

104.9181901
6457.510814

6384.499107

5.360668291

67.6510385
16801.13168

16611.17004

13.94737019

176.0142629 


\begin{tabular}{|c|c|c|c|}
\hline SimaPro 7.1 & Inventory & Date: & $0 / 13$ \\
\hline Project & \multicolumn{3}{|c|}{ Thesis_Dredging Limited LCA } \\
\hline $\begin{array}{l}\text { Title: } \\
\text { Method: } \\
\text { Per sub-compartment: } \\
\text { Skip unused: } \\
\text { Indicator: } \\
\text { Category: } \\
\text { Cut-off: } \\
\text { Relative mode: }\end{array}$ & $\begin{array}{l}\text { Comparing produ } \\
\text { Eco-indicator } 95 \\
\text { No } \\
\text { Yes } \\
\text { Characterization } \\
\text { acidification } \\
0 \% \\
\text { Non }\end{array}$ & $\begin{array}{l}\text { uct stages } \\
\text { V2.03 / Europe }\end{array}$ & e e \\
\hline No & $\begin{array}{l}\text { Substance } \\
\text { Total } \\
1 \text { Nitric oxide } \\
2 \text { Nitrogen oxides } \\
3 \text { Sulfur oxides }\end{array}$ & $\begin{array}{l}\text { Compartment } \\
\text { Air } \\
\text { Air } \\
\text { Air }\end{array}$ & $\begin{array}{l}\text { Unit } \\
\mathrm{kg} \mathrm{SO} 2 \\
\mathrm{~kg} \mathrm{SO} 2 \\
\mathrm{~kg} \mathrm{SO} 2 \\
\mathrm{~kg} \mathrm{SO} 2\end{array}$ \\
\hline
\end{tabular}

CPD_100k 1.5 Avg CPD_100k 1.5 High CPD_100k 1.5 Low MBD_100k 1.5 Avg MBD_100k 1.5 High MBD_100k_1.5_Low 73083.66885 45248.20307

$\mathrm{kg} \mathrm{SO} 2$

368.5959881

16.62006652

61.36382817

37.99211235

27979.2996

79696.97094
78795.87885

3 Sulfur oxides

$\mathrm{kg} \mathrm{SO} 2$

774.4046967
23.22686689

293.1204807

834.9320666 


\begin{tabular}{|c|c|c|c|c|c|c|c|c|c|}
\hline $\begin{array}{l}\text { SimaPro } 7.1 \\
\text { Project }\end{array}$ & $\begin{array}{l}\text { Inventory } \\
\text { Thesis_Dredging }\end{array}$ & $\begin{array}{l}\text { Date: } \\
\text { Limited LCA }\end{array}$ & $8 / 13 / 2008$ & Time: & 2:31:04 PM & & & & \\
\hline $\begin{array}{l}\text { Title: } \\
\text { Method: } \\
\text { Per sub-compartment: } \\
\text { Skip unused: } \\
\text { Indicator: } \\
\text { Category: } \\
\text { Cut-off: } \\
\text { Relative mode: }\end{array}$ & $\begin{array}{l}\text { Comparing produ } \\
\text { Eco-indicator } 95 \\
\text { No } \\
\text { Yes } \\
\text { Characterization } \\
\text { acidification } \\
0 \% \\
\text { Non }\end{array}$ & $\begin{array}{l}\text { Jct stages } \\
\text { V2.03 / Europe }\end{array}$ & & & & & & & \\
\hline No & $\begin{array}{l}\text { Substance } \\
\text { Total } \\
1 \text { Nitric oxide } \\
2 \text { Nitrogen oxides } \\
3 \text { Sulfur oxides }\end{array}$ & $\begin{array}{l}\text { Compartment } \\
\text { Air } \\
\text { Air } \\
\text { Air }\end{array}$ & $\begin{array}{l}\text { Unit } \\
\text { kg SO2 } \\
\text { kg SO2 } \\
\text { kg SO2 } \\
\text { kg SO2 }\end{array}$ & $\begin{array}{r}\text { CPD_100k_1.9_Avg } \\
43900.85548 \\
43404.4914 \\
36.44406191 \\
459.920014\end{array}$ & $\begin{array}{r}\text { CPD_100k_1.9_High } \\
24924.05637 \\
24642.25307 \\
20.69057296 \\
261.112733\end{array}$ & $\begin{array}{r}\text { CPD_100k_1.9_Low } \\
92379.05544 \\
91334.57364 \\
76.68798202 \\
967.7938165\end{array}$ & $\begin{array}{r}\text { MBD_100k_1.9_Avg } \\
46574.43684 \\
46047.84397 \\
38.66352127 \\
487.9293447\end{array}$ & $\begin{array}{r}\text { MBD_100k_1.9_High } \\
28788.08502 \\
28462.59316 \\
23.89827581 \\
301.5935868\end{array}$ & $\begin{array}{r}\text { MBD_100k_1.9_Low } \\
80505.75636 \\
79595.51976 \\
66.83142588 \\
843.4051726\end{array}$ \\
\hline
\end{tabular}




$\begin{array}{ll}\begin{array}{l}\text { SimaPro 7.1 } \\ \text { Project }\end{array} & \begin{array}{l}\text { Inventory Date: } \\ \text { Thesis_Dredging Limited LCA }\end{array} \\ & \\ \text { Title: } & \begin{array}{l}\text { Comparing product stages } \\ \text { Eco-indicator 95 V2.03/ Europe e }\end{array} \\ \text { Method: } & \text { No } \\ \text { Per sub-compartment: } & \text { Yes } \\ \text { Skip unused: } & \text { Characterization } \\ \text { Indicator: } & \text { acidification } \\ \text { Category: } & 0 \% \\ \text { Cut-off: } & \text { Non } \\ \text { Relative mode: } & \end{array}$

No

\section{Substance \\ Compartment Unit} Total

1 Nitric oxide

2 Nitrogen oxides Air

3 Sulfur oxides

Air

Air

Air $\mathrm{kg} \mathrm{SO} 2$

$\mathrm{kg} \mathrm{SO} 2$

$\mathrm{kg} \mathrm{SO} 2$

$\mathrm{kg} \mathrm{SO} 2$

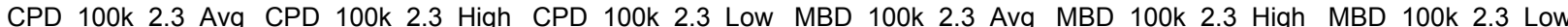
52617.81315

52022.89098

43.680398

29827.42625

29490.18309

24.76107941

312.4820723

110838.89

109585.6925

92.01231558

551.2417719
47383.22226

46847.48488

39.33493019

496.4024507
29596.87044

24.56968474

310.0666928
29262.23407

81314.54178

80395.16067

67.5028348

851.8782787 


\begin{tabular}{|c|c|c|c|c|c|c|c|c|c|}
\hline $\begin{array}{l}\text { SimaPro } 7.1 \\
\text { Project }\end{array}$ & $\begin{array}{l}\text { Inventory } \\
\text { Thesis_Dredging }\end{array}$ & $\begin{array}{l}\text { Date: } \\
\text { g Limited LCA }\end{array}$ & $8 / 13 / 2008$ & Time: & 2:40:25 PM & & & & \\
\hline $\begin{array}{l}\text { Title: } \\
\text { Method: } \\
\text { Per sub-compartment: } \\
\text { Skip unused: } \\
\text { Indicator: } \\
\text { Category: } \\
\text { Cut-off: } \\
\text { Relative mode: }\end{array}$ & $\begin{array}{l}\text { Comparing prod } \\
\text { Eco-indicator } 95 \\
\text { No } \\
\text { Yes } \\
\text { Characterization } \\
\text { acidification } \\
0 \% \\
\text { Non }\end{array}$ & $\begin{array}{l}\text { luct stages } \\
\text { V2.03 / Europe }\end{array}$ & & & & & & & \\
\hline No & $\begin{array}{l}\text { Substance } \\
\text { Total } \\
1 \text { Nitric oxide } \\
2 \text { Nitrogen oxides } \\
3 \text { Sulfur oxides }\end{array}$ & $\begin{array}{l}\text { Compartment } \\
\text { Air } \\
\text { Air } \\
\text { Air }\end{array}$ & $\begin{array}{l}\text { Unit } \\
\text { kg SO2 } \\
\text { kg SO2 } \\
\text { kg SO2 } \\
\text { kg SO2 }\end{array}$ & $\begin{array}{r}\text { CPD_100k_3.0_Avg } \\
69849.31565 \\
69059.56587 \\
57.98503825 \\
731.7647432\end{array}$ & $\begin{array}{r}\text { CPD_100k_3.0_High } \\
39523.32602 \\
39076.45638 \\
32.81007909 \\
414.0595544\end{array}$ & $\begin{array}{r}\text { CPD_100k_3.0_Low } \\
147320.6113 \\
145654.934 \\
122.2974227 \\
1543.379892\end{array}$ & $\begin{array}{r}\text { MBD_100k_3.0_Avg } \\
48798.59676 \\
48246.85647 \\
40.50989581 \\
511.2303863\end{array}$ & $\begin{array}{r}\text { MBD_100k_3.0_High } \\
31012.24493 \\
30661.60566 \\
25.74465035 \\
324.8946283\end{array}$ & $\begin{array}{r}\text { MBD_100k_3.0_Low } \\
82729.91628 \\
81794.53226 \\
68.67780042 \\
866.7062142\end{array}$ \\
\hline
\end{tabular}




\begin{tabular}{|c|c|c|c|c|c|c|c|c|c|}
\hline $\begin{array}{l}\text { SimaPro } 7.1 \\
\text { Project }\end{array}$ & $\begin{array}{l}\text { Inventory } \\
\text { Thesis_Dredging Limite }\end{array}$ & $\begin{array}{l}\text { Date: } \\
\text { d LCA }\end{array}$ & $8 / 13 / 2008$ & Time: & 2:44:25 PM & & & & \\
\hline $\begin{array}{l}\text { Title: } \\
\text { Method: } \\
\text { Per sub-compartment: } \\
\text { Skip unused: } \\
\text { Indicator: } \\
\text { Category: } \\
\text { Cut-off: } \\
\text { Relative mode: }\end{array}$ & $\begin{array}{l}\text { Comparing product stag } \\
\text { Eco-indicator } 95 \mathrm{~V} 2.03 / \\
\text { No } \\
\text { Yes } \\
\text { Characterization } \\
\text { carcinogens } \\
0 \% \\
\text { Non }\end{array}$ & Europe e & & & & & & & \\
\hline No & $\begin{array}{l}\text { Substance } \\
\text { Total } \\
1 \text { Benzene } \\
\text { PAH, polycyclic } \\
2 \text { aromatic hydrocarbons }\end{array}$ & $\begin{array}{l}\text { Compartment } \\
\text { Air }\end{array}$ & 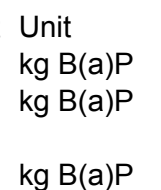 & $\begin{array}{r}\text { CPD_1k_1.5_Avg } \\
0.020410267 \\
1.03705 \mathrm{E}-05 \\
\\
0.020399896\end{array}$ & $\begin{array}{r}\text { CPD_1k_1.5_High } \\
0.016863299 \\
8.56824 \mathrm{E}-06 \\
\\
\\
0.016854731\end{array}$ & $\begin{array}{r}\text { CPD_1k_1.5_Low } \\
0.029475303 \\
1.49764 \mathrm{E}-05 \\
\\
0.029460327\end{array}$ & $\begin{array}{r}\text { MBD_1k_1.5_Avg } \\
0.018104738 \\
9.19901 \mathrm{E}-06 \\
\\
0.018095539\end{array}$ & $\begin{array}{r}\text { MBD_1k_1.5_High } \\
0.013944651 \\
7.08527 \mathrm{E}-06 \\
\\
\\
0.013937566\end{array}$ & $\begin{array}{r}\text { MBD_1k_1.5_Low } \\
0.026049946 \\
1.3236 \mathrm{E}-05 \\
\\
0.02603671\end{array}$ \\
\hline
\end{tabular}




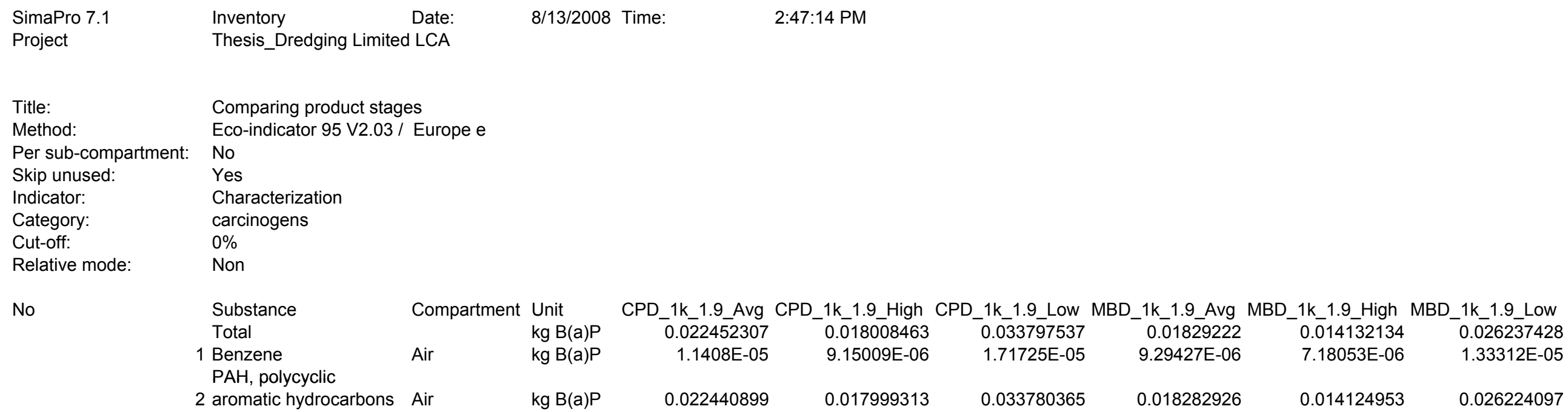

Compartment Unit

kg B(a)P

$\mathrm{PAH}$, polycyclic Air $\quad \mathrm{kg} \mathrm{B}(\mathrm{a}) \mathrm{P}$

2 aromatic hydrocarbons Air

kg B(a)P

CPD_1k_1.9_Avg CPD_1k_1.9 High CPD 1k 1.9 Low MBD 1k 1.9 Avg MBD_1k 1.9 High MBD 1k 1.9 Low

$\begin{array}{llllll}0.022452307 & 0.018008463 & 0.033797537 & 0.01829222 & 0.014132134 & 0.026237428\end{array}$ 1.1408E-05

$1.33312 \mathrm{E}-05$

0.022440899

0.017999313

$0.018282926-0.014124953$

0.026224097 


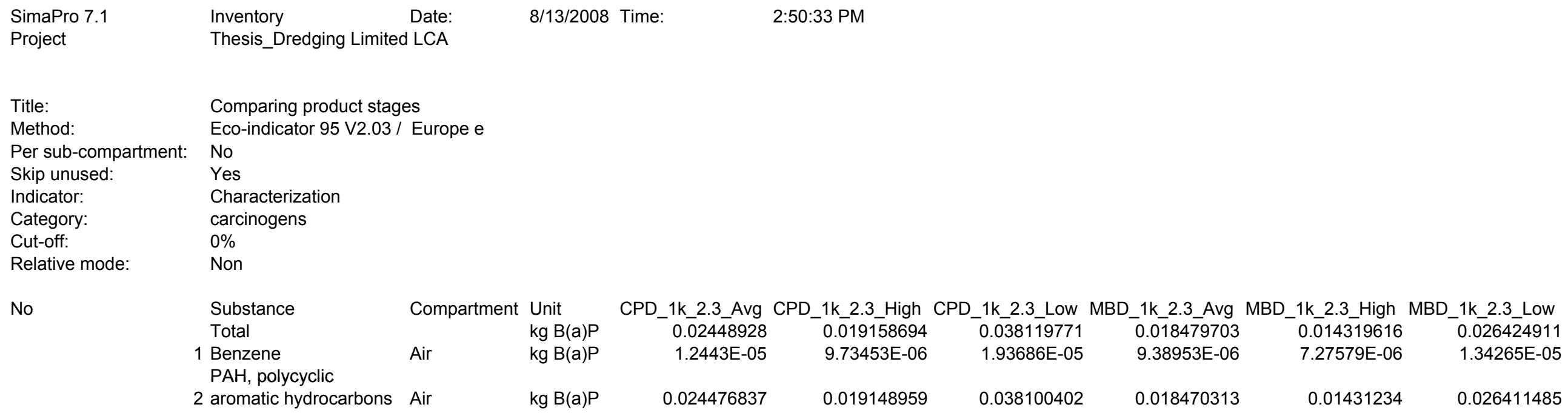

Compartment Unit

$\mathrm{kg} \mathrm{B}(\mathrm{a}) \mathrm{P}$

$\mathrm{kg} \mathrm{B}(\mathrm{a}) \mathrm{P}$

$\mathrm{PAH}$, polycyclic

Air

2 aromatic hydrocarbons Air

CPD_1k_2.3_Avg CPD_1k_2.3_High CPD_1k_2.3_Low MBD_1k_2.3_Avg MBD_1k_2.3_High MBD_1k_2.3_Low
0.02448928
0.019158694
0.038119771
0.018479703
0.014319616
0.026424911
9.73453E-06
1.93686E-05
9.38953E-06
7.27579E-06
1.34265E-05

kg B(a)P

0.024476837

0.038100402

0.018470313

0.01431234

0.026411485 


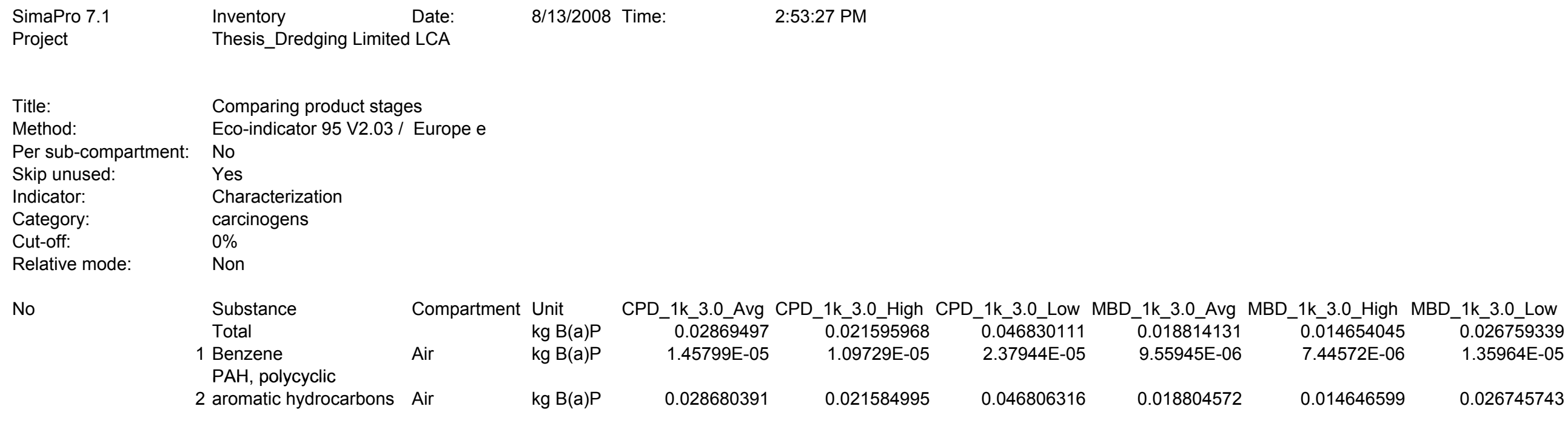

0.021584995

0.018804572 


\begin{tabular}{|c|c|c|c|c|c|c|c|c|c|}
\hline $\begin{array}{l}\text { SimaPro } 7.1 \\
\text { Project }\end{array}$ & $\begin{array}{l}\text { Inventory } \\
\text { Thesis_Dredging Limite }\end{array}$ & $\begin{array}{l}\text { Date: } \\
\text { d LCA }\end{array}$ & $8 / 13 / 2008$ & Time: & 3:08:50 PM & & & & \\
\hline $\begin{array}{l}\text { Title: } \\
\text { Method: } \\
\text { Per sub-compartment: } \\
\text { Skip unused: } \\
\text { Indicator: } \\
\text { Category: } \\
\text { Cut-off: } \\
\text { Relative mode: }\end{array}$ & $\begin{array}{l}\text { Comparing product stag } \\
\text { Eco-indicator } 95 \mathrm{~V} 2.03 / \\
\text { No } \\
\text { Yes } \\
\text { Characterization } \\
\text { carcinogens } \\
0 \% \\
\text { Non }\end{array}$ & Europe e & & & & & & & \\
\hline No & $\begin{array}{l}\text { Substance } \\
\text { Total } \\
1 \text { Benzene } \\
\text { PAH, polycyclic } \\
2 \text { aromatic hydrocarbons }\end{array}$ & $\begin{array}{l}\text { Compartment } \\
\text { Air }\end{array}$ & $\begin{array}{l}\text { Unit } \\
\text { kg B(a)P } \\
\text { kg B(a)P } \\
\text { kg B(a)P }\end{array}$ & $\begin{array}{r}\text { CPD_5k_1.5_Avg } \\
0.052859956 \\
2.68581 \mathrm{E}-05 \\
\\
0.052833098\end{array}$ & $\begin{array}{r}\text { CPD_5k_1.5_High } \\
0.035114982 \\
1.78419 \mathrm{E}-05 \\
\\
0.035097141\end{array}$ & $\begin{array}{r}\text { CPD_5k_1.5_Low } \\
0.098190206 \\
4.98904 \mathrm{E}-05 \\
\\
0.098140316\end{array}$ & $\begin{array}{r}\text { MBD_5k_1.5_Avg } \\
0.060653151 \\
3.08178 \mathrm{E}-05 \\
\\
0.060622334\end{array}$ & $\begin{array}{r}\text { MBD_5k_1.5_High } \\
0.039837517 \\
2.02414 \mathrm{E}-05 \\
\\
0.039817275\end{array}$ & $\begin{array}{r}\text { MBD_5k_1.5_Low } \\
0.100363991 \\
5.09949 \mathrm{E}-05 \\
\\
\\
0.100312996\end{array}$ \\
\hline
\end{tabular}




\begin{tabular}{|c|c|c|c|c|c|c|c|c|c|}
\hline $\begin{array}{l}\text { SimaPro } 7.1 \\
\text { Project }\end{array}$ & $\begin{array}{l}\text { Inventory } \\
\text { Thesis Dredging Limite }\end{array}$ & $\begin{array}{l}\text { Date: } \\
\text { d LCA }\end{array}$ & 8/13/2008 & Time: & 3:11:23 PM & & & & \\
\hline Title: & Comparing product stag & & & & & & & & \\
\hline Method: & Eco-indicator 95 V2.03 & Europe e & & & & & & & \\
\hline Per sub-compartment & No & & & & & & & & \\
\hline Skip unused: & Yes & & & & & & & & \\
\hline Indicator: & Characterization & & & & & & & & \\
\hline Category: & carcinogens & & & & & & & & \\
\hline Cut-off: & $0 \%$ & & & & & & & & \\
\hline Relative mode: & Non & & & & & & & & \\
\hline \multirow[t]{4}{*}{ No } & Substance & Compartment & Unit & CPD_5k_1.9_Avg & CPD_5k_1.9_High & CPD_5k_1.9_Low & MBD_5k_1.9_Avg & MBD_5k_1.9_High & MBD_5k_1.9_Low \\
\hline & Total & & $\mathrm{kg} \mathrm{B}(\mathrm{a}) \mathrm{P}$ & 0.063060023 & 0.040850936 & 0.119796308 & 0.061600699 & 0.040785064 & 0.101311538 \\
\hline & $\begin{array}{l}1 \text { Benzene } \\
\text { PAH, polycyclic }\end{array}$ & Air & $\mathrm{kg} \mathrm{B}(\mathrm{a}) \mathrm{P}$ & $3.20408 \mathrm{E}-05$ & $2.07563 \mathrm{E}-05$ & 6.08685E-05 & 3.12993E-05 & $2.07229 \mathrm{E}-05$ & $5.14764 \mathrm{E}-05$ \\
\hline & 2 aromatic hydrocarbons & Air & $\mathrm{kg} \mathrm{B}(\mathrm{a}) \mathrm{P}$ & 0.063027982 & 0.04083018 & 0.11973544 & 0.061569399 & 0.040764341 & 0.101260062 \\
\hline
\end{tabular}




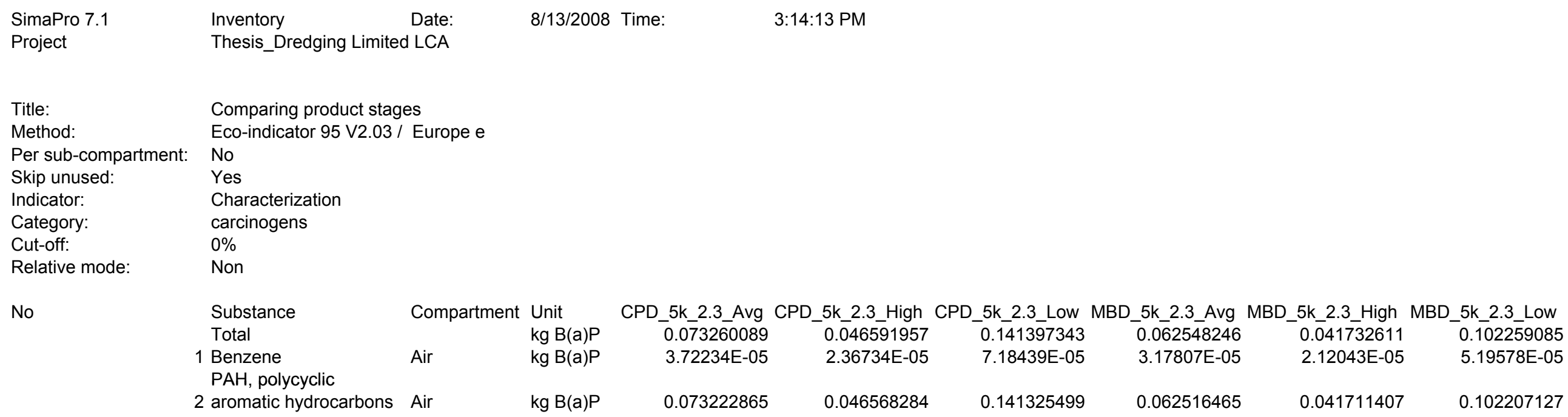

0.073222865

0.046568284

7.18439E-05

3.17807E-05

2.3 High MBD_5k_2.3_Low

2 aromatic hydrocarbons Air

$\operatorname{kg~B(a)P}$

0.141325499

0.062516465

0.102259085

$5.19578 \mathrm{E}-05$

(

(a)




\begin{tabular}{|c|c|c|c|c|c|c|c|c|c|}
\hline $\begin{array}{l}\text { SimaPro } 7.1 \\
\text { Project }\end{array}$ & $\begin{array}{l}\text { Inventory } \\
\text { Thesis Dredging Limite }\end{array}$ & $\begin{array}{l}\text { Date: } \\
\text { d LCA }\end{array}$ & 8/13/2008 & Time: & 3:17:48 PM & & & & \\
\hline Title: & Comparing product stag & & & & & & & & \\
\hline Method: & Eco-indicator 95 V2.03 & Europe e & & & & & & & \\
\hline Per sub-compartment & No & & & & & & & & \\
\hline Skip unused: & Yes & & & & & & & & \\
\hline Indicator: & Characterization & & & & & & & & \\
\hline Category: & carcinogens & & & & & & & & \\
\hline Cut-off: & $0 \%$ & & & & & & & & \\
\hline Relative mode: & Non & & & & & & & & \\
\hline \multirow[t]{4}{*}{ No } & Substance & Compartment & Unit & CPD_5k_3.0_Avg & CPD_5k_3.0_High & CPD_5k_3.0_Low & MBD_5k_3.0_Avg & MBD_5k_3.0_High & MBD_5k_3.0_Low \\
\hline & Total & & $\mathrm{kg} \mathrm{B}(\mathrm{a}) \mathrm{P}$ & 0.093594349 & 0.058099335 & 0.184259916 & 0.064200119 & 0.043384485 & 0.103910959 \\
\hline & $\begin{array}{l}1 \text { Benzene } \\
\text { PAH, polycyclic }\end{array}$ & Air & $\mathrm{kg} \mathrm{B}(\mathrm{a}) \mathrm{P}$ & $4.75553 \mathrm{E}-05$ & 2.95203E-05 & 9.36224E-05 & $3.26201 \mathrm{E}-05$ & $2.20436 \mathrm{E}-05$ & $5.27971 \mathrm{E}-05$ \\
\hline & 2 aromatic hydrocarbons & Air & $\mathrm{kg} \mathrm{B}(\mathrm{a}) \mathrm{P}$ & 0.093546794 & 0.058069814 & 0.184166294 & 0.064167499 & 0.043362441 & 0.103858162 \\
\hline
\end{tabular}




\begin{tabular}{|c|c|c|c|c|c|c|c|c|c|}
\hline $\begin{array}{l}\text { SimaPro } 7.1 \\
\text { Project }\end{array}$ & $\begin{array}{l}\text { Inventory } \\
\text { Thesis_Dredging Limited }\end{array}$ & $\begin{array}{l}\text { Date: } \\
\text { LCA }\end{array}$ & $8 / 13 / 2008$ & Time: & 2:57:14 PM & & & & \\
\hline $\begin{array}{l}\text { Title: } \\
\text { Method: } \\
\text { Per sub-compartment: } \\
\text { Skip unused: } \\
\text { Indicator: } \\
\text { Category: } \\
\text { Cut-off: } \\
\text { Relative mode: }\end{array}$ & $\begin{array}{l}\text { Comparing product stage } \\
\text { Eco-indicator } 95 \mathrm{~V} 2.03 \text { / } \\
\text { No } \\
\text { Yes } \\
\text { Characterization } \\
\text { carcinogens } \\
0 \% \\
\text { Non }\end{array}$ & Europe e & & & & & & & \\
\hline No & $\begin{array}{l}\text { Substance } \\
\text { Total } \\
1 \text { Benzene } \\
\text { PAH, polycyclic aromatic } \\
2 \text { hydrocarbons }\end{array}$ & $\begin{array}{l}\text { Compartment } \\
\text { Air } \\
\text { Air }\end{array}$ & $\begin{array}{l}\text { Unit } \\
\text { kg B(a)P } \\
\text { kg B(a)P } \\
\text { kg B(a)P }\end{array}$ & $\begin{array}{r}\text { CPD_20k_1.5_Avg } \\
0.174541224 \\
8.86843 \mathrm{E}-05\end{array}$ & $\begin{array}{r}\text { CPD_20k_1.5_High } \\
0.103561329 \\
5.26195 \mathrm{E}-05\end{array}$ & $\begin{array}{r}\text { CPD_20k_1.5_Low } \\
0.355872359 \\
0.000180819 \\
\\
0.35569154\end{array}$ & $\begin{array}{r}\text { MBD_20k_1.5_Avg } \\
0.22021097 \\
0.000111889 \\
\\
0.220099081\end{array}$ & $\begin{array}{r}\text { MBD_20k_1.5_High } \\
0.136948431 \\
6.95835 \mathrm{E}-05 \\
\\
0.136878848\end{array}$ & $\begin{array}{r}\text { MBD_20k_1.5_Low } \\
0.379054328 \\
0.000192597 \\
\\
0.37886173\end{array}$ \\
\hline
\end{tabular}




\begin{tabular}{|c|c|c|c|c|c|c|c|c|c|}
\hline $\begin{array}{l}\text { SimaPro } 7.1 \\
\text { Project }\end{array}$ & $\begin{array}{l}\text { Inventory } \\
\text { Thesis_Dredging Limited }\end{array}$ & $\begin{array}{l}\text { Date: } \\
\text { LCA }\end{array}$ & $8 / 13 / 2008$ & Time: & 3:00:04 PM & & & & \\
\hline $\begin{array}{l}\text { Title: } \\
\text { Method: } \\
\text { Per sub-compartment: } \\
\text { Skip unused: } \\
\text { Indicator: } \\
\text { Category: } \\
\text { Cut-off: } \\
\text { Relative mode: }\end{array}$ & $\begin{array}{l}\text { Comparing product stage } \\
\text { Eco-indicator } 95 \mathrm{~V} 2.03 \text { / } \\
\text { No } \\
\text { Yes } \\
\text { Characterization } \\
\text { carcinogens } \\
0 \% \\
\text { Non }\end{array}$ & Europe e & & & & & & & \\
\hline No & $\begin{array}{l}\text { Substance } \\
\text { Total } \\
1 \text { Benzene } \\
\text { PAH, polycyclic aromatic } \\
2 \text { hydrocarbons }\end{array}$ & $\begin{array}{l}\text { Compartment } \\
\text { Air } \\
\text { Air }\end{array}$ & $\begin{array}{l}\text { Unit } \\
\text { kg B(a)P } \\
\text { kg B(a)P } \\
\text { kg B(a)P }\end{array}$ & $\begin{array}{r}\text { CPD_20k_1.9_Avg } \\
0.215351624 \\
0.00010942\end{array}$ & $\begin{array}{r}\text { CPD_20k_1.9_High } \\
0.126515279 \\
6.42824 \mathrm{E}-05\end{array}$ & $\begin{array}{r}\text { CPD_20k_1.9_Low } \\
0.442286631 \\
0.000224726\end{array}$ & $\begin{array}{r}\text { MBD_20k_1.9_Avg } \\
0.224001158 \\
0.000113815\end{array}$ & $\begin{array}{r}\text { MBD_20k_1.9_High } \\
0.14073862 \\
7.15093 \mathrm{E}-05 \\
\\
0.140667111\end{array}$ & $\begin{array}{r}\text { MBD_20k_1.9_Low } \\
0.382844516 \\
0.000194523 \\
\\
0.382649993\end{array}$ \\
\hline
\end{tabular}




\begin{tabular}{|c|c|c|c|c|c|c|c|c|c|}
\hline $\begin{array}{l}\text { SimaPro } 7.1 \\
\text { Project }\end{array}$ & $\begin{array}{l}\text { Inventory } \\
\text { Thesis_Dredging Limited }\end{array}$ & $\begin{array}{l}\text { Date: } \\
\text { LCA }\end{array}$ & $8 / 13 / 2008$ & Time: & 3:02:52 PM & & & & \\
\hline $\begin{array}{l}\text { Title: } \\
\text { Method: } \\
\text { Per sub-compartment: } \\
\text { Skip unused: } \\
\text { Indicator: } \\
\text { Category: } \\
\text { Cut-off: } \\
\text { Relative mode: }\end{array}$ & $\begin{array}{l}\text { Comparing product stage } \\
\text { Eco-indicator } 95 \mathrm{~V} 2.03 / \\
\text { No } \\
\text { Yes } \\
\text { Characterization } \\
\text { carcinogens } \\
0 \% \\
\text { Non }\end{array}$ & Europe e & & & & & & & \\
\hline No & $\begin{array}{l}\text { Substance } \\
\text { Total } \\
1 \text { Benzene } \\
\text { PAH, polycyclic aromatic } \\
2 \text { hydrocarbons }\end{array}$ & $\begin{array}{l}\text { Compartment } \\
\text { Air } \\
\text { Air }\end{array}$ & $\begin{array}{l}\text { Unit } \\
\text { kg B(a)P } \\
\text { kg B(a)P } \\
\text { kg B(a)P }\end{array}$ & $\begin{array}{r}\text { CPD_20k_2.3_Avg } \\
0.256156956 \\
0.000130153\end{array}$ & $\begin{array}{r}\text { CPD_20k_2.3_High } \\
0.149469228 \\
7.59453 \mathrm{E}-05\end{array}$ & $\begin{array}{r}\text { CPD_20k_2.3_Low } \\
0.528705971 \\
0.000268635\end{array}$ & $\begin{array}{r}\text { MBD_20k_2.3_Avg } \\
0.22778628 \\
0.000115738\end{array}$ & $\begin{array}{r}\text { MBD_20k_2.3_High } \\
0.144523741 \\
7.34325 \mathrm{E}-05\end{array}$ & $\begin{array}{r}\text { MBD_20k_2.3_Low } \\
0.386629638 \\
0.000196446\end{array}$ \\
\hline
\end{tabular}




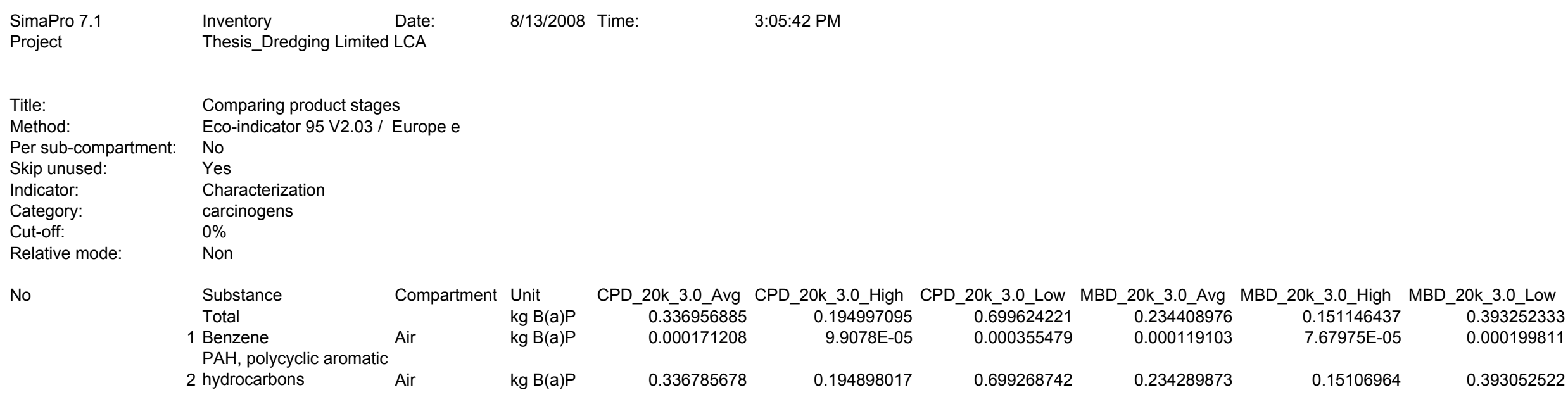




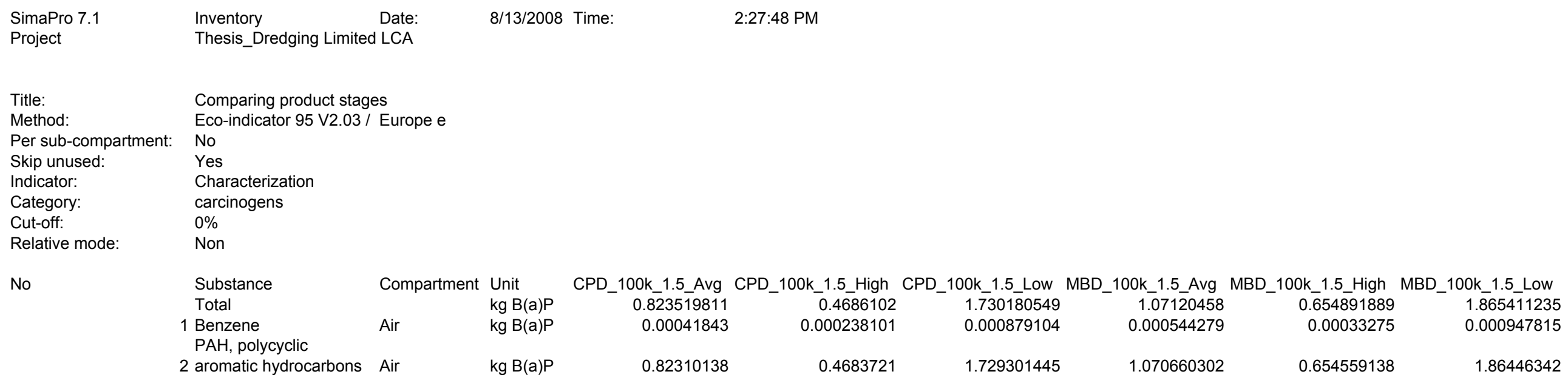

Substance Total

1 Benzene

kg B(a)P

$\mathrm{PAH}$, polycyclic

Air

kg B(a)P

2 aromatic hydrocarbons Air

CPD_100k_1.5_Avg CPD_100k_1.5_High CPD_100 0.823519811

0.000238101

$1 . \overline{7} 30180549$

0.000879104

0.82310138

0.4683721

1.729301445

0.000544279

0.654891889

0.654891889
0.00033275

100k_1.5_Low

1.865411235

0.000947815

$\mathrm{kg} \mathrm{B}(\mathrm{a}) \mathrm{P}$

1.070660302

0.654559138

1.86446342 


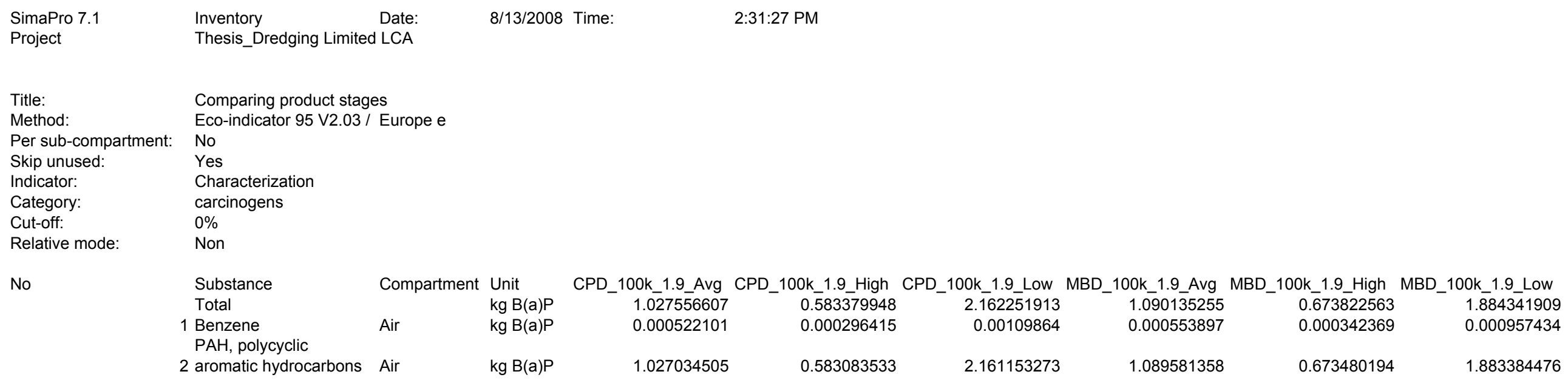

Substance Total

1 Benzene $\mathrm{kg} \mathrm{B}(\mathrm{a}) \mathrm{P}$

$\mathrm{PAH}$, polycyclic

2 aromatic hydrocarbons Air

$\begin{array}{ll} & \mathrm{kg} \mathrm{B}(\mathrm{a}) \mathrm{P} \\ \text { Air } & \mathrm{kg} \mathrm{B}(\mathrm{a}) \mathrm{P}\end{array}$

kg B(a)P

CPD_100k_1.9_Avg CPD_100k_1.9_High CPD_100k 1.9 Low MBD_100 1.027556607 CPD_O 79948 0.000296415 2. $\overline{162251913}$ 0.000522101

0.583083533

0.00109864

1.027034505

2.161153273

$100 \mathrm{k} 1.9 \mathrm{Avg}$ 1.090135255 0.000553897

1.089581358

100k_1.9_High 0.673822563 0.000342369

0.673480194

00k 1.9 Low 1.884341909 0.000957434

1.883384476 


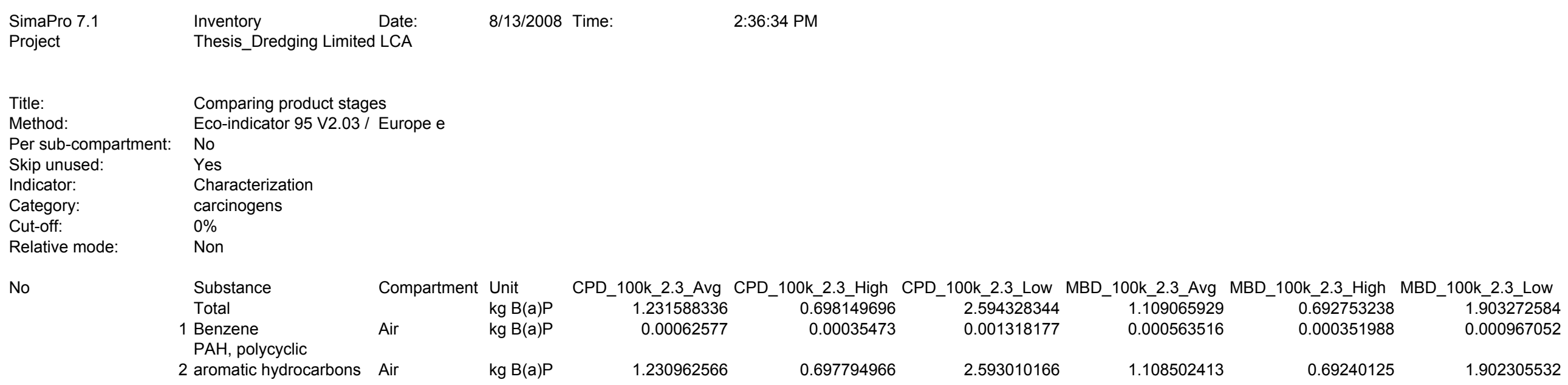

Title:

Method:

Per sub-compartment:

Skip unused:

Indicator:

Category:

Cut-off:

Relative mode:

No

Comparing product stages

Eco-indicator 95 V2.03 / Europe e

No

Characterization

carcinogens

$0 \%$

Non

Substance

Total

kg B(a)P

kg B(a)P

$\mathrm{PAH}$, polycyclic

Air

kg B(a)P

CPD_100k_2.3_Avg CPD_100k_2.3_High CPD_10

$1.231588336 \quad 0.698149696$

0.00062577

0.00035473

1.230962566

0.697794966

0.001318177

0.000563516

2.593010166

1.108502413

0.692753238

0.692753238
0.000351988

0.69240125

100k 2.3 Low 1.903272584 0.000967052

1.902305532 


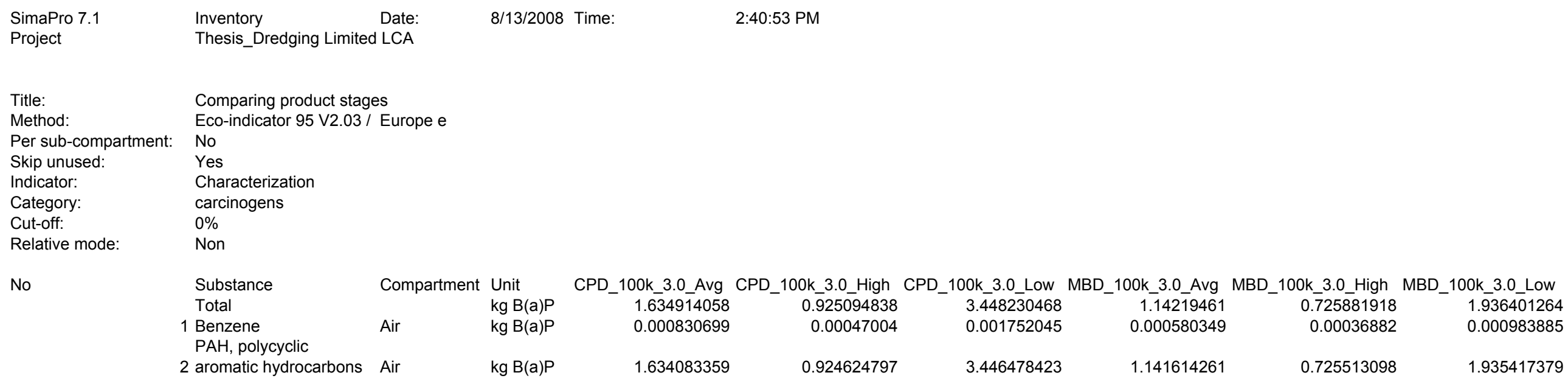

1.634083359

0.924624797

0.001752045

1.14219461

0.000580349

0.725881918
0.00036882

100k_3.0_Low

PAH, polycyclic

kg B(a)P

3.446478423

1.141614261

0.725513098

1.936401264

0.000983885

( 


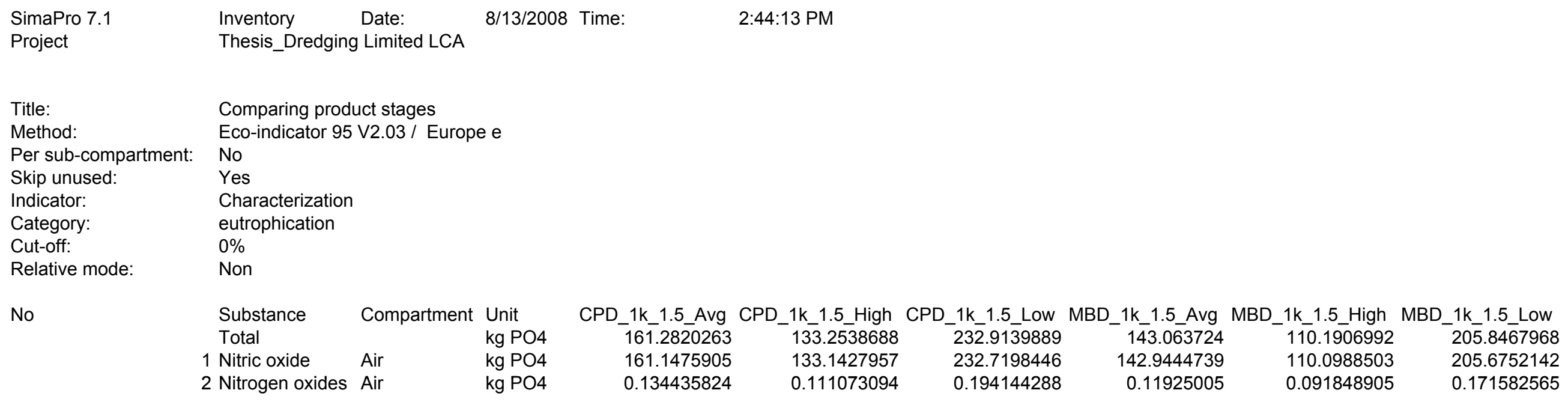

\begin{tabular}{|c|c|c|}
\hline $\begin{array}{l}\text { Substance } \\
\text { Total }\end{array}$ & Compartment & $\begin{array}{l}\text { Unit } \\
\text { kg PO4 }\end{array}$ \\
\hline Nitric oxide & Air & PO4 \\
\hline Nitrogen oxides & Air & O4 \\
\hline
\end{tabular}

CPD 1k 1.5 Avg CPD 1k 1.5 High CPD 1k 1.5 Low MBD 1k 1.5 Avg MBD 1k 1.5 High MBD 1k 1.5 Low

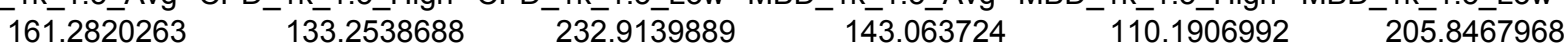
$\begin{array}{llllll}161.1475905 & 133.1427957 & 232.7198446 & 142.9444739 & 110.0988503 & 205.6752142\end{array}$ 


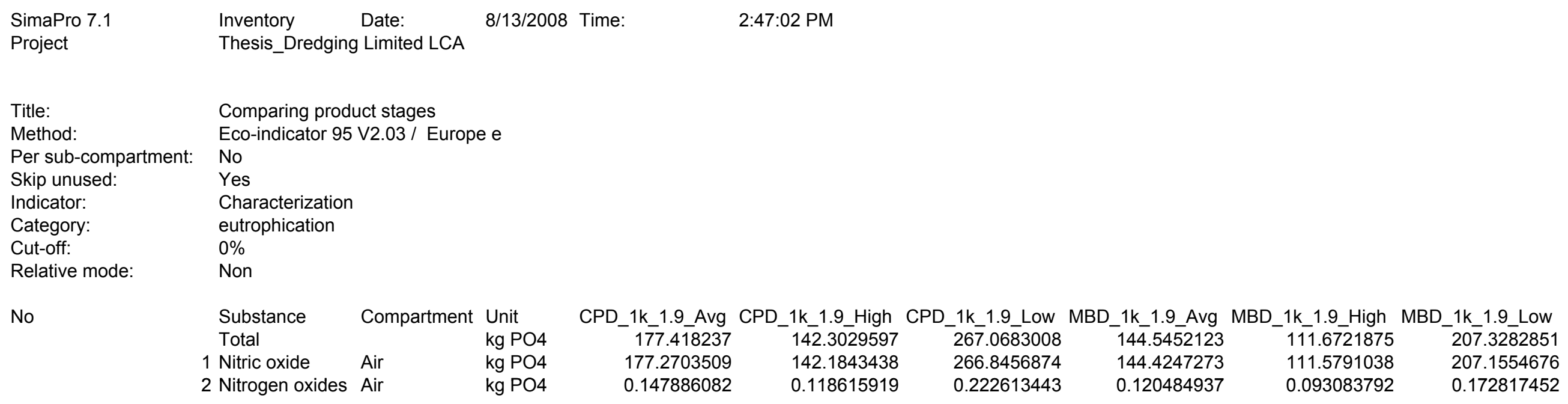

$\begin{array}{lll}\begin{array}{l}\text { Substance } \\ \text { Total }\end{array} & \text { Compartment } & \begin{array}{l}\text { Unit } \\ \text { kg PO4 }\end{array} \\ 1 \text { Nitric oxide } & \text { Air } & \text { kg PO4 } \\ 2 \text { Nitrogen oxides } & \text { Air } & \text { kg PO4 }\end{array}$

CPD 1k 1.9 Avg CPD 1k 1.9 High CPD 1k 1.9 Low MBD 1k 1.9 Avg MBD 1k 1.9 High MBD 1k 1.9 Low

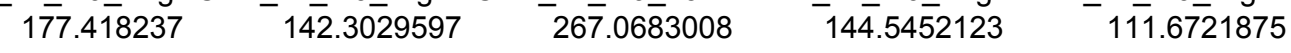
$177.2703509 \quad 142.1843438$

$0.147886082 \quad 0.118615919$

266.8456874

144.4247273

111.5791038 $20 \overline{7} .32 \overline{8} 2851$

2 Nitrogen oxides Air $\quad$ kg PO4

0.222613443

0.120484937

0.093083792 207.1554676 0.172817452 


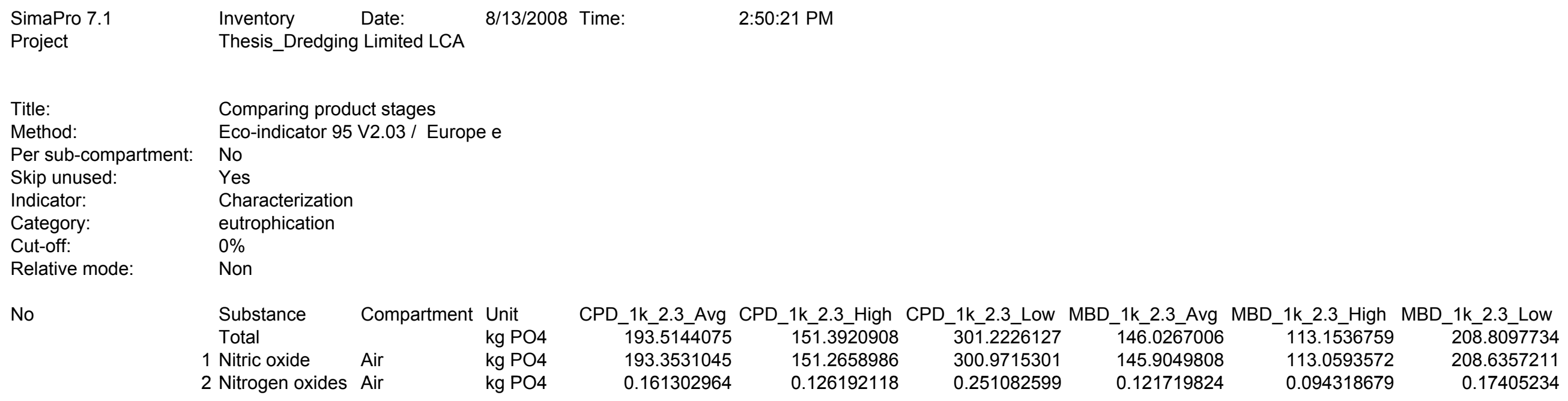

Substance Compartment Unit

$$
\text { Total }
$$

1 Nitric oxide Air

2 Nitrogen oxides Air

CPD 1k 2.3 Avg CPD 1k 2.3 High CPD 1k 2.3 Low MBD 1k 2.3 Avg MBD 1k 2.3 High MBD 1k 2.3 Low $193.5144075 \quad 151.3920908$ $193.3531045 \quad 151.2658986$ $\mathrm{kgPO}$ kg PO4

0.161302964

$\begin{array}{rr}301.2226127 & 146.0267006 \\ 300.9715301 & 145.9049808\end{array}$

0.126192118

0.121719824

113.1536759

113.0593572

0.094318679 208.8097734 208.6357211 0.17405234 


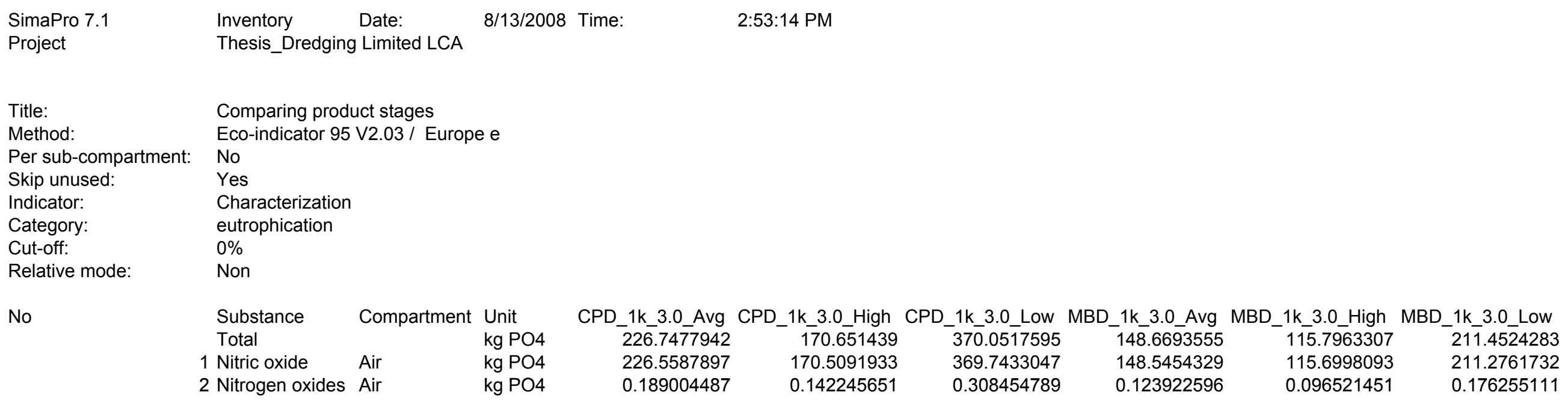

Substance Compartment Unit

$$
\text { Total }
$$

1 Nitric oxide Air

2 Nitrogen oxides Air

CPD 1k 3.0 Avg CPD 1k 3.0 High CPD 1k 3.0 Low MBD 1k 3.0 Avg MBD 1k 3.0 High MBD 1k 3.0 Low

\begin{tabular}{rrrrr}
\hline 226.7477942 & 170.651439 & 370.0517595 & 148.6693555 & 115.7963307 \\
226.5587897 & 170.5091933 & 369.7433047 & 148.5454329 & 115.6998093
\end{tabular} $226.5587897 \quad 170.5091933$

$0.189004487 \quad 0.142245651$

148.5454329

$\mathrm{kg} \mathrm{PO} 4$

$\mathrm{kg} \mathrm{PO} 4$

0.123922596

0.096521451

$21 \overline{1} .4524283$

211.2761732

0.176255111 


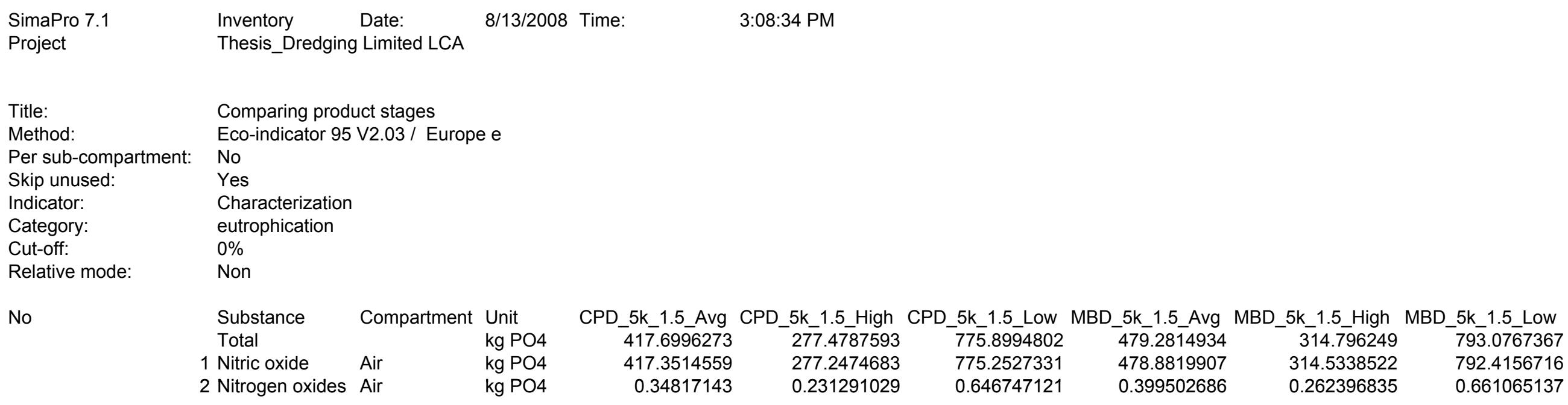

$\begin{array}{lll}\begin{array}{l}\text { Substance } \\ \text { Total }\end{array} & \text { Compartment } & \begin{array}{l}\text { Unit } \\ \text { kg PO4 }\end{array} \\ 1 \text { Nitric oxide } & \text { Air } & \text { kg PO4 } \\ 2 \text { Nitrogen oxides } & \text { Air } & \text { kg PO4 }\end{array}$

CPD 5k 1.5 Avg CPD 5k 1.5 High CPD 5k 1.5 Low MBD 5k 1.5 Avg MBD 5k 1.5 High MBD 5k 1.5 Low $41 \overline{7} .6996273 \quad-27 \overline{7} .4787593$ $417.3514559 \quad 277.2474683$ $77 \overline{5} .89 \overline{9} 4802$ $47 \overline{9} .28 \overline{14934}$ 775.2527331 478.8819907 314.796249 $79 \overline{3} .07 \overline{6} 7367$ $0.34817143 \quad 0.231291029$ 0.646747121

314.5338522

0.262396835 


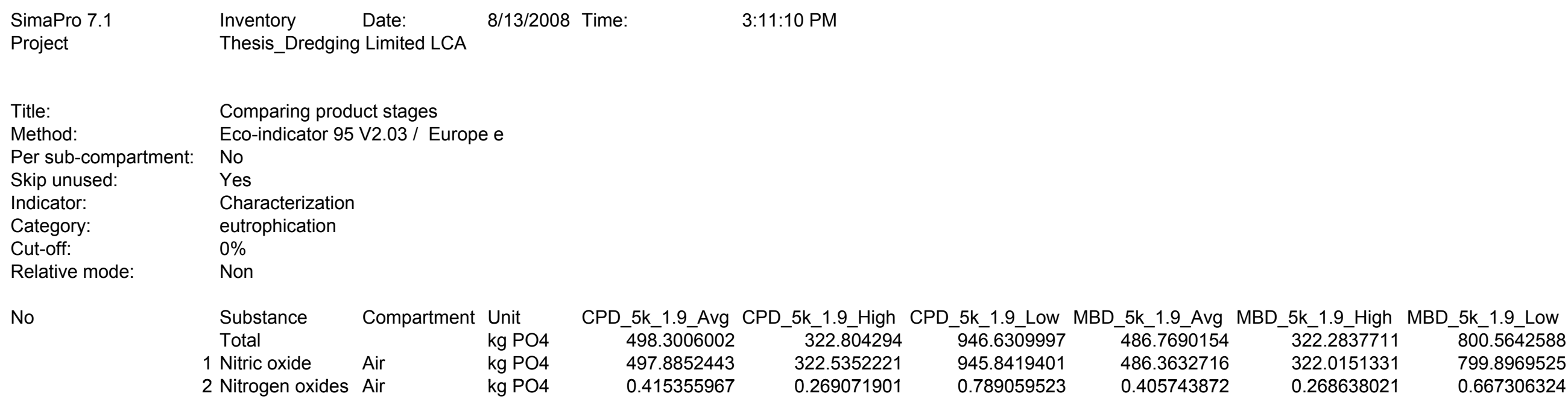

3:11:10 PM

Title:

Method:

Per sub-compartment:

Skip unused:

Indicator:

Category:

Cut-off:

Relative mode:

No

Thesis_Dredging Limited LCA

Comparing product stages

Eco-indicator 95 V2.03 / Europe e

No

Yes

Characterization

eutrophication

$0 \%$

Non

Substance Compartment Unit

Total

$\mathrm{kg} \mathrm{PO} 4$

1 Nitric oxide Air $\quad$ kg PO4

kg PO4

CPD 5k 19 Avg CPD 5k 19 High CPD 5k 19 Low MBD 5k 1.9 Avg MBD 5k 1.9 High MBD 5k 1.9 Low

$498.3006002 \quad-322.804294 \quad 94 \overline{6} .6309997 \quad-48 \overline{6} .7690154$ 497.8852443

0.415355967

322.5352221

0.269071901

945.8419401

0.789059523

486.3632716

0.405743872

322.2837711

322.0151331

0.268638021

800.5642588

799.8969525

0.667306324 


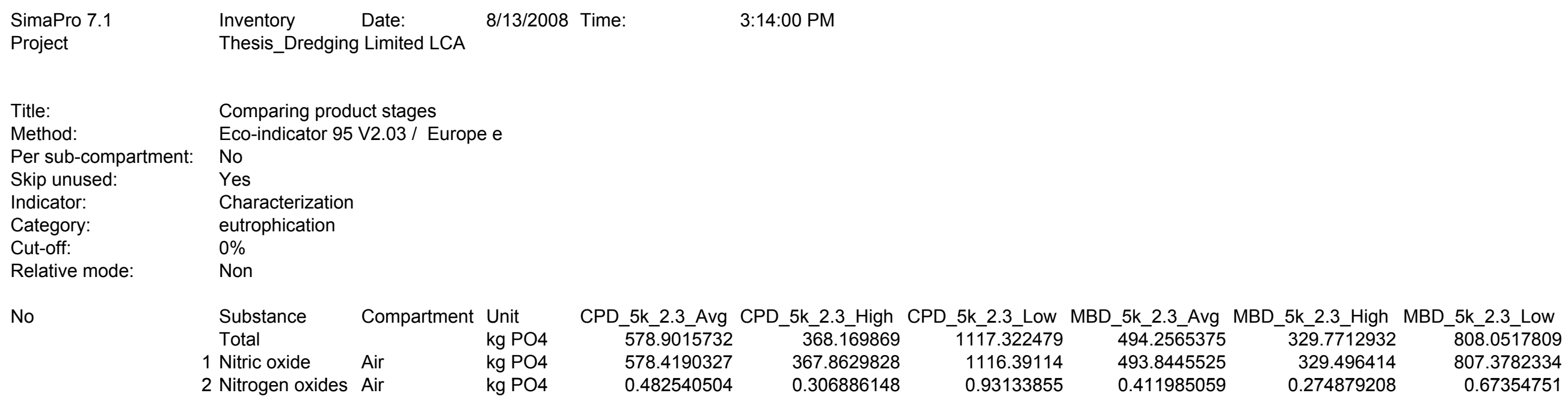

CPD 5k 2.3 Avg CPD 5k 2.3 High CPD 5k 2.3 Low MBD 5k 2.3 Avg MBD 5k 2.3 High MBD 5k 2.3 Low

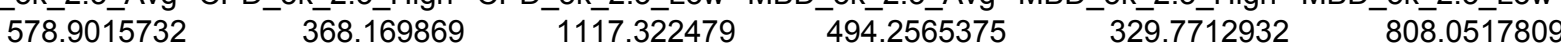
$\begin{array}{llllll}578.4190327 & 367.8629828 & 1116.39114 & 493.8445525 & 329.496414 & 807.3782334\end{array}$ $0.482540504 \quad 0.306886148$

0.93133855

0.41198

0.274879208

0.67354751 


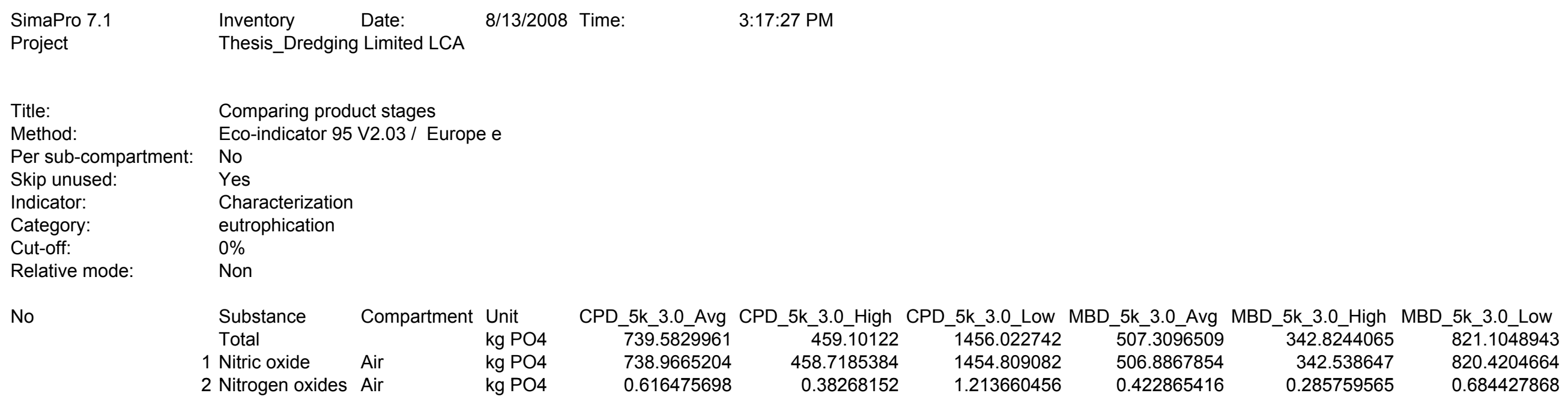

CPD 5k 3.0 Avg CPD 5k 3.0 High CPD 5k 3.0 Low MBD 5k 3.0 Avg MBD 5k 3.0 High MBD 5k 3.0 Low $739.5829961 \quad-459.10122 \quad-14 \overline{5} 6.022742 \quad 507.3096509 \quad-342.8244065 \quad 821.1048943$ $\begin{array}{llllll}738.9665204 & 458.7185384 & 1454.809082 & 506.8867854 & 342.538647 & 820.4204664\end{array}$ $\begin{array}{llllll}0.616475698 & 0.38268152 & 1.213660456 & 0.422865416 & 0.285759565 & 0.684427868\end{array}$ 


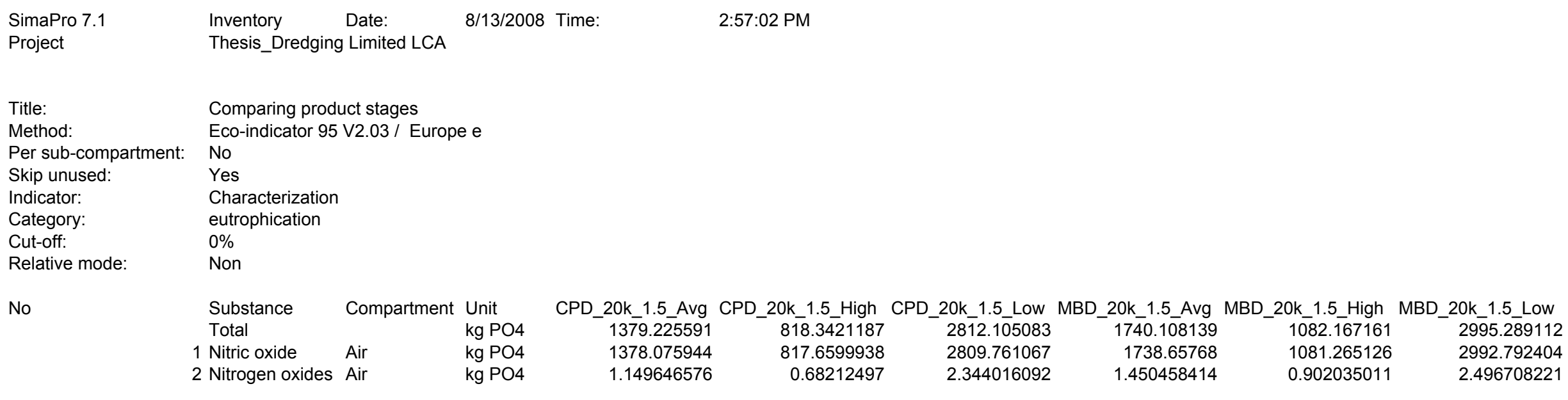

Title:

Method:

Per sub-compartment:

Skip unused:

Indicator:

Category:

Cut-off:

Relative mode:

Comparing product stages

Eco-indicator $95 \mathrm{~V} 2.03$ / Europe e

No

Yes

Characterization

eutrophication

$0 \%$
Non

Substance Compartment Unit

kg PO4

1 Nitric oxide Air $\quad \mathrm{kg} \mathrm{PO} 4$

2 Nitrogen oxides Air $\quad \mathrm{kgPO} 4$ CPD_20k_1.5_Avg CPD_20k

1378.075944

20k_1.5_High CPD
818.3421187

817.6599938

0.68212497

PD_20k_1.5_Low
2812.105083
2809.761067
2.344016092

BD_20k_1.5_Avg
1740.108139
1738.65768

MBD_20k_1.5_High MBD_20k_1.5_Low

2992.792404

1.149646576

1.450458414

1081.265126

2.496708221 


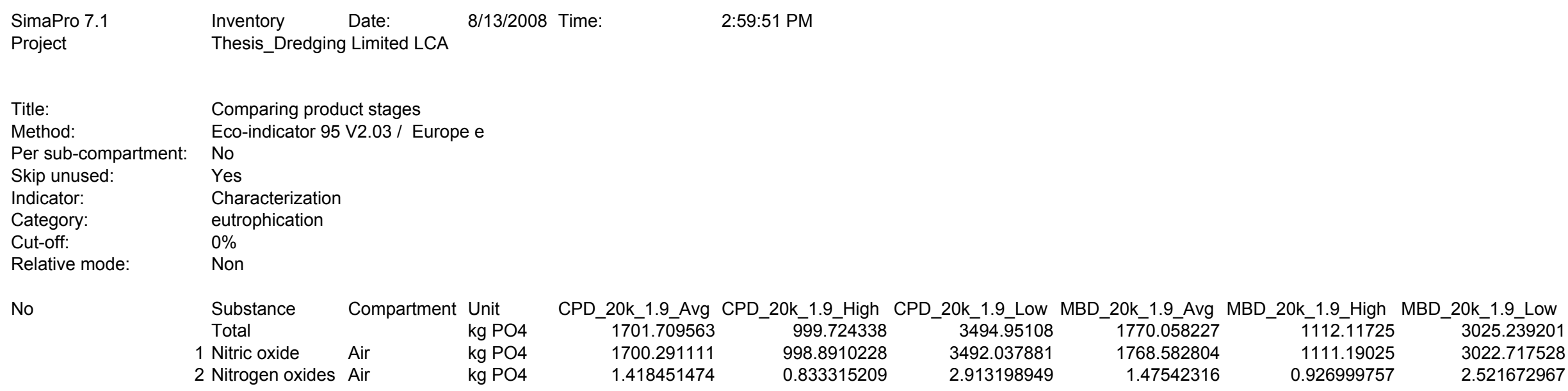

CPD_20k_1.9_Avg CPD_20k_1.9_High CPD_20k_1.9_Low MBD_20k_1.9_Avg MBD_20k_1.9_High MBD_20k_1.9_Low

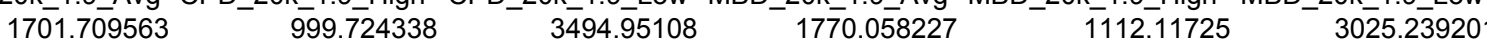




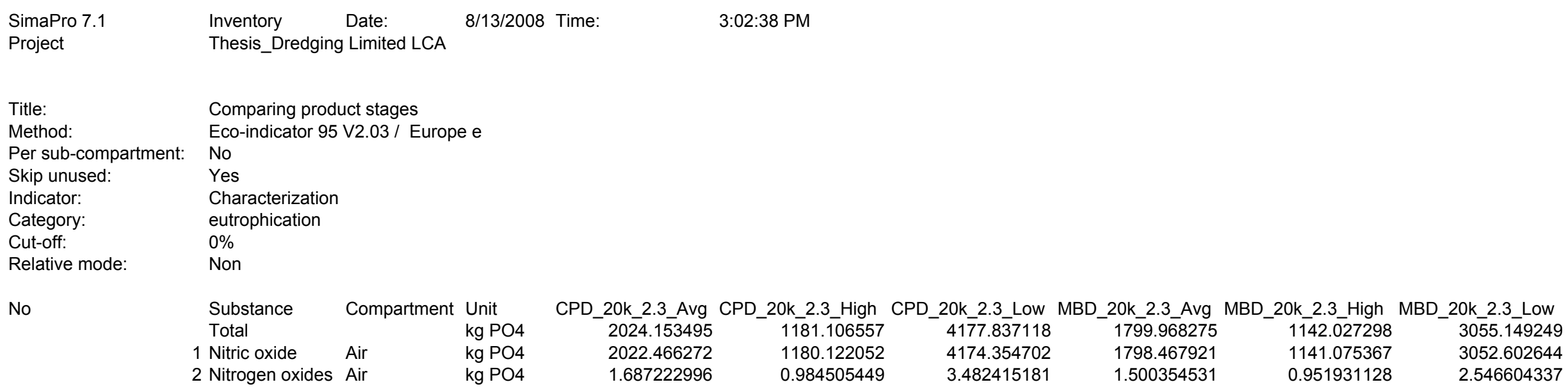

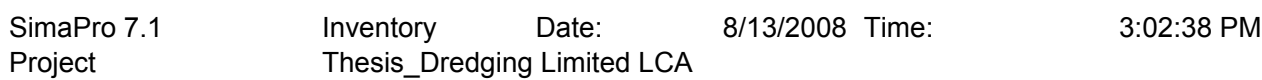

Title:

Method:

Per sub-compartment:

Skip unused:

Indicator:

Category:

Cut-off:

Relative mode:

No

Comparing product stages

Eco-indicator $95 \mathrm{~V} 2.03$ / Europe e

No

Yes

Characterization

eutrophication

$0 \%$
Non

Substance Compartment Unit

Total

Nitric oxide Air

Nitrogen oxides Air

kg PO4

CPD_20k_2.3_Avg CPD_20k_2.3_High CPD_20k_2.3_Low MBD_20k_2.3_Avg MBD_20k_2.3_High MBD_20k_2.3_Low 2024.153495 1181.106557

2022.466272

1.687222996

4177.837118

4174.354702

3.482415181

1142.027298

3055.149249

1798.467921

141.075367

3052.602644

2.546604337 


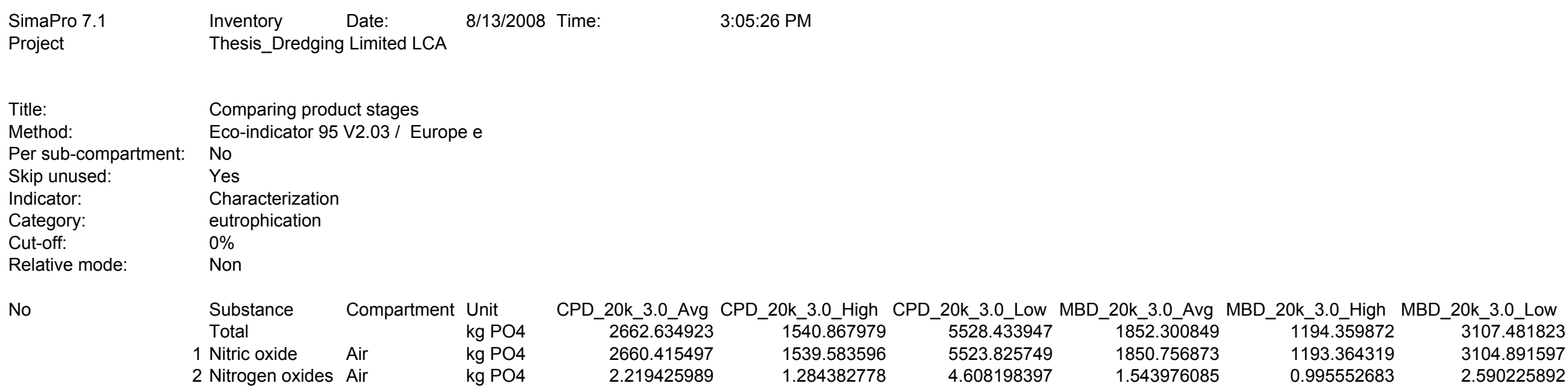

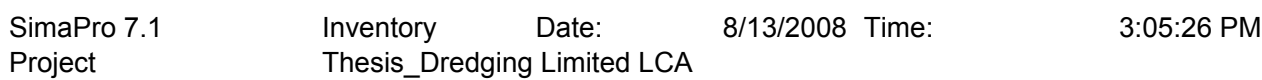

Title:

Method:

Per sub-compartment:

Skip unused:

Indicator:

Category:

Cut-off:

Relative mode:

No

Comparing product stages

Eco-indicator $95 \mathrm{~V} 2.03$ / Europe e

No

Yes

Characterization

eutrophication

$0 \%$
Non

Substance Compartment Unit

Total

Nitric oxide Air

2 Nitrogen oxides Air $\quad \mathrm{kg} \mathrm{PO} 4$

CPD_20k_3.0_Avg CPD_20k_3.0_High CPD_20k_3.0_Low MBD_20k_3.0_Avg MBD_20k_3.0_High MBD_20k_3.0_Low $2662.634923 \quad 1540.867979$ $2660.415497 \quad 1539.583596$

$2.219425989 \quad 1.284382778$

5528.433947

4.608198397

1852.300849
1850.756873

1.543976085

1194.359872

1193.364319

0.995552683

3104.891597

2.590225892 


\section{SimaPro 7.1 \\ Project}

Title:

Method:

Per sub-compartment:

Skip unused:

Indicator:

Category:

Cut-off:

Relative mode:

No
Inventory Date:

8/13/2008 Time:

Thesis_Dredging Limited LCA

Comparing product stages

Eco-indicator 95 V2.03 / Europe e

No

Yes

Characterization

eutrophication

$0 \%$

Non

Substance Compartment Unit

Total$$
\text { Total }
$$

$\mathrm{kg} \mathrm{PO} 4$

1 Nitric oxide

Air

kg PO4
2:27:33 PM

(1)

CPD_100k_1.5_Avg CPD_100k_1.5_High CPD_100

5.424258561

3699.873465

13671.89499
13660.49885

13660.49885
11.39613952
MBD_100k_1.5_Avg MBD_100k_1.5_High MBD_100k_1.5_Low
$\begin{array}{lll}8464.663728 & 5174.958841 & 14740.48852\end{array}$
$\begin{array}{lrr}8457.60805 & 5170.64528 & 14728.20165\end{array}$
$\begin{array}{lll}7.055678008 & 4.313560994 & 12.28686029\end{array}$




\section{SimaPro 7.1 \\ Project}

Title:

Method:

Per sub-compartment:

Skip unused:

Indicator:

Category:

Cut-off:

Relative mode:

No
Inventory Date: 8/13/2008 Time:

Thesis_Dredging Limited LCA

Comparing product stages

Eco-indicator 95 V2.03 / Europe e

No

Yes

Characterization

eutrophication

$0 \%$

Non

Substance Compartment Unit

Total

$$
\text { Total }
$$

$\mathrm{kg} \mathrm{PO} 4$

1 Nitric oxide

Air

kg PO4

CPD_100k_1.9_Avg CPD_100k

8119.75723

8112.989047

6.768182926

4609.871145

4606.028611

3.842534979

17086.12498
17071.88292

14.2420538
$86 \overline{14} .2 \overline{5} 4008$
8607.07364
7.180368236

Avg
5324.549122
5320.11087
4.438251223

MBD_100k_1.9_Low

14890.0788

14877.66725 


\section{SimaPro 7.1 \\ Project}

Title:

Method:

Per sub-compartment:

Skip unused:

Indicator:

Category:

Cut-off:

Relative mode:

No
Inventory Date: 8/13/2008 Time:

Thesis_Dredging Limited LCA

Comparing product stages

Eco-indicator 95 V2.03 / Europe e

No

Yes

Characterization

eutrophication

$0 \%$

Non

Substance Compartment Unit

Total

$$
\text { Total }
$$

$\mathrm{kg} \mathrm{PO} 4$

1 Nitric oxide Air

2 Nitrogen oxides Air

kg PO4

CPD_100k_2.3_Avg
9732.01693

9723.904856

8.112073915

$5 \overline{516.782242}$

5516.782242
5512.183756

4.598486176

20500.395

20483.307

17.08800146

$87 \overline{6} 3.8 \overline{4} 4289$

8763.844289
8756.539231

7.305058465

5474.139402
5469.576461

4.562941451
_100k_2.3_Low 15039.66908 12.53624075




\section{SimaPro 7.1 \\ Project}

Title:

Method:

Per sub-compartment:

Skip unused:

Indicator:

Category:

Cut-off:

Relative mode:

No
Inventory Date: 8/13/2008 Time:

Thesis_Dredging Limited LCA

Comparing product stages

Eco-indicator 95 V2.03 / Europe e

No

Yes

Characterization

eutrophication

$0 \%$

Non

Substance Compartment Unit

Total

$$
\text { Total }
$$

$\mathrm{kg} \mathrm{PO} 4$

1 Nitric oxide

Air

kg PO4

CPD_100

2:40:38 PM

$12 \overline{9} 19 . \overline{0} 9872$

12908.33007

10.76864996

7310.10384

7304.010539

6.093300402

CPD_100

27247.93368 MB

27247.93368
27225.2213

22.7123785
9025.62728

9018.104014
7.523266364

9018.104014
7.523266364

5735.922393
5731.141244
4.781149351
100k_3.0_Low 15301.45207 15288.69762 


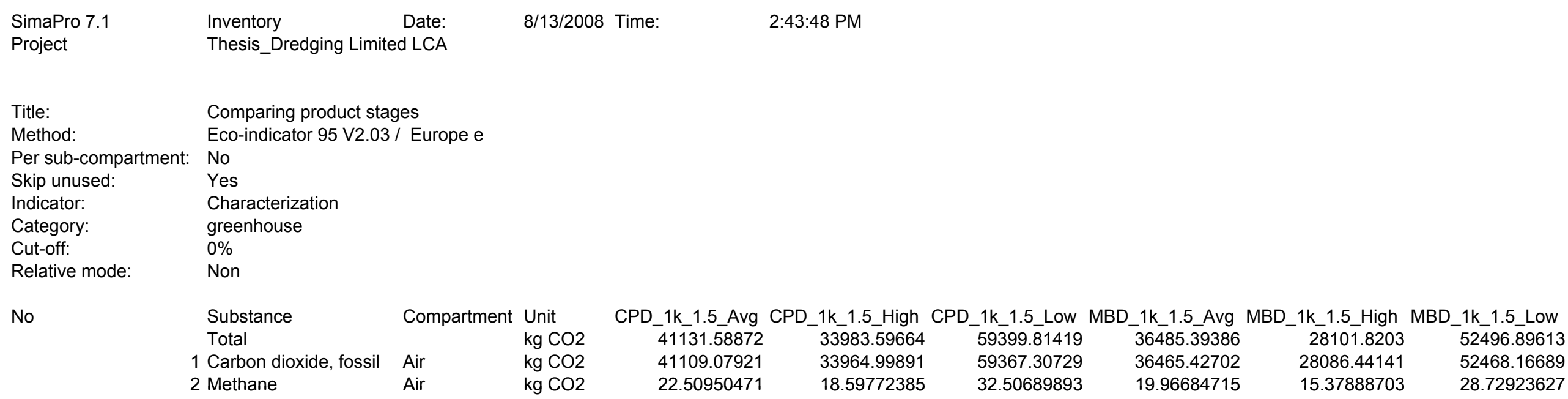

Substance Compartment Unit

Total

1 Carbon dioxide, fossil Air $\quad \mathrm{kg} \mathrm{CO} 2$

2 Methane

CPD_1k_1.5_Avg CPD 41131.58872

41109.07921

22.5095047

$\mathrm{kg} \mathrm{CO} 2$

$\begin{array}{cc}\text { CPD_1k_1.5_High CPD_1k_1.5_Low MBD } & \\ 33983.59664 & 59399.81419 \\ 33964.99891 & 59367.30729\end{array}$

18.59772385

MBD
MBD_1k_1.5_Avg MBD_1k_1.5_High MBD_1k_1.5_Low $\begin{array}{lll}36485.39386 & 28101.8203 & 52496.89613\end{array}$ $36465.42702 \quad 28086.44141 \quad 52468.16689$ $\begin{array}{lll}19.96684715 & 15.37888703 & 28.72923627\end{array}$ 


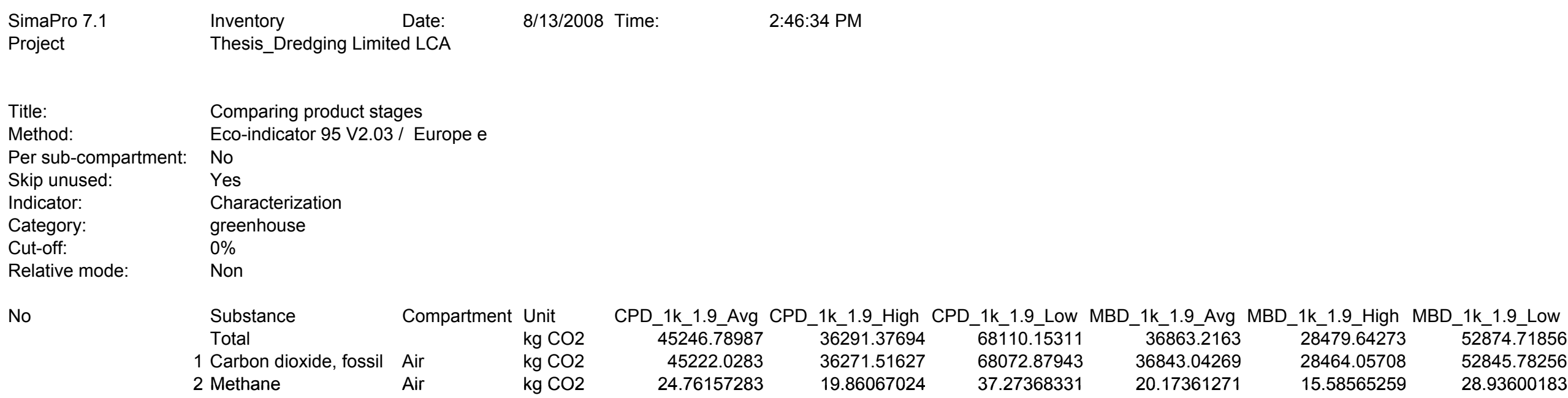

Substance

Total

Compartment Unit

$\mathrm{kg} \mathrm{CO} 2$

1 Carbon dioxide, fossil Air

$\mathrm{kg} \mathrm{CO} 2$

Air

$\mathrm{kg} \mathrm{CO} 2$

CPD_1k_1.9_Avg CPD_1k_1.9_High CPD_1k_1.9_Low MBD_1k_1.9_Avg MBD 1k 1.9 High MBD 1k 1.9 Low $\begin{array}{llllll}45246.78987 & 36291.37694 & 68110.15311 & 36863.2163 & 28479.64273 & 52874.71856\end{array}$ $\begin{array}{llllll}45222.0283 & 36271.51627 & 68072.87943 & 36843.04269 & 28464.05708 & 52845.78256\end{array}$ 28.93600183 


\section{SimaPro 7.1}

Project

Title:

Method:

Per sub-compartment:

Skip unused:

Indicator:

Category:

Cut-off:

Relative mode:

No
Inventory Date:
Thesis Dredging Limited LCA

Comparing product stages

Eco-indicator 95 V2.03 / Europe e

No

Yes

Characterization

greenhouse

$0 \%$

Non

Substance Compartment Unit

Total

$\mathrm{kg} \mathrm{CO} 2$

1 Carbon dioxide, fossil Air

2 Methane

Air

$\mathrm{kg} \mathrm{CO} 2$

$\mathrm{kg} \mathrm{CO} 2$
CPD_1k_2.3_Avg CPD_1k_2.3_High CPD_1k_2.3_Low MBD_1k_2.3_Avg MBD_1k_2.3_High MBD_1k_2.3_Low $\begin{array}{llllll}49351.77961 & 38609.36865 & 76820.49203 & 37241.03874 & 28857.46517 & 53252.541\end{array}$ $\begin{array}{llllll}49324.77156 & 38588.23945 & 76778.45157 & 37220.65836 & 28841.67275 & 53223.39824\end{array}$
21.12920489

20.38037827

15.79241815

29.14276739 


\section{SimaPro 7.1}

Project

Title:

Method:

Per sub-compartment:

Skip unused:

Indicator:

Category:

Cut-off:

Relative mode:

No
Inventory Date:
Thesis Dredging Limited LCA

Comparing product stages

Eco-indicator 95 V2.03 / Europe e

No

Yes

Characterization

greenhouse

$0 \%$

Non

Substance Compartment Unit

Total

$\mathrm{kg} \mathrm{CO} 2$

1 Carbon dioxide, fossil Air

2 Methane

Air

$\mathrm{kg} \mathrm{CO} 2$

$\mathrm{kg} \mathrm{CO} 2$ 57827.25593 $\begin{array}{lrrrrr}57795.60963 & 43497.2432 & 94322.27162 & 37894.24308 & 29515.25747 & 53896.98295\end{array}$

2:52:46 PM

31.64630714

23.81715716

51.64668384

20.74920332

16.1612432

29.51159244 


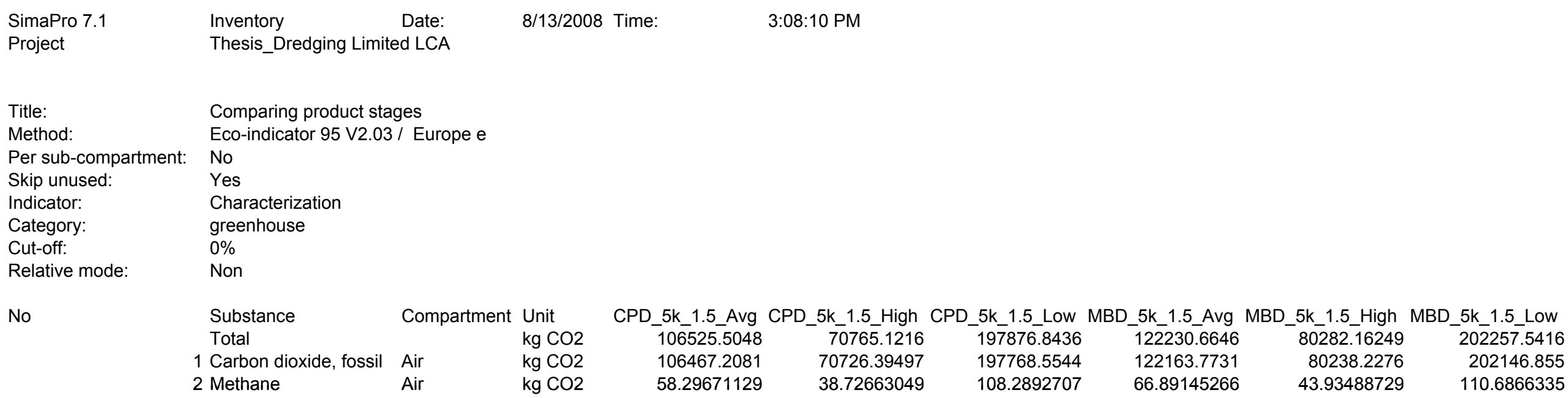

Compartment Unit

$\mathrm{kg} \mathrm{CO} 2$

1 Carbon dioxide, fossil Air

2 Methane

$\mathrm{kg} \mathrm{CO} 2$

$\mathrm{kg} \mathrm{CO} 2$

CPD_5k_1.5_High CPD_5k_1.5_Low MBD_5k $\begin{array}{rrr}106525.5048 & 7076 \overline{5} .1216 & 197876.8436 \\ 106467.2081 & 70726.39497 & 197768.5544\end{array}$

58.29671129 38.72663049

BD_5k_1.5_Avg MBD_5k 122230.6646 122163.7731 66.89145266

108.2892707 202257.5416 $80238.2276 \quad 202146.855$ $43.93488729 \quad 110.6866335$

BD_5k_1.5_High MBD_5k_1.5_Low 


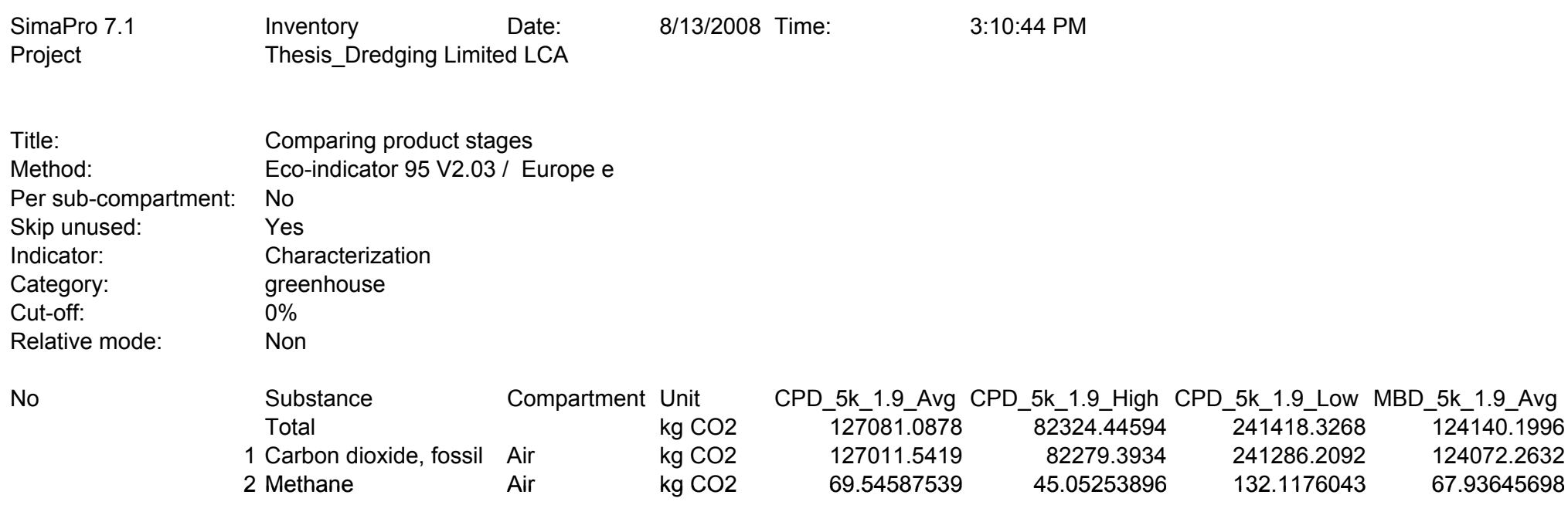

Substance

Total

Compartment Unit

$\mathrm{kg} \mathrm{CO} 2$

1 Carbon dioxide, fossil Air

2 Methane

Air

$\mathrm{kg} \mathrm{CO} 2$

$\mathrm{kg} \mathrm{CO} 2$

CPD_5k_1.9_Avg CPD 127081.0878

127011.5419
82324.44594
82279.3934

69.54587539

45.05253896 241286.2092
132.1176043

241418.3268

BD_5

$$
\begin{aligned}
& 124140.1996 \\
& 124072.2632
\end{aligned}
$$

67.93645698 


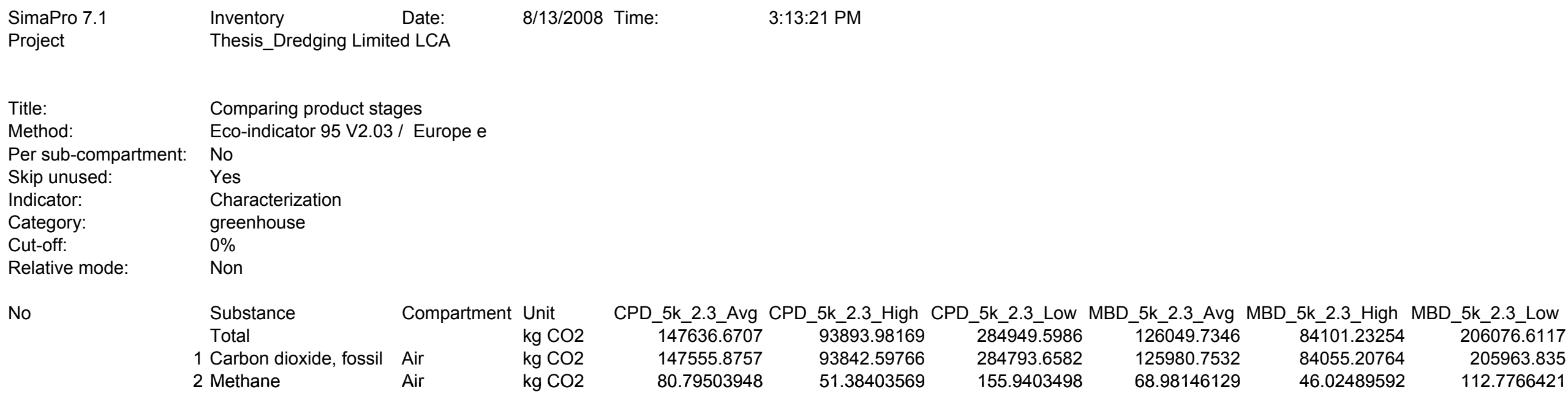

Substance

Total

Compartment Unit

$\mathrm{kg} \mathrm{CO} 2$

1 Carbon dioxide, fossil Air

2 Methane

Air

$\mathrm{kg} \mathrm{CO} 2$

$\mathrm{kg} \mathrm{CO} 2$

CPD_5k_2.3_Avg CPD 5 147636.6707

147555.8757

93893.98169 93842.59766

80.79503948

51.38403569 284793.6582 155.9403498

284949.5986

MBD_5k_2.3_Avg MBD_5k 126049.7346
125980.7532 125980.7532
68.98146129

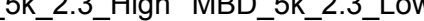 $84101.23254 \quad 206076.6117$ $84055.20764 \quad 205963.835$ $46.02489592 \quad 112.7766421$




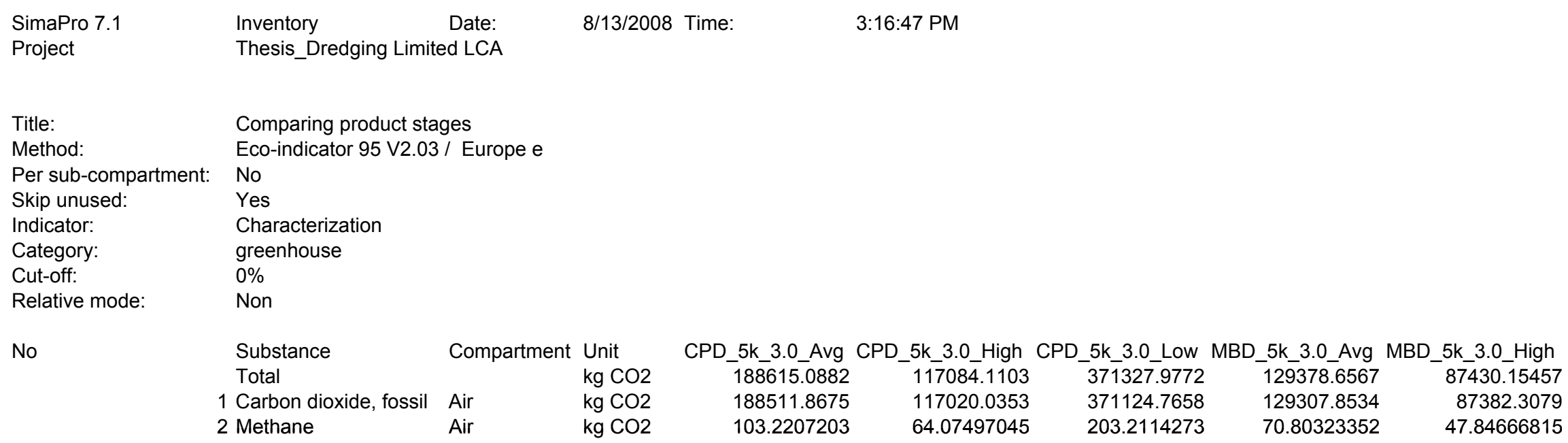

Substance

Total

Compartment Unit

$\mathrm{kg} \mathrm{CO} 2$

1 Carbon dioxide, fossil Air

2 Methane

Air

$\mathrm{kg} \mathrm{CO} 2$

$\mathrm{kg} \mathrm{CO} 2$ 188615.0882
188511.8675

CPD_5k_3.0_High CPD_5k_3.0_Low MBD_ 117084.1103 117020.0353 371327.9772

103.2207203

64.07497045

371124.7658

203.2114273

129378.6567
129307.8534

129307.8534
70.80323352 87430.15457 87382.3079 47.84666815




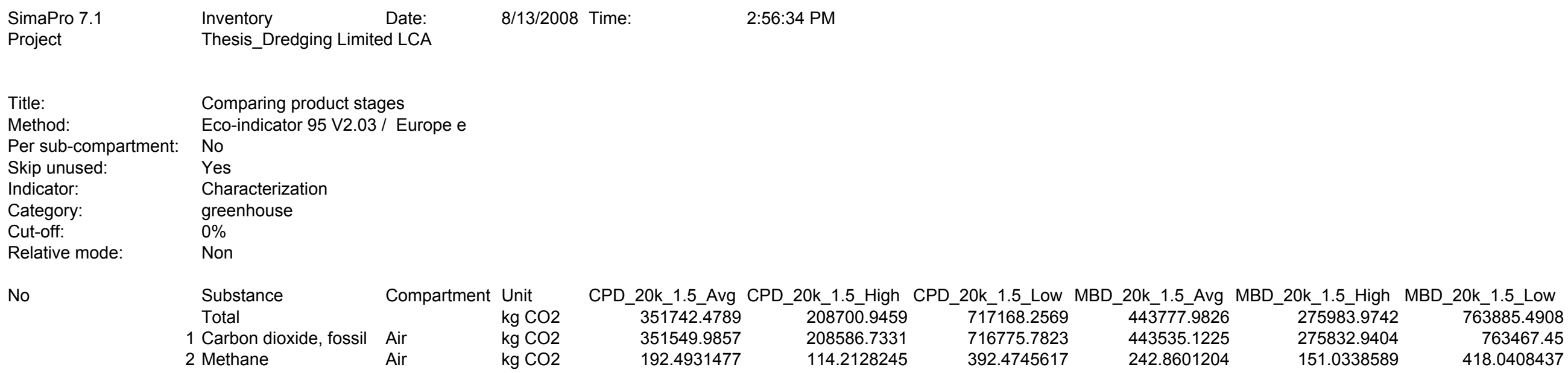

Title:

Method:

Per sub-compartment:

Skip unused:

Indicator:

Category:

Cut-off:

Relative mode:

No

Thesis_Dredging Limited LCA

Comparing product stages

Eco-indicator 95 V2.03 / Europe e

No

Yes

Characterization

greenhouse

$0 \%$

Non

Substance Compartment Unit

Total

1 Carbon dioxide, fossil Air

$\mathrm{kg} \mathrm{CO} 2$

2 Methane

$\mathrm{kg} \mathrm{CO} 2$

CPD_20k_1.5_Avg CPD_20k

351742.4789

351549.9857

192.4931477

208700.9459

208586.7331

114.2128245

717168.256

716775.7823

392.4745617

43777.9826

443535.1225

242.8601204

(75983.9742

275832.9404

151.0338589

763885.490

763467.45 


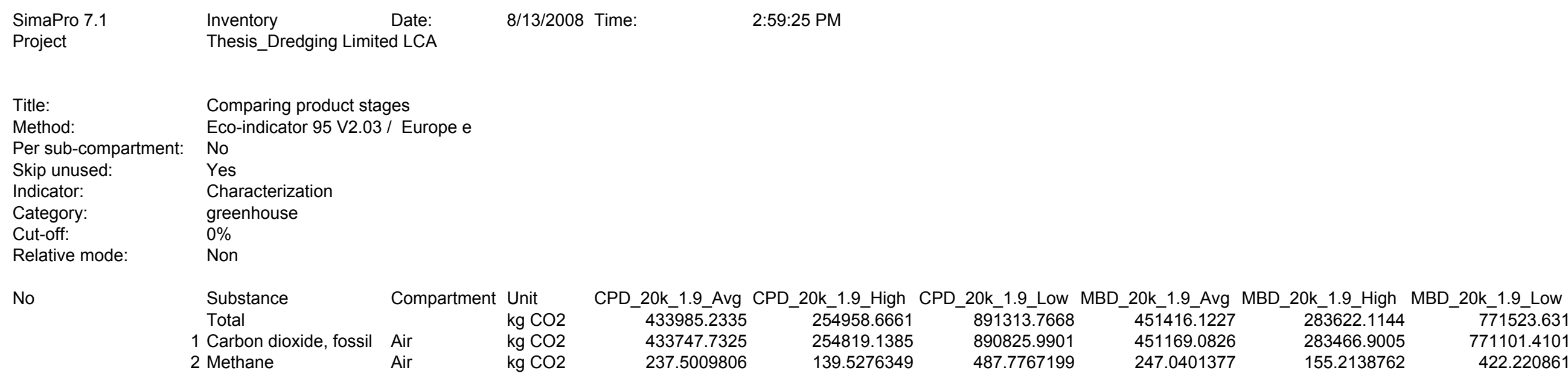

$\mathrm{kg} \mathrm{CO} 2$

CPD_20k_1.9 Avg CPD 20k_1.9 High CPD 20k_1.9 Low MBD_20k_1.9_Avg MBD_20k_1.9_High MBD 20k 1.9 Low 433985.2335

433747.7325 254958.6661

891313.7668

451416.1227

283622.114

254819.1385

890825.9901

451169.0826

283466.9005

237.5009806

139.5276349

487.7767199

247.0401377

155.2138762

771523.631

422.22086 


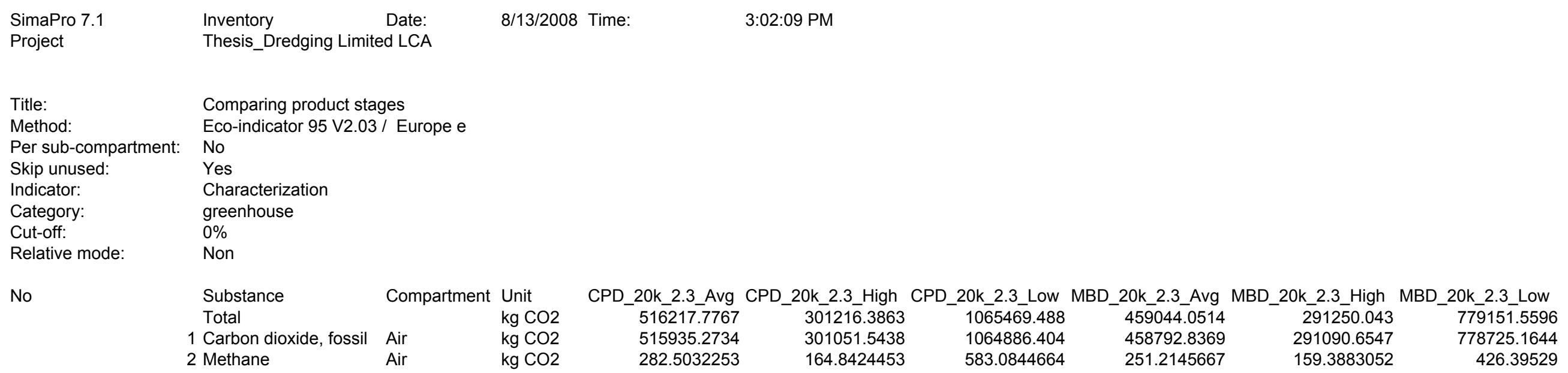

1065469.488

1064886.404

583.0844664

459044.0514

459044.0514
458792.8369

251.2145667

291250.04

291250.043
291090.6547

159.3883052

$20 k \_2.3$ Low 779151.5596 426.39529 


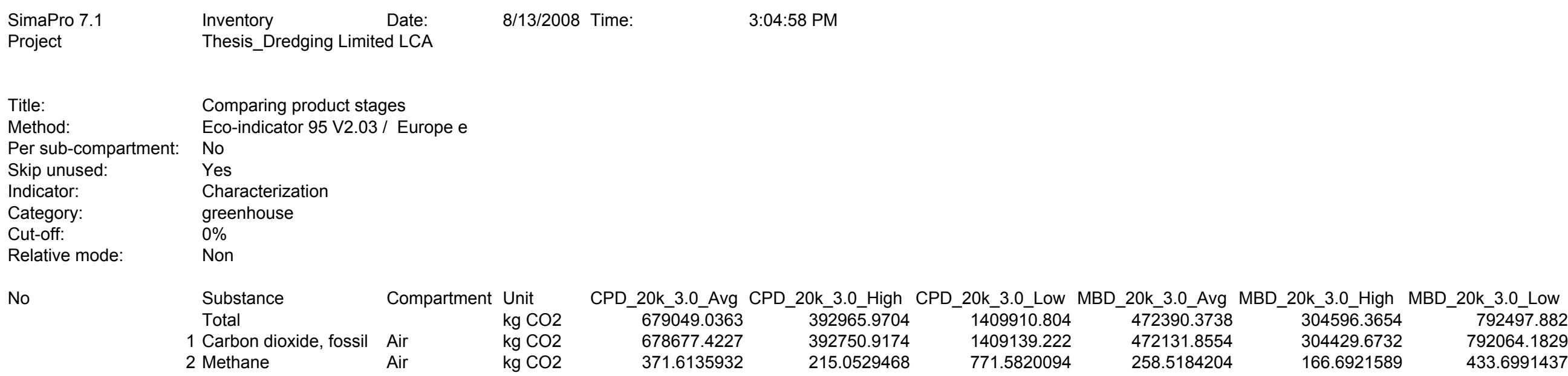

Substance Compartment Unit

Total

$\mathrm{kg} \mathrm{CO} 2$

1 Carbon dioxide, fossil Air

2 Methane

$\mathrm{kg} \mathrm{CO} 2$

$\mathrm{kg} \mathrm{CO} 2$

CPD_20k_3.0_Avg CPD 20k 679049.0363

678677.4227

371.6135932

392965.9704

392750.9174

215.0529468

1409139.222

771.5820094

472390.3738
472131.8554

472131.8554
258.5184204

304596.3654
304429.6732
166.6921589

_20k_3.0_Low

792497.882

433.6991437 


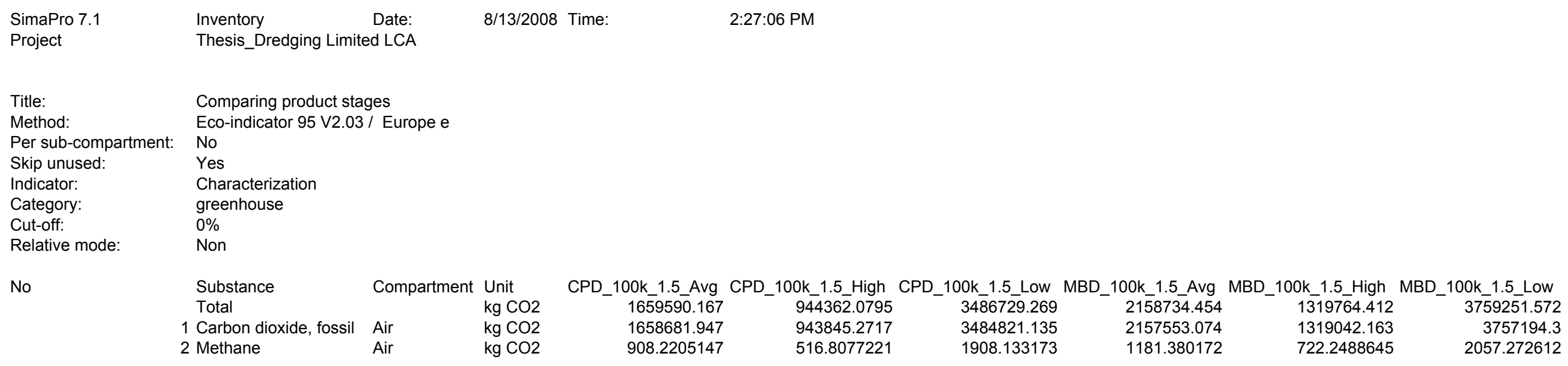

Substance Compartment Unit

Total

1 Carbon dioxide, fossil Air $\quad \mathrm{kg} \mathrm{CO} 2$

2 Methane

$\mathrm{kg} \mathrm{CO} 2$

CPD_100k_1.5_Avg CPD_100k_1.5_High CPD_100k_1.5_Low MBD_100k_1.5_Avg MBD_100k_1.5_High MBD_100k_1.5_Low

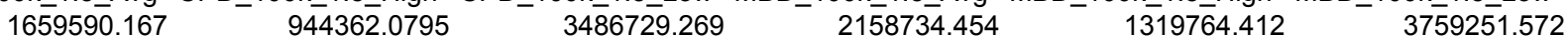

1658681.947

908.2205147

3484821.135

.157553.0

1319042.163

3757194.3

722.2488645

2057.272612 


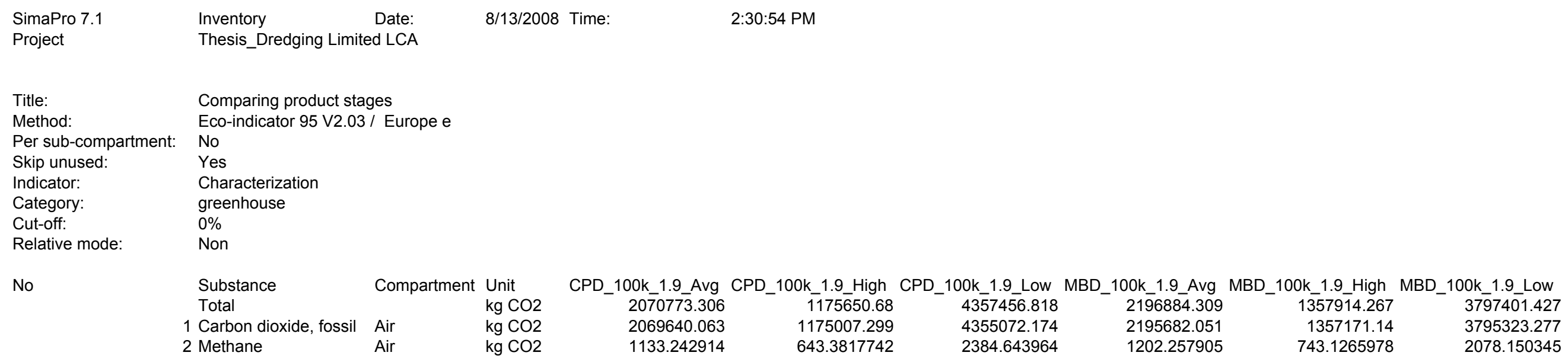

Substance Compartment Unit

Total

1 Carbon dioxide, fossil Air $\quad \mathrm{kg} \mathrm{CO} 2$

2 Methane

$\mathrm{kg} \mathrm{CO} 2$

CPD_100k_1.9_Avg CPD_100k_1.9_High CPD_100k_1.9_Low MBD_100k_1.9_Avg MBD_100k_1.9_High MBD_100k_1.9_Low

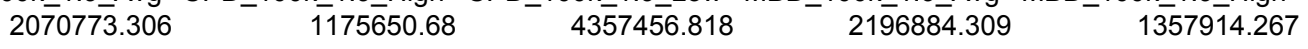

3797401.427

282.05

743.1265978

3795323.277

2078.150345 


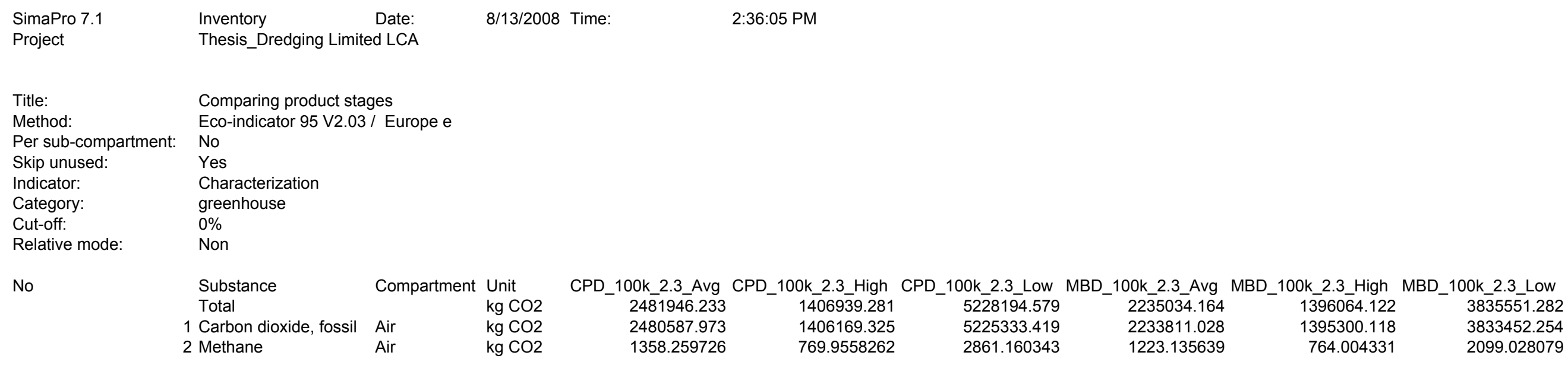

Substance Compartment Unit

Total

1 Carbon dioxide, fossil Air $\quad \mathrm{kg} \mathrm{CO} 2$

2 Methane

kg CO2

CPD_100k_2.3_Avg CPD_100k_2.3_High CPD_100k_2.3_Low MBD_100k_2.3_Avg MBD_100k_2.3_High MBD_100k_2.3_Low $\begin{array}{lllll}2481946.233 & 1406939.281 & 5228194.579 & 2235034.164 & 1396064.122\end{array}$ $\begin{array}{lllll}2480587.973 & 1406169.325 & 5225333.419 & 2233811.028 & 1395300.118\end{array}$ 3835551.282

2861.160343

1223.135639 


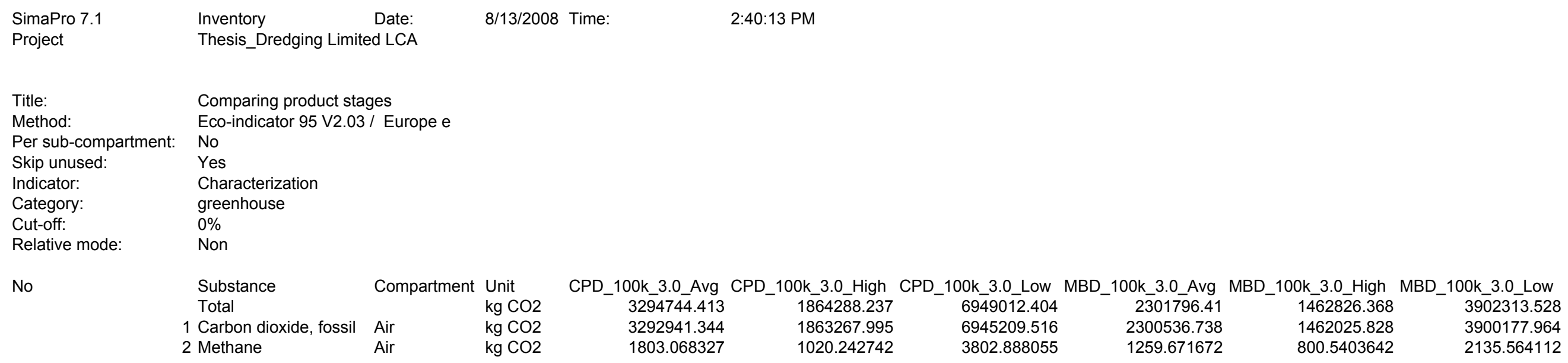

Substance Compartment Unit

Total

1 Carbon dioxide, fossil Air

2 Methane

$\mathrm{kg} \mathrm{CO} 2$

$\mathrm{kg} \mathrm{CO} 2$

$\mathrm{kg} \mathrm{CO} 2$

CPD_100k_3.0_Avg CPD_100k_3.0_High CPD_100k 3294744.413

3292941.344

1803.068327

1864288.237

1863267.995

1020.242742

$69 \overline{4} 9012.404$

3802.888055

MBD_100k_3.0_Avg MBD_100k 2301796.41

2300536.738

1259.671672

1462826.368
1462025.828

800.5403642

MBD_100k_3.0_Low 3902313.528

3900177.964

2135.564112 


\begin{tabular}{|c|c|c|c|c|c|c|c|c|c|}
\hline $\begin{array}{l}\text { SimaPro } 7.1 \\
\text { Project }\end{array}$ & $\begin{array}{l}\text { Inventory } \\
\text { Thesis Dredging Limite }\end{array}$ & $\begin{array}{r}\text { Date: } \\
\text { d LCA }\end{array}$ & $8 / 13 / 2008$ & Time: & 2:44:50 PM & & & & \\
\hline $\begin{array}{l}\text { Title: } \\
\text { Method: } \\
\text { Per sub-compartment: } \\
\text { Skip unused: } \\
\text { Indicator: } \\
\text { Category: } \\
\text { Cut-off: } \\
\text { Relative mode: }\end{array}$ & $\begin{array}{l}\text { Comparing product stag } \\
\text { Eco-indicator } 95 \mathrm{~V} 2.03 \\
\text { No } \\
\text { Yes } \\
\text { Characterization } \\
\text { summer smog } \\
0 \% \\
\text { Non }\end{array}$ & Europe e & & & & & & & \\
\hline No & $\begin{array}{l}\text { Substance } \\
\text { Total } \\
1 \text { Acetaldehyde } \\
2 \text { Acrolein } \\
3 \text { Benzene } \\
4 \text { Formaldehyde } \\
5 \text { Methane } \\
\text { PAH, polycyclic } \\
6 \text { aromatic hydrocarbons } \\
7 \text { Propene } \\
8 \text { Toluene } \\
\text { VOC, volatile organic } \\
9 \text { compounds }\end{array}$ & $\begin{array}{l}\text { Compartment } \\
\text { Air } \\
\text { Air } \\
\text { Air } \\
\text { Air } \\
\text { Air }\end{array}$ & $\begin{array}{l}\text { Unit } \\
\text { kg C2H4 } \\
\text { kg C2H4 } \\
\text { kg C2H4 } \\
\text { kg C2H4 } \\
\text { kg C2H4 } \\
\text { kg C2H4 }\end{array}$ & $\begin{array}{r}\text { CPD_1k_1.5_Avg } \\
9.252386942 \\
0.102063795 \\
0.014102059 \\
0.044545798 \\
0.126148234 \\
0.01432423\end{array}$ & $\begin{array}{r}\text { CPD_1k_1.5_High } \\
7.644474614 \\
0.08432679 \\
0.011651353 \\
0.036804473 \\
0.10422575 \\
0.011834915\end{array}$ & $\begin{array}{r}\text { CPD_1k_1.5_Low } \\
13.36175145 \\
0.147394512 \\
0.020365361 \\
0.064330414 \\
0.182175838 \\
0.020686208\end{array}$ & $\begin{array}{r}\text { MBD_1k_1.5_Avg } \\
8.207243929 \\
0.090534742 \\
0.0125091 \\
0.039513937 \\
0.11189862 \\
0.012706175\end{array}$ & $\begin{array}{r}\text { MBD_1k_1.5_High } \\
6.321392469 \\
0.069731768 \\
0.009634773 \\
0.030434468 \\
0.086186678 \\
0.009786564\end{array}$ & $\begin{array}{r}\text { MBD_1k_1.5_Low } \\
11.80896754 \\
0.130265633 \\
0.01799868 \\
0.056854506 \\
0.161004983 \\
0.018282241\end{array}$ \\
\hline
\end{tabular}




\begin{tabular}{|c|c|c|c|c|c|c|c|c|c|}
\hline $\begin{array}{l}\text { SimaPro } 7.1 \\
\text { Project }\end{array}$ & $\begin{array}{l}\text { Inventory } \\
\text { Thesis_Dredging Limite }\end{array}$ & $\begin{array}{l}\text { Date: } \\
\text { d LCA }\end{array}$ & $8 / 13 / 2008$ & Time: & 2:47:45 PM & & & & \\
\hline $\begin{array}{l}\text { Title: } \\
\text { Method: } \\
\text { Per sub-compartment: } \\
\text { Skip unused: } \\
\text { Indicator: } \\
\text { Category: } \\
\text { Cut-off: } \\
\text { Relative mode: }\end{array}$ & $\begin{array}{l}\text { Comparing product stag } \\
\text { Eco-indicator } 95 \mathrm{~V} 2.03 \text { / } \\
\text { No } \\
\text { Yes } \\
\text { Characterization } \\
\text { summer smog } \\
0 \% \\
\text { Non }\end{array}$ & Europe e & & & & & & & \\
\hline No & $\begin{array}{l}\text { Substance } \\
\text { Total } \\
1 \text { Acetaldehyde } \\
2 \text { Acrolein } \\
3 \text { Benzene } \\
4 \text { Formaldehyde } \\
5 \text { Methane } \\
\\
\text { PAH, polycyclic } \\
6 \text { aromatic hydrocarbons } \\
7 \text { Propene } \\
8 \text { Toluene } \\
\text { VOC, volatile organic } \\
9 \text { compounds }\end{array}$ & $\begin{array}{l}\text { Compartment } \\
\text { Air } \\
\text { Air } \\
\text { Air } \\
\text { Air } \\
\text { Air }\end{array}$ & $\begin{array}{l}\text { Unit } \\
\text { kg C2H4 } \\
\text { kg C2H4 } \\
\text { kg C2H4 } \\
\text { kg C2H4 } \\
\text { kg C2H4 } \\
\text { kg C2H4 } \\
\\
\text { kg C2H4 } \\
\text { kg C2H4 } \\
\text { kg C2H4 } \\
\text { kg C2H4 }\end{array}$ & $\begin{array}{r}\text { CPD_1k_1.9_Avg } \\
10.17808504 \\
0.112275242 \\
0.015512965 \\
0.04900259 \\
0.138769321 \\
0.015757365 \\
\\
\\
0.002309652 \\
0.741118698 \\
0.064159205 \\
\\
9.039180003\end{array}$ & $\begin{array}{r}\text { CPD_1k_1.9_High } \\
8.163600594 \\
0.090053309 \\
0.012442581 \\
0.039303815 \\
0.111303581 \\
0.012638608\end{array}$ & $\begin{array}{r}\text { CPD_1k_1.9_Low } \\
15.32110747 \\
0.16900832 \\
0.023351721 \\
0.073763772 \\
0.208889951 \\
0.023719617\end{array}$ & $\begin{array}{r}\text { MBD_1k_1.9_Avg } \\
8.292233581 \\
0.091472269 \\
0.012638637 \\
0.039923121 \\
0.11305738 \\
0.012837754\end{array}$ & $\begin{array}{r}\text { MBD_1k_1.9_High I } \\
6.406382121 \\
0.070669296 \\
0.00976431 \\
0.030843652 \\
0.087345438 \\
0.009918143\end{array}$ & $\begin{array}{r}\text { MBD_1k_1.9_Low } \\
11.8939572 \\
0.13120316 \\
0.018128217 \\
0.05726369 \\
0.162163743 \\
0.018413819\end{array}$ \\
\hline
\end{tabular}




\begin{tabular}{|c|c|c|c|c|c|c|c|c|c|}
\hline $\begin{array}{l}\text { SimaPro } 7.1 \\
\text { Project }\end{array}$ & $\begin{array}{l}\text { Inventory } \\
\text { Thesis_Dredging Limite }\end{array}$ & $\begin{array}{l}\text { Date: } \\
\text { d LCA }\end{array}$ & $8 / 13 / 2008$ & Time: & 2:51:03 PM & & & & \\
\hline $\begin{array}{l}\text { Title: } \\
\text { Method: } \\
\text { Per sub-compartment: } \\
\text { Skip unused: } \\
\text { Indicator: } \\
\text { Category: } \\
\text { Cut-off: } \\
\text { Relative mode: }\end{array}$ & $\begin{array}{l}\text { Comparing product stag } \\
\text { Eco-indicator } 95 \mathrm{~V} 2.03 \text { / } \\
\text { No } \\
\text { Yes } \\
\text { Characterization } \\
\text { summer smog } \\
0 \% \\
\text { Non }\end{array}$ & Europe e & & & & & & & \\
\hline No & $\begin{array}{l}\text { Substance } \\
\text { Total } \\
1 \text { Acetaldehyde } \\
2 \text { Acrolein } \\
3 \text { Benzene } \\
4 \text { Formaldehyde } \\
5 \text { Methane } \\
\\
\text { PAH, polycyclic } \\
6 \text { aromatic hydrocarbons } \\
7 \text { Propene } \\
8 \text { Toluene } \\
\text { VOC, volatile organic } \\
9 \text { compounds }\end{array}$ & $\begin{array}{l}\text { Compartment } \\
\text { Air } \\
\text { Air } \\
\text { Air } \\
\text { Air } \\
\text { Air }\end{array}$ & $\begin{array}{l}\text { Unit } \\
\text { kg C2H4 } \\
\text { kg C2H4 } \\
\text { kg C2H4 } \\
\text { kg C2H4 } \\
\text { kg C2H4 } \\
\text { kg C2H4 } \\
\\
\text { kg C2H4 } \\
\text { kg C2H4 } \\
\text { kg C2H4 } \\
\text { kg C2H4 }\end{array}$ & $\begin{array}{r}\text { CPD_1k_2.3_Avg } \\
11.10148612 \\
0.122461351 \\
0.01692037 \\
0.053448322 \\
0.15135909 \\
0.017186943 \\
\\
0.002519194 \\
0.808356278 \\
0.069980013\end{array}$ & $\begin{array}{r}\text { CPD_1k_2.3_High } \\
8.685023592 \\
0.095805166 \\
0.01323731 \\
0.041814216 \\
0.118412729 \\
0.013445858 \\
\\
0.00197084 \\
0.632401218 \\
0.054747451 \\
\\
7.713188804\end{array}$ & $\begin{array}{r}\text { CPD_1k_2.3_Low } \\
17.2804635 \\
0.190622127 \\
0.02633808 \\
0.08319713 \\
0.235604063 \\
0.026753025\end{array}$ & $\begin{array}{r}\text { MBD_1k_2.3_Avg } \\
8.377223232 \\
0.092409796 \\
0.012768175 \\
0.040332305 \\
0.114216139 \\
0.012969332\end{array}$ & $\begin{array}{c}\text { MBD_1k_2.3_High I } \\
6.491371772 \\
0.071606823 \\
0.009893847 \\
0.031252837 \\
0.088504198 \\
0.010049721\end{array}$ & $\begin{array}{r}\text { MBD_1k_2.3_Low } \\
11.97894685 \\
0.132140688 \\
0.018257755 \\
0.057672874 \\
0.163322503 \\
0.018545397\end{array}$ \\
\hline
\end{tabular}




\begin{tabular}{|c|c|c|c|c|c|c|c|c|c|}
\hline $\begin{array}{l}\text { SimaPro } 7.1 \\
\text { Project }\end{array}$ & $\begin{array}{l}\text { Inventory } \\
\text { Thesis_Dredging Limite }\end{array}$ & $\begin{array}{l}\text { Date: } \\
\text { d LCA }\end{array}$ & $8 / 13 / 2008$ & Time: & 2:53:52 PM & & & & \\
\hline $\begin{array}{l}\text { Title: } \\
\text { Method: } \\
\text { Per sub-compartment: } \\
\text { Skip unused: } \\
\text { Indicator: } \\
\text { Category: } \\
\text { Cut-off: } \\
\text { Relative mode: }\end{array}$ & $\begin{array}{l}\text { Comparing product stag } \\
\text { Eco-indicator } 95 \mathrm{~V} 2.03 \text { / } \\
\text { No } \\
\text { Yes } \\
\text { Characterization } \\
\text { summer smog } \\
0 \% \\
\text { Non }\end{array}$ & Europe e & & & & & & & \\
\hline No & $\begin{array}{l}\text { Substance } \\
\text { Total } \\
1 \text { Acetaldehyde } \\
2 \text { Acrolein } \\
3 \text { Benzene } \\
4 \text { Formaldehyde } \\
5 \text { Methane } \\
\\
\text { PAH, polycyclic } \\
6 \text { aromatic hydrocarbons } \\
7 \text { Propene } \\
8 \text { Toluene } \\
\text { VOC, volatile organic } \\
9 \text { compounds }\end{array}$ & $\begin{array}{l}\text { Compartment } \\
\text { Air } \\
\text { Air } \\
\text { Air } \\
\text { Air } \\
\text { Air }\end{array}$ & $\begin{array}{l}\text { Unit } \\
\text { kg C2H4 } \\
\text { kg C2H4 } \\
\text { kg C2H4 } \\
\text { kg C2H4 } \\
\text { kg C2H4 } \\
\text { kg C2H4 } \\
\\
\text { kg C2H4 } \\
\text { kg C2H4 } \\
\text { kg C2H4 } \\
\text { kg C2H4 }\end{array}$ & $\begin{array}{r}\text { CPD_1k_3.0_Avg } \\
13.00801074 \\
0.143492371 \\
0.019826206 \\
0.062627323 \\
0.177352892 \\
0.020138559 \\
\\
\\
0.00295183 \\
0.947180138 \\
0.081998099 \\
11.55244332\end{array}$ & $\begin{array}{r}\text { CPD_1k_3.0_High } \\
9.789889064 \\
0.107993022 \\
0.014921294 \\
0.047133613 \\
0.133476607 \\
0.015156373 \\
\\
\\
0.002221561 \\
0.712852154 \\
0.061712149 \\
\\
8.694422292\end{array}$ & $\begin{array}{r}\text { CPD_1k_3.0_Low } \\
21.22903677 \\
0.234179144 \\
0.032356312 \\
0.102207614 \\
0.289439419 \\
0.032866072\end{array}$ & $\begin{array}{r}\text { MBD_1k_3.0_Avg } \\
8.528826395 \\
0.094082143 \\
0.012999241 \\
0.041062202 \\
0.116283116 \\
0.013204038\end{array}$ & $\begin{array}{r}\text { MBD_1k_3.0_High } \\
6.642974935 \\
0.073279169 \\
0.010124914 \\
0.031982733 \\
0.090571175 \\
0.010284427\end{array}$ & $\begin{array}{r}\text { MBD_1k_3.0_Low } \\
12.13055001 \\
0.133813034 \\
0.018488821 \\
0.058402771 \\
0.16538948 \\
0.018780104\end{array}$ \\
\hline
\end{tabular}




\begin{tabular}{|c|c|c|c|c|c|c|c|c|c|}
\hline $\begin{array}{l}\text { SimaPro } 7.1 \\
\text { Project }\end{array}$ & $\begin{array}{l}\text { Inventory } \\
\text { Thesis_Dredging Limite }\end{array}$ & $\begin{array}{l}\text { Date: } \\
\text { d LCA }\end{array}$ & $8 / 13 / 2008$ & Time: & 3:09:14 PM & & & & \\
\hline $\begin{array}{l}\text { Title: } \\
\text { Method: } \\
\text { Per sub-compartment: } \\
\text { Skip unused: } \\
\text { Indicator: } \\
\text { Category: } \\
\text { Cut-off: } \\
\text { Relative mode: }\end{array}$ & $\begin{array}{l}\text { Comparing product stag } \\
\text { Eco-indicator } 95 \mathrm{~V} 2.03 \\
\text { No } \\
\text { Yes } \\
\text { Characterization } \\
\text { summer smog } \\
0 \% \\
\text { Non }\end{array}$ & $\begin{array}{l}\text { ges } \\
\text { / Europe e }\end{array}$ & & & & & & & \\
\hline No & $\begin{array}{l}\text { Substance } \\
\text { Total } \\
1 \text { Acetaldehyde } \\
2 \text { Acrolein } \\
3 \text { Benzene } \\
4 \text { Formaldehyde } \\
5 \text { Methane } \\
\\
\text { PAH, polycyclic } \\
6 \text { aromatic hydrocarbons } \\
7 \text { Propene } \\
8 \text { Toluene } \\
\text { VOC, volatile organic } \\
9 \text { compounds }\end{array}$ & $\begin{array}{l}\text { Compartment } \\
\text { Air } \\
\text { Air } \\
\text { Air } \\
\text { Air } \\
\text { Air }\end{array}$ & $\begin{array}{l}\text { Unit } \\
\text { kg C2H4 } \\
\mathrm{kg} \mathrm{C} 2 \mathrm{H} 4 \\
\mathrm{~kg} \mathrm{C} 2 \mathrm{H} 4 \\
\mathrm{~kg} \mathrm{C} 2 \mathrm{H} 4 \\
\mathrm{~kg} \mathrm{C} 2 \mathrm{H} 4 \\
\mathrm{~kg} \mathrm{C} 2 \mathrm{H} 4 \\
\\
\\
\mathrm{~kg} \mathrm{C} 2 \mathrm{H} 4 \\
\mathrm{~kg} \mathrm{C} 2 \mathrm{H} 4 \\
\mathrm{~kg} \mathrm{C} 2 \mathrm{H} 4\end{array}$ & $\begin{array}{r}\text { CPD_5k_1.5_Avg } \\
23.96248773 \\
0.264332052 \\
0.036522511 \\
0.115367867 \\
0.326707641 \\
0.037097907 \\
\\
\\
0.005437664 \\
1.744831926 \\
0.151051416\end{array}$ & $\begin{array}{r}\text { CPD_5k_1.5_High } \\
15.91833205 \\
0.17559635 \\
0.024261983 \\
0.076639122 \\
0.217032587 \\
0.024644219 \\
\\
0.003612252 \\
1.159095595 \\
0.10034378\end{array}$ & $\begin{array}{r}\text { CPD_5k_1.5_Low } \\
44.51160729 \\
0.491010977 \\
0.067842525 \\
0.214302006 \\
0.606876981 \\
0.068911354 \\
\\
\\
0.010100752 \\
3.241118966 \\
0.280586114\end{array}$ & $\begin{array}{r}\text { MBD_5k_1.5_Avg } \\
27.49530082 \\
0.303302786 \\
0.041907061 \\
0.132376665 \\
0.374874469 \\
0.042567288 \\
\\
\\
0.006239344 \\
2.002074209 \\
0.173321075\end{array}$ & $\begin{array}{r}\text { MBD_5k_1.5_High } \\
18.05915247 \\
0.199211905 \\
0.027524922 \\
0.086946143 \\
0.246220808 \\
0.027958565 \\
\\
\\
0.004098055 \\
1.314979735 \\
0.113838788\end{array}$ & $\begin{array}{r}\text { MBD_5k_1.5_Low } \\
45.49702785 \\
0.501881227 \\
0.069344457 \\
0.219046332 \\
0.620312331 \\
0.070436949\end{array}$ \\
\hline
\end{tabular}




\begin{tabular}{|c|c|c|c|c|c|c|c|c|c|}
\hline $\begin{array}{l}\text { SimaPro } 7.1 \\
\text { Project }\end{array}$ & $\begin{array}{l}\text { Inventory } \\
\text { Thesis_Dredging Limite }\end{array}$ & $\begin{array}{l}\text { Date: } \\
\text { d LCA }\end{array}$ & $8 / 13 / 2008$ & Time: & 3:11:45 PM & & & & \\
\hline $\begin{array}{l}\text { Title: } \\
\text { Method: } \\
\text { Per sub-compartment: } \\
\text { Skip unused: } \\
\text { Indicator: } \\
\text { Category: } \\
\text { Cut-off: } \\
\text { Relative mode: }\end{array}$ & $\begin{array}{l}\text { Comparing product stag } \\
\text { Eco-indicator } 95 \mathrm{~V} 2.03 / \\
\text { No } \\
\text { Yes } \\
\text { Characterization } \\
\text { summer smog } \\
0 \% \\
\text { Non }\end{array}$ & Europe e & & & & & & & \\
\hline No & $\begin{array}{l}\text { Substance } \\
\text { Total } \\
1 \text { Acetaldehyde } \\
2 \text { Acrolein } \\
3 \text { Benzene } \\
4 \text { Formaldehyde } \\
5 \text { Methane } \\
\\
\text { PAH, polycyclic } \\
6 \text { aromatic hydrocarbons } \\
7 \text { Propene } \\
8 \text { Toluene } \\
\text { VOC, volatile organic } \\
9 \text { compounds }\end{array}$ & $\begin{array}{l}\text { Compartment } \\
\text { Air } \\
\text { Air } \\
\text { Air } \\
\text { Air } \\
\text { Air }\end{array}$ & $\begin{array}{l}\text { Unit } \\
\text { kg C2H4 } \\
\text { kg C2H4 } \\
\text { kg C2H4 } \\
\text { kg C2H4 } \\
\text { kg C2H4 } \\
\text { kg C2H4 } \\
\\
\text { kg C2H4 } \\
\text { kg C2H4 } \\
\text { kg C2H4 }\end{array}$ & $\begin{array}{r}\text { CPD_5k_1.9_Avg } \\
28.58638419 \\
0.315338611 \\
0.043570039 \\
0.137629707 \\
0.38975044 \\
0.044256466 \\
\\
\\
0.006486937 \\
2.081521598 \\
0.180198895\end{array}$ & $\begin{array}{r}\text { CPD_5k_1.9_High } \\
18.51855599 \\
0.204279621 \\
0.028225123 \\
0.089157951 \\
0.252484375 \\
0.028669798 \\
\\
\\
0.004202305 \\
1.348431268 \\
0.116734712\end{array}$ & $\begin{array}{r}\text { CPD_5k_1.9_Low } \\
54.30609039 \\
0.599054676 \\
0.082770821 \\
0.261457736 \\
0.740416224 \\
0.084074839 \\
\\
\\
0.012323355 \\
3.954305635 \\
0.342327222\end{array}$ & $\begin{array}{r}\text { MBD_5k_1.9_Avg } \\
27.92484311 \\
0.308041101 \\
0.042561749 \\
0.134444704 \\
0.380730904 \\
0.043232291 \\
\\
\\
0.006336817 \\
2.033351392 \\
0.176028764\end{array}$ & $\begin{array}{r}\text { MBD_5k_1.9_High } \\
18.48869476 \\
0.20395022 \\
0.02817961 \\
0.089014183 \\
0.252077243 \\
0.028623567\end{array}$ & $\begin{array}{r}\text { MBD_5k_1.9_Low } \\
45.92657014 \\
0.506619542 \\
0.069999146 \\
0.221114372 \\
0.626168766 \\
0.071101951\end{array}$ \\
\hline
\end{tabular}




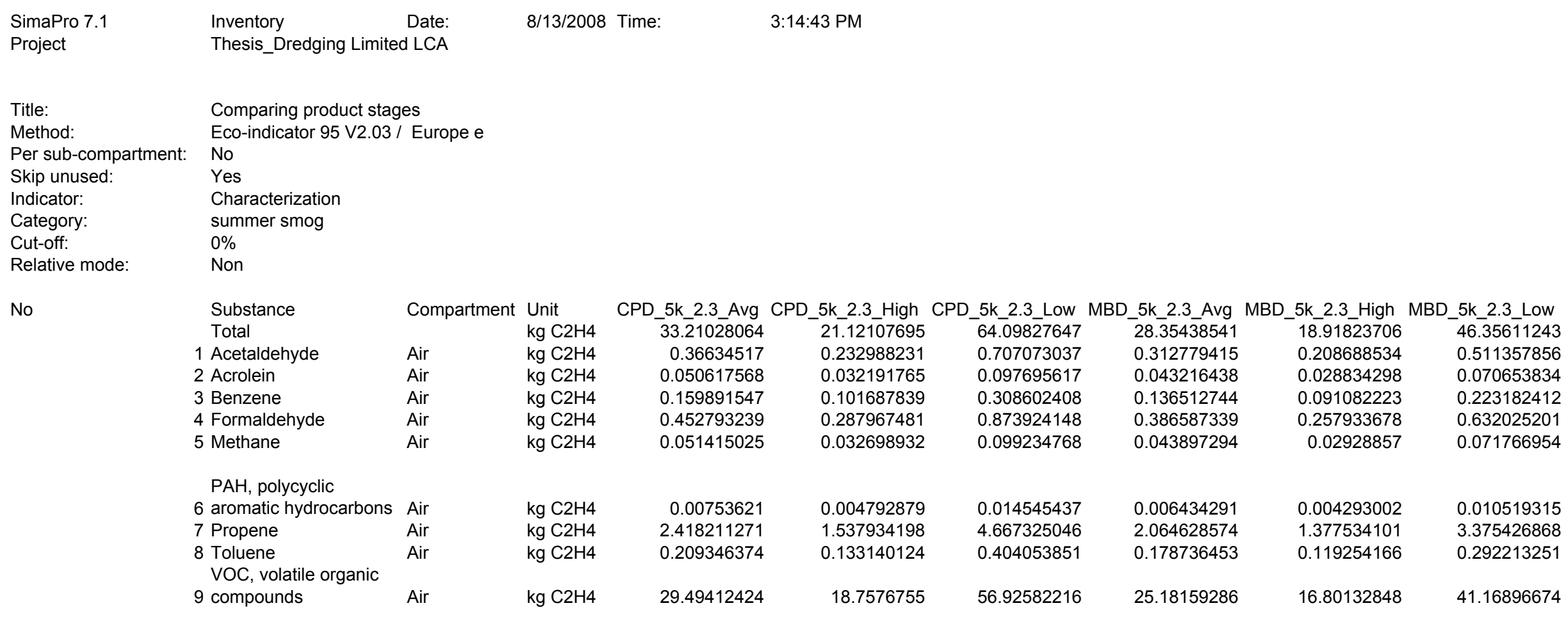




\begin{tabular}{|c|c|c|c|c|c|c|c|c|c|}
\hline $\begin{array}{l}\text { SimaPro } 7.1 \\
\text { Project }\end{array}$ & $\begin{array}{l}\text { Inventory } \\
\text { Thesis_Dredging Limite }\end{array}$ & $\begin{array}{l}\text { Date: } \\
\text { d LCA }\end{array}$ & $8 / 13 / 2008$ & Time: & 3:18:25 PM & & & & \\
\hline $\begin{array}{l}\text { Title: } \\
\text { Method: } \\
\text { Per sub-compartment: } \\
\text { Skip unused: } \\
\text { Indicator: } \\
\text { Category: } \\
\text { Cut-off: } \\
\text { Relative mode: }\end{array}$ & $\begin{array}{l}\text { Comparing product stag } \\
\text { Eco-indicator } 95 \mathrm{~V} 2.03 \text { / } \\
\text { No } \\
\text { Yes } \\
\text { Characterization } \\
\text { summer smog } \\
0 \% \\
\text { Non }\end{array}$ & Europe e & & & & & & & \\
\hline No & $\begin{array}{l}\text { Substance } \\
\text { Total } \\
1 \text { Acetaldehyde } \\
2 \text { Acrolein } \\
3 \text { Benzene } \\
4 \text { Formaldehyde } \\
5 \text { Methane } \\
\\
\text { PAH, polycyclic } \\
6 \text { aromatic hydrocarbons } \\
7 \text { Propene } \\
8 \text { Toluene } \\
\text { VOC, volatile organic } \\
9 \text { compounds }\end{array}$ & $\begin{array}{l}\text { Compartment } \\
\text { Air } \\
\text { Air } \\
\text { Air } \\
\text { Air } \\
\text { Air }\end{array}$ & $\begin{array}{l}\text { Unit } \\
\text { kg C2H4 } \\
\text { kg C2H4 } \\
\text { kg C2H4 } \\
\text { kg C2H4 } \\
\text { kg C2H4 } \\
\text { kg C2H4 } \\
\\
\text { kg C2H4 } \\
\text { kg C2H4 } \\
\text { kg C2H4 } \\
\text { kg C2H4 }\end{array}$ & $\begin{array}{r}\text { CPD_5k_3.0_Avg } \\
42.42821232 \\
0.468028886 \\
0.064667111 \\
0.20427146 \\
0.578471706 \\
0.065685913 \\
\\
\\
0.00962798 \\
3.089416267 \\
0.267453097\end{array}$ & $\begin{array}{r}\text { CPD_5k_3.0_High } \\
26.33760394 \\
0.290532143 \\
0.040142553 \\
0.12680291 \\
0.359090281 \\
0.040774981 \\
\\
\\
0.005976634 \\
1.917776348 \\
0.166023345\end{array}$ & $\begin{array}{r}\text { CPD_5k_3.0_Low } \\
83.52874845 \\
0.921412074 \\
0.12731064 \\
0.402150796 \\
1.138841703 \\
0.129316363\end{array}$ & $\begin{array}{r}\text { MBD_5k_3.0_Avg } \\
29.10321315 \\
0.321039791 \\
0.044357766 \\
0.14011799 \\
0.396796953 \\
0.045056603\end{array}$ & $\begin{array}{r}\text { MBD_5k_3.0_High I } \\
19.6670648 \\
0.21694891 \\
0.029975627 \\
0.094687469 \\
0.268143292 \\
0.03044788\end{array}$ & $\begin{array}{r}\text { MBD_5k_3.0_Low } \\
47.10494018 \\
0.519618232 \\
0.071795162 \\
0.226787657 \\
0.642234815 \\
0.072926264\end{array}$ \\
\hline
\end{tabular}




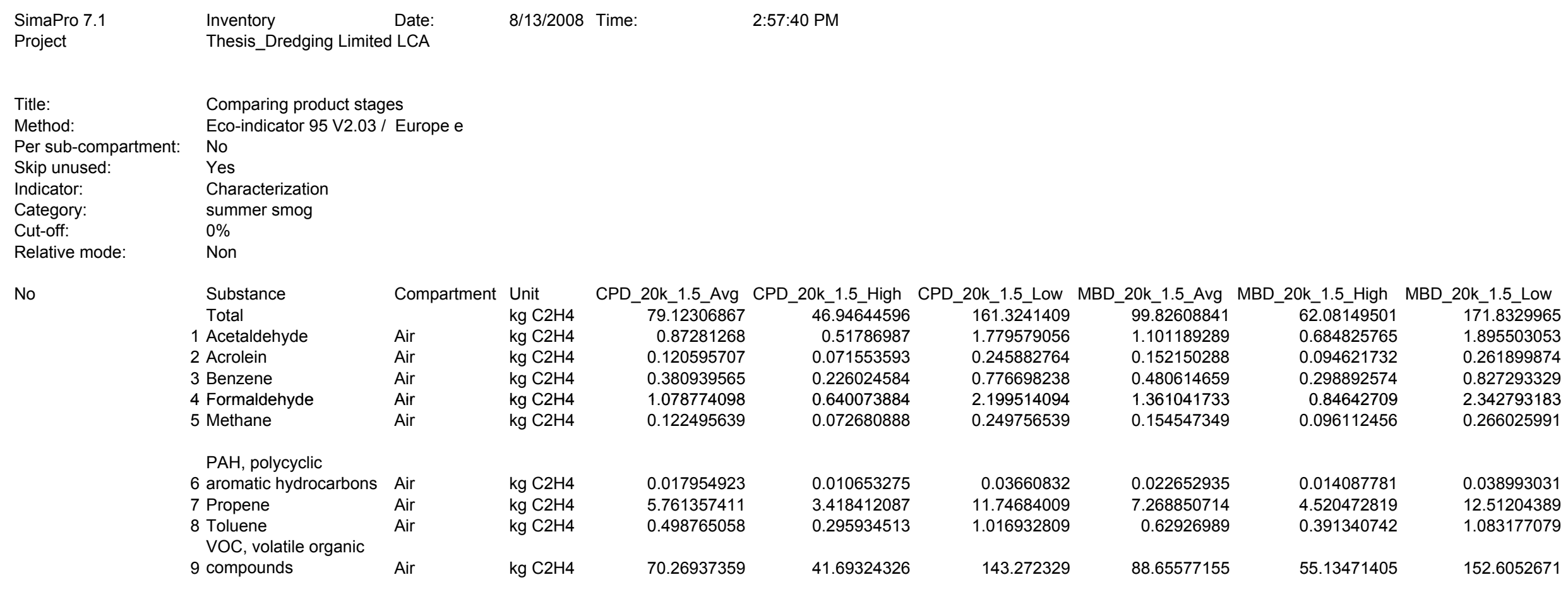




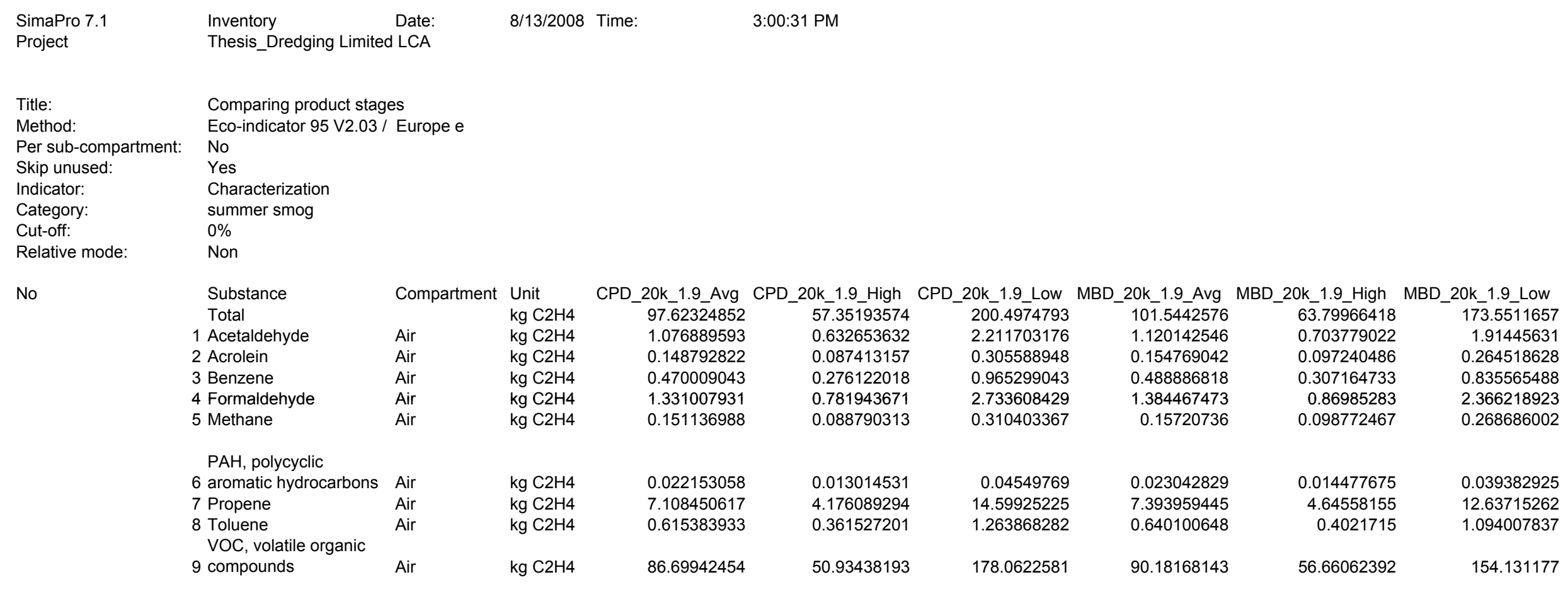




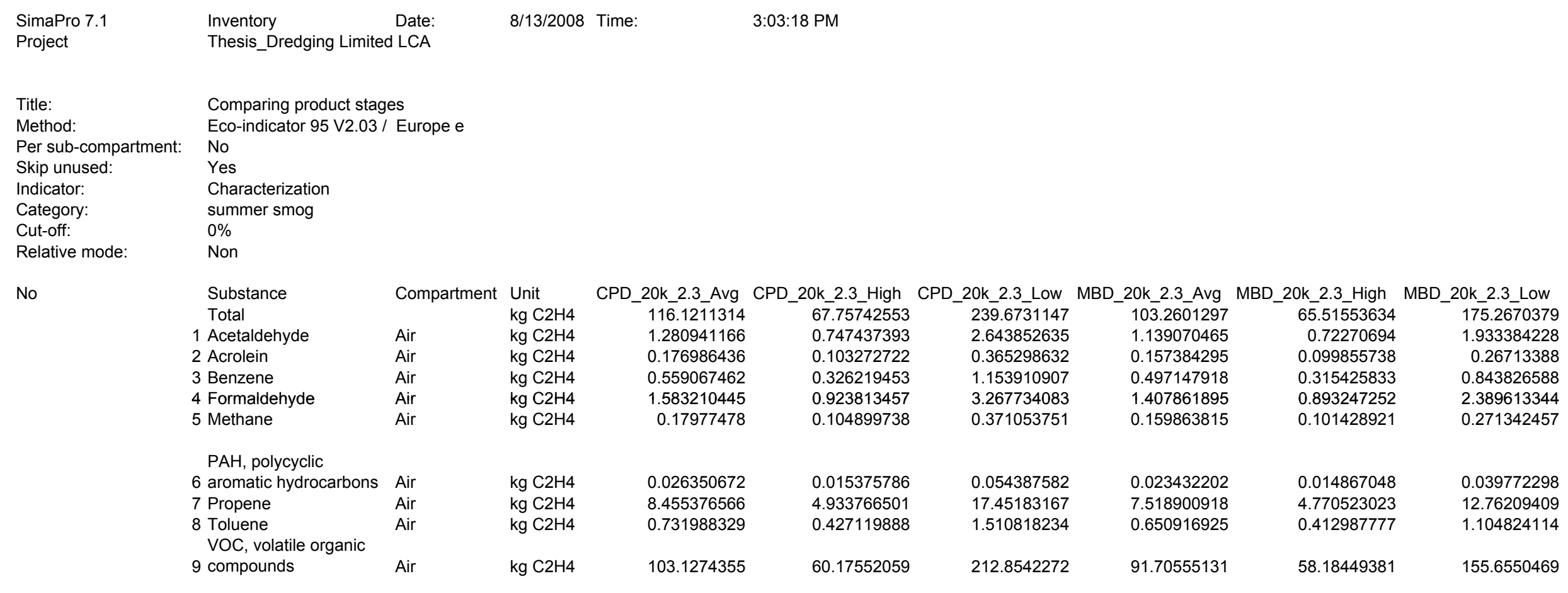




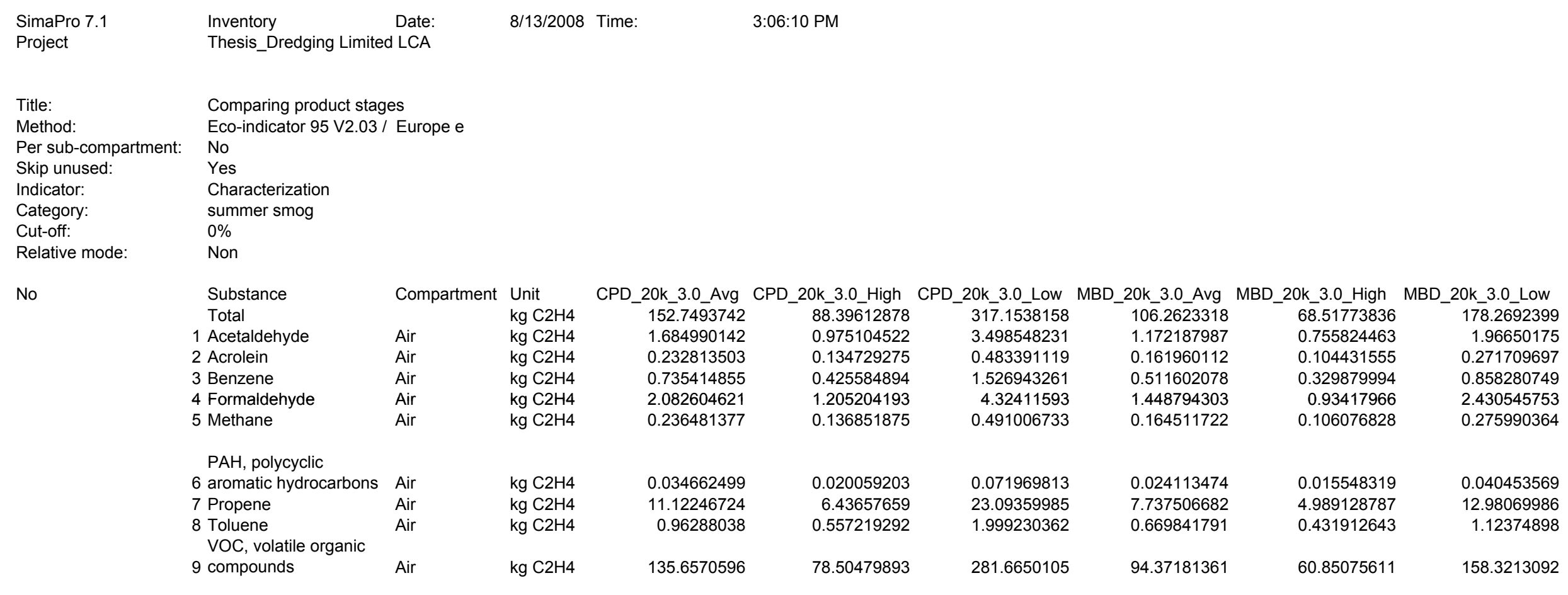




\begin{tabular}{|c|c|c|c|c|c|c|c|c|c|}
\hline $\begin{array}{l}\text { SimaPro } 7.1 \\
\text { Project }\end{array}$ & $\begin{array}{l}\text { Inventory } \\
\text { Thesis_Dredging Limite }\end{array}$ & $\begin{array}{l}\text { Date: } \\
\text { d LCA }\end{array}$ & 8/13/2008 & Time: & 2:28:13 PM & & & & \\
\hline $\begin{array}{l}\text { Title: } \\
\text { Method: } \\
\text { Per sub-compartment: } \\
\text { Skip unused: } \\
\text { Indicator: } \\
\text { Category: } \\
\text { Cut-off: } \\
\text { Relative mode: }\end{array}$ & $\begin{array}{l}\text { Comparing product stag } \\
\text { Eco-indicator } 95 \mathrm{~V} 2.03 \\
\text { No } \\
\text { Yes } \\
\text { Characterization } \\
\text { summer smog } \\
0 \% \\
\text { Non }\end{array}$ & / Europe e & & & & & & & \\
\hline No & $\begin{array}{l}\text { Substance } \\
\text { Total } \\
1 \text { Acetaldehyde } \\
2 \text { Acrolein } \\
3 \text { Benzene } \\
4 \text { Formaldehyde } \\
5 \text { Methane } \\
\text { PAH, polycyclic } \\
6 \text { aromatic hydrocarbons } \\
7 \text { Propene } \\
8 \text { Toluene } \\
\text { VOC, volatile organic } \\
9 \text { compounds }\end{array}$ & $\begin{array}{l}\text { Compartment } \\
\text { Air } \\
\text { Air } \\
\text { Air } \\
\text { Air } \\
\text { Air }\end{array}$ & $\begin{array}{l}\text { Unit } \\
\text { kg C2H4 } \\
\text { kg C2H4 } \\
\text { kg C2H4 } \\
\text { kg C2H4 } \\
\text { kg C2H4 } \\
\text { kg C2H4 } \\
\\
\text { kg C2H4 } \\
\text { kg C2H4 } \\
\text { kg C2H4 }\end{array}$ & $\begin{array}{r}\text { CPD_100k_1.5_Avg } \\
373.3181934 \\
4.118101818 \\
0.568994255 \\
1.797347757 \\
5.089868281 \\
0.577958509 \\
\\
\\
0.084714858 \\
27.18321693 \\
2.353271599\end{array}$ & $\begin{array}{r}\text { CPD_100k_1.5_High } \\
212.4304858 \\
2.343337092 \\
0.323776682 \\
1.022750736 \\
2.896304575 \\
0.328877641 \\
\\
\\
0.048205576 \\
15.4681558 \\
1.339089918\end{array}$ & $\begin{array}{r}\text { CPD_100k_1.5_Low } \\
784.3258518 \\
8.651959034 \\
1.195433042 \\
3.776152182 \\
10.69359958 \\
1.214266565\end{array}$ & $\begin{array}{r}\text { MBD_100k_1.5_Avg } \\
485.5987113 \\
5.356676881 \\
0.740127006 \\
2.337924511 \\
6.620715308 \\
0.751787382\end{array}$ & $\begin{array}{r}\text { MBD_100k_1.5_High } \\
296.8757443 \\
3.274859259 \\
0.452484224 \\
1.429314088 \\
4.047642094 \\
0.459612914\end{array}$ & $\begin{array}{r}\text { MBD_100k_1.5_Low } \\
845.6286578 \\
9.328195021 \\
1.288867933 \\
4.071295743 \\
11.52940992 \\
3 \\
1.30917348\end{array}$ \\
\hline
\end{tabular}




\begin{tabular}{|c|c|c|c|c|c|c|c|c|c|}
\hline $\begin{array}{l}\text { SimaPro } 7.1 \\
\text { Project }\end{array}$ & $\begin{array}{l}\text { Inventory } \\
\text { Thesis_Dredging Limite }\end{array}$ & $\begin{array}{l}\text { Date: } \\
\text { d LCA }\end{array}$ & 8/13/2008 & Time: & 2:31:49 PM & & & & \\
\hline $\begin{array}{l}\text { Title: } \\
\text { Method: } \\
\text { Per sub-compartment: } \\
\text { Skip unused: } \\
\text { Indicator: } \\
\text { Category: } \\
\text { Cut-off: } \\
\text { Relative mode: }\end{array}$ & $\begin{array}{l}\text { Comparing product stag } \\
\text { Eco-indicator } 95 \mathrm{~V} 2.03 / \\
\text { No } \\
\text { Yes } \\
\text { Characterization } \\
\text { summer smog } \\
0 \% \\
\text { Non }\end{array}$ & / Europe e & & & & & & & \\
\hline No & $\begin{array}{l}\text { Substance } \\
\text { Total } \\
1 \text { Acetaldehyde } \\
2 \text { Acrolein } \\
3 \text { Benzene } \\
4 \text { Formaldehyde } \\
5 \text { Methane }\end{array}$ & $\begin{array}{l}\text { Compartment } \\
\text { Air } \\
\text { Air } \\
\text { Air } \\
\text { Air } \\
\text { Air }\end{array}$ & $\begin{array}{l}\text { Unit } \\
\text { kg C2H4 } \\
\text { kg C2H4 } \\
\text { kg C2H4 } \\
\text { kg C2H4 } \\
\text { kg C2H4 } \\
\text { kg C2H4 }\end{array}$ & $\begin{array}{r}\text { CPD_100k_1.9_Avg } \\
465.8122016 \\
5.138410364 \\
0.709969327 \\
2.242661972 \\
6.350943489 \\
0.721154582\end{array}$ & $\begin{array}{r}\text { CPD_100k_1.9_High } \\
264.4579347 \\
2.917255898 \\
0.403074504 \\
1.273237909 \\
3.605653508 \\
0.409424765\end{array}$ & $\begin{array}{r}\text { CPD_100k_1.9_Low } \\
980.1925436 \\
10.81257964 \\
1.493963959 \\
4.719156208 \\
13.36407125 \\
1.517500704\end{array}$ & $\begin{array}{rr}\text { MBD_100k_1.9_Avg } \\
494.1803691 \\
5.451341811 \\
0.753206771 \\
2.379241071 \\
6.737718735 \\
0.765073212\end{array}$ & $\begin{array}{r}\text { MBD_100k_1.9_High } \\
305.4574021 \\
3.369524189 \\
0.465563988 \\
1.470630648 \\
4.164645521 \\
0.472898744\end{array}$ & $\begin{array}{rr}\text { MBD_100k_1.9_Low } \\
854.2103156 \\
9.422859951 \\
1.301947697 \\
3.112612303 \\
11.64641335 \\
1.322459311\end{array}$ \\
\hline & $\begin{array}{l}\text { PAH, polycyclic } \\
6 \text { aromatic hydrocarbons } \\
7 \text { Propene } \\
8 \text { Toluene } \\
\text { VOC, volatile organic } \\
9 \text { compounds }\end{array}$ & $\begin{array}{l}\text { Air } \\
\text { Air } \\
\text { Air }\end{array}$ & $\begin{array}{l}\mathrm{kg} \mathrm{C} 2 \mathrm{H} 4 \\
\mathrm{~kg} \mathrm{C} 2 \mathrm{H} 4 \\
\mathrm{~kg} \mathrm{C} 2 \mathrm{H} 4\end{array}$ & $\begin{array}{l}0.105703969 \\
33.91818119 \\
2.936322536\end{array}$ & $\begin{array}{l}0.060011853 \\
19.25654183 \\
1.667053355\end{array}$ & $\begin{array}{l}0.222429214 \\
71.37285838 \\
6.178802198\end{array}$ & $\begin{array}{l}0.112141387 \\
35.98381331 \\
3.115145867\end{array}$ & $\begin{array}{l}0.069315616 \\
22.24192384 \\
1.925500127\end{array}$ & $\begin{array}{l}0.193840823 \\
62.19944467 \\
5.384652852\end{array}$ \\
\hline
\end{tabular}




\begin{tabular}{|c|c|c|c|c|c|c|c|c|c|}
\hline $\begin{array}{l}\text { SimaPro } 7.1 \\
\text { Project }\end{array}$ & $\begin{array}{l}\text { Inventory } \\
\text { Thesis_Dredging Limite }\end{array}$ & $\begin{array}{l}\text { Date: } \\
\text { d LCA }\end{array}$ & $8 / 13 / 2008$ & Time: & 2:37:01 PM & & & & \\
\hline $\begin{array}{l}\text { Title: } \\
\text { Method: } \\
\text { Per sub-compartment: } \\
\text { Skip unused: } \\
\text { Indicator: } \\
\text { Category: } \\
\text { Cut-off: } \\
\text { Relative mode: }\end{array}$ & $\begin{array}{l}\text { Comparing product stag } \\
\text { Eco-indicator } 95 \mathrm{~V} 2.03 / \\
\text { No } \\
\text { Yes } \\
\text { Characterization } \\
\text { summer smog } \\
0 \% \\
\text { Non }\end{array}$ & / Europe e & & & & & & & \\
\hline No & $\begin{array}{l}\text { Substance } \\
\text { Total } \\
1 \text { Acetaldehyde } \\
2 \text { Acrolein } \\
3 \text { Benzene } \\
4 \text { Formaldehyde } \\
5 \text { Methane }\end{array}$ & $\begin{array}{l}\text { Compartment } \\
\text { Air } \\
\text { Air } \\
\text { Air } \\
\text { Air } \\
\text { Air }\end{array}$ & $\begin{array}{l}\text { Unit } \\
\text { kg C2H4 } \\
\text { kg C2H4 } \\
\text { kg C2H4 } \\
\text { kg C2H4 } \\
\text { kg C2H4 } \\
\text { kg C2H4 }\end{array}$ & $\begin{array}{r}\text { CPD_100k_2.3_Avg } \\
558.3039128 \\
6.158693572 \\
0.850940898 \\
2.687965128 \\
7.611987379 \\
0.864347098\end{array}$ & $\begin{array}{r}\text { CPD_100k_2.3_High } \\
316.4853836 \\
3.491174705 \\
0.482372325 \\
1.523725081 \\
4.31500244 \\
0.489971889\end{array}$ & $\begin{array}{r}\text { CPD_100k_2.3_Low } \\
1176.061532 \\
12.97322558 \\
1.792498376 \\
5.662171293 \\
16.03457425 \\
1.8207384\end{array}$ & $\begin{array}{r}\text { MBD_100k_2.3_Avg } \\
502.7620269 \\
5.54600674 \\
0.766286535 \\
2.42055763 \\
6.854722161 \\
0.778359043\end{array}$ & $\begin{array}{r}\text { MBD_100k_2.3_High } \\
314.0390599 \\
3.464189119 \\
0.478643752 \\
1.511947207 \\
4.281648947 \\
0.486184574\end{array}$ & $\begin{array}{rr}\text { MBD_100k_2.3_Low } \\
862.7919734 \\
9.517524881 \\
1.315027461 \\
4.153928862 \\
11.76341677 \\
1.335745141\end{array}$ \\
\hline & $\begin{array}{l}\text { PAH, polycyclic } \\
6 \text { aromatic hydrocarbons } \\
7 \text { Propene } \\
8 \text { Toluene } \\
\text { VOC, volatile organic } \\
9 \text { compounds }\end{array}$ & $\begin{array}{l}\text { Air } \\
\text { Air } \\
\text { Air }\end{array}$ & $\begin{array}{l}\mathrm{kg} \mathrm{C} 2 \mathrm{H} 4 \\
\mathrm{~kg} \mathrm{C} 2 \mathrm{H} 4 \\
\mathrm{~kg} \mathrm{C} 2 \mathrm{H} 4\end{array}$ & $\begin{array}{l}0.126692558 \\
40.65297819 \\
3.519358993\end{array}$ & $\begin{array}{r}0.07181813 \\
23.04492787 \\
1.995016792\end{array}$ & $\begin{array}{l}0.266876589 \\
85.63508644 \\
7.413494041\end{array}$ & $\begin{array}{l}0.114088771 \\
36.60868794 \\
3.169241734\end{array}$ & $\begin{array}{r}0.071263 \\
22.86679846 \\
1.979595995\end{array}$ & $\begin{array}{r}0.195788207 \\
62.8243193 \\
5.43874872\end{array}$ \\
\hline
\end{tabular}




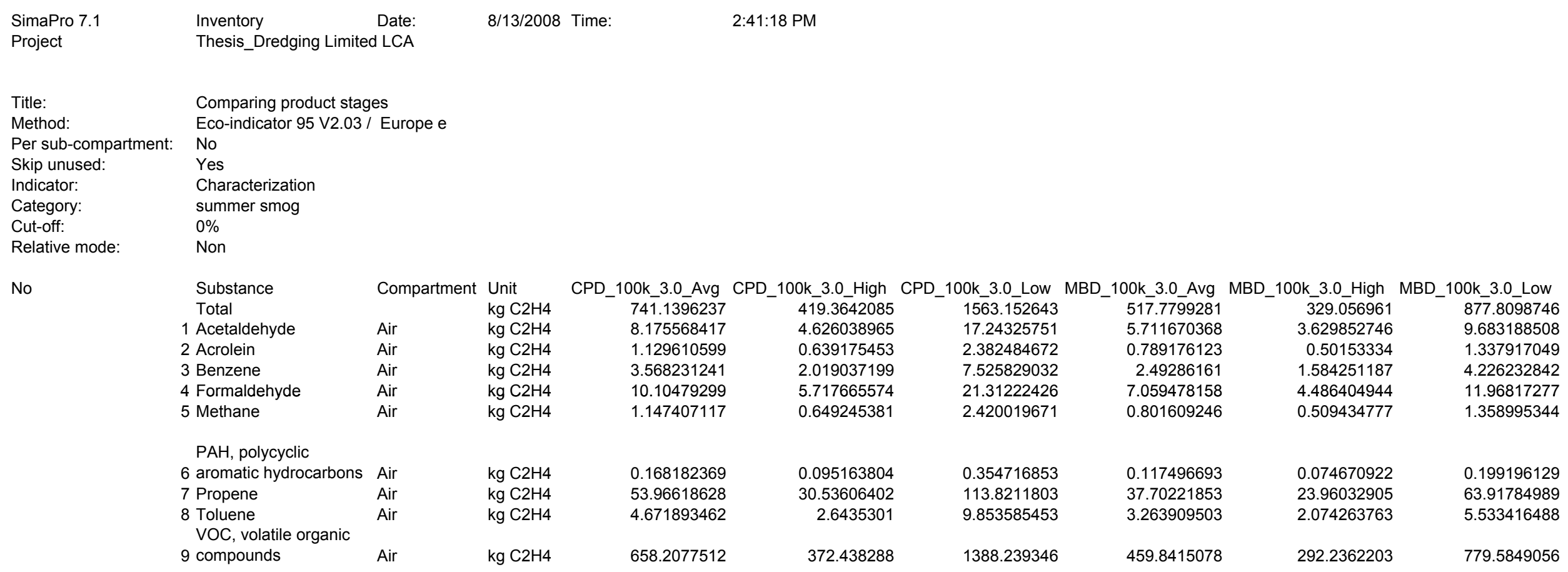




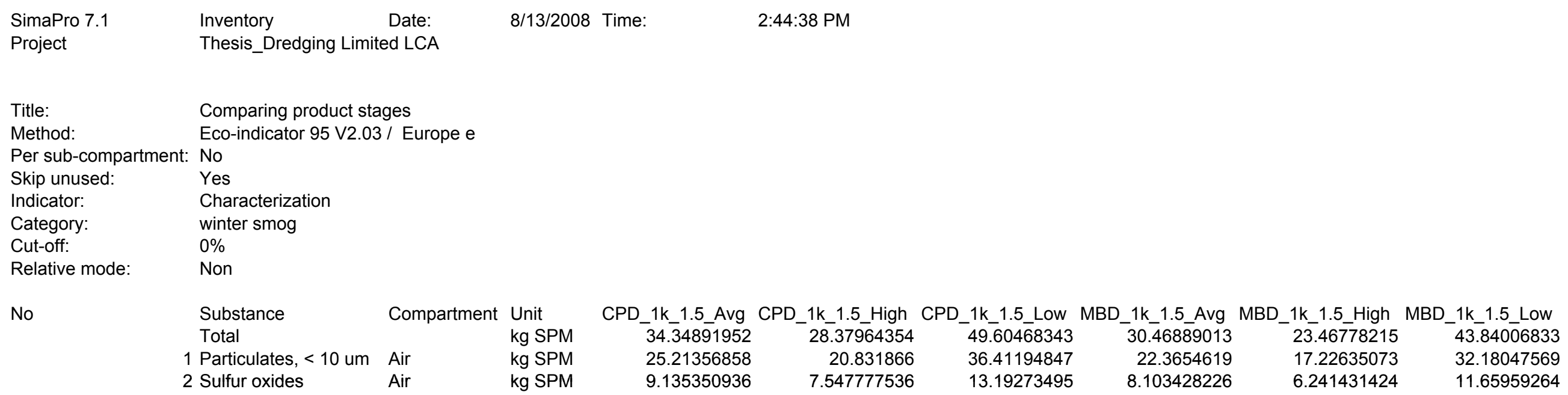

CPD 1k_1.5 Avg CPD 1k 1.5 High CPD 1k 1.5 Low MBD 1k 1.5 Avg MBD 1k 1.5 High MBD_1k_1.5 Low

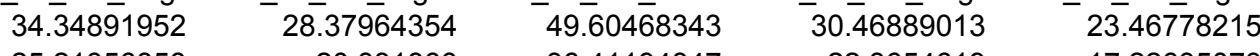
23.46778215
17.22635073 43.84006833 25.21356858 22.3654619 17.22635073

7.547777536

13.19273495

8.103428226

6.241431424

11.65959264 


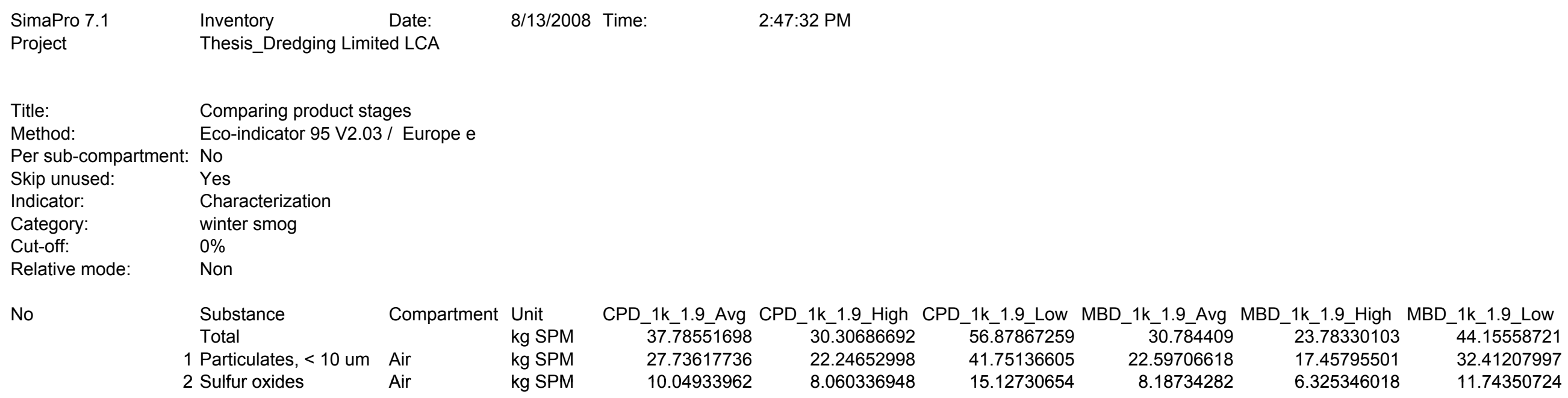

Substance Compartment Unit

Total

1 Particulates, $<10$ um Air

2 Sulfur oxides

$\mathrm{kg}$ SPM

kg SPM

$\mathrm{kg}$ SPM

CPD_1k_1.9_Avg CPD_1k 37.78551698
27.73617736 27.73617736 10.04933962

\subsection{24652998 \\ 8.060336948}

30.30686692
56.87867259
41.75136605

15.12730654 30.784409 30.784409
22.59706618 8.18734282

MBD_1k_1.9_High MBD_1k_1.9_Low 23.78330103 17.45795501 6.325346018

44.15558721 32.41207997

11.74350724 


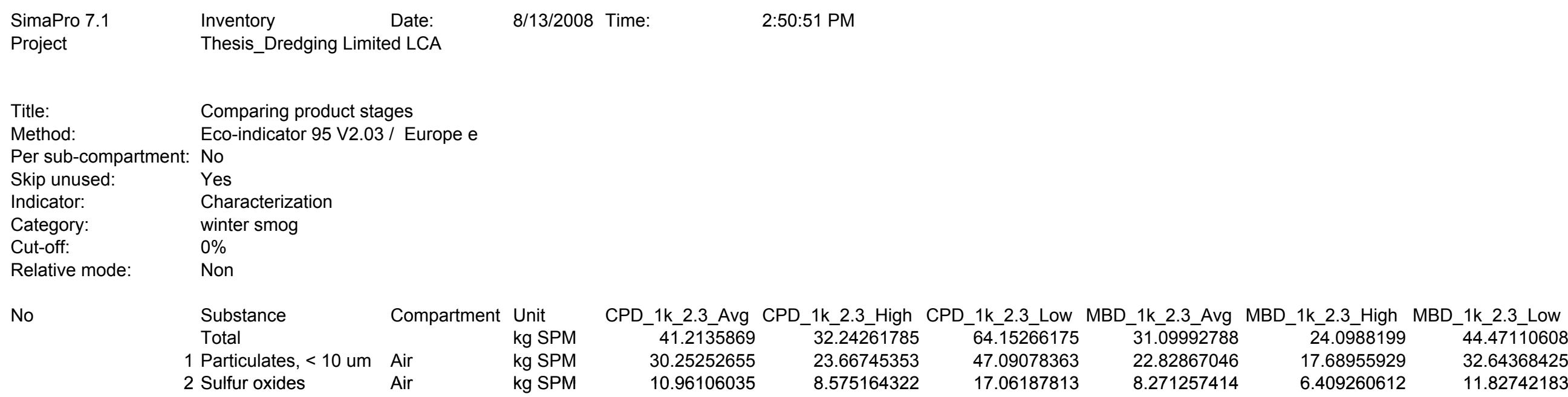

Substance Compartment Unit

Total

kg SPM

1 Particulates, < 10 um Air

$\mathrm{kg}$ SPM

CPD_1k_2.3_Avg

41.2135869

30.25252655

10.96106035
23.66745353
8.575164322

- 32.24261785

64.15266175

47.09078363

17.06187813

_1k_2.3_Avg

31.09992788
22.82867046

8.271257414

_1k_2.3_High

24.0988199

17.68955929

6.409260612

_1k 2.3_Low 44.47110608 32.64368425 11.82742183 


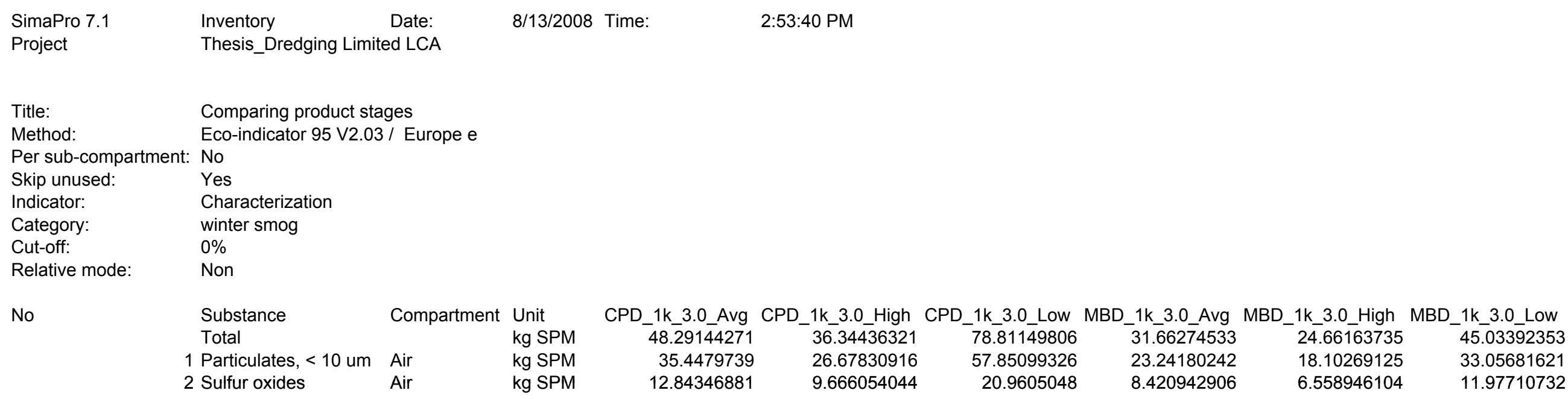

Substance Compartment Unit

Total

$\mathrm{kg} \mathrm{SPM}$

1 Particulates, $<10$ um Air $\quad$ kg SPM

2 Sulfur oxides Air $\quad$ kg SPM

35.4479739

PD_1k_3.0_High CPD 36.34436321

_ $1 \mathrm{k}$ _3.0_Low MBD

57.85099326

26.67830916

20.9605048

_1k_3.0_Avg

31.66274533

D_1k_3.0_High

24.66163735

18.10269125

8.420942906

6.558946104

Low 45.03392353 33.0568162 11.97710732 


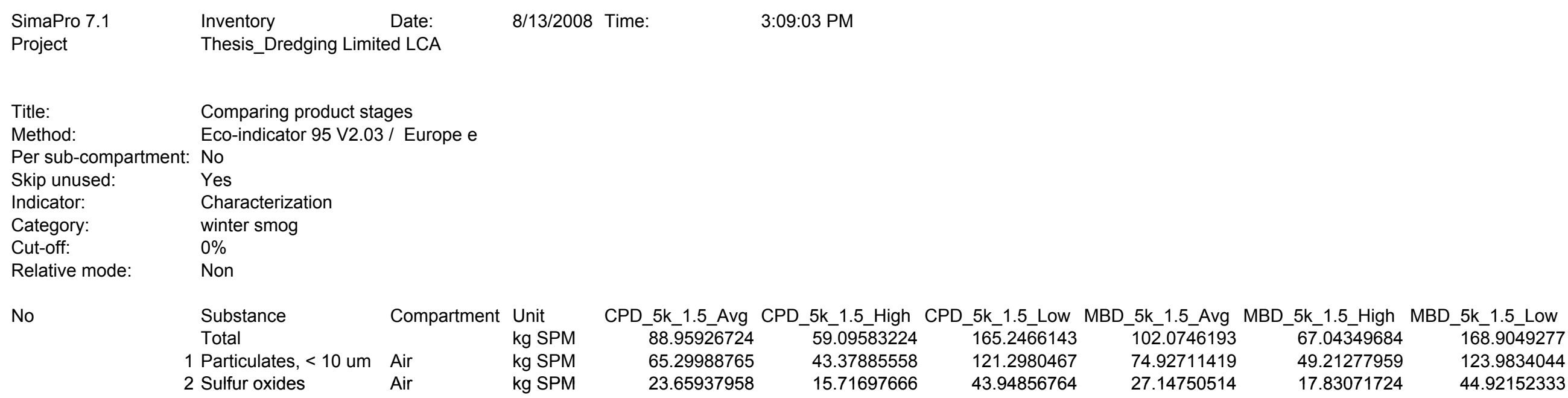

Substance Compartment Unit

Total

$\mathrm{kg}$ SPM

1 Particulates, $<10$ um Air kg SPM

2 Sulfur oxides Air $\quad$ kg SPM

CPD_5k_1.5_Avg CPD 5k 88.95926724

65.29988765

23.65937958

59.0958322 PD_5k_1.5_Low MBD_5k_1.5_Avg MBD_5k_1.5_High MBD_5k_1.5_Low 49.21277959 168.9049277 43.37885558

121.2980467 74.92711419

17.83071724

123.9834044 44.92152333 


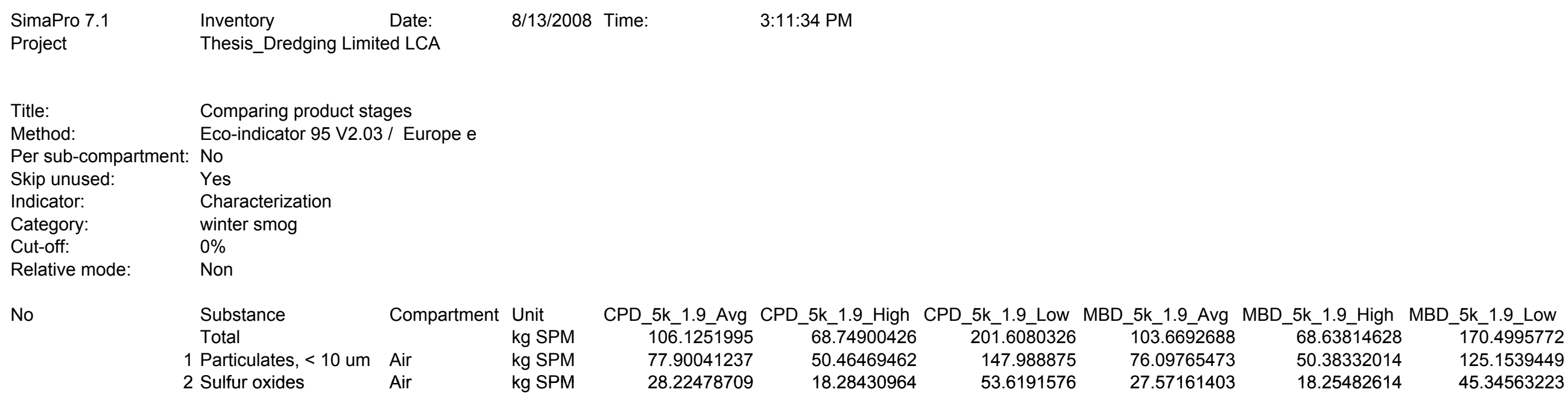

Substance Compartment Unit

Total

1 Particulates, < 10 um Air

2 Sulfur oxides

$\mathrm{kg}$ SPM

kg SPM

kg SPM

CPD_5k_1.9_Avg CPD_5k_1.9_High CPD_5 106.1251995
77.90041237 77.90041237 68.74900426 50.46469462 18.28430964

201.6080326

147.988875

53.6191576

5k_1.9_Avg 103.6692688 76.09765473 27.57161403

68.63814628

68.63814628
50.38332014

18.25482614

MBD_5k_1.9_Low 170.4995772 125.1539449 45.34563223 


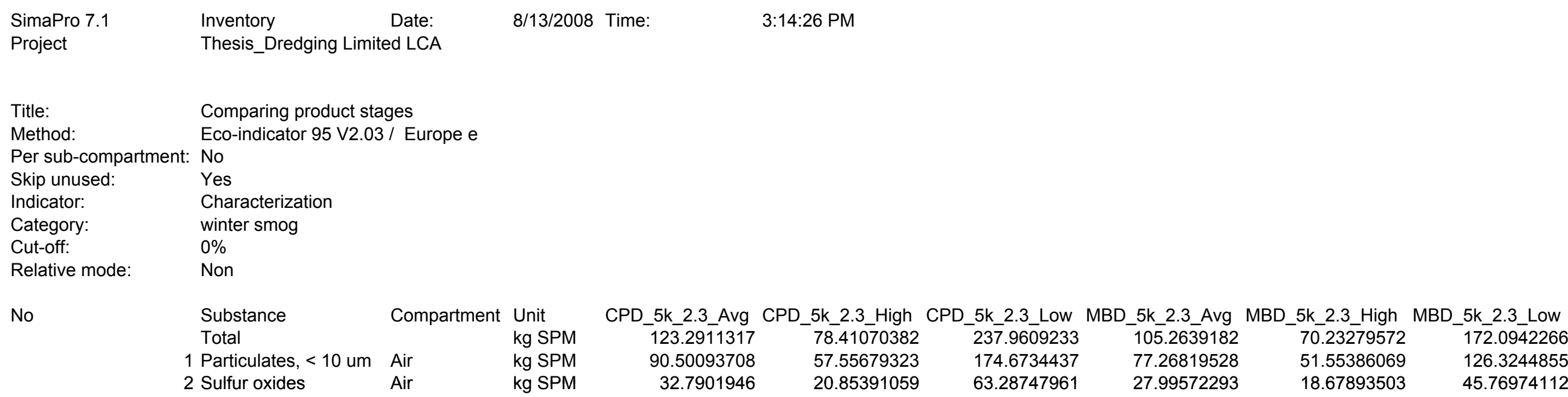

Substance

Total

1 Particulates, $<10$ um Air

2 Sulfur oxides

Compartment Unit

kg SPM

kg SPM

$\mathrm{kg}$ SPM

CPD_5k_2.3_Avg CPD_5k_2.3_High CPD 123.2911317
90.50093708 32.7901946

78.41070382

57.55679323

20.85391059

_5k_2.3_Low
237.9609233
174.6734437
63.28747961

_5k_2.3_Avg

105.2639182

77.26819528

27.99572293

70.23279572
51.55386069

51.55386069

18.67893503

$5 \mathrm{k} \_2.3$ Low 172.0942266 126.3244855 45.76974112 


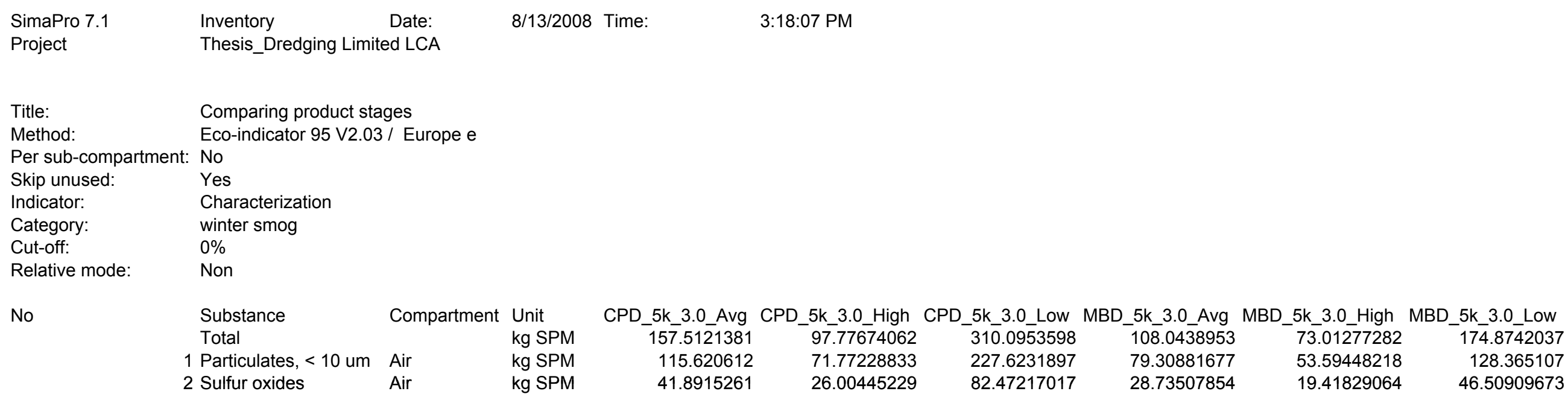

\section{Substance}

Total

1 Particulates, $<10$ um Air

2 Sulfur oxides

Compartment Unit

$\mathrm{kg}$ SPM

$\mathrm{kg}$ SPM

$\mathrm{kg}$ SPM

CPD 5k 3.0 Avg CPD 5k 3.0 High CPD 5k 3.0 Low MBD 5k 3.0 Avg MBD 5k 3.0 High MBD 5k_3.0_Low 157.5121381 97.77674062 310.0953598 227.6231897 108.0438953

79.30881677

28.73507854 $17 \overline{4} .8742037$

115.620612

26.00445229

82.47217017

128.365107

46.50909673 


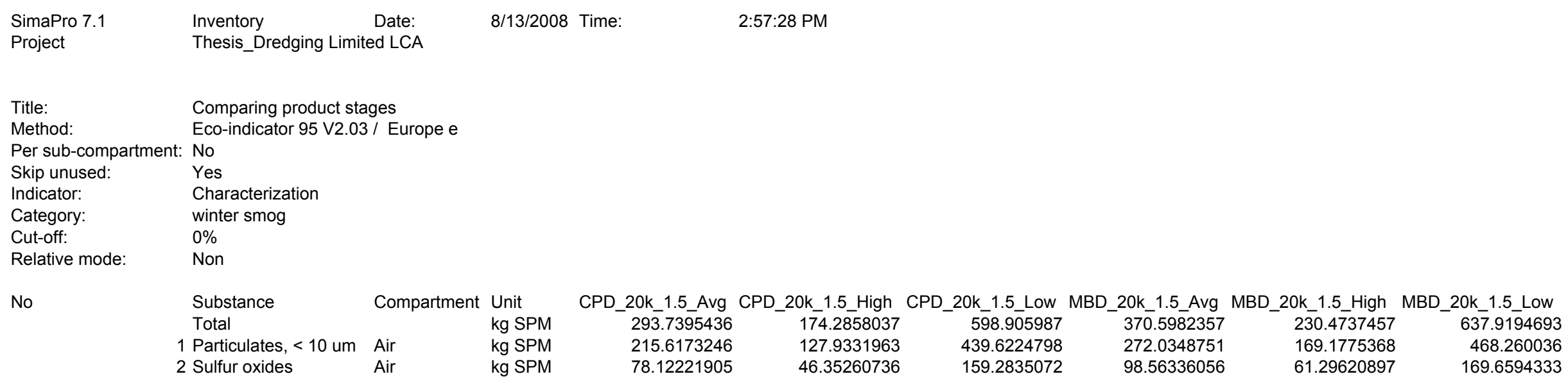

Substance Compartment Unit

$\mathrm{kg}$ SPM

1 Particulates, $<10$ um Air

2 Sulfur oxides

Air

CPD 20k 1.5 Avg CPD 20k 1.5 High CPD 293.7395436

215.6173246 174.2858037
127.9331963 46.35260736

598.905987
439.6224798

159.2835072

D_20k_1.5_Avg MBD_20

370.5982357

272.0348751

98.56336056

20k 1.5 High MBD 20k 1.5 Low 230.4737457 169.1775368

61.29620897 $63 \overline{7} .9194693$ 468.260036 169.6594333 


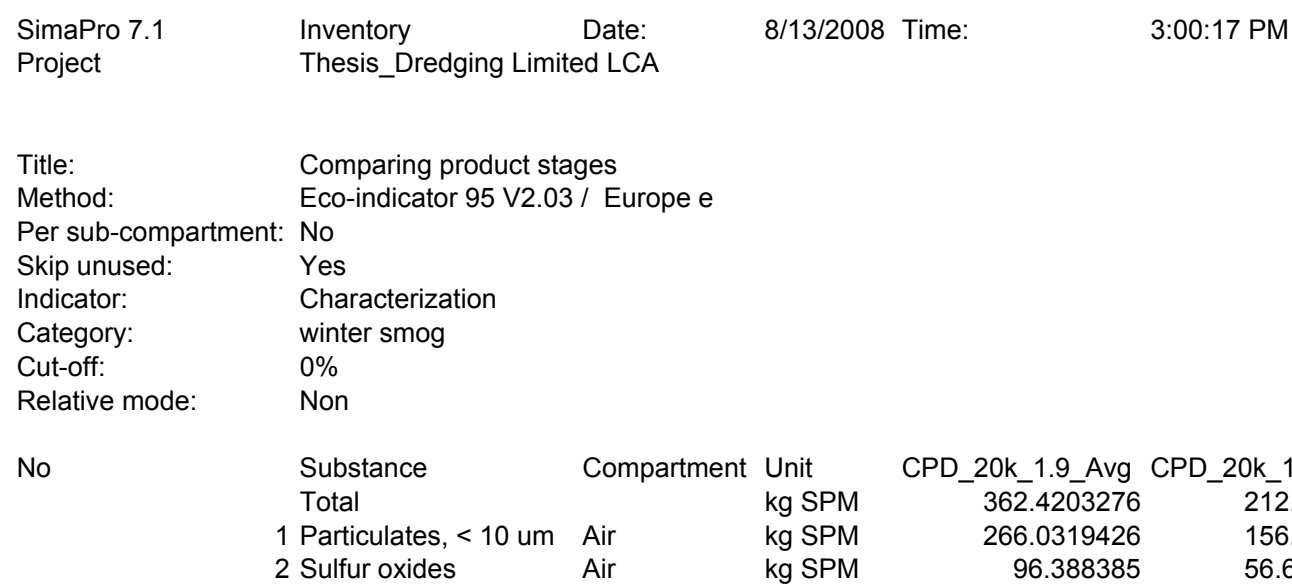

Substance Total

kg SPM

$\mathrm{kg}$ SPM

1 Particulates, $<10$ um Air

kg SPM

CPD_

2 Sulfur oxides

Air

kg SPM 


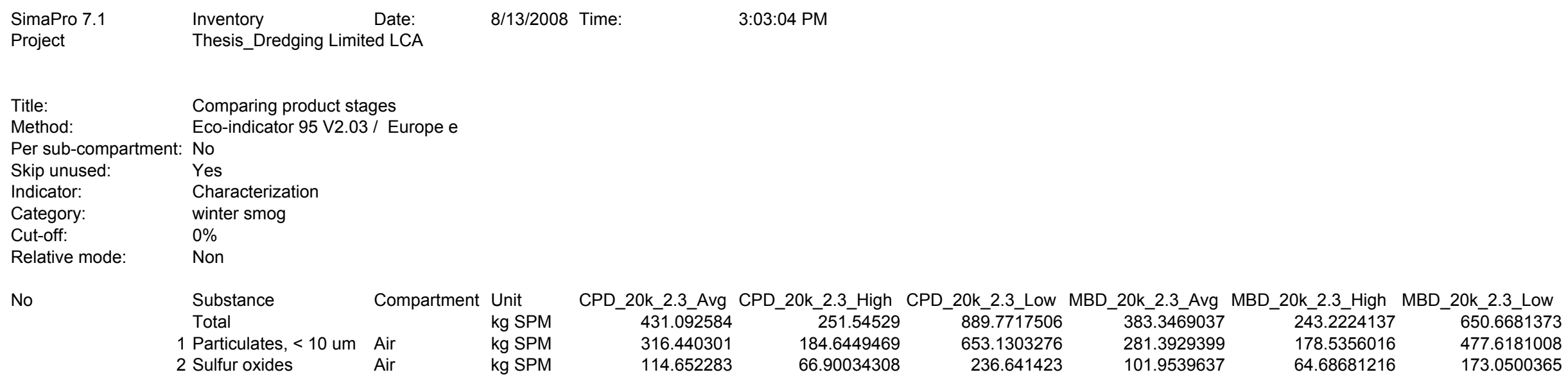

Indicator:

Characterization

Category:

Cut-off: winter smog

Relative mode:

$0 \%$

No

\section{Substance} Total

Compartment Unit

Particulates, $<10$ um Air

kg SPM

2 Sulfur oxides

Air

$\mathrm{kg}$ SPM

CPD_20k_2.3_Avg CPD_20k_2.3_High CPD 431.092584
316.440301 251.54529

251.54529
184.6449469 20k_2.3_Low MBD
889.7717506

114.652283

66.90034308

653.1303276
236.641423

383.3469037

20k 2.3 High MBD 20k 2.3 Low

101.9539637

243.2224137

178.5356016

650.6681373

477.6181008

173.0500365 


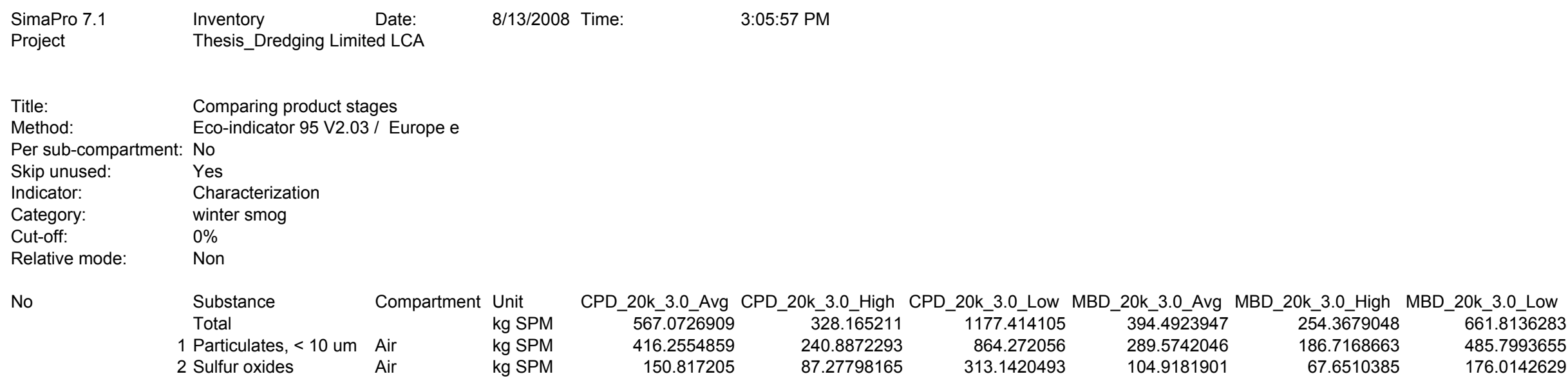

Compartment Unit

1 Particulates, $<10$ um Air

2 Sulfur oxides

$\mathrm{kg}$ SPM

kg SPM

CPD 20k 3.0 Avg CPD 20k 3.0 High CPD 567.0726909 416.2554859

150.817205

328.165211

240.8872293

87.27798165

1177.414105
864.272056

313.1420493

20k 3.0 Avg MBD 20k 3.0 High MBD 20k 3.0 Low $394.4923947 \quad 254.3679048 \quad-661.8136283$ 485.7993655
176.0142629 


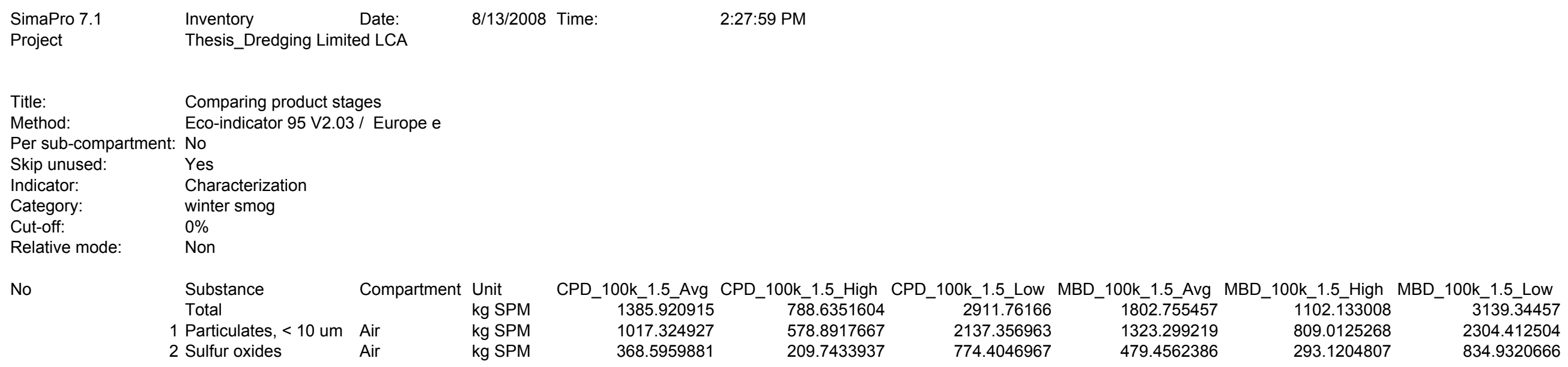

Substance Compartment Unit Total

1 Particulates, < 10 um Air

2 Sulfur oxides

kg SPM

$\mathrm{kg}$ SPM

kg SPM

CPD_100k_1.5_Avg CPD_100k_1.5_High CPD_100k_1.5_Low MBD_100k_1.5_Avg MBD_100k_1.5_High MBD_100k_1.5_Low $1385.920915-788.6351604-2911.76166 \quad 1802.755457$

368.5959881

578.8917667

37.356963

1323.299219

209.7433937

774.4046967

479.4562386

1102.133008

3139.34457

2304.412504

834.9320666 


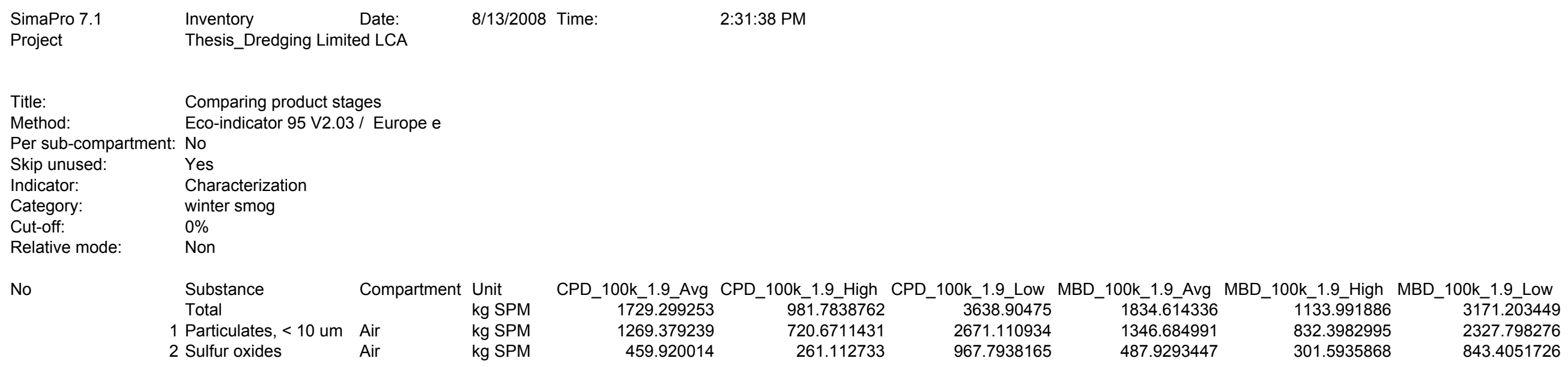

Substance Compartment Unit Total

1 Particulates, $<10$ um Air

2 Sulfur oxides

kg SPM

$\mathrm{kg}$ SPM

kg SPM

CPD_100k_1.9_Avg CPD_100k_1.9_High CPD_100k_1.9_Low MBD_100k_1.9_Avg MBD_100k_1.9_High MBD_100k_1.9_Low $\begin{array}{lllllr}17 \overline{2} 9.299253 & 981.7838762 & 3638.90475 & 1834.614336 & 1133.991886 & 3171.203449\end{array}$ $\begin{array}{llllll}1269.379239 & 720.6711431 & 2671.110934 & 1346.684991 & 832.3982995 & 2327.798276\end{array}$ $459.920014-367.7938165-487.9293447$ 843.4051726 


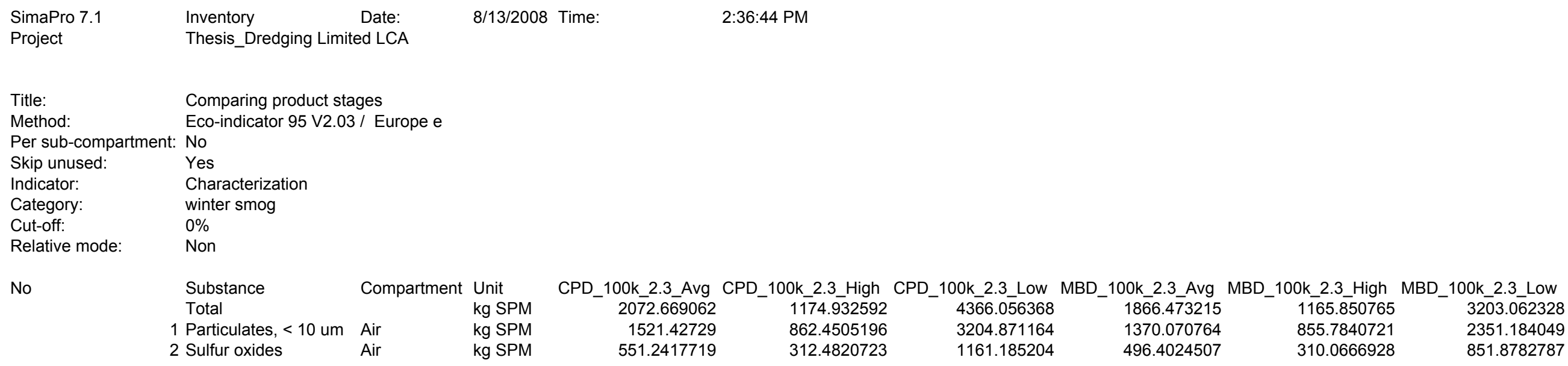

Substance Compartment Unit Total

1 Particulates, < 10 um Air

2 Sulfur oxides

$\mathrm{kg}$ SPM

$\mathrm{kg} S P M$

CPD_100k_2.3_Avg CPD_100k_2.3_High CPD_100k_2.3_Low MBD_100k_2.3_Avg MBD_100k_2.3_High MBD_100k_2.3_Low $20 \overline{7} 2.669062-1174 . \overline{3} 2592-4366.056368-18 \overline{6} 6.4 \overline{7} 3215 \quad-1165.850765$ $1521.42729-\quad 862.4505196$

$551.2417719 \quad 312.4820723$

1370.070764

496.4024507

855.7840721

310.0666928 


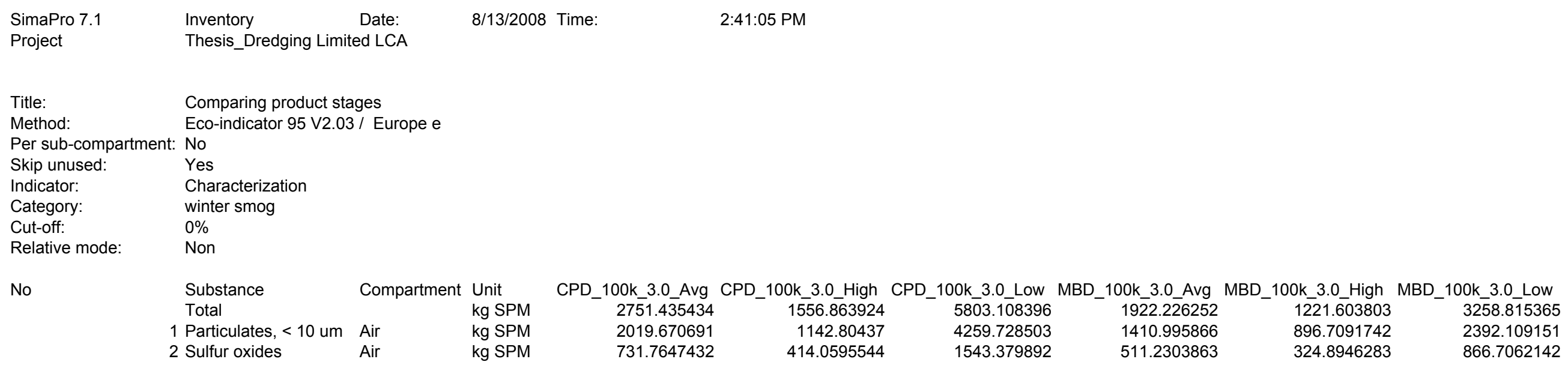

Substance Compartment Unit Total

1 Particulates, < 10 um Air $\quad$ kg SPM

2 Sulfur oxides

Air

$\mathrm{kg}$ SPM

$\mathrm{kg}$ SPM

CPD_100k_3.0_Avg CPD_100k_3.0_High CPD_100k_3.0_Low MBD_100 $27 \overline{51} .435434$

2019.670691

1556.863924

5803.108396

4259.728503

414.0595544

1543.379892

1922.226252

1410.995866

511.2303863

731.7647432

1221.603803

896.7091742

324.8946283

_100k_3.0_Low

3258.815365

2392.109151

866.7062142 


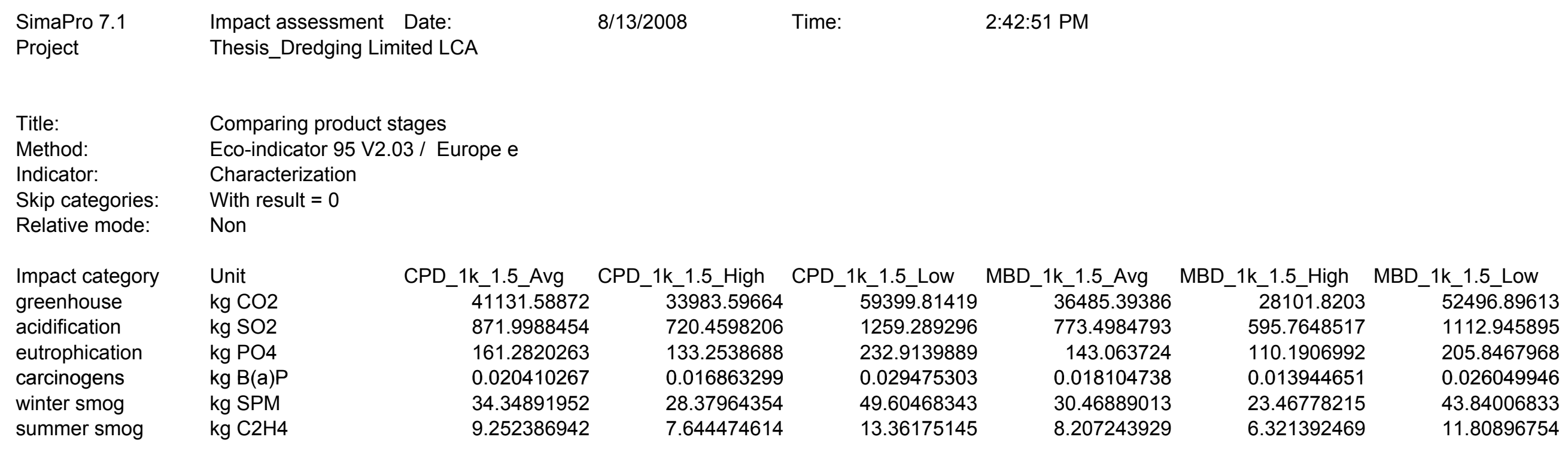




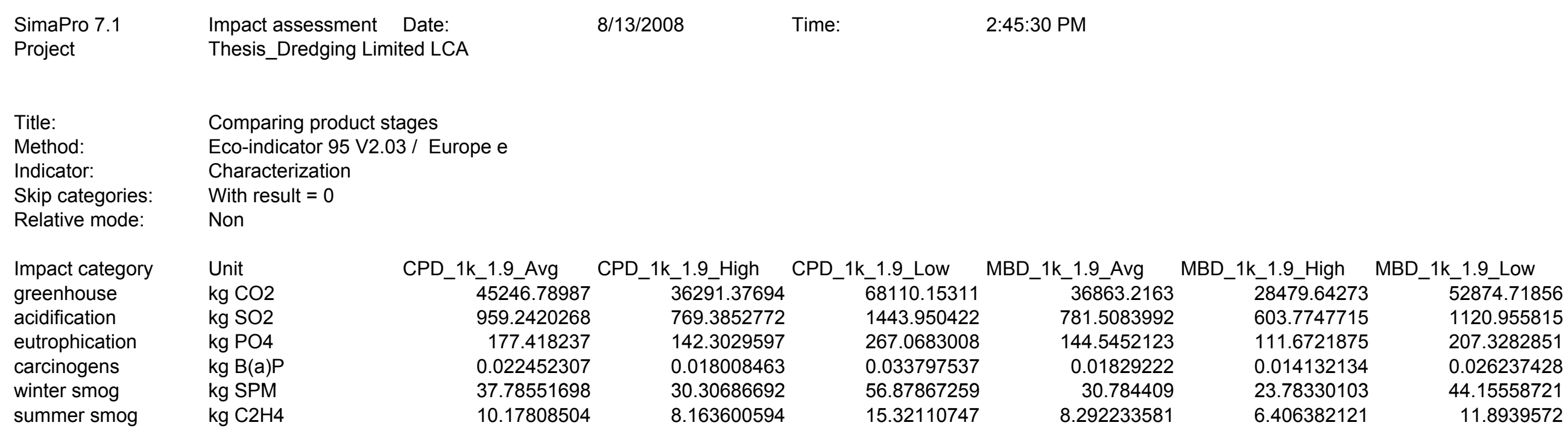




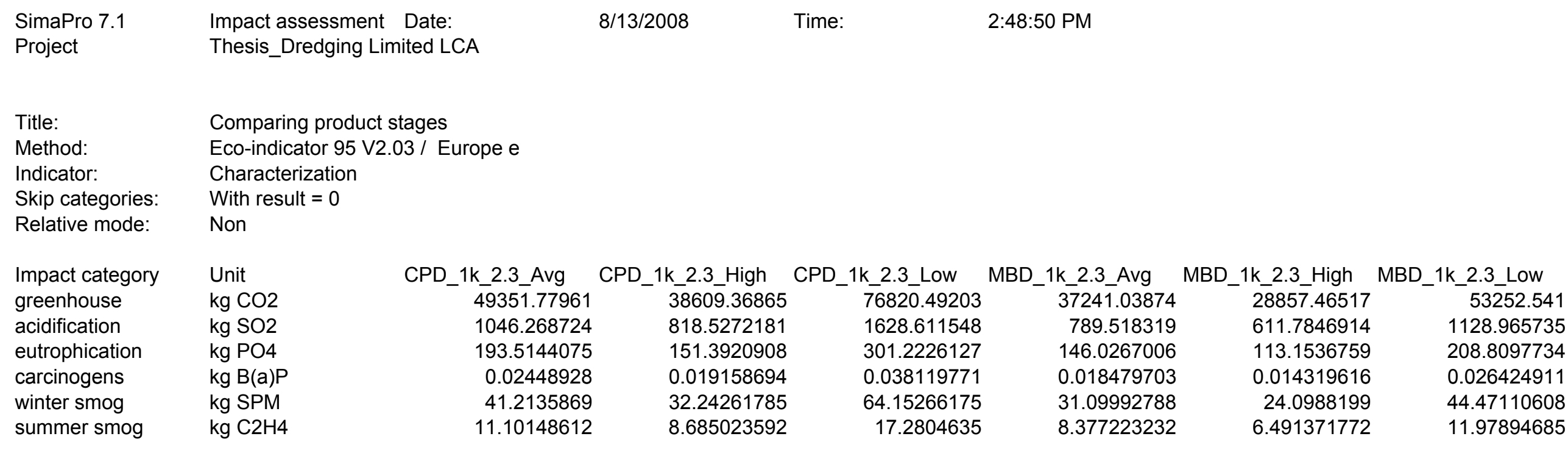




\begin{tabular}{|c|c|c|c|c|c|c|c|}
\hline $\begin{array}{l}\text { SimaPro } 7.1 \\
\text { Project }\end{array}$ & $\begin{array}{l}\text { Impact assessment } \\
\text { Thesis_Dredging Lin }\end{array}$ & $\begin{array}{l}\text { Date: } \\
\text { nited LCA }\end{array}$ & $8 / 13 / 2008$ & Time: & 2:51:43 PM & & \\
\hline $\begin{array}{l}\text { Title: } \\
\text { Method: } \\
\text { Indicator: } \\
\text { Skip categories: } \\
\text { Relative mode: }\end{array}$ & $\begin{array}{l}\text { Comparing product } \\
\text { Eco-indicator } 95 \mathrm{~V} 2 \text {. } \\
\text { Characterization } \\
\text { With result }=0 \\
\text { Non }\end{array}$ & $\begin{array}{l}\text { tages } \\
03 \text { / Europe e }\end{array}$ & & & & & \\
\hline $\begin{array}{l}\text { Impact category } \\
\text { greenhouse } \\
\text { acidification } \\
\text { eutrophication } \\
\text { carcinogens } \\
\text { winter smog } \\
\text { summer smog }\end{array}$ & $\begin{array}{l}\text { Unit } \\
\text { kg CO2 } \\
\text { kg SO2 } \\
\text { kg PO4 } \\
\text { kg B(a)P } \\
\text { kg SPM } \\
\text { kg C2H4 }\end{array}$ & $\begin{array}{r}\text { CPD_1k_3.0_Avg } \\
57827.25593 \\
1225.95071 \\
226.7477942 \\
0.02869497 \\
48.29144271 \\
13.00801074\end{array}$ & $\begin{array}{r}\text { CPD_1k_3.0_High } \\
43521.06036 \\
922.6561765 \\
170.651439 \\
0.021595968 \\
36.34436321 \\
9.789889064\end{array}$ & $\begin{array}{r}\text { CPD_1k_3.0_Low } \\
94373.9183 \\
2000.748096 \\
370.0517595 \\
0.046830111 \\
78.81149806 \\
21.22903677\end{array}$ & $\begin{array}{r}\text { MBD_1k_3.0_Avg } \\
37914.99228 \\
803.8062842 \\
148.6693555 \\
0.018814131 \\
31.66274533 \\
8.528826395\end{array}$ & $\begin{array}{r}\text { MBD_1k_3.0_High } \\
29531.41871 \\
626.0726566 \\
115.7963307 \\
0.014654045 \\
24.66163735 \\
6.642974935\end{array}$ & $\begin{array}{r}\text { MBD_1k_3.0_Low } \\
53926.49454 \\
1143.2537 \\
211.4524283 \\
0.026759339 \\
45.03392353 \\
12.13055001\end{array}$ \\
\hline
\end{tabular}




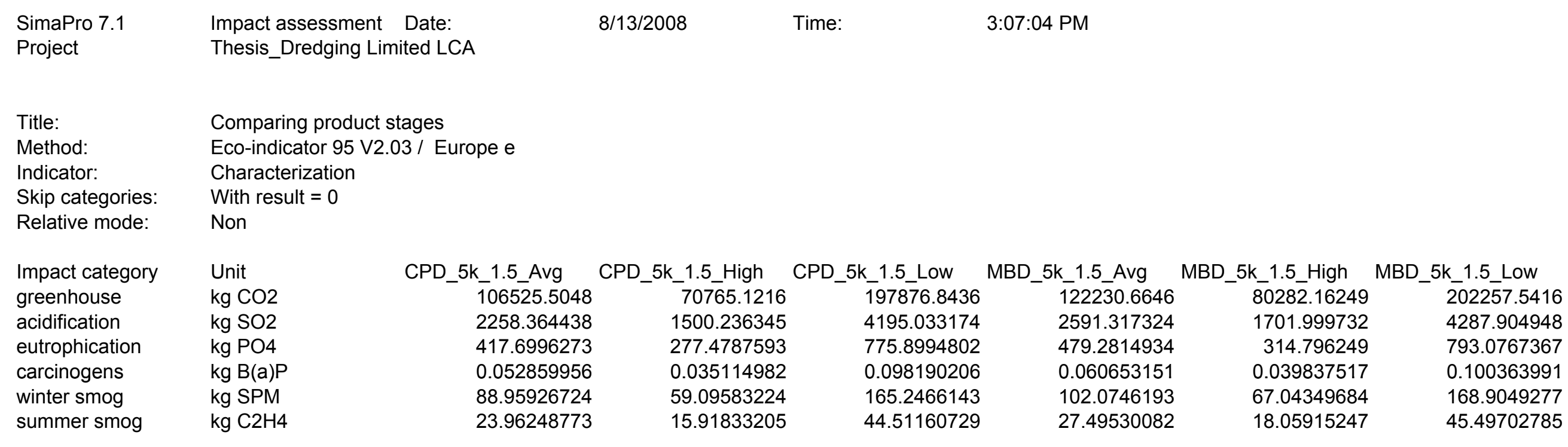




\begin{tabular}{|c|c|c|c|c|c|c|c|}
\hline $\begin{array}{l}\text { SimaPro } 7.1 \\
\text { Project }\end{array}$ & $\begin{array}{l}\text { Impact assessment } \\
\text { Thesis_Dredging Limit }\end{array}$ & $\begin{array}{l}\text { Date: } \\
\text { ted LCA }\end{array}$ & $8 / 13 / 2008$ & Time: & 3:09:49 PM & & \\
\hline $\begin{array}{l}\text { Title: } \\
\text { Method: } \\
\text { Indicator: } \\
\text { Skip categories: } \\
\text { Relative mode: }\end{array}$ & $\begin{array}{l}\text { Comparing product sta } \\
\text { Eco-indicator } 95 \text { V2.03 } \\
\text { Characterization } \\
\text { With result = } 0 \\
\text { Non }\end{array}$ & $\begin{array}{l}\text { ages } \\
3 \text { / Europe e }\end{array}$ & & & & & \\
\hline $\begin{array}{l}\text { Impact category } \\
\text { greenhouse } \\
\text { acidification } \\
\text { eutrophication } \\
\text { carcinogens } \\
\text { winter smog } \\
\text { summer smog }\end{array}$ & $\begin{array}{l}\text { Unit } \\
\text { kg CO2 } \\
\text { kg SO2 } \\
\text { kg PO4 } \\
\text { kg B(a)P } \\
\text { kg SPM } \\
\text { kg C2H4 }\end{array}$ & $\begin{array}{r}\text { CPD_5k_1.9_Avg } \\
\text { 127081.0878 } \\
2694.147376 \\
498.3006002 \\
0.063060023 \\
106.1251995 \\
28.58638419\end{array}$ & $\begin{array}{r}\text { CPD_5k_1.9_High } \\
82324.44594 \\
1745.296597 \\
322.804294 \\
0.040850936 \\
68.74900426 \\
18.51855599\end{array}$ & $\begin{array}{r}\text { CPD_5k_1.9_Low } \\
241418.3268 \\
5118.122319 \\
946.6309997 \\
0.119796308 \\
201.6080326 \\
54.30609039\end{array}$ & $\begin{array}{r}\text { MBD_5k_1.9_Avg } \\
124140.1996 \\
2631.799892 \\
486.7690154 \\
0.061600699 \\
103.6692688 \\
27.92484311\end{array}$ & $\begin{array}{r}\text { MBD_5k_1.9_High } \\
82191.69751 \\
1742.482301 \\
322.2837711 \\
0.040785064 \\
68.63814628 \\
18.48869476\end{array}$ & $\begin{array}{r}\text { MBD_5k_1.9_Low } \\
\text { 204167.0767 } \\
4328.387516 \\
800.5642588 \\
0.101311538 \\
170.4995772 \\
45.92657014\end{array}$ \\
\hline
\end{tabular}




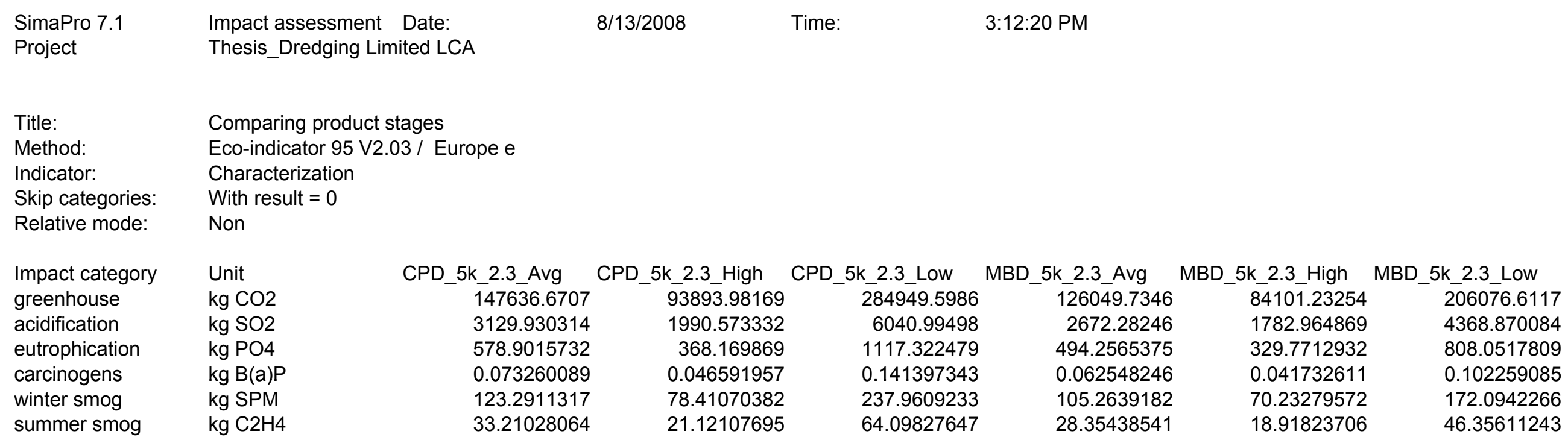




\begin{tabular}{|c|c|c|c|c|c|c|c|}
\hline $\begin{array}{l}\text { SimaPro } 7.1 \\
\text { Project }\end{array}$ & $\begin{array}{l}\text { Impact assessment } \\
\text { Thesis_Dredging Limit }\end{array}$ & $\begin{array}{l}\text { Date: } \\
\text { ited LCA }\end{array}$ & $8 / 13 / 2008$ & Time: & 3:15:32 PM & & \\
\hline $\begin{array}{l}\text { Title: } \\
\text { Method: } \\
\text { Indicator: } \\
\text { Skip categories: } \\
\text { Relative mode: }\end{array}$ & $\begin{array}{l}\text { Comparing product sta } \\
\text { Eco-indicator } 95 \text { V2.03 } \\
\text { Characterization } \\
\text { With result = } 0 \\
\text { Non }\end{array}$ & $\begin{array}{l}\text { ages } \\
3 \text { / Europe e }\end{array}$ & & & & & \\
\hline $\begin{array}{l}\text { Impact category } \\
\text { greenhouse } \\
\text { acidification } \\
\text { eutrophication } \\
\text { carcinogens } \\
\text { winter smog } \\
\text { summer smog }\end{array}$ & $\begin{array}{l}\text { Unit } \\
\text { kg CO2 } \\
\text { kg SO2 } \\
\text { kg PO4 } \\
\text { kg B(a)P } \\
\text { kg SPM } \\
\text { kg C2H4 }\end{array}$ & $\begin{array}{r}\text { CPD_5k_3.0_Avg } \\
\text { 188615.0882 } \\
3998.681895 \\
739.5829961 \\
0.093594349 \\
157.5121381 \\
42.42821232\end{array}$ & $\begin{array}{r}\text { CPD_5k_3.0_High } \\
117084.1103 \\
2482.209226 \\
459.10122 \\
0.058099335 \\
97.77674062 \\
26.33760394\end{array}$ & $\begin{array}{r}\text { CPD_5k_3.0_Low } \\
371327.9772 \\
7872.235852 \\
1456.022742 \\
0.184259916 \\
310.0953598 \\
83.52874845\end{array}$ & $\begin{array}{r}\text { MBD_5k_3.0_Avg } \\
129378.6567 \\
2742.856348 \\
507.3096509 \\
0.064200119 \\
108.0438953 \\
29.10321315\end{array}$ & $\begin{array}{r}\text { MBD_5k_3.0_High } \\
87430.15457 \\
1853.538757 \\
342.8244065 \\
0.043384485 \\
73.01277282 \\
19.6670648\end{array}$ & $\begin{array}{r}\text { MBD_5k_3.0_Low } \\
209405.5337 \\
4439.443973 \\
821.1048943 \\
0.103910959 \\
174.8742037 \\
47.10494018\end{array}$ \\
\hline
\end{tabular}




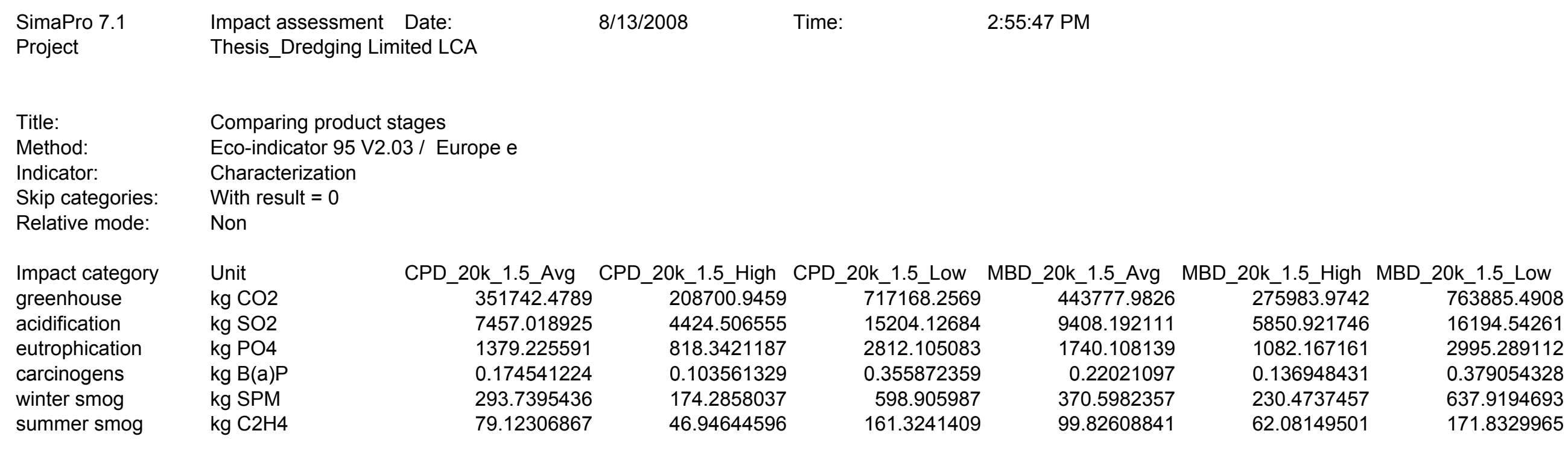




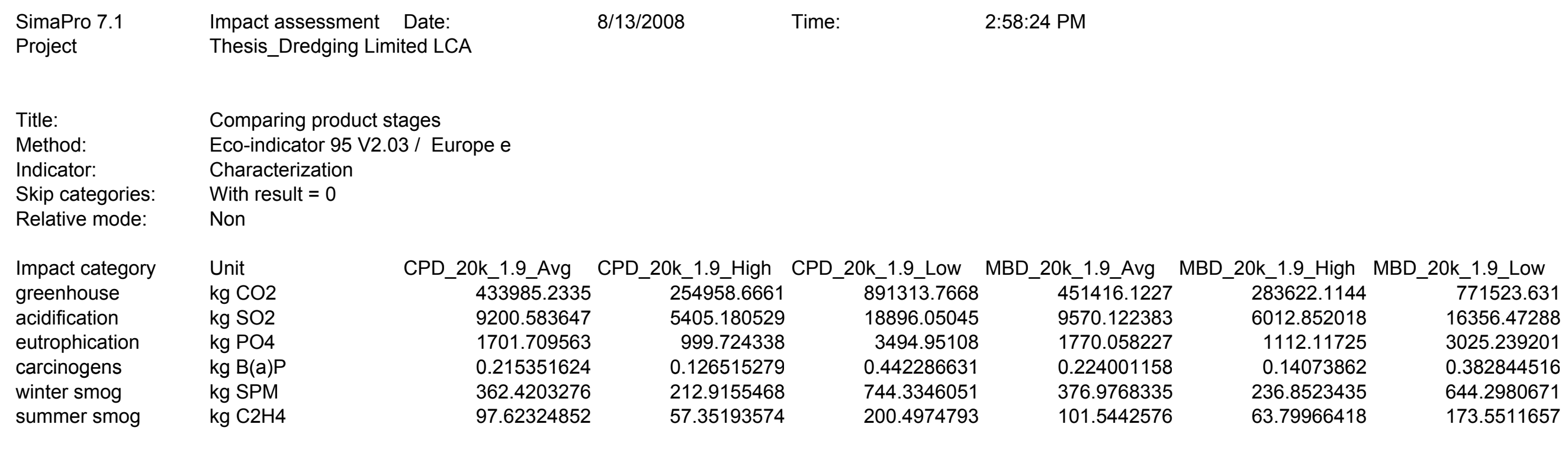




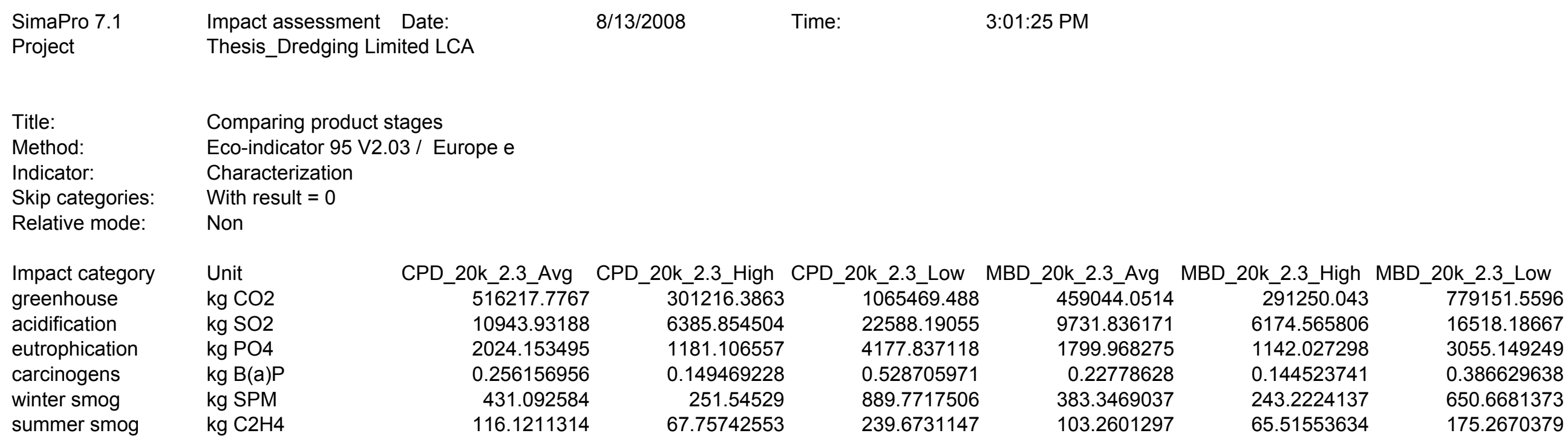




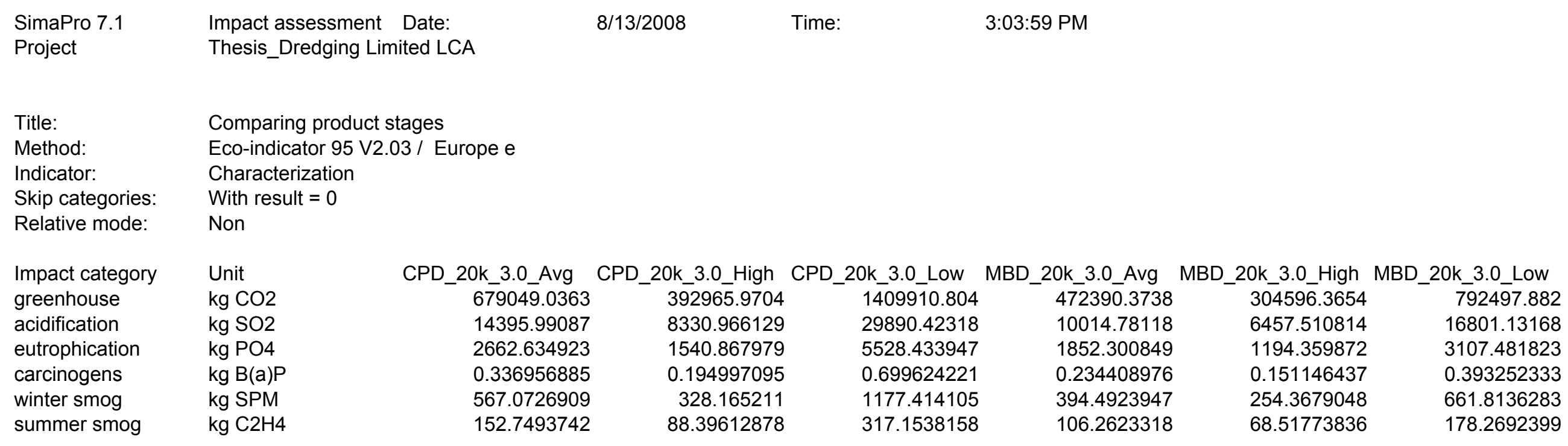




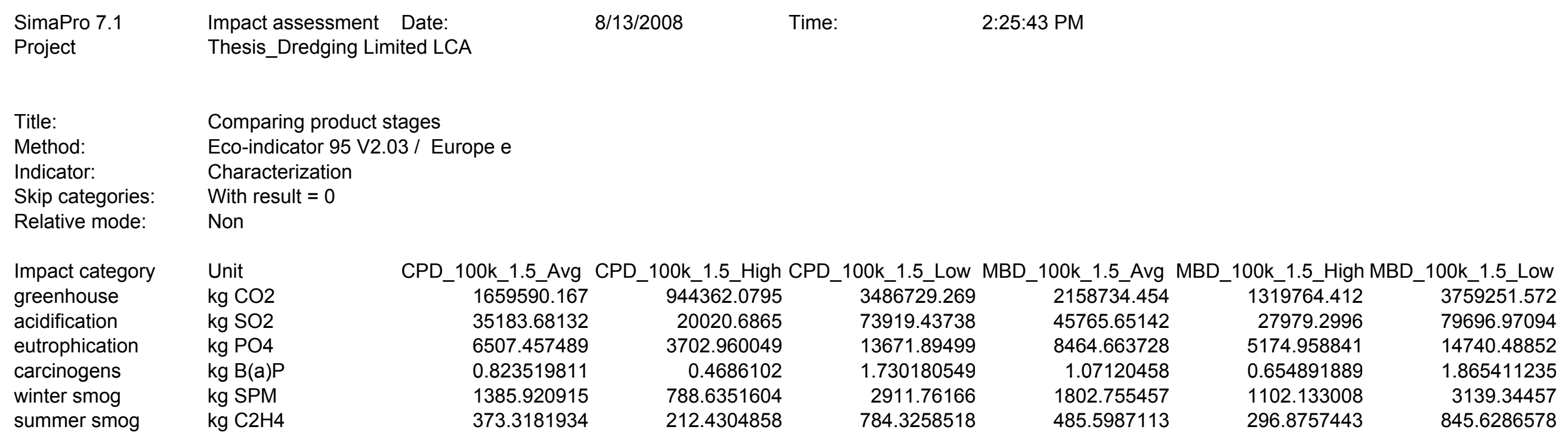




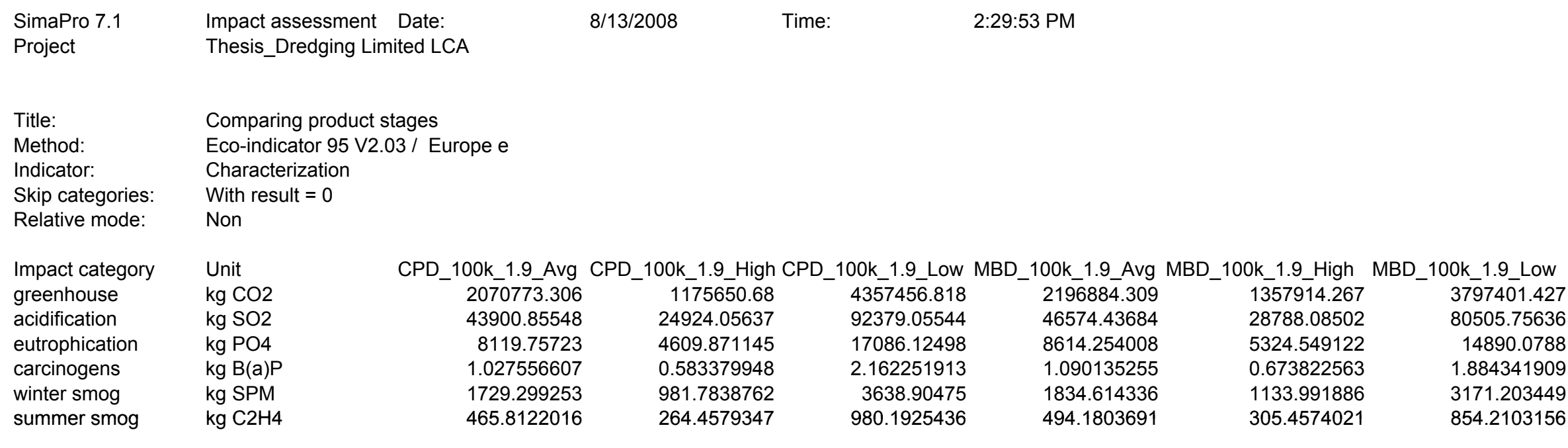




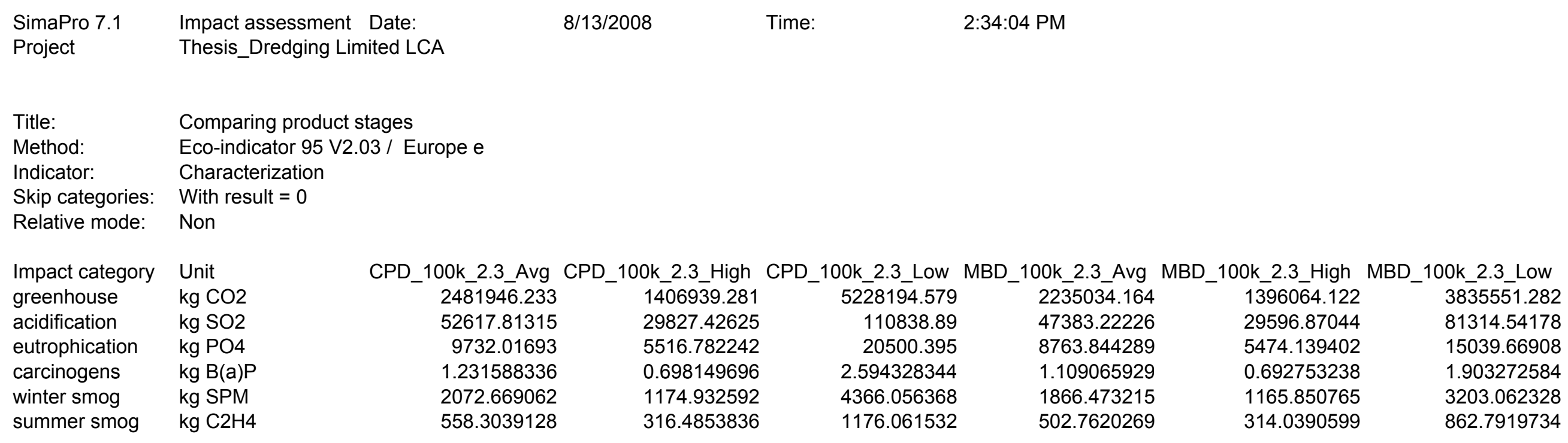




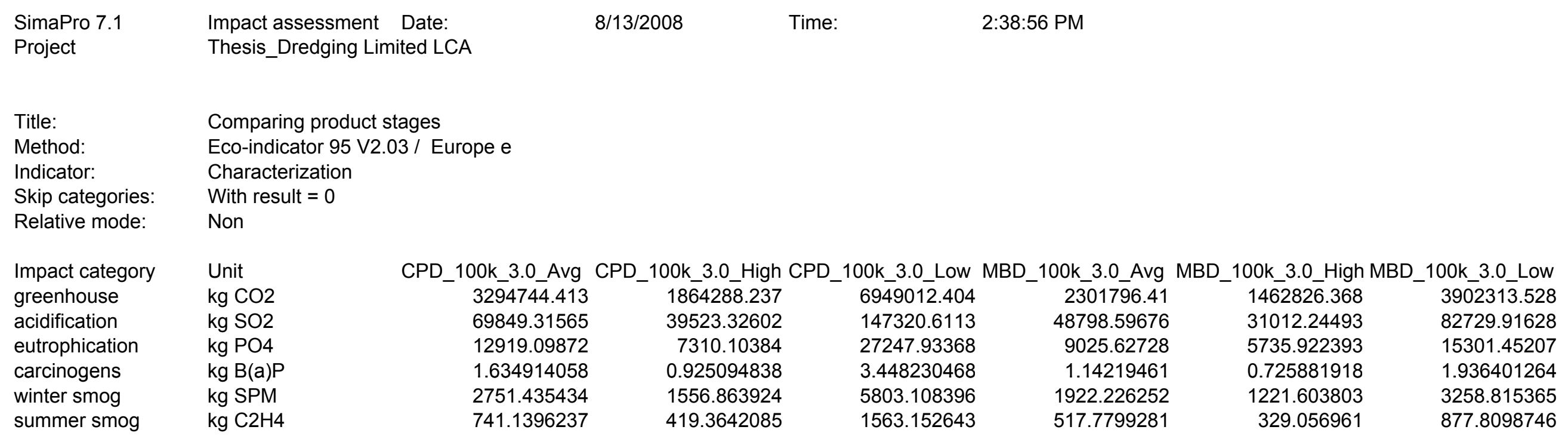




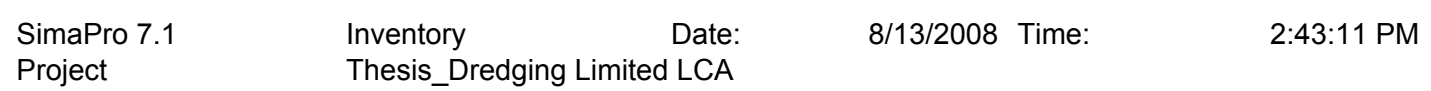

Title:

Method:

Per sub-compartment:

Default units:

Indicator:

Relative mode:

No
Comparing product stages

Eco-indicator 95 V2.03 / Europe e

No

Inventory

Non

Substance

1 Acetaldehyde

2 Acrolein

3 Benzene

4 Butadiene

5 Carbon dioxide, fossil

6 Carbon monoxide

7 Formaldehyde

8 Methane

9 Nitric oxide

10 Nitrogen oxides

$\mathrm{PAH}$, polycyclic

11 aromatic hydrocarbons Ai

12 Particulates, < 10 um Air

13 Propene

14 Sulfur oxides

15 Toluene

VOC, volatile organic

16 compounds

17 Xylene

$\begin{array}{ll}\text { Compartment } & \text { Unit } \\ \text { Air } & \mathrm{kg} \\ \text { Air } & \mathrm{kg} \\ \text { Air } & \mathrm{kg} \\ \text { Air } & \mathrm{kg} \\ \text { Air } & \mathrm{kg} \\ \text { Air } & \mathrm{kg} \\ \text { Air } & \mathrm{kg} \\ \text { Air } & \mathrm{kg} \\ \text { Air } & \mathrm{kg} \\ \text { Air } & \mathrm{kg} \\ & \\ \text { Air } & \mathrm{kg} \\ \text { Air } & \mathrm{kg} \\ \text { Air } & \mathrm{kg} \\ \text { Air } & \mathrm{kg} \\ \text { Air } & \mathrm{kg} \\ & \\ \text { Air } & \mathrm{kg} \\ \text { Air } & \mathrm{kg}\end{array}$

CPD 1k 1.5 Avg CPD 1k 1.5 High CPD

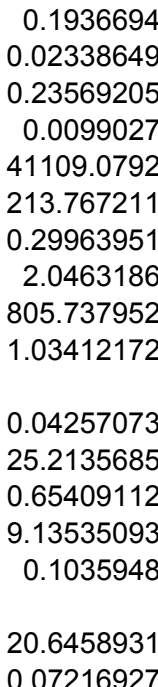

0.160012884

0.01932231

0.19473266

0.008181791

33964.99891

176.6179943

0.247567103

1.690702168

665.7139787

0.854408417

0.035172643

20.831866

0.540420872

7.547777536

0.085591797

17.05797723

0.059627443
1k_1.5_Low MB

0.279685981

0.033773401

0.340372562

0.014300925

59367.30729

308.7099979

0.432721706

2.95517263

1163.599223

1.493417597

0.061478145

36.41194847

0.944599823

13.19273495

0.149605614

29.815581

0.104222606
-1k_1.5_Avg

0.020744776

0.209068448

0.008784116

36465.42702

189.6202205

0.265792446

1.815167923

714.7223695

0.917308075

0.037761976

22.3654619

0.580205461

8.103428226

0.091892876

18.31374779

0.064017083
$1 \mathrm{k} 1.5$ High MBD $1 \mathrm{k} 15$ Low $0.132318346 \quad 0.24718336$

$0.015978064 \quad 0.029848557$

$0.161028931 \quad 0.30081749$

$0.006765712 \quad 0.012638998$

$28086.44141 \quad 52468.16689$

$146.0494953 \quad 272.8344678$

$0.204718951 \quad 0.382434639$

$1.398080639 \quad 2.611748752$

$550.4942516 \quad 1028.376071$

$0.706530037 \quad 1.319865887$

0.02908507

17.22635073

0.44688649

6.241431424

0.070777832

14.10563502

0.049307308
0.054333702

3218047569

0.834826833

11.65959264

0.132219781

26.35067937

0.092110782 


$\begin{array}{llll}\text { SimaPro 7.1 } & \text { Inventory } \quad \text { Date: } & \text { 8/13/2008 Time: } & \text { 2:45:59 PM } \\ \text { Project } & \text { Thesis_Dredging Limited LCA } & \end{array}$

Title:

Method:

Per sub-compartment:

Default units:

Indicator:

Relative mode:

No
Comparing product stages

Eco-indicator 95 V2.03 / Europe e

No

Inventory

Non

Substance

1 Acetaldehyde

2 Acrolein

3 Benzene

4 Butadiene

5 Carbon dioxide, fossi

6 Carbon monoxide

7 Formaldehyde

8 Methane

9 Nitric oxide

10 Nitrogen oxides

$\mathrm{PAH}$, polycyclic

11 aromatic hydrocarbons Air

12 Particulates, < 10 um Air

13 Propene Air

14 Sulfur oxides Air

15 Toluene

VOC, volatile organic

16 compounds

17 Xylene
Compartment Unit

Air

Air

Air

Air

Air

Air

Air

Ai

Air

$\begin{array}{ll}\text { Air } & \mathrm{kg} \\ \text { Air } & \mathrm{kg} \\ \text { Air } & \mathrm{kg} \\ \text { Air } & \mathrm{kg} \\ \text { Air } & \mathrm{kg} \\ & \\ \text { Air } & \mathrm{kg} \\ \text { Air } & \mathrm{kg}\end{array}$

CPD 1k 1.9 Avg CPD 1k 1.9 High CPD 1k 1.9 Low MBD 1k 1.9 Avg MBD 1k 1.9 High MBD 1k 1.9 Low 0.213046 0.170879143 0.320698899 $0.1735 \overline{7} 1668$

0.020959598

0.020634463

0.207956693

0.259272962

0.010893484

0.008737405

36271.51627

188.6118846

0.264379052

1.805515476

710.9217188

0.912430143

0.038725905

0.211233445

$0.016398 \quad 0.00887508$

235.1545472

.251052075

886.3517547

1.137585245

0.046829923

27.73617736

0.719532717

10.04933962

0.113959511

0.03756117

22.24652998

0.577120125

8.060336948

0.091404221

08072.87943

36843.04269

191.583822

353.978973

6175655

3.388516665

1334.228437

0.268544844

1.833964792

722.1236367

0.926807207

0.070493248

41.75136605

1.083115148

15.12730654

0.171543656

22.71150755

0.079389783
18.2163615

0.063676662
34.18771278

0.119505722
0.038153018

2259706618

0.586213746

8.18734282

0.092844468

18.50339477

0.064680008
0.134097336 - 248962353

$0.016192886 \quad 0.030063379$

$0.163193927 \quad 0.302982487$

$0.006856675 \quad 0.012729962$

$28464.05708 \quad 52845.78256$

$148.0130968 \quad 274.7980693$

0.385187037

$1.416877508 \quad 2.630545621$

$557.8955188 \quad 1035.777338$

1.329365019

$0.029476112 \quad 0.054724744$

$17.45795501 \quad 32.41207997$

$0.452894775 \quad 0.840835118$

$6.325346018 \quad 11.74350724$

$0.071729424 \quad 0.133171372$

$14.295282 \quad 26.54032635$

$0.049970234 \quad 0.092773707$ 


$\begin{array}{llll}\text { SimaPro 7.1 } & \text { Inventory } \quad \text { Date: } & \text { 8/13/2008 Time: } & \text { 2:49:05 PM } \\ \text { Project } & \text { Thesis_Dredging Limited LCA } & \end{array}$

Title:

Method:

Per sub-compartment:

Default units:

Indicator:

Relative mode:

No
Comparing product stages

Eco-indicator 95 V2.03 / Europe e

No

Inventory

Non

Substance

1 Acetaldehyde

2 Acrolein

3 Benzene

4 Butadiene

5 Carbon dioxide, fossil

6 Carbon monoxide

7 Formaldehyde

8 Methane

9 Nitric oxide

10 Nitrogen oxides

$\mathrm{PAH}$, polycyclic

11 aromatic hydrocarbons Air

12 Particulates, < 10 um Air

13 Propene Air

14 Sulfur oxides Air

15 Toluene

VOC, volatile organic

16 compounds

17 Xylene
Compartment Unit

Air

Air

Air

Air

Air

Air

Air

Air

Air

$\mathrm{kg}$
$\mathrm{kg}$
$\mathrm{kg}$
$\mathrm{kg}$
$\mathrm{kg}$
$\mathrm{kg}$
$\mathrm{kg}$
$\mathrm{kg}$
$\mathrm{kg}$
$\mathrm{kg}$

$\mathrm{kg}$

$\mathrm{kg}$

$\mathrm{kg}$

$\mathrm{kg}$

$\mathrm{kg}$

$\mathrm{kg}$

$\mathrm{kg}$
CPD 1k 2.3 Avg CPD 1k 2.3 High CPD 1k 2.3 Low MBD 1k 2.3 Avg MBD 1k 2.3 High MBD 1k_2.3 Low

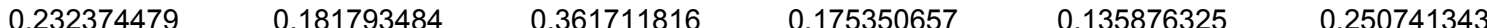

$\begin{array}{llllrr}0.028060314 & 0.021952421 & 0.043678408 & 0.021174419 & 0.016407707 & 0.0302782\end{array}$

$\begin{array}{llllll}0.282795357 & 0.22123924 & 0.440196456 & 0.213398441 & 0.165358924 & 0.305147483\end{array}$

$\begin{array}{llllll}0.011881789 & 0.009295478 & 0.018495076 & 0.008966043 & 0.006947639 & 0.012820925\end{array}$

$\begin{array}{llllll}49324.77156 & 38588.23945 & 76778.45157 & 37220.65836 & 28841.67275 & 53223.39824\end{array}$

$\begin{array}{llllll}256.4888121 & 200.6588451 & 399.2479481 & 193.5474235 & 149.9766983 & 276.7616708\end{array}$

$\begin{array}{llllll}0.359522779 & 0.28126539 & 0.559629603 & 0.271297243 & 0.210223748 & 0.387939436\end{array}$

$\begin{array}{llllll}2.455277518 & 1.920836808 & 3.8218607 & 1.852761661 & 1.435674377 & 2.64934249\end{array}$

$\begin{array}{llllrr}966.7655225 & 756.3294932 & 1504.857651 & 729.5249039 & 565.296786 & 1043.178605\end{array}$

$\begin{array}{llllll}1.240792031 & 0.970708601 & 1.931404604 & 0.936306339 & 0.725528301 & 1.338864151\end{array}$

$\begin{array}{llllll}0.051078541 & 0.039960266 & 0.079508352 & 0.03854406 & 0.029867154 & 0.055115786\end{array}$

$\begin{array}{llllrr}30.25252655 & 23.66745353 & 47.09078363 & 22.82867046 & 17.68955929 & 32.64368425\end{array}$

$\begin{array}{llllrr}0.784811921 & 0.613981765 & 1.221630474 & 0.592222031 & 0.45890306 & 0.846843403\end{array}$

$\begin{array}{llllll}10.96106035 & 8.575164322 & 17.06187813 & 8.271257414 & 6.409260612 & 11.82742183\end{array}$

$\begin{array}{llllll}0.124298424 & 0.097242363 & 0.193481698 & 0.093796059 & 0.072681015 & 0.134122964\end{array}$

$\begin{array}{llllll}24.77199638 & 19.37987137 & 38.55984456 & 18.69304176 & 14.48492898 & 26.72997334\end{array}$

$\begin{array}{llllll}0.086592377 & 0.067743798 & 0.134788837 & 0.065342934 & 0.050633159 & 0.093436632\end{array}$ 


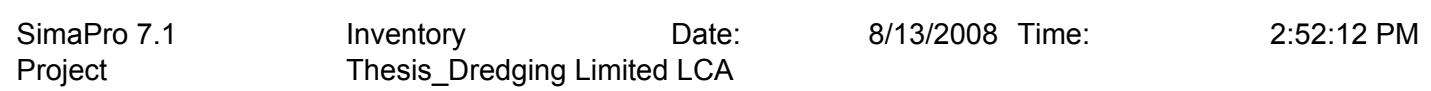

Title:

Method:

Per sub-compartment:

Default units:

Indicator:

Relative mode:

No
Comparing product stages

Eco-indicator 95 V2.03 / Europe e

No

Inventory

Non

Substance

1 Acetaldehyde

2 Acrolein

3 Benzene

4 Butadiene

5 Carbon dioxide, fossil

6 Carbon monoxide

7 Formaldehyde

8 Methane

9 Nitric oxide

10 Nitrogen oxides

Nitrogen oxides

$\mathrm{PAH}$, polycyclic

11 aromatic hydrocarbons Air

12 Particulates, $<10$ um Air

13 Propene Air

14 Sulfur oxides Air

15 Toluene

VOC, volatile organic

16 compounds

17 Xylene
Compartment Unit

Air

Air

Air

Air

Air

Air

Air

Air

$\begin{array}{ll}\text { Air } & \mathrm{kg} \\ \text { Air } & \mathrm{kg} \\ \text { Air } & \mathrm{kg} \\ \text { Air } & \mathrm{kg} \\ \text { Air } & \mathrm{kg} \\ & \\ \text { Air } & \mathrm{kg} \\ \text { Air } & \mathrm{kg}\end{array}$

CPD_1k_3.0_Avg CPD_1k_3.0_High CPD_1k_3.0_Low MBD_1k_3.0_Avg MBD_1k_3.0_High MBD_1k_3.0_Low 0.272281539 0.03287928

0.331361495

0.01392232

57795.60963

300.5371701

0.421265777

2.876937013

1132.793949

1.453880669

0.059850565

35.4479739

0.919592367

12.84346881

0.145644936

29.0262395

0.101463404

\subsection{6 \\ 0.444362702}

0.024745098

0.249384194

0.010478003

43497.2432

226.1856646

0.317046573

2.165196106

852.5459667

1.094197318

0.045043812

26.67830916

0.69208947

9.666054044

0.109613053

21.84528214

0.076361827
0.053658892

0.540781024

0.022721187

94322.27162

490.4758124

0.687504558

4.695153076

1848.716524

2.372729144

0.097675952

57.85099326

1.500772144

20.9605048

0.237692124

47.37074086

0.165587988
0.17852399

0.021557614

0.217260327

0.009128302

37894.24308

197.050064

0.276206927

1.886291211

742.7271643

0.953250737

0.039241594

23.24180242

0.602939512

8.420942906

0.095493493

19.03133097

0.066525449
$0.139049657 \quad 0.253914675$

$0.016790902 \quad 0.030661395$

$0.169220809 \quad 0.309009369$

$0.007109898 \quad 0.012983184$

$29515.25747 \quad 53896.98295$

$153.4793388 \quad 280.2643113$

$0.215133432 \quad 0.39284912$

$1.469203927 \quad 2.68287204$

$578.4990464 \quad 1056.380866$

1.355808549

0.030564689

18.10269125

0.469620541

6.558946104

0.074378449

14.8232182

0.051815674
0.05581332

33.05681621

0.857560884

11.97710732

0.135820397

27.06826255

0.094619148 


$\begin{array}{llll}\text { SimaPro 7.1 } & \text { Inventory } \quad \text { Date: } & \text { 8/13/2008 Time: } & \text { 3:07:30 PM } \\ \text { Project } & \text { Thesis_Dredging Limited LCA } & \end{array}$

Title:

Method:

Per sub-compartment:

Default units:

Indicator:

Relative mode:

No
Comparing product stages

Eco-indicator 95 V2.03 / Europe e

No

Inventory

Non

Substance

1 Acetaldehyde

2 Acrolein

3 Benzene

4 Butadiene

5 Carbon dioxide, fossil

6 Carbon monoxide

7 Formaldehyde

8 Methane

9 Nitric oxide

10 Nitrogen oxides

$\mathrm{PAH}$, polycyclic

11 aromatic hydrocarbons Air

12 Particulates, $<10$ um Air

13 Propene Air

14 Sulfur oxides Air

15 Toluene

VOC, volatile organic

16 compounds

17 Xylene
Compartment Unit

Air $\quad \mathrm{kg}$

Air

Air

Air

Air

Air

$\begin{array}{ll}\text { Air } & \mathrm{kg} \\ \text { Air } & \mathrm{kg} \\ \text { Air } & \mathrm{kg} \\ \text { Air } & \mathrm{kg} \\ \text { Air } & \mathrm{kg} \\ & \\ \text { Air } & \mathrm{kg} \\ \text { Air } & \mathrm{kg}\end{array}$

CPD_5k_1.5_Avg CPD_5k_1.5_High CPD_5k_1.5_Low MBD_5k_1.5_Avg MBD_5k_1.5_High MBD_5k_1.5_Low 0.501578847

0.060568012 0.333199905 0.04023546

0.405497998

0.610411993

0.017037203

0.025646767

106467.2081

553.6294823

0.77602765

5.299701027

2086.757279

2.678241769

70726.39497

367.7772538

0.515516834

3.520602772

1386.237341

1.779161758

0.931709634

0.112508333

1.133873045

0.047640247

197768.5544

1028.396483

1.441513018

9.84447915

3876.263665

4.974977856

0.110252709

65.29988765

1.694011578

23.65937958

0.268297364

53.47019786

0.186909099
0.073241111

43.37885558

1.125335529

15.71697666

0.178230515

35.52036725

0.124164116
0.204800325

121.2980467

3.146717443

43.94856764

0.498376757

99.32376286

0.347193684
0.575527109

0.069497613

0.700405633

0.029427896

122163.7731

635.2516203

0.890438169

6.081041151

2394.409953

3.073097582

0.126507374

74.92711419

1.943761368

27.14750514

0.307852708

61.35336162

0.214465291
$0 . \overline{3} 78011206 \quad 0.952336295$

$0.045646636 \quad 0.1149991$

$0.460032505 \quad 1.158975302$

$0.019328497 \quad 0.048694931$

$80238.2276 \quad 202146.855$

$417.2387835 \quad 1051.163646$

$0.584847526 \quad 1.473425965$

$3.994080663 \quad 10.06242123$

$1572.669261 \quad 3962.078358$

$2.018437192 \quad 5.085116441$

$0.083091142 \quad 0.209334299$

$49.21277959 \quad 123.9834044$

$1.276679355 \quad 3.216381071$

$17.83071724 \quad 44.92152333$

$0.202200334 \quad 0.509410075$

40.29742097

0.140862666

101.5226427

0.354880034 


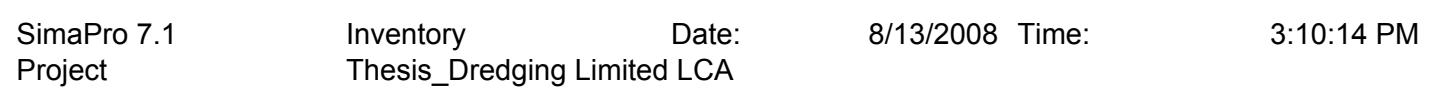

Title:

Method:

Per sub-compartment:

Default units:

Indicator:

Relative mode:

No
Comparing product stages

Eco-indicator 95 V2.03 / Europe e

No

Yes

Inventory

Non

Substance

1 Acetaldehyde

2 Acrolein

3 Benzene

4 Butadiene

5 Carbon dioxide, fossil

6 Carbon monoxide

7 Formaldehyde

8 Methane

9 Nitric oxide

10 Nitrogen oxides

Nitrogen oxides

$\mathrm{PAH}$, polycyclic

11 aromatic hydrocarbons Air

12 Particulates, $<10$ um Air

13 Propene Air

14 Sulfur oxides Air

15 Toluene

VOC, volatile organic

16 compounds

17 Xylene
Compartment Unit

Air

Air

Air

Air

Air

Air

Air

$\mathrm{kg}$
$\mathrm{kg}$
$\mathrm{kg}$
$\mathrm{kg}$
$\mathrm{kg}$
$\mathrm{kg}$
$\mathrm{kg}$
$\mathrm{kg}$
$\mathrm{kg}$
$\mathrm{kg}$

$\mathrm{kg}$

$\mathrm{kg}$

$\mathrm{kg}$

$\mathrm{kg}$

$\mathrm{kg}$

$\mathrm{kg}$

$\mathrm{kg}$ CPD_5k_1.9_Avg CPD_5k_1.9_High CPD_5k_1.9_Low MBD_ 0.598365486 0.387627364

0.046807833

0.471735189

0.019820192

82279.3934

0.72819950

0.030595669

127011.5419

660.4600179

0.925773017

6.322352308

2489.426221

3.195045899

427.8528457

0.599725356

4.09568536

1612.676111

$1 . \overline{136726141}$

0.137265043

1.383374266

0.058123167

241286.2092

1254.688288

1.758708369

12.0106913

4729.209701

6.069688641

0.131527508

77.90041237

2.020894756

28.22478709

0.320069086

50.46469462

1.309156571

18.28430964

147.988875

3.839131684

53.6191576

$0.207344071 \quad 0.608041247$

121.1792962
41.3225398

0.144446046
0.423591345
_5k_1.9_Avg MBD

0.070583332

0.711347642

0.02988763

124072.2632

645.1757684

0.90434894

6.176041544

2431.816358

3.121106709

0.128483721

76.09765473

1.974127565

27.57161403

0.312662103

62.31184772

0.217815751
$5 \mathrm{k} 1.9$ High MBD 5k 1.9 Low $0.387002314 \quad 0.961327403$

$0.046732355 \quad 0.116084819$

$0.470974514 \quad 1.169917311$

$0.019788232 \quad 0.049154665$

$82146.71762 \quad 204055.345$

$427.1629316 \quad 1061.087794$

$0.598758297 \quad 1.487336737$

$4.089081055 \quad 10.15742162$

$1610.075665 \quad 3999.484763$

2.066446319

$0.08506749 \quad 0.211310646$

$50.38332014 \quad 125.1539449$

$1.307045551 \quad 3.246747268$

$18.25482614 \quad 45.34563223$

$0.207009728 \quad 0.514219469$

41.25590707

0.144213126

102.4811288

0.358230495 


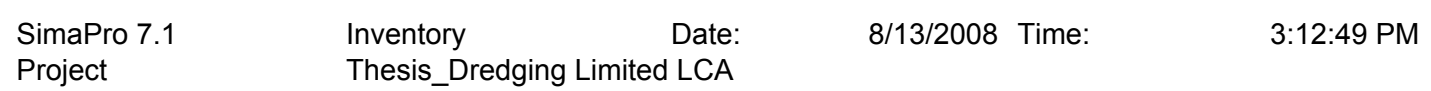

Title:

Method:

Per sub-compartment:

Default units:

Indicator:

Relative mode:

No
Comparing product stages

Eco-indicator 95 V2.03 / Europe e

No

Yes

Inventory

Non

Substance

1 Acetaldehyde

2 Acrolein

3 Benzene

4 Butadiene

5 Carbon dioxide, fossil

6 Carbon monoxide

7 Formaldehyde

8 Methane

9 Nitric oxide

10 Nitrogen oxides

$\mathrm{PAH}$, polycyclic

11 aromatic hydrocarbons Air

12 Particulates, < 10 um Air

13 Propene Air

14 Sulfur oxides Air

15 Toluene

VOC, volatile organic

16 compounds

17 Xylene
Compartment Unit

Air $\quad \mathrm{kg}$

Air

Air

Air

Air

Air

$\begin{array}{ll}\text { Air } & \mathrm{kg} \\ \text { Air } & \mathrm{kg} \\ \text { Air } & \mathrm{kg} \\ \text { Air } & \mathrm{kg} \\ \text { Air } & \mathrm{kg} \\ & \\ \text { Air } & \mathrm{kg} \\ \text { Air } & \mathrm{kg}\end{array}$

CPD 5k 2.3 Avg CPD 5k 2.3 High CPD 5k_2.3 Low MBD 5k 2.3 Avg MBD 5k 2.3 High MBD 5k 2.3 Low 0.695152125

0.083942898

0.845987021

0.035544571

147555.8757

767.2905535

1.075518383

7.34500359

2892.095163

3.711850028

0.152802307

90.50093708

2.347777933

32.7901946

0.371840807

74.10583979

0.259042537

$\begin{array}{lrc}0.442102905 & 1.341694568 & 0.593509326 \\ 0.053386011 & 0.162015948 & 0.071669051 \\ 0.538030893 & 1.632816974 & 0.722289652 \\ 0.022605639 & 0.068603628 & 0.030347364 \\ 93842.59766 & 284793.6582 & 125980.7532 \\ 487.9815078 & 1480.927023 & 655.0999165 \\ 0.684008267 & 2.075829331 & 0.918259712 \\ 4.671275972 & 14.17639543 & 6.271041936 \\ 1839.314914 & 5581.955702 & 2469.222762 \\ 2.360662679 & 7.164142692 & 3.169115835\end{array}$

2.360662679

0.097179223

57.55679323

1.493139998

20.85391059

0.236483346

47.12983793

0.164745894
0.294919655

174.6734437

4.53138354

63.28747961

0.717680019

143.0297039

0.499971089
0.130460069

77.26819528

2.004493762

27.99572293

0.317471498

63.27033382

0.221166211
2.3_High MBD_5k_2.3_Low

$\begin{array}{ll}0.395993423 & 0.970318512 \\ 0.047818074 & 0.117170537\end{array}$

$0.481916524 \quad 1.180859321$

$0.020247966 \quad 0.049614399$

$84055.20764 \quad 205963.835$

$437.0870797 \quad 1071.011942$

$0.612669069 \quad 1.501247509$

$4.184081447 \quad 10.25242201$

$1647.48207 \quad 4036.891167$

$2.114455446 \quad 5.181134695$

$0.087043837 \quad 0.213286994$

$51.55386069 \quad 126.3244855$

$1.337411748 \quad 3.277113464$

$18.67893503 \quad 45.76974112$

$0.211819123 \quad 0.519028864$

42.21439317

0.147563587

103.4396149

0.361580955 


$\begin{array}{llll}\text { SimaPro 7.1 } & \text { Inventory } \quad \text { Date: } & \text { 8/13/2008 Time: } & \text { 3:16:06 PM } \\ \text { Project } & \text { Thesis_Dredging Limited LCA } & \end{array}$

Title:

Method:

Per sub-compartment:

Default units:

Indicator:

Relative mode:

No
Comparing product stages

Eco-indicator 95 V2.03 / Europe e

No

Yes

Inventory

Non

Substance

1 Acetaldehyde

2 Acrolein

3 Benzene

4 Butadiene

5 Carbon dioxide, fossil

6 Carbon monoxide

7 Formaldehyde

8 Methane

9 Nitric oxide

10 Nitrogen oxides

$\mathrm{PAH}$, polycyclic

11 aromatic hydrocarbons Air

12 Particulates, $<10$ um Air

13 Propene Air

14 Sulfur oxides Air

15 Toluene

VOC, volatile organic

16 compounds

17 Xylene
Compartment Unit

Air

Air

Air

Air

Air

Air

Air

$\mathrm{kg}$
$\mathrm{kg}$
$\mathrm{kg}$
$\mathrm{kg}$
$\mathrm{kg}$
$\mathrm{kg}$
$\mathrm{kg}$
$\mathrm{kg}$
$\mathrm{kg}$
$\mathrm{kg}$

$\mathrm{kg}$

$\mathrm{kg}$

$\mathrm{kg}$

$\mathrm{kg}$

$\mathrm{kg}$

$\mathrm{kg}$

$\mathrm{kg}$
CPD 5k_3.0 Avg CPD 5k 3.0 High CPD 5k 3.0 Low MBD 5k 3.0 Avg MBD 5k 3.0 High MBD 5k 3.0_Low

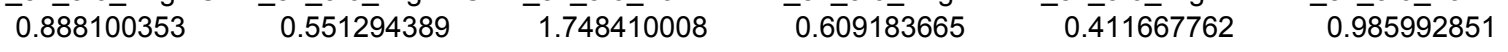

$\begin{array}{llllll}0.107242307 & 0.066571398 & 0.211128756 & 0.073561801 & 0.049710824 & 0.119063288\end{array}$

$\begin{array}{llllll}1.080801373 & 0.670914869 & 2.12778199 & 0.741365026 & 0.500991899 & 1.199934696\end{array}$

$\begin{array}{llllll}0.045410414 & 0.028188826 & 0.089399832 & 0.031148825 & 0.021049427 & 0.050415861\end{array}$

$\begin{array}{lllrrr}188511.8675 & 117020.0353 & 371124.7658 & 129307.8534 & 87382.3079 & 209290.9353\end{array}$

$\begin{array}{llllll}980.2617108 & 608.5041836 & 1929.848782 & 672.4008378 & 454.3880011 & 1088.312864\end{array}$

$\begin{array}{llllll}1.374042056 & 0.852946035 & 2.705087182 & 0.942510576 & 0.636919933 & 1.525498373\end{array}$

$\begin{array}{llllll}9.383701847 & 5.824997313 & 18.47376612 & 6.436657593 & 4.349697104 & 10.41803767\end{array}$

$\begin{array}{llllll}3694.832602 & 2293.592692 & 7274.045409 & 2534.433927 & 1712.693235 & 4102.102332\end{array}$

$\begin{array}{llllll}4.742120755 & 2.943703999 & 9.335849663 & 3.252810891 & 2.198150501 & 5.26482975\end{array}$

$\begin{array}{llllll}0.195214512 & 0.121180748 & 0.384320313 & 0.133905466 & 0.090489234 & 0.216732391\end{array}$

$\begin{array}{llllrr}115.620612 & 71.77228833 & 227.6231897 & 79.30881677 & 53.59448218 & 128.365107\end{array}$

$\begin{array}{rrrrrr}2.999433269 & 1.861918784 & 5.905007384 & 2.057431623 & 1.39034961 & 3.330051326\end{array}$

$\begin{array}{llllll}41.8915261 & 26.00445229 & 82.47217017 & 28.73507854 & 19.41829064 & 46.50909673\end{array}$

$\begin{array}{llllll}0.475049906 & 0.294890489 & 0.93523441 & 0.325855791 & 0.220203416 & 0.527413157\end{array}$

$\begin{array}{llllll}94.67484899 & 58.77006218 & 186.3871046 & 64.9412775 & 43.88533686 & 105.1105586\end{array}$

$\begin{array}{llllll}0.330943056 & 0.205435173 & 0.651530144 & 0.22700712 & 0.153404496 & 0.367421864\end{array}$ 


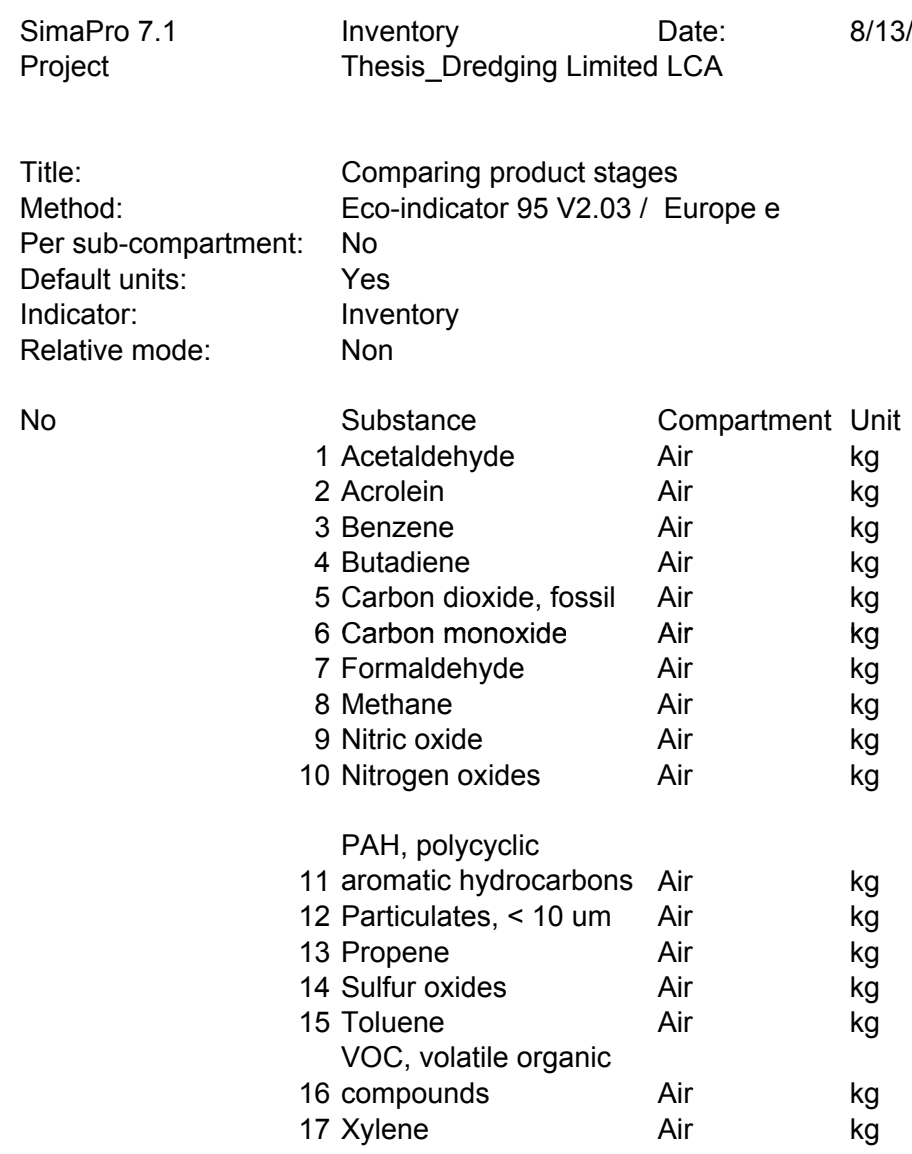

CPD_20k_1.5_Avg CPD_20k_1.5_High CPD_20k_1.5_Low MBD_20k_1.5_Avg MBD_20k_1.5_High MBD_20k_1.5_Low

$\begin{array}{rrrrrr}1.656191044 & 0.982675276 & 3.376810352 & 2.089543244 & 1.29947963 & 3.596779987 \\ 0.199992881 & 0.118662675 & 0.407765778 & 0.252322203 & 0.156918295 & 0.434328149 \\ 2.015553252 & 1.19589727 & 4.109514485 & 2.542934702 & 1.581442192 & 4.37721338 \\ 0.084684485 & 0.050246226 & 0.172663322 & 0.106842683 & 0.066445091 & 0.183910826 \\ 351549.9857 & 208586.7331 & 716775.7823 & 443535.1225 & 275832.9404 & 763467.45 \\ 1828.059926 & 1084.651012 & 3727.234068 & 2306.382637 & 1434.33129 & 3970.03074 \\ 2.562408785 & 1.520365521 & 5.224499036 & 3.232878226 & 2.010515654 & 5.564829413 \\ 17.49937707 & 10.38298405 & 35.67950561 & 22.07819276 & 13.73035081 & 38.00371307 \\ 6890.37972 & 4088.299969 & 14048.80533 & 8693.288401 & 5406.325632 & 14963.96202 \\ 8.843435197 & 5.247115153 & 18.03089301 & 11.15737242 & 6.938730856 & 19.20544785\end{array}$

$0.285640334-0.790612959$
169.1775368

0.790612959
968.260036

$\begin{array}{llllll}5.593550884 & 3.318846687 & 11.40469911 & 7.057136616 & 4.388808563 & 12.14761543\end{array}$

$\begin{array}{llllll}78.12221905 & 46.35260736 & 159.2835072 & 98.56336056 & 61.29620897 & 169.6594333\end{array}$

$\begin{array}{llllll}0.885905964 & 0.525638567 & 1.806274971 & 1.117708509 & 0.69509901 & 1.923937974\end{array}$

$\begin{array}{llllll}176.5562151 & 104.7568926 & 359.9807262 & 222.7531949 & 138.5294323 & 383.4303193\end{array}$

$\begin{array}{llllll}0.617165531 & 0.366185598 & 1.258339707 & 0.778650548 & 0.484240051 & 1.340309523\end{array}$ 


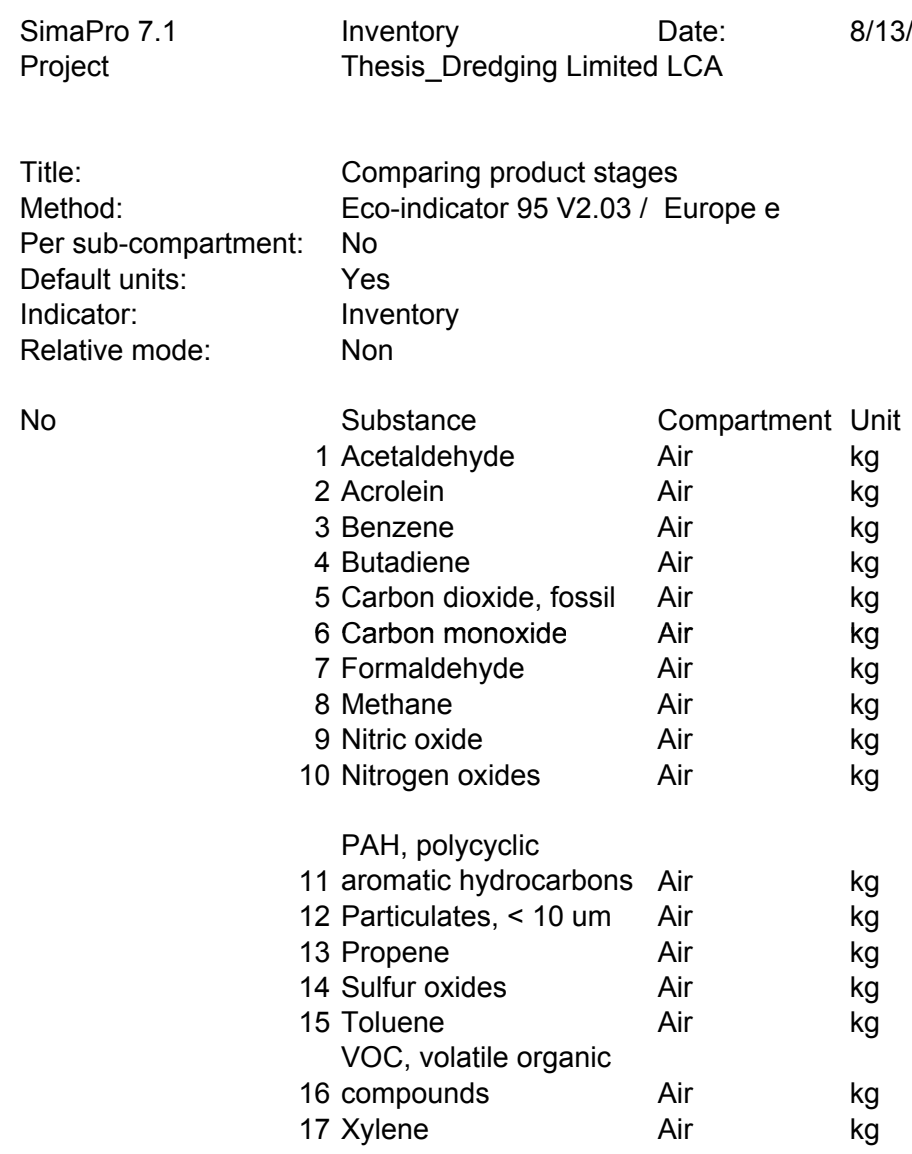

$\begin{array}{rrrrrr}\text { CPD_20k_1.9_Avg } & \text { CPD_20k_1.9_High } & \text { CPD_20k_1.9_Low } & \text { MBD_20k_1.9_Avg } & \text { MBD_20k_1.9_High } & \text { MBD_20k_1.9_Low } \\ \text { 2.043433762 } & 1.200481275 & 4.19678022 & 2.125507678 & 1.335444064 & 3.632744421 \\ 0.246754266 & 0.144963777 & 0.506781008 & 0.256665078 & 0.16126117 & 0.438671024 \\ 2.486820333 & 1.460963061 & 5.107402343 & 2.58670274 & 1.625210229 & 4.420981418 \\ 0.104485009 & 0.061383099 & 0.214590083 & 0.108681619 & 0.068284027 & 0.185749762 \\ 433747.7325 & 254819.1385 & 890825.9901 & 451169.0826 & 283466.9005 & 771101.4101 \\ 2255.488209 & 1325.05952 & 4632.295148 & 2346.07923 & 1474.027882 & 4009.727332 \\ 3.161539028 & 1.857348387 & 6.493131661 & 3.288521313 & 2.066158741 & 5.6204725 \\ 21.59099824 & 12.68433045 & 44.34333817 & 22.45819433 & 14.11035238 & 38.38371464 \\ 8501.455557 & 4994.455114 & 17460.18941 & 8842.914019 & 5555.951249 & 15113.58764 \\ 10.91116518 & 6.410116994 & 22.40922268 & 11.34940892 & 7.130767363 & 19.39748436 \\ & & & & & \\ 0.449169874 & 0.263879375 & 0.922499803 & 0.46721065 & 0.293545724 & 0.798518349 \\ 266.0319426 & 156.2890716 & 546.3732739 & 276.7170373 & 173.859699 & 472.9421982 \\ 6.901408366 & 4.054455625 & 14.17403131 & 7.178601403 & 4.51027335 & 12.26908021 \\ 96.388385 & 56.62647522 & 197.9613311 & 100.2597961 & 62.99264455 & 171.3558689 \\ 1.093044286 & 0.642144229 & 2.244881495 & 1.136946088 & 0.714336589 & 1.943175553 \\ 217.8377501 & 127.975834 & 447.3926084 & 226.5871393 & 142.3633767 & 387.2642637 \\ 0.761468242 & 0.447349154 & 1.563894516 & 0.792052389 & 0.497641892 & 1.353711364\end{array}$




\begin{tabular}{|c|c|}
\hline SimaPro 7.1 & Inventory \\
\hline Project & Thesis_Dredging Limited LCA \\
\hline Title: & Comparing product stages \\
\hline Method: & Eco-indicator 95 V2.03 / Europe e \\
\hline Per sub-compartment: & No \\
\hline Default units: & Yes \\
\hline Indicator: & Inventory \\
\hline Relative mode: & Non \\
\hline
\end{tabular}

No

$\begin{array}{lll}\text { Substance } & \text { Compartment } & \text { Unit } \\ 1 \text { Acetaldehyde } & \text { Air } & \mathrm{kg} \\ 2 \text { Acrolein } & \text { Air } & \mathrm{kg} \\ 3 \text { Benzene } & \text { Air } & \mathrm{kg} \\ 4 \text { Butadiene } & \text { Air } & \mathrm{kg} \\ 5 \text { Carbon dioxide, fossil } & \text { Air } & \mathrm{kg} \\ 6 \text { Carbon monoxide } & \text { Air } & \mathrm{kg} \\ 7 \text { Formaldehyde } & \text { Air } & \mathrm{kg} \\ 8 \text { Methane } & \text { Air } & \mathrm{kg} \\ 9 \text { Nitric oxide } & \text { Air } & \mathrm{kg} \\ 10 \text { Nitrogen oxides } & \text { Air } & \mathrm{kg}\end{array}$

$\mathrm{PAH}$, polycyclic

11 aromatic hydrocarbons Air

12 Particulates, < 10 um Air

13 Propene

14 Sulfur oxides

15 Toluene

VOC, volatile organic

16 compounds

17 Xylene

$\begin{array}{ll}\text { Air } & \mathrm{kg} \\ \text { Air } & \mathrm{kg} \\ \text { Air } & \mathrm{kg} \\ \text { Air } & \mathrm{kg} \\ \text { Air } & \mathrm{kg} \\ & \\ \text { Air } & \mathrm{kg} \\ \text { Air } & \mathrm{kg}\end{array}$

CPD_20k_2.3_Avg CPD_20k_2.3_High CP

2.430628399
0.293509844
2.958028901
0.124283075
515935.2734
2682.863422
3.760594882
25.68211139
10112.33136
12.97863843

0.171264878

1.726028851

0.072519972

301051.5438

1565.468028

2.194331253

14.98567685

5900.610259

7.573118836

0.534279639

316.440301

8.209103462

114.652283

1.300156889

259.1141595

0.905753036
0.311755599

184.6449469

4.790064564

66.90034308

0.75864989

151.1947754

0.52851271
$20 k$ 2.3_Low MBD
5.016798168
0.605802043 5.016798168
0.605802043

6.105348714

0.256519303

1064886.404

5537.409299

7.761838676

53.00767876

20871.77351

26.78780909

1.102749031

653.1303276

16.94352589

236.641423

2.683513737

534.8096161

1.869467242 20k_2.3_Avg MBD_20 0.261002147

2.630412265

0.110518097

458792.8369

2385.722752

3.344090011

22.83768788

8992.339603

11.5411887

0.475105471

281.3929399

7.299903804

101.9539637

1.156157949

230.4159581

0.805436314
1.371360418

0.165598239

1.668919754

0.070120504

291090.6547

1513.671405

2.121727439

14.48984592

5705.376833

7.322547137

0.301440545

178.5356016

4.631575751

64.68681216

0.73354845

146.1921955

0.511025816
20k_2.3_Low $3 . \overline{6} 686 \overline{6} 0774$ .443008094 4.464690942 0.18758624 778725.1644 4049.370855 5.676041198 38.76320818 15263.01322 19.58926413

0.80641317 477.6181008 12.39038262 173.0500365 1.962387414

391.0930825 1.367095289 


$\begin{array}{llll}\text { SimaPro 7.1 } & \text { Inventory } \quad \text { Date: } & \text { 8/13/2008 Time: } & \text { 3:04:28 PM } \\ \text { Project } & \text { Thesis_Dredging Limited LCA } & \end{array}$

Title:

Method:

Per sub-compartment:

Default units:

Indicator:
Comparing product stages

Eco-indicator 95 V2.03 / Europe e

No

Yes

Inventory

Non

\section{Substance}

1 Acetaldehyde

2 Acrolein

3 Benzene

4 Butadiene

5 Carbon dioxide, fossil

6 Carbon monoxide

7 Formaldehyde

8 Methane

9 Nitric oxide

10 Nitrogen oxides

$\begin{array}{ll}\text { Compartment } & \text { Unit } \\ \text { Air } & \mathrm{kg} \\ \text { Air } & \mathrm{kg} \\ \text { Air } & \mathrm{kg} \\ \text { Air } & \mathrm{kg} \\ \text { Air } & \mathrm{kg} \\ \text { Air } & \mathrm{kg} \\ \text { Air } & \mathrm{kg} \\ \text { Air } & \mathrm{kg} \\ \text { Air } & \mathrm{kg} \\ \text { Air } & \mathrm{kg}\end{array}$

$\mathrm{PAH}$, polycyclic

11 aromatic hydrocarbons Air

12 Particulates, < 10 um Air

13 Propene

14 Sulfur oxides

15 Toluene

VOC, volatile organic

16 compounds

17 Xylene

$\begin{array}{ll}\text { Air } & \mathrm{kg} \\ \text { Air } & \mathrm{kg} \\ \text { Air } & \mathrm{kg} \\ \text { Air } & \mathrm{kg} \\ \text { Air } & \mathrm{kg} \\ & \\ \text { Air } & \mathrm{kg} \\ \text { Air } & \mathrm{kg}\end{array}$

CPD_20k_3.0_Avg CPD_2

$$
\begin{array}{r}
3.197324747 \\
0.386092045 \\
3.89108389 \\
0.16348585 \\
678677.4227 \\
3529.122598 \\
4.946804325 \\
33.78305393 \\
13302.07748 \\
17.07250761
\end{array}
$$

0.702808175

416.2554859

10.79851188

150.817205

1.710267105

340.8468834

1.19145592

$$
\begin{aligned}
& 1.8 \\
& 0.2 \\
& 2.25 \\
& 0.09 \\
& 39 \\
& 20 \\
& 2.8 \\
& 19 \\
& 76 \\
& 9.87 \\
& \\
& \\
& 0.40 \\
& 24 \\
& 6.24 \\
& 87 \\
& 0.98 \\
& \\
& 197 \\
& 0.68
\end{aligned}
$$

20k_3.0_High CPD_2Ok

850293211 6.638611444

$\quad 0.801643646$

8.079064871

8.079064871
0.339445981

1409139.222

7327.523953

10.27105922

70.14381904

27619.12875

35.44767998

0.406715394

240.8872293

6.249103486

87.27798165

0.989732312

197.2482385

0.689496055
1.45924195

864.272056

22.42097073

313.1420493

3.551030839

707.7010313

2.473822189

20k_3.0_Avg MBD_2
2.22426563
0.268590567
2.706889304
0.113731318
472131.8554
2455.085648
3.441316635
23.50167458
9253.784365
11.87673912

$$
\begin{array}{r}
1.434 \\
0.173 \\
1.745 \\
0.073 \\
3044 \\
1583 \\
2.218 \\
15.15 \\
5966 \\
7.658
\end{array}
$$
1.434202016 $3 . \overline{731502373}$ $\quad 0.450596513$ $1.745396793 \quad 4.541167982$ $0.073333726 \quad 0.190799461$ $304429.6732 \quad 792064.1829$ $1583.034301 \quad 4118.733751$ $2.218954063 \quad 5.773267822$ $15.15383262 \quad 39.42719488$ $5966.821596 \quad 15524.45798$ $7.658097558 \quad 19.92481456$

0.488918766 289.5742046

7.51214241

104.9181901

0.315253839

186.7168663

4.843814356

67.6510385

0.767162777

237.1151096

0.828853702

152.891347 0.534443204

0.820226465 485.7993655 12.60262122 176.0142629 1.996001741

397.7922341 1.390512677 
SimaPro 7.1

Project

Inventory

Thesis_Dredging Limited LCA

Comparing product stages

Title:

Eco-indicator 95 V2.03 / Europe e

Method:

No

Default units:

Indicator:

Relative mode:

No
Yes

Inventory

Non tance

1 Acetaldehyde

2 Acrolein

3 Benzene

5 Carbon dioxide, fossil

6 Carbon monoxide

7 Formaldehyde

8 Methane

9 Nitric oxide

10 Nitrogen oxides

$\mathrm{PAH}$, polycyclic

1 aromatic hydrocarbons Air

12 Particulates, < 10 um

13 Propene

14 Sulfur oxides

15 Toluene

VOC, volatile organic

16 compounds

17 Xylene

Compartment Unit

Air

Air

Air

Air

Air

Air

Air

$\mathrm{kg}$

8/13/2008 Time:

2:26:42 PM
CPD_100k_1.5_Avg CPD_100k_1.5_High CPD_100k_1.5_Low MBD_10

7.814234948
0.94360573

0.399558051

8625.146122

12.08994841

82.56550134

32510.16615

41.72506586

1.717657305

1017.324927

26.39147275

368.5959881

4.179878505

833.0269332

2.911908306
$4.446559947 \quad 16.41737957$

.536943088

5.411379558

0.227361839

943845.2717

4907.995413

6.879583314

46.98252019

18499.36733

23.74295217

0.977404215

578.8917667

15.01762699

2.378490085

474.0200698

1.65697281
1.982476024

19.97964118

0.839454691

3484821.135

18121.0699

25.40047405

173.4666521

68302.49425

87.66261167

3.608725887

2137.356963

55.44737629

774.4046967

8.781749261

1750.154615

6.117797104
$100 k \_1.5 \_$Avg MBD_100k
10.16447226

1.227407971

12.36997096

0.519730563

2157553.074

11219.27598

15.72616463

107.3981975

42288.04025

54.27444621

2.234266072

1323.299219

34.32906669

479.4562386

5.437033746

1083.571099

3.787704285

$$
\begin{array}{r}
100 \mathrm{k} \\
6.2 \\
0.7 \\
7.5 \\
0.31 \\
13 \\
68 \\
9.6 \\
65 \\
2 \\
33 \\
\\
1 . \\
80 \\
20 . \\
29 \\
3.323 \\
66 \\
2.315
\end{array}
$$

00k_1.5_High MBD_100k_1.5_Low $6.214154191 \quad 17.70055981$ 2.137426091 7.562508403 $\begin{array}{lr}7.562508403 & 0.90506636\end{array}$ $1319042.163 \quad 3757194.3$ $6859.019249 \quad 19537.41036$ 27.38577178 187.0247829 $25853.2264 \quad 73641.00827$ $33.18123842 \quad 94.51430994$

1.36594144 809.0125268 20.98742642 293.1204807 3.323986251 2.315651798
3.89078343 2304.412504 59.78113597

34.9320666 9.468129635

1886.946471 6.595963326 
SimaPro 7.1

Project

Inventory

Thesis_Dredging Limited LCA

Comparing product stages

Title:

Eco-indicator 95 V2.03 / Europe e

Method:

No

Default units:

Indicator:

Relative mode:

No
Yes

Inventory

Non stance

1 Acetaldehyd

2 Acrolein

3 Benzene

5 Carbon dioxide, fossil

6 Carbon monoxide

7 Formaldehyde

8 Methane

9 Nitric oxide

10 Nitrogen oxides

Compartment Unit

Air

Air

Air

Air

Air

Air

Air

Air

PAH, polycyclic

11 aromatic hydrocarbons Air

12 Particulates, < 10 um

13 Propene

14 Sulfur oxides

15 Toluene

VOC, volatile organic

16 compounds

17 Xylene $\mathrm{kg}$

$\mathrm{kg}$

$\mathrm{kg}$

$\mathrm{kg}$

$\mathrm{kg}$

$\mathrm{kg}$

$\mathrm{kg}$

$\mathrm{kg}$
$\mathrm{kg}$

\section{$\mathrm{kg}$}

$\mathrm{kg}$

$\mathrm{kg}$

$\mathrm{kg}$

$\mathrm{kg}$
/13/2008 Time:

2:30:19 PM

$\begin{array}{rrrrrr}\text { CPD_100k_1.9_Avg } & \text { CPD_100k_1.9_High } & \text { CPD_100k_1.9_Low } & \text { MBD_100k_1.9_Avg } & \text { MBD_100k_1.9_High } & \text { MBD_100k_1.9_Low } \\ 9.750304296 & 5.53558994 & 20.51722891 & 10.34410211 & 6.393784039 & 17.88018966 \\ 1.177395236 & 0.668448597 & 2.47755217 & 1.249099122 & 0.772079582 & 2.159117242 \\ 11.86593636 & 6.736708512 & 24.96908047 & 12.58857709 & 7.781114538 & 21.75985345 \\ 0.498553295 & 0.283046203 & 1.049088497 & 0.52891541 & 0.326927448 & 0.914251207 \\ 2069640.063 & 1175007.299 & 4355072.174 & 2195682.051 & 1357171.14 & 3795323.277 \\ 10762.12833 & 6110.037953 & 22646.37531 & 11417.54667 & 7057.28993 & 19735.68104 \\ 15.08537646 & 8.564497643 & 31.74363718 & 16.00408251 & 9.892269646 & 27.66368966 \\ 103.0220831 & 58.4892522 & 216.7858149 & 109.2961732 & 67.55696343 & 188.9227587 \\ 40564.94523 & 23030.14305 & 85359.41461 & 43035.3682 & 26600.55435 & 74388.33623 \\ 52.06294558 & 29.55796138 & 109.55426 & 55.23360182 & 34.14039402 & 95.47346554 \\ & & & & & \\ 2.143227265 & 1.216785336 & 4.509919185 & 2.273750746 & 1.405426114 & 3.930268104 \\ 1269.379239 & 720.6711431 & 2671.110934 & 1346.684991 & 832.3982995 & 2327.798276 \\ 32.930273 & 18.69567168 & 69.29403726 & 34.93574108 & 21.59410081 & 60.38781036 \\ 459.920014 & 261.112733 & 967.7938165 & 487.9293447 & 301.5935868 & 843.4051726 \\ 5.215492959 & 2.961018392 & 10.97478188 & 5.533118769 & 3.420071274 & 9.564214658 \\ 1039.419232 & & & & & \\ 3.63336811 & 2.062790591 & 7.64557115 & 3.854641823 & 2.382589335 & 6.662900864\end{array}$


Substance

1 Acetaldehyde

2 Acrolein

3 Benzene

5 Carbon dioxide, fossil

6 Carbon monoxide

7 Formaldehyde

8 Methane

9 Nitric oxide

10 Nitrogen oxides

$\mathrm{PAH}$, polycyclic

11 aromatic hydrocarbons Air

12 Particulates, < 10 um

13 Propene

14 Sulfur oxides

15 Toluene

VOC, volatile organic

16 compounds

17 Xylene
CPD_100k_2.3_Avg CPD_100k

$\begin{array}{ccc}\text { 11.68632556 } & \text { CPD_100k_2.3_High } & \text { CPD_100k_2.3_Low MBD_10 } \\ 6.624619933 & 24.61712633\end{array}$ 11.68632556

14.22203771 0.799954105

0.597546081 8.062037466

0.338730566

2480587.973

12899.05746

18.08073012

123.4781569

48619.52428

62.40056858

7312.080492

10.24941197

69.9959842

27560.91878

35.37297059

2.568786657

1521.42729
39.46891087

551.2417719

6.251081693

1.456166457

862.4505196

22.37371638

312.4820723

3.5435467

1245.806404

4.354809998
706.2094834 2.468608371
2.972634123

29.95857827

1.258724761

5225333.419

27171.73378

38.0868747

260.1054857

102416.535

131.4461651

5.411123052

3204.871164

83.14086062

1161.185204

13.16784022

2624.278561

9.173363113

\subsection{9}

1.270790274

12.80718323

0.538100257

2233811.028

11615.81735

16.28200038

111.194149

43782.69615

56.19275742

2.31323542

1370.070764

35.54241547

496.4024507

5.629203791

1121.869539

3.921579361 k 2.3 High MBD_100k 2.3 Low

$6.573413887 \quad 18.05981951$

$0.793770734 \quad 2.180808393$

$7.999720674 \quad 21.97845959$

$\begin{array}{ll}7.336112295 & 0.923436054\end{array}$

$1395300.118 \quad 3833452.254$

$7255.560611 \quad 19933.95172$

$10.17018752 \quad 27.94160754$

$69.45493919 \quad 190.8207344$

$27347.8823 \quad 75135.66418$

$35.09954962 \quad 96.43262115$

$1.444910788 \quad 3.969752779$

$355.7840721 \quad 2351.184049$
22.2007752

$22.2007752 \quad 60.99448475$

$310.0666928 \quad 851.8782787$

$3.516156296 \quad 9.66029968$

700.7507257

2.449526873

1925.24491

6.729838401 
Substance

1 Acetaldehyde

2 Acrolein

3 Benzene

5 Carbon dioxide, fossil

6 Carbon monoxide

7 Formaldehyde

8 Methane

9 Nitric oxide

10 Nitrogen oxides

$\mathrm{PAH}$, polycyclic

11 aromatic hydrocaron

12 Particulates, < 10 um

13 Propene

14 Sulfur oxides

15 Toluene

VOC, volatile organic

16 compounds

17 Xylene

Compartment Unit

Air

Air
Air

Air

Air

Air

Air

Air

Air

$\mathrm{kg}$
$\mathrm{kg}$
$\mathrm{kg}$
$\mathrm{kg}$
$\mathrm{kg}$
$\mathrm{kg}$
$\mathrm{kg}$
$\mathrm{kg}$
$\mathrm{kg}$
$\mathrm{kg}$

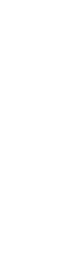

$$
\begin{gathered}
\text { 100k_3.0_Avg } \\
15.51341256 \\
1.873317743 \\
18.87953037 \\
0.793232982 \\
3292941.344 \\
17123.29499 \\
24.00188358 \\
163.9153025 \\
64541.65035 \\
82.83576893
\end{gathered}
$$

3.410023703

2019.670691

52.39435561

731.7647432

8.298212188

1653.78832

5.780941471
CPD_100k_3.0_High CPD_100k_3.0_Low MBD_10
8.778062553 .778062553

1.059992459
10.6827365

0.448840557

1863267.995

9688.993572

13.58115338

92.74934018

36520.0527

46.87154156

1.929517523

1142.80437

29.64666409

414.0595544

4.695435347

935.7745929

3.27107048
32.71965372

3.951052525

1.673023803

6945209.516

36115.08948

50.62286047

345.7170959

136126.1065

174.7106038

7.192150299

4259.728503

110.5060003

17.50192798

3488.038557

12.19270115

\section{k_3.0_Avg MBD_100k \\ 0.83808419}

1.308749789

3.18974397

0.554173739

2300536.738

11962.79104

16.76835667

114.5156065

45090.52007

57.87127973

2.3823336

1410.995866

36.60409566

511.2303863

5.79735258

1155.380673

4.038720052
3.0_High MBD_100k_3.0_Low

$0.831730249 \quad 2.218767908$

$8.382281411 \quad 22.36102033$

$0.352185777 \quad 0.939509536$

$1462025.828 \quad 3900177.964$

$7602.534303 \quad 20280.92541$

$10.65654381 \quad 28.42796383$

$\begin{array}{ll}72.77639675 & 194.142192\end{array}$

$28655.70622 \quad 76443.48809$

$36.77807193 \quad 98.11114345$

1.514008968

896.7091742

23.26245539

324.8946283

3.684305085

734.2618601

2.566667564
4.038850958

2392.109151

2.05616494

40.7062142

9.828448469

1958.756044

6.846979092 
SimaPro 7.1

Project

Title:

Method:

Indicator:

Skip categories:

Relative mode:

Impact category Unit

Total

greenhouse

acidification

eutrophication

carcinogens

winter smog

summer smog

Non

$\mathrm{Pt}$

$\mathrm{Pt}$

$\mathrm{Pt}$

$\mathrm{Pt}$

$\mathrm{Pt}$

$\mathrm{Pt}$
Impact assessment Date:

Thesis_Dredging Limited LCA

Comparing product stages

Eco-indicator 95 V2.03 / Europe e

Single score

With result $=0$
$8 / 13 / 2008$

Time:

2:42:38 PM
CPD 1k 1.5 Avg CPD 1k 1.5 High CPD 1k 1.5 Low MBD 1k 1.5 Avg MBD 1k 1.5 High MBD 1k 1.5 Low $128.3165055 \quad 106.0172121 \quad 185.3071282 \quad 113.8219648$ 7.866416342

77.43349747

21.12794545

18.77744549

1.820492735

1.290707978
6.499362857

63.97683207

17.45625682

15.514235

1.504121107

1.066404209
11.36021446

111.8248895

30.51173254

27.11727915

2.629048222

1.863964327
6.977831577

68.68666496

18.74134784

16.65635867

1.614851177
1.144910528
87.6680792

5.374473131

52.90391883

14.4349816

12.82907894

1.243792454

0.881834249
$163.7 \overline{7} 2382$

10.04003138

98.82959545

26.96593038

23.96595016

2.323523622
1.647350973 
SimaPro 7.1

Project

Title:

Method:

Indicator:

Skip categories:

Relative mode:

Impact category Unit

Total

greenhouse

acidification

eutrophication

carcinogens

winter smog

summer smog

Non

$\mathrm{Pt}$

Pt

$\mathrm{Pt}$

$\mathrm{Pt}$

$\mathrm{Pt}$
Impact assessment Date:

Thesis_Dredging Limited LCA

Comparing product stages

Eco-indicator 95 V2.03 / Europe e

Single score

With result $=0$
$8 / 13 / 2008$

Time:

2:45:43 PM

CPD $1 \mathrm{k} 19$ 141.1545272

8.653448563

85.18069198

23.24178905

20.65612238

2.0026324

1.419842863
113.2166982

6.940725839

68.32141261

18.64168772

16.56778582

1.606263947

1.138822283
CPD 1k 1.9 Low MBD 1k 1.9 Avg MBD 1k 1.9 High MBD 1k 1.9 Low $212.48041 \quad 115.0006417 \quad 88.84675614$ $\begin{array}{lll}13.02606678 & 7.050090118 & 5.446731673\end{array}$ $128.2227974 \quad 69.39794585 \quad 53.61519971$ $34.98594741 \quad 18.93542281 \quad 14.62905657$ $31.09373421 \quad 16.82884266 \quad 13.00156293$ $3.014569647 \quad 1.631573677 \quad 1.260514954$ $2.137294493 \quad 1.156766584 \quad 0.893690306$
164.9510589

10.11228993

99.54087634

27.16000535

24.13843415 2.340246122

1.659207029 
SimaPro 7.1

Project

Title:

Method:

Indicator:

Skip categories:

Relative mode:

Impact category Unit

Total

greenhouse

acidification

eutrophication

carcinogens

winter smog

summer smog

Non

$\mathrm{Pt}$

$\mathrm{Pt}$

$\mathrm{Pt}$

$\mathrm{Pt}$

$\mathrm{Pt}$
Impact assessment Date:

Thesis_Dredging Limited LCA

Comparing product stages

Eco-indicator 95 V2.03 / Europe e

Single score

With result $=0$
$8 / 13 / 2008$

Time:

2:48:38 PM

CPD_1k_2.3_Avg CPD 153.9606929

9.43852785

92.90866268

25.35038738

22.53013755

2.184320106

1.548657314

\begin{abstract}
120.4480405
7.384041755

72.68521696

19.83236389

17.62599836

1.708858746

1.211560791
\end{abstract}

PD_1k_2.3_Low MBD_1k_2.3_Avg MBD_ $239.6536918 \quad 116.1793186$ $14.6919191 \quad 7.122348659$ $144.6207054 \quad 70.10922673$ $39.46016227 \quad 19.12949778$ $35.07018928 \quad 17.00132664$ $3.400091073 \quad 1.648296177$

$2.410624658 \quad 1.168622641$ k 2.3 High MBD 1k 2.3 Low 90.02543308 5.518990214

54.3264806 14.82313154

13.17404691

1.277237455

0.905546362
166.1297358

10.18454847

100.2521572

27.35408032

24.31091813

2.356968622

1.671063085 
SimaPro 7.1

Project

Title:

Method:

Indicator:

Skip categories:

Relative mode:

Impact category Unit

Total

greenhouse

acidification

eutrophication

carcinogens

winter smog

summer smog

Non

$\mathrm{Pt}$

$\mathrm{Pt}$

Pt

$\mathrm{Pt}$

$\mathrm{Pt}$

$\mathrm{Pt}$
Impact assessment Date:

Thesis_Dredging Limited LCA

Comparing product stages

Eco-indicator 95 V2.03 / Europe e

Single score

With result $=0$
$8 / 13 / 2008$

Time:

2:51:57 PM

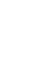

$\begin{array}{rrrrrr}\text { CPD_1k_3.0_Avg } & \text { CPD_1k_3.0_High } & \text { CPD_1k_3.0_Low } & \text { MBD_1k_3.0_Avg } & \text { MBD_1k_3.0_High } & \text { MBD_1k_3.0_Low } \\ \text { 180.4012836 } & 135.7708407 & 294.4143852 & 118.2818234 & 92.12793788 & 168.2322407 \\ 11.0594627 & 8.323402793 & 18.04901188 & 7.251242274 & 5.647883829 & 10.31344208 \\ 108.8644231 & 81.93186847 & 177.6664309 & 71.37799804 & 55.59525191 & 101.5209285 \\ 29.70396104 & 22.35533851 & 48.4767805 & 19.47568556 & 15.16931933 & 27.7002681 \\ 26.39937284 & 19.86829014 & 43.08370189 & 17.30900077 & 13.48172104 & 24.61859226 \\ 2.559446464 & 1.92625125 & 4.177009397 & 1.678125502 & 1.30706678 & 2.386797947 \\ 1.814617498 & 1.365689524 & 2.96145063 & 1.189771282 & 0.926695003 & 1.692211726\end{array}$




\begin{tabular}{|c|c|c|c|c|c|c|c|}
\hline $\begin{array}{l}\text { SimaPro } 7.1 \\
\text { Project }\end{array}$ & $\begin{array}{l}\text { Impact assessment } \\
\text { Thesis_Dredging Limi }\end{array}$ & $\begin{array}{l}\text { Date: } \\
\text { ited LCA }\end{array}$ & $8 / 13 / 2008$ & Time: & 3:07:18 PM & & \\
\hline $\begin{array}{l}\text { Title: } \\
\text { Method: } \\
\text { Indicator: } \\
\text { Skip categories: } \\
\text { Relative mode: }\end{array}$ & $\begin{array}{l}\text { Comparing product st } \\
\text { Eco-indicator } 95 \mathrm{~V} 2.0 \\
\text { Single score } \\
\text { With result = } 0 \\
\text { Non }\end{array}$ & $\begin{array}{l}\text { ages } \\
3 \text { / Europe e }\end{array}$ & & & & & \\
\hline Impact category & Unit & CPD_5k_1.5_Avg & CPD_5k_1.5_High & CPD_5k_1.5_Low & MBD_5k_1.5_Avg & MBD_5k_1.5_High & MBD_5k_1.5_Low \\
\hline Total & $\mathrm{Pt}$ & 332.323184 & 220.7630047 & $61 \overline{7} .3081536$ & 381.3179172 & 250.452921 & 630.9744349 \\
\hline greenhouse & $\mathrm{Pt}$ & 20.3730028 & 13.53382951 & 37.84394634 & 23.3766146 & 15.35396358 & 38.68175484 \\
\hline acidification & $\mathrm{Pt}$ & 200.5427621 & 133.2209875 & 372.5189459 & 230.1089783 & 151.1375762 & 380.7659594 \\
\hline eutrophication & $\mathrm{Pt}$ & 54.71865118 & 36.34971747 & 101.6428319 & 62.78587563 & 41.23830862 & 103.8930525 \\
\hline carcinogens & $\mathrm{Pt}$ & 48.63115972 & 32.30578382 & 90.33498974 & 55.80089933 & 36.6505155 & 92.3348716 \\
\hline winter smog & $\mathrm{Pt}$ & 4.714841164 & 3.132079109 & 8.758070559 & 5.409954824 & 3.553305332 & 8.95196117 \\
\hline summer smog & $\mathrm{Pt}$ & 3.342767039 & 2.220607321 & 6.209369217 & 3.835594464 & 2.519251769 & 6.346835385 \\
\hline
\end{tabular}




\begin{tabular}{|c|c|c|c|c|c|c|c|}
\hline $\begin{array}{l}\text { SimaPro } 7.1 \\
\text { Project }\end{array}$ & $\begin{array}{l}\text { Impact assessment } \\
\text { Thesis_Dredging Limi }\end{array}$ & $\begin{array}{l}\text { Date: } \\
\text { ited LCA }\end{array}$ & $8 / 13 / 2008$ & Time: & 3:10:03 PM & & \\
\hline $\begin{array}{l}\text { Title: } \\
\text { Method: } \\
\text { Indicator: } \\
\text { Skip categories: } \\
\text { Relative mode: }\end{array}$ & $\begin{array}{l}\text { Comparing product st } \\
\text { Eco-indicator } 95 \mathrm{~V} 2.0 \\
\text { Single score } \\
\text { With result = } 0 \\
\text { Non }\end{array}$ & $\begin{array}{l}\text { ages } \\
3 \text { / Europe e }\end{array}$ & & & & & \\
\hline Impact category & Unit & CPD_5k_1.9_Avg & CPD_5k_1.9_High & CPD_5k_1.9_Low & MBD_5k_1.9_Avg & MBD_5k_1.9_High & MBD_5k_1.9_Low \\
\hline Total & $\mathrm{Pt}$ & 396.4495806 & 256.8241477 & 753.1427066 & 387.2750141 & 256.410018 & 636.9315318 \\
\hline greenhouse & $\mathrm{Pt}$ & 24.30425804 & 15.74455029 & 46.171255 & 23.74181318 & 15.71916215 & 39.04695341 \\
\hline acidification & $\mathrm{Pt}$ & 239.240287 & 154.9823378 & 454.489262 & 233.7038304 & 154.7324283 & 384.3608114 \\
\hline eutrophication & $\mathrm{Pt}$ & 65.27737863 & 42.28736252 & 124.008661 & 63.76674102 & 42.21917401 & 104.8739179 \\
\hline carcinogens & $\mathrm{Pt}$ & 58.01522073 & 37.58286135 & 110.2126033 & 56.6726427 & 37.52225887 & 93.20661497 \\
\hline winter smog & $\mathrm{Pt}$ & 5.624635571 & 3.643697226 & 10.68522573 & 5.494471245 & 3.637821753 & 9.03647759 \\
\hline summer smog & $\mathrm{Pt}$ & 3.987800594 & 2.583338561 & 7.57569961 & 3.895515614 & 2.579172919 & 6.406756535 \\
\hline
\end{tabular}


SimaPro 7.1

Project

Title:

Method:

Indicator:

Skip categories:

Relative mode:

Impact category Unit

Total

greenhouse

acidification

eutrophication

carcinogens

winter smog

summer smog

Non

$\mathrm{Pt}$

$\mathrm{Pt}$

$\mathrm{Pt}$

$\mathrm{Pt}$

$\mathrm{Pt}$
Impact assessment Date:

Thesis_Dredging Limited LCA

Comparing product stages

Eco-indicator 95 V2.03 / Europe e

Single score

With result $=0$
$8 / 13 / 2008$

Time:

3:12:36 PM

CPD 5k 2.3 A 460.5759772 28.23551328

277.9378119

75.83610609

67.39928175

6.534429979

4.632834149
-5k_2.3_High CP 17.957224

176.7629119

48.23025283

42.86460061

4.155767302

2.946390234
5k_2.3_Low 888.9454034 54.49661073

536.4403542

146.3692447

130.0855552

12.61192894

8.941709568
_5k_2.3_Avg MBD_5 393.2321111 24.10701175 237.2986824 64.74760641 57.54438608 5.578987665

3.955436764
$5 \mathrm{k} 2.3$ High MBD 5k 2.3 Low 262.3671149 16.08436072

158.3272803

43.20003941

38.39400225

3.722338173

2.639094069
642.8886288

39.41215199 387.9556635 105.8547833

94.07835834

9.120994011

6.466677685 
SimaPro 7.1

Project

Title:

Method:

Indicator:

Skip categories:

Relative mode:

Impact category Unit

Total

greenhouse

acidification

eutrophication

carcinogens

winter smog

summer smog

Non

$\mathrm{Pt}$

Pt

Pt

$\mathrm{Pt}$

$\mathrm{Pt}$

$\mathrm{Pt}$
Impact assessment Date:

Thesis_Dredging Limited LCA

Comparing product stages

Eco-indicator 95 V2.03 / Europe e

Single score

With result $=0$
$8 / 13 / 2008$

Time:

3:15:49 PM

CPD_5k_3.0_Avg CPD 5 588.4146406 36.07263561

355.0829523

96.88537249

86.1068013

8.348143322

5.918735618

365.2624259

22.39233609

220.4201792

60.14225981

53.45138778

5.182167253

3.67409575
PD_5k_3.0_Low MBD_

1158.416436

71.01647564

190.7389792

169.5191231

16.43505407

11.65226041
699.0545437
403.6172106

24.74366809

243.5656437

66.45756426

59.06410982

5.726326451

4.059898234 5k 3.0 High MBD 5k 3.0 Low

272.7522144

16.72101706

164.5942416

44.90999725

39.91372599

3.86967696

2.743555539
653.2737283

40.04880832

394.2226248

107.5647411

95.59808209

9.268332797

6.571139155 


\begin{tabular}{|c|c|c|c|c|c|c|c|}
\hline $\begin{array}{l}\text { SimaPro } 7.1 \\
\text { Project }\end{array}$ & $\begin{array}{l}\text { Impact assessment } \\
\text { Thesis_Dredging Lim }\end{array}$ & $\begin{array}{l}\text { Date: } \\
\text { iited LCA }\end{array}$ & $8 / 13 / 2008$ & Time: & 2:55:28 PM & & \\
\hline $\begin{array}{l}\text { Title: } \\
\text { Method: } \\
\text { Indicator: } \\
\text { Skip categories: } \\
\text { Relative mode: }\end{array}$ & $\begin{array}{l}\text { Comparing product s } \\
\text { Eco-indicator } 95 \mathrm{~V} 2.0 \\
\text { Single score } \\
\text { With result }=0 \\
\text { Non }\end{array}$ & $\begin{array}{l}\text { tages } \\
3 \text { / Europe e }\end{array}$ & & & & & \\
\hline Impact category & Unit & CPD_20k_1.5_Avg & CPD_20k_1.5_High & CPD_20k_1.5_Low & MBD_20k_1.5_Avg & MBD_20k_1.5_High & MBD_20k_1.5_Low \\
\hline Total & $\mathrm{Pt}$ & 1097.316372 & 651.0756551 & $22 \overline{3} 7.319963$ & 1384.435703 & 860.9757183 & $23 \overline{8} 3.061774$ \\
\hline greenhouse & $\mathrm{Pt}$ & 67.27074909 & 39.91405591 & 137.1584291 & 84.87253918 & 52.78193507 & 146.0931001 \\
\hline acidification & $\mathrm{Pt}$ & 662.1832805 & 392.896182 & 1350.126463 & 835.4474594 & 519.5618511 & 1438.075384 \\
\hline eutrophication & $\mathrm{Pt}$ & 180.6785524 & 107.2028176 & 368.3857658 & 227.9541662 & 141.7638981 & 392.3828737 \\
\hline carcinogens & $\mathrm{Pt}$ & 160.5779263 & 95.27642277 & 327.4025699 & 202.5940922 & 125.9925569 & 348.7299813 \\
\hline winter smog & $\mathrm{Pt}$ & 15.56819581 & 9.237147594 & 31.74201731 & 19.64170649 & 12.21510852 & 33.80973187 \\
\hline summer smog & $\mathrm{Pt}$ & 11.03766808 & 6.549029212 & 22.50471766 & 13.92573933 & 8.660368554 & 23.97070302 \\
\hline
\end{tabular}




\begin{tabular}{|c|c|c|c|c|c|c|c|}
\hline $\begin{array}{l}\text { SimaPro } 7.1 \\
\text { Project }\end{array}$ & $\begin{array}{l}\text { Impact assessment } \\
\text { Thesis_Dredging Limi }\end{array}$ & $\begin{array}{l}\text { Date: } \\
\text { iited LCA }\end{array}$ & $8 / 13 / 2008$ & Time: & 2:58:39 PM & & \\
\hline $\begin{array}{l}\text { Title: } \\
\text { Method: } \\
\text { Indicator: } \\
\text { Skip categories: } \\
\text { Relative mode: }\end{array}$ & $\begin{array}{l}\text { Comparing product sta } \\
\text { Eco-indicator } 95 \mathrm{~V} 2.03 \\
\text { Single score } \\
\text { With result }=0 \\
\text { Non }\end{array}$ & $\begin{array}{l}\text { tages } \\
3 \text { / Europe e }\end{array}$ & & & & & \\
\hline Impact category & Unit & CPD_20k_1.9_Avg & CPD_20k_1.9_High & CPD_20k_1.9_Low & MBD_20k_1.9_Avg & MBD_20k_1.9_High & MBD_20k_1.9_Low \\
\hline Total & $\mathrm{Pt}$ & 1353.885671 & 795.3839395 & 2780.594463 & 1408.264091 & 884.8041061 & 2406.890161 \\
\hline greenhouse & $\mathrm{Pt}$ & 82.9996759 & 48.76084489 & 170.4637579 & 86.33333347 & 54.24272937 & 147.5538944 \\
\hline acidification & $\mathrm{Pt}$ & 817.0118278 & 479.980031 & 1677.96928 & 849.8268676 & 533.9412592 & 1452.454792 \\
\hline eutrophication & $\mathrm{Pt}$ & 222.9239527 & 130.9638883 & 457.8385915 & 231.8776277 & 145.6873597 & 396.3063353 \\
\hline carcinogens & $\mathrm{Pt}$ & 198.1234939 & 116.3940563 & 406.9037008 & 206.0810657 & 129.4795304 & 352.2169548 \\
\hline winter smog & $\mathrm{Pt}$ & 19.20827736 & 11.28452398 & 39.44973407 & 19.97977217 & 12.55317421 & 34.14779756 \\
\hline summer smog & $\mathrm{Pt}$ & 13.61844317 & 8.000595036 & 27.96939836 & 14.16542393 & 8.900053153 & 24.21038762 \\
\hline
\end{tabular}




\begin{tabular}{|c|c|c|c|c|c|c|c|}
\hline $\begin{array}{l}\text { SimaPro } 7.1 \\
\text { Project }\end{array}$ & $\begin{array}{l}\text { Impact assessment } \\
\text { Thesis_Dredging Limi }\end{array}$ & $\begin{array}{l}\text { Date: } \\
\text { iited LCA }\end{array}$ & $8 / 13 / 2008$ & Time: & 3:01:10 PM & & \\
\hline $\begin{array}{l}\text { Title: } \\
\text { Method: } \\
\text { Indicator: } \\
\text { Skip categories: } \\
\text { Relative mode: }\end{array}$ & $\begin{array}{l}\text { Comparing product sta } \\
\text { Eco-indicator } 95 \mathrm{~V} 2.03 \\
\text { Single score } \\
\text { With result }=0 \\
\text { Non }\end{array}$ & $\begin{array}{l}\text { tages } \\
\text { O3 / Europe e }\end{array}$ & & & & & \\
\hline Impact category & Unit & CPD_20k_2.3_Avg & CPD_20k_2.3_High & CPD_20k_2.3_Low & MBD_20k_2.3_Avg & MBD_20k_2.3_High & MBD_20k_2.3_Low \\
\hline Total & $\mathrm{Pt}$ & 1610.423113 & 939.692224 & 3323.900818 & 1432.060622 & 908.6006377 & 2430.686693 \\
\hline greenhouse & $\mathrm{Pt}$ & 98.72664979 & 57.60763388 & 203.7710396 & 87.79217484 & 55.70157073 & 149.0127358 \\
\hline acidification & $\mathrm{Pt}$ & 971.8211513 & 567.0638799 & 2005.831321 & 864.1870519 & 548.3014436 & 1466.814976 \\
\hline eutrophication & $\mathrm{Pt}$ & 265.1641078 & 154.724959 & 547.2966624 & 235.795844 & 149.605576 & 400.2245516 \\
\hline carcinogens & $\mathrm{Pt}$ & 235.6643997 & 137.5116899 & 486.4094935 & 209.5633775 & 132.9618422 & 355.6992666 \\
\hline winter smog & $\mathrm{Pt}$ & 22.84790695 & 13.33190037 & 47.15790278 & 20.3173859 & 12.89078793 & 34.48541128 \\
\hline summer smog & $\mathrm{Pt}$ & 16.19889782 & 9.452160861 & 33.4343995 & 14.4047881 & 9.139417319 & 24.44975178 \\
\hline
\end{tabular}




\begin{tabular}{|c|c|c|c|c|c|c|c|}
\hline $\begin{array}{l}\text { SimaPro } 7.1 \\
\text { Project }\end{array}$ & $\begin{array}{l}\text { Impact assessment } \\
\text { Thesis_Dredging Lim }\end{array}$ & $\begin{array}{l}\text { Date: } \\
\text { iited LCA }\end{array}$ & $8 / 13 / 2008$ & Time: & 3:04:11 PM & & \\
\hline $\begin{array}{l}\text { Title: } \\
\text { Method: } \\
\text { Indicator: } \\
\text { Skip categories: } \\
\text { Relative mode: }\end{array}$ & $\begin{array}{l}\text { Comparing product s } \\
\text { Eco-indicator } 95 \mathrm{~V} 2.0 \\
\text { Single score } \\
\text { With result }=0 \\
\text { Non }\end{array}$ & $\begin{array}{l}\text { tages } \\
3 \text { / Europe e }\end{array}$ & & & & & \\
\hline Impact category & Unit & CPD_20k_3.0_Avg & CPD_20k_3.0_High & CPD_20k_3.0_Low & MBD_20k_3.0_Avg & MBD_20k_3.0_High & MBD_20k_3.0_Low \\
\hline Total & $\mathrm{Pt}$ & $21 \overline{18.401017}$ & 1225.919583 & $43 \overline{9} 8.4 \overline{4} 0055$ & 1473.696589 & 950.2366041 & 2472.32266 \\
\hline greenhouse & $\mathrm{Pt}$ & 129.8681282 & 75.15474183 & 269.6454412 & 90.34465899 & 58.25405488 & 151.5652199 \\
\hline acidification & $\mathrm{Pt}$ & 1278.363989 & 739.7897922 & 2654.269579 & 889.3125686 & 573.4269603 & 1491.940493 \\
\hline eutrophication & $\mathrm{Pt}$ & 348.8051749 & 201.8537053 & 724.2248471 & 242.6514112 & 156.4611432 & 407.0801188 \\
\hline carcinogens & $\mathrm{Pt}$ & 310.0003345 & 179.3973274 & 643.6542834 & 215.6562576 & 139.0547223 & 361.7921467 \\
\hline winter smog & $\mathrm{Pt}$ & 30.05485262 & 17.39275618 & 62.40294758 & 20.90809692 & 13.48149895 & 35.0761223 \\
\hline summer smog & $\mathrm{Pt}$ & 21.3085377 & 12.33125996 & 44.2429573 & 14.82359528 & 9.558224501 & 24.86855896 \\
\hline
\end{tabular}




\begin{tabular}{|c|c|c|c|c|c|c|c|}
\hline $\begin{array}{l}\text { SimaPro } 7.1 \\
\text { Project }\end{array}$ & \multicolumn{2}{|c|}{$\begin{array}{l}\text { Impact assessment Date: } \\
\text { Thesis_Dredging Limited LCA }\end{array}$} & $8 / 13 / 2008$ & Time: & 2:26:00 PM & & \\
\hline Title: & \multicolumn{7}{|c|}{ Comparing product stages } \\
\hline Method: & \multicolumn{7}{|c|}{ Eco-indicator 95 V2.03 / Europe e } \\
\hline Indicator: & \multicolumn{7}{|c|}{ Single score } \\
\hline Skip categories: & \multicolumn{7}{|l|}{ With result $=0$} \\
\hline Relative mode: & \multicolumn{7}{|l|}{ Non } \\
\hline Impact category & Unit & CPD_100k_1.5_Avg & CPD_100k_1.5_High & CPD_100k_1.5_Low & MBD_100k_1.5_Avg & MBD_100k_1.5_High $\mid$ & MBD_100k_1.5_Low \\
\hline Total & $\mathrm{Pt}$ & $51 \overline{7} 7.3 \overline{5} 4374$ & 2946.087076 & $10 \overline{8} 77.40418$ & $67 \overline{3} 4.514032$ & $4 \overline{117.214109}$ & $11 \overline{7} 27 . \overline{5} 8067$ \\
\hline greenhouse & $\mathrm{Pt}$ & 317.3966195 & 180.6092477 & 666.8369726 & 412.8579643 & 252.4049438 & 718.9568632 \\
\hline acidification & $\mathrm{Pt}$ & 3124.310901 & 1777.836961 & 6564.046039 & 4063.989846 & 2484.561804 & 7077.091019 \\
\hline eutrophication & $\mathrm{Pt}$ & 852.4769311 & 485.0877664 & 1791.018244 & 1108.870948 & 677.9196082 & 1931.003995 \\
\hline carcinogens & $\mathrm{Pt}$ & 757.6382257 & 431.1213844 & 1591.766105 & 985.508214 & 602.5005374 & 1716.178336 \\
\hline winter smog & $\mathrm{Pt}$ & 73.45380851 & 41.7976635 & 154.323368 & 95.54603924 & 58.4130494 & 166.3852622 \\
\hline summer smog & $\mathrm{Pt}$ & 52.07788798 & 29.63405277 & 109.4134563 & 67.74102023 & 41.41416633 & 117.9651978 \\
\hline
\end{tabular}




\begin{tabular}{|c|c|c|c|c|c|c|c|}
\hline $\begin{array}{l}\text { SimaPro } 7.1 \\
\text { Project }\end{array}$ & $\begin{array}{l}\text { Impact assessment } \\
\text { Thesis_Dredging Limi }\end{array}$ & $\begin{array}{l}\text { Date: } \\
\text { ited LCA }\end{array}$ & $8 / 13 / 2008$ & Time: & 2:30:08 PM & & \\
\hline $\begin{array}{l}\text { Title: } \\
\text { Method: } \\
\text { Indicator: } \\
\text { Skip categories: } \\
\text { Relative mode: }\end{array}$ & $\begin{array}{l}\text { Comparing product ste } \\
\text { Eco-indicator } 95 \mathrm{~V} 2.03 \\
\text { Single score } \\
\text { With result = } 0 \\
\text { Non }\end{array}$ & $\begin{array}{l}\text { tages } \\
3 \text { / Europe e }\end{array}$ & & & & & \\
\hline Impact category & Unit & CPD_100k_1.9_Avg & CPD_100k_1.9_High & CPD_100k_1.9_Low & MBD_100k_1.9_Avg & MBD_100k_1.9_High & MBD_100k_1.9_Low \\
\hline Total & $\mathrm{Pt}$ & 6460.105299 & $\quad 3667.628498$ & 13593.77668 & 6853.528547 & $4 \overline{23} 6 . \overline{22} 8624$ & 11846.59519 \\
\hline greenhouse & $\mathrm{Pt}$ & 396.0353947 & 224.8431926 & 833.3636165 & 420.1541241 & 259.7011036 & 726.253023 \\
\hline acidification & $\mathrm{Pt}$ & 3898.395966 & 2213.256206 & 8203.260123 & 4135.809991 & 2556.38195 & 7148.911165 \\
\hline eutrophication & $\mathrm{Pt}$ & 1063.688197 & 603.8931201 & 2238.282372 & 1128.467275 & 697.5159349 & 1950.600322 \\
\hline carcinogens & $\mathrm{Pt}$ & 945.3520781 & 536.7095523 & 1989.27176 & 1002.924435 & 619.916758 & 1733.594556 \\
\hline winter smog & $\mathrm{Pt}$ & 91.65286039 & 52.03454544 & 192.8619517 & 97.23455981 & 60.10156997 & 168.0737828 \\
\hline summer smog & $\mathrm{Pt}$ & 64.98080212 & 36.89188189 & 136.7368598 & 68.93816149 & 42.61130759 & 119.162339 \\
\hline
\end{tabular}




\begin{tabular}{|c|c|c|c|c|c|c|c|}
\hline $\begin{array}{l}\text { SimaPro } 7.1 \\
\text { Project }\end{array}$ & $\begin{array}{l}\text { Impact assessment } \\
\text { Thesis_Dredging Limi }\end{array}$ & $\begin{array}{l}\text { Date: } \\
\text { ited LCA }\end{array}$ & $8 / 13 / 2008$ & Time: & 2:33:54 PM & & \\
\hline $\begin{array}{l}\text { Title: } \\
\text { Method: } \\
\text { Indicator: } \\
\text { Skip categories: } \\
\text { Relative mode: }\end{array}$ & $\begin{array}{l}\text { Comparing product st } \\
\text { Eco-indicator } 95 \mathrm{~V} 2.0 \\
\text { Single score } \\
\text { With result = } 0 \\
\text { Non }\end{array}$ & $\begin{array}{l}\text { tages } \\
3 \text { / Europe e }\end{array}$ & & & & & \\
\hline Impact category & Unit & CPD_100k_2.3_Avg & CPD_100k_2.3_High & CPD_100k_2.3_Low & MBD_100k_2.3_Avg & MBD_100k_2.3_High & MBD_100k_2.3_Low \\
\hline Total & $\mathrm{Pt}$ & 7742.824367 & 4389.16992 & 16310.18104 & 6972.543061 & 4355.243138 & 11965.6097 \\
\hline greenhouse & $\mathrm{Pt}$ & 474.6722171 & 269.0771375 & 999.8922133 & 427.4502838 & 266.9972633 & 733.5491827 \\
\hline acidification & $\mathrm{Pt}$ & 4672.461808 & 2648.675451 & 9842.49343 & 4207.630137 & 2628.202095 & 7220.73131 \\
\hline eutrophication & $\mathrm{Pt}$ & 1274.894218 & 722.6984737 & 2685.551745 & 1148.063602 & 717.1122617 & 1970.196649 \\
\hline carcinogens & $\mathrm{Pt}$ & 1133.061269 & 642.2977202 & 2386.782076 & 1020.340655 & 637.3329785 & 1751.010777 \\
\hline winter smog & $\mathrm{Pt}$ & 109.8514603 & 62.27142737 & 231.4009875 & 98.92308038 & 61.79009054 & 169.7623034 \\
\hline summer smog & $\mathrm{Pt}$ & 77.88339583 & 44.14971102 & 164.0605838 & 70.13530275 & 43.80844885 & 120.3594803 \\
\hline
\end{tabular}




\begin{tabular}{|c|c|}
\hline SimaPro 7.1 & Impac \\
\hline Title: & \\
\hline Method: & \\
\hline Indicator: & \\
\hline Skip categories: & \\
\hline Relative mode: & $\mathrm{Nol}$ \\
\hline Impact category & Unit \\
\hline Total & $\mathrm{Pt}$ \\
\hline greenhouse & $\mathrm{Pt}$ \\
\hline acidification & $\mathrm{Pt}$ \\
\hline eutrophication & $\mathrm{Pt}$ \\
\hline carcinogens & $\mathrm{Pt}$ \\
\hline winter smog & $\mathrm{Pt}$ \\
\hline summer smog & $\mathrm{Pt}$ \\
\hline
\end{tabular}

$8 / 13 / 2008$

Time:

2:39:12 PM

hesis_Dredging Limited LCA

Comparing product stages

co-indicator 95 V2.03 / Europe e

Single score

With result $=0$

CPD_100k_3.0_Avg CPD_100k

$\begin{array}{rr}10278.47702 & 5815.942425 \\ 630.1198689 & 356.5451254 \\ 6202.61923 & 3509.67135 \\ 1692.401932 & 957.623603 \\ 1504.120933 & 851.0872506 \\ 145.826078 & 82.513788 \\ 103.3889775 & 58.50130708\end{array}$

$100 \mathrm{k}$ 3.0_Low MBD
21678.54479
1328.998622
13082.07028
3569.479312
3172.372031
307.564745
218.0597938

100k_3.0_Avg MBD
7180.818461
440.2185634
4333.315392
1182.357174
1050.819041
101.8779914
72.23029997

$\begin{array}{rr}\text { 100k_3.0_High } & \text { MBD_100k_3.0_Low } \\ 4563.518539 & 12173.8851 \\ 279.7655429 & 746.3174623 \\ 2753.88735 & 7346.416565 \\ 751.4058335 & 2004.490221 \\ 667.8113645 & 1781.489163 \\ 64.74500154 & 172.7172144 \\ 45.90344606 & 122.4544775\end{array}$




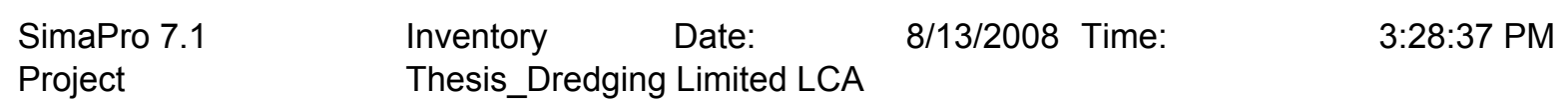

Title:

Method:

Per sub-compartment:

Skip unused:

Indicator:

Category:

Cut-off:

Relative mode:

No
Comparing product stages

Eco-indicator 95 V2.03 / Europe e

No

Yes

Characterization

acidification

$0 \%$

Non
Substance Compartment Unit

Total

1 Nitric oxide

2 Nitrogen oxides Air

3 Sulfur oxides $\mathrm{kg} \mathrm{SO} 2$

$\mathrm{kg} \mathrm{SO} 2$

$\mathrm{kg} \mathrm{SO} 2$

$\mathrm{kg} \mathrm{SO} 2$
CPD_1k_1.5_Avg CPD_1k 871.9988454

862.1396092

0.723885208

9.135350936
1k_1.5_High

712.3139572

0.598085892

7.547777536
PD_1k_1.5_Low CPD

1245.051169

1.045392318

13.19273495
CPD_1k_1.9_Avg CPD_1k_1.9_High 959.2420268

948.3963775

0.796309672

10.04933962 769.3852772

760.6862391

0.6387011

8.060336948 


\begin{tabular}{|c|c|c|c|c|c|c|c|}
\hline & & & & & & & \\
\hline $14 \overline{4} 3.9 \overline{5} 0422$ & 1046.268724 & $8 \overline{18} .5272181$ & $16 \overline{2} 8.6 \overline{1} 1548$ & $1225 . \overline{95071}$ & 922.6561765 & $20 \overline{0} 0.7 \overline{4} 8096$ & $77 \overline{3} .4984793$ \\
\hline 1427.6 & 1034.439109 & 809.2725577 & 1610.197686 & 1212.089525 & 912.2241843 & 1978.12668 & 764.75 \\
\hline 1.198 & 4422 & 0.679496021 & 1.351983223 & 1.017716468 & 938122 & 1.660910401 & 53 \\
\hline 15.12730654 & 10.96106035 & 8.575164322 & 17.06187813 & 12.84346881 & 9.666054044 & 20.9605048 & 8.103428226 \\
\hline
\end{tabular}




\begin{tabular}{|c|c|c|c|c|c|c|c|}
\hline $\begin{array}{l}\text { 1k_1.5_High } \\
595.7648517\end{array}$ & $\begin{array}{l}\text {-1k_1.5_Low } \\
1112.945895\end{array}$ & 781.5083992 & 603.7747715 & 1120.955815 & 789.518319 & 611.7846914 & 1128.965735 \\
\hline & 1100.362396 & 772.6722913 & 596.9482051 & 31752 & 780.5916472 & 7561 & 1108 \\
\hline 0.494 & 0.923906121 & 0.648765045 & 0.501220418 & 0.930555513 & 0.655414437 & 0.507869811 & 0.937204906 \\
\hline 6.241431424 & 11.65959264 & 8.18734282 & 6.325346018 & 11.74350724 & 8.271257414 & 6.409260612 & 11.82742183 \\
\hline
\end{tabular}


MBD_1k_3.0_Avg MBD_1k_3.0_High MBD_1k_3.0_Low 803.8062842 626.0726566

618.9939796

0.519730889

1143.2537

794.7180658

1130.327526

0.667275516

6.558946104

0.949065984

8.420942906

11.97710732 


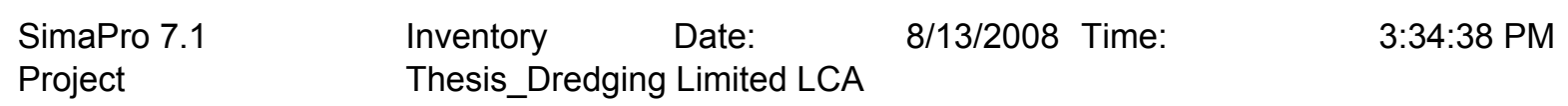

Title:

Method:

Per sub-compartment:

Skip unused:

Indicator:

Category:

Cut-off:

Relative mode:

No
Comparing product stages

Eco-indicator 95 V2.03 / Europe e

No

Yes

Characterization

acidification

$0 \%$

Non
Substance Compartment Unit

Total

1 Nitric oxide

2 Nitrogen oxides Air

3 Sulfur oxides $\mathrm{kg} \mathrm{SO} 2$

$\mathrm{kg} \mathrm{SO} 2$

$\mathrm{kg} \mathrm{SO} 2$

$\mathrm{kg} \mathrm{SO} 2$
CPD_5k_1.5_Avg CPD_5k_1.5_High CPD_5k_1.5_Low CPD_5k_1.9_Avg CPD_5k_1.9_High 2258.364438 2232.830289 1.874769238

23.65937958 1500.236345

1483.273955

1.245413231

15.71697666 4195.033174

4147.602122

3.482484499

43.94856764
2694.147376

2663.686057

2.236532129

28.22478709
1745.296597

1725.563438

1.448848696

18.28430964 


\begin{tabular}{|c|c|c|c|c|c|c|c|}
\hline 5k 1.9 Low & ( 5 & & & & & & \\
\hline $51 \overline{1} 8.1 \overline{2} 2319$ & $31 \overline{29} .930314$ & $19 \overline{9} 0 . \overline{57} 3332$ & $6 \overline{0} 40 . \overline{9} 9498$ & $39 \overline{98} .6 \overline{8} 1895$ & 2482.209226 & $78 \overline{7} 2.2 \overline{3} 5852$ & $25 \overline{9} 1.3 \overline{17} 324$ \\
\hline 5060 & 3094.541825 & 1968.066958 & 5972.692601 & 3953.470884 & 2454.144181 & 7783.228587 & 2.01865 \\
\hline 4.2487 & 2.59829502 & 1.652463875 & 5.014899884 & 3.319484528 & 2.0605928 & 6.535094764 & 07 \\
\hline 53.6191576 & 32.7901946 & 20.85391059 & 63.28747961 & 41.8915261 & 26.00445229 & 82.47217017 & 27.1475 \\
\hline
\end{tabular}




\begin{tabular}{|c|c|c|c|c|c|c|c|}
\hline 1701.999732 & 4287.904948 & 2631.799892 & $1 \overline{742.482301}$ & $43 \overline{2} 8.387516$ & 2672.28246 & $1 \overline{8} 2 . \overline{96} 4869$ & 43 \\
\hline 1682. & 4239.423843 & 2602.043503 & 1722.780962 & 4279.448696 & 2642.068356 & 1762.805815 & \\
\hline 1.412906034 & 3.559581509 & 2.184774696 & 1.446512423 & 3.593187898 & 2.218381085 & 1.480118812 & $.0 \angle 0 / y^{2}$ \\
\hline $17.8307^{\prime}$ & 44.92152333 & 27.57161403 & 18.25482614 & 45.34563223 & 27.99572293 & 18.67893503 & \\
\hline
\end{tabular}


MBD_5k_3.0_Avg MBD_5k_3.0_High MBD_5k_3.0_Low 2742.856348

2711.844302

2.276967624

1853.538757

4439.443973

$1832.581761 \quad 4389.249495$

$1.538705351 \quad 3.685380825$

28.73507854

19.41829064

46.50909673 


\begin{tabular}{|c|c|c|c|c|c|c|c|}
\hline $\begin{array}{l}\text { SimaPro } 7.1 \\
\text { Project }\end{array}$ & $\begin{array}{l}\text { Inventory } \\
\text { Thesis_Dredging }\end{array}$ & $\begin{array}{l}\text { Date: } \\
\text { Limited LCA }\end{array}$ & $8 / 13 / 2008$ & Time: & 3:31:47 PM & & \\
\hline $\begin{array}{l}\text { Title: } \\
\text { Method: } \\
\text { Per sub-compartment: } \\
\text { Skip unused: } \\
\text { Indicator: } \\
\text { Category: } \\
\text { Cut-off: } \\
\text { Relative mode: }\end{array}$ & $\begin{array}{l}\text { Comparing produ } \\
\text { Eco-indicator } 95 \\
\text { No } \\
\text { Yes } \\
\text { Characterization } \\
\text { acidification } \\
0 \% \\
\text { Non }\end{array}$ & $\begin{array}{l}\text { uct stages } \\
\text { V2.03 / Europe }\end{array}$ & & & & & \\
\hline No & $\begin{array}{l}\text { Substance } \\
\text { Total } \\
1 \text { Nitric oxide } \\
2 \text { Nitrogen oxides } \\
3 \text { Sulfur oxides }\end{array}$ & $\begin{array}{l}\text { Compartment } \\
\text { Air } \\
\text { Air } \\
\text { Air }\end{array}$ & $\begin{array}{l}\text { Unit } \\
\mathrm{kg} \mathrm{SO} 2 \\
\mathrm{~kg} \mathrm{SO} 2 \\
\mathrm{~kg} \mathrm{SO} 2 \\
\mathrm{~kg} \mathrm{SO} 2\end{array}$ & $\begin{array}{r}\text { CPD_20k_1.5_Avg } \\
7457.018925 \\
7372.706301 \\
6.190404638 \\
78.12221905\end{array}$ & $\begin{array}{r}\text { CPD_20k_1.5_High } \\
4424.506555 \\
4374.480967 \\
3.672980607 \\
46.35260736\end{array}$ & $\begin{array}{r}\text { CPD_20k_1.5_Low } \\
15204.12684 \\
15032.22171 \\
12.62162511 \\
159.2835072\end{array}$ & $\begin{array}{r}\text { CPD_20k_1.9_Avg } \\
9200.583647 \\
9096.557446 \\
7.637815627 \\
96.388385\end{array}$ \\
\hline
\end{tabular}




\begin{tabular}{|c|c|c|c|c|c|c|c|}
\hline & & & & & & & \\
\hline 180529 & 18896.05045 & 10943.93188 & 6385.854504 & 22588.19055 & $14 \overline{395} .99087$ & 8330.966129 & 42 \\
\hline 5344.066972 & 18682.40266 & 10820.19455 & 6313.652977 & 22332.79766 & 14233.22291 & 8236.77224 & \\
\hline 4.487081896 & 15.68645588 & 9.085046904 & 5.301183185 & 18.75146636 & 11.95075533 & 6.915907266 & 4.81337 \\
\hline 56.62647522 & 197.9613311 & 114.652283 & 66.90034308 & 236.641423 & 150.817205 & 87.27798165 & 13.14 \\
\hline
\end{tabular}




$\begin{array}{rrrrrr}\text { MBD_20k_1.5_Avg } & \text { MBD_20k_1.5_High } & \text { MBD_20k_1.5_Low } & \text { MBD_20k_1.9_Avg } & \text { MBD_20k_1.9_High } & \text { MBD_20k_1.9_Low } \\ \text { 9408.192111 } & 5850.921746 & 16194.54261 & 9570.122383 & 6012.852018 & 16356.47288 \\ 9301.818589 & 5784.768426 & 16011.43936 & 9461.918 & 5944.867837 & 16171.53877 \\ 7.810160691 & 4.857111599 & 13.4438135 & 7.944586246 & 4.991537154 & 13.57823905 \\ 98.56336056 & 61.29620897 & 169.6594333 & 100.2597961 & 62.99264455 & 171.3558689\end{array}$




$\begin{array}{rrrrr}\text { MBD_20k_2.3_High } & \text { MBD_20k_2.3_Low } & \text { MBD_20k_3.0_Avg } & \text { MBD_20k_3.0_High } & \text { MBD_20k_3.0_Low } \\ \text { 6174.565806 } & 16518.18667 & 10014.78118 & 6457.510814 & 16801.13168 \\ 6104.753211 & 16331.42415 & 9901.549271 & 6384.499107 & 16611.17004 \\ 5.125782996 & 13.71248489 & 8.313717382 & 5.360668291 & 13.94737019 \\ 64.68681216 & 173.0500365 & 104.9181901 & 67.6510385 & 176.0142629\end{array}$




\begin{tabular}{|c|c|c|c|c|c|c|c|}
\hline $\begin{array}{l}\text { SimaPro } 7.1 \\
\text { Project }\end{array}$ & $\begin{array}{l}\text { Inventory } \\
\text { Thesis_Dredging }\end{array}$ & $\begin{array}{l}\text { Date: } \\
\text { Limited LCA }\end{array}$ & $8 / 13 / 2008$ & Time: & 3:24:37 PM & & \\
\hline $\begin{array}{l}\text { Title: } \\
\text { Method: } \\
\text { Per sub-compartment: } \\
\text { Skip unused: } \\
\text { Indicator: } \\
\text { Category: } \\
\text { Cut-off: } \\
\text { Relative mode: }\end{array}$ & $\begin{array}{l}\text { Comparing produ } \\
\text { Eco-indicator } 95 \\
\text { No } \\
\text { Yes } \\
\text { Characterization } \\
\text { acidification } \\
0 \% \\
\text { Non }\end{array}$ & V2.03/ Europe & & & & & \\
\hline No & $\begin{array}{l}\text { Substance } \\
\text { Total } \\
1 \text { Nitric oxide } \\
2 \text { Nitrogen oxides } \\
3 \text { Sulfur oxides }\end{array}$ & $\begin{array}{l}\text { Compartment } \\
\text { Air } \\
\text { Air } \\
\text { Air }\end{array}$ & $\begin{array}{l}\text { Unit } \\
\text { kg SO2 } \\
\text { kg SO2 } \\
\text { kg SO2 } \\
\text { kg SO2 }\end{array}$ & $\begin{array}{r}\text { CPD_100k_1.5_Avg } \\
35183.68132 \\
34785.87778 \\
29.2075461 \\
368.5959881\end{array}$ & $\begin{array}{r}\text { CPD_100k_1.5_High } \\
20020.6865 \\
19794.32304 \\
16.62006652 \\
209.7433937\end{array}$ & $\begin{array}{r}\text { CPD_100k_1.5_Low } \\
73919.43738 \\
73083.66885 \\
61.36382817 \\
774.4046967\end{array}$ & $\begin{array}{r}\text { CPD_100k_1.9_Avg } \\
43900.85548 \\
43404.4914 \\
36.44406191 \\
459.920014\end{array}$ \\
\hline
\end{tabular}


CPD_100k_1.9_High CPD_100k_1.9_Low CPD_100k_2.3_Avg CPD_100k_2.3_High CPD_100k_2.3_Low CPD_100k_3.0_Avg CPD_100k_3.0_High 24924.05637 92379.05544 52617.81315 52022.89098 29827.42625

29490.18309 69849.31565 69059.56587 39523.32602

24642.25307

91334.57364

24.76107941

110838.89

76.68798202

43.680398

109585.6925

92.01231558

261.112733

967.7938165

551.2417719

312.4820723

1161.185204

57.98503825

39076.45638

32.81007909

414.0595544 


$\begin{array}{rrrrrrr}\text { CPD_100k_3.0_Low } & \text { MBD_100k_1.5_Avg } & \text { MBD_100k_1.5_High } & \text { MBD_100k_1.5_Low } & \text { MBD_100k_1.9_Avg } & \text { MBD_100k_1.9_High } & \text { MBD_100k_1.9_Low } \\ 147320.6113 & 45765.65142 & 27979.2996 & 79696.97094 & 46574.43684 & 28788.08502 \\ 145654.934 & 45248.20307 & 27662.95225 & 78795.87885 & 46047.84397 & 28462.59316 \\ 122.2974227 & 37.99211235 & 23.22686689 & 66.16001696 & 38.66352127 & 23.89827581 \\ 1543.379892 & 479.4562386 & 293.1204807 & 834.9320666 & 487.9293447 & 301.5935868\end{array}$




$\begin{array}{rrrrrr}\text { MBD_100k_2.3_Avg } & \text { MBD_100k_2.3_High } & \text { MBD_100k_2.3_Low } & \text { MBD_100k_3.0_Avg } & \text { MBD_100k_3.0_High } & \text { MBD_100k_3.0_Low } \\ 47383.22226 & 29596.87044 & 81314.54178 & 48798.59676 & 31012.24493 & 82729.91628 \\ 46847.48488 & 29262.23407 & 80395.16067 & 48246.85647 & 30661.60566 & 81794.53226 \\ 39.33493019 & 24.56968474 & 67.5028348 & 40.50989581 & 25.74465035 & 68.67780042 \\ 496.4024507 & 310.0666928 & 851.8782787 & 511.2303863 & 324.8946283 & 866.7062142\end{array}$




\begin{tabular}{|c|c|c|c|c|c|c|c|}
\hline $\begin{array}{l}\text { SimaPro } 7.1 \\
\text { Project }\end{array}$ & $\begin{array}{l}\text { Inventory } \\
\text { Thesis_Dredging Limite }\end{array}$ & $\begin{array}{l}\text { Date: } \\
\text { LCA }\end{array}$ & $8 / 13 / 2008$ & Time: & 3:29:00 PM & & \\
\hline $\begin{array}{l}\text { Title: } \\
\text { Method: } \\
\text { Per sub-compartment: } \\
\text { Skip unused: } \\
\text { Indicator: } \\
\text { Category: } \\
\text { Cut-off: } \\
\text { Relative mode: }\end{array}$ & $\begin{array}{l}\text { Comparing product stag } \\
\text { Eco-indicator } 95 \mathrm{~V} 2.03 / \\
\text { No } \\
\text { Yes } \\
\text { Characterization } \\
\text { carcinogens } \\
0 \% \\
\text { Non }\end{array}$ & Europe e & & & & & \\
\hline No & $\begin{array}{l}\text { Substance } \\
\text { Total } \\
1 \text { Benzene } \\
\text { PAH, polycyclic } \\
2 \text { aromatic hydrocarbons }\end{array}$ & $\begin{array}{l}\text { Compartment } \\
\text { Air } \\
\text { Air }\end{array}$ & $\begin{array}{l}\text { Unit } \\
\text { kg B(a)P } \\
\text { kg B(a)P } \\
\text { kg B(a)P }\end{array}$ & $\begin{array}{r}\text { CPD_1k_1.5_Avg } \\
0.020410267 \\
1.03705 \mathrm{E}-05 \\
\\
0.020399896\end{array}$ & $\begin{array}{r}\text { CPD_1k_1.5_High } \\
0.016863299 \\
8.56824 \mathrm{E}-06 \\
\\
0.016854731\end{array}$ & $\begin{array}{r}\text { CPD_1k_1.5_Low } \\
0.029475303 \\
1.49764 \mathrm{E}-05 \\
\\
0.029460327\end{array}$ & $\begin{array}{r}\text { CPD_1k_1.9_Avg } \\
0.022452307 \\
1.1408 \mathrm{E}-05 \\
\\
0.022440899\end{array}$ \\
\hline
\end{tabular}




\begin{tabular}{|c|c|c|c|c|c|c|c|}
\hline & w & & & & & & \\
\hline $0 . \overline{0} 18008463$ & $0 . \overline{03} 37 \overline{9} 7537$ & $0 . \overline{0} 24 \overline{48928}$ & $0 . \overline{0} 19 \overline{15} 8694$ & $0 . \overline{03811} 9771$ & $0 . \overline{0} 28 \overline{6} 9497$ & $0 . \overline{0} 21595968$ & $0 . \overline{0} 68 \overline{3} 0111$ \\
\hline 9.15009E-06 & 1.71725E-05 & 1.2443E-05 & 9.73453E-06 & 1.93686E-05 & 1.45799E-05 & 1.09729E-05 & 2.37944E-05 \\
\hline 0.0 & 0.033780365 & 0.024476837 & 0.019148959 & 0.038100402 & 0.028680391 & 0.021 & 0.046806316 \\
\hline
\end{tabular}




\begin{tabular}{|c|c|c|c|c|c|c|c|}
\hline $\begin{array}{l}-1 \mathrm{k} \_1.5 \_ \text {Avg } \\
0.018104738\end{array}$ & 0.013944651 & 0.026049946 & 0.01829222 & 0.014132134 & $0 . \overline{02} 62 \overline{3} 7428$ & $0 . \overline{1} 84 \overline{7} 9703$ & 0.0143196 \\
\hline 9.19901E-06 & 7.08527E-06 & 1.3236E-05 & $9.29427 \mathrm{E}-06$ & 7.18053E-06 & 1.33312E-05 & 9.38953E-06 & $7.27579 \mathrm{E}$ \\
\hline 0.018 & 0.013937566 & 0.02603671 & 0.018282926 & 0.014124953 & 0.026224097 & 0.018470313 & \\
\hline
\end{tabular}




$\begin{array}{rrrr}\text { MBD_1k_2.3_Low } & \text { MBD_1k_3.0_Avg } & \text { MBD_1k_3.0_High } & \text { MBD_1k_3.0_Low } \\ 0.026424911 & 0.018814131 & 0.014654045 & 0.026759339 \\ 1.34265 \mathrm{E}-05 & 9.55945 \mathrm{E}-06 & 7.44572 \mathrm{E}-06 & 1.35964 \mathrm{E}-05 \\ & & & \\ 0.026411485 & 0.018804572 & 0.014646599 & 0.026745743\end{array}$




\begin{tabular}{|c|c|c|c|c|c|c|c|}
\hline $\begin{array}{l}\text { SimaPro } 7.1 \\
\text { Project }\end{array}$ & $\begin{array}{l}\text { Inventory } \\
\text { Thesis_Dredging Limite }\end{array}$ & $\begin{array}{l}\text { Date: } \\
\text { d LCA }\end{array}$ & $8 / 13 / 2008$ & Time: & 3:35:16 PM & & \\
\hline $\begin{array}{l}\text { Title: } \\
\text { Method: } \\
\text { Per sub-compartment: } \\
\text { Skip unused: } \\
\text { Indicator: } \\
\text { Category: } \\
\text { Cut-off: } \\
\text { Relative mode: }\end{array}$ & $\begin{array}{l}\text { Comparing product stag } \\
\text { Eco-indicator } 95 \mathrm{~V} 2.03 \\
\text { No } \\
\text { Yes } \\
\text { Characterization } \\
\text { carcinogens } \\
0 \% \\
\text { Non }\end{array}$ & Europe e & & & & & \\
\hline No & $\begin{array}{l}\text { Substance } \\
\text { Total } \\
1 \text { Benzene } \\
\text { PAH, polycyclic } \\
2 \text { aromatic hydrocarbons }\end{array}$ & $\begin{array}{l}\text { Compartment } \\
\text { Air }\end{array}$ & $\begin{array}{l}\text { Unit } \\
\text { kg B(a)P } \\
\text { kg B(a)P } \\
\text { kg B(a)P }\end{array}$ & $\begin{array}{r}\text { CPD_5k_1.5_Avg } \\
0.052859956 \\
2.68581 \mathrm{E}-05 \\
\\
0.052833098\end{array}$ & $\begin{array}{r}\text { CPD_5k_1.5_High } \\
0.035114982 \\
1.78419 \mathrm{E}-05 \\
\\
0.035097141\end{array}$ & $\begin{array}{r}\text { CPD_5k_1.5_Low } \\
0.098190206 \\
4.98904 \mathrm{E}-05 \\
\\
\\
0.098140316\end{array}$ & $\begin{array}{r}\text { CPD_5k_1.9_Avg } \\
0.063060023 \\
3.20408 \mathrm{E}-05 \\
\\
0.063027982\end{array}$ \\
\hline
\end{tabular}




\begin{tabular}{|c|c|c|c|c|c|c|c|}
\hline ligh & $\mathrm{w}$ & & & & & & \\
\hline 0.040850936 & 0.119796308 & 0.073260089 & 0.046591957 & 0.141397343 & 0.093594349 & 0.058099335 & 0.184259916 \\
\hline 2.07563E-05 & 6.08685E-05 & 3.72234E-05 & 2.36734E-05 & 7.18439E-05 & 4.75553E-05 & 2.95203E-05 & 9.36224E-05 \\
\hline 0.040 & 0.11973544 & 0.073222865 & 0.046568284 & 0.141325499 & 0.093546794 & 0.058069814 & 0.18 \\
\hline
\end{tabular}




\begin{tabular}{|c|c|c|c|c|c|c|c|}
\hline & & & & & & & \\
\hline 0.060653151 & 0.039837517 & $0 . \overline{100363991}$ & 0.061600699 & 0.040785064 & $0 . \overline{10131} 1538$ & 0.062548246 & 0.041732611 \\
\hline 3.08178E-05 & $2.02414 \mathrm{E}-05$ & 5.09949E-05 & 3.12993E-05 & $2.07229 \mathrm{E}-05$ & $5.14764 \mathrm{E}-05$ & 3.17807E-05 & $2.12043 \mathrm{E}-05$ \\
\hline & 0.039817275 & 0.100312996 & 0.061569399 & 0.040764341 & 0.101260062 & 0.062516465 & 0.0417 \\
\hline
\end{tabular}


MBD_5k_2.3_Low MBD_5k_3.0_Avg MBD_5k_3.0_High MBD_5k_3.0_Low $0.102259085 \quad 0.064200119 \quad-0.043384485 \quad-0.103910959$

$5.19578 \mathrm{E}-05$

3.26201E-05

$2.20436 \mathrm{E}-05$

5.27971E-05

0.102207127

0.064167499

0.043362441

0.103858162 


\begin{tabular}{|c|c|c|c|c|c|c|c|}
\hline $\begin{array}{l}\text { SimaPro } 7.1 \\
\text { Project }\end{array}$ & $\begin{array}{l}\text { Inventory } \\
\text { Thesis_Dredging Limite }\end{array}$ & $\begin{array}{l}\text { Date: } \\
\text { d LCA }\end{array}$ & $8 / 13 / 2008$ & Time: & 3:32:13 PM & & \\
\hline $\begin{array}{l}\text { Title: } \\
\text { Method: } \\
\text { Per sub-compartment: } \\
\text { Skip unused: } \\
\text { Indicator: } \\
\text { Category: } \\
\text { Cut-off: } \\
\text { Relative mode: }\end{array}$ & $\begin{array}{l}\text { Comparing product stag } \\
\text { Eco-indicator } 95 \mathrm{~V} 2.03 \\
\text { No } \\
\text { Yes } \\
\text { Characterization } \\
\text { carcinogens } \\
0 \% \\
\text { Non }\end{array}$ & Europe e & & & & & \\
\hline No & $\begin{array}{l}\text { Substance } \\
\text { Total } \\
1 \text { Benzene } \\
\text { PAH, polycyclic } \\
2 \text { aromatic hydrocarbons }\end{array}$ & $\begin{array}{l}\text { Compartment } \\
\text { Air }\end{array}$ & $\begin{array}{l}\text { Unit } \\
\text { kg } B(a) P \\
\text { kg B(a)P } \\
\text { kg B(a)P }\end{array}$ & $\begin{array}{r}\text { CPD_20k_1.5_Avg } \\
0.174541224 \\
8.86843 \mathrm{E}-05 \\
\\
0.17445254\end{array}$ & $\begin{array}{r}\text { CPD_20k_1.5_High } \\
0.103561329 \\
5.26195 \mathrm{E}-05 \\
\\
0.10350871\end{array}$ & $\begin{array}{r}\text { CPD_20k_1.5_Low } \\
0.355872359 \\
0.000180819 \\
0.35569154\end{array}$ & $\begin{array}{r}\text { CPD_20k_1.9_Avg } \\
0.215351624 \\
0.00010942 \\
\\
0.215242204\end{array}$ \\
\hline
\end{tabular}




\begin{tabular}{|c|c|c|c|c|c|c|c|}
\hline D_20k_1.9_High & CPD_20k & $\lg$ & h & w & a & gh & \\
\hline $0 . \overline{1} 265 \overline{15279}$ & $0 . \overline{44} 22 \overline{8} 6631$ & $0.2 \overline{5} 61 \overline{5} 6956$ & $0 . \overline{1} 49 \overline{46} 6228$ & $0 . \overline{52} 87 \overline{0} 5971$ & $0 . \overline{33} 6956885$ & $0 . \overline{1} 94997095$ & $0 . \overline{69} 96 \overline{2} 4221$ \\
\hline 6.42824E-05 & 0.000224726 & 0.000130153 & 7.59453E-05 & 0.000268635 & 0.000171208 & $9.9078 \mathrm{E}-05$ & 0.000355479 \\
\hline 0.12 & 0.442061906 & 0.256026803 & 0.149393283 & 0.528437336 & 0.336785678 & 0.194898017 & $0.6 s$ \\
\hline
\end{tabular}




$\begin{array}{rrrrrrr}\text { MBD_20k_1.5_Avg } & \text { MBD_20k_1.5_High } & \text { MBD_20k_1.5_Low } & \text { MBD_20k_1.9_Avg } & \text { MBD_20k_1.9_High } & \text { MBD_20k_1.9_Low } & \text { MBD_20k_2.3_Avg } \\ 0.22021097 & 0.136948431 & 0.379054328 & 0.224001158 & 0.14073862 & 0.382844516 \\ 0.000111889 & 6.95835 E-05 & 0.000192597 & 0.000113815 & 7.15093 E-05 & 0.000194523 & 0.000115738 \\ & & & & & \\ 0.220099081 & 0.136878848 & 0.37886173 & 0.223887343 & 0.140667111 & 0.382649993\end{array}$




$\begin{array}{ccccc}\text { MBD_20k_2.3_High } & \text { MBD_20k_2.3_Low } & \text { MBD_20k_3.0_Avg } & \text { MBD_20k_3.0_High } & \text { MBD_20k_3.0_Low } \\ 0.144523741 & 0.386629638 & 0.234408976 & 0.151146437 & 0.393252333 \\ 7.34325 \mathrm{E}-05 & 0.000196446 & 0.000119103 & 7.67975 \mathrm{E}-05 & 0.000199811 \\ & & & & \\ 0.144450309 & 0.386433191 & 0.234289873 & 0.15106964 & 0.393052522\end{array}$




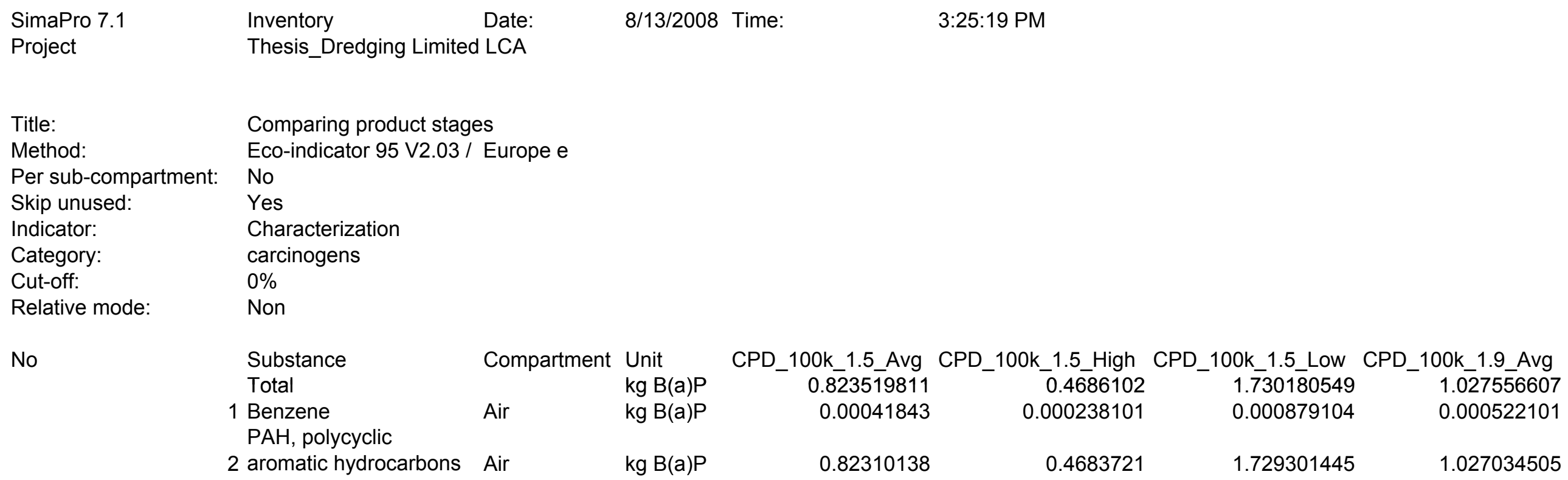

\section{Substance}

Total

\section{Benzene}

$\mathrm{PAH}$, polycyclic

2 aromatic hydrocarbons

\section{Compartment Unit}

$\operatorname{kg~B}(a) P$

Air

Air

\begin{abstract}
$\operatorname{kg~B}(a) P$
\end{abstract}
kg B(a)P

CPD_100k_1.5_Avg CPD_100k_1.5_High CPD_100k_1.5_Low CPD_100k_1.9_Avg

$\begin{array}{lll}0.8235 \overline{19811} & 0.4686102 & 1 . \overline{730180549}-1.0275 \overline{5} 6607\end{array}$

0.00041843

0.000238101

0.000879104

0.000522101

0.4683721

1.729301445

1.027034505 


$\begin{array}{rrrrrr}\text { CPD_100k_1.9_High } & \text { CPD_100k_1.9_Low } & \text { CPD_100k_2.3_Avg } & \text { CPD_100k_2.3_High } & \text { CPD_100k_2.3_Low } & \text { CPD_100k_3.0_Avg CPD_100k_3.0_High } \\ 0.583379948 & 2.162251913 & 1.231588336 & 0.698149696 & 2.594328344 & 1.634914058 \\ 0.000296415 & 0.00109864 & 0.00062577 & 0.00035473 & 0.001318177 & 0.000830699 \\ & & & & & 0.925094838 \\ 0.583083533 & 2.161153273 & 1.230962566 & 0.697794966 & 2.593010166 & 1.634083359\end{array}$




$\begin{array}{rrrrrrr}\text { CPD_100k_3.0_Low } & \text { MBD_100k_1.5_Avg } & \text { MBD_100k_1.5_High } & \text { MBD_100k_1.5_Low } & \text { MBD_100k_1.9_Avg } & \text { MBD_100k_1.9_High } & \text { MBD_100k_1.9_Low } \\ \text { 3.448230468 } & 1.07120458 & 0.654891889 & 1.865411235 & 1.090135255 & 0.673822563 \\ 0.001752045 & 0.000544279 & 0.00033275 & 0.000947815 & 0.000553897 & 0.000342369 \\ & & & & & \\ 3.446478423 & 1.070660302 & 0.654559138 & 1.86446342 & 1.089581358 & 0.673480194\end{array}$




$\begin{array}{rrrrrr}\text { MBD_100k_2.3_Avg } & \text { MBD_100k_2.3_High } & \text { MBD_100k_2.3_Low } & \text { MBD_100k_3.0_Avg } & \text { MBD_100k_3.0_High } & \text { MBD_100k_3.0_Low } \\ 1.109065929 & 0.692753238 & 1.903272584 & 1.14219461 & 0.725881918 & 1.936401264 \\ 0.000563516 & 0.000351988 & 0.000967052 & 0.000580349 & 0.00036882 & 0.000983885 \\ & & & & & \\ 1.108502413 & 0.69240125 & 1.902305532 & 1.141614261 & 0.725513098 & 1.935417379\end{array}$




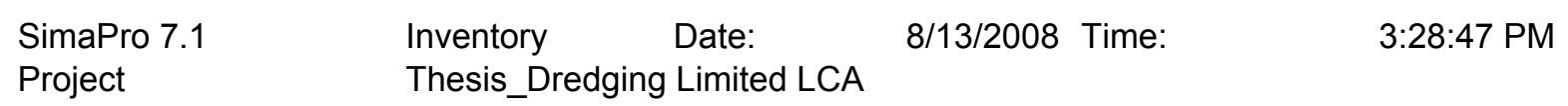

Title:

Method:

Per sub-compartment:

Skip unused:

Indicator:

Category:

Cut-off:

Relative mode:

No

Comparing product stages

Eco-indicator 95 V2.03 / Europe e

No

Yes

Characterization

eutrophication

$0 \%$

Non

Substance Compartment Unit

Total

1 Nitric oxide

Air

2 Nitrogen oxides Air $\mathrm{kg} \mathrm{PO} 4$

$\mathrm{kg} \mathrm{PO} 4$

kg PO4
CPD_1k_1.5_Avg CPD_1k_1.5_High CPD_1k_1.5_Low CPD_1k_1.9_Avg CPD_1k_1.9_High 161.2820263 133.2538688

133.1427957

0.111073094
232.9139889

232.7198446

0.194144288
177.418237

177.2703509

0.147886082 142.3029597

0.134435824

142.1843438

0.118615919 
CPD_1k_1.9_Low CPD_1k_2.3_Avg CPD_1k_2.3_High CPD_1k_2.3_Low CPD_1k_3.0_Avg CPD_1k_3.0_High CPD_1k_3.0_Low MBD_1k_1.5_Avg 267.0683008 193.5144075 151.3920908 301.2226127 226.7477942

266.8456874 193.3531045

151.2658986 300.9715301 226.5587897 0.222613443

0.161302964

0.126192118

0.251082599

0.189004487 170.651439 370.0517595 143.063724 170.5091933 369.7433047 142.9444739

\begin{abstract}
0.142245651
\end{abstract}
0.308454789

0.11925005 


\begin{tabular}{|c|c|c|c|c|c|c|c|}
\hline 110.1906992 & 205.8467968 & 144.5452123 & 111.6721875 & 207.3282851 & 146.0267006 & 113.1536759 & $20 \overline{8} .80 \overline{9} 77$ \\
\hline 110.0988503 & 205.6752142 & 144.4247273 & 111.5791038 & 207.1554676 & 145.9049808 & 113.0593572 & 208.63572 \\
\hline 0.091848905 & 0.171582565 & 0.120484937 & 0.093083792 & 0.172817452 & 0.121719824 & 0.094318679 & 0.174052 \\
\hline
\end{tabular}


MBD_1k_3.0_Avg MBD_1k_3.0_High MBD_1k_3.0_Low

$148.6693555 \quad 115.7963307 \quad 211.4524283$
148.5454329
211.2761732

0.123922596

0.096521451

0.176255111 


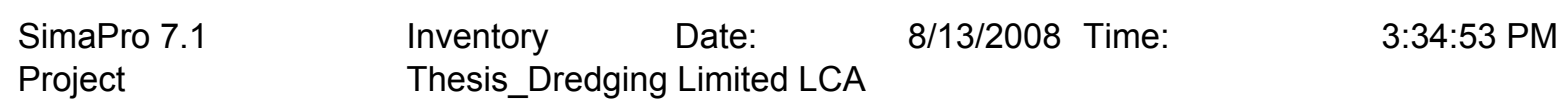

Title:

Method:

Per sub-compartment:

Skip unused:

Indicator:

Category:

Cut-off:

Relative mode:

No

Comparing product stages

Eco-indicator 95 V2.03 / Europe e

No

Yes

Characterization

eutrophication

$0 \%$

Non

Substance Compartment Unit

Total

1 Nitric oxide

Air

2 Nitrogen oxides Air $\mathrm{kg} \mathrm{PO} 4$

$\mathrm{kg} \mathrm{PO} 4$

kg PO4
CPD_5k_1.5_Avg CPD_5k_1.5_High CPD_5k_1.5_Low CPD_5k_1.9_Avg CPD_5k_1.9_High 417.6996273 277.4787593 277.2474683 0.231291029
775.8994802

775.2527331

0.646747121
498.3006002

497.8852443

0.415355967
322.804294

322.5352221

0.34817143

0.269071901 
CPD_5k_1.9_Low CPD_5k_2.3_Avg CPD_5k_2.3_High CPD_5k_2.3_Low CPD_5k_3.0_Avg CPD_5k_3.0_High CPD_5k_3.0_Low MBD_5k_1.5_Avg 946.6309997 578.9015732 368.169869 1117.322479

739.5829961

945.8419401 578.4190327

367.8629828

$\begin{array}{r}1116.39114 \\ \hline\end{array}$

0.789059523

0.482540504

0.306886148

0.93133855

0.616475698

459.10122

1456.022742

1454.809082

479.2814934

458.7185384

1.213660456

0.399502686 
MBD_5k_1.5_High MBD_5k_1.5_Low MBD_5k_1.9_Avg MBD_5k_1.9_High MBD_5k_1.9_Low MBD_5k_2.3_Avg MBD_5k_2.3_High MBD_5k_2.3_Low $314.796249 \quad 793.0767367$

314.5338522

792.4156716

486.7690154

322.2837711

800.5642588

486.3632716

322.0151331

799.8969525

494.2565375

493.8445525

329.7712932

808.0517809

0.262396835

0.661065137

0.405743872

0.667306324

0.411985059

807.3782334

0.67354751 
MBD_5k_3.0_Avg MBD_5k_3.0_High MBD_5k_3.0_Low $507.3096509 \quad 342.8244065$

$506.8867854 \quad 342.538647$

$0.422865416 \quad 0.285759565$

821.1048943

820.4204664

0.684427868 


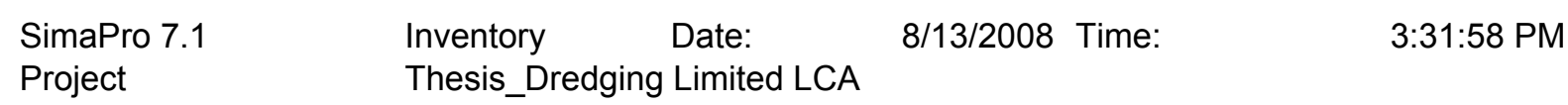

Title:

Method:

Per sub-compartment:

Skip unused:

Indicator:

Category:

Cut-off:

Relative mode:

No
Comparing product stages

Eco-indicator 95 V2.03 / Europe e

No

Yes

Characterization

eutrophication

$0 \%$

Non

\section{Substance Compartment Unit}

Total

1 Nitric oxide

Air

2 Nitrogen oxides Air

$\mathrm{kg} \mathrm{PO} 4$

$\mathrm{kg} \mathrm{PO} 4$

$\mathrm{kg} \mathrm{PO} 4$
CPD_20k_1.5_Avg CPD_20k_1.5_High CPD_20k_1.5_Low CPD_20k_1.9_Avg

$1379.225591 \quad 818.3421187 \quad 2812.105083$

1378.075944

817.6599938

2809.761067

1701.709563

1.149646576
2.344016092
1700.291111

1.418451474 


\begin{tabular}{|c|c|c|c|c|c|c|c|}
\hline $\begin{array}{r}\text { D_20k_1.9_High } \\
999.724338\end{array}$ & $\begin{array}{r}\text { CPD_20k_1.9_Low } \\
3494.95108\end{array}$ & $\begin{array}{r}\text { CPD_20k_2.3_Avg } \\
2024.153495\end{array}$ & $\begin{array}{r}\text { PPD_20k_2.3_High } \\
1181.106557\end{array}$ & 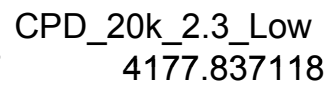 & $\begin{array}{r}\text { CF__CUK_3.U_Avg } \\
2662.634923\end{array}$ & $\begin{array}{r}1540.867979 \\
1\end{array}$ & 5528.433947 \\
\hline 998.8910228 & 3492.037881 & 2022.466272 & 1180.122052 & 4174.354702 & 2660.415497 & 1539.583596 & 5523.825749 \\
\hline 0.833315209 & 2.913198949 & 1.687222996 & 0.984505449 & 3.482415181 & 2.219425989 & 1.284382778 & 4.608198397 \\
\hline
\end{tabular}




\begin{tabular}{|c|c|c|c|c|c|c|}
\hline $\begin{array}{r}\text { MBD_20k_1.5_Avg } \\
1740.108139\end{array}$ & $\begin{array}{l}\text { MBD_20k_1.5_High } \\
1082.167161\end{array}$ & $\begin{array}{r}\text { MBD_20k_1.5_Low } \\
2995.289112\end{array}$ & $\begin{array}{r}\text { MBD_20k_1.9_Avg } \\
1770.058227\end{array}$ & $\begin{array}{l}\text { 20k_1.9_High } \\
1112.11725\end{array}$ & $\begin{array}{r}\text { MBD_20k_1.9_Low } \\
3025.239201\end{array}$ & $\begin{array}{r}\text { MBD_20k_2.3_Avg } \\
1799.968275\end{array}$ \\
\hline 1738.65768 & 1081.265126 & 2992.792404 & 1768.582804 & 1111.19025 & 3022.717528 & 1798.467921 \\
\hline 1.450458414 & 0.902035011 & 2.496708221 & 1.47542316 & 0.926999757 & 2.521672967 & 1.500354531 \\
\hline
\end{tabular}




$\begin{array}{rrrrr}\text { MBD_20k_2.3_High } & \text { MBD_20k_2.3_Low } & \text { MBD_20k_3.0_Avg } & \text { MBD_20k_3.0_High } & \text { MBD_20k_3.0_Low } \\ 1142.027298 & 3055.149249 & 1852.300849 & 1194.359872 & 3107.481823 \\ 1141.075367 & 3052.602644 & 1850.756873 & 1193.364319 & 3104.891597 \\ 0.951931128 & 2.546604337 & 1.543976085 & 0.995552683 & 2.590225892\end{array}$




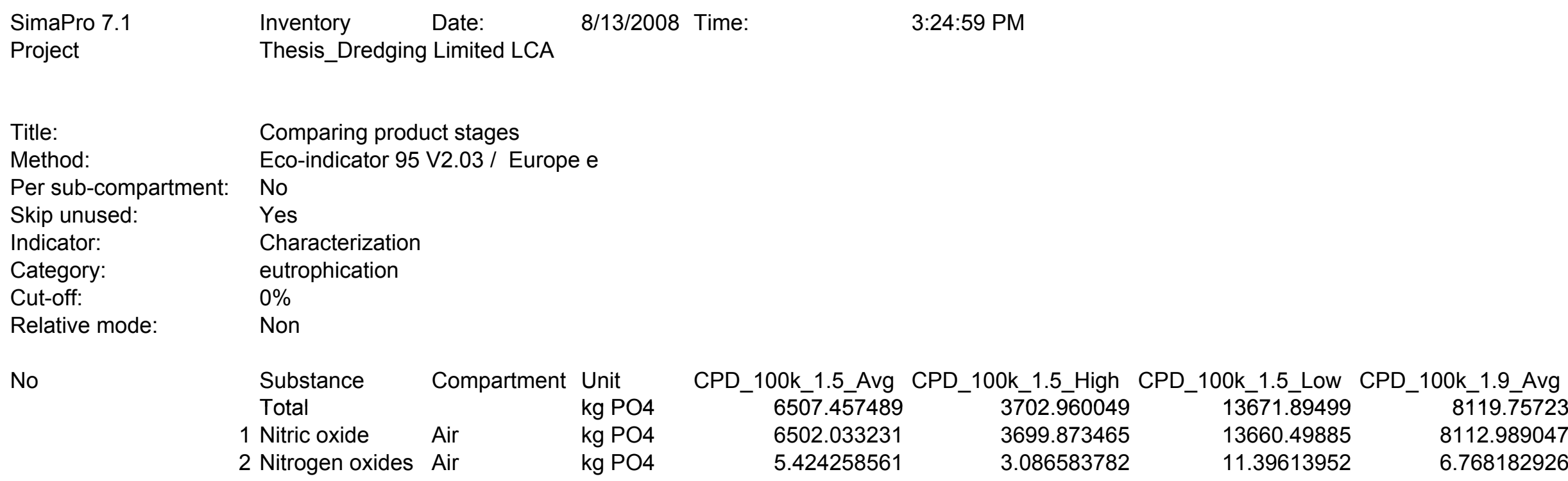

Substance

Total

1 Nitric oxide

Compartment Unit

$\mathrm{kg} \mathrm{PO} 4$

2 Nitrogen oxides Air

CPD_100k_1.5_Avg CPD_100k_1.5_High CPD_100k_1.5_Low CPD_100k_1.9_Avg $\begin{array}{lll}6507.457489 & 3702.960049 & 13671.89499\end{array}$ $6502.033231 \quad 3699.873465 \quad 13660.49885$ 8119.75723

5.424258561

3.086583782 
CPD_100k_1.9_High CPD_100k_1.9_Low CPD_100k_2.3_Avg CPD_100k_2.3_High CPD_100k_2.3_Low CPD_100k_3.0_Avg CPD_100k_3.0_High 4609.871145 17086.12498

17071.88292

9732.01693

4606.028611

9723.904856

5516.782242

20500.395

20483.307

12919.09872

7310.10384

3.842534979

14.2420538

4.598486176

17.08800146

12908.33007

7304.010539

8.112073915

10.76864996

6.093300402 
CPD_100k_3.0_Low MBD_100k_1.5_Avg MBD_100k_1.5_High MBD_100k_1.5_Low MBD_100k_1.9_Avg MBD_100k_1.9_High MBD_100k_1.9_Low 27247.93368 8464.663728

8457.60805

5174.958841

$14 \overline{7} 40.48852$

27225.2213

$\begin{array}{r}5170.64528 \\ \hline\end{array}$

22.7123785

7.055678008

4.313560994

8614.254008

8607.07364

7.180368236

5324.549122

5320.11087

4.438251223

14890.0788

14877.66725

12.41155052 


$\begin{array}{rrrrrr}\text { MBD_100k_2.3_Avg } & \text { MBD_100k_2.3_High } & \text { MBD_100k_2.3_Low } & \text { MBD_100k_3.0_Avg } & \text { MBD_100k_3.0_High } & \text { MBD_100k_3.0_Low } \\ 8763.844289 & 5474.139402 & 15039.66908 & 9025.62728 & 5735.922393 & 15301.45207 \\ 8756.539231 & 5469.576461 & 15027.13284 & 9018.104014 & 5731.141244 & 15288.69762 \\ 7.305058465 & 4.562941451 & 12.53624075 & 7.523266364 & 4.781149351 & 12.75444865\end{array}$


SimaPro 7.1

Project

Title:

Method:

Per sub-compartment:

Skip unused:

Indicator:

Category:

Cut-off:

Relative mode:

No
Inventory Date:

Thesis_Dredging Limited LCA

Comparing product stages

Eco-indicator 95 V2.03 / Europe e

No

Yes

Characterization

greenhouse

$0 \%$

Non

\section{Substance \\ Compartment Unit}

Total

1 Carbon dioxide, fossil Air

2 Methane $\mathrm{kg} \mathrm{CO} 2$

$\mathrm{kg} \mathrm{CO} 2$

kg CO2
CPD_1k_1.5_Avg CPD_1k_1.5_High CPD_1k_1.5_Low CPD_1k_1.9_Avg $41131.58872 \quad 33983.59664$

$41109.07921 \quad 33964.99891$ 59399.81419 45246.78987

$22.50950471 \quad 18.59772385$

45222.0283

24.76157283 


\begin{tabular}{|c|c|c|c|c|c|c|c|}
\hline ligh & $\mathrm{w}$ & 23 Avg & $23 \mathrm{Hiah}$ & .3_Low & 3.0 Avq & 1k_3.0_High & \\
\hline 36291.37694 & 68110.15311 & 49351.77961 & 38609.36865 & 76820.49203 & 57827.25593 & 43521.06036 & 94373.9183 \\
\hline 36271.51627 & 68072.87943 & 49324.77156 & 38588.23945 & 76778.45157 & 57795.60963 & 43497.2432 & 94322.27162 \\
\hline 19.86067024 & 37.27368331 & 27.00805269 & 21.12920489 & 42.0404677 & 31.64630714 & 23.81715716 & 51.64668384 \\
\hline
\end{tabular}




\begin{tabular}{|c|c|c|c|c|c|c|c|}
\hline $\begin{array}{r}\text { MBD_1k_1.5_Avg } \\
36485.39386\end{array}$ & MBD_1k_1.5_High & $\begin{array}{l}\text {-1k_1.5_Low } \\
52496.89613\end{array}$ & $\begin{array}{l}\text { 1k_1.9_Avg } \\
36863.2163\end{array}$ & 28479.64273 & 52874.71856 & $\begin{array}{r}\text { MBD_1k_2.3_Avg } \\
37241.03874\end{array}$ & $\begin{array}{l}\text { 1k_2.3_High } \\
28857.46517\end{array}$ \\
\hline 36465.42702 & 28086.44141 & 52468.16689 & 36843.04269 & 28464.05708 & 52845.78256 & 37220.65836 & 28841.67275 \\
\hline 19.96684715 & 15.37888703 & 28.72923627 & 20.17361271 & 15.58565259 & 28.93600183 & 20.38037827 & 15.792418 \\
\hline
\end{tabular}


MBD_1k_2.3_Low MBD_1k_3.0_Avg MBD_1k_3.0_High MBD_1k_3.0_Low 53252.541 $37914.99228 \quad-29531.41871 \quad 53926.49454$ $53223.39824 \quad 37894.24308$

$29.14276739 \quad 20.74920332$

29515.25747

53896.98295

16.1612432

29.51159244 
SimaPro 7.1

Project

Title:

Method:

Per sub-compartment:

Skip unused:

Indicator:

Category:

Cut-off:

Relative mode:

No
Inventory Date:

Thesis_Dredging Limited LCA

Comparing product stages

Eco-indicator 95 V2.03 / Europe e

No

Yes

Characterization

greenhouse

$0 \%$

Non

$\begin{array}{lll}\text { Substance } & \text { Compartment } & \text { Unit } \\ \text { Total } & & \mathrm{kg} \mathrm{CO} 2 \\ \text { 1 Carbon dioxide, fossil } & \text { Air } & \mathrm{kg} \mathrm{CO} 2 \\ 2 \text { Methane } & \text { Air } & \mathrm{kg} \mathrm{CO} 2\end{array}$

CPD_5k_1.5_Avg CPD_5k_1.5_High CPD_5k_1.5_Low CPD_5k_1.9_Avg $106525.5048 \quad 70765.1216 \quad 197876.8436$

$106467.2081 \quad 70726.39497 \quad 197768.5544$

$\begin{array}{lll}58.29671129 & 38.72663049 & 108.2892707\end{array}$
127081.0878

127011.5419

69.54587539 


$\begin{array}{rrrrrrr}\text { CPD_5k_1.9_High } & \text { CPD_5k_1.9_Low } & \text { CPD_5k_2.3_Avg } & \text { CPD_5k_2.3_High } & \text { CPD_5k_2.3_Low } & \text { CPD_5k_3.0_Avg } & \text { CPD_5k_3.0_High CPD_5k_3.0_Low } \\ \text { 82324.44594 } & 241418.3268 & 147636.6707 & 93893.98169 & 284949.5986 & 188615.0882 & 117084.1103 \\ 82279.3934 & 241286.2092 & 147555.8757 & 93842.59766 & 284793.6582 & 188511.8675 & 117020.0353 \\ 45.05253896 & 132.1176043 & 80.79503948 & 51.38403569 & 155.9403498 & 103.2207203 & 64.07497045\end{array}$




\begin{tabular}{|c|c|c|c|c|c|c|c|}
\hline 122230.6646 & 80282.16249 & 202257.5416 & 124140.1996 & 82191.69751 & $20 \overline{4} 16 \overline{-0767}$ & 126049.7346 & $8 \overline{4101.232}$ \\
\hline 122163.7731 & 80238.2276 & 202146.855 & 124072.2632 & 82146.71762 & 204055.345 & 125980.7532 & 84055.2076 \\
\hline 66.89145266 & 43.93488729 & 110.6866335 & 67.93645698 & 44.9798916 & 111.7316378 & 68.98146129 & 46.0248959 \\
\hline
\end{tabular}


MBD_5k_2.3_Low MBD_5k_3.0_Avg MBD_5k_3.0_High MBD_5k_3.0_Low 206076.6117

205963.835

129378.6567

87430.15457

209405.5337

112.7766421

(29307.8534

87382.3079

209290.9353

112.7766421

70.80323352

47.84666815

114.5984144 


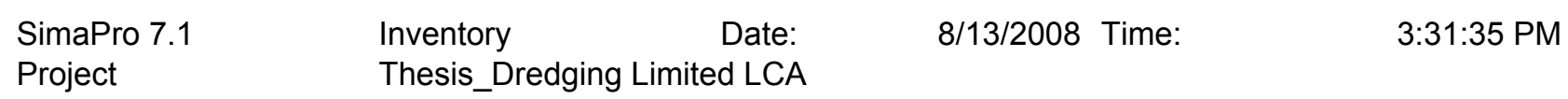

Title:

Method:

Per sub-compartment:

Skip unused:

Indicator:

Category:

Cut-off:

Relative mode:

No
Comparing product stages

Eco-indicator 95 V2.03 / Europe e

No

Yes

Characterization

greenhouse

$0 \%$

Non

$\begin{array}{lll}\text { Substance } & \text { Compartment } & \text { Unit } \\ \text { Total } & & \text { kg CO2 } \\ \text { 1 Carbon dioxide, fossil } & \text { Air } & \text { kg CO2 } \\ 2 \text { Methane } & \text { Air } & \text { kg CO2 }\end{array}$

CPD_20k_1.5_Avg CPD_20k_1.5_High CPD_20k_1.5_Low CPD_20k_1.9_Avg 351742.4789 351549.9857

192.4931477 208700.9459

208586.7331

114.2128245
717168.2569

716775.7823

392.4745617
433985.2335

433747.7325

237.5009806 


\begin{tabular}{|c|c|c|c|c|c|c|c|}
\hline 1.9_High & -ow & CPD_20k_2.3_Avg & CPD_20k_2.3_High & W & 20k_3.0_Avg & h & CPD 20k 30 Low \\
\hline 254958.6661 & 891313.7668 & 516217.7767 & 301216.3863 & 1065469.488 & 679049.0363 & 392965.9704 & 1409910.804 \\
\hline 254819.1385 & 890825.9901 & 515935.2734 & 301051.5438 & 1064886.404 & 678677.4227 & 392750.9174 & 1409139.222 \\
\hline 139.5276349 & 487.7767199 & 282.5032253 & 164.8424453 & 583.0844664 & 371.6135932 & 215.0529468 & 771.5820094 \\
\hline
\end{tabular}




$\begin{array}{rrrrrrr}\text { MBD_20k_1.5_Avg } & \text { MBD_20k_1.5_High } & \text { MBD_20k_1.5_Low } & \text { MBD_20k_1.9_Avg } & \text { MBD_20k_1.9_High } & \text { MBD_20k_1.9_Low } & \text { MBD_20k_2.3_Avg } \\ \text { 443777.9826 } & 275983.9742 & 763885.4908 & 451416.1227 & 283622.1144 & 771523.631 \\ 443535.1225 & 275832.9404 & 763467.45 & 451169.0826 & 283466.9005 & 771101.4101 \\ 242.8601204 & 151.0338589 & 418.0408437 & 247.0401377 & 155.2138762 & 45874.0514 \\ & 1522.220861 & 251.2145667\end{array}$




$\begin{array}{rrrrr}\text { MBD_20k_2.3_High } & \text { MBD_20k_2.3_Low } & \text { MBD_20k_3.0_Avg } & \text { MBD_20k_3.0_High } & \text { MBD_20k_3.0_Low } \\ \text { 291250.043 } & 779151.5596 & 472390.3738 & 304596.3654 & 792497.882 \\ 291090.6547 & 778725.1644 & 472131.8554 & 304429.6732 & 792064.1829 \\ 159.3883052 & 426.39529 & 258.5184204 & 166.6921589 & 433.6991437\end{array}$




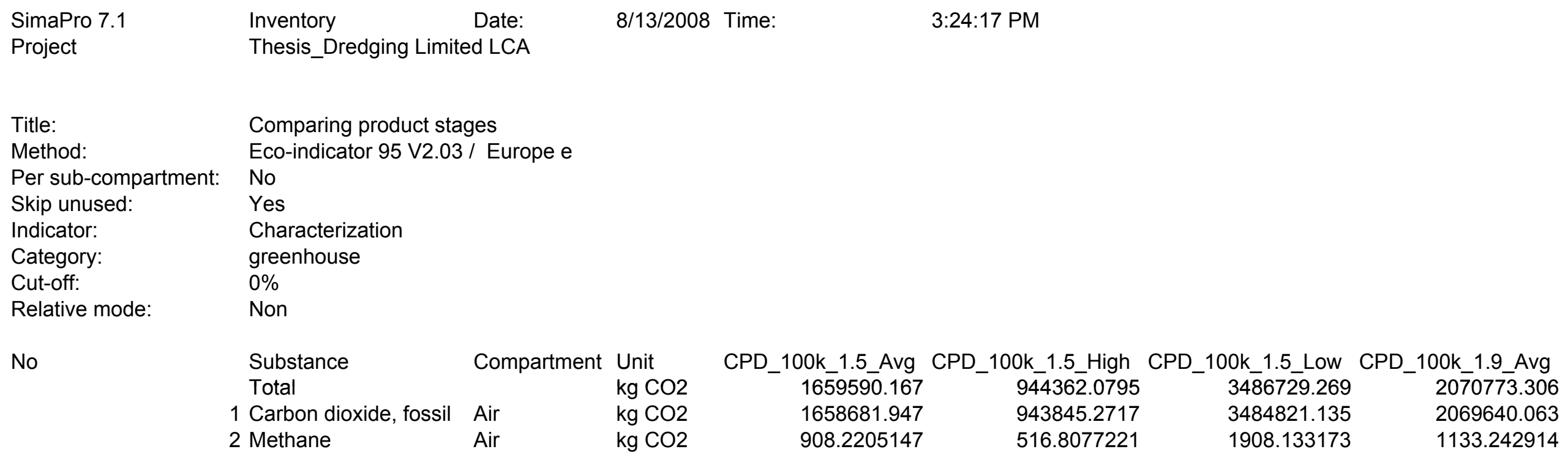

$\begin{array}{lll}\text { Substance } & \text { Compartment } & \text { Unit } \\ \text { Total } & & \mathrm{kg} \mathrm{CO} 2 \\ \text { 1 Carbon dioxide, fossil } & \text { Air } & \text { kg CO2 } \\ \text { 2 Methane } & \text { Air } & \text { kg CO2 }\end{array}$
CPD_100k_1.5_Avg CPD_100k_1.5_High CPD_100k_1.5_Low CPD_100k_1.9_Avg $\begin{array}{llll}1659590.167 & 944362.0795 & 3486729.269 & 2070773.306\end{array}$ $\begin{array}{llll}1658681.947 & 943845.2717 & 3484821.135 & 2069640.063\end{array}$

$\begin{array}{llll}908.2205147 & 516.8077221 & 1908.133173 & 1133.242914\end{array}$


CPD_100k_1.9_High CPD_100k_1.9_Low CPD_100k_2.3_Avg CPD_100k_2.3_High CPD_100k_2.3_Low CPD_100k_3.0_Avg CPD_100k_3.0_High 1175650.68 4357456.818 2481946.233

1175007.299

4357456.818
4355072.174

2480587.973

1406939.281

5228194.579

3294744.413

1864288.237

643.3817742

2384.643964

1358.259726

760169.325

5225333.419

3292941.344

1863267.995

769.9558262

2861.160343

1803.068327

1020.242742 
CPD_100k_3.0_Low MBD_100k_1.5_Avg MBD_100k_1.5_High MBD_100k_1.5_Low MBD_100k_1.9_Avg MBD_100k_1.9_High MBD_100k_1.9_Low $6949012.404 \quad 2158734.454$ 6945209.516 1319764.412 3759251.572 2196884.309 1357914.267

3797401.427

3802.888055

2157553.074

1319042.163

3757194.3

2195682.051

1357914.267
1357171.14

1181.380172

722.2488645

2057.272612

1202.257905

743.1265978

2078.150345 


$\begin{array}{rrrrrr}\text { MBD_100k_2.3_Avg } & \text { MBD_100k_2.3_High } & \text { MBD_100k_2.3_Low } & \text { MBD_100k_3.0_Avg } & \text { MBD_100k_3.0_High } & \text { MBD_100k_3.0_Low } \\ \text { 2235034.164 } & 1396064.122 & 3835551.282 & 2301796.41 & 1462826.368 & 3902313.528 \\ 2233811.028 & 1395300.118 & 3833452.254 & 2300536.738 & 1462025.828 & 3900177.964 \\ 1223.135639 & 764.004331 & 2099.028079 & 1259.671672 & 800.5403642 & 2135.564112\end{array}$




\section{SimaPro 7.1}

Project

Title:

Method:

Indicator:

Skip categories:

Relative mode:

Impact category

greenhouse

acidification

eutrophication

carcinogens

winter smog

summer smog
Impact assessment Date:

Thesis_Dredging Limited LCA

Comparing product stages

Eco-indicator 95 V2.03 / Europe e

Characterization

With result $=0$

Non

Unit

$\mathrm{kg} \mathrm{CO} 2$

$\mathrm{kg} \mathrm{SO} 2$

$\mathrm{kg} \mathrm{PO} 4$

$\mathrm{kg} \mathrm{B}(\mathrm{a}) \mathrm{P}$

$\mathrm{kg}$ SPM

$\mathrm{kg} \mathrm{C} 2 \mathrm{H} 4$
$8 / 13 / 2008$

Time:

3:27:29 PM
CPD 1k 1.9 High CPD $1 \mathrm{k} 1.9$ Low 36291.37694 769.3852772

142.3029597

0.018008463

30.30686692

8.163600594
68110.15311

1443.950422

267.0683008

0.033797537

56.87867259

15.32110747 


\begin{tabular}{|c|c|c|c|c|c|c|c|}
\hline CPD_1k_2.3_Avg & CPD_1k_2.3_High & CPD_1k_2.3_Low & CPD_1k_3.0_Avg & CPD_1k_3.0_High & 1k_3.0_Low & MBD_1k_1.5_A & MBD_1k \\
\hline 49351.77961 & 38609.36865 & 76820.49203 & 57827.25593 & 43521.06036 & 94373.9183 & 36485.39386 & 03 \\
\hline 1046.268724 & 818.5272181 & 1628.611548 & 1225.95071 & 922.6561765 & 2000.748096 & 773.4984793 & 595.7648517 \\
\hline 193.5144075 & 151.3920908 & 301.2226127 & 226.7477942 & 170.651439 & 370.0517595 & 143.063724 & 110.1906992 \\
\hline 0.02448928 & 0.019158694 & 0.038119771 & 0.02869497 & 0.021595968 & 0.046830111 & 0.018104738 & 0.013944651 \\
\hline 41.2135869 & 32.24261785 & 64.15266175 & 48.29144271 & 36.34436321 & 78.81149806 & 30.46889013 & 23.46778215 \\
\hline 11.10148612 & 8.685023592 & 17.2804635 & 13.00801074 & 9.789889064 & 21.22903677 & 8.207243929 & 6.321392469 \\
\hline
\end{tabular}




$\begin{array}{rrrrrrrr}\text { MBD_1k_1.5_Low } & \text { MBD_1k_1.9_Avg } & \text { MBD_1k_1.9_High } & \text { MBD_1k_1.9_Low } & \text { MBD_1k_2.3_Avg } & \text { MBD_1k_2.3_High } & \text { MBD_1k_2.3_Low } & \text { MBD_1k_3.0_Avg } \\ 52496.89613 & 36863.2163 & 28479.64273 & 52874.71856 & 37241.03874 & 28857.46517 & 53252.541 & 37914.99228 \\ 1112.945895 & 781.5083992 & 603.7747715 & 1120.955815 & 789.518319 & 611.7846914 & 1128.965735 & 803.8062842 \\ 205.8467968 & 144.5452123 & 111.6721875 & 207.3282851 & 146.0267006 & 113.1536759 & 208.8097734 \\ 0.026049946 & 0.01829222 & 0.014132134 & 0.026237428 & 0.018479703 & 0.014319616 & 0.026424911 \\ 43.84006833 & 30.784409 & 23.78330103 & 44.15558721 & 31.09992788 & 0.018814131 \\ 11.80896754 & 8.292233581 & 6.406382121 & 11.8939572 & 8.377223232 & 6.491371772 & 11.978946858 & 8.528826395\end{array}$


MBD_1k_3.0_High MBD_1k_3.0_Low 29531.41871 53926.49454 $626.0726566 \quad 1143.2537$

$115.7963307 \quad 211.4524283$

$0.014654045 \quad 0.026759339$

$24.66163735 \quad 45.03392353$

$6.642974935 \quad 12.13055001$ 


\section{SimaPro 7.1}

Project

Title:

Method:

Indicator:

Skip categories:

Relative mode:

Impact category

greenhouse

acidification

eutrophication

carcinogens

winter smog

summer smog
Impact assessment Date:

Thesis_Dredging Limited LCA

Comparing product stages

Eco-indicator 95 V2.03 / Europe e

Characterization

With result $=0$

Non

Unit

$\mathrm{kg} \mathrm{CO} 2$

$\mathrm{kg} \mathrm{SO} 2$

$\mathrm{kg} \mathrm{PO} 4$

$\mathrm{kg} \mathrm{B}(\mathrm{a}) \mathrm{P}$

$\mathrm{kg}$ SPM

$\mathrm{kg} \mathrm{C} 2 \mathrm{H} 4$
$8 / 13 / 2008$

Time:

\section{3:33:26 PM}

CPD_5k_1.9_Avg 127081.0878 2694.147376 498.3006002 0.063060023 106.1251995 28.58638419
CPD 5k 1.9 High CPD 5k 1.9 Low 82324.44594 1745.296597 322.804294 0.040850936 68.74900426 18.51855599 241418.3268 5118.122319 946.6309997 0.119796308 201.6080326 $88.95926724 \quad 59.09583224$ 165.2466143 $23.96248773 \quad 15.91833205$ 
CPD_5k_2.3_Avg 147636.6707 3129.930314 578.9015732 0.073260089 123.2911317 33.21028064
CPD_5k_2.3_High CPD_5k_2.3_Low 93893.98169 1990.573332

368.169869 0.046591957 78.41070382

21.12107695

\author{
284949.5986 \\ 6040.99498 \\ 1117.322479 \\ 0.141397343 \\ 237.9609233 \\ 64.09827647
}

CPD_5k_3.0_Avg 3998.681895 739.5829961 0.093594349 157.5121381 42.42821232
CPD_5k_3.0_High 117084.1103 2482.209226

459.10122 0.058099335 97.77674062 26.33760394
CPD_5k_3.0_Low MBD_5k_1.5_Avg MBD_5k_1.5_High 371327.9772 7872.235852

1456.022742

0.184259916

310.0953598

83.52874845

$\begin{array}{rr}122230.6646 & 80282.16249 \\ 2591.317324 & 1701.999732 \\ 479.2814934 & 314.796249 \\ 0.060653151 & 0.039837517 \\ 102.0746193 & 67.04349684 \\ 27.49530082 & 18.05915247\end{array}$




$\begin{array}{rrrrrrrr}\text { MBD_5k_1.5_Low } & \text { MBD_5k_1.9_Avg } & \text { MBD_5k_1.9_High } & \text { MBD_5k_1.9_Low } & \text { MBD_5k_2.3_Avg } & \text { MBD_5k_2.3_High } & \text { MBD_5k_2.3_Low } & \text { MBD_5k_3.0_Avg } \\ \text { 202257.5416 } & 124140.1996 & 82191.69751 & 204167.0767 & 126049.7346 & 84101.23254 & 206076.6117 & 129378.6567 \\ 4287.904948 & 2631.799892 & 1742.482301 & 4328.387516 & 2672.28246 & 1782.964869 & 4368.870084 & 2742.856348 \\ 793.0767367 & 486.7690154 & 322.2837711 & 800.5642588 & 494.2565375 & 329.7712932 & 808.0517809 & 507.3096509 \\ 0.100363991 & 0.061600699 & 0.040785064 & 0.101311538 & 0.062548246 & 0.041732611 & 0.102259085 & 0.064200119 \\ 168.9049277 & 103.6692688 & 68.63814628 & 170.4995772 & 105.2639182 & 70.23279572 & 172.0942266 & 108.0438953 \\ 45.49702785 & 27.92484311 & 18.48869476 & 45.92657014 & 28.35438541 & 18.91823706 & 46.35611243 & 29.10321315\end{array}$


MBD 5k 3.0 High MBD 5k 3.0 Low 87430.15457 1853.538757

342.8244065

0.043384485

73.01277282

209405.5337

4439.443973

821.1048943

0.103910959

174.8742037

19.6670648

47.10494018 


\section{SimaPro 7.1}

Project

Title:

Method:

Indicator:

Skip categories:

Relative mode:

Impact category

greenhouse

acidification

eutrophication

carcinogens

winter smog

summer smog
Impact assessment Date:

Thesis_Dredging Limited LCA

Comparing product stages

Eco-indicator 95 V2.03 / Europe e

Characterization

With result $=0$

Non

Unit

$\mathrm{kg} \mathrm{CO} 2$

$\mathrm{kg} \mathrm{SO} 2$

$\mathrm{kg} \mathrm{PO} 4$

$\mathrm{kg} \mathrm{B}(\mathrm{a}) \mathrm{P}$

$\mathrm{kg}$ SPM

kg C2H4
$8 / 13 / 2008$

Time:

3:30:29 PM

$\begin{array}{lrrrrr}\text { 20k_1.5_Avg } & \text { CPD_20k_1.5_High } & \text { CPD_20k_1.5_Low } & \text { CPD_20k_1.9_Avg } & \text { CPD_20k_1.9_High } & \text { CPD_20k_1.9_Low } \\ 351742.4789 & 208700.9459 & 717168.2569 & 433985.2335 & 254958.6661 & 891313.7668 \\ 7457.018925 & 4424.506555 & 15204.12684 & 9200.583647 & 5405.180529 & 18896.05045 \\ 1379.225591 & 818.3421187 & 2812.105083 & 1701.709563 & 999.724338 & 3494.95108 \\ 0.174541224 & 0.103561329 & 0.355872359 & 0.215351624 & 0.126515279 & 0.442286631 \\ 293.7395436 & 174.2858037 & 598.905987 & 362.4203276 & 212.9155468 & 744.3346051 \\ 79.12306867 & 46.94644596 & 161.3241409 & 97.62324852 & 57.35193574 & 200.4974793\end{array}$




\begin{tabular}{|c|c|c|c|c|c|c|c|}
\hline $\begin{array}{r}\text { PD_20k_2.3_Avg } \\
516217.7767\end{array}$ & $\begin{array}{r}\text { CPD_20k_2.3_High } \\
301216.3863\end{array}$ & $\begin{array}{r}\text { CPD_20k_2.3_Low } \\
1065469.488\end{array}$ & $\begin{array}{r}\text { CPD_20k_3.0_Avg } \\
\text { 679049.0363 }\end{array}$ & $\begin{array}{r}\text { CPD_20k_3.0_High } \\
392965.9704\end{array}$ & $\begin{array}{r}\text { CPD_20k_3.0_Low } \\
1409910.804\end{array}$ & $\begin{array}{r}\text { MBD_20k_1.5_Avg } \\
443777.9826\end{array}$ & $5 \quad 275983.9742$ \\
\hline 10943.93188 & 6385.854504 & 22588.19055 & 14395.99087 & 8330.966129 & 29890.42318 & 9408.192111 & 5850.921746 \\
\hline 2024.153495 & 1181.106557 & 4177.837118 & 2662.634923 & 1540.867979 & 5528.433947 & 1740.108139 & 1082.167161 \\
\hline 0.256156956 & 0.149469228 & 0.528705971 & 0.336956885 & 0.194997095 & 0.699624221 & 0.22021097 & 0.136948431 \\
\hline 431.092584 & 251.54529 & 889.7717506 & 567.0726909 & 328.165211 & 1177.414105 & 370.5982357 & 230.4737457 \\
\hline 116.1211314 & 67.75742553 & 239.6731147 & 152.7493742 & 88.39612878 & 317.1538158 & 99.82608841 & 62.08149501 \\
\hline
\end{tabular}




$\begin{array}{rrrrrrr}\text { MBD_20k_1.5_Low } & \text { MBD_20k_1.9_Avg } & \text { MBD_20k_1.9_High } & \text { MBD_20k_1.9_Low } & \text { MBD_20k_2.3_Avg } & \text { MBD_20k_2.3_High } & \text { MBD_20k_2.3_Low } \\ \text { 763885.4908 } & 451416.1227 & 283622.1144 & 771523.631 & 459044.0514 & 291250.043 \\ 16194.54261 & 9570.122383 & 6012.852018 & 16356.47288 & 9731.836171 & 6174.565806 \\ 2995.289112 & 1770.058227 & 1112.11725 & 3025.239201 & 1799.968275 & 1142.027298 \\ 0.379054328 & 0.224001158 & 0.14073862 & 0.382844516 & 0.22778628 & 0.144523741 \\ 637.9194693 & 376.9768335 & 236.8523435 & 644.2980671 & 383.3469037 & 243.2224137 \\ 171.8329965 & 101.5442576 & 63.79966418 & 173.5511657 & 103.2601297 & 65.18667 \\ & & & & \end{array}$


MBD 20k 3.0 Avg MBD 20k 3.0 High MBD 20k 3.0 Low 472390.3738

10014.78118

304596.3654

6457.510814

$7 \overline{9} 2497.882$

1852.300849

1194.359872

16801.13168

0.234408976

0.151146437

3107.481823

394.4923947

0.393252333

106.2623318

254.3679048

661.8136283

68.51773836

178.2692399 


\section{SimaPro 7.1}

Project

Title:

Method:

Indicator:

Skip categories:

Relative mode:

Impact category

greenhouse

acidification

eutrophication

carcinogens

winter smog

summer smog
Impact assessment Date:

Thesis_Dredging Limited LCA

Comparing product stages

Eco-indicator 95 V2.03 / Europe e

Characterization

With result $=0$

Non

Unit

$\mathrm{kg} \mathrm{CO} 2$

$\mathrm{kg} \mathrm{SO} 2$

$\mathrm{kg} \mathrm{PO} 4$

$\mathrm{kg} \mathrm{B}(\mathrm{a}) \mathrm{P}$

$\mathrm{kg}$ SPM

kg C2H4
$8 / 13 / 2008$

Time:

3:21:44 PM

$\begin{array}{rrrrr}1659590.167 & 944362.0795 & 3486729.269 & 2070773.306 & 1175650.68 \\ 35183.68132 & 20020.6865 & 73919.43738 & 43900.85548 & 24924.05637 \\ 6507.457489 & 3702.960049 & 13671.89499 & 8119.75723 & 4609.871145 \\ 0.823519811 & 0.4686102 & 1.730180549 & 1.027556607 & 0.583379948 \\ 1385.920915 & 788.6351604 & 2911.76166 & 1729.299253 & 981.7838762 \\ 373.3181934 & 212.4304858 & 784.3258518 & 465.8122016 & 264.4579347\end{array}$




\begin{tabular}{|c|c|c|c|c|c|c|}
\hline CPD_100k_1.9_Low & CPD_100k_2.3_Avg & 00k_2.3 & 100k_2.3_Low & 00k_3.0_A & $P$ & $P L_{2}$ \\
\hline 4357456.818 & 2481946.233 & 1406939.281 & 5228194.579 & 3294744.413 & 1864288.237 & 6949012.404 \\
\hline 92379.05544 & 52617.81315 & 29827.42625 & 110838.89 & 69849.31565 & 39523.32602 & 147320.6113 \\
\hline 17086.12498 & 9732.01693 & 5516.782242 & 20500.395 & 12919.09872 & 7310.10384 & 27247.93368 \\
\hline 2.162251913 & 1.231588336 & 0.698149696 & 2.594328344 & 1.634914058 & 0.925094838 & 3.448230468 \\
\hline 3638.90475 & 2072.669062 & 1174.932592 & 4366.056368 & 2751.435434 & 1556.863924 & 5803.108396 \\
\hline 980.1925436 & 558.3039128 & 316.4853836 & 1176.061532 & 741.1396237 & 419.3642085 & 1563.152643 \\
\hline
\end{tabular}




$\begin{array}{rrrrrrr}\text { MBD_100k_1.5_Avg } & \text { MBD_100k_1.5_High } & \text { MBD_100k_1.5_Low } & \text { MBD_100k_1.9_Avg } & \text { MBD_100k_1.9_High } & \text { MBD_100k_1.9_Low } & \text { MBD_100k_2.3_Avg } \\ \text { 2158734.454 } & 1319764.412 & 3759251.572 & 2196884.309 & 1357914.267 & 3797401.427 & 2235034.164 \\ 45765.65142 & 27979.2996 & 79696.97094 & 46574.43684 & 28788.08502 & 80505.75636 \\ 8464.663728 & 5174.958841 & 14740.48852 & 8614.254008 & 5324.549122 & 47383.22226 \\ 1.07120458 & 0.654891889 & 1.865411235 & 1.090135255 & 0.673822563 & 14890.0788 \\ 1802.755457 & 1102.133008 & 3139.34457 & 1834.614336 & 1133.991886 & 8763.844289 \\ 485.5987113 & 296.8757443 & 845.6286578 & 494.1803691 & 305.4574021 & 8541.203449 & 1.109065929 \\ & & & & \end{array}$


MBD_100k_2.3_High MBD_100k_2.3_Low MBD_100k_3.0_Avg MBD_100k_3.0_High MBD_100k_3.0_Low 1396064.122 29596.87044

5474.139402

0.692753238

1165.850765

3835551.282

81314.54178

15039.66908

1.903272584

2301796.41

1462826.368

48798.59676

31012.24493

3902313.528

9025.62728

5735.922393

82729.91628

1.14219461

0.725881918

15301.45207

3203.062328

1922.226252

1221.603803

1.936401264

314.0390599

862.7919734

517.7799281

3258.815365

877.8098746 
SimaPro 7.1

Project

Title:

Method:

Per sub-compartment:

Skip unused:

Indicator:

Category:

Cut-off:

Relative mode:

No
Inventory Date:

Thesis_Dredging Limited LCA

Comparing product stages

Eco-indicator 95 V2.03 / Europe e

No

Yes

Characterization

summer smog

$0 \%$

Non

\section{Substance}

Total

1 Acetaldehyde

2 Acrolein

3 Benzene

4 Formaldehyde

5 Methane

$\mathrm{PAH}$, polycyclic

6 aromatic hydrocarbons

7 Propene

8 Toluene

VOC, volatile organic

9 compounds
Compartment Unit

$\mathrm{kg} \mathrm{C} 2 \mathrm{H} 4$

$\mathrm{kg} \mathrm{C} 2 \mathrm{H} 4$

$\mathrm{kg} \mathrm{C} 2 \mathrm{H} 4$

$\mathrm{kg} \mathrm{C} 2 \mathrm{H} 4$

$\mathrm{kg} \mathrm{C} 2 \mathrm{H} 4$

$\mathrm{kg} \mathrm{C} 2 \mathrm{H} 4$

$\mathrm{kg} \mathrm{C} 2 \mathrm{H} 4$

$\mathrm{kg} \mathrm{C} 2 \mathrm{H} 4$

$\mathrm{kg} \mathrm{C} 2 \mathrm{H} 4$

$\mathrm{kg} \mathrm{C} 2 \mathrm{H} 4$

Air $\quad \mathrm{kg} \mathrm{C} 2 \mathrm{H}$

CPD_1k_1.5_Avg CPD_1k_1.5_High CPD_1k_1.5_Low CPD_1k_1.9_Avg $9.252386942 \quad 7.644474614 \quad 13.36175145$ $\begin{array}{lll}0.102063795 & 0.08432679 & 0.147394512\end{array}$ $\begin{array}{lll}0.014102059 & 0.011651353 & 0.020365361\end{array}$

$\begin{array}{lll}0.044545798 & 0.036804473 & 0.064330414\end{array}$

$\begin{array}{lll}0.126148234 & 0.10422575 & 0.182175838\end{array}$

$\begin{array}{lll}0.01432423 & 0.011834915 & 0.020686208\end{array}$

0.002099589

0.001734715

0.556633498

0.003032102

0.972937817

0.084227961

0.058323917

0.048188182

8.21706546

6.789074938

11.86660124

10.17808504

0.112275242

0.015512965

0.04900259

0.138769321

0.015757365

0.002309652

0.741118698

0.064159205

9.039180003

11.86660 


\begin{tabular}{|c|c|c|c|c|c|c|c|}
\hline 1.9_High & ow & & & & & High & \\
\hline 8.163600594 & 15.32110747 & 11.10148612 & 8.685023592 & 17.2804635 & 13.00801074 & 9.789889064 & 21.22903677 \\
\hline 0.090053309 & 0.16900832 & 0.122461351 & 0.095805166 & 0.190622127 & 0.143492371 & 0.107993022 & 0.234179144 \\
\hline 0.012442581 & 0.023351721 & 0.01692037 & 0.01323731 & 0.02633808 & 0.019826206 & 0.014921294 & 0.032356312 \\
\hline 0.039303815 & 0.073763772 & 0.053448322 & 0.041814216 & 0.08319713 & 0.062627323 & 0.047133613 & 0.102207614 \\
\hline 0.111303581 & 0.208889951 & 0.15135909 & 0.118412729 & 0.235604063 & 0.177352892 & 0.133476607 & 0.289439419 \\
\hline 0.012638608 & 0.023719617 & 0.017186943 & 0.013445858 & 0.026753025 & 0.020138559 & 0.015156373 & 0.032866072 \\
\hline 0.001852517 & 0.003476727 & 0.002519194 & 0.00197084 & 0.003921352 & 0.00295183 & 0.002221561 & 0.004817378 \\
\hline 0.594433729 & 1.115608603 & 0.808356278 & 0.632401218 & 1.258279388 & 0.947180138 & 0.712852154 & 1.545795308 \\
\hline 0.051460576 & 0.096579078 & 0.069980013 & 0.054747451 & 0.108930196 & 0.081998099 & 0.061712149 & 0.133820666 \\
\hline 7.250111878 & 13.60670969 & 9.85925456 & 7.713188804 & 15.34681814 & 11.55244332 & 8.694422292 & 18.85355486 \\
\hline
\end{tabular}




\begin{tabular}{|c|c|c|c|c|c|c|c|}
\hline BD_1k_1.5_Avg & MBD_1k_1.5_High & MBD & MBD_1k_1.9_Avg & High & Low & MBL & MBD \\
\hline 8.207243929 & 6.321392469 & 11.80896754 & 8.292233581 & 6.406382121 & 11.8939572 & 8.377223232 & 6.491371772 \\
\hline 0.090534742 & 0.069731768 & 0.130265633 & 0.091472269 & 0.070669296 & 0.13120316 & 0.092409796 & 0.071606823 \\
\hline 0.0125091 & 0.009634773 & 0.01799868 & 0.012638637 & 0.00976431 & 0.018128217 & 0.012768175 & 0.009893847 \\
\hline 0.039513937 & 0.030434468 & 0.056854506 & 0.039923121 & 0.030843652 & 0.05726369 & 0.040332305 & 0.031252837 \\
\hline 0.11189862 & 0.086186678 & 0.161004983 & 0.11305738 & 0.087345438 & 0.162163743 & 0.114216139 & 0.088504198 \\
\hline 0.012706175 & 0.009786564 & 0.018282241 & 0.012837754 & 0.009918143 & 0.018413819 & 0.012969332 & 0.010049721 \\
\hline 0.001862421 & 0.001434476 & 0.002679738 & 0.001881707 & 0.001453762 & 0.002699024 & 0.001900993 & 0.001473048 \\
\hline 0.597611625 & 0.460293085 & 0.859871638 & 0.603800158 & 0.466481618 & 0.866060172 & 0.609988692 & 0.472670152 \\
\hline 0.051735689 & 0.03984792 & 0.074439736 & 0.052271435 & 0.040383666 & 0.074975482 & 0.052807181 & 0.040919412 \\
\hline 7.288871621 & 5.614042737 & 10.48757039 & 7.36435112 & 5.689522236 & 10.56304989 & 7.439830619 & 5.765001735 \\
\hline
\end{tabular}




$\begin{array}{rrrr}\text { MBD_1k_2.3_Low } & \text { MBD_1k_3.0_Avg } & \text { MBD_1k_3.0_High } & \text { MBD_1k_3.0_Low } \\ 11.97894685 & 8.528826395 & 6.642974935 & 12.13055001 \\ 0.132140688 & 0.094082143 & 0.073279169 & 0.133813034 \\ 0.018257755 & 0.012999241 & 0.010124914 & 0.018488821 \\ 0.057672874 & 0.041062202 & 0.031982733 & 0.058402771 \\ 0.163322503 & 0.116283116 & 0.090571175 & 0.16538948 \\ 0.018545397 & 0.013204038 & 0.010284427 & 0.018780104 \\ & & & \\ 0.002718311 & 0.001935395 & 0.00150745 & 0.002752713 \\ 0.872248705 & 0.621027697 & 0.483709157 & 0.883287711 \\ 0.075511228 & 0.053762836 & 0.041875067 & 0.076466884 \\ & & & \\ 10.63852939 & 7.574469725 & 5.899640842 & 10.77316849\end{array}$




\section{SimaPro 7.1}

Project

Title:

Method:

Per sub-compartment:

Skip unused:

Indicator:

Category:

Cut-off:

Relative mode:
Inventory Date:
Thesis_Dredging Limited LCA

Comparing product stages

Eco-indicator 95 V2.03 / Europe e

No

Yes

Characterization

summer smog

$0 \%$

Non

\section{Substance}

Total

1 Acetaldehyde

2 Acrolein

3 Benzene

4 Formaldehyde

5 Methane

$\mathrm{PAH}$, polycyclic

6 aromatic hydrocarbons

7 Propene

8 Toluene

VOC, volatile organic

9 compounds
Compartment Unit

$\mathrm{kg} \mathrm{C} 2 \mathrm{H} 4$

$\mathrm{kg} \mathrm{C} 2 \mathrm{H} 4$

$\mathrm{kg} \mathrm{C} 2 \mathrm{H} 4$

$\mathrm{kg} \mathrm{C} 2 \mathrm{H} 4$

$\mathrm{kg} \mathrm{C} 2 \mathrm{H} 4$

$\mathrm{kg} \mathrm{C} 2 \mathrm{H} 4$

$\mathrm{kg} \mathrm{C} 2 \mathrm{H} 4$

$\mathrm{kg} \mathrm{C} 2 \mathrm{H} 4$

$\mathrm{kg} \mathrm{C} 2 \mathrm{H} 4$

$\mathrm{kg} \mathrm{C} 2 \mathrm{H} 4$
CPD_5k_1.5_Avg CPD_5k_1.5_High CPD_5k_1.5_Low CPD_5k_1.9_Avg $23.96248773 \quad 15.91833205$

$0.264332052 \quad 0.17559635$

$0.036522511 \quad 0.024261983$

$0.115367867 \quad 0.076639122$

$0.326707641 \quad 0.217032587$

$0.037097907 \quad 0.024644219$

0.005437664

0.003612252

1.744831926

1.159095595

0.10034378

21.28113875

14.13710617
44.51160729

0.067842525

0.214302006

0.606876981

0.068911354

0.010100752

3.241118966

0.280586114

39.53085762
0.491010977
28.58638419

0.315338611

0.043570039

0.137629707

0.38975044

0.044256466

0.006486937

2.081521598

0.180198895

25.38763149 


\begin{tabular}{|c|c|c|c|c|c|c|c|}
\hline PD_5k_1.9_High & CPD_5k_1.9_Low & CPD_5k_2.3_Avg & CPD_5k & $P D_{-}$ & SPD_5 & CPD_5K & CPD \\
\hline 18.51855599 & 54.30609039 & 33.21028064 & 21.12107695 & 64.09827647 & 42.42821232 & 26.33760394 & 83.52874845 \\
\hline 0.204279621 & 0.599054676 & 0.36634517 & 0.232988231 & 0.707073037 & 0.468028886 & 0.290532143 & 0.921412074 \\
\hline 0.028225123 & 0.082770821 & 0.050617568 & 0.032191765 & 0.097695617 & 0.064667111 & 0.040142553 & 0.12731064 \\
\hline 0.089157951 & 0.261457736 & 0.159891547 & 0.101687839 & 0.308602408 & 0.20427146 & 0.12680291 & 0.402150796 \\
\hline 0.252484375 & 0.740416224 & 0.452793239 & 0.287967481 & 0.873924148 & 0.578471706 & 0.359090281 & 1.138841703 \\
\hline 0.028669798 & 0.084074839 & 0.051415025 & 0.032698932 & 0.099234768 & 0.065685913 & 0.040774981 & 0.129316363 \\
\hline 0.004202305 & 0.012323355 & 0.00753621 & 0.004792879 & 45437 & 0.00962798 & 0.005976634 & 0.018954678 \\
\hline 1.348431268 & 3.954305635 & 2.418211271 & 1.537934198 & 4.667325046 & 3.089416267 & 1.917776348 & 6.082157606 \\
\hline 0.116734712 & 0.342327222 & 0.209346374 & 0.133140124 & 0.404053851 & 0.267453097 & 0.166023345 & 0.526536973 \\
\hline 16.44637084 & 48.22935988 & 29.49412424 & 18.7576755 & 56.92582216 & 37.6805899 & 23.39048475 & 74.18206762 \\
\hline
\end{tabular}




\begin{tabular}{|c|c|c|c|c|c|c|c|}
\hline 5k_1.5_Avg & MBD_ & ow & $\operatorname{lvg}$ & $\mathrm{BC}$ & & $\mathrm{AB}$ & \\
\hline 27.49530082 & 18.05915247 & 45.49702785 & 27.92484311 & 18.48869476 & 45.92657014 & 28.35438541 & 18.91823706 \\
\hline 0.303302786 & 0.199211905 & 0.501881227 & 0.308041101 & 0.20395022 & 0.506619542 & 0.312779415 & 0.208688534 \\
\hline 0.041907061 & 0.027524922 & 0.069344457 & 0.042561749 & 0.02817961 & 0.069999146 & 0.043216438 & 0.028834298 \\
\hline 0.132376665 & 0.086946143 & 0.219046332 & 0.134444704 & 0.089014183 & 0.221114372 & 0.136512744 & 0.091082223 \\
\hline 0.374874469 & 0.246220808 & 0.620312331 & 0.380730904 & 0.252077243 & 0.626168766 & 0.386587339 & 0.257933678 \\
\hline 0.042567288 & 0.027958565 & 0.070436949 & 0.043232291 & 0.028623567 & 0.071101951 & 0.043897294 & 0.02928857 \\
\hline 0.006239344 & 0.004098055 & 0.010324368 & 0.006336817 & 0.004195529 & 0.010421841 & 0.006434291 & 0.004293002 \\
\hline 2.002074209 & 1.314979735 & 3.312872503 & 2.033351392 & 1.346256918 & 3.344149686 & 2.064628574 & 1.377534101 \\
\hline 0.173321075 & 0.113838788 & 0.286797872 & 0.176028764 & 0.116546477 & 0.289505561 & 0.178736453 & 0.119254166 \\
\hline 24.41863792 & 16.03837355 & 40.40601181 & 24.80011539 & 16.41985101 & 40.78748928 & 25.18159286 & 16.80132848 \\
\hline
\end{tabular}




$\begin{array}{rrrr}\text { MBD_5k_2.3_Low } & \text { MBD_5k_3.0_Avg } & \text { MBD_5k_3.0_High } & \text { MBD_5k_3.0_Low } \\ \text { 46.35611243 } & 29.10321315 & 19.6670648 & 47.10494018 \\ 0.511357856 & 0.321039791 & 0.21694891 & 0.519618232 \\ 0.070653834 & 0.044357766 & 0.029975627 & 0.071795162 \\ 0.223182412 & 0.14011799 & 0.094687469 & 0.226787657 \\ 0.632025201 & 0.396796953 & 0.268143292 & 0.642234815 \\ 0.071766954 & 0.045056603 & 0.03044788 & 0.072926264 \\ & & & \\ 0.010519315 & 0.006604218 & 0.004462929 & 0.010689242 \\ 3.375426868 & 2.119154572 & 1.432060098 & 3.429952866 \\ 0.292213251 & 0.18345681 & 0.123974523 & 0.296933607 \\ 41.16896674 & 25.84662845 & 17.46636407 & 41.83400233\end{array}$


SimaPro 7.1

Project

Title:

Method:

Per sub-compartment:

Skip unused:

Indicator:

Category:

Cut-off:

Relative mode:

No
Inventory Date:
Thesis_Dredging Limited LCA

Comparing product stages

Eco-indicator 95 V2.03 / Europe e

No

Yes

Characterization

summer smog

$0 \%$

Non

\section{Substance}

Total

1 Acetaldehyde

2 Acrolein

3 Benzene

4 Formaldehyde

5 Methane

$\mathrm{PAH}$, polycyclic

6 aromatic hydrocarbons

7 Propene

8 Toluene

VOC, volatile organic

9 compounds
Compartment Unit

$\mathrm{kg} \mathrm{C} 2 \mathrm{H} 4$

$\mathrm{kg} \mathrm{C} 2 \mathrm{H} 4$

$\mathrm{kg} \mathrm{C} 2 \mathrm{H} 4$

$\mathrm{kg} \mathrm{C} 2 \mathrm{H} 4$

$\mathrm{kg} \mathrm{C} 2 \mathrm{H} 4$

$\mathrm{kg} \mathrm{C} 2 \mathrm{H} 4$

$\mathrm{kg} \mathrm{C} 2 \mathrm{H} 4$

$\mathrm{kg} \mathrm{C} 2 \mathrm{H} 4$

$\mathrm{kg} \mathrm{C} 2 \mathrm{H} 4$

$\mathrm{kg} \mathrm{C} 2 \mathrm{H} 4$
CPD_20k_1.5_Avg CPD_20k_1.5_High CPD_20k_1.5_Low CPD_20k_1.9_Avg $\begin{array}{llll}79.12306867 & 46.94644596 & 161.3241409 & 97.62324852\end{array}$

$\begin{array}{llll}0.87281268 & 0.51786987 & 1.779579056 & 1.076889593\end{array}$

$\begin{array}{llll}0.120595707 & 0.071553593 & 0.245882764 & 0.148792822\end{array}$

$\begin{array}{llll}0.380939565 & 0.226024584 & 0.776698238 & 0.470009043\end{array}$

$\begin{array}{llll}1.078774098 & 0.640073884 & 2.199514094 & 1.331007931\end{array}$

$\begin{array}{llll}0.122495639 & 0.072680888 & 0.249756539 & 0.151136988\end{array}$

$\begin{array}{llll}0.017954923 & 0.010653275 & 0.03660832 & 0.022153058\end{array}$

$\begin{array}{llll}5.761357411 & 3.418412087 & 11.74684009 & 7.108450617\end{array}$

$\begin{array}{llll}0.498765058 & 0.295934513 & 1.016932809 & 0.615383933\end{array}$

$\begin{array}{lll}70.26937359 & 41.69324326 & 143.272329\end{array}$

86.69942454 


\begin{tabular}{|c|c|c|c|c|c|c|c|}
\hline PD_20k_1.9_High & CPD_2 & CPD_2 & CTL & , & JTU_2 & JTD & CPD \\
\hline 57.35193574 & 200.4974793 & 116.1211314 & 67.75742553 & $239.67 \overline{3} 1147$ & $15 \overline{2} .7493742$ & 88.39612878 & $31 \overline{7} .15 \overline{3} 8158$ \\
\hline 0.632653632 & 2.211703176 & 1.280941166 & 0.747437393 & 2.643852635 & 1.684990142 & 0.975104522 & 3.498548231 \\
\hline 0.087413157 & 0.305588948 & 0.176986436 & 0.103272722 & 0.365298632 & 0.232813503 & 0.134729275 & 0.483391119 \\
\hline 0.276122018 & 0.965299043 & 0.559067462 & 0.326219453 & 1.153910907 & 0.735414855 & 0.425584894 & 1.526943261 \\
\hline 0.781943671 & 2.733608429 & 1.583210445 & 0.923813457 & 3.267734083 & 2.082604621 & 1.205204193 & 4.32411593 \\
\hline 0.088790313 & 0.310403367 & 0.17977478 & 0.104899738 & 0.371053751 & 0.236481377 & 0.136851875 & 0.491006733 \\
\hline 0.013014531 & 0.04549769 & 0.026350672 & 0.015375786 & 0.054387582 & 0.034662499 & 0.020059203 & 0.071969813 \\
\hline 4.176089294 & 14.59925225 & 8.455376566 & 4.933766501 & 17.45183167 & 11.12246724 & 6.43657659 & 23.09359985 \\
\hline 0.361527201 & 1.263868282 & 0.731988329 & 0.427119888 & 1.510818234 & 0.96288038 & 0.557219292 & 1.999230362 \\
\hline 50.93438193 & 178.0622581 & 103.1274355 & 60.17552059 & 212.8542272 & 135.6570596 & 78.50479893 & 281.6650105 \\
\hline
\end{tabular}




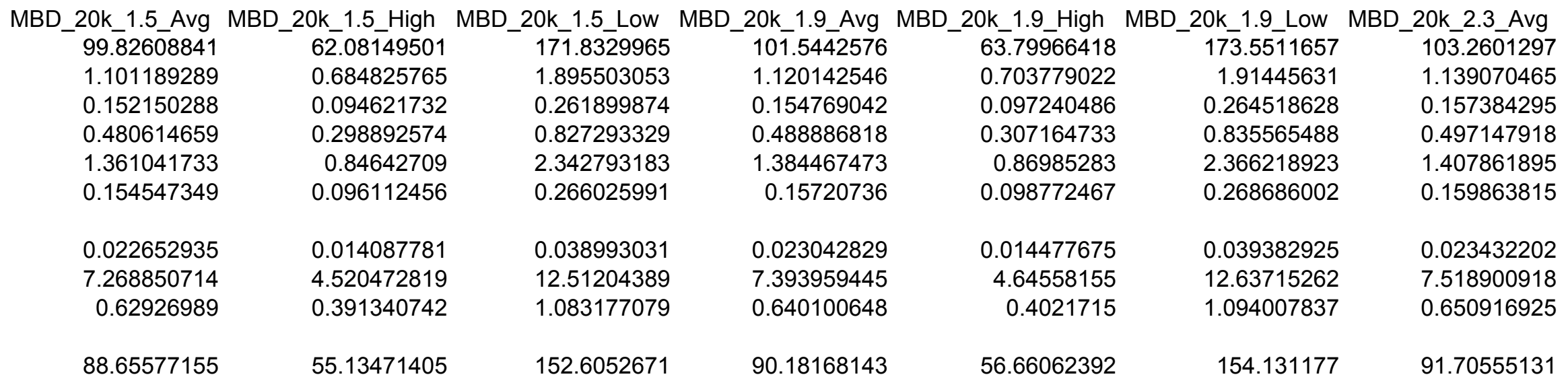




$\begin{array}{rrrrr}\text { MBD_20k_2.3_High } & \text { MBD_20k_2.3_Low } & \text { MBD_20k_3.0_Avg } & \text { MBD_20k_3.0_High } & \text { MBD_20k_3.0_Low } \\ 65.51553634 & 175.2670379 & 106.2623318 & 68.51773836 & 178.2692399 \\ 0.72270694 & 1.933384228 & 1.172187987 & 0.755824463 & 1.96650175 \\ 0.099855738 & 0.26713388 & 0.161960112 & 0.104431555 & 0.271709697 \\ 0.315425833 & 0.843826588 & 0.511602078 & 0.329879994 & 0.858280749 \\ 0.893247252 & 2.389613344 & 1.448794303 & 0.93417966 & 2.430545753 \\ 0.101428921 & 0.271342457 & 0.164511722 & 0.106076828 & 0.275990364 \\ & & & & \\ 0.014867048 & 0.039772298 & 0.024113474 & 0.015548319 & 0.040453569 \\ 4.770523023 & 12.76209409 & 7.737506682 & 4.989128787 & 12.98069986 \\ 0.412987777 & 1.104824114 & 0.669841791 & 0.431912643 & 1.12374898 \\ 58.18449381 & 155.6550469 & 94.37181361 & 60.85075611 & 158.3213092\end{array}$


SimaPro 7.1

Project

Title:

Method:

Per sub-compartment:

Skip unused:

Indicator:

Category:

Cut-off:

Relative mode:

No
Inventory Date:
Thesis_Dredging Limited LCA

Comparing product stages

Eco-indicator 95 V2.03 / Europe e

No

Yes

Characterization

summer smog

$0 \%$

Non

\section{Substance}

Total

1 Acetaldehyde

2 Acrolein

3 Benzene

4 Formaldehyde

5 Methane

$\mathrm{PAH}$, polycyclic

6 aromatic hydrocarbons

7 Propene

8 Toluene

VOC, volatile organic

9 compounds
Compartment Unit

$\mathrm{kg} \mathrm{C} 2 \mathrm{H} 4$

$\mathrm{kg} \mathrm{C} 2 \mathrm{H} 4$

$\mathrm{kg} \mathrm{C} 2 \mathrm{H} 4$

$\mathrm{kg} \mathrm{C} 2 \mathrm{H} 4$

$\mathrm{kg} \mathrm{C} 2 \mathrm{H} 4$

$\mathrm{kg} \mathrm{C} 2 \mathrm{H} 4$

$\mathrm{kg} \mathrm{C} 2 \mathrm{H} 4$

$\mathrm{kg} \mathrm{C} 2 \mathrm{H} 4$

$\mathrm{kg} \mathrm{C} 2 \mathrm{H} 4$

$\mathrm{kg} \mathrm{C} 2 \mathrm{H} 4$
CPD_100k_1.5_Avg CPD_100k_1.5_High CPD_100k_1.5_Low CPD_100k_1.9_Avg $373.3181934 \quad 212.4304858 \quad 784.3258518$

$\begin{array}{lll}4.118101818 & 2.343337092 & 8.651959034\end{array}$

$\begin{array}{lll}0.568994255 & 0.323776682 & 1.195433042\end{array}$

$\begin{array}{lll}1.797347757 & 1.022750736 & 3.776152182\end{array}$

$\begin{array}{lll}5.089868281 & 2.896304575 & 10.69359958\end{array}$

$\begin{array}{lll}0.577958509 & 0.328877641 & 1.214266565\end{array}$

0.177982361

57.11079758

4.944124834

696.5615366

465.8122016

5.138410364

0.709969327

2.242661972

6.350943489

0.721154582

0.048205576

15.4681558

1.339089918

331.5447194

188.6599878

0.105703969

33.91818119

2.936322536

413.6888542 


\begin{tabular}{|c|c|c|c|c|c|c|}
\hline PD_100k_1.9_High & CPD_100k_1.9_Low & CPD_100k_2.3_Avg & CPD_100k_2.3_High & CPD_100K & CPD_100 & CPD_100 \\
\hline 264.4579347 & 980.1925436 & 558.3039128 & 316.4853836 & 1176.061532 & 741.1396237 & 419.3642085 \\
\hline 2.917255898 & 10.81257964 & 6.158693572 & 3.491174705 & 12.97322558 & 8.175568417 & 4.626038965 \\
\hline 0.403074504 & 1.493963959 & 0.850940898 & 0.482372325 & 1.792498376 & 1.129610599 & 0.639175453 \\
\hline 1.273237909 & 4.719156208 & 2.687965128 & 1.523725081 & 5.662171293 & 3.568231241 & 2.019037199 \\
\hline 3.605653508 & 13.36407125 & 7.611987379 & 4.31500244 & 16.03457425 & 10.10479299 & 5.717665574 \\
\hline 0.409424765 & 1.517500704 & 0.864347098 & 0.489971889 & 1.8207384 & 1.147407117 & 0.649245381 \\
\hline 0.060011853 & 0.222429214 & 0.126692558 & 0.07181813 & 0.266876589 & 0.168182369 & 0.095163804 \\
\hline 19.25654183 & 71.37285838 & 40.65297819 & 23.04492787 & 85.63508644 & 53.96618628 & 30.53606402 \\
\hline 1.667053355 & 6.178802198 & 3.519358993 & 1.995016792 & 7.413494041 & 4.671893462 & 2.6435301 \\
\hline 234.8656811 & 870.5111821 & 495.830949 & 281.0713744 & 1044.462867 & 658.2077512 & 372.438288 \\
\hline
\end{tabular}




\begin{tabular}{|c|c|c|c|c|c|c|}
\hline PD 100k 3.0 Low & MBD 100 & MBD 100 & MBD 10 & $3 \mathrm{D} 10$ & BD & 100 \\
\hline $15 \overline{6} 3.1 \overline{5} 2643$ & $48 \overline{5} .59 \overline{8} 7113$ & $2 \overline{96} .8 \overline{757443}$ & $84 \overline{5} .62 \overline{8} 6578$ & $49 \overline{4} .180 \overline{3} 691$ & $3 \overline{05.4574021}$ & $85 \overline{4} .2103156$ \\
\hline 17.24325751 & 5.356676881 & 3.274859259 & 9.328195021 & 5.451341811 & 3.369524189 & 9.422859951 \\
\hline 2.382484672 & 0.740127006 & 0.452484224 & 1.288867933 & 0.753206771 & 0.465563988 & 1.301947697 \\
\hline 7.525829032 & 2.337924511 & 1.429314088 & 4.071295743 & 2.379241071 & 1.470630648 & 4.112612303 \\
\hline 21.31222426 & 6.620715308 & 4.047642094 & 11.52940992 & 6.737718735 & 4.164645521 & 11.64641335 \\
\hline 2.420019671 & 0.751787382 & 0.459612914 & 1.30917348 & 0.765073212 & 0.472898744 & 1.322459311 \\
\hline 0.354716853 & 0.110194003 & 0.067368232 & 0.191893439 & 0.112141387 & 0.069315616 & 0.193840823 \\
\hline 113.8211803 & 35.35893869 & 21.61704921 & 61.57457005 & 35.98381331 & 22.24192384 & 62.19944467 \\
\hline 9.853585453 & 3.061049999 & 1.87140426 & 5.330556985 & 3.115145867 & 1.925500127 & 5.384652852 \\
\hline 1388.239346 & 431.2612975 & 263.65601 & 751.0046953 & 438.882687 & 271.2773994 & 758.6260847 \\
\hline
\end{tabular}




$\begin{array}{rrrrrr}\text { MBD_100k_2.3_Avg } & \text { MBD_100k_2.3_High } & \text { MBD_100k_2.3_Low } & \text { MBD_100k_3.0_Avg } & \text { MBD_100k_3.0_High } & \text { MBD_100k_3.0_Low } \\ 502.7620269 & 314.0390599 & 862.7919734 & 517.7799281 & 329.056961 & 877.8098746 \\ 5.54600674 & 3.464189119 & 9.517524881 & 5.711670368 & 3.629852746 & 9.683188508 \\ 0.766286535 & 0.478643752 & 1.315027461 & 0.789176123 & 0.50153334 & 1.337917049 \\ 2.42055763 & 1.511947207 & 4.153928862 & 2.49286161 & 1.584251187 & 4.226232842 \\ 6.854722161 & 4.281648947 & 11.76341677 & 7.059478158 & 4.486404944 & 11.96817277 \\ 0.778359043 & 0.486184574 & 1.335745141 & 0.801609246 & 0.509434777 & 1.358995344 \\ & & & & & \\ 0.114088771 & 0.071263 & 0.195788207 & 0.117496693 & 0.074670922 & 0.199196129 \\ 36.60868794 & 22.86679846 & 62.8243193 & 37.70221853 & 23.96032905 & 63.91784989 \\ 3.169241734 & 1.979595995 & 5.43874872 & 3.263909503 & 2.074263763 & 5.533416488 \\ & & & & & \\ 446.5040764 & 278.8987888 & 766.2474741 & 459.8415078 & 292.2362203 & 779.5849056\end{array}$


SimaPro 7.1

Project

Title:

Method:

Per sub-compartment:

Skip unused:

Indicator:

Category:

Cut-off:

Relative mode:

No
Inventory Date:

Thesis_Dredging Limited LCA

Comparing product stages

Eco-indicator 95 V2.03 / Europe e

No

Yes

Characterization

winter smog

$0 \%$

Non

$\begin{array}{lll}\text { Substance } & \text { Compartment } & \text { Unit } \\ \text { Total } & & \text { kg SPM } \\ 1 \text { Particulates, < 10 um } & \text { Air } & \text { kg SPM } \\ 2 \text { Sulfur oxides } & \text { Air } & \text { kg SPM }\end{array}$

CPD_1k_1.5_Avg CPD_1k_1.5_High CPD_1k_1.5_Low CPD_1k_1.9_Avg

$34.34891952 \quad 28.37964354 \quad 49.60468343$

25.21356858

9.135350936
36.41194847

13.19273495
37.78551698

27.73617736

10.04933962
7.547777536 


\begin{tabular}{|c|c|c|c|c|c|c|c|}
\hline igh & 1k 1.9 Low & 23 Avg & 1k 23 Hiah & _2.3_Low & 3.0 Avq & 1k_3.0_High & CPD $1 \mathrm{k} 30$ \\
\hline 30.30686692 & 56.87867259 & 41.2135869 & 32.24261785 & 64.15266175 & 48.29144271 & 36.34436321 & 78.81149806 \\
\hline 22.24652998 & 41.75136605 & 30.25252655 & 23.66745353 & 47.09078363 & 35.4479739 & 26.67830916 & 57.85099326 \\
\hline 8.060336948 & 15.12730654 & 10.96106035 & 8.575164322 & 17.06187813 & 12.84346881 & 9.666054044 & 20.9605048 \\
\hline
\end{tabular}




\begin{tabular}{|c|c|c|c|c|c|c|c|}
\hline $\begin{array}{r}\text { MBD_1k_1.5_Avg } \\
30.46889013\end{array}$ & $\begin{array}{l}\text { MBD_1k_1.5_High } \\
23.46778215\end{array}$ & $\begin{array}{l}1 \mathrm{k} \text {-1.5_Low } \\
-43.84006833\end{array}$ & 30.784409 & 23.78330103 & 44.15558721 & $\begin{array}{r}\text { IVISD_TK_2.3_AVg } \\
31.09992788\end{array}$ & 24.0988199 \\
\hline 22.3654619 & 17.22635073 & 32.18047569 & 22.59706618 & 17.45795501 & 32.41207997 & 22.82867046 & 17.68955929 \\
\hline 8.103428226 & 6.241431424 & 11.65959264 & 8.18734282 & 6.325346018 & 11.74350724 & 8.271257414 & 6.4092606 \\
\hline
\end{tabular}


MBD_1k_2.3_Low MBD_1k_3.0_Avg MBD_1k_3.0_High MBD_1k_3.0_Low 44.47110608

31.66274533

24.66163735

45.03392353

32.64368425

23.24180242

18.10269125

33.05681621

11.82742183

8.420942906

6.558946104

11.97710732 
SimaPro 7.1

Project

Title:

Method:

Per sub-compartment:

Skip unused:

Indicator:

Category:

Cut-off:

Relative mode:

No
Inventory Date:

Thesis_Dredging Limited LCA

Comparing product stages

Eco-indicator 95 V2.03 / Europe e

No

Yes

Characterization

winter smog

$0 \%$

Non

$\begin{array}{lll}\text { Substance } & \text { Compartment } & \text { Unit } \\ \text { Total } & & \text { kg SPM } \\ 1 \text { Particulates, < 10 um } & \text { Air } & \text { kg SPM } \\ 2 \text { Sulfur oxides } & \text { Air } & \text { kg SPM }\end{array}$

CPD_5k_1.5_Avg CPD_5k_1.5_High CPD_5k_1.5_Low CPD_5k_1.9_Avg $88.95926724 \quad 59.09583224$

$65.29988765 \quad 43.37885558$

$23.65937958 \quad 15.71697666$
165.2466143

121.2980467

43.94856764
106.1251995

77.90041237

28.22478709 
CPD_5k_1.9_High CPD_5k_1.9_Low CPD_5k_2.3_Avg CPD_5k_2.3_High CPD_5k_2.3_Low CPD_5k_3.0_Avg CPD_5k_3.0_High CPD_5k_3.0_Low 68.74900426 201.6080326 123.2911317

78.41070382

237.9609233

50.46469462 147.988875

90.50093708

57.55679323 157.5121381

97.77674062

310.0953598

18.28430964

53.6191576

32.7901946

20.85391059

174.6734437

63.28747961

71.77228833

227.6231897

82.47217017 
MBD_5k_1.5_Avg MBD_5k_1.5_High MBD_5k_1.5_Low MBD_5k_1.9_Avg MBD_5k_1.9_High MBD_5k_1.9_Low MBD_5k_2.3_Avg MBD_5k_2.3_High 102.0746193 67.04349684 49.21277959 168.9049277 103.6692688

74.92711419 123.9834044 68.63814628 170.4995772 105.2639182 76.09765473 50.38332014 125.1539449 77.26819528 70.23279572 27.14750514

17.83071724

44.92152333

27.57161403

18.25482614

45.34563223

27.99572293

51.55386069

18.67893503 
MBD_5k_2.3_Low MBD_5k_3.0_Avg MBD_5k_3.0_High MBD_5k_3.0_Low 172.0942266

126.3244855

108.0438953

79.30881677

73.01277282

174.8742037

45.76974112

28.73507854

53.59448218

128.365107

$19.41829064 \quad 46.50909673$ 
SimaPro 7.1

Project

Title:

Method:

Per sub-compartment:

Skip unused:

Indicator:

Category:

Cut-off:

Relative mode:

No
Inventory Date:

Thesis_Dredging Limited LCA

Comparing product stages

Eco-indicator 95 V2.03 / Europe e

No

Yes

Characterization

winter smog

$0 \%$

Non

$\begin{array}{lll}\text { Substance } & \text { Compartment } & \text { Unit } \\ \text { Total } & & \text { kg SPM } \\ 1 \text { Particulates, < 10 um } & \text { Air } & \text { kg SPM } \\ 2 \text { Sulfur oxides } & \text { Air } & \text { kg SPM }\end{array}$
CPD_20k_1.5_Avg CPD_20k_1.5_High CPD_20k_1.5_Low CPD_20k_1.9_Avg $\begin{array}{llll}293.7395436 & 174.2858037 & 598.905987 & 362.4203276\end{array}$




\begin{tabular}{|c|c|c|c|c|c|c|c|}
\hline $\begin{array}{l}\text { CPD_20k_1.9_High } \\
212.9155468\end{array}$ & $\begin{array}{r}\text { CPD_20k_1.9_Low } \\
744.3346051\end{array}$ & $\begin{array}{r}\text { CPD_20k_2.3_Avg } \\
431.092584\end{array}$ & $\begin{array}{r}20 k \_2.3 \_H i g h \\
251.54529\end{array}$ & $\begin{array}{l}\text { 20k_2.3_Low } \\
889.7717506\end{array}$ & 567.0726909 & $\begin{array}{l}\text { K_3.0_HIgn } \\
328.165211\end{array}$ & 1177.414105 \\
\hline 156.2890716 & 546.3732739 & 316.440301 & 184.6449469 & 653.1303276 & 416.2554859 & 240.8872293 & 864.272056 \\
\hline 56.62647522 & 197.9613311 & 114.652283 & 66.90034308 & 236.641423 & 150.817205 & 87.27798165 & 313.1420493 \\
\hline
\end{tabular}




$\begin{array}{rrrrrrr}\text { MBD_20k_1.5_Avg } & \text { MBD_20k_1.5_High } & \text { MBD_20k_1.5_Low } & \text { MBD_20k_1.9_Avg } & \text { MBD_20k_1.9_High } & \text { MBD_20k_1.9_Low } & \text { MBD_20k_2.3_Avg } \\ \text { 370.5982357 } & 230.4737457 & 637.9194693 & 376.9768335 & 236.8523435 & 644.2980671 \\ 272.0348751 & 169.1775368 & 468.260036 & 276.7170373 & 173.859699 & 472.9421982 \\ 98.56336056 & 61.29620897 & 169.6594333 & 100.2597961 & 62.99264455 & 171.3558689\end{array}$




$\begin{array}{rrrrr}\text { MBD_20k_2.3_High } & \text { MBD_20k_2.3_Low } & \text { MBD_20k_3.0_Avg } & \text { MBD_20k_3.0_High } & \text { MBD_20k_3.0_Low } \\ \text { 243.2224137 } & 650.6681373 & 394.4923947 & 254.3679048 & 661.8136283 \\ 178.5356016 & 477.6181008 & 289.5742046 & 186.7168663 & 485.7993655 \\ 64.68681216 & 173.0500365 & 104.9181901 & 67.6510385 & 176.0142629\end{array}$




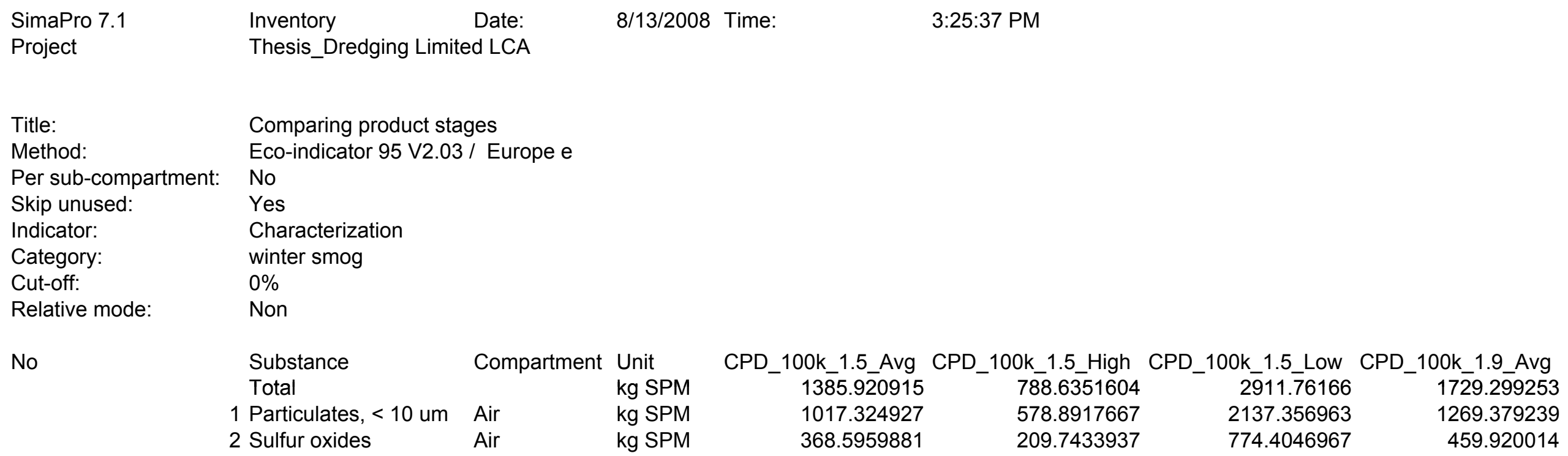

Substance Compartment Unit

Total

1 Particulates, $<10$ um

2 Sulfur oxides
CPD_100k_1.5_Avg CPD_100k_1.5_High CPD_100k_1.5_Low CPD_100k_1.9_Avg $\begin{array}{llll}1385.920915 & 788.6351604 & 2911.76166 & 1729.299253\end{array}$ $\begin{array}{llll}1017.324927 & 578.8917667 & 2137.356963 & 1269.379239\end{array}$

$\begin{array}{llll}368.5959881 & 209.7433937 & 774.4046967 & 459.920014\end{array}$ 
CPD_100k_1.9_High CPD_100k_1.9_Low CPD_100k_2.3_Avg CPD_100k_2.3_High CPD_100k_2.3_Low CPD_100k_3.0_Avg CPD_100k_3.0_High 981.7838762 3638.90475 2072.669062 1174.932592 4366.056368 2751.435434 1556.863924

720.6711431 2671.110934

1521.42729

862.4505196

3204.871164

2751.435434
2019.670691

261.112733

967.7938165

551.2417719

312.4820723

1161.185204

731.7647432

1142.80437 
CPD_100k_3.0_Low MBD_100k_1.5_Avg MBD_100k_1.5_High MBD_100k_1.5_Low MBD_100k_1.9_Avg MBD_100k_1.9_High MBD_100k_1.9_Low 5803.108396 1802.755457

1323.299219 1102.133008

4259.728503

809.0125268 3139.34457

2304.412504

1834.614336

1133.991886

1346.684991

3171.203449

1543.379892

479.4562386

293.1204807

834.9320666

487.9293447

832.3982995

2327.798276

843.4051726 


$\begin{array}{rrrrrr}\text { MBD_100k_2.3_Avg } & \text { MBD_100k_2.3_High } & \text { MBD_100k_2.3_Low } & \text { MBD_100k_3.0_Avg } & \text { MBD_100k_3.0_High } & \text { MBD_100k_3.0_Low } \\ 1866.473215 & 1165.850765 & 3203.062328 & 1922.226252 & 1221.603803 & 3258.815365 \\ 1370.070764 & 855.7840721 & 2351.184049 & 1410.995866 & 896.7091742 & 2392.109151 \\ 496.4024507 & 310.0666928 & 851.8782787 & 511.2303863 & 324.8946283 & 866.7062142\end{array}$


SimaPro 7.1

Project

Title:

Method:

Per sub-compartment:

Default units:

Indicator:

Relative mode:

No
Inventory Date:
Thesis_Dredging Limited LCA

Comparing product stages

Eco-indicator 95 V2.03 / Europe e

No

Yes

Inventory

Non

\section{Substance}

1 Acetaldehyde

2 Acrolein

3 Benzene

4 Butadiene

5 Carbon dioxide, fossil

6 Carbon monoxide

7 Formaldehyde

8 Methane

9 Nitric oxide

10 Nitrogen oxides

$\mathrm{PAH}$, polycyclic

11 aromatic hydrocarbons

12 Particulates, < 10 um

13 Propene

14 Sulfur oxides

15 Toluene

VOC, volatile organic

16 compounds

17 Xylene

$\begin{array}{ll}\text { Compartment } & \text { Unit } \\ \text { Air } & \mathrm{kg} \\ \text { Air } & \mathrm{kg} \\ \text { Air } & \mathrm{kg} \\ \text { Air } & \mathrm{kg} \\ \text { Air } & \mathrm{kg} \\ \text { Air } & \mathrm{kg} \\ \text { Air } & \mathrm{kg} \\ \text { Air } & \mathrm{kg} \\ \text { Air } & \mathrm{kg} \\ \text { Air } & \mathrm{kg}\end{array}$

$\mathrm{kg}$

$\mathrm{kg}$

$\mathrm{kg}$

$\mathrm{kg}$

$\mathrm{kg}$

$\mathrm{kg}$

$\mathrm{kg}$

$\mathrm{kg}$

$\mathrm{kg}$

$\mathrm{kg}$
CPD_1k_1.5_Avg CPD_1k_1.5_High CPD_1k_1.5_Low CPD_1k_1.9_Avg $\begin{array}{llll}0.19366944 & 0.160012884 & 0.279685981 & 0.213046\end{array}$

$\begin{array}{llll}0.023386498 & 0.01932231 & 0.033773401 & 0.025726309\end{array}$

$\begin{array}{llll}0.235692054 & 0.19473266 & 0.340372562 & 0.259272962\end{array}$

$\begin{array}{llll}0.00990272 & 0.008181791 & 0.014300925 & 0.010893484\end{array}$

$\begin{array}{llll}41109.07921 & 33964.99891 & 59367.30729 & 45222.0283\end{array}$

$\begin{array}{llll}213.7672119 & 176.6179943 & 308.7099979 & 235.1545472\end{array}$

$\begin{array}{llll}0.299639511 & 0.247567103 & 0.432721706 & 0.32961834\end{array}$

$\begin{array}{llll}2.04631861 & 1.690702168 & 2.95517263 & 2.251052075\end{array}$

$\begin{array}{llll}805.7379526 & 665.7139787 & 1163.599223 & 886.3517547\end{array}$

$\begin{array}{llll}1.034121726 & 0.854408417 & 1.493417597 & 1.137585245\end{array}$

$\begin{array}{llll}0.042570735 & 0.035172643 & 0.061478145 & 0.046829923\end{array}$

$\begin{array}{llll}25.21356858 & 20.831866 & 36.41194847 & 27.73617736\end{array}$

$\begin{array}{llll}0.654091127 & 0.540420872 & 0.944599823 & 0.719532717\end{array}$

$\begin{array}{llll}9.135350936 & 7.547777536 & 13.19273495 & 10.04933962\end{array}$

$\begin{array}{llll}0.10359488 & 0.085591797 & 0.149605614 & 0.113959511\end{array}$

$\begin{array}{llll}20.64589312 & 17.05797723 & 29.815581 & 22.71150755\end{array}$

$\begin{array}{llll}0.072169272 & 0.059627443 & 0.104222606 & 0.079389783\end{array}$ 


\begin{tabular}{|c|c|c|c|c|c|c|c|}
\hline 1.9 High & CPD & PD & $\mathrm{CP}$ & & & & CPL \\
\hline $0 . \overline{1} 70879143$ & $0 . \overline{32} 2069 \overline{9} 8899$ & $0.2 \overline{3} 2374479$ & $0 . \overline{181793484}$ & $0 . \overline{36} 17 \overline{11} 1816$ & $0.2 \overline{7} 228 \overline{1539}$ & $0 . \overline{2} 049 \overline{2} 0346$ & $0 . \overline{4} 4436 \overline{6} 2702$ \\
\hline 0.020634463 & 0.038725905 & 0.028060314 & 0.021952421 & 0.043678408 & 0.03287928 & 0.024745098 & 0.053658892 \\
\hline 0.207956693 & 0.390284509 & 0.282795357 & 0.22123924 & 0.440196456 & 0.331361495 & 0.249384194 & 0.540781024 \\
\hline 0.008737405 & 0.016398 & 0.011881789 & 0.009295478 & 0.018495076 & 0.01392232 & 0.010478003 & 0.022721187 \\
\hline 36271.51627 & 68072.87943 & 49324.77156 & 38588.23945 & 76778.45157 & 57795.60963 & 43497.2432 & 94322.27162 \\
\hline 188.6118846 & 353.978973 & 256.4888121 & 200.6588451 & 399.2479481 & 300.5371701 & 226.1856646 & 490.4758124 \\
\hline 0.264379052 & 0.496175655 & 0.359522779 & 0.28126539 & 0.559629603 & 0.421265777 & 0.317046573 & 0.687504558 \\
\hline 1.805515476 & 3.388516665 & 2.455277518 & 1.920836808 & 3.8218607 & 2.876937013 & 2.165196106 & 4.695153076 \\
\hline 710.9217188 & 1334.228437 & 966.7655225 & 756.3294932 & 1504.857651 & 1132.793949 & 852.5459667 & 1848.716524 \\
\hline 0.912430143 & 1.7124111 & 1.240792031 & 0.970708601 & 1.931404604 & 1.453880669 & 1.094197318 & 2.372729144 \\
\hline 0.03756117 & 0.070493248 & 0.051078541 & 0.039960266 & 0.079508352 & 0.059850565 & 0.045043812 & 0.097675952 \\
\hline 22.24652998 & 41.75136605 & 30.25252655 & 23.66745353 & 47.09078363 & 35.4479739 & 26.67830916 & 57.85099326 \\
\hline 0.577120125 & 1.083115148 & 0.784811921 & 0.613981765 & 1.221630474 & 0.919592367 & 0.69208947 & 1.500772144 \\
\hline 8.060336948 & 15.12730654 & 10.96106035 & 8.575164322 & 17.06187813 & 12.84346881 & 9.666054044 & 20.9605048 \\
\hline 0.091404221 & 0.171543656 & 0.124298424 & 0.097242363 & 0.193481698 & 0.145644936 & 0.109613053 & 0.237692124 \\
\hline 18.2163615 & 34.18771278 & 24.77199638 & 19.37987137 & 38.55984456 & 29.0262395 & 21.84528214 & 47.37074086 \\
\hline 0.063676662 & 0.119505722 & 0.086592377 & 0.067743798 & 0.134788837 & 0.101463404 & 0.076361827 & 0.165587988 \\
\hline
\end{tabular}




\begin{tabular}{|c|c|c|c|c|c|c|c|}
\hline $\begin{array}{r}B D_{1} \text { 1k_1.5_Avg } \\
0.171792678\end{array}$ & 0.132318346 & 0.247183364 & 0.173571668 & 0.134097336 & 0.248962353 & 0.175350657 & 0.135876325 \\
\hline 0.020744776 & 0.015978064 & 0.029848557 & 0.020959598 & 0.016192886 & 0.030063379 & 0.021174419 & 0.016407707 \\
\hline 0.209068448 & 0.161028931 & 0.30081749 & 0.211233445 & 0.163193927 & 0.302982487 & 0.213398441 & 0.165358924 \\
\hline 0.008784116 & 0.006765712 & 0.012638998 & 0.00887508 & 0.006856675 & 0.012729962 & 0.008966043 & 0.006947639 \\
\hline 36465.42702 & 28086.44141 & 52468.16689 & 36843.04269 & 28464.05708 & 52845.78256 & 37220.65836 & 28841.67275 \\
\hline 189.6202205 & 146.0494953 & 272.8344678 & 191.583822 & 148.0130968 & 274.7980693 & 193.5474235 & 149.9766983 \\
\hline 0.265792446 & 0.204718951 & 0.382434639 & 0.268544844 & 0.207471349 & 0.385187037 & 0.271297243 & 0.210223748 \\
\hline 1.815167923 & 1.398080639 & 2.611748752 & 1.833964792 & 1.416877508 & 2.630545621 & 1.852761661 & 1.435674377 \\
\hline 714.7223695 & 550.4942516 & 1028.376071 & 722.1236367 & 557.8955188 & 1035.777338 & 729.5249039 & 565.296786 \\
\hline 0.917308075 & 0.706530037 & 1.319865887 & 0.926807207 & 0.716029169 & 1.329365019 & 0.936306339 & 0.725528301 \\
\hline 0.037761976 & 0.02908507 & 0.054333702 & 0.038153018 & 0.029476112 & 0.054724744 & 0.03854406 & 0.029867154 \\
\hline 22.3654619 & 17.22635073 & 32.18047569 & 22.59706618 & 17.45795501 & 32.41207997 & 22.82867046 & 17.68955929 \\
\hline 0.580205461 & 0.44688649 & 0.834826833 & 0.586213746 & 0.452894775 & 0.840835118 & 0.592222031 & 0.45890306 \\
\hline 8.103428226 & 6.241431424 & 11.65959264 & 8.18734282 & 6.325346018 & 11.74350724 & 8.271257414 & 6.409260612 \\
\hline 0.091892876 & 0.070777832 & 0.132219781 & 0.092844468 & 0.071729424 & 0.133171372 & 0.093796059 & 0.072681015 \\
\hline 18.31374779 & 14.10563502 & 26.35067937 & 18.50339477 & 14.295282 & 26.54032635 & 18.69304176 & 14.48492898 \\
\hline 0.064017083 & 0.049307308 & 0.092110782 & 0.064680008 & 0.049970234 & 0.092773707 & 0.065342934 & 0.050633159 \\
\hline
\end{tabular}




$\begin{array}{rrrr}\text { MBD_1k_2.3_Low } & \text { MBD_1k_3.0_Avg } & \text { MBD_1k_3.0_High } & \text { MBD_1k_3.0_Low } \\ 0.250741343 & 0.17852399 & 0.139049657 & 0.253914675 \\ 0.0302782 & 0.021557614 & 0.016790902 & 0.030661395 \\ 0.305147483 & 0.217260327 & 0.169220809 & 0.309009369 \\ 0.012820925 & 0.009128302 & 0.007109898 & 0.012983184 \\ 53223.39824 & 37894.24308 & 29515.25747 & 53896.98295 \\ 276.7616708 & 197.050064 & 153.4793388 & 280.2643113 \\ 0.387939436 & 0.276206927 & 0.215133432 & 0.39284912 \\ 2.64934249 & 1.886291211 & 1.469203927 & 2.68287204 \\ 1043.178605 & 742.7271643 & 578.4990464 & 1056.380866 \\ 1.338864151 & 0.953250737 & 0.742472699 & 1.355808549 \\ & & & \\ 0.055115786 & 0.039241594 & 0.030564689 & 0.05581332 \\ 32.64368425 & 23.24180242 & 18.10269125 & 33.05681621 \\ 0.846843403 & 0.602939512 & 0.469620541 & 0.857560884 \\ 11.82742183 & 8.420942906 & 6.558946104 & 11.97710732 \\ 0.134122964 & 0.095493493 & 0.074378449 & 0.135820397 \\ & & & \\ 26.72997334 & 19.03133097 & 14.8232182 & 27.06826255 \\ 0.093436632 & 0.066525449 & 0.051815674 & 0.094619148\end{array}$


SimaPro 7.1

Project

Title:

Method:

Per sub-compartment:

Default units:

Indicator:

Relative mode:

No
Inventory Date
Thesis_Dredging Limited LCA

Comparing product stages

Eco-indicator 95 V2.03 / Europe e

No

Yes

Inventory

Non

\section{Substance}

1 Acetaldehyde

2 Acrolein

3 Benzene

4 Butadiene

5 Carbon dioxide, fossil

6 Carbon monoxide

7 Formaldehyde

8 Methane

9 Nitric oxide

10 Nitrogen oxides

$\mathrm{PAH}$, polycyclic aromatic

11 hydrocarbons

12 Particulates, < 10 um

13 Propene

14 Sulfur oxides

15 Toluene

VOC, volatile organic

16 compounds

17 Xylene

$\begin{array}{ll}\text { Compartment } & \text { Unit } \\ \text { Air } & \mathrm{kg} \\ \text { Air } & \mathrm{kg} \\ \text { Air } & \mathrm{kg} \\ \text { Air } & \mathrm{kg} \\ \text { Air } & \mathrm{kg} \\ \text { Air } & \mathrm{kg} \\ \text { Air } & \mathrm{kg} \\ \text { Air } & \mathrm{kg} \\ \text { Air } & \mathrm{kg} \\ \text { Air } & \mathrm{kg}\end{array}$

Air

Air

Air

Air

Air

Air

Air
8/13/2008 Time:

3:33:57 PM
CPD_5k_1.5_Avg CPD_5k_1.5_High CPD_5k_1.5_Low CPD_5k_1.9_Avg 0.501578847

0.060568012

0.610411993

0.025646767

106467.2081

553.6294823

0.77602765

5.299701027

2086.757279

2.678241769

0.110252709

65.29988765

1.694011578

23.65937958

0.268297364

53.47019786

0.186909099
0.333199905

0.04023546

0.405497998

0.017037203

70726.39497

367.7772538

0.515516834

3.520602772

1386.237341

1.779161758

0.073241111

43.37885558

1.125335529

15.71697666

0.178230515

35.52036725

0.124164116
0.931709634

0.112508333

1.133873045

0.047640247

197768.5544

1028.396483

1.441513018

9.84447915

3876.263665

4.974977856

0.204800325

121.2980467

3.146717443

43.94856764

0.498376757

99.32376286

0.347193684
0.598365486

0.072255455

0.728199507

0.030595669

127011.5419

660.4600179

0.925773017

6.322352308

2489.426221

3.195045899

0.131527508

77.90041237

2.020894756

28.22478709

0.320069086

63.78801882

0.222975818 


\begin{tabular}{|c|c|c|c|c|c|c|c|}
\hline 1.9_High & CPD & PD & CPL & & & $\mathrm{CP}$ & CPD \\
\hline 0.387627364 & 1.136726141 & 0.695152125 & 0.442102905 & 1.341694568 & 0.888100353 & 0.551294389 & 1.748410008 \\
\hline 0.046807833 & 0.137265043 & 0.083942898 & 0.053386011 & 0.162015948 & 0.107242307 & 0.066571398 & 0.211128756 \\
\hline 0.471735189 & 1.383374266 & 0.845987021 & 0.538030893 & 1.632816974 & 1.080801373 & 0.670914869 & 2.12778199 \\
\hline 0.019820192 & 0.058123167 & 0.035544571 & 0.022605639 & 0.068603628 & 0.045410414 & 0.028188826 & 0.089399832 \\
\hline 82279.3934 & 241286.2092 & 147555.8757 & 93842.59766 & 284793.6582 & 188511.8675 & 117020.0353 & 371124.7658 \\
\hline 427.8528457 & 1254.688288 & 767.2905535 & 487.9815078 & 1480.927023 & 980.2617108 & 608.5041836 & 1929.848782 \\
\hline 0.599725356 & 1.758708369 & 1.075518383 & 0.684008267 & 2.075829331 & 1.374042056 & 0.852946035 & 2.705087182 \\
\hline 4.09568536 & 12.0106913 & 7.34500359 & 4.671275972 & 14.17639543 & 9.383701847 & 5.824997313 & 18.47376612 \\
\hline 1612.676111 & 4729.209701 & 2892.095163 & 1839.314914 & 5581.955702 & 3694.832602 & 2293.592692 & 7274.045409 \\
\hline 2.069783852 & 6.069688641 & 3.711850028 & 2.360662679 & 7.164142692 & 4.742120755 & 2.943703999 & 9.335849663 \\
\hline 0.085204883 & 0.249865274 & 0.152802307 & 0.097179223 & 0.294919655 & 0.195214512 & 0.121180748 & 0.384320313 \\
\hline 50.46469462 & 147.988875 & 90.50093708 & 57.55679323 & 174.6734437 & 115.620612 & 71.77228833 & 227.6231897 \\
\hline 1.309156571 & 3.839131684 & 2.347777933 & 1.493139998 & 4.53138354 & 2.999433269 & 1.861918784 & 5.905007384 \\
\hline 18.28430964 & 53.6191576 & 32.7901946 & 20.85391059 & 63.28747961 & 41.8915261 & 26.00445229 & 82.47217017 \\
\hline 0.207344071 & 0.608041247 & 0.371840807 & 0.236483346 & 0.717680019 & 0.475049906 & 0.294890489 & 0.93523441 \\
\hline 41.3225398 & 121.1792962 & 74.10583979 & 47.12983793 & 143.0297039 & 94.67484899 & 58.77006218 & 186.3871046 \\
\hline 0.144446046 & 0.423591345 & 0.259042537 & 0.164745894 & 0.499971089 & 0.330943056 & 0.205435173 & 0.651530144 \\
\hline
\end{tabular}


MBD_5k_1.5_Avg MBD_5k_1.5_High MBD_5k_1.5_Low MBD_5k_1.9_Avg MBD_5k_1.9_High MBD_5k_1.9_Low MBD_5k_2.3_Avg MBD_5k_2.3_High 0.575527109 0.378011206

0.045646636

0.460032505

0.019328497

80238.2276

417.2387835

0.584847526

3.994080663

1572.669261

0.952336295

0.584518218

0.387002314

0.1149991

0.070583332

0.046732355

1.158975302

0.711347642

0.470974514

0.048694931

202146.855

1051.163646

635.2516203

0.890438169

6.081041151

1.473425965

0.02988763

124072.2632

0.019788232

82146.71762

645.1757684

427.1629316

0.90434894

0.598758297
4.089081055

10.06242123

6.176041544

3962.078358

2431.816358

1610.075665

3.073097582

2.018437192

5.085116441

3.121106709

2.066446319

0.209334299

0.128483721

0.08506749

76.09765473

74.92711419

0.083091142

123.9834044

1.276679355

27.14750514

17.83071724

3.216381071

1.974127565

44.92152333

27.57161403

0.307852708

0.202200334

0.509410075

0.312662103

50.38332014

1.307045551

18.25482614

0.207009728

61.35336162

40.29742097

101.5226427

62.31184772

41.25590707

0.961327403

0.116084819

0.395993423

0.214465291

0.140862666

0.354880034

0.217815751

0.144213126

1.169917311

0.049154665

204055.345

1061.087794

1.487336737

10.15742162

3999.484763

5.133125568

0.071669051

0.047818074

$0.722289652 \quad 0.481916524$

$0.030347364 \quad 0.020247966$

125980.7532

655.0999165

84055.20764

0.918259712

6.271041936

2469.222762

437.0870797

0.612669069

4.184081447

1647.48207

3.169115835

2.114455446

0.211310646

0.130460069

0.087043837

125.1539449

3.246747268

77.26819528

2.004493762

51.55386069

45.34563223

27.99572293

1.337411748

0.514219469

0.317471498

18.67893503

102.4811288

63.27033382

0.211819123

0.358230495

0.221166211

42.21439317

0.147563587 


$\begin{array}{rrrr}\text { MBD_5k_2.3_Low } & \text { MBD_5k_3.0_Avg } & \text { MBD_5k_3.0_High } & \text { MBD_5k_3.0_Low } \\ 0.970318512 & 0.609183665 & 0.411667762 & 0.985992851 \\ 0.117170537 & 0.073561801 & 0.049710824 & 0.119063288 \\ 1.180859321 & 0.741365026 & 0.500991899 & 1.199934696 \\ 0.049614399 & 0.031148825 & 0.021049427 & 0.050415861 \\ 205963.835 & 129307.8534 & 87382.3079 & 209290.9353 \\ 1071.011942 & 672.4008378 & 454.3880011 & 1088.312864 \\ 1.501247509 & 0.942510576 & 0.636919933 & 1.525498373 \\ 10.25242201 & 6.436657593 & 4.349697104 & 10.41803767 \\ 4036.891167 & 2534.433927 & 1712.693235 & 4102.102332 \\ 5.181134695 & 3.252810891 & 2.198150501 & 5.26482975 \\ & & & \\ 0.213286994 & 0.133905466 & 0.090489234 & 0.216732391 \\ 126.3244855 & 79.30881677 & 53.59448218 & 128.365107 \\ 3.277113464 & 2.057431623 & 1.39034961 & 3.330051326 \\ 45.76974112 & 28.73507854 & 19.41829064 & 46.50909673 \\ 0.519028864 & 0.325855791 & 0.220203416 & 0.527413157 \\ & & & \\ 103.4396149 & 64.9412775 & 43.88533686 & 105.1105586 \\ 0.361580955 & 0.22700712 & 0.153404496 & 0.367421864\end{array}$


SimaPro 7.1

Project

Title:

Method:

Per sub-compartment:

Default units:

Indicator:

Relative mode:

No
Inventory Date
Thesis_Dredging Limited LCA

Comparing product stages

Eco-indicator 95 V2.03 / Europe e

No

Yes

Inventory

Non

\section{Substance}

1 Acetaldehyde

2 Acrolein

3 Benzene

4 Butadiene

5 Carbon dioxide, fossil

6 Carbon monoxide

7 Formaldehyde

8 Methane

9 Nitric oxide

10 Nitrogen oxides

$\mathrm{PAH}$, polycyclic aromatic

11 hydrocarbons

12 Particulates, < 10 um

13 Propene

14 Sulfur oxides

15 Toluene

VOC, volatile organic

16 compounds

17 Xylene

$\begin{array}{ll}\text { Compartment } & \text { Unit } \\ \text { Air } & \mathrm{kg} \\ \text { Air } & \mathrm{kg} \\ \text { Air } & \mathrm{kg} \\ \text { Air } & \mathrm{kg} \\ \text { Air } & \mathrm{kg} \\ \text { Air } & \mathrm{kg} \\ \text { Air } & \mathrm{kg} \\ \text { Air } & \mathrm{kg} \\ \text { Air } & \mathrm{kg} \\ \text { Air } & \mathrm{kg}\end{array}$

Air

Air

Air

Air

Air

Air

Air
8/13/2008 Time:

3:31:05 PM

$\begin{array}{lrrrr}\text { Unit } & \text { CPD_20k_1.5_Avg } & \text { CPD_20k_1.5_High } & \text { CPD_20k_1.5_Low } & \text { CPD_20k_1.9_Avg } \\ \mathrm{kg} & 1.656191044 & 0.982675276 & 3.376810352 & 2.043433762 \\ \mathrm{~kg} & 0.199992881 & 0.118662675 & 0.407765778 & 0.246754266 \\ \mathrm{~kg} & 2.015553252 & 1.19589727 & 4.109514485 & 2.486820333 \\ \mathrm{~kg} & 0.084684485 & 0.050246226 & 0.172663322 & 0.104485009 \\ \mathrm{~kg} & 351549.9857 & 208586.7331 & 716775.7823 & 433747.7325 \\ \mathrm{~kg} & 1828.059926 & 1084.651012 & 3727.234068 & 2255.488209 \\ \mathrm{~kg} & 2.562408785 & 1.520365521 & 5.224499036 & 3.161539028 \\ \mathrm{~kg} & 17.49937707 & 10.38298405 & 35.67950561 & 21.59099824 \\ \mathrm{~kg} & 6890.37972 & 4088.299969 & 14048.80533 & 8501.455557 \\ \mathrm{~kg} & 8.843435197 & 5.247115153 & 18.03089301 & 10.91116518 \\ & & & & \\ \mathrm{~kg} & 0.364049541 & 0.21600315 & 0.742261143 & 0.449169874 \\ \mathrm{~kg} & 215.6173246 & 127.9331963 & 439.6224798 & 266.0319426 \\ \mathrm{~kg} & 5.593550884 & 3.318846687 & 11.40469911 & 6.901408366 \\ \mathrm{~kg} & 78.12221905 & 46.35260736 & 159.2835072 & 96.388385 \\ \mathrm{~kg} & 0.885905964 & 0.525638567 & 1.806274971 & 1.093044286 \\ \mathrm{~kg} & & & & \\ \mathrm{~kg} & 176.5562151 & 104.7568926 & 359.9807262 & 217.8377501 \\ & 0.617165531 & 0.366185598 & 1.258339707 & 0.761468242\end{array}$




\begin{tabular}{|c|c|c|c|c|c|c|c|}
\hline CPD_20k_1.9_High & CPD_20k_1.9_Low & CPD_20k_2.3_Avg & CPD & CPD & CPD & $\mathrm{CPD}_{-}$ & CPD_ \\
\hline 1.200481275 & 4.19678022 & 2.430628399 & 1.418287273 & 5.016798168 & 3.197324747 & 1.850293211 & 6.638611444 \\
\hline 0.144963777 & 0.506781008 & 0.293509844 & 0.171264878 & 0.605802043 & 0.386092045 & 0.223431633 & 0.801643646 \\
\hline 1.460963061 & 5.107402343 & 2.958028901 & 1.726028851 & 6.105348714 & 3.89108389 & 2.251771926 & 8.079064871 \\
\hline 0.061383099 & 0.214590083 & 0.124283075 & 0.072519972 & 0.256519303 & 0.16348585 & 0.094609332 & 0.339445981 \\
\hline 254819.1385 & 890825.9901 & 515935.2734 & 301051.5438 & 1064886.404 & 678677.4227 & 392750.9174 & 1409139.222 \\
\hline 1325.05952 & 4632.295148 & 2682.863422 & 1565.468028 & 5537.409299 & 3529.122598 & 2042.304771 & 7327.523953 \\
\hline 1.857348387 & 6.493131661 & 3.760594882 & 2.194331253 & 7.761838676 & 4.946804325 & 2.862717798 & 10.27105922 \\
\hline 12.68433045 & 44.34333817 & 25.68211139 & 14.98567685 & 53.00767876 & 33.78305393 & 19.55026789 & 70.14381904 \\
\hline 4994.455114 & 17460.18941 & 10112.33136 & 5900.610259 & 20871.77351 & 13302.07748 & 7697.917981 & 27619.12875 \\
\hline 6.410116994 & 22.40922268 & 12.97863843 & 7.573118836 & 26.78780909 & 17.07250761 & 9.879867522 & 35.44767998 \\
\hline 0.263879375 & 0.922499803 & 0.534279639 & 0.311755599 & 1.102749031 & 0.702808175 & 0.406715394 & 1.45924195 \\
\hline 156.2890716 & 546.3732739 & 316.440301 & 184.6449469 & 653.1303276 & 416.2554859 & 240.8872293 & 864.272056 \\
\hline 4.054455625 & 14.17403131 & 8.209103462 & 4.790064564 & 16.94352589 & 10.79851188 & 6.249103486 & 22.42097073 \\
\hline 56.62647522 & 197.9613311 & 114.652283 & 66.90034308 & 236.641423 & 150.817205 & 87.27798165 & 313.1420493 \\
\hline 0.642144229 & 2.244881495 & 1.300156889 & 0.75864989 & 2.683513737 & 1.710267105 & 0.989732312 & 3.551030839 \\
\hline 127.975834 & 447.3926084 & 259.1141595 & 151.1947754 & 534.8096161 & 340.8468834 & 197.2482385 & 707.7010313 \\
\hline 0.447349154 & 1.563894516 & 0.905753036 & 0.52851271 & 1.869467242 & 1.19145592 & 0.689496055 & 2.473822189 \\
\hline
\end{tabular}




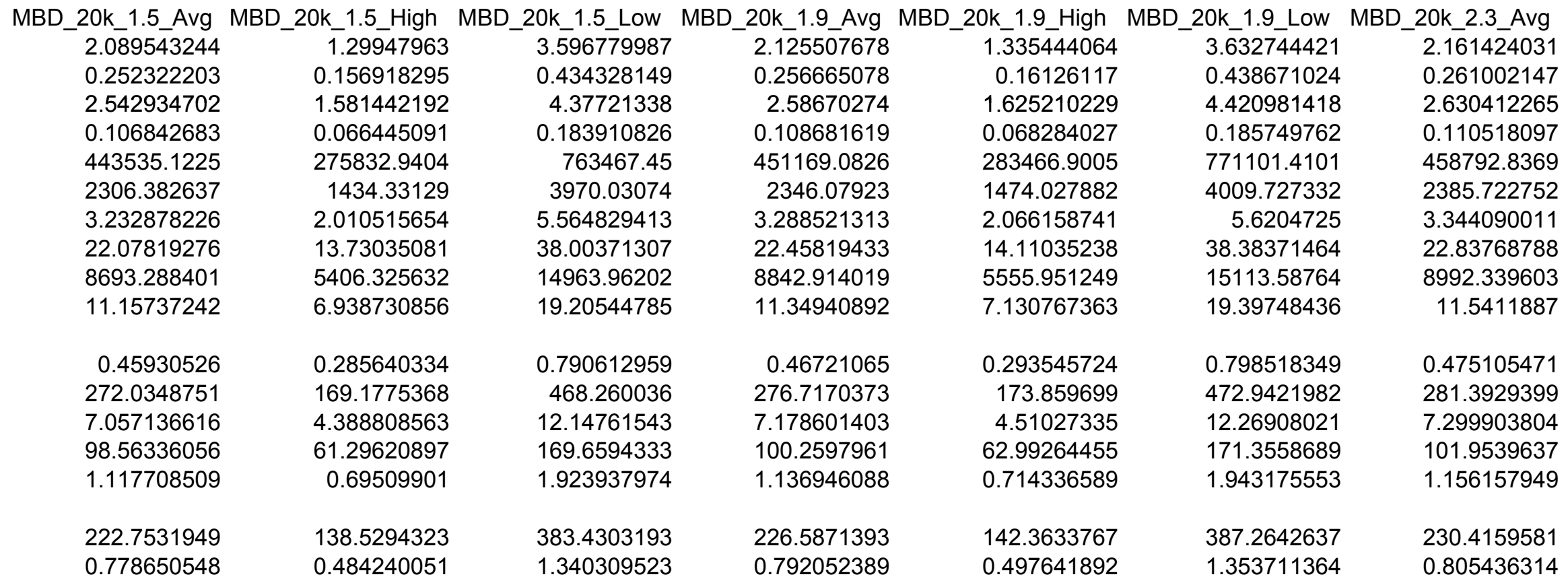




$\begin{array}{rrrrr}\text { MBD_20k_2.3_High } & \text { MBD_20k_2.3_Low } & \text { MBD_20k_3.0_Avg } & \text { MBD_20k_3.0_High } & \text { MBD_20k_3.0_Low } \\ 1.371360418 & 3.668660774 & 2.22426563 & 1.434202016 & 3.731502373 \\ 0.165598239 & 0.443008094 & 0.268590567 & 0.173186659 & 0.450596513 \\ 1.668919754 & 4.464690942 & 2.706889304 & 1.745396793 & 4.541167982 \\ 0.070120504 & 0.18758624 & 0.113731318 & 0.073333726 & 0.190799461 \\ 291090.6547 & 778725.1644 & 472131.8554 & 304429.6732 & 792064.1829 \\ 1513.671405 & 4049.370855 & 2455.085648 & 1583.034301 & 4118.733751 \\ 2.121727439 & 5.676041198 & 3.441316635 & 2.218954063 & 5.773267822 \\ 14.48984592 & 38.76320818 & 23.50167458 & 15.15383262 & 39.42719488 \\ 5705.376833 & 15263.01322 & 9253.784365 & 5966.821596 & 15524.45798 \\ 7.322547137 & 19.58926413 & 11.87673912 & 7.658097558 & 19.92481456 \\ & & & & \\ 0.301440545 & 0.80641317 & 0.488918766 & 0.315253839 & 0.820226465 \\ 178.5356016 & 477.6181008 & 289.5742046 & 186.7168663 & 485.7993655 \\ 4.631575751 & 12.39038262 & 7.51214241 & 4.843814356 & 12.60262122 \\ 64.68681216 & 173.0500365 & 104.9181901 & 67.6510385 & 176.0142629 \\ 0.73354845 & 1.962387414 & 1.189772276 & 0.767162777 & 1.996001741 \\ 146.1921955 & 391.0930825 & 237.1151096 & & \\ 0.511025816 & 1.367095289 & 0.828853702 & 0.534443204 & 1.390512677\end{array}$


SimaPro 7.1

Project

Title:

Method:

Per sub-compartment:

Default units:

Indicator:

Relative mode:

No
Inventory Date
Thesis_Dredging Limited LCA

Comparing product stages

Eco-indicator 95 V2.03 / Europe e

No

Yes

Inventory

Non

\section{Substance}

1 Acetaldehyde

2 Acrolein

3 Benzene

4 Butadiene

5 Carbon dioxide, fossil

6 Carbon monoxide

7 Formaldehyde

8 Methane

9 Nitric oxide

10 Nitrogen oxides

$\mathrm{PAH}$, polycyclic aromatic

11 hydrocarbons

12 Particulates, < 10 um

13 Propene

14 Sulfur oxides

15 Toluene

VOC, volatile organic

16 compounds

17 Xylene

$\begin{array}{ll}\text { Compartment } & \text { Unit } \\ \text { Air } & \mathrm{kg} \\ \text { Air } & \mathrm{kg} \\ \text { Air } & \mathrm{kg} \\ \text { Air } & \mathrm{kg} \\ \text { Air } & \mathrm{kg} \\ \text { Air } & \mathrm{kg} \\ \text { Air } & \mathrm{kg} \\ \text { Air } & \mathrm{kg} \\ \text { Air } & \mathrm{kg} \\ \text { Air } & \mathrm{kg}\end{array}$

Air

Air

Air

Air

Air

Air

Air
8/13/2008 Time:

3:22:33 PM

$\begin{array}{lrrrr}\text { Unit } & \text { CPD_100k_1.5_Avg } & \text { CPD_100k_1.5_High } & \text { CPD_100k_1.5_Low } & \text { CPD_100k_1.9_Avg } \\ \mathrm{kg} & 7.814234948 & 4.446559947 & 16.41737957 & 9.750304296 \\ \mathrm{~kg} & 0.94360573 & 0.536943088 & 1.982476024 & 1.177395236 \\ \mathrm{~kg} & 9.509776494 & 5.411379558 & 19.97964118 & 11.86593636 \\ \mathrm{~kg} & 0.399558051 & 0.227361839 & 0.839454691 & 0.498553295 \\ \mathrm{~kg} & 1658681.947 & 943845.2717 & 3484821.135 & 2069640.063 \\ \mathrm{~kg} & 8625.146122 & 4907.995413 & 18121.0699 & 10762.12833 \\ \mathrm{~kg} & 12.08994841 & 6.879583314 & 25.40047405 & 15.08537646 \\ \mathrm{~kg} & 82.56550134 & 46.98252019 & 173.4666521 & 103.0220831 \\ \mathrm{~kg} & 32510.16615 & 18499.36733 & 68302.49425 & 40564.94523 \\ \mathrm{~kg} & 41.72506586 & 23.74295217 & 87.66261167 & 52.06294558 \\ & & & & \\ \mathrm{~kg} & 1.717657305 & 0.977404215 & 3.608725887 & 2.143227265 \\ \mathrm{~kg} & 1017.324927 & 578.8917667 & 2137.356963 & 1269.379239 \\ \mathrm{~kg} & 26.39147275 & 15.01762699 & 55.44737629 & 32.930273 \\ \mathrm{~kg} & 368.5959881 & 209.7433937 & 774.4046967 & 459.920014 \\ \mathrm{~kg} & 4.179878505 & 2.378490085 & 8.781749261 & 5.215492959 \\ & & & & \\ \mathrm{~kg} & 833.0269332 & 474.0200698 & 1750.154615 & 1039.419232 \\ \mathrm{~kg} & 2.911908306 & 1.65697281 & 6.117797104 & 3.63336811\end{array}$




\begin{tabular}{|c|c|c|c|c|c|c|}
\hline CPD_100k_1.9_High & CPD_100k_1.9_Low & CPD_100k & CPD & Low & Avg & $\mathrm{CPL}$ \\
\hline 5.53558994 & 20.51722891 & 11.68632556 & 6.624619933 & 24.61712633 & 15.51341256 & 8.778062553 \\
\hline 0.668448597 & 2.47755217 & 1.411178936 & 0.799954105 & 2.972634123 & 1.873317743 & 1.059992459 \\
\hline 6.736708512 & 24.96908047 & 14.22203771 & 8.062037466 & 29.95857827 & 18.87953037 & 10.6827365 \\
\hline 0.283046203 & 1.049088497 & 0.597546081 & 0.338730566 & 1.258724761 & 0.793232982 & 0.448840557 \\
\hline 1175007.299 & 4355072.174 & 2480587.973 & 1406169.325 & 5225333.419 & 3292941.344 & 1863267.995 \\
\hline 6110.037953 & 22646.37531 & 12899.05746 & 7312.080492 & 27171.73378 & 17123.29499 & 9688.993572 \\
\hline 8.564497643 & 31.74363718 & 18.08073012 & 10.24941197 & 38.0868747 & 24.00188358 & 13.58115338 \\
\hline 58.4892522 & 216.7858149 & 123.4781569 & 69.9959842 & 260.1054857 & 163.9153025 & 92.74934018 \\
\hline 23030.14305 & 85359.41461 & 48619.52428 & 27560.91878 & 102416.535 & 64541.65035 & 36520.0527 \\
\hline 29.55796138 & 109.55426 & 62.40056858 & 35.37297059 & 131.4461651 & 82.83576893 & 46.87154156 \\
\hline 1.216785336 & 4.509919185 & 2.568786657 & 1.456166457 & 5.411123052 & 3.410023703 & 1.929517523 \\
\hline 720.6711431 & 2671.110934 & 1521.42729 & 862.4505196 & 3204.871164 & 2019.670691 & 1142.80437 \\
\hline 18.69567168 & 69.29403726 & 39.46891087 & 22.37371638 & 83.14086062 & 52.39435561 & 29.64666409 \\
\hline 261.112733 & 967.7938165 & 551.2417719 & 312.4820723 & 1161.185204 & 731.7647432 & 414.0595544 \\
\hline 2.961018392 & 10.97478188 & 6.251081693 & 3.5435467 & 13.16784022 & 8.298212188 & 4.695435347 \\
\hline 590.1147766 & 2187.214025 & 1245.806404 & 706.2094834 & 2624.278561 & 1653.78832 & 935.7745929 \\
\hline 2.062790591 & 7.64557115 & 4.354809998 & 2.468608371 & 9.173363113 & 5.780941471 & 3.27107048 \\
\hline
\end{tabular}




\begin{tabular}{|c|c|c|c|c|c|c|}
\hline $\begin{array}{r}\text { CPD_100k_3.0_Low } \\
32.71965372\end{array}$ & $\begin{array}{r}\text { MBD_100k_1.5_Avg } \\
10.16447226\end{array}$ & $\begin{array}{r}\text { MBD_100k_1.5_High } \\
6.214154191\end{array}$ & $\begin{array}{r}\text { MBD_100k_1.5_Low } \\
17.70055981\end{array}$ & $\begin{array}{r}\text { MBD_100k_1.9_Avg } \\
10.34410211\end{array}$ & $\begin{array}{r}\text { MBD_100k_1.9_High } \\
6 . \overline{393784039}\end{array}$ & $\begin{array}{r}\text { MBD_100k_1.9_Low } \\
17.88018966\end{array}$ \\
\hline 3.951052525 & 1.227407971 & 0.750388431 & 2.137426091 & 1.249099122 & 0.772079582 & 2.159117242 \\
\hline 39.81920123 & 12.36997096 & 7.562508403 & 21.54124732 & 12.58857709 & 7.781114538 & 21.75985345 \\
\hline 1.673023803 & 0.519730563 & 0.317742601 & 0.90506636 & 0.52891541 & 0.326927448 & 0.914251207 \\
\hline 6945209.516 & 2157553.074 & 1319042.163 & 3757194.3 & 2195682.051 & 1357171.14 & 3795323.277 \\
\hline 36115.08948 & 11219.27598 & 6859.019249 & 19537.41036 & 11417.54667 & 7057.28993 & 19735.68104 \\
\hline 50.62286047 & 15.72616463 & 9.614351768 & 27.38577178 & 16.00408251 & 9.892269646 & 27.66368966 \\
\hline 345.7170959 & 107.3981975 & 65.65898768 & 187.0247829 & 109.2961732 & 67.55696343 & 188.9227587 \\
\hline 136126.1065 & 42288.04025 & 25853.2264 & 73641.00827 & 43035.3682 & 26600.55435 & 74388.33623 \\
\hline 174.7106038 & 54.27444621 & 33.18123842 & 94.51430994 & 55.23360182 & 34.14039402 & 95.47346554 \\
\hline 7.192150299 & 2.234266072 & 1.36594144 & 3.89078343 & 2.273750746 & 1.405426114 & 3.930268104 \\
\hline 4259.728503 & 1323.299219 & 809.0125268 & 2304.412504 & 1346.684991 & 832.3982995 & 2327.798276 \\
\hline 110.5060003 & 34.32906669 & 20.98742642 & 59.78113597 & 34.93574108 & 21.59410081 & 60.38781036 \\
\hline 1543.379892 & 479.4562386 & 293.1204807 & 834.9320666 & 487.9293447 & 301.5935868 & 843.4051726 \\
\hline 17.50192798 & 5.437033746 & 3.323986251 & 9.468129635 & 5.533118769 & 3.420071274 & 9.564214658 \\
\hline 3488.038557 & 1083.571099 & 662.4522864 & 1886.946471 & 1102.720319 & 681.6015061 & 1906.09569 \\
\hline 12.19270115 & 3.787704285 & 2.315651798 & 6.595963326 & 3.854641823 & 2.382589335 & 6.662900864 \\
\hline
\end{tabular}




$\begin{array}{rrrrrr}\text { MBD_100k_2.3_Avg } & \text { MBD_100k_2.3_High } & \text { MBD_100k_2.3_Low } & \text { MBD_100k_3.0_Avg } & \text { MBD_100k_3.0_High } & \text { MBD_100k_3.0_Low } \\ 10.52373196 & 6.573413887 & 18.05981951 & 10.83808419 & 6.887766121 & 18.37417174 \\ 1.270790274 & 0.793770734 & 2.180808393 & 1.308749789 & 0.831730249 & 2.218767908 \\ 12.80718323 & 7.999720674 & 21.97845959 & 13.18974397 & 8.382281411 & 22.36102033 \\ 0.538100257 & 0.336112295 & 0.923436054 & 0.554173739 & 0.352185777 & 0.939509536 \\ 2233811.028 & 1395300.118 & 3833452.254 & 2300536.738 & 1462025.828 & 3900177.964 \\ 11615.81735 & 7255.560611 & 19933.95172 & 11962.79104 & 7602.534303 & 20280.92541 \\ 16.28200038 & 10.17018752 & 27.94160754 & 16.76835667 & 10.65654381 & 28.42796383 \\ 111.194149 & 69.45493919 & 190.8207344 & 114.5156065 & 72.77639675 & 194.142192 \\ 43782.69615 & 27347.8823 & 75135.66418 & 45090.52007 & 28655.70622 & 76443.48809 \\ 56.19275742 & 35.09954962 & 96.43262115 & 57.87127973 & 36.77807193 & 98.11114345 \\ & & & & & \\ 2.31323542 & 1.444910788 & 3.969752779 & 2.3823336 & 1.514008968 & 4.038850958 \\ 1370.070764 & 855.7840721 & 2351.184049 & 1410.995866 & 896.7091742 & 2392.109151 \\ 35.54241547 & 22.2007752 & 60.99448475 & 36.60409566 & 23.26245539 & 62.05616494 \\ 496.4024507 & 310.0666928 & 851.8782787 & 511.2303863 & 324.8946283 & 866.7062142 \\ 5.629203791 & 3.516156296 & 9.66029968 & 5.79735258 & 3.684305085 & 9.828448469 \\ 1121.869539 & 700.7507257 & 1925.24491 & 1155.380673 & 734.2618601 & 1958.756044 \\ 3.921579361 & 2.449526873 & 6.729838401 & 4.038720052 & 2.566667564 & 6.846979092\end{array}$


SimaPro 7.1

Project

Title:

Method:

Indicator:

Skip categories:

Relative mode:

Impact category Unit

Total

greenhouse

acidification

eutrophication

carcinogens

winter smog

summer smog

Non

$\mathrm{Pt}$

$\mathrm{Pt}$

Pt

$\mathrm{Pt}$

$\mathrm{Pt}$

$\mathrm{Pt}$
Impact assessment Date:

Thesis_Dredging Limited LCA

Comparing product stages

Eco-indicator 95 V2.03 / Europe e

Single score

With result $=0$
$8 / 13 / 2008$

Time:

3:27:41 PM

$\begin{array}{rrrrrr}\text { CPD_1k_1.5_Avg } & \text { CPD_1k_1.5_High } & \text { CPD_1k_1.5_Low } & \text { CPD_1k_1.9_Avg } & \text { CPD_1k_1.9_High } & \text { CPD_1k_1.9_Low } \\ \text { 128.3165055 } & 106.0172121 & 185.3071282 & 141.1545272 & 113.2166982 & 212.48041 \\ 7.866416342 & 6.499362857 & 11.36021446 & 8.653448563 & 6.940725839 & 13.02606678 \\ 77.43349747 & 63.97683207 & 111.8248895 & 85.18069198 & 68.32141261 & 128.2227974 \\ 21.12794545 & 17.45625682 & 30.51173254 & 23.24178905 & 18.64168772 & 34.98594741 \\ 18.77744549 & 15.514235 & 27.11727915 & 20.65612238 & 16.56778582 & 31.09373421 \\ 1.820492735 & 1.504121107 & 2.629048222 & 2.0026324 & 1.606263947 & 3.014569647 \\ 1.290707978 & 1.066404209 & 1.863964327 & 1.419842863 & 1.138822283 & 2.137294493\end{array}$




\begin{tabular}{|c|c|c|c|c|c|c|c|}
\hline 2 & & & & & & & \\
\hline 153.9606929 & 120.4480405 & 239.6536918 & 180.4012836 & 135.7708407 & $29 \overline{4} .41 \overline{4} 3852$ & 113.8219648 & $\overline{87.6680792}$ \\
\hline 9.43852785 & 7.384041755 & 14.6919191 & 11.0594627 & 8.323402793 & 18.04901188 & 6.977831577 & 5.374473131 \\
\hline 92.90866268 & 72.68521696 & 144.6207054 & 108.8644231 & 81.93186847 & 177.6664309 & 68.68666496 & 52.90391883 \\
\hline 25.35038738 & 19.83236389 & 39.46016227 & 29.70396104 & 22.35533851 & 48.4767805 & 18.74134784 & 14.4349816 \\
\hline 22.53013755 & 17.62599836 & 35.07018928 & 26.39937284 & 19.86829014 & 43.08370189 & 16.65635867 & 12.82907894 \\
\hline 2.184320106 & 1.708858746 & 3.400091073 & 2.559446464 & 1.92625125 & 4.177009397 & 1.614851177 & 1.243792454 \\
\hline 1.548657314 & 1.211560791 & 2.410624658 & 1.814617498 & 1.365689524 & 2.96145063 & 1.144910528 & 0.881834249 \\
\hline
\end{tabular}


MBD 1k 1.5 Low MBD 1k 1.9 Avg MBD_1k 1.9 High MBD_1k 1.9 Low MBD_1k 2.3 Avg MBD_1k 2.3 High MBD_1k 2.3 Low MBD 1k 3.0 Avg $163.7 \overline{7} 2382 \quad 115.0006417 \quad 88.84675614$ 10.04003138 7.050090118 164.9510589 $5.446731673 \quad 10.11228993$ 69.39794585 18.93542281 53.61519971 98.8295954 26.96593038 23.96595016 2.323523622 16.82884266 1.631573677 14.62905657 99.54087634 27.16000535 $13.00156293 \quad 24.13843415$ $1.260514954 \quad 2.340246122$ 116.1793186 7.122348659 90.02543308 166.1297358 118.2818234 1.647350973

1.156766584

0.893690306

1.659207029

70.10922673

19.12949778

17.00132664

1.648296177

5.518990214

10.18454847

7.251242274

54.3264806

100.2521572

71.37799804

14.82313154

27.35408032

19.47568556

13.17404691

1.277237455

24.31091813

17.30900077

1.168622641

0.905546362

2.356968622

1.678125502

1.189771282 
MBD 1k 3.0 High MBD 1k 3.0 Low 92.12793788 5.647883829 168.2322407 10.31344208

$55.59525191 \quad 101.5209285$

$15.16931933 \quad 27.7002681$

$13.48172104 \quad 24.61859226$

$1.30706678 \quad 2.386797947$

0.926695003

1.692211726 
SimaPro 7.1

Project

Title:

Method:

Indicator:

Skip categories:

Relative mode:

Impact category Unit

Total

greenhouse

acidification

eutrophication

carcinogens

winter smog

summer smog

Non

$\mathrm{Pt}$

$\mathrm{Pt}$

$\mathrm{Pt}$

$\mathrm{Pt}$

$\mathrm{Pt}$
Impact assessment Date:

Thesis_Dredging Limited LCA

Comparing product stages

Eco-indicator 95 V2.03 / Europe e

Single score

With result $=0$
$8 / 13 / 2008$

Time:

3:33:38 PM

CPD_5k 1.5 Avg CP 332.323184 20.3730028

200.5427621

54.71865118

48.63115972

4.714841164

3.342767039
_5k_1.5_High CP 220.7630047

13.53382951

133.2209875

36.34971747

32.30578382

3.132079109

2.220607321
5k_1.5_Low $61 \overline{7} .3081536$

37.84394634

372.5189459

101.6428319

90.33498974

8.758070559

6.209369217
PD_5k_1.9 Avg CPD 396.4495806 24.30425804 239.240287 65.27737863

58.01522073

5.624635571

3.987800594
CPD 5k 1.9 High CPD 5k 1.9 Low 256.8241477 15.74455029

154.9823378

42.28736252

37.58286135

3.643697226

2.583338561
753.1427066

46.171255

454.489262

124.008661

110.2126033

10.68522573

7.57569961 


\begin{tabular}{|c|c|c|c|c|c|c|c|}
\hline OK_L.J_Avg & & & & & & & \\
\hline 460.5759772 & 292.9171469 & $88 \overline{8} .94 \overline{5} 4034$ & $58 \overline{8} .4146406$ & 365.2624259 & $11 \overline{5} 8.416436$ & 381.3179172 & $250 . \overline{452921}$ \\
\hline 28.23551328 & 17.957224 & 54.49661073 & 36.07263561 & 22.39233609 & 71.01647564 & 23.3766146 & 15.35396358 \\
\hline 277.9378119 & 176.7629119 & 536.4403542 & 355.0829523 & 220.4201792 & 699.0545437 & 230.1089783 & 151.1375762 \\
\hline 75.83610609 & 48.23025283 & 146.3692447 & 96.88537249 & 60.14225981 & 190.7389792 & 62.78587563 & 41.23830862 \\
\hline 67.39928175 & 42.86460061 & 130.0855552 & 86.1068013 & 53.45138778 & 169.5191231 & 55.80089933 & 36.6505155 \\
\hline 6.534429979 & 4.155767302 & 12.61192894 & 8.348143322 & 5.182167253 & 16.43505407 & 5.409954824 & 3.553305332 \\
\hline 4.632834149 & 2.946390234 & 8.941709568 & 5.918735618 & 3.67409575 & 11.65226041 & 3.835594464 & 2.519251769 \\
\hline
\end{tabular}



630.9744349 387.2750141 23.74181318 233.7038304 63.76674102 56.6726427 5.494471245 3.895515614 256.410018 15.71916215 154.7324283 42.21917401 37.52225887 3.637821753

2.579172919
636.9315318

39.04695341

384.3608114

104.8739179

93.20661497

9.03647759

6.406756535 393.2321111 24.10701175 237.2986824 64.74760641 57.54438608 5.578987665 3.955436764 262.3671149 16.08436072 158.3272803 43.20003941 38.39400225

3.722338173

2.639094069
642.8886288

39.41215199

387.9556635

105.8547833

94.07835834

9.120994011

6.466677685
403.6172106

24.74366809

243.5656437

66.45756426

59.06410982

5.726326451

4.059898234 
MBD 5k 3.0 High MBD 5k 3.0 Low 272.7522144 16.72101706

164.5942416

44.90999725

39.91372599

3.86967696

$65 \overline{3} .27 \overline{3} 7283$

40.04880832

394.2226248

107.5647411

95.59808209

9.268332797

2.743555539

6.571139155 


\begin{tabular}{|c|c|c|c|c|c|c|c|}
\hline $\begin{array}{l}\text { SimaPro } 7.1 \\
\text { Project }\end{array}$ & $\begin{array}{l}\text { Impact assessment } \\
\text { Thesis_Dredging Lim }\end{array}$ & $\begin{array}{l}\text { Date: } \\
\text { lited LCA }\end{array}$ & $8 / 13 / 2008$ & Time: & 3:30:40 PM & & \\
\hline $\begin{array}{l}\text { Title: } \\
\text { Method: } \\
\text { Indicator: } \\
\text { Skip categories: } \\
\text { Relative mode: }\end{array}$ & $\begin{array}{l}\text { Comparing product st } \\
\text { Eco-indicator } 95 \mathrm{~V} 2.0 \\
\text { Single score } \\
\text { With result = } 0 \\
\text { Non }\end{array}$ & $\begin{array}{l}\text { tages } \\
3 \text { / Europe e }\end{array}$ & & & & & \\
\hline Impact category & Unit & CPD_20k_1.5_Avg & CPD_20k_1.5_High & CPD_20k_1.5_Low & CPD_20k_1.9_Avg & CPD_20k_1.9_High & CPD_20k_1.9_Low \\
\hline Total & $\mathrm{Pt}$ & 1097.316372 & 651.0756551 & $22 \overline{37} .319963$ & 1353.885671 & 795.3839395 & $27 \overline{80} .594463$ \\
\hline greenhouse & $\mathrm{Pt}$ & 67.27074909 & 39.91405591 & 137.1584291 & 82.9996759 & 48.76084489 & 170.4637579 \\
\hline acidification & $\mathrm{Pt}$ & 662.1832805 & 392.896182 & 1350.126463 & 817.0118278 & 479.980031 & 1677.96928 \\
\hline eutrophication & $\mathrm{Pt}$ & 180.6785524 & 107.2028176 & 368.3857658 & 222.9239527 & 130.9638883 & 457.8385915 \\
\hline carcinogens & $\mathrm{Pt}$ & 160.5779263 & 95.27642277 & 327.4025699 & 198.1234939 & 116.3940563 & 406.9037008 \\
\hline winter smog & $\mathrm{Pt}$ & 15.56819581 & 9.237147594 & 31.74201731 & 19.20827736 & 11.28452398 & 39.44973407 \\
\hline summer smog & $\mathrm{Pt}$ & 11.03766808 & 6.549029212 & 22.50471766 & 13.61844317 & 8.000595036 & 27.96939836 \\
\hline
\end{tabular}




\begin{tabular}{|c|c|c|c|c|c|c|c|}
\hline CPD 20k 2.3 Avg & CPD 20k 2.3 High & CPD 20k 2.3 Low & CPD 20k $3.0 \mathrm{Avg}$ & CPD 20k 3.0 High & CPD 20k 3.0 Lo & MBD $20 k$ & MBL \\
\hline $16 \overline{10} .4 \overline{2} 3113$ & $\overline{939} . \overline{692224}$ & $33 \overline{2} 3.900818$ & $21 \overline{18} .401017$ & 1225.919583 & $43 \overline{9} 8.4 \overline{4} 0055$ & $13 \overline{84} .4 \overline{3} 5703$ & $8 \overline{60} .9757183$ \\
\hline 98.72664979 & 57.60763388 & 203.7710396 & 129.8681282 & 75.15474183 & 269.6454412 & 84.87253918 & 52.78193507 \\
\hline 971.8211513 & 567.0638799 & 2005.831321 & 1278.363989 & 739.7897922 & 2654.269579 & 835.4474594 & 519.5618511 \\
\hline 265.1641078 & 154.724959 & 547.2966624 & 348.8051749 & 201.8537053 & 724.2248471 & 227.9541662 & 141.7638981 \\
\hline 235.6643997 & 137.5116899 & 486.4094935 & 310.0003345 & 179.3973274 & 643.6542834 & 202.5940922 & 125.9925569 \\
\hline 22.84790695 & 13.33190037 & 47.15790278 & 30.05485262 & 17.39275618 & 62.40294758 & 19.64170649 & 12.21510852 \\
\hline 16.19889782 & 9.452160861 & 33.4343995 & 21.3085377 & 12.33125996 & 44.2429573 & 13.92573933 & 8.660368554 \\
\hline
\end{tabular}




\begin{tabular}{|c|c|c|c|c|c|c|}
\hline MBD_20k_1.5_Low & MBD_20k & MBD_20k_1.9_High & MBD_20k & MBD_20 & MBD_20k & MBD_20 \\
\hline 146.0931001 & 86.33333347 & 54.24272937 & 147.5538944 & 87.79217484 & 55.70157073 & 149.0127358 \\
\hline 1438.075384 & 849.8268676 & 533.9412592 & 1452.454792 & 864.1870519 & 548.3014436 & 1466.814976 \\
\hline 392.3828737 & 231.8776277 & 145.6873597 & 396.3063353 & 235.795844 & 149.605576 & 400.2245516 \\
\hline 33.80973187 & 19.97977217 & 12.55317421 & 34.14779756 & 20.3173859 & 12.89078793 & 34.48541128 \\
\hline 23.97070302 & 14.16542393 & 8.900053153 & 24.21038762 & 14.4047881 & 9.139417319 & 24.44975178 \\
\hline
\end{tabular}


MBD_20k_3.0_Avg MBD_20k_3.0_High MBD_20k3.0 Low 1473.696589 950.2366041 2472.32266 90.34465899 58.25405488

573.4269603

156.4611432

(2)

151.5652199

242.6514112

1491.940493

215.6562576

407.0801188

20.90809692

139.0547223

361.7921467

$13.48149895 \quad 35.0761223$

14.82359528

9.558224501

24.86855896 


\begin{tabular}{|c|c|c|c|c|c|c|}
\hline $\begin{array}{l}\text { SimaPro } 7.1 \\
\text { Project }\end{array}$ & $\begin{array}{l}\text { Impact assessment } \\
\text { Thesis_Dredging Lim }\end{array}$ & $\begin{array}{l}\text { Date: } \\
\text { ited LCA }\end{array}$ & $8 / 13 / 2008$ & Time: & 3:22:08 PM & \\
\hline $\begin{array}{l}\text { Title: } \\
\text { Method: } \\
\text { Indicator: } \\
\text { Skip categories: } \\
\text { Relative mode: }\end{array}$ & $\begin{array}{l}\text { Comparing product st } \\
\text { Eco-indicator } 95 \mathrm{~V} 2.0 \\
\text { Single score } \\
\text { With result = } 0 \\
\text { Non }\end{array}$ & $\begin{array}{l}\text { tages } \\
3 / \text { Europe e }\end{array}$ & & & & \\
\hline Total & $\mathrm{Pt}$ & 5177.354374 & 2946.087076 & $10 \overline{8} 77 . \overline{4} 0418$ & $64 \overline{6} 0.105299$ & 3667.628498 \\
\hline greenhouse & $\mathrm{Pt}$ & 317.3966195 & 180.6092477 & 666.8369726 & 396.0353947 & 224.8431926 \\
\hline acidification & $\mathrm{Pt}$ & 3124.310901 & 1777.836961 & 6564.046039 & 3898.395966 & 2213.256206 \\
\hline eutrophication & $\mathrm{Pt}$ & 852.4769311 & 485.0877664 & 1791.018244 & 1063.688197 & 603.8931201 \\
\hline carcinogens & $\mathrm{Pt}$ & 757.6382257 & 431.1213844 & 1591.766105 & 945.3520781 & 536.7095523 \\
\hline winter smog & $\mathrm{Pt}$ & 73.45380851 & 41.7976635 & 154.323368 & 91.65286039 & 52.03454544 \\
\hline summer smog & $\mathrm{Pt}$ & 52.07788798 & 29.63405277 & 109.4134563 & 64.98080212 & 36.89188189 \\
\hline
\end{tabular}




\begin{tabular}{|c|c|c|c|c|c|c|}
\hline CPD_100k_1.9_Low & CPD_100k_2.3_Avg & 00k_2.3_High & U0K_z. & $P L$ & CPl & $01070=1$ \\
\hline $13 \overline{5} 93 . \overline{7} 7668$ & 7742.824367 & 4389.16992 & 16310.18104 & 10278.47702 & 5815.942425 & $21 \overline{6} 78 . \overline{5} 4479$ \\
\hline 833.3636165 & 474.6722171 & 269.0771375 & 999.8922133 & 630.1198689 & 356.5451254 & 1328.998622 \\
\hline 8203.260123 & 4672.461808 & 2648.675451 & 9842.49343 & 6202.61923 & 3509.67135 & 13082.0702 \\
\hline 2238.282372 & 1274.894218 & 722.6984737 & 2685.551745 & 1692.401932 & 957.623603 & 3569.47931 \\
\hline 1989.27176 & 1133.061269 & 642.2977202 & 2386.782076 & 1504.120933 & 851.0872506 & 3172.37203 \\
\hline 192.8619517 & 109.8514603 & 62.27142737 & 231.4009875 & 145.826078 & 82.513788 & 307.564745 \\
\hline 136.7368598 & 77.88339583 & 44.14971102 & 164.0605838 & 103.3889775 & 58.50130708 & 218.05979 \\
\hline
\end{tabular}




\begin{tabular}{|c|c|c|c|c|c|c|}
\hline 00k_1.5_Avg & DU & & & & & \\
\hline $67 \overline{3} 4.5 \overline{1} 4032$ & $4 \overline{117.214109}$ & 11727.58067 & $68 \overline{5} 3.528547$ & $4 \overline{2} 36.228624$ & $11846 . \overline{5} 9519$ & 6972.543061 \\
\hline 412.8579643 & 252.4049438 & 718.9568632 & 420.1541241 & 259.7011036 & 726.253023 & 427.4502838 \\
\hline 4063.989846 & 2484.561804 & 7077.091019 & 4135.809991 & 2556.38195 & 7148.911165 & 4207.630137 \\
\hline 1108.870948 & 677.9196082 & 1931.003995 & 1128.467275 & 697.5159349 & 1950.600322 & 1148.063602 \\
\hline 985.508214 & 602.5005374 & 1716.178336 & 1002.924435 & 619.916758 & 1733.594556 & 1020.340655 \\
\hline 95.54603924 & 58.4130494 & 166.3852622 & 97.23455981 & 60.10156997 & 168.0737828 & 98.92308038 \\
\hline 67.74102023 & 41.41416633 & 117.9651978 & 68.93816149 & 42.61130759 & 119.162339 & 70.13530275 \\
\hline
\end{tabular}


MBD_100k_2.3_High MBD_100k_2.3_Low MBD_100k_3.0_Avg MBD_100k_3.0_High MBD_100k_3.0_Low 4355.243138 266.9972633 11965.6097 733.5491827

7220.73131

2628.202095 7180.818461 4563.518539 279.7655429

2753.88735

717.1122617

440.2185634

12173.8851

1970.196649

637.3329785

4333.315392

751.4058335

61.79009054

(1)

667.8113645

169.7623034

1050.819041

746.3174623

101.8779914

64.74500154

7346.416565

43.80844885

120.3594803

72.23029997

45.90344606

004.490221

1781.489163

172.7172144

122.4544775 


\section{APPENDIX E}

\section{COPYRIGHT PERMISION DOCUMENTATION}




\section{APPENDIX E - COPYRIGHT PERMISSION DOCUMENTATION}

All figures, photographs, and tables included in this thesis were either the original work of the author or taken from the public domain. Unless a citation follows a figure or table the work was the authors. The following statements serve as documentation that the related figures or photographs were accessed from the public domain. 
August 16, 2008

Hello Mr. Anderson,

Mark, thank you for allowing the District Library the opportunity to assist you in your informational needs. This is a formal letter of confirmation for the use of material provided by the US Corps of Engineers - Rock Island District and District Library. The material requested, photos, images, etc. fall into the public domain for use and viewing.

The only requirement we ask is that the following indicated trailer be used -

\section{"...the following material courtesy of The U.S. Army Corps of Engineers, Rock Island District."}

I sincerely wish you the best in your continued work and professional efforts. Please feel free to call if you have questions or concerns.

Respectfully,

Robert Romic

District Librarian

USACE Technical Library

Rock Island District

Clock Tower Building

Rodman Avenue

Rock Island, IL 61201

309.794.5576 (voice)

309.794.5807 (fax)

Robert.L.Romic@usace.army.mil 


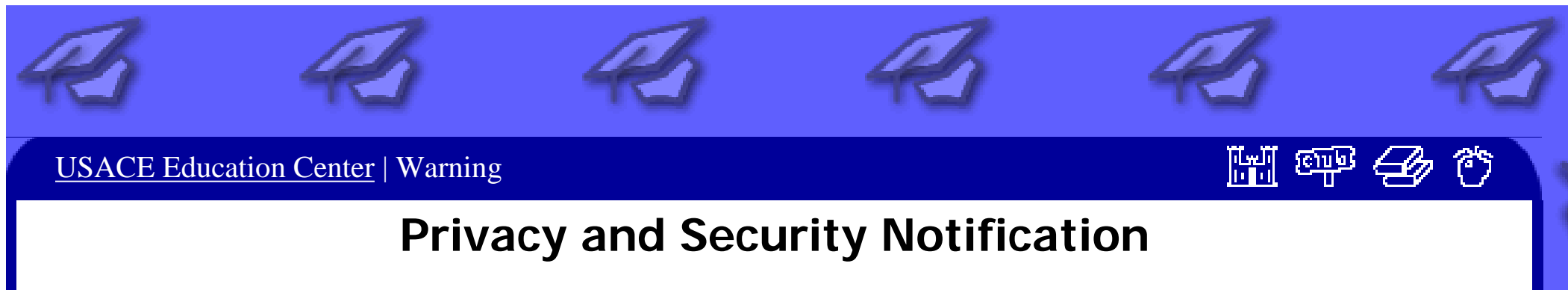

\section{ATTENTI ON!}

1. CorpsWeb is provided as a public service by the U.S. Army Corps of Engineers (USACE).

2. Information presented on CorpsWeb public web sites is considered public information and may be distributed or copied. Use of appropriate byline/photo/image credits is requested.

3. For site management, information collected at CorpsWeb public web sites is for statistical purposes. These government computer systems use software programs to create summary statistics, which are used for such purposes as assessing what information is of most and least interest, determining technical design specifications, and identifying system performance or problem areas.

4. For site security purposes and to ensure that this service remains available to all users, these government computer systems employs software programs to monitor network traffic to identify unauthorized attempts to upload or change information, or otherwise cause damage.

5. Except for authorized law enforcement investigations, no other attempts are made to identify individual users or their usage habits. Raw data logs are used for no other purposes and are scheduled for regular destruction in accordance with Modern Army Record Keeping System (MARKS). All data collection activities are in strict accordance with Department of Defense Directive 5240.1 (reference (p)).

6. Unauthorized attempts to upload information or change information on these services are strictly prohibited and may be punishable under the Computer Fraud and Abuse Act of 1987 and the National Information Infrastructure Protection Act.

7. If you have any questions or comments about the information presented here, please forward them to Thomas J. Aubin, Information Systems Security Program Manager, United States Army Corps of Engineers, E-Mail: thomas.j.aubin@usace.army.mil.

Established: April 23, 2002

Comments/Whom to contact

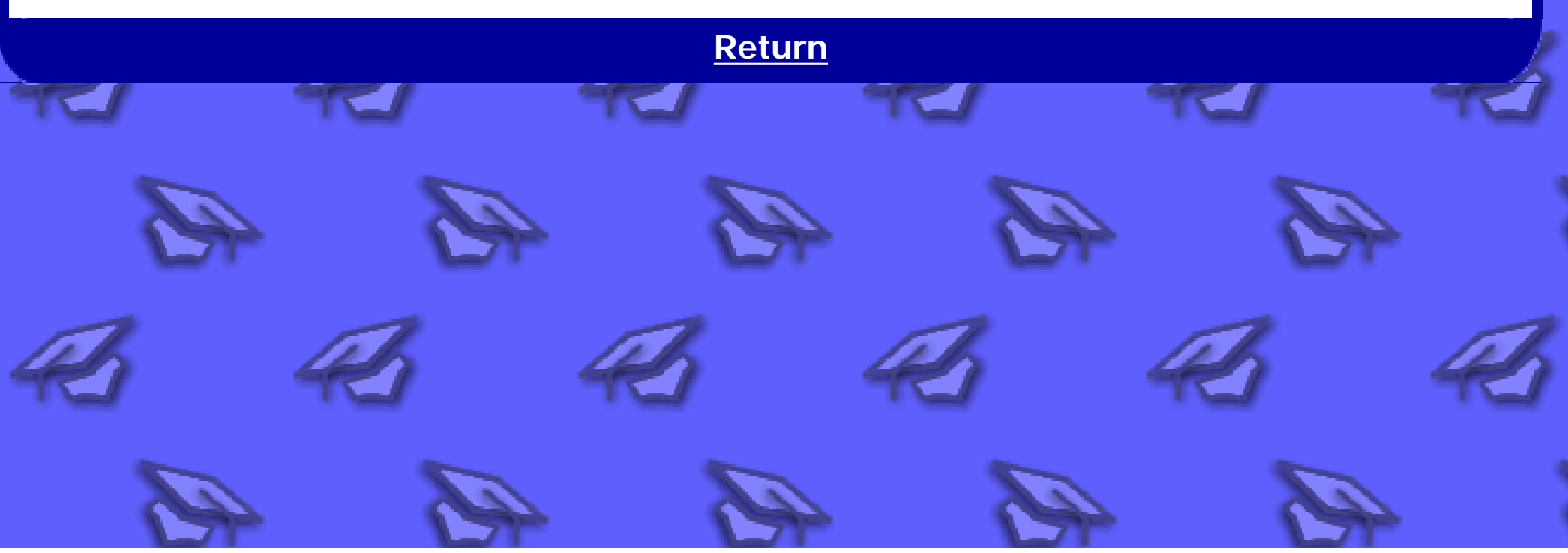




\section{Privacy and Security Notification}

\section{ATTENTION!}

1. CorpsWeb is provided as a public service by the U.S. Army Corps of Engineers (USACE).

2. Information presented on CorpsWeb public web sites is considered public information and may be distributed or copied. Use of appropriate byline/photo/image credits is requested.

3. For site management, information collected at CorpsWeb public web sites is for statistical purposes. These government computer systems use software programs to create summary statistics, which are used for such purposes as assessing what information is of most and least interest, determining technical design specifications, and identifying system performance or problem areas.

4. For site security purposes and to ensure that this service remains available to all users, these government computer systems employs software programs to monitor network traffic to identify unauthorized attempts to upload or change information, or otherwise cause damage.

5. Except for authorized law enforcement investigations, no other attempts are made to identify individual users or their usage habits. Raw data logs are used for no other purposes and are scheduled for regular destruction in accordance with AR 25-400-2 Army Records I nformation Management System (ARIMS) and National Archives and Records Administration General Records Schedule 20. All data collection activities are in strict accordance with Department of Defense Directive 5240.1.

6. Unauthorized attempts to upload information or change information on these services are strictly prohibited and may be punishable under the Computer Fraud and Abuse Act of 1987 and the National I nformation Infrastructure Protection Act.

7. If you have any questions or comments about this 
Privacy and Security Warning for Department of Defense

notification, please forward them to J oy Renfro, Information Assurance Program Manager, United States Army Corps of Engineers, E-Mail: Loy.Renfro@usace. army.mil. 